Prepared for the U.S. Department of Energy

under Contract DE-AC05-76RL01830

\title{
Pulse Jet Mixer Overblow Testing for Assessment of Loadings During Multiple Overblows
}

DM Pfund

JR Bontha

TE Michener

F Nigl
ST Yokuda

RJ Leigh

EC Golovich
AW Baumann

DE Kurath

M Hoza
WH Combs

JA Fort

OP Bredt

July 2009 


\title{
DISCLAIMER
}

This report was prepared as an account of work sponsored by an agency of the United States Government. Neither the United States Government nor any agency thereof, nor Battelle Memorial Institute, nor any of their employees, makes any warranty, express or implied, or assumes any legal liability or responsibility for the accuracy, completeness, or usefulness of any information, apparatus, product, or process disclosed, or represents that its use would not infringe privately owned rights. Reference herein to any specific commercial product, process, or service by trade name, trademark, manufacturer, or otherwise does not necessarily constitute or imply its endorsement, recommendation, or favoring by the United States Government or any agency thereof, or Battelle Memorial Institute. The views and opinions of authors expressed herein do not necessarily state or reflect those of the United States Government or any agency thereof.

\author{
PACIFIC NORTHWEST NATIONAL LABORATORY \\ operated by \\ BATTELLE \\ for the \\ UNITED STATES DEPARTMENT OF ENERGY \\ under Contract DE-AC05-76RL01830 \\ Printed in the United States of America \\ Available to DOE and DOE contractors from the \\ Office of Scientific and Technical Information, \\ P.O. Box 62, Oak Ridge, TN 37831-0062; \\ ph: (865) 576-8401 \\ fax: (865) 576-5728 \\ email: reports@adonis.osti.gov
}

Available to the public from the National Technical Information Service, U.S. Department of Commerce, 5285 Port Royal Rd., Springfield, VA

22161

ph: (800) 553-6847

fax: (703) 605-6900

email: orders@ntis.fedworld.gov

online ordering: http://www.ntis.gov/ordering.htm 
PNNL-17231 Rev. 1

WTP-RPT-150 Rev. 1

\section{Pulse Jet Mixer Overblow Testing for Assessment of Loadings During Multiple Overblows}

$\begin{array}{llll}\text { DM Pfund } & \text { ST Yokuda } & \text { AW Baumann } & \text { WH Combs } \\ \text { JR Bontha } & \text { RJ Leigh } & \text { DE Kurath } & \text { JA Fort } \\ \text { TE Michener } & \text { EC Golovich } & \text { M Hoza } & \text { OP Bredt } \\ \text { F Nigl } & & & \end{array}$

July 2009

Test specification: $\quad$ 24590-WTP-TSP-RT-06-001 Rev. 0

Test plan:

TP-RPP-WTP-452 Rev. 0

Test exceptions:

24590-WTP-TEF-RT-06-00003

24590-WTP-TEF-RT-07-00003

24590-WTP-TEF-RT-07-00009

24590-WTP-TEF-RT-07-00011

R\&T focus area:

Pretreatment \& HLW Vitrification

Prepared for

the U.S. Department of Energy

under Contract DE-AC05-76RL01830

Pacific Northwest National Laboratory

Richland, Washington 99354 
PNNL-17231 Rev. 1

WTP-RPT-150 Rev. 1

\section{Completeness of Testing}

This report describes the results of work and testing specified by Test Specification 24590-WTP-TSP-RT-06-001, Rev. 0 and Test Plan TP-RPP-WTP-452 Rev. 0 as modified by test exceptions 24590-WTP-TEF-RT-06-00003, 24590-WTP-TEF-RT07-00003, 24590-WTP-TEF-RT-07-00009, 24590-WTP-TEF-RT-07-00011. The work and any associated testing followed the quality assurance requirements outlined in the Test Specification and Test Plan. The descriptions provided in this test report are an accurate account of both the conduct of the work and the data collected. Test plan results are reported. Also reported are any unusual or anomalous occurrences that are different from expected results. The test results and this report have been reviewed and verified.

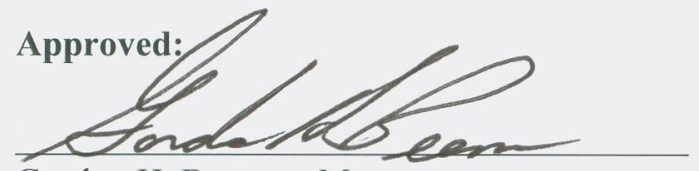

Gordon H. Beeman, Manager WTP R\&T Support Project

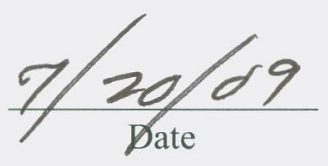




\section{Revision Log}

\begin{tabular}{|c|c|c|c|}
\hline $\begin{array}{c}\text { Rev. } \\
\text { No. }\end{array}$ & Date & Describe Changes & Pages Changed \\
\hline 0 & $03 / 07 / 2008$ & Original document & n/a \\
\hline 1 & $07 / 08 / 2009$ & $\begin{array}{c}\text { Included the Clay Simulant Density Data in } \\
\text { Appendix F }\end{array}$ & F.1 \\
\hline
\end{tabular}





\section{Contents}

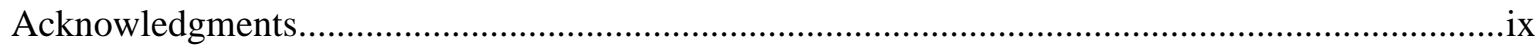

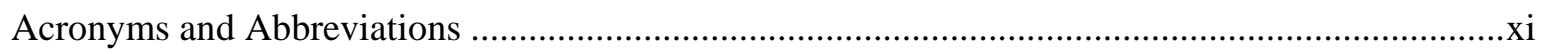

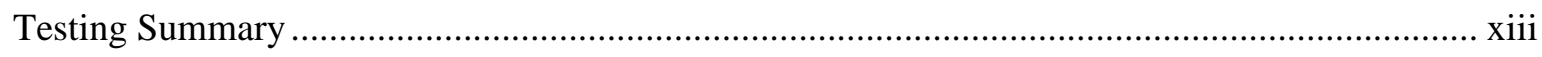

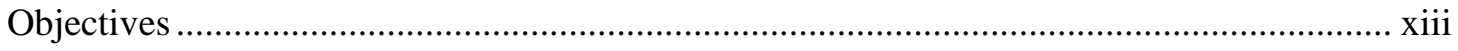

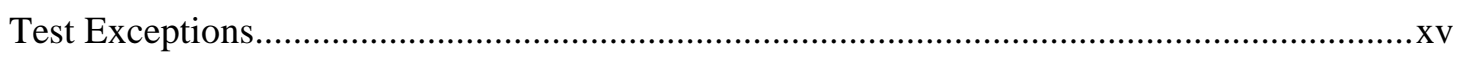

Results and Performance against Success Criteria .............................................................Xv

Quality Requirements ..................................................................................................

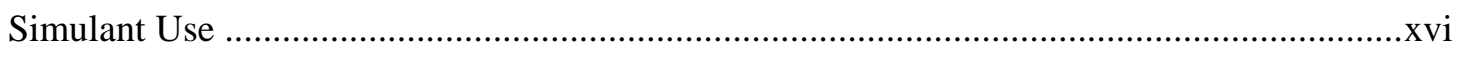

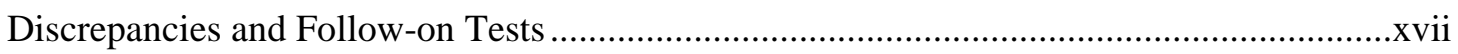

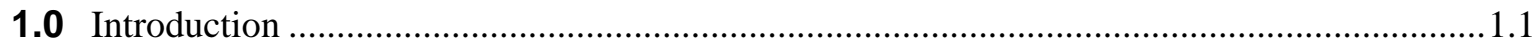

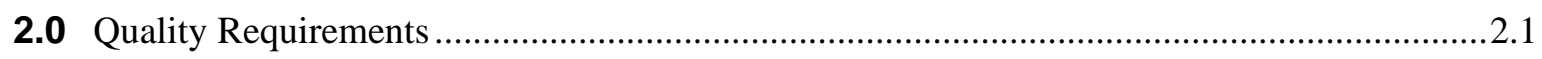

2.1 Application of RPP-WTP Quality Assurance Requirements .......................................2.1

2.2 Conduct of Experimental and Analytical Work ........................................................... 2.1

2.3 Internal Data Verification and Validation ...............................................................2.2

3.0 Instrumentation and Data Acquisition System Description.................................................... 3.1

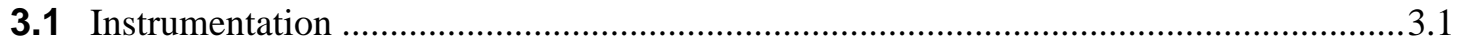

3.1.1 PJM Pressures ......................................................................................... 3.1

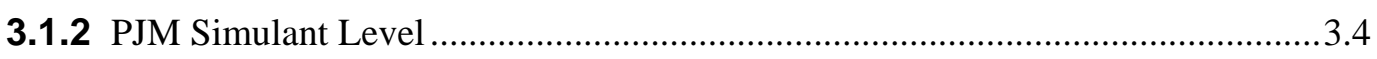

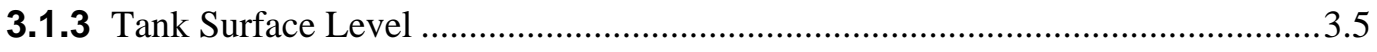

3.1.4 Simulant Temperature ................................................................................ 3.5

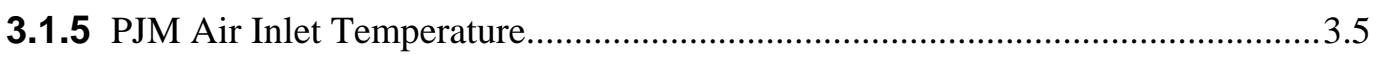

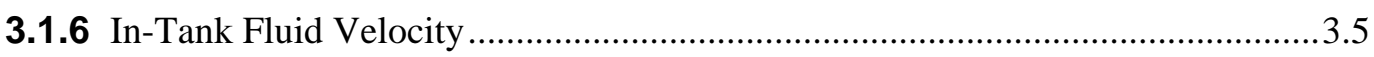

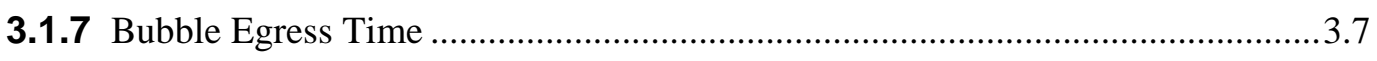

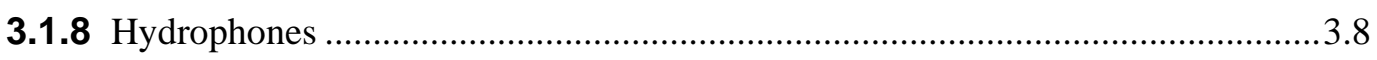

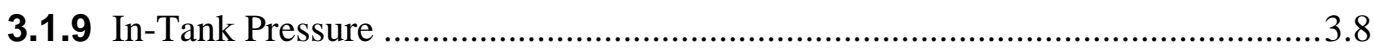

3.1.10Probe Mast Acceleration ................................................................................. 3.9

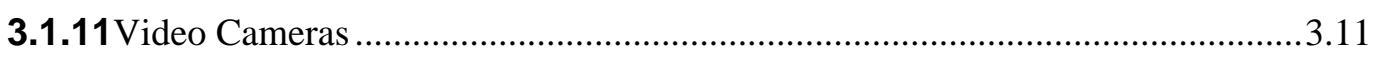

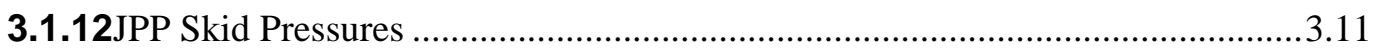

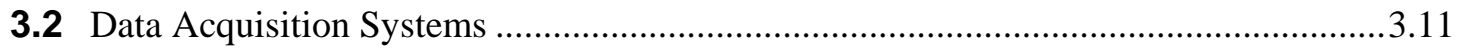

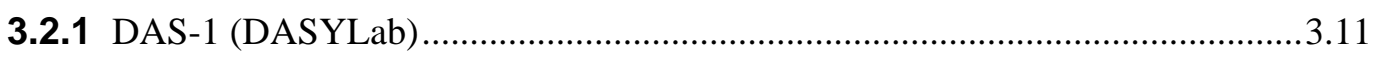

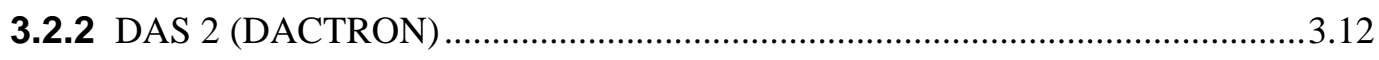

3.2.3 DAS 4 (High-Speed Video Camera) ….............................................................12

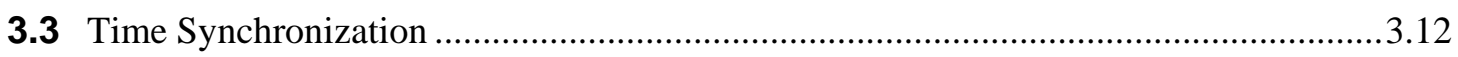

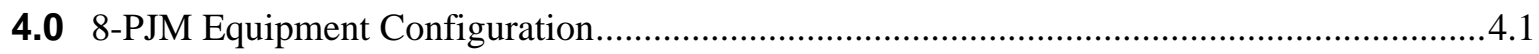

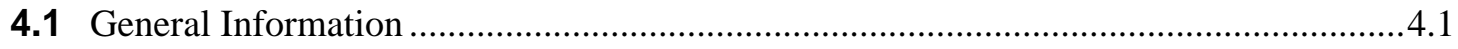




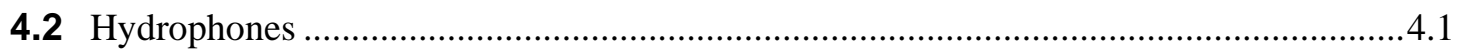

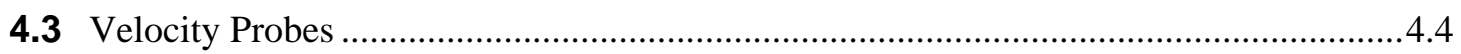

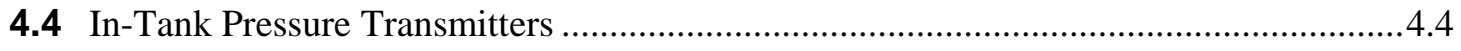

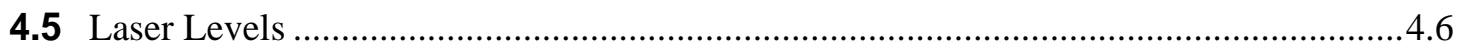

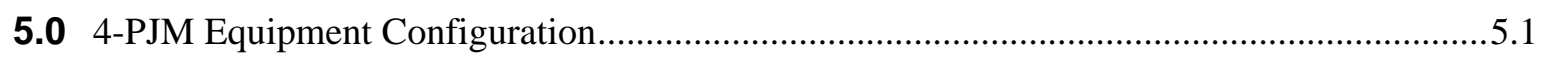

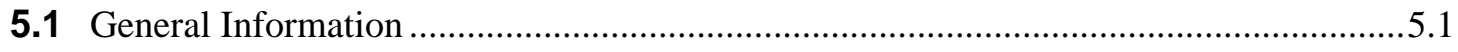

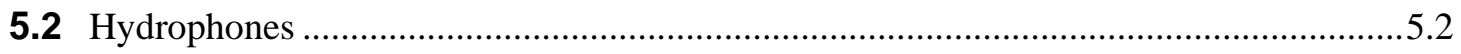

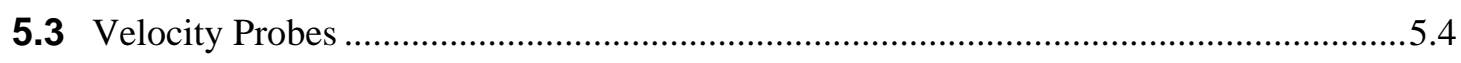

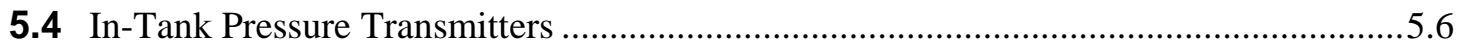

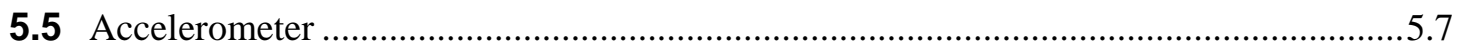

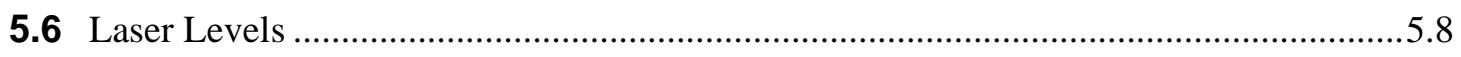

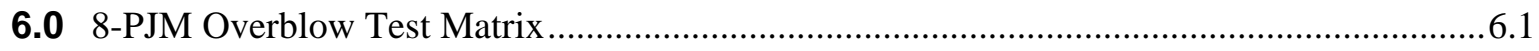

7.0 4-PJM Overblow Test Matrix ........................................................................................ 7.1

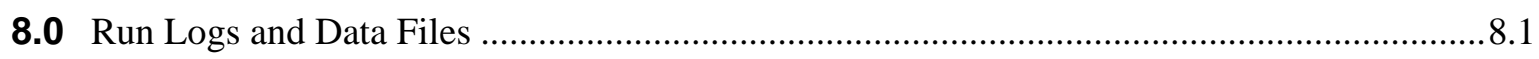

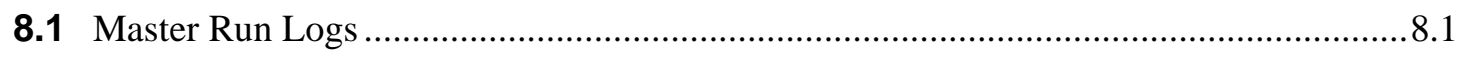

8.2 DAS-1 (DASYLAB) File Naming Convention and Description of File Contents .........8.2

8.3 DAS-2 (DACTRON) File Naming Nomenclature ......................................................... 8.5

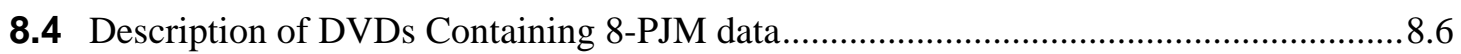

8.5 Description of the Portable Hard Disk Drives Containing 4-PJM Data..........................8.7

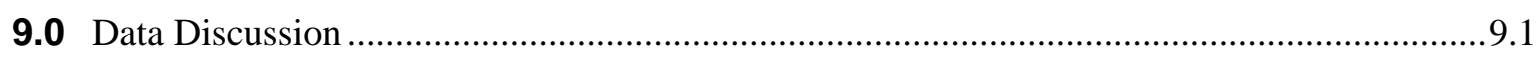

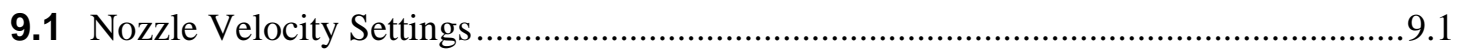

9.1.1 Peak Average Nozzle Velocity Settings............................................................. 9.1

9.1.2 Rack Pressure Settings for 4-PJM Configuration................................................. 9.1

9.2 K Value Calculations for Water and Clay .....................................................................

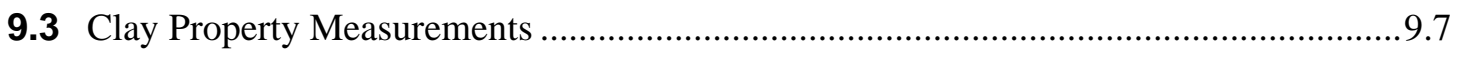

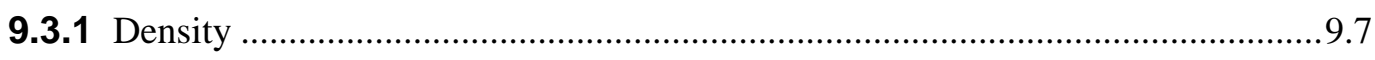

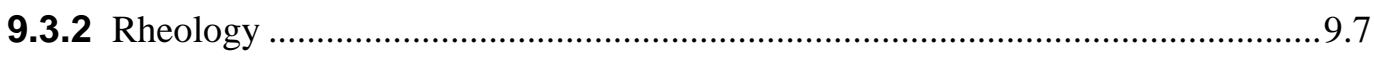

9.4 General Comments on Overblow Experiments ............................................................

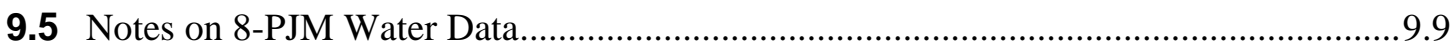

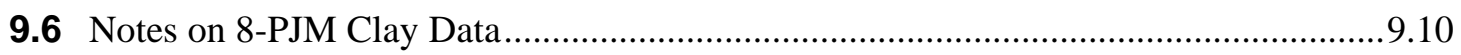

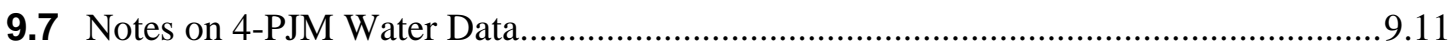

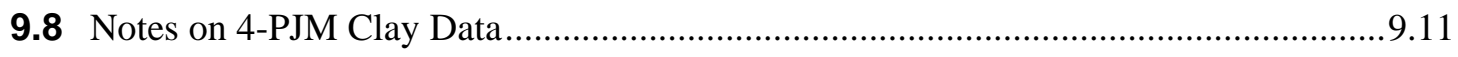

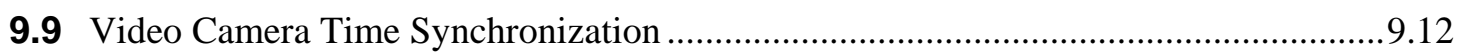

9.10 Linear Approximation for Nozzle Velocity Determination .........................................12

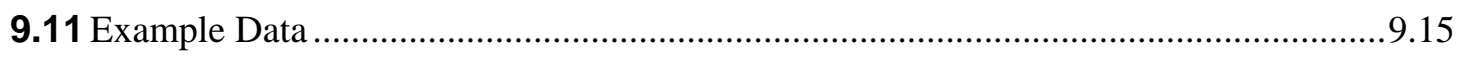

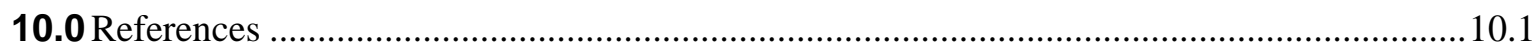

Appendix A Master Run Log, 8-PJM Configuration...................................................................

Appendix B Master Run Log, 4-PJM Configuration ............................................................... 1

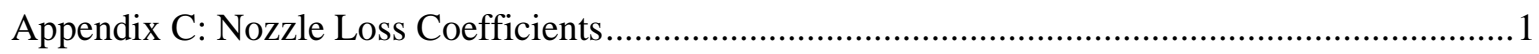




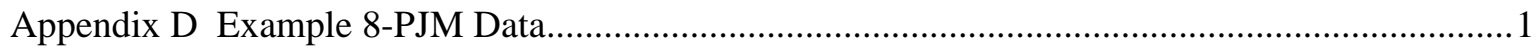

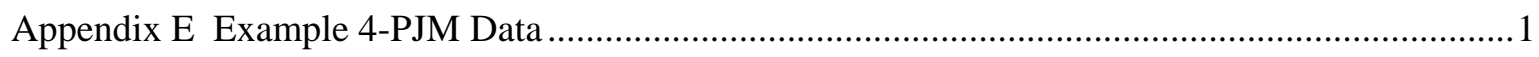

Appendix F: Clay Simulant Density Data...................................................................................

\section{Figures}

Figure 3.1. PJM Level, Pressure, and Temperature Sensor Arrangement on Top of the PJM (the spool piece shown was present only in the 8-PJM configuration) ....................................................... 3.4

Figure 3.2. Detail of a Velocity Probe Mount (looking down) ............................................................... 3.6

Figure 3.3. Velocity Probe Inside the Tank (in the 4-PJM configuration) at an Early Stage of the

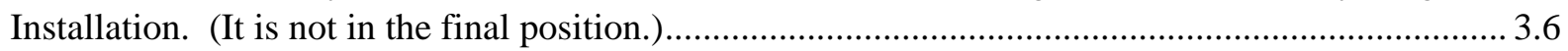

Figure 3.4. In-Tank Pressure Sensor Mounting Tubes at Top (Left), Middle (Center) and Bottom

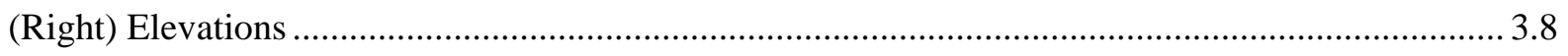

Figure 3.5. Lower In-Tank Pressure Sensors in the Tank (4-PJM configuration). Note the flush

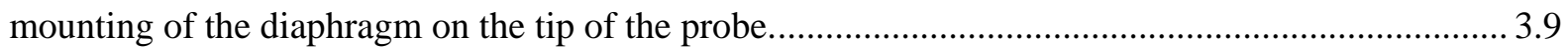

Figure 3.6. Accelerometer Housing (dimensions in inches) …............................................................... 3.10

Figure 3.7. Accelerometer Housing Inside the Tank in 4-PJM Configuration (the distance from the PJM was changed slightly after this picture was taken).......................................................... 3.10

Figure 4.1. Plan View of the 8-PJM Configuration (see Bontha et al. 2005) ...................................... 4.2

Figure 4.2. Radial Location of the Four Hydrophones Installed in the 8-PJM Configuration................. 4.2

Figure 4.3. Hydrophone Spacing in the 8-PJM Configuration .............................................................. 4.3

Figure 4.4. Plan View Showing Location of Velocity Probe and Mast Installed in 8-PJM

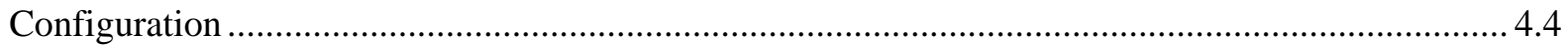

Figure 4.5. Plan View of the Tank Showing the Location of the Pressure Transmitter Tree Mast

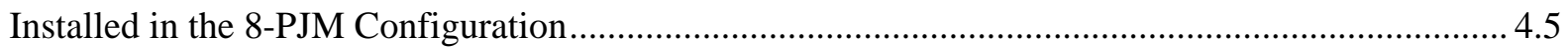

Figure 4.6. Location of the Laser Levels, 8-PJM Configuration ........................................................... 4.6

Figure 5.1. Plan View of the 4-PJM Configuration (see Bontha et al. 2003b) ..................................... 5.1

Figure 5.2. Radial Location of the Four Hydrophones Installed in the 4-PJM Configuration................. 5.2

Figure 5.3. Hydrophone Mounting Columns (top left, bottom end with black tip of hydrophone protruding from the end; top right, rising shaft with rubber snubber mounted on red crossbeam; bottom, top of column attached to frame mounted on handrails above tank)................................... 5.3

Figure 5.4. The Four Hydrophone Levels in the 4-PJM Configuration .................................................. 5.4

Figure 5.5. Plan View Showing Location of Velocity Probes and Mast Installed in 4-PJM

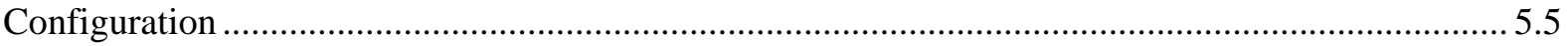


Figure 5.6. Plan View of the Tank Showing the Location of the Pressure Transmitter Tree Mast

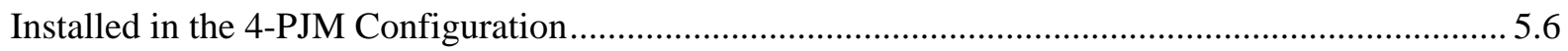

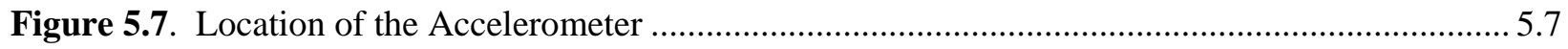

Figure 5.8. The Mount for the Accelerometer Mast ......................................................................... 5.8

Figure 5.9. Location of the Laser Levels, 4-PJM Configuration ....................................................... 5.9

Figure 9.1. N Nozzle Velocity Versus Rack Pressure, 8-PJM Configuration ～(values from Tables 9.1 and 9.2$) \quad 9.2$

Figure 9.2. Nozzle Velocity Versus Rack Pressure, 4-PJM Configuration, Water Simulant (driving all four PJMs; values from Table 9.3).

Figure 9.3. Nozzle Velocity Versus Rack Pressure, 4-PJM Configuration, Clay Simulant (driving all four PJMs; values from Tables 9.4)

Figure 9.4. Illustration of Linear Approximation for Nozzle Velocity Determination for 8-PJM Low- Velocity Case (8 m/s) Using DAS-1 Data from Run E0515 ............................................ 9.13

Figure 9.5. Illustration of the Linear Approximation for Nozzle Velocity Determination for the 8PJM High-Velocity Case (14 m/s) Using DAS-1 Data from Run E0481 ................................. 9.13

Figure 9.6. Illustration of the Linear Approximation for Nozzle Velocity Determination for the 4-PJM Low-Velocity Case (6 m/s) Using DAS-1 Data from Run E0875 ........................................ 9.14

Figure 9.7. Illustration of the Linear Approximation for Nozzle Velocity Determination for the 4-PJM High-Velocity Case (12 m/s) Using DAS-1 Data from Run E0896. 9.14

\section{Tables}

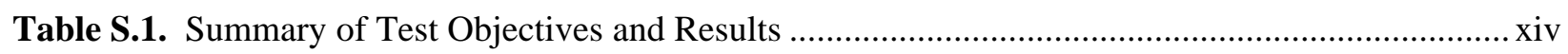

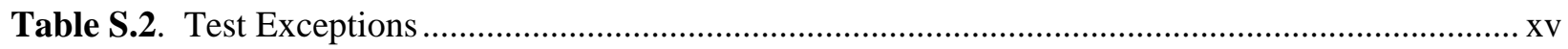

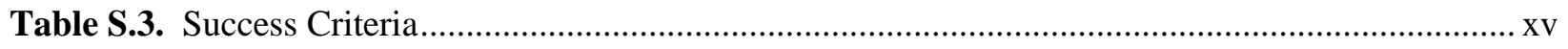

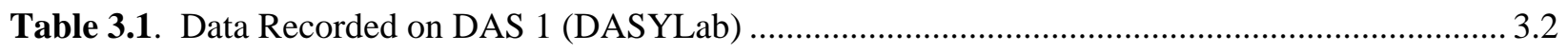

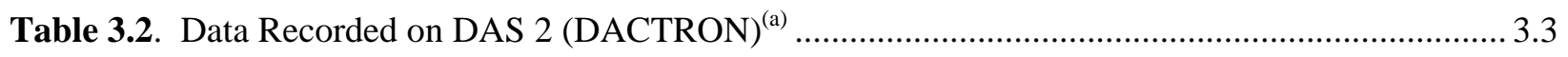

Table 4.1. General Information Relating to all as-Built Measurements, 8-PJM Configuration............... 4.1

Table 4.2. Hydrophone Locations, 8-PJM Configuration ..................................................................... 4.3

Table 4.3. Velocity Probe, Laser Level, and Pressure Transmitter Mast Locations, 8-PJM Configuration4.5

Table 4.4. In-Tank Pressure Transmitter Nomenclature, Orientation, and As-Built Information, 8-

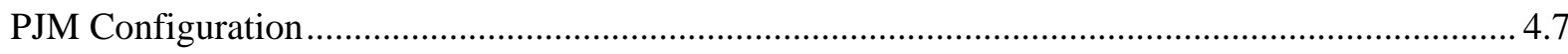

Table 4.5. As-Built Information of the In-Tank Pressure Transmitter Distances from PJM 5 Nozzle,

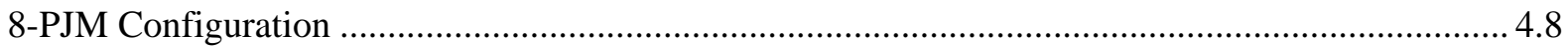

Table 5.1. General Information Relating to all as-Built Measurements, 4-PJM Configuration................ 5.2 
Table 5.2. Hydrophone Locations, 4-PJM Configuration

Table 5.3. Velocity Probe, Laser Level and Pressure Transmitter Mast Locations, 4-PJM Configuration5.5

Table 5.4. As-Built Information of the In-Tank Pressure Transmitters, 4-PJM Configuration ...... 5.7

Table 6.1. Simultaneous Overblow Test Conditions for the 8-PJM Configuration

Table 6.2. Single and Double Overblow Tests Performed to Investigate the Effect of Reynolds Number $\quad$ on Loadings in the 8-PJM Configuration......................................................................... 6.2

Table 6.3. Tests Performed to Investigate the Effect of Multiple Overblows on Loadings in the

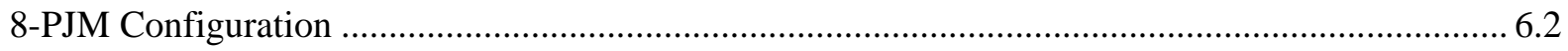

Table 7.1. Simultaneous Overblow Test Conditions for the 4-PJM Configuration ................................ 7.2

Table 7.2. $\quad$ Single and Double Overblow Tests Performed to Investigate the Effect of Reynolds Number on Loadings in the 4-PJM Configuration....................................................................... 7.2

Table 7.3. Tests Performed to Investigate the Effect of Multiple Overblows on Loadings in the

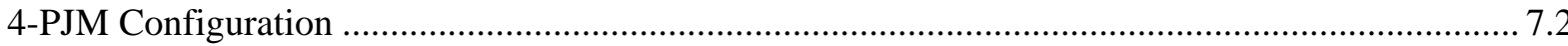

Table 8.1. Channel Names as Used in the DAS-1 Log Files with a Brief Description (8-PJM

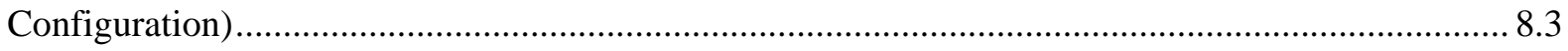

Table 8.2. Channel Names as Used in the DAS-1 Log Files with a Brief Description (4-PJM

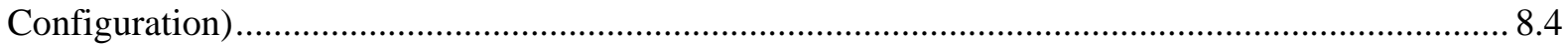

Table 8.3. Channel Numbers and Names as Used in the DAS-2 Log Files with a Brief Description

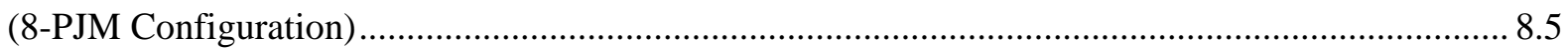

Table 8.4. Channel Numbers and Names as Used in the DAS-2 Log Files with a Brief Description

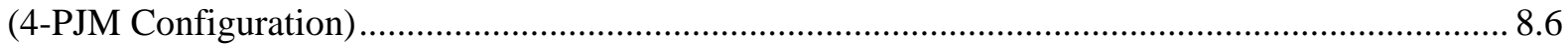

Table 9.1. Peak Average Nozzle Velocities and Loss Coefficients with Water, 8-PJM

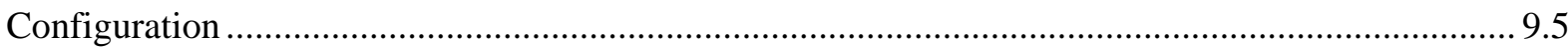

Table 9.2. Peak Average Velocities and Drag Loss Coefficients with Clay, 8-PJM Configuration ........ 9.5

Table 9.3. Peak Average Nozzle Velocities and Loss Coefficients with Water, 4-PJM

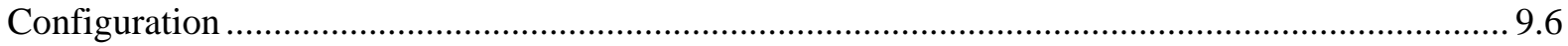

Table 9.4. Peak Average Velocities and Nozzle Loss Coefficients with Clay, 4-PJM Configuration..... 9.7

Table 9.5. Target and Estimated Peak Average Nozzle Velocities Using the Linear Approximation... 9.15 



\section{Acknowledgments}

The authors would like to thank Matt Fountain for his patient and careful technical reviews of this report and other project documentation. In addition, we would like to the many people that have worked hard in the lab or in preparing the data packages for this project including Aaron Richter, Naveen Karri, Shelly Carlson, Keith Peterson, Bob Fulton, Anna Lundeby, Anthony Guzman, Mike Johnson and Mike White. 



\section{Acronyms and Abbreviations}

AEA

Bar, g

BNI

DAS

DEI

DOE

HPAV

JPP

PJM

PNNL

PNWD

QA

RFO

RPP

WTP
Atomic Energy Agency of United Kingdom

gauge pressure, bar

Bechtel National, Inc.

data acquisition system

Dominion Engineering Inc.

U.S. Department of Energy

hydrogen in pipes and ancillary vessels

jet pump pair

pulse jet mixer

Pacific Northwest National Laboratory

Battelle - Pacific Northwest Division

quality assurance

(JPP drive air) regulators fully open

River Protection Project

Waste Treatment Plant 



\section{Testing Summary}

The U.S. Department of Energy (DOE) Office of River Protection's Waste Treatment Plant (WTP) is being designed and built to pretreat and then vitrify a large portion of the wastes in Hanford's 177 underground waste storage tanks. The WTP consists of three primary facilities: pretreatment, lowactivity waste (LAW) vitrification, and high-level waste (HLW) vitrification. The pretreatment facility will receive waste feed from the Hanford tank farms and separate it into 1) a high-volume, low-activity liquid stream stripped of most solids and radionuclides and 2) a much smaller volume of HLW slurry containing most of the solids and most of the radioactivity.

Many of the vessels in the pretreatment facility will contain pulse jet mixers (PJMs) that will provide some or all of the mixing in the vessels. This technology was selected for use in so-called "black cell" regions of the WTP, where maintenance capability will not be available for the operating life of the WTP. PJM technology was selected for use in these regions because it has no moving mechanical parts that require maintenance. The vessels with the most concentrated slurries will also be mixed with air spargers and/or steady jets in addition to the mixing provided by the PJMs.

This report contains the results of single and multiple PJM overblow tests conducted in a large, $\sim 13$-ft-diameter $\times 15$-ft-tall tank located in the high bay of the Pacific Northwest National Laboratory (PNNL) 336 Building test facility. These single and multiple PJM overblow tests were conducted using water and a clay simulant to bound the lower and upper rheological properties of the waste streams anticipated to be processed in the WTP. Hydrodynamic pressures were measured at a number of locations in the test vessel using an array of nine pressure sensors and four hydrophones. These measurements were made under normal and limiting vessel operating conditions (i.e., maximum PJM fluid emptying velocity, maximum and minimum vessel contents for PJM operation, and maximum and minimum rheological properties). Test data collected from the PJM overblow tests were provided to Bechtel National, Inc. (BNI) for assessing hydrostatic, dynamic, and acoustic pressure loadings on in-tank structures during 1) single overblows; 2) multiple overlapping overblows of two to four PJMs; 3) simultaneous overblows of pairs of PJMs.

\section{Objectives}

Table S.1 summarizes objectives and results of the PJM overblow testing. 
Table S.1. Summary of Test Objectives and Results

\begin{tabular}{|c|c|c|}
\hline Test Objective & $\begin{array}{c}\text { Objective } \\
\text { Met? }\end{array}$ & Discussion \\
\hline $\begin{array}{l}\text { Measure the hydrodynamic } \\
\text { pressures associated with } \\
\text { single and simultaneous } \\
\text { multiple PJM overblows in } \\
\text { WTP vessels during the drive } \\
\text { phase of the PJM cycle. The } \\
\text { hydrodynamic pressures will } \\
\text { be measured at a number of } \\
\text { locations in the test vessel } \\
\text { using an array of pressure } \\
\text { sensors and up to four } \\
\text { hydrophones. }\end{array}$ & Yes & $\begin{array}{l}\text { An array of four hydrophones measured acoustic pressures over a bandwidth } \\
\text { of } 1 \text { to } 5120 \mathrm{~Hz} \text { at three (for the 8-PJM configuration) to four (for the 4-PJM } \\
\text { configuration) different elevations in the tank. } \\
\text { An array of nine in-tank pressure sensors measured dynamic pressures over } \\
\text { the same bandwidth at three elevations in the tank and for three independent } \\
\text { directions at each elevation. Overblow pressures were measured over a } \\
\text { range of } \pm 10 \text { psig. } \\
\text { Instrument types, models, and locations, the test matrix, and the formats of } \\
\text { supplied data were approved by BNI before testing. } \\
\text { Measurements were performed for single, multiple, and simultaneous } \\
\text { overblows, as specified in the Test Specification and Test Exceptions. }\end{array}$ \\
\hline \begin{tabular}{|l|} 
The overblows and \\
measurements will be made \\
under normal and limiting \\
vessel operating conditions \\
(i.e., maximum PJM fluid \\
emptying velocity, maximum \\
and minimum vessel \\
contents for PJM operation, \\
and maximum and minimum \\
rheological properties).
\end{tabular} & Yes & $\begin{array}{l}\text { Data were collected over a broad range of liquid levels and drive velocities. } \\
\text { Liquid height to tank diameter ratios ranged between } 0.3 \text { and } 0.8 \text { - the usable } \\
\text { range of the test vessel. Drive velocities were } 8 \text { to } 15 \mathrm{~m} / \mathrm{s} \text { in the } 8 \text {-PJM } \\
\text { configuration and } 6 \text { to } 12 \mathrm{~m} / \mathrm{s} \text { in the 4-PJM configuration, the upper } \\
\text { velocities being limited by the flow capacity of the drive air regulators on the } \\
\text { BNI-supplied jet pump pair (JPP) skids. These velocities and fluid properties } \\
\text { cover a limiting range of process conditions as defined in the Test } \\
\text { Specification and Test Exceptions. } \\
\text { Water was used as a test fluid to represent the lower limit of viscosity for } \\
\text { Newtonian fluids in the WTP. A slurry of } 29 \mathrm{wt} \% \text { clay (consisting of } 80 \\
\text { wt\% kaolin and } 20 \text { wt\% bentonite clays) in water was used represent the } \\
\text { upper limit of yield strength for non-Newtonian fluids in the WTP. }\end{array}$ \\
\hline $\begin{array}{l}\text { Data will be obtained for } \\
\text { selection of scaling } \\
\text { approaches for multiple PJM } \\
\text { overblows and development } \\
\text { of load specifications for } \\
\text { plan vessel internal } \\
\text { components. }\end{array}$ & Yes & $\begin{array}{l}\text { The PNNL test matrix was refined continuously based on discussions with } \\
\text { BNI and Dominion Engineering, Inc. (DEI; the BNI contracted organization } \\
\text { developing the load specifications). } \\
\text { All data called for in the BNI and DEI-approved Test Specification, Test } \\
\text { Plan, and Test Exceptions have been delivered to BNI and DEI as electronic } \\
\text { data files. }\end{array}$ \\
\hline
\end{tabular}




\section{Test Exceptions}

A summary description of test exceptions applied to PJM overblow testing is presented in Table S.2.

Table S.2. Test Exceptions

\begin{tabular}{|c|c|}
\hline Test Exceptions & Description of Test Exceptions \\
\hline $\begin{array}{l}24590-W T P-T E F-R T-06- \\
00003\end{array}$ & $\begin{array}{l}\text { Added scope after review of the Test Plan by BNI and DEI. This exception } \\
\text { defined instrumentation necessary to enable making the needed structural } \\
\text { engineering analysis. Added scoping tests of new instrumentation, and more } \\
\text { instrumentation, including: } \\
\text { - Conductivity probes for overblow detection } \\
\text { - Accelerometer } \\
\text { - High-speed submerged video } \\
\text { - Velocity probes. }\end{array}$ \\
\hline $\begin{array}{l}24590-\text { WTP-TEF-RT-07- } \\
00003\end{array}$ & $\begin{array}{l}\text { Made changes to test conditions, control and data requirements based on scoping } \\
\text { test results. Modified test conditions to facilitate testing and to meet the test } \\
\text { objectives. Set targets for overblow duration and maximum PJM velocity. }\end{array}$ \\
\hline $\begin{array}{l}24590-\text { WTP-TEF-RT-07- } \\
00009\end{array}$ & $\begin{array}{l}\text { Added additional high speed submerged video tests requested by DEI for the } \\
\text { 4-PJM test stand. }\end{array}$ \\
\hline $\begin{array}{l}24590-W T P-T E F-R T-07- \\
00011\end{array}$ & \begin{tabular}{|l|} 
After discussions with BNI and DEI, the target drive velocities for 4-PJM testing \\
were revised to $6,8,10$, and $12 \mathrm{~m} / \mathrm{s}$ (instead of the original $8,12,14$, and $15 \mathrm{~m} / \mathrm{s}$ ).
\end{tabular} \\
\hline
\end{tabular}

\section{Results and Performance against Success Criteria}

The research and technology success criteria are discussed in Table S.3.

Table S.3. Success Criteria

\begin{tabular}{|l|l||}
\hline \multicolumn{1}{|c|}{ Success Criterion } & \multicolumn{1}{|c|}{ How Testing Did or Did Not Meet Success Criterion } \\
\hline $\begin{array}{l}\text { Provide the hydrodynamic pressure } \\
\text { profiles with supporting data and } \\
\text { testing documentation for each set } \\
\text { of conditions tested. }\end{array}$ & $\begin{array}{l}\text { All data called for in the BNI and DEI approved Test Specification, Test Plan } \\
\text { and Test Exceptions have been delivered to BNI and DEI as electronic data } \\
\text { files. } \\
\text { Supporting data in the form of instrument and equipment descriptions, } \\
\text { dimensions, experimental conditions, run parameters, and data file formats } \\
\text { are included in this report. } \\
\text { Instrument calibrations, analysis spreadsheets and software, bench sheets and } \\
\text { laboratory record books have been documented, crosschecked, and reviewed } \\
\text { as specified in the QA requirements listed below. }\end{array}$ \\
\hline $\begin{array}{l}\text { Data will be appropriate for } \\
\text { selection of scaling approaches for } \\
\text { multiple overblows and } \\
\text { development of load specifications } \\
\text { for plant vessel internal components. }\end{array}$ & $\begin{array}{l}\text { The data collected are considered suitable for the purpose intended based on } \\
\text { the needs listed in the Test Specification, Test Plan and Test Exceptions. } \\
\text { Continuous reassessment of needs was done in conjunction with BNI and } \\
\text { DEI. Such discussions of data resulted in the Test Exceptions listed above. }\end{array}$ \\
\hline $\begin{array}{l}\text { Data profiles will be suitable for } \\
\text { application with component } \\
\text { structural analysis. }\end{array}$ & See above. \\
\hline
\end{tabular}




\section{Quality Requirements}

Pacific Northwest National Laboratory (PNNL) is operated by Battelle for the U.S. Department of Energy. Battelle’s Pacific Northwest Division (PNWD) has a Quality Assurance Program based on requirements defined in U.S. Department of Energy (DOE) Order 414.1C, Quality Assurance, and 10 CFR 830, Energy/Nuclear Safety Management, Subpart A, Quality Assurance Requirements. PNWD has chosen to implement the requirements of DOE Order 414.1C and 10 CFR 830 Subpart A by integrating them into PNNL's management systems and daily operating processes. Procedures necessary to implement the requirements are documented through the Laboratory's Standards-Based Management System.

PNNL implements the RPP-WTP quality requirements by performing work in accordance with the River Protection Project - Waste Treatment Plant Support Program (RPP-WTP) Quality Assurance Plan (RPP-WTP-QA-001, QAP). Work was performed to the quality requirements of NQA-1-1989 Part I, Basic and Supplementary Requirements; NQA-2a-1990, Part 2.7; and DOE/RW-0333P, Rev 13, Quality Assurance Requirements and Descriptions (QARD). These quality requirements are implemented through the River Protection Project - Waste Treatment Plant Support Program (RPP-WTP) Quality Assurance Manual (RPP-WTP-QA-003, QAM).

General laboratory procedures and calibration experiments were performed in accordance with RPPWTP's procedures QA-RPP-WTP-1101, “Scientific Investigations,” and QA-RPP-WTP-1201, "Calibration Control System," ensuring that sufficient data are taken with properly calibrated measuring and test equipment to obtain quality results. The requirements of DOE/RW-0333P Rev 13, Quality Assurance Requirements and Descriptions ( $Q A R D)$, were not required for this work because the work is not high-level-waste quality affecting.

Reportable measurements of distance were made using standard commercially available equipment (e.g., tape measure) and needed no traceable calibration requirements. All other test equipment generating reportable data were calibrated according to PNWD’s WTPSP QA program.

RPP-WTP addresses internal verification and validation activities by conducting an Independent Technical Review of the final data report in accordance with RPP-WTP's procedure QA-RPP-WTP-604. This review verifies that the reported results are traceable, that inferences and conclusions are soundly based, and the reported work satisfies the Test Plan objectives. This review procedure is part of PNNL's RPP-WTP Quality Assurance Manual.

\section{Simulant Use}

Two simulants were used in this testing and were selected to bound the expected rheological properties to be encountered in the WTP. Water was used to provide a fluid with rheological properties at the lower bound. A kaolin-bentonite clay mixture was selected to provide a fluid with rheological properties at the upper bound. The clay simulant used was selected based on actual waste slurry rheology measurements that indicate the WTP non-Newtonian waste stream can be represented by a Bingham plastic rheology model, which is represented by 


$$
\tau=\kappa \dot{\gamma}+\tau_{\mathrm{y}}
$$

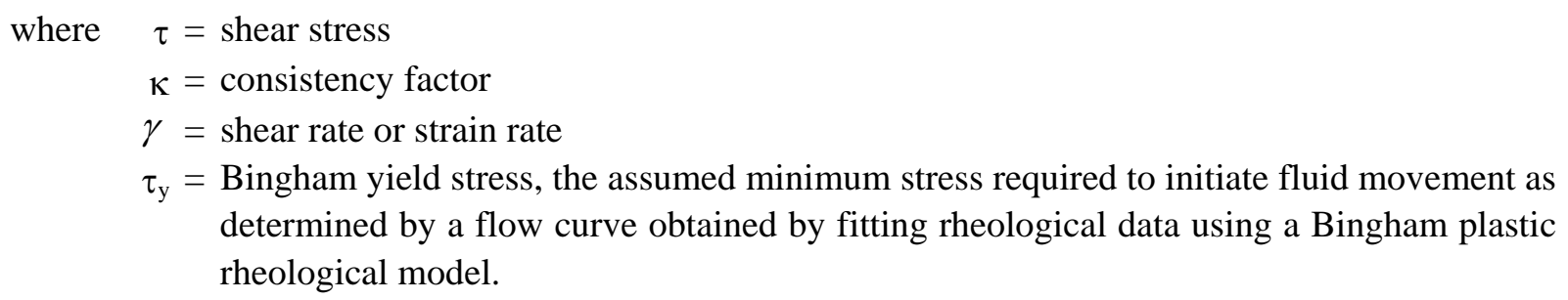

The non-Newtonian waste stream upper bounding rheological value of $\tau_{\mathrm{y}}=30 \mathrm{~Pa}$ was identified based on limited data from actual waste slurries that can be represented by a Bingham plastic rheology model (Poloski et al. 2006). These values provide the basis for the simulant used for this testing. Additional information on the selection and development of the kaolin-bentonite clay simulant may be found in Poloski et al. (2004).

\section{Discrepancies and Follow-on Tests}

The drive air flow capacity of the jet pump pairs was insufficient to achieve the original target velocity of $15 \mathrm{~m} / \mathrm{s}$ in the 4-PJM system. Additional testing with the 4-PJM system may be needed to meet the testing objective of providing data at the limiting conditions of PJM operation in the WTP. Air flow was limited by the maximum capacity of the supply regulators on the JPP skids.

A QA surveillance of the vendor providing the calibration services for the Valeport velocity probes revealed that the vendor did not correct the reported velocities for wall effects arising from the use of an 8-inch pipe diameter for the tow vessel during the probe calibration. For water simulant, the wall correction can be determined theoretically, and the inaccuracy of the reported velocities is estimated to be $+6 \%$ (i.e., the fluid velocities measured by the Valeport velocity probes were $6 \%$ more than the actual velocities). For the clay simulant, however, the determination of the wall effect correction was complicated by the non-Newtonian nature of the simulant and the unknown effect of the viscosity on the Valeport velocity probe performance. Based on the deviation of the probe response from a 1:1 correspondence with the tow velocity, it is estimated this error could be as high as $+25 \%$ (i.e., the fluid velocities measured by the Valeport velocity probes were $25 \%$ more than the actual velocities. Therefore, additional testing of the Valeport velocity probes may be required after assessment by BNI and DEI, particularly to reduce/eliminate the errors associated with these probes in the clay simulant. 



\subsection{Introduction}

Previous pulse jet mixer (PJM) tests in the half-scale lag storage vessel (Bontha et al. 2005) have shown that the planned baseline method of PJM operation at 50\% stroke does not meet the hydrogen in pipes and ancillary vessels (HPAV) requirements for hydrogen control by turning over the PJM vessel contents. The testing indicates that the PJMs need to be operated by a control system that produces a longer stroke, during which about $85 \%$ (often referred to as full-stroke operation) of the waste is expelled from the PJM on each drive stroke. This stroke length is sufficient for meeting the HPAV requirements, but will increase the probability of overblows. The adopted HPAV solution to use an $85 \%$ stroke requires vessels and vessel internals to be evaluated against the hydrodynamic forces associated with multiple PJM overblows. Testing is needed to characterize the vessel components loading associated with multiple overblows, and an analysis is required of these effects on typical Waste Treatment Plant (WTP) vessel components.

Overblow testing was performed to measure the hydrodynamic pressures associated with single, multiple, and simultaneous PJM drive overblows (i.e., when more than one PJM overblow occurs at any particular time), for both clay simulant and water. This testing is required to provide data for a possible change in design criteria for PJM-mixed vessels to include loading associated with the simultaneous drive overblow of all PJMs within a vessel. Current vessel design includes loading for single PJM drive overblows. PJM-agitated vessels in the WTP are equipped with up to 12 PJMs. Mixing requirements of these vessels have been evaluated for and are anticipated to require synchronous operation of these PJMs in the WTP, increasing the likelihood of multiple overblows.

The objective of the PJM overblow testing was to measure the hydrodynamic pressures associated with single and simultaneous multiple-PJM overblows in WTP vessels during the drive phase of the PJM cycle. The hydrodynamic pressures were measured at several locations in the test vessel using an array of nine in-tank pressure sensors and four hydrophones. Pressure, level, and conductivity sensors were also used to monitor PJM operation and the start of the overblow. Overblow measurements were made under normal and limiting vessel operating conditions (i.e., minimum/maximum PJM fluid emptying velocity, maximum and minimum vessel contents for PJM operation, and maximum and minimum rheological properties). The data generated through this testing were provided to Bechtel National, Inc. (BNI) for selecting scaling approaches for multiple PJM overblows and development of load specifications for planned vessel internal components.

This document discusses the conditions of the overblow tests conducted with the 8-PJM and 4-PJM test stands (Bontha et al. 2005, Bamberger et al. 2005) using water and clay simulants. The clay simulant consisted of a mixture of kaolin and bentonite clays in water with a yield stress $30 \pm 5 \mathrm{~Pa}$. Water represents waste with rheological properties at the lower bound of the rheological limits set for the WTP. 



\subsection{Quality Requirements}

\subsection{Application of RPP-WTP Quality Assurance Requirements}

Pacific Northwest National Laboratory (PNNL) is operated by Battelle for the U.S. Department of Energy. PNNL has a Quality Assurance Program that is based on requirements defined in the U.S. Department of Energy (DOE) Order 414.1C, Quality Assurance, and 10 CFR 830, Energy/Nuclear Safety Management, Subpart A, Quality Assurance Requirements. PNWD has chosen to implement the requirements of DOE Order 414.1C and 10 CFR 830, Subpart A by integrating them into PNNL's management systems and daily operating processes. The procedures necessary to implement the requirements are documented through the laboratory's Standards-Based Management System.

PNNL implements the RPP-WTP quality requirements by performing work in accordance with the River Protection Project - Waste Treatment Plant Support Program (RPP-WTP) Quality Assurance Plan (RPP-WTP-QA-001, QAP). Work was performed to the quality requirements of NQA-1-1989 Part I, Basic and Supplementary Requirements; NQA-2a-1990, Part 2.7; and DOE/RW-0333P, Rev 13, Quality Assurance Requirements and Descriptions (QARD). These quality requirements are implemented through the River Protection Project - Waste Treatment Plant Support Program (RPP-WTP) Quality Assurance Manual (RPP-WTP-QA-003, QAM).

The work discussed in this report was planned, executed, reviewed and documented in accord with the above noted requirements.

\subsection{Conduct of Experimental and Analytical Work}

Test requirements that were specific to the overblow experiments were listed in Test Specification Pulse Jet Mixer Overblow Testing (24590-WTP-TSP-RT-06-001) and in Test Plan for Pulse Jet Mixer Overblow Testing (TP RPP-WTP-452), together with subsequent Test Exceptions (24590-WTP-TEF-RT06-00003, 24590-WTP-TEF-RT-07-00003, 24590-WTP-TEF-RT-07-00009 and 24590-WTP-TEF-RT07-00011) .

General laboratory procedures and calibration experiments were performed in accordance with RPPWTP’s procedures QA-RPP-WTP-1101, “Scientific Investigations,” and QA-RPP-WTP-1201, "Calibration Control System," ensuring that data are taken with properly calibrated measuring and test equipment to obtain quality results. The requirements of DOE/RW-0333P Rev 13, Quality Assurance Requirements and Descriptions (QARD), were not required for this work.

Additional equipment that was used included a thermometer, clock, and balances. The thermometer, for monitoring simulant temperature, and the clock were standard laboratory equipment used as indicators only. Balances were calibrated yearly by a qualified contractor, QC Services Portland, Oregon per quality assurance requirements. 


\subsection{Internal Data Verification and Validation}

RPP-WTP addresses internal verification and validation activities by conducting an Independent Technical Review (ITR) of the final data report in accordance with RPP-WTP's procedure QA-RPPWTP-604. This review verifies that the reported results are traceable, that inferences and conclusions are soundly based, and the reported work satisfies the Test Plan objectives. This review procedure is part of PNNL's RPP-WTP Quality Assurance Manual. For this project ITRs were conducted on laboratory record books, bench data sheets, experimental checklists, and run logs. ITRs were also conducted on data acquisition computer programs and on data processing software and spreadsheets.

Electronic data are not considered records under the RPP-WTP QA Program. However, the accuracy of electronic file data transfers to portable (DVD and portable hard disk drives) media was verified. 


\subsection{Instrumentation and Data Acquisition System Description}

This section contains a description of the various instrumentation and data acquisition systems used during the overblow testing.

\subsection{Instrumentation}

Several analytical instruments were used to collect and record data during the overblow testing in the 8- and 4-PJM configurations. These are listed in Tables 3.1 and 3.2. All instruments listed in Table 3.1 were connected to Data Acquisition System-1 (or DAS-1; see Section 3.2.1) and were sampled/recorded at frequency of $1 \mathrm{kHz}$. Similarly, all instruments listed in Table 3.2 were connected to DAS-2 (see Section 3.2.2) and sampled/recorded at a frequency of $10.24 \mathrm{kHz}$. All instruments listed in Tables 3.1 and 3.2 were calibrated or performance checked according to RPP-WTP QA requirements. The signal conditioners for the DAS- 1 and DAS-2 channels were calibrated according to the RPP-WTP QA assurance requirements.

Additional data were recorded manually in either laboratory record books (LRB) or bench sheets. Tank liquid fill levels were measured with an ordinary tape measure. Uncalibrated pressure sensors on the AEA-built jet pump pair (JPP) skids provided approximate indications of drive and suction pressures on the controller display. These data were recorded on bench sheets for information only. In-tank temperatures were measured with J-type thermocouples installed at two levels in the tank. A hand-held readout was temporarily connected twice a day and the simulant temperatures were entered into the LRB.

Videotape recordings were made of the liquid surface for a subset of the experiments. In addition, for the subset of those experiments done with water, high speed and high-resolution subsurface videos were made of the fluid jet emerging out of the PJM nozzle. The video recordings involve no calibration and no performance requirements were placed upon them in the Test Specification. Video records are considered to be "for information only."

This section contains a description of the instruments. Equipment and instrument locations are discussed in Sections 4 and 5. Unless otherwise noted, the values for the response times and accuracy were obtained from vendor literature for the indicated sensor. These accuracy values do not include uncertainty that may be introduced by signal noise, signal conditioners or transmitters.

\subsubsection{PJM Pressures}

Air pressures inside the PJMs were measured using Endress + Hauser pressure transmitters (Model PMP 135-A4G01R4R) with an operating pressure range of 0 to 150 psia and an accuracy of $\pm 0.5 \%$ of full scale $( \pm 0.75 \mathrm{psi})$. In the 8-PJM configuration, the pressure transmitters were mounted in one leg of a cross that was attached to $\sim$-ft-long spool piece that was included on top of the pulse tubes (see Figure 3.1). In the 4-PJM configuration the spool piece was removed. 
Table 3.1. Data Recorded on DAS 1 (DASYLab)

\begin{tabular}{|c|c|c|c|c|c|c|c|}
\hline Parameter & Sensor Type & Manufacturer & Model & Qty & Range & Bandwidth $^{(a)}$ & Accuracy $^{(a)}$ \\
\hline PJM pressure & Pressure transmitter & $\mathrm{E}+\mathrm{H}$ PMP & 135-A4G01R4R & $8^{(\mathrm{b}, \mathrm{c})}$ & 0 to 150 psia & $2 \mathrm{kHz}$ & $\pm 0.75 \mathrm{psi}$ \\
\hline PJM level & Capacitance level probe & Drexelbrook & $700-0002-057$ & $8^{(\mathrm{b}, \mathrm{c})}$ & $0 \sim 144$ inch $^{(\mathrm{d})}$ & $>1 \mathrm{~Hz}^{(\mathrm{e})}$ & $\pm 1 \%$ of nominal \\
\hline Tank surface level & Laser level transmitter & Optech & Sentinel 3100 & $3^{(\mathrm{f})}$ & 0.2 to $150 \mathrm{~m}$ & $2 \mathrm{~Hz}^{(\mathrm{g})}$ & $\begin{array}{l} \pm 7 \mathrm{~mm}^{(\mathrm{g})} \text { (accuracy) } \\
\pm 4 \mathrm{~mm} \text { (repeatability) }\end{array}$ \\
\hline $\begin{array}{l}\text { PJM \#5/A air inlet } \\
\text { temperature }\end{array}$ & Type J thermocouple & Not available & Not available & 2 & 0 to $50^{\circ} \mathrm{C}$ & $0.25 \mathrm{~Hz}^{(\mathrm{h})}$ & $\pm 2.2^{\circ} \mathrm{C}$ \\
\hline $\begin{array}{l}\text { Velocity (two axes; } \\
\text { vertical and radial) }\end{array}$ & $\begin{array}{l}\text { Velocity probe; } 3.2 \mathrm{~cm} \\
\text { diameter probe head disk }\end{array}$ & Valeport & Transmitter model 802 & 3 & $\pm 5 \mathrm{~m} / \mathrm{s}$ & $16 \mathrm{~Hz}^{(\mathrm{i})}$ & $\begin{array}{l}\text { Water, }+6 \% \text {; clay, } \\
\text { up to }+25 \%{ }^{(j)}\end{array}$ \\
\hline
\end{tabular}

(a) Bandwidth and accuracy values are the vendors' nominal values and are presented for information only.

(b) All data were sampled by and recorded on DAS-1 at a frequency of $1 \mathrm{kHz}$. Where a quantity of 8 is listed (for the PJM pressure and PJM level) the number refers to the maximum number of sensors that were used in the 8-PJM configuration. The corresponding quantities are 4 in 4 -PJM configuration.

(c) In the 8-PJM configuration all eight pulse tubes had pressure transmitters, Data were recorded from only 5 of these transmitters at any one time.

(d) Nominal range.

(e) Response is an estimate from a Drexelbrook technical representative because an integration capacitor was removed from the transmitter circuit board to improve response.

(f) Laser levels do not function properly with water due to a lack of a reflective surface.

(g) Operating accuracy at a measurement rate of 2 readings per second. Depends upon limited variations in temperature, material, and distance associated with installation. The $2 \mathrm{~Hz}$ value in the bandwidth column was the sampling rate (max theoretical bandwidth $1 \mathrm{~Hz}$ ) used during the majority of the experiments. At $10 \mathrm{~Hz}$ sampling rate accuracy decreased to $+/-15 \mathrm{~mm}$ and repeatability decreased to $+/-9 \mathrm{~mm}$.

(h) The response time is typical of a $1 / 16^{\text {th }}$-inch O.D. bare thermocouple wire in air at room temperature and atmospheric pressure moving with a velocity of $65 \mathrm{ft} / \mathrm{sec}$. The time constant is defined as the time required to reach $63.2 \%$ of an instantaneous temperature change; here it is expressed in Hz (1/response time).

(i) According to the Valeport operations manual, there is a digital finite impulse response filter that attenuates signals with a frequency greater than 4 Hz with a cutoff at $8 \mathrm{~Hz}$ and results in a phase delay in the data. If data are being synchronized with other sources of data, this delay needs to be taken into account in data processing. At a $16 \mathrm{~Hz}$ rate the data delay is $0.3125 \mathrm{sec}$.

(j) See Section 3.1.6 for more detailed discussion of the measurement uncertainty associated with the velocity sensors. 
Table 3.2. Data Recorded on DAS 2 (DACTRON) ${ }^{(\mathrm{a})}$

\begin{tabular}{|c|c|c|c|c|c|c|c|}
\hline Parameter & Sensor Type & Manufacturer & Model & Qty & Range & Bandwidth $^{(b)}$ & Accuracy $^{(\mathrm{b})}$ \\
\hline \multirow[t]{3}{*}{ PJM overblow } & Hydrophones & Reson & 4040 & 4 & \multirow[t]{3}{*}{$\mathrm{ND}(\mathrm{Pa})$} & 1 to $80 \mathrm{kHz}^{(\mathrm{c})}$ & ND \\
\hline & Charge amplifier & Dytran Inst. Inc & 4705M3 & 4 & & 1 to $10 \mathrm{kHz}$ & $\mathrm{ND}$ \\
\hline & Signal analyzer & Dactron & Focus II & 1 & & - & ND \\
\hline In-tank pressure & Pressure transmitter & Entran & EPX-V0-1-10P & 9 & 0-10 psig & $20 \mathrm{kHz}$ & $1.44 \%^{(\mathrm{d})}$ \\
\hline \multirow{2}{*}{$\begin{array}{l}\text { Bubble egress time } \\
\text { from nozzle }\end{array}$} & Conductivity probe & NA; wire leads used & NA; wire leads used & $5^{(\mathrm{e})}$ & NA & NA & $\mathrm{NA}^{-(\mathrm{f})}$ \\
\hline & $\begin{array}{l}\text { Conductivity } \\
\text { Signal conditioner }\end{array}$ & Analog Devices & 5B41-02 & 5 & $\begin{array}{c}-5 \text { to }+5 \mathrm{~V} \text { input and } \\
\text { output }\end{array}$ & $10 \mathrm{kHz}$ & $N A^{(t)}$ \\
\hline \multirow{2}{*}{$\begin{array}{l}\text { Probe mast tip } \\
\text { acceleration }^{(\mathrm{g})}\end{array}$} & Tri-axial accelerometer & PCB Piezotronics & $356 A 15$ & 1 & $\pm 50 \mathrm{~g}$ & 1.4 to $6500 \mathrm{~Hz}$ & $1 \%(\mathrm{~h})$ \\
\hline & $\begin{array}{l}\text { ICP power supply and } \\
\text { amplifier }\end{array}$ & PCB Piezotronics & 482A16 & 1 & $\pm 10 \mathrm{~V}$ max output & $\begin{array}{l}0.225 \text { to } \\
100 \mathrm{kHz}\end{array}$ & ND \\
\hline
\end{tabular}

(a) All data on the DAS 2 DACTRON were recorded at a sampling rate of $10.24 \mathrm{kHz}$.

(b) Bandwidth and accuracy values are the vendors' nominal values and are presented for information only.

(c) Linear frequency $1-80 \mathrm{kHz}$ at $\pm 2 \mathrm{db}$.

(d) Based on a combination of noise, linearity, hysteresis, non-repeatability, and thermal shift. Precision is estimated at +/- 0.027 psi at the $95 \%$ confidence level, based on field calibration data.

(e) Only the pulse tubes that provided test data had bubble detectors. For the 8-PJM tests, these were pulse tubes 4, 5, 6, 7, and 8. For the 4-PJM tests all pulse tubes A, B, C and D had detectors.

(f) Accuracy is not applicable because these were just used to determine the time of bubble egress from the PJM nozzle.

(g) The accelerometer was installed and used only during the 4-PJM tests. It was not installed during the 8-PJM tests.

(h) Nonlinearity

ND=no data. 


\subsubsection{PJM Simulant Level}

The change of liquid height in each pulse tube was individually measured using $~ 12$-ft-long, Tefloncoated capacitance liquid-level sensors fabricated by Drexelbrook, Inc. These sensors were mounted in the center of each pulse tube through one end of a cross fitting and routed through the $\sim 4$-ft-long spool (removed in the 4-PJM configuration) piece connected to the top of the pulse tube (see Figure 3.1).

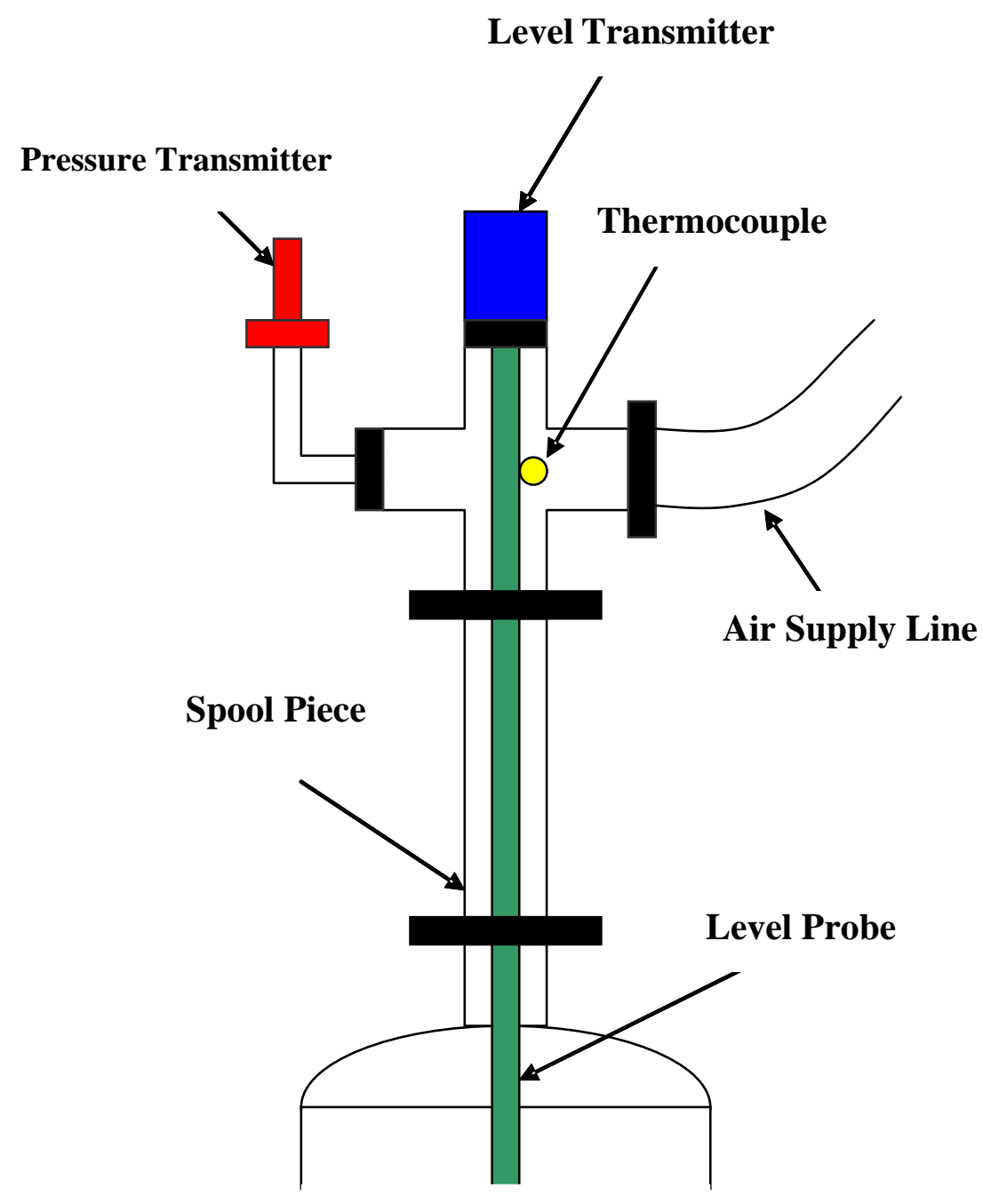

Figure 3.1. PJM Level, Pressure, and Temperature Sensor Arrangement on Top of the PJM (the spool piece shown was present only in the 8-PJM configuration)

The capacitance level sensors were performance checked in place by varying the level of the each simulant in the tank and recording the voltage output from the PJM level probes. Probe voltage measurements were compared to levels obtained with a tape measure. This was done at least at four points, and a linear least squares fit was obtained for the simulant level versus voltage. The output from the level probes varied from 1 to 5 volts with 1 volt corresponding to zero level. 


\subsubsection{Tank Surface Level}

The simulant level in the tank was measured manually using a tape measure ( \pm 0.5 -inch accuracy). In addition, three Sentinel (Model 3100) laser level sensors mounted on the top of the tank were used to record the level of the simulant continuously throughout the testing with clay. Laser level devices do not work with transparent fluids such as water. The laser level data were used to determine the PJM nozzle velocity and loss coefficients (K values) for the 8-PJM configuration(a) and to obtain information on the overblow phenomena by observing the clay simulant surface lift. These level sensors have a range of $0.2-150 \mathrm{~m}$, an absolute accuracy of $\pm 2 \mathrm{~cm}$, an operating accuracy of $\pm 7 \mathrm{~mm}$, and a resolution of $4 \mathrm{~mm}$.

\subsubsection{Simulant Temperature}

Two type $\mathrm{J}$ thermocouples, located at depths of 62 and $136 \pm$ 3inches (as measured from the tank rim) were used to measure the temperature of the simulant in the tank. The accuracy of this type of thermocouple is $\pm 2^{\circ} \mathrm{C}$. During testing, the simulant temperature was periodically recorded using a handheld Fluke Model 52 II thermocouple reader. The temperatures were measured at the start and end of each day of overblow testing.

\subsubsection{PJM Air Inlet Temperature}

Two type $\mathrm{J}$ thermocouples were used to measure the temperature of the air entering the PJM during the drive phase. The first was located in the air line just after the JPP connecting to PJM \#5 (8-PJM configuration) or PJM A (4-PJM configuration); the other thermocouple was positioned in the cross located on the top of the same PJM (see Figure 3.1).

\subsubsection{In-Tank Fluid Velocity}

The velocity of the fluid at three locations in the tank was measured using 3.2-cm (1.26-inch) discshaped Valeport 802 electromagnetic flow sensors. The Valeport electromagnetic flow sensors were chosen for this application primarily because of their ruggedness and their applicability for measuring velocities in the presence of solids in the test system (i.e., clay simulant). In addition, Valeport sensors also have the advantage of measuring the flow in two dimensions. In this application, the local velocity changes were measured vertically and radially. These probes had a range of measurable velocities of $\pm 5 \mathrm{~m} / \mathrm{s}$. According to the velocity probe operating manual, the sensing volume was a cylinder with a diameter of 0.8 inches and a height of 0.4 inches out from the sensor.

The three velocity sensors were mounted on a vertical mast at three elevations in the tank. The elevations and locations are discussed in Sections 4 and 5. Pictured in Figure 3.2 is a detail of the mount used to attach each velocity probe to the mast. The mast passes down through the hole shown, normal to the plane of the page. The probe disk was offset from the mast $2 \frac{1}{2}$ inches in one direction and $12 \frac{1}{2} 2$ inches in the other in the horizontal plane. The probe disk was attached vertically at the end of the $12 \frac{1}{2} \mathrm{inch}$ rod shown in the figure. Figure 3.3 is a photograph of a probe in the tank (in the 4-PJM system).

(a) For the 4-PJM configuration, the laser level data was found to be too noisy for use in determining the nozzle loss coefficients and therefore the PJM level data were used. 


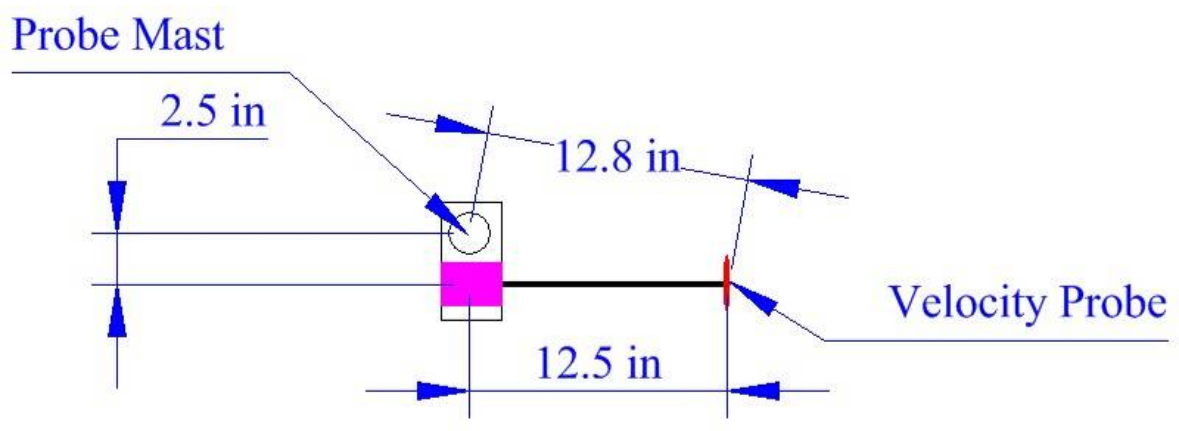

Figure 3.2. Detail of a Velocity Probe Mount (looking down)

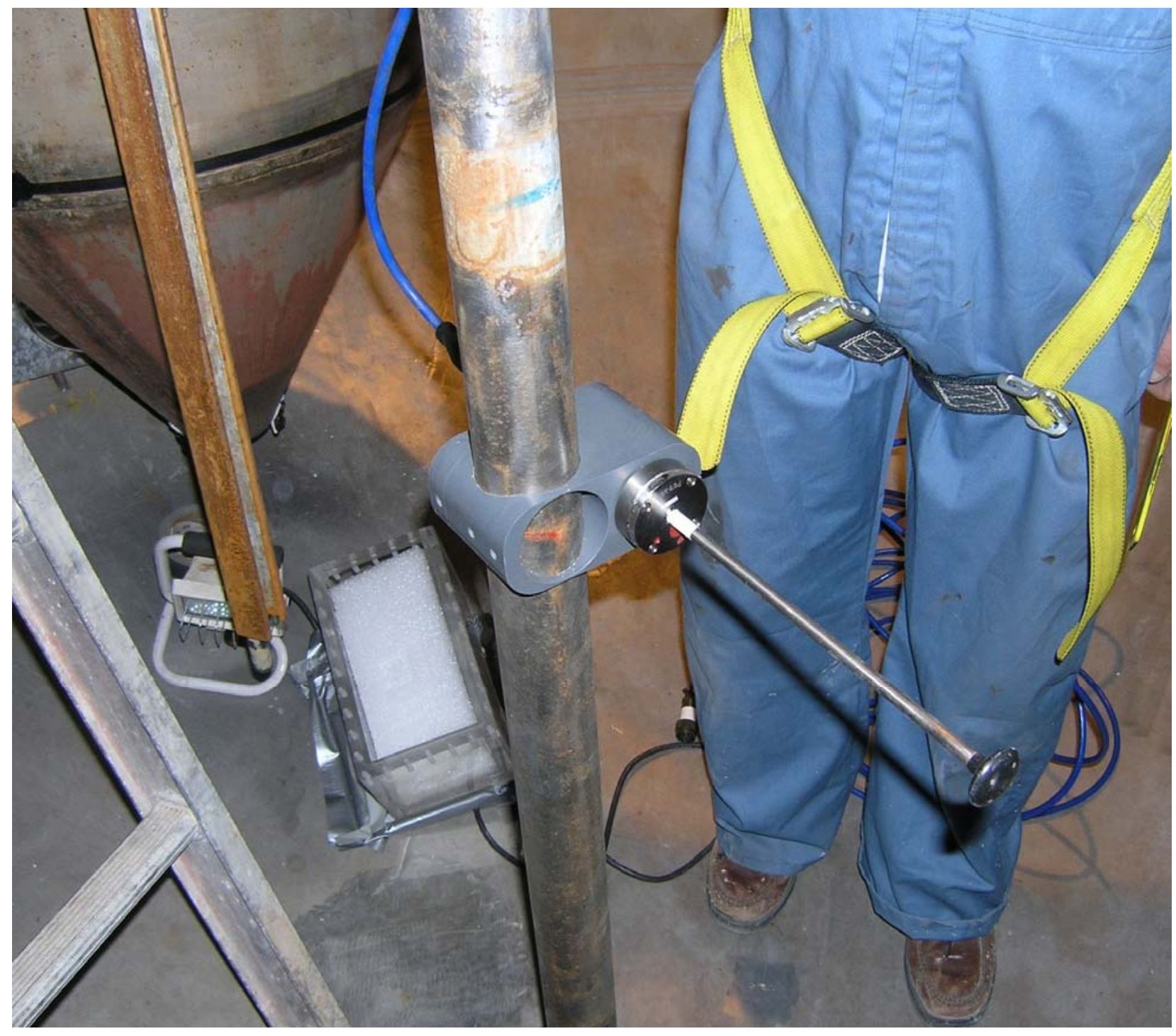

Figure 3.3. Velocity Probe Inside the Tank (in the 4-PJM configuration) at an Early Stage of the Installation. (It is not in the final position.) 
The probe disks had factory-supplied orientation marks on the faces. The probes were installed in the tank with the marks pointing up. In this orientation the vertical component of the velocity indicated positive for downward fluid flow. The radial/horizontal component indicated positive for flow from right to left across the open probe face (from top to bottom in Figure 3.2). In the 8-PJM configuration radial/horizontal velocities had a positive sign for radial flow in the direction from the tank center outwards towards PJM 4. In the 4-PJM configuration radial/horizontal velocities had a positive sign for flow in the direction from the center outwards towards PJM C.

A QA surveillance of the vendor providing the calibration services for the Valeport velocity probes revealed that the vendor did not correct the reported velocities for wall effects arising from the use of an 8-inch pipe diameter for the tow vessel during the probe calibration. For water simulant, the wall correction can be determined theoretically, and the inaccuracy of the reported velocities is estimated(a) to be $+6 \%$ (i.e., the fluid velocities measured by the Valeport velocity probes were $6 \%$ more than the actual velocities). For the clay simulant, however, the determination of the wall effect correction was complicated by the non-Newtonian nature of the simulant and the unknown effect of the viscosity on the Valeport velocity probe performance. Based on the deviation of the probe response from a 1:1 correspondence with the tow velocity, it is estimated this error could be as high as $+25 \%$ (i.e., the fluid velocities measured by the Valeport velocity probes were $25 \%$ more than the actual velocities).

Finally, the velocity probe used at the 18-inch elevation(b) during the 4-PJM water and clay testing (see Section 5 for more detail about the velocity probe location) was calibrated only between $\sim \pm 2.5 \mathrm{~m} / \mathrm{s}$, while all other probes in both the 8- and 4-PJM configurations were calibrated between $\pm 5 \mathrm{~m} / \mathrm{s}$. This was due to calibration problems observed during the calibration at high tow tank velocities. For the velocity probe located at the 18-inch elevation in the 4-PJM configuration, the calibration coefficients are considered to be applicable to the full range of the probe response (i.e., $\pm 5 \mathrm{~m} / \mathrm{s}$ ) because the Valeport velocity probes respond linearly with velocity.

\subsubsection{Bubble Egress Time}

The time at which the air in each pulse tube egresses or leaves the nozzle (the start of an overblow) was determined by the sudden change in the conductivity of the solution between two custom-made electrodes mounted at the end of each PJM nozzle. The bubble egress time was used to ensure simultaneous or near-simultaneous overblow (i.e., within 20 to $250 \mathrm{~ms}$ ) of the PJMs during the multiple PJM overblow tests.

Measurement of the solution conductivity was achieved by a signal conditioner that applies 5 volts between two resistors in series. The second resistor was wired in parallel with the electrodes attached to the PJM nozzle. The signal conditioner sensed the voltage drop across the second resistor/electrode combination and sent this value to the DAS-2. For example, when water was in contact with the electrodes, the voltage drop was on the order of 1.4 volts. During an overblow, the conductivity was very low, and the voltage recorded rose to approximately 1.8 volts.

(a) This uncertainty was determined assuming that the probe was positioned at the center of the tow vessel.

(b) The velocity probe at the 18-inch location was replaced during the 4-PJM testing due to a drift in the baseline velocity during the 8-PJM clay testing. 


\subsubsection{Hydrophones}

Four Reson TC4040 hydrophones were used to measure the acoustic and dynamic pressure signals associated with single and multiple (simultaneous) PJM drive overblows. The hydrophones were connected through Dytran Instruments, Inc., model 4705M3 inline charge amplifiers. The charge amplifiers converted the charge signal from the hydrophone to low impedance voltage signals. These signals were then passed through an LDS Dactron Focus II spectrum analyzer (DAS-2), where voltage data were converted to meaningful pressure units $(\mathrm{Pa})$.

\subsubsection{In-Tank Pressure}

Pressure transmitters mounted on an instrument tree support were used to measure hydrodynamic and static pressures. Nine pressure transmitters, Entran model EPX-V0-10P units with a range of 0-10 psig and a response time $<1 \mathrm{~ms}$, were mounted on the instrument tree. These sensors were miniature units with small (0.15-inch diameter) flush mounted stainless steel diaphragms. Each transmitter was mounted at the submerged end of a length of 1/2-inch O.D. stainless steel tubing in such a way that its diaphragm was fully wetted and not inside a pocket or recess.

The nine sensors were mounted at three different elevations in the tank, as will be discussed in detail in Sections 4 and 5. Figure 3.4 contains photographs of the $1 / 2$-inch mounting tubes at the top (on the left), middle (in the center) and bottom (on the right) elevations, taken before installation of the pressure sensors in the tubes and before mounting the tubes in the tank. At the upper elevation one sensor pointed down and angled slightly off of vertical (denoted as the 'TA' sensor elsewhere in this report), another pointed straight down (the 'TD' sensor) and another pointed horizontally (the 'TT' or 'top tangential' sensor). A similar arrangement was used at the middle elevation in the tank. At the bottom elevation, one sensor pointed down at approximately $45^{\circ}$ (the 'BAD' sensor) while another pointed up at approximately $45^{\circ}$ (the 'BAU' sensor) and the third pointed horizontally (the 'BT' sensor).
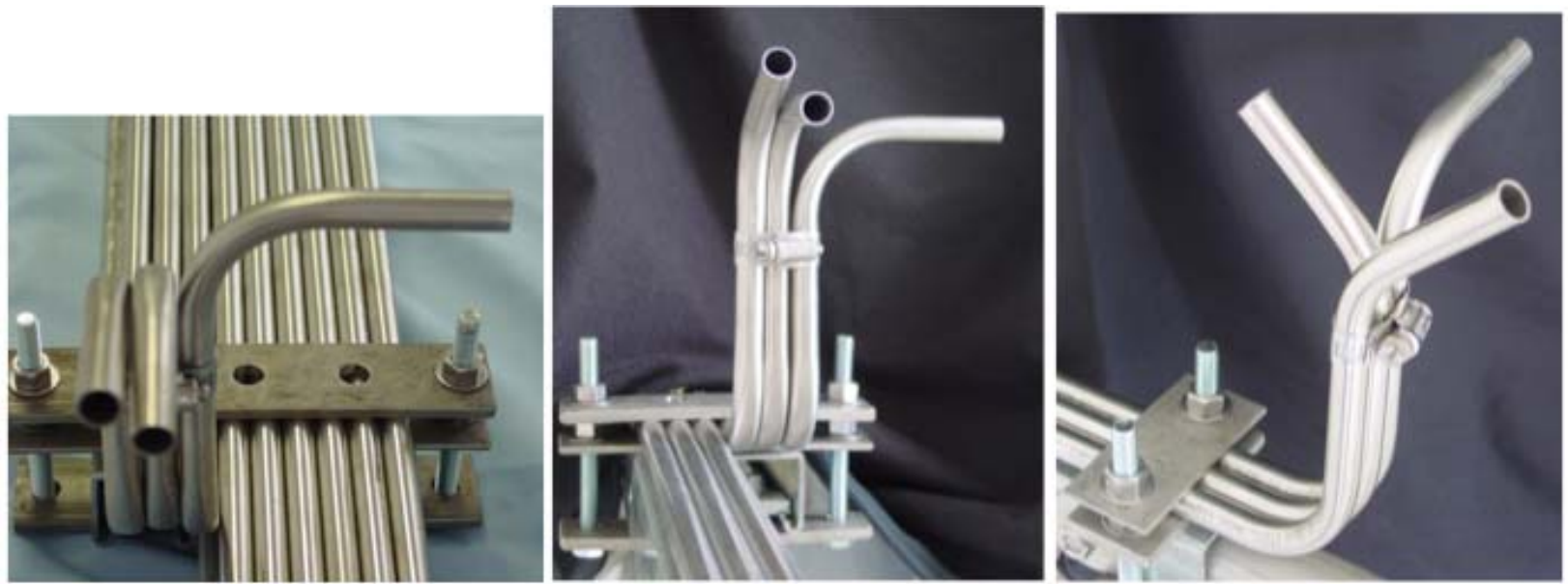

Figure 3.4. In-Tank Pressure Sensor Mounting Tubes at Top (Left), Middle (Center) and Bottom (Right) Elevations 
Each sensor was screwed into a plug that was machined to fit snug into the submerged end of the $1 / 2$-inch tubing after de-burring the tube ends. The sensor cables were threaded up the tubing and the plugs were epoxied into place at the ends of the tubes. The sensor threads, vent tubes and cable splices were all sealed with a marine silicone sealant as further protection of the sensors against water damage. As noted above, the sensor diaphragms were flush with the exposed plug faces. Figure 3.5 is a photograph of the lower sensors installed in the tank (in the 4-PJM system).

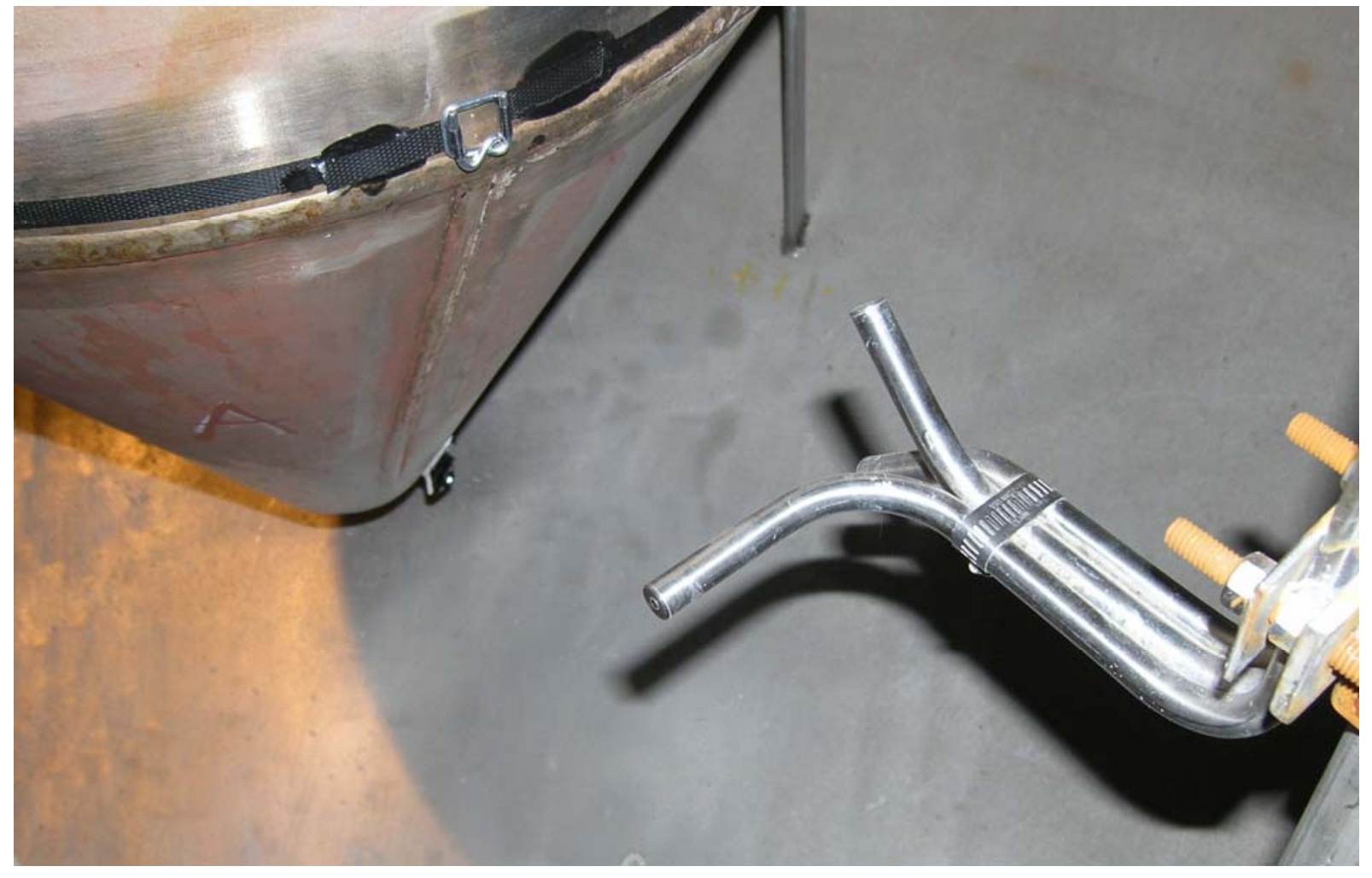

Figure 3.5. Lower In-Tank Pressure Sensors in the Tank (4-PJM configuration). Note the flush mounting of the diaphragm on the tip of the probe.

\subsubsection{Probe Mast Acceleration}

A submerged accelerometer was used during testing in the 4-PJM configuration. The accelerometer was installed at the end of a vertical mast that was positioned between PJM A and PJM D. The mast was constructed from 2-inch schedule 80 stainless steel pipe, and the accelerometer was mounted inside a housing at the end of the pipe. (Note: the schedule 80 stainless steel pipe mast of the accelerometer was approved by DEI upon examination of preliminary PJM overblow data collected with the accelerometer in the tank.) The mast was rigidly clamped to PJM support cross beams at the top and again farther down, but the submerged end of the pipe was allowed to swing freely. Refer to Section 5.5 for a detailed discussion of the mast dimensions and mounting. The accelerometer was glued (with Loctite 454) to the inside of a flange plate that bolted to the base of the housing. Figure 3.6 is a drawing of the housing. The accelerometer was glued to the vertical mounting tab inside the flange plate. Figure 3.7 is a photograph of the housing inside the tank (in the 4-PJM system). 


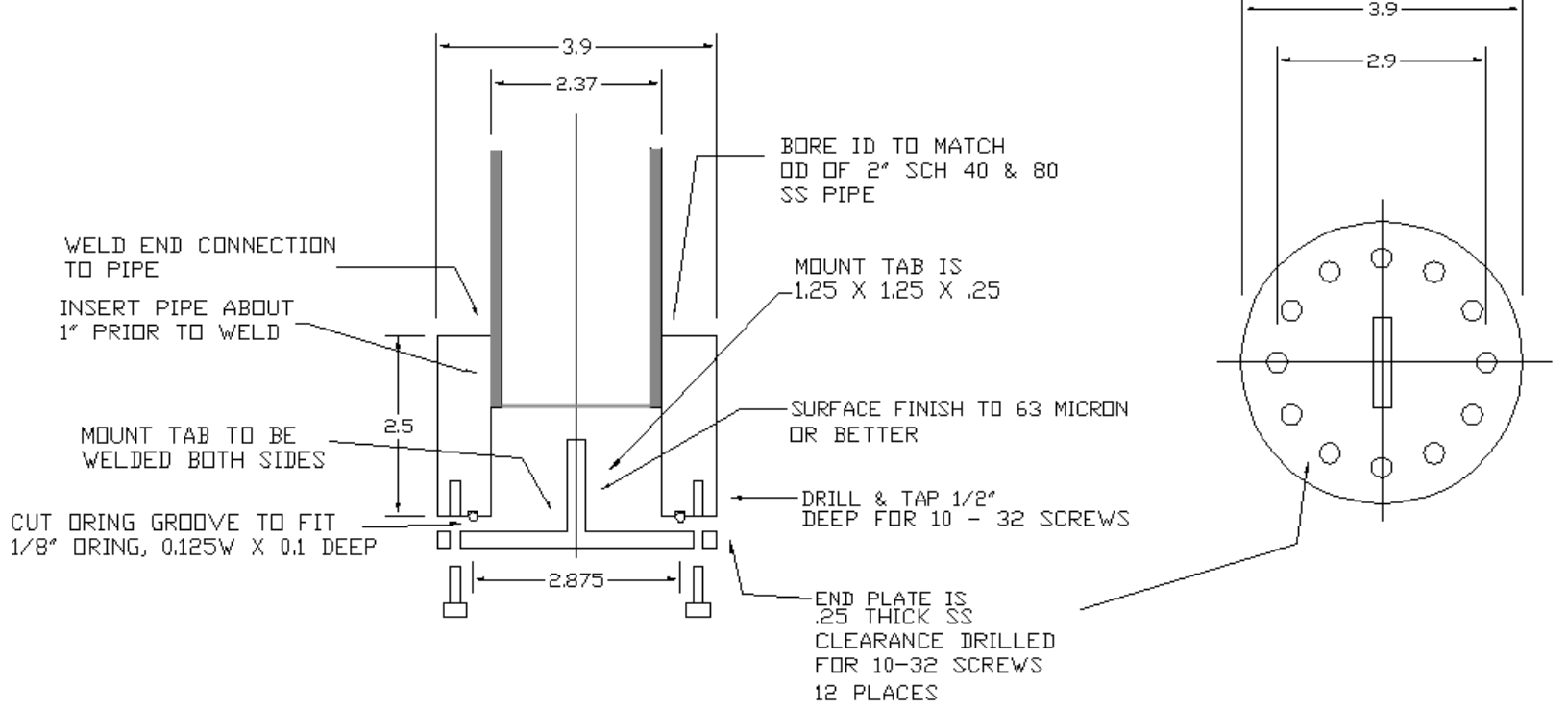

Figure 3.6. Accelerometer Housing (dimensions in inches)

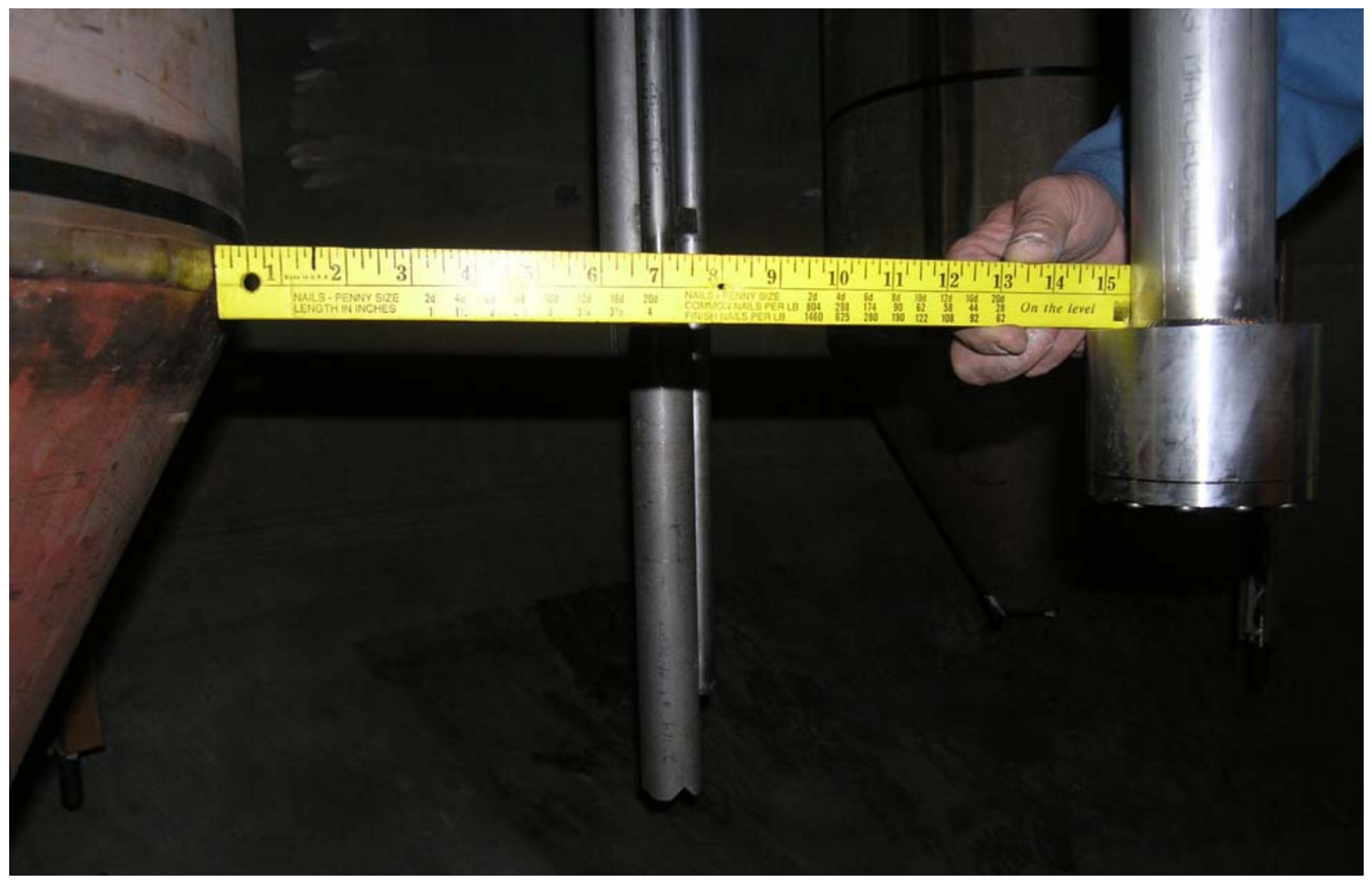

Figure 3.7. Accelerometer Housing Inside the Tank in 4-PJM Configuration (the distance from the PJM was changed slightly after this picture was taken) 
The accelerometer (PCB model 356A15) measured acceleration along three orthogonal directions. The manufacturer's specifications were for $<5 \%$ off-axis sensitivity in each direction. One axis (z-axis) was pointed toward the center of the tank, another (y-axis) circumferentially, and a third (x-axis) down along the center of the mast. The tab that the accelerometer was glued to was normal to the z-axis. The three output signals passed through a signal conditioning unit before being sent to DAS-2. The unit was a PCB model 482A16.

\subsubsection{Video Cameras}

Standard video cameras were used to provide a visual recording of overblows and to aid in understanding the overblow phenomena. The video cameras were either mounted above the tank rim to view the tank surface or were held by hand from the bridge above the tank. These standard cameras run at $30 \mathrm{fps}$ and were used to record selected overblows.

For selected water tests, a Photron 1280 PCI high-speed digital video camera placed in a waterproof enclosure and fixed to the tank bottom near a PJM nozzle was used to record videos of overblows. The camera was mounted near PJM \#7 during the 8-PJM tests and near PJM B during the 4-PJM tests. Subsurface videos were obtained at each water level and at each overblow condition, as discussed in Sections 6 and 7. The camera employed a 10-bit complementary metal oxide semiconductor sensor and had an electronic shutter that could operate as fast as $7.8 \mu \mathrm{s}$. It was capable of up to a 500 -frame-persecond frame rate at a resolution of 1,280 x 1,024 pixels and up to 16,000 frames per second at reduced resolution. High-speed video recordings were made at between 250 and $1000 \mathrm{fps}$. The frame rate used appears in the images.

\subsubsection{JPP Skid Pressures}

The drive and suction pressures at the JPP skids were measured using Druck (Model PTX-611) pressure transmitters. These pressure transmitters had a range of 0-to-10 Bar-gauge with an accuracy of $\pm 0.01 \%$ of full scale. The drive and suction pressures recorded by the pressure transmitters on the JPP skids did not feed into either of PNNL's data acquisition systems but rather into a BNI-provided controller. Pressure indications from the controller were recorded manually into the LRB or the bench sheets used during the tests. These data are provided for indication only.

\subsection{Data Acquisition Systems}

Several data acquisition systems were used to obtain and record data from the various instruments used in the present testing. These systems are discussed in this section.

\subsubsection{DAS-1 (DASYLab)}

Data that did not require extremely high data recording rates were recorded digitally on a computer using DASYLab Version 8.0 data acquisition software. The list of the various instruments connected to DAS-1 is presented in Table 3.1. This system could handle up to 64 channels of input. The number of inputs used was limited to a maximum of 35 at our desired sampling rates and durations of data logging. 


\subsubsection{DAS 2 (DACTRON)}

The hydrophones and other instruments (see Table 3.2) that required high ( $>10 \mathrm{kHz}$ ) data sampling rates were connected to an LDS-Dactron Focus II spectrum analyzer that converted the input voltages to output in meaningful units (e.g., Pa). During 8-PJM testing, one Focus II unit was used that sampled 20 channels at $10.24 \mathrm{kHz}$. During 4-PJM testing, a second unit was added to sample a total of 22 channels at $10.24 \mathrm{kHz}$. The Focus II units can sample at up to $42 \mathrm{kHz}$; however, preliminary testing revealed that the lower rate used provided sufficient over-sampling. The units discretized all channels to 24-bit resolution.

\subsubsection{DAS 4 (High-Speed Video Camera)}

The computer that controlled the high-speed underwater video camera and temporarily stored the video files was denoted as DAS-4.

\subsection{Time Synchronization}

The data recorded on DAS-1 and DAS-2 included a time stamp signal that provided a common time reference in the output files of each system. The signal was a voltage pulse triggered by a manually operated push button. The rise times of the pulses were of the order of $1 \mathrm{~ms}$. The button was generally pushed twice during each experiment, so usually two synchronization pulses were recorded in each file.

The subsurface video controller DAS-4 sent a trigger signal to DAS-2 that indicated the start and the stop of high-speed video recording. This timing signal was recorded by DAS-2 to allow the video frames to be correlated with the pressure and acoustic signals. During testing it was discovered that there was a small time delay between the start of the video recording and initiation of the timing signal. This time delay is discussed in Section 9.9. 


\subsection{8-PJM Equipment Configuration}

As discussed in Section 3, a variety of instruments including hydrophones, pressure transmitters, and velocity were included in the tank to characterize the PJM overblow phenomena. This section discusses the location of these instruments in the tank during the 8-PJM testing. Information regarding the 8-PJM test configuration is presented in Bontha et al. (2005). All dimensions presented in this section were obtained with a standard tape measure, or were derived from such measurements, and are considered to be within \pm 0.5 inch of the true values. Except where otherwise noted, stated angles were estimated from other measurements using the program "TurboCAD" and are considered to be within \pm 1 degree of the true values.

\subsection{General Information}

Table 4.1 lists the general information relating to all as-built measurements of the instrument locations made in the tank. This information is presented in plan view in Figure 4.1. Shown in the figure are the locations of the spargers and the diameter of the central shroud. Also shown is the width of the overhead walkway - a dimension that is important in determining the locations of instruments that were mounted from the sides of the walkway. See Bontha et al. (2005) for more details of the 8-PJM configuration.

Table 4.1. General Information Relating to all as-Built Measurements, 8-PJM Configuration

\begin{tabular}{lc}
\hline \multicolumn{1}{c}{ General Information } & $\begin{array}{c}\text { Distance } \\
\text { (inches) }\end{array}$ \\
\hline Tank inside diameter & 153 \\
Tank height as measured from the tank centerline & 178.2 \\
Vertical distance from top of hand rail to top of tank & 70.5 \\
Vertical distance of top of tank rim to center of perimeter nozzles & 168.0 \\
\hline
\end{tabular}

\subsection{Hydrophones}

A plan view of the radial locations of the four hydrophones installed in the tank in the 8-PJM configuration is shown in Figure 4.2. Corresponding dimensions are listed in Table 4.2. The dimensions listed in the table were derived from a collection of as-built measurements of instrument and PJM locations inside the tank, together with the manufactured dimensions of the tank itself.

The hydrophones were secured at the end of unistrut columns. The columns were supported by mounts on the upper and lower handrails of the bridge over the tank. This design had the advantage of allowing the hydrophone vertical positions in the tank to be varied, but had the disadvantage of allowing some movement of the hydrophones in the horizontal plane. According to the test specification for the overblow testing in the 8-PJM system, the lowest, middle, and highest elevation of the hydrophones correspond to 18,48 , and $96( \pm 2)$ inches from the tip of the hydrophone down to the level of a perimeter PJM nozzle. The specified hydrophone levels relative to the nozzles are illustrated in the vertical section drawing (Figure 4.3). 


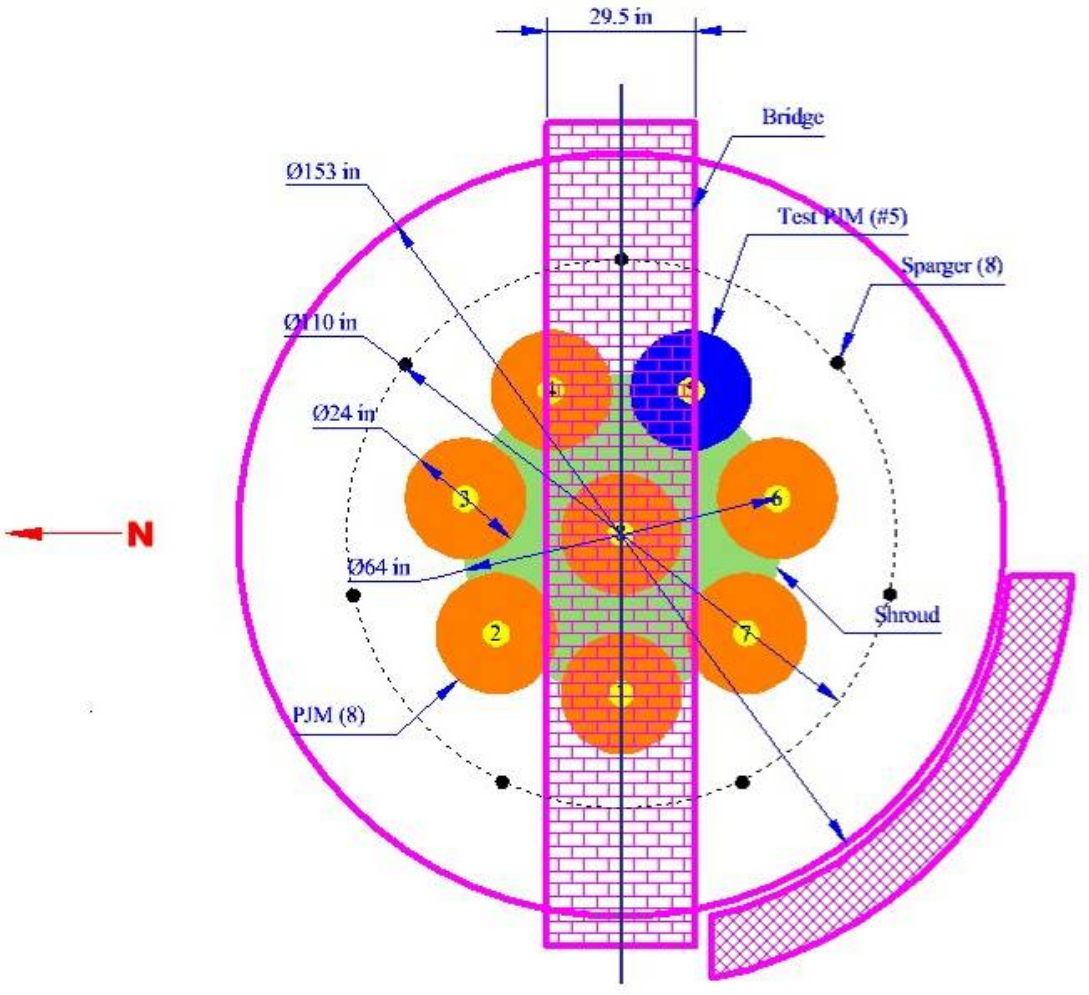

Figure 4.1. Plan View of the 8-PJM Configuration (see Bontha et al. 2005)

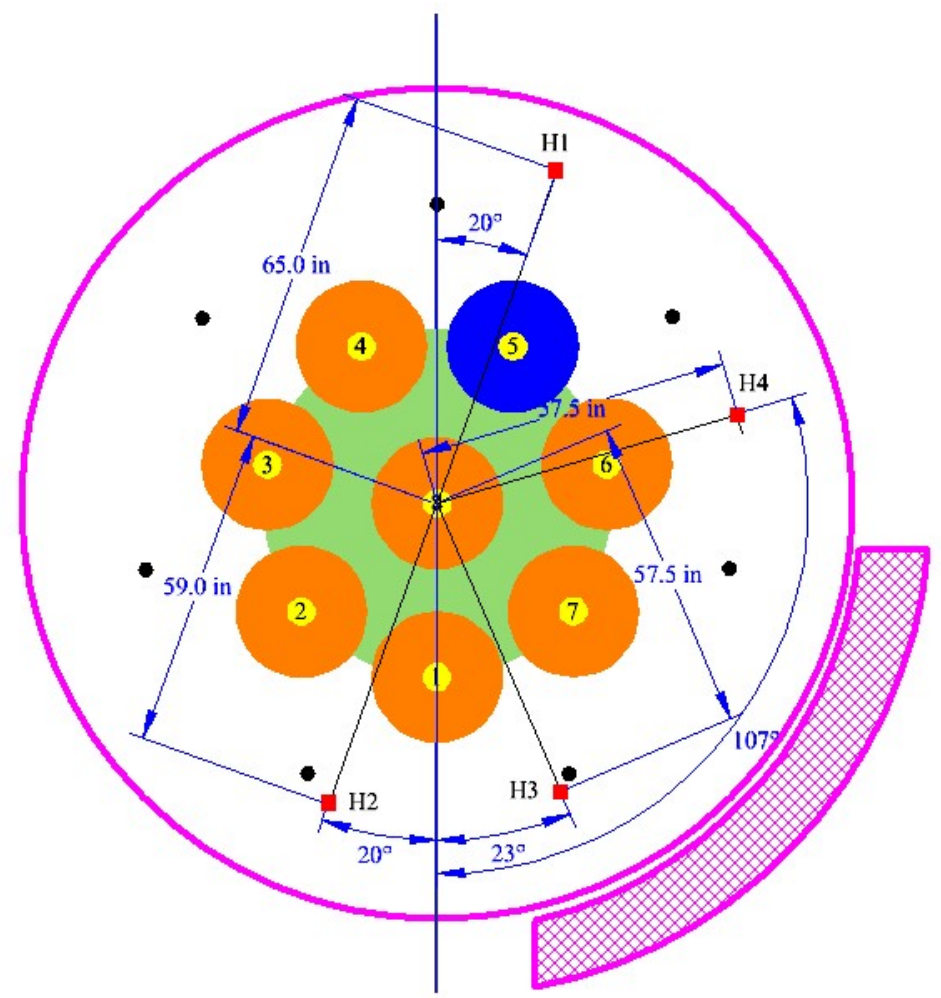

Figure 4.2. Radial Location of the Four Hydrophones Installed in the 8-PJM Configuration 
Table 4.2. Hydrophone Locations, 8-PJM Configuration

\begin{tabular}{|c|c|c|c|c|c|c|c|c|}
\hline & \multirow{2}{*}{$\begin{array}{l}\text { Radial Pos. R } \\
\text { (in.) }^{(\text {a) }}\end{array}$} & \multirow{2}{*}{$\begin{array}{l}\text { Angular Pos. } \theta \\
\text { (deg) }^{(\mathrm{b})}\end{array}$} & \multicolumn{3}{|c|}{$\begin{array}{c}\text { Elevation Above Tank } \\
\text { Floor (in.) }\end{array}$} & \multicolumn{3}{|c|}{$\begin{array}{c}\text { Elevation Above Perimeter } \\
\text { PJM Nozzle (in.) }\end{array}$} \\
\hline & & & Low & Mid & High & Low & Mid & High \\
\hline Hydrophone 1 & 65.0 & 160 & 28.2 & 58.0 & 105.6 & 18.0 & 47.8 & 95.4 \\
\hline Hydrophone 2 & 59.0 & 340 & 28.4 & 58.2 & 105.8 & 18.2 & 48.0 & 95.6 \\
\hline Hydrophone 3 & 57.5 & 23 & 28.4 & 58.0 & 106.4 & 18.2 & 47.8 & 96.2 \\
\hline Hydrophone 4 & 57.6 & 107 & 28.2 & 58.0 & 106.2 & 18.0 & 47.8 & 96.0 \\
\hline
\end{tabular}

(a) All radial positions are measured from the tank center line.

(b) All angular positions are measured counterclockwise from the line joining the tank center and the center of PJM 1.

(c) All elevations above the tank floor are determined from the tank centerline.

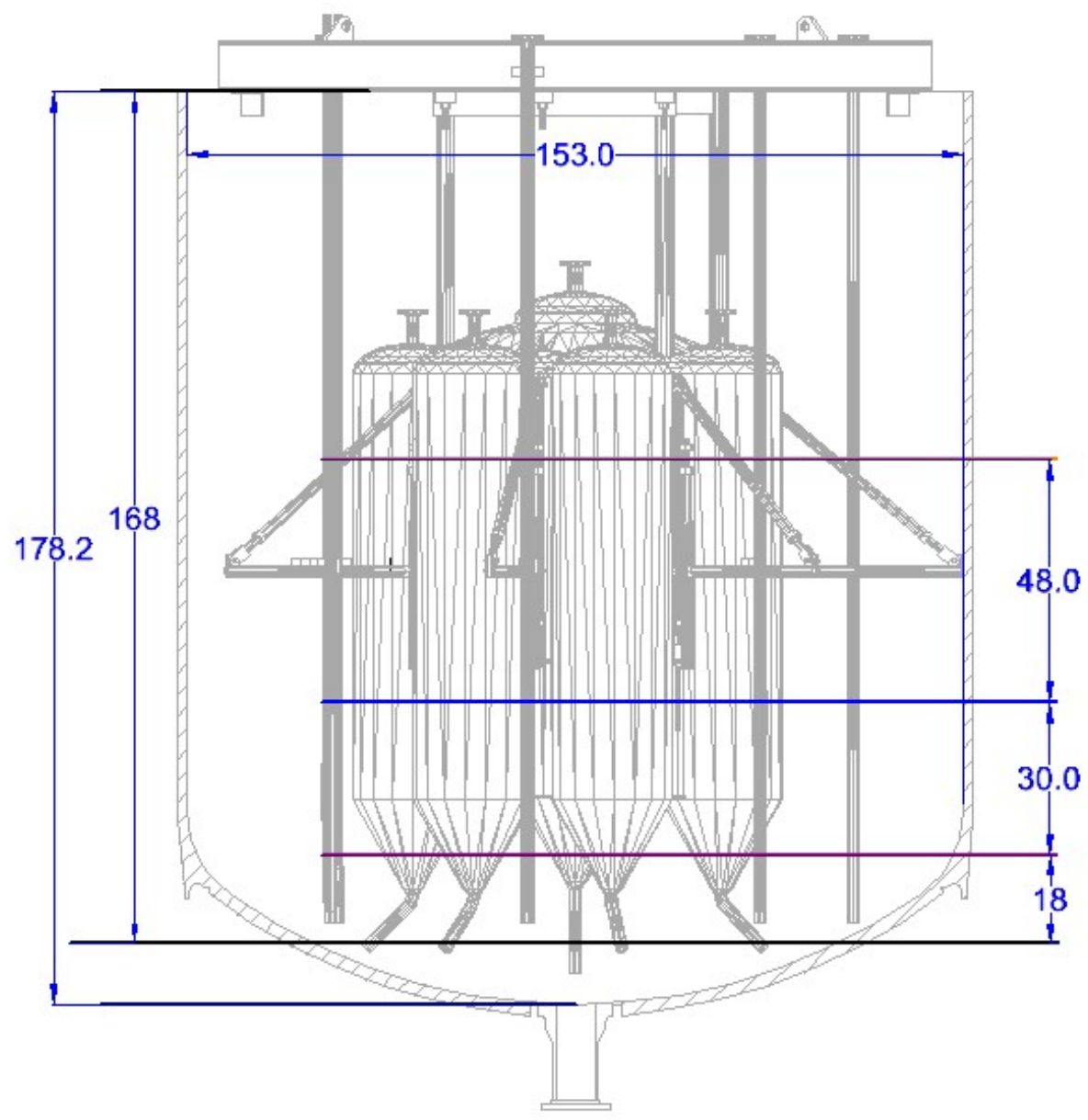

Figure 4.3. Hydrophone Spacing in the 8-PJM Configuration 


\subsection{Velocity Probes}

Three velocity probe sensors were mounted on a vertical mast that was rigidly positioned in the tank by fixing the top of the tree to the bridge above the tank and inserting the bottom of the tree into a cup glued to the bottom of the tank. Figure 4.4 shows a plan view of the radial location of velocity probe center and the mast holding the probes. The corresponding dimensions are listed in Table 4.3. The three probes were arrayed on the mast at elevations of 18, 48, and $96( \pm 2)$ inches above the perimeter PJM nozzles.

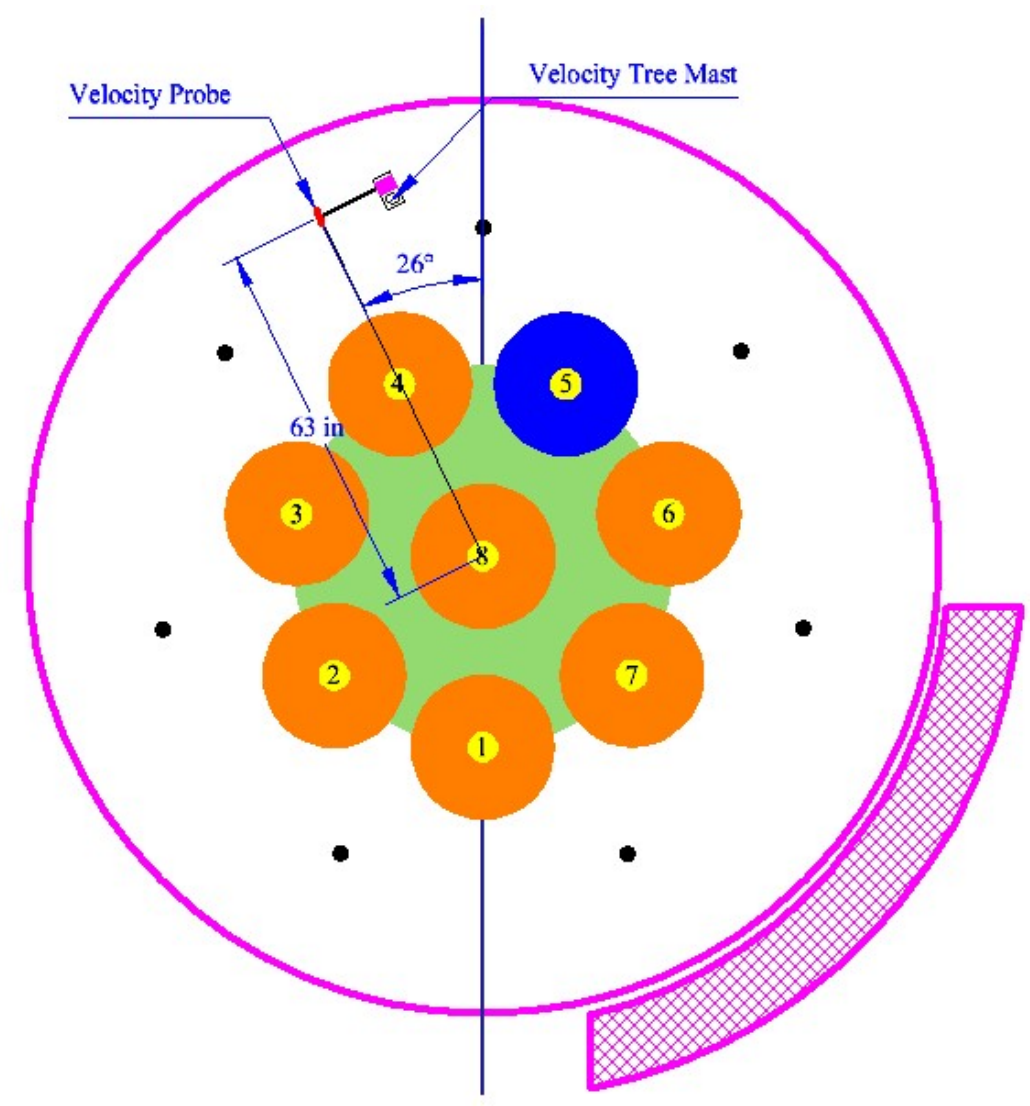

Figure 4.4. Plan View Showing Location of Velocity Probe and Mast Installed in 8-PJM Configuration

\subsection{In-Tank Pressure Transmitters}

Nine in-tank pressure transmitters were positioned at three elevations in the tank (with three sensors at each elevation) by mounting each transmitter in a separate tube oriented in the desired direction and affixing the tubes onto a mast. The mast was rigidly positioned in the tank by fixing the top of the mast to the bridge above the tank and inserting the bottom of the tree into a cup glued to the bottom of the tank. The pressure tree was mounted close to hydrophone 1. A plan view showing the radial location of the pressure transmitter tree mast is presented in Figure 4.5. The corresponding dimensions are included in Table 4.3. Additional as-built measurements of the pressure sensor locations, with details about their 
Table 4.3. Velocity Probe, Laser Level, and Pressure Transmitter Mast Locations, 8-PJM Configuration

\begin{tabular}{|c|c|c|c|c|c|c|c|c|}
\hline \multirow[b]{2}{*}{ Instrument } & \multirow{2}{*}{$\begin{array}{l}\text { Radial Pos. R } \\
\quad \text { (in.) }\end{array}$} & \multirow{2}{*}{$\begin{array}{l}\text { Angular Pos., } \theta \\
\text { (deg) }^{(\mathrm{b})}\end{array}$} & \multicolumn{3}{|c|}{$\begin{array}{l}\text { Elevation Above Tank Floor } \\
\text { (in.) }^{(\mathrm{c})}\end{array}$} & \multicolumn{3}{|c|}{$\begin{array}{l}\text { Elevation Above Perimeter } \\
\text { PJM Nozzle (in.) }\end{array}$} \\
\hline & & & Low & Mid & High & Low & Mid & High \\
\hline Velocity Probe & 63.0 & 206 & 28.2 & 58.2 & 106.2 & 18.0 & 48.0 & 96.0 \\
\hline Laser Probe 1 & 59.7 & 118 & NA & NA & NA & NA & NA & NA \\
\hline Laser probe 2 & 50.5 & 212 & NA & NA & NA & NA & NA & NA \\
\hline Laser Probe 4 & 50.2 & 53 & NA & NA & NA & NA & NA & NA \\
\hline $\begin{array}{l}\text { Press. Trans. Tree } \\
\text { Mast }\end{array}$ & 62.0 & 156 & \multicolumn{6}{|c|}{$\begin{array}{l}\text { See Tables } 4.4 \text { and } 4.5 \text { for additional information about } \\
\text { pressure sensor location }\end{array}$} \\
\hline
\end{tabular}

(a) All radial positions are measured from the tank center line.

(b) All angular positions are measured counterclockwise from the line joining the tank center and the center of PJM 1.

(c) All elevations above the tank floor are determined from the tank centerline.

relative orientations and the positions of the active diaphragms relative to the mast and to the PJMs are listed in Tables 4.4 and 4.5. The distances listed in Table 4.5 are straight lines between the tip of the PJM-5 nozzle and the tips of the sensors. They are not elevations (they include the $\mathrm{x}, \mathrm{y}$ and $\mathrm{z}$ displacements of the nozzle tip from the PJM centerline and the $\mathrm{x}, \mathrm{y}$ and $\mathrm{z}$ displacements of the sensor tip from the mast centerline).

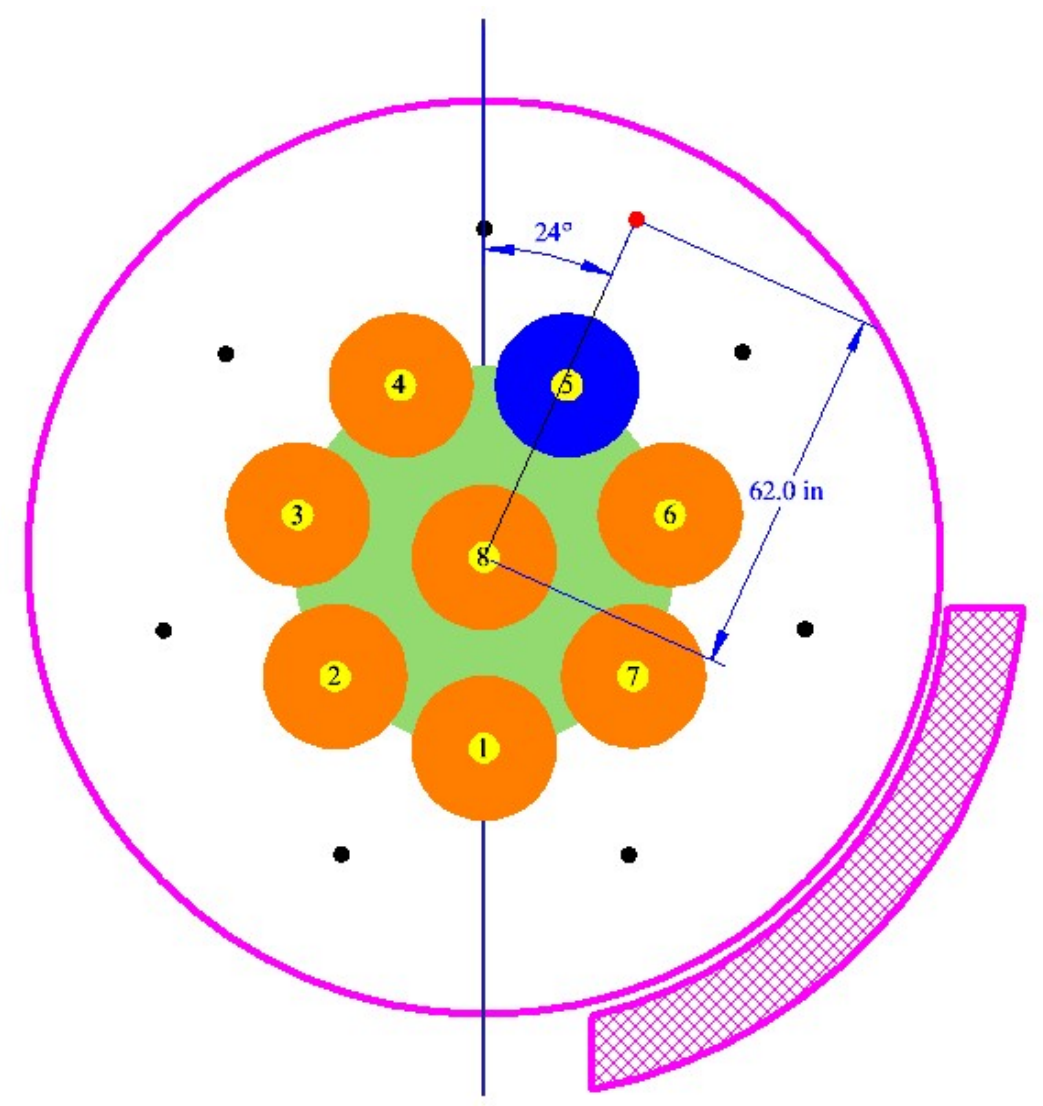

Figure 4.5. Plan View of the Tank Showing the Location of the Pressure Transmitter Tree Mast Installed in the 8-PJM Configuration 


\subsection{Laser Levels}

The locations of the laser beam strike points are illustrated with red stars in Figure 4.6. They were positioned to measure levels near operating PJMs 4-7. Corresponding dimensions are listed in Table 4.3.

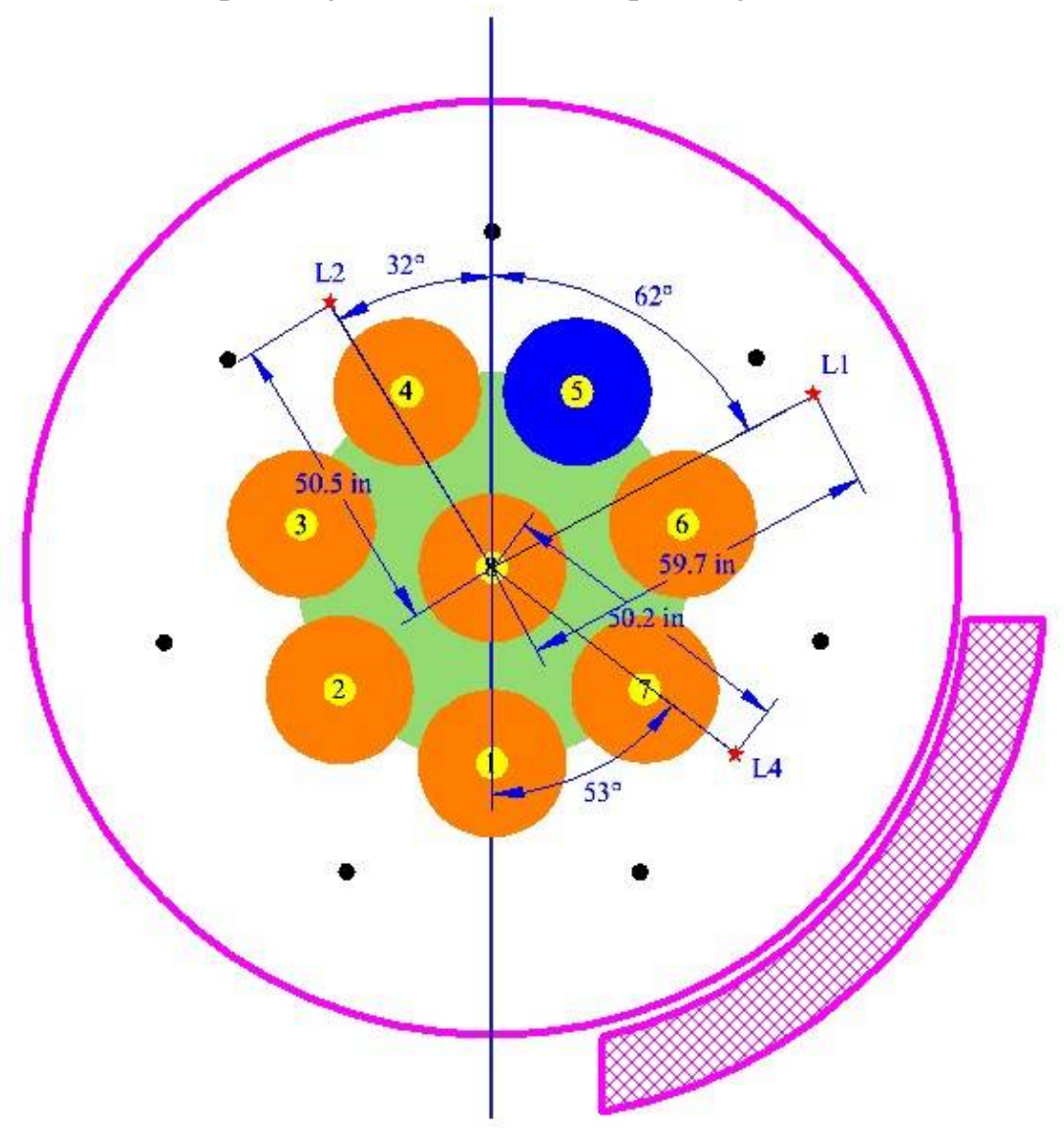

Figure 4.6. Location of the Laser Levels, 8-PJM Configuration 
Table 4.4. In-Tank Pressure Transmitter Nomenclature, Orientation, and As-Built Information, 8-PJM Configuration

\begin{tabular}{|c|c|c|c|c|c|}
\hline \multirow[b]{2}{*}{ Code } & \multirow[b]{2}{*}{ Transmitter Name } & \multirow[b]{2}{*}{ Diaphragm Orientation $^{(a)}$} & \multirow{2}{*}{$\begin{array}{l}\text { Vertical Distance of } \\
\text { Sensor Tip Below } \\
\text { Tank Rim (inches) }\end{array}$} & \multicolumn{2}{|c|}{ Offset of Sensor Tip from Centerline of Mast ${ }^{(\mathrm{b})}$} \\
\hline & & & & $\begin{array}{l}\text { Radially Toward PJM } 5 \\
\text { (in.) }\end{array}$ & $\begin{array}{l}\text { Tangentially Toward SW } \\
\text { (in.) }\end{array}$ \\
\hline $\mathrm{BT}$ & Bottom tangential & Tangential, pointing toward SW $\mathrm{SW}^{(\mathrm{c})}$ & $146.9^{(\mathrm{d})}$ & 7.6 & 4.5 \\
\hline BAD & Bottom angled down & $\begin{array}{l}\text { Angled down } 44^{\circ} \text { facing PJM } 5 \\
\text { nozzle }\end{array}$ & $148.5^{(\mathrm{d})}$ & 8.5 & 0 \\
\hline BAU & Bottom angled up & $\begin{array}{l}\text { Angled up } 46^{\circ} \text {,facing PJM } 5 \\
\text { nozzle }\end{array}$ & $145.8^{(d)}$ & 8.6 & 0 \\
\hline MT & Middle tangential & Tangential, pointing toward SW $\mathrm{S}^{(\mathrm{c})}$ & $123.0^{(\mathrm{e})}$ & 7.0 & 5.5 \\
\hline MD & Middle straight down & $\begin{array}{l}\text { Pointing straight down, facing } \\
\text { PJM } 5 \text { nozzle }\end{array}$ & $126.5^{(\mathrm{e})}$ & 7.3 & 0 \\
\hline MA & Middle angled down & $\begin{array}{l}\text { Angled down } 69^{\circ} \text {, facing PJM } 5 \\
\text { nozzle }\end{array}$ & $126.1^{(\mathrm{e})}$ & 7.8 & 0 \\
\hline TT & Top tangential & Tangential, pointing toward SW ${ }^{(\mathrm{c})}$ & $75.0^{(f)}$ & 7.5 & 2.0 \\
\hline TD & Top straight down & $\begin{array}{l}\text { Pointing straight down, facing } \\
\text { PJM } 5 \text { nozzle }\end{array}$ & $79.1^{(\mathrm{f})}$ & 7.3 & -1.5 \\
\hline TA & Top angled down & $\begin{array}{l}\text { Angled down } 79^{\circ} \text {, facing PJM } 5 \\
\text { nozzle }\end{array}$ & $79.1^{(\mathrm{f})}$ & 7.5 & -2.0 \\
\hline
\end{tabular}

(a) Up/down diaphragm orientation angles listed are considered to be within \pm 3 degrees of the true values.

(b) The location of the mast within the tank is illustrated in Figure 4.5.

(c) Positive tangential (circumferential) offsets were to the SW (clockwise in Figure 4.5) from the mast centerline. Negative tangential offsets were to the NE (counter-clockwise) from the mast centerline.

(d) The bottom sensors were 19.5 to 22.2 inches above the perimeter 8-PJM nozzles. Thus they were slightly above the low hydrophone and velocity probe elevations listed in Tables 4.2 and 4.3.

(e) The middle sensors were 41.5 to 45 inches above the perimeter 8-PJM nozzles. Thus they were slightly below the mid hydrophone and velocity probe elevations listed in Tables 4.2 and 4.3.

(f) The top sensors were 88.9 to 93 inches above the perimeter 8-PJM nozzles. Thus they were slightly below the high hydrophone and velocity probe elevations listed in Tables 4.2 and 4.3. 
Table 4.5. As-Built Information of the In-Tank Pressure Transmitter Distances from PJM 5 Nozzle, 8-PJM Configuration

\begin{tabular}{|c|c|}
\hline Measurement & $\begin{array}{l}\text { Distance } \\
\text { (inches) }\end{array}$ \\
\hline Straight line distance from center of PJM 5 nozzle to tip of center of pressure transmitter 'BT' & 26.5 \\
\hline Straight line distance from center of PJM 5 nozzle to tip of center of pressure transmitter 'BAD' & 23.8 \\
\hline Straight line distance from center of PJM 5 nozzle to tip of center of pressure transmitter 'BAU' & 27.3 \\
\hline Straight line distance from center of PJM 5 nozzle to tip of center of pressure transmitter 'MT' & 48.5 \\
\hline Straight line distance from center of PJM 5 nozzle to tip of center of pressure transmitter 'MD' & 44.8 \\
\hline Straight line distance from center of PJM 5 nozzle to tip of center of pressure transmitter 'MA' & 44.8 \\
\hline Straight line distance from center of PJM 5 nozzle to tip of center of pressure transmitter 'TT' & 95.0 \\
\hline Straight line distance from center of PJM 5 nozzle to tip of center of pressure transmitter 'TD' & 91.5 \\
\hline Straight line distance from center of PJM 5 nozzle to tip of center of pressure transmitter 'TA' & 91.5 \\
\hline
\end{tabular}




\subsection{4-PJM Equipment Configuration}

During 4-PJM testing, hydrophones, pressure transmitters, and velocity probes used in the earlier 8-PJM testing were relocated, and a submerged accelerometer was installed for the 4-PJM testing. This section discusses the location of these instruments in the tank. Information regarding the 4-PJM equipment configuration is presented in Bontha et al. (2003a,b). All dimensions presented herein were obtained with a standard tape measure — or derived from such measurements—and are considered to be within \pm 0.5 inch of the true values. Except where otherwise noted, stated angles were estimated from other measurements using "TurboCAD” and are considered to be within \pm 1 degree of the true values.

\subsection{General Information}

Figure 5.1 is the plan view, and Table 5.1 shows the general information relating to all as-built measurements of the instrument locations made in the tank. Shown in the figure are the relative locations of the PJMs. Also shown is the width of the overhead walkway - a dimension that is important in determining the locations of instruments that were mounted from the sides of the walkway. See Bontha et al. (2003b) for more details of the 4-PJM configuration.

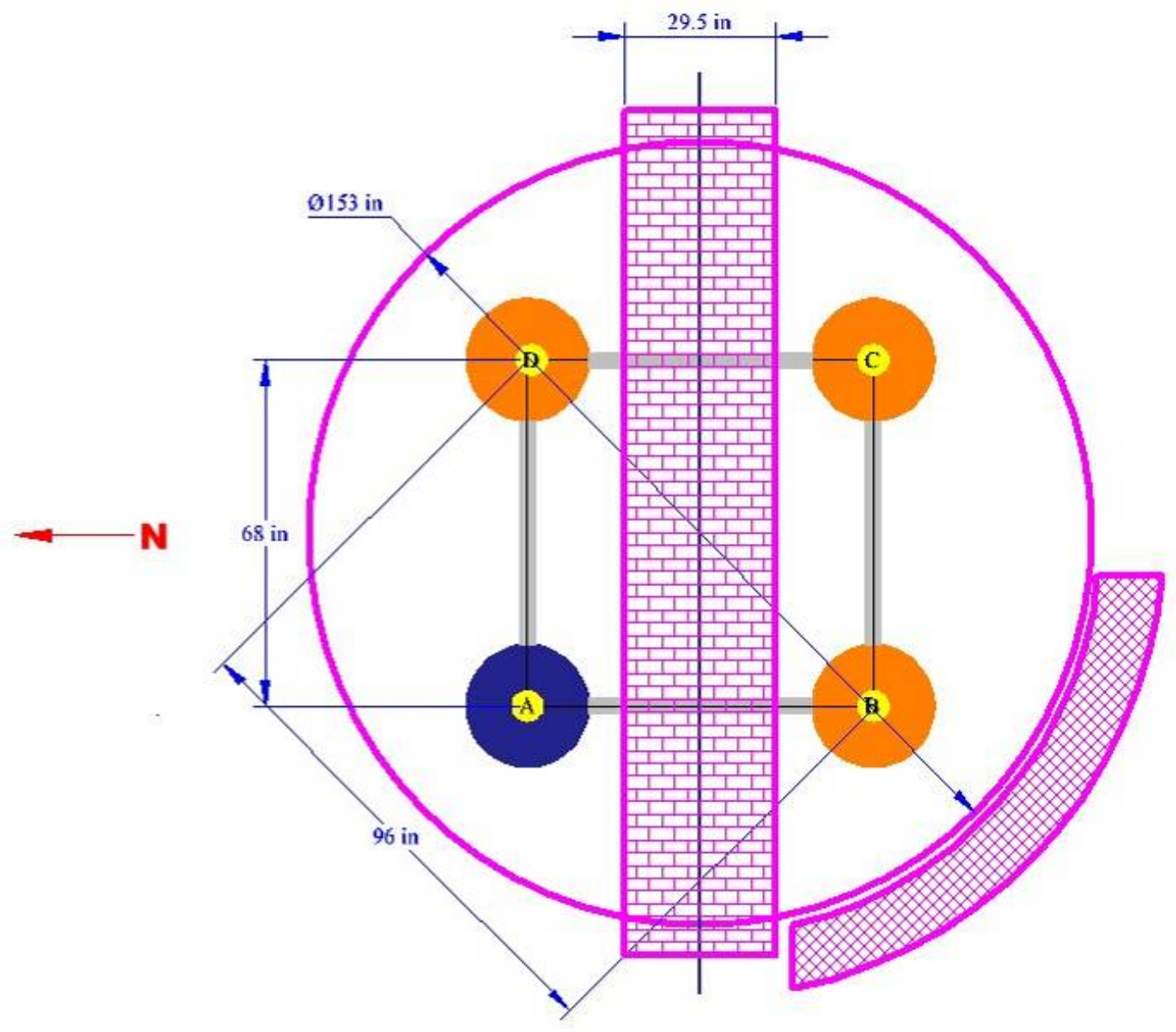

Figure 5.1. Plan View of the 4-PJM Configuration (see Bontha et al. 2003b) 
Table 5.1. General Information Relating to all as-Built Measurements, 4-PJM Configuration

\begin{tabular}{lc}
\hline \multicolumn{1}{c}{ General Information } & $\begin{array}{c}\text { Distance } \\
\text { (inches) }\end{array}$ \\
\hline Tank inside diameter & 153 \\
Tank height as measured from the tank centerline & 178.2 \\
Vertical distance of top of tank rim to center of perimeter nozzles & 162.5 \\
\hline
\end{tabular}

\subsection{Hydrophones}

A plan view of the radial locations of the four hydrophones installed in the tank in the 4-PJM configuration is shown in Figure 5.2, and corresponding dimensions are listed in Table 5.2. The dimensions listed in the table were derived from a collection of as-built measurements of instrument and PJM locations inside the tank, together the manufactured dimensions of the tank itself. The hydrophones were secured at the end of unistrut columns. The columns were supported by mounts on the upper and lower handrails of the bridge over the tank. Figure 5.3 contains photographs of such columns.

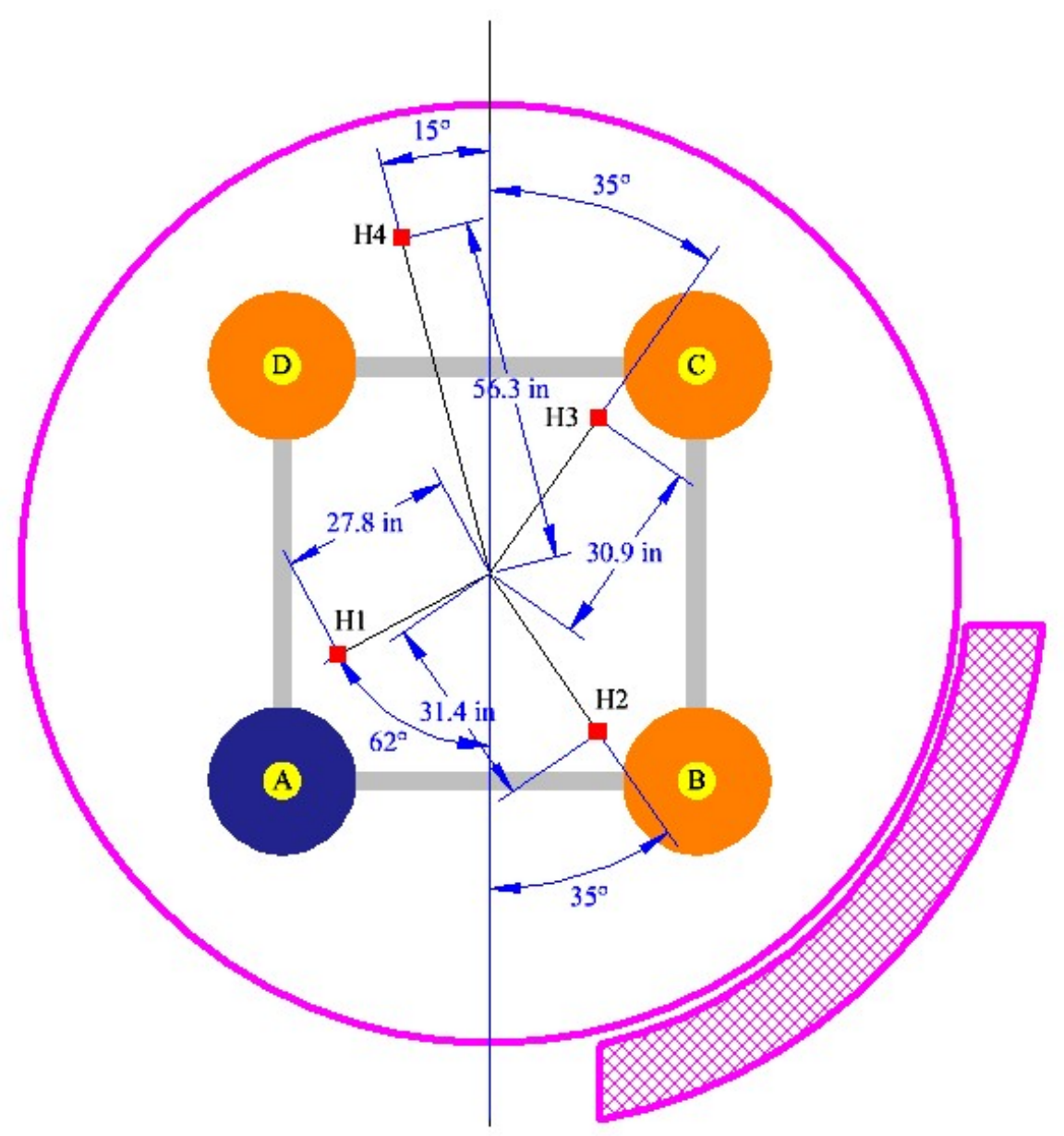

Figure 5.2. Radial Location of the Four Hydrophones Installed in the 4-PJM Configuration 
Table 5.2. Hydrophone Locations, 4-PJM Configuration

\begin{tabular}{lcccccccccc}
\hline & $\begin{array}{c}\text { Radial } \\
\text { Pos. R } \\
\text { (in.) }^{(\text {(a) }}\end{array}$ & $\begin{array}{c}\text { Angular } \\
\text { Pos. } \theta\end{array}$ & \multicolumn{3}{c}{$\begin{array}{c}\text { Elevation above Tank Floor } \\
\text { (deg) }^{(\text {b) }}\end{array}$} & $\begin{array}{c}\text { (in.) } \\
\text { (c) }\end{array}$ & \multicolumn{3}{c}{$\begin{array}{c}\text { Elevation above Perimeter } \\
\text { PJM Nozzle (in.) }\end{array}$} \\
\hline Hyd. 1 & 27.8 & 298 & 15.7 & 33.7 & 63.7 & 111.7 & 0.0 & 18.0 & 48.0 & 96.0 \\
Hyd. 2 & 31.4 & 35 & 15.7 & 33.7 & 63.7 & 111.7 & 0.0 & 18.0 & 48.0 & 96.0 \\
Hyd. 3 & 30.9 & 145 & 15.7 & 33.7 & 63.7 & 111.7 & 0.0 & 18.0 & 48.0 & 96.0 \\
Hyd. 4 & 56.3 & 195 & 15.7 & 33.7 & 63.7 & 111.7 & 0.0 & 18.0 & 48.0 & 96.0 \\
\hline
\end{tabular}

(a) All radial positions are measured from the tank center line.

(b) All angular positions are measured counterclockwise from the line joining the tank center and the line passing through the center of PJMs A and B.

(c) All elevations above the tank floor are determined from the tank centerline.

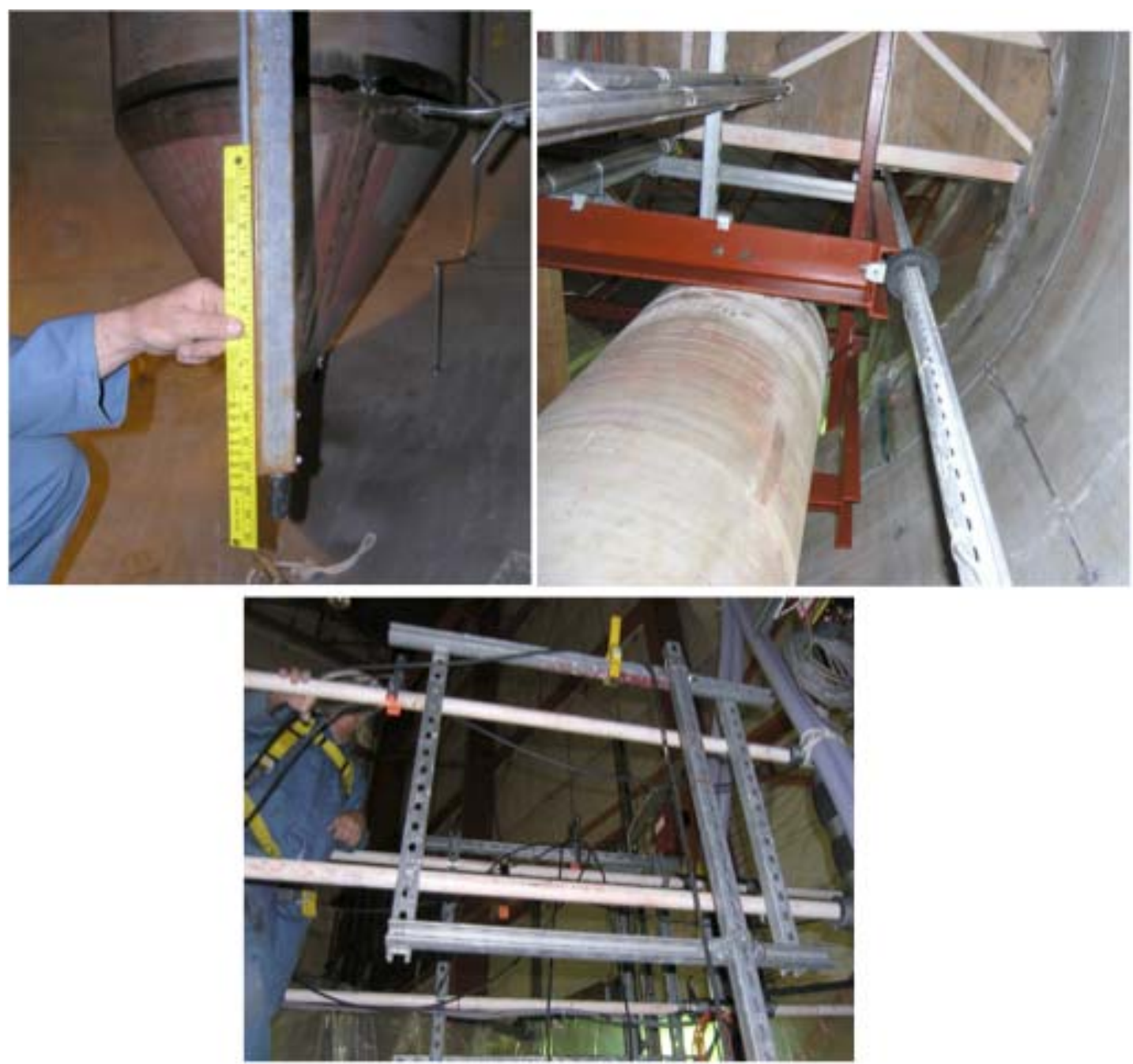

Figure 5.3. Hydrophone Mounting Columns (top left, bottom end with black tip of hydrophone protruding from the end; top right, rising shaft with rubber snubber mounted on red crossbeam; bottom, top of column attached to frame mounted on handrails above tank) 
This design had the advantage of allowing the hydrophone vertical positions in the tank to be varied, but had the disadvantage of allowing some movement of the hydrophones in the horizontal plane. During experiments, the vertical position of the hydrophones was set at either the low (in line with the PJM nozzles), other (18 inches above the nozzles), middle (48 inches above the nozzles) or upper (96 inches above the nozzles) vertical level. The levels relative to nozzles are illustrated in the vertical section drawing (Figure 5.4). The low hydrophone level in the 4-PJM configuration is not the same as the low level in the 8-PJM configuration (the "other" hydrophone level is the same as the low level in the 8-PJM configuration).

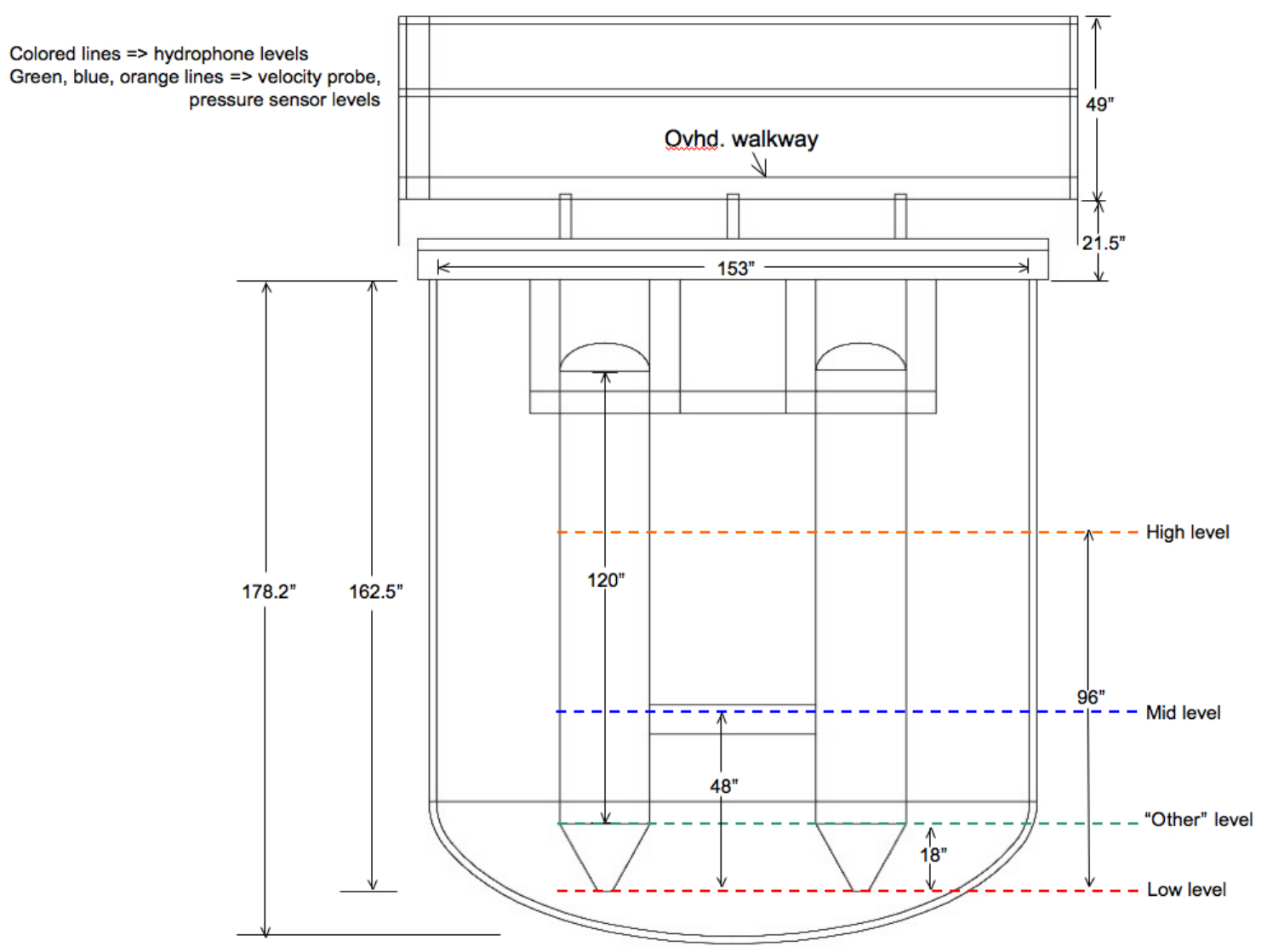

Figure 5.4. The Four Hydrophone Levels in the 4-PJM Configuration

\subsection{Velocity Probes}

Three velocity probe sensors were mounted on a vertical tree that was rigidly positioned in the tank by fixing the top of the tree to the bridge above the tank and inserting the bottom of the tree into a cup glued to the bottom of the tank. A plan view of the radial location of velocity probe center and the mast holding the probes is shown in Figure 5.5. The corresponding dimensions are listed in Table 5.3. The mast was placed so that the probe heads were directly above the bottom dead center of the tank. The three probes were positioned at levels of 18 , 48, and 96 inches above the PJM nozzles, as illustrated in Figure 5.4. The lowest velocity probe level (18 inches above the nozzles) is the same as the "other" hydrophone level in the 4-PJM configuration. 


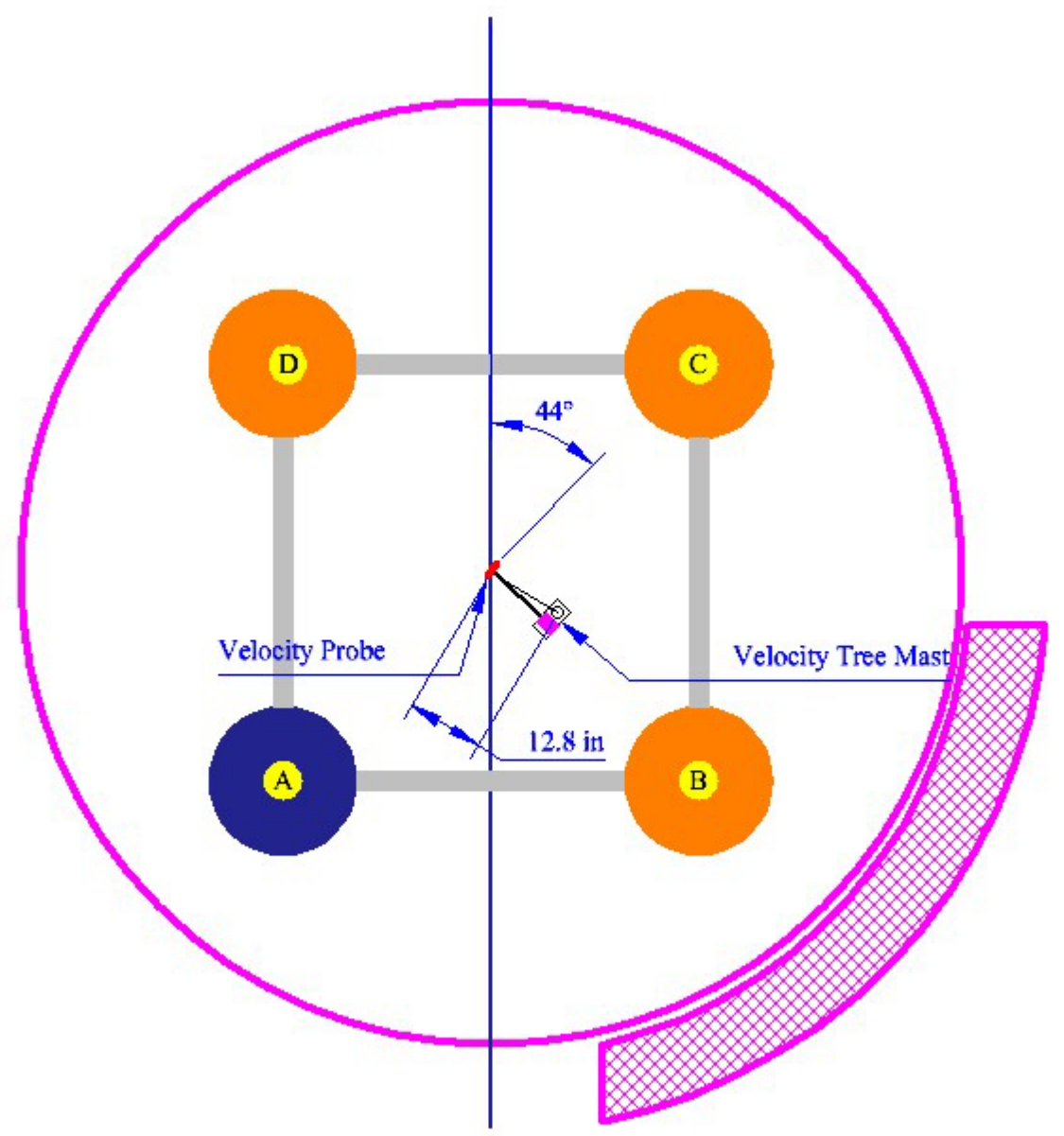

Figure 5.5. Plan View Showing Location of Velocity Probes and Mast Installed in 4-PJM Configuration

Table 5.3. Velocity Probe, Laser Level and Pressure Transmitter Mast Locations, 4-PJM Configuration

\begin{tabular}{|c|c|c|c|c|c|c|c|c|}
\hline & \multirow{2}{*}{$\begin{array}{l}\text { Radial } \\
\text { Pos. R } \\
\text { (in.) }^{(\text {a) }}\end{array}$} & \multirow{2}{*}{$\begin{array}{c}\text { Angular } \\
\text { Pos., } \theta \text { (deg) }{ }^{(\mathrm{b})}\end{array}$} & \multicolumn{3}{|c|}{$\begin{array}{l}\text { Elevation above Tank } \\
\text { Floor (in.) }\end{array}$} & \multicolumn{3}{|c|}{$\begin{array}{l}\text { Elevation above Perimeter } \\
\text { PJM Nozzle } \\
\text { (in.) }\end{array}$} \\
\hline & & & Low & Mid & High & Low & Mid & High \\
\hline Velocity Probe & 0 & 136 & 33.7 & 63.7 & 111.7 & 18.0 & 48.0 & 96.0 \\
\hline Laser Probe 2 & 28.0 & 90 & NA & NA & NA & NA & NA & NA \\
\hline Laser probe 3 & 28.0 & 270 & NA & NA & NA & NA & NA & NA \\
\hline Laser Probe 4 & 61.3 & 158 & NA & NA & NA & NA & NA & NA \\
\hline $\begin{array}{l}\text { Press. Trans. } \\
\text { Tree Mast }\end{array}$ & 38.0 & 283 & \multicolumn{6}{|c|}{$\begin{array}{l}\text { See Table } 5.4 \text { for additional information about pressure } \\
\text { sensor location }\end{array}$} \\
\hline Accelerometer & 18.6 & 225 & \multicolumn{3}{|c|}{29.7} & \multicolumn{3}{|c|}{14.0} \\
\hline \multicolumn{9}{|c|}{$\begin{array}{l}\text { (a) All radial positions are measured from the tank center line. } \\
\text { (b) All angular positions are angles (measured counterclockwise) from the line joining the tank center and the line } \\
\text { passing through the center of PJM A and PJM B. } \\
\text { (c) All elevations above the tank floor are determined from the tank centerline. }\end{array}$} \\
\hline
\end{tabular}




\subsection{In-Tank Pressure Transmitters}

Nine in-tank pressure transmitters were positioned at three elevations in the tank (with three sensors at each elevation) by mounting each transmitter in a separate tube oriented in the desired direction and affixing the tubes onto a mast. The mast was rigidly positioned in the tank by fixing the top of the mast to the bridge above the tank and inserting the bottom of the mast into a cup glued to the bottom of the tank.

A plan view showing the radial location of the pressure transmitter tree mast is shown in Figure 5.6. The corresponding dimensions are included in Table 5.3. The names of the sensors and their orientations relative to each other remain the same as in the 8-PJM configuration unless otherwise noted in the table. Additional as-built measurements of the pressure sensor locations are listed in Table 5.4.

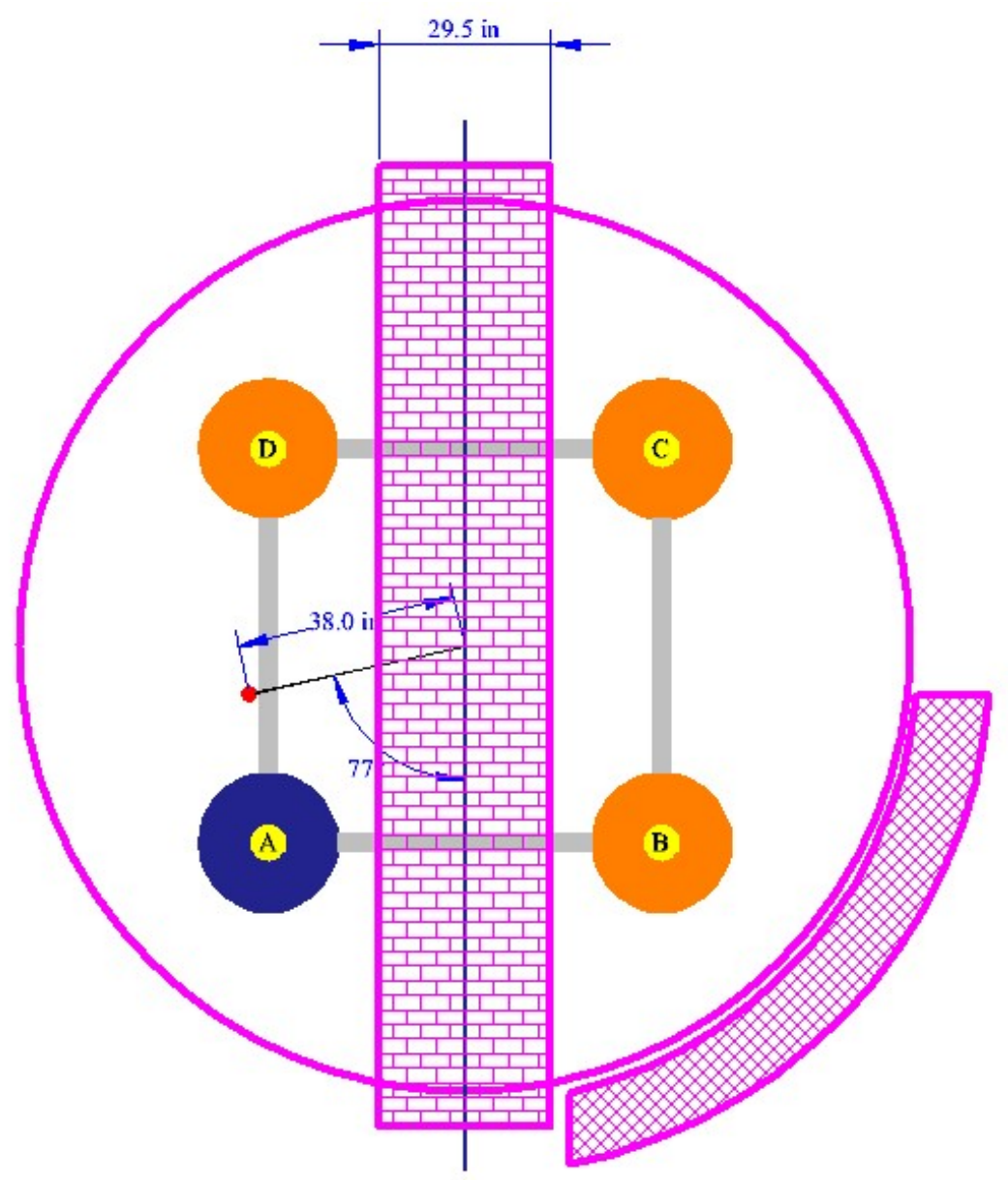

Figure 5.6. Plan View of the Tank Showing the Location of the Pressure Transmitter Tree Mast Installed in the 4-PJM Configuration 
Table 5.4. As-Built Information of the In-Tank Pressure Transmitters, 4-PJM Configuration

\begin{tabular}{lc}
\hline \multicolumn{1}{c}{ Measurement } & $\begin{array}{c}\text { Distance } \\
\text { (inches) }\end{array}$ \\
\hline BT pressure sensor to tank centerline & 35.75 \\
BT pressure sensor to nozzle level (PJM A) & 18 \\
BT pressure sensor to MT pressure sensor & $24^{(\text {a) }}$ \\
BT pressure sensor to TT pressure sensor & $72^{(\mathrm{b})}$ \\
MT pressure sensor to tank centerline & 34.75 \\
TT pressure sensor to tank centerline & 36 \\
Center of pressure tree mast to tank centerline & 38 \\
Center of PJM A nozzle to pressure tree mast & 25.75 \\
\hline (a) Test plan specification is 30 in. Dimension was changed to move the sensors away from a crossbeam. \\
(b) Test plan specification is 78 inches. The relative spacing between the middle and upper sensors was kept \\
at the specification in the Test Plan. & \\
(c) Relative orientations of the pressure sensors to each other remain the same as the 8-PJM configuration. \\
\hline
\end{tabular}

\subsection{Accelerometer}

As discussed in Section 3.1.10, the accelerometer was mounted at the end of a 2-inch schedule 80 stainless steel mast. The accelerometer probe mast was hung at the location shown in the plan view (Figure 5.7) between PJMs A and D. Locating dimensions are listed in Table 5.3.

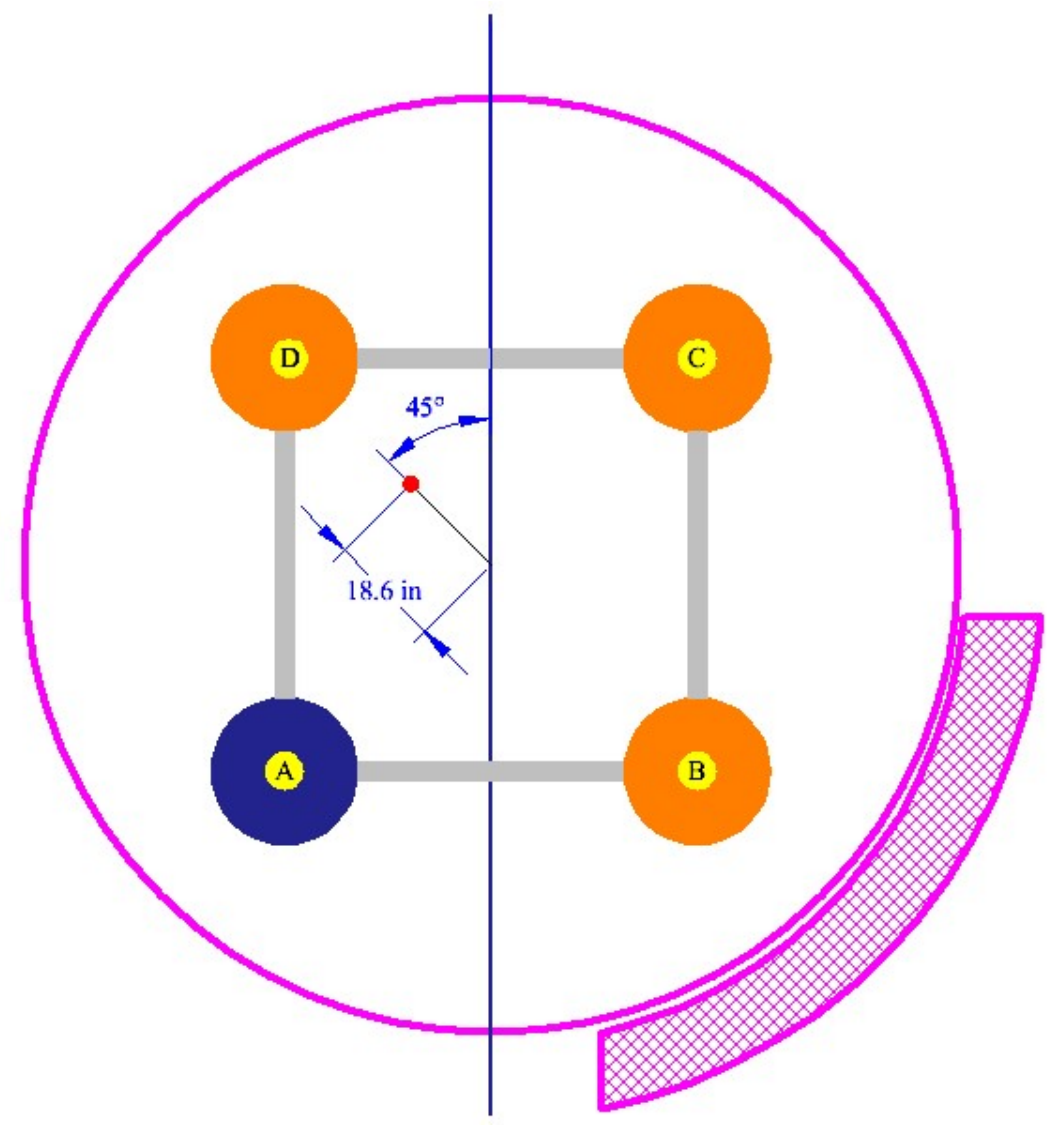

Figure 5.7. Location of the Accelerometer 
The accelerometer probe mast was clamped with a unistrut bracket at a point on top of an 8-inch-tall beam that rested on the rim of the tank. It was similarly clamped on top of a 6-inch L-beam (open side facing the mast) the top of which was 30 inches below the tank rim. The total supported length of mast was approximately 39-inches. A vertical unistrut backbone was run between the two beams and was butted against the mast. The mast was attached to the backbone with two U-bolts. Figure 5.8 is a photograph of this upper portion of the mast. The bottom of the mast was 148.5 inches below the tank rim. The unsupported length of the mast was approximately 118.5 inches. The length of the mast was sufficient to make sure that the wetted end was always at least 12 inches below the liquid level during overblow at the lowest tank fill height.

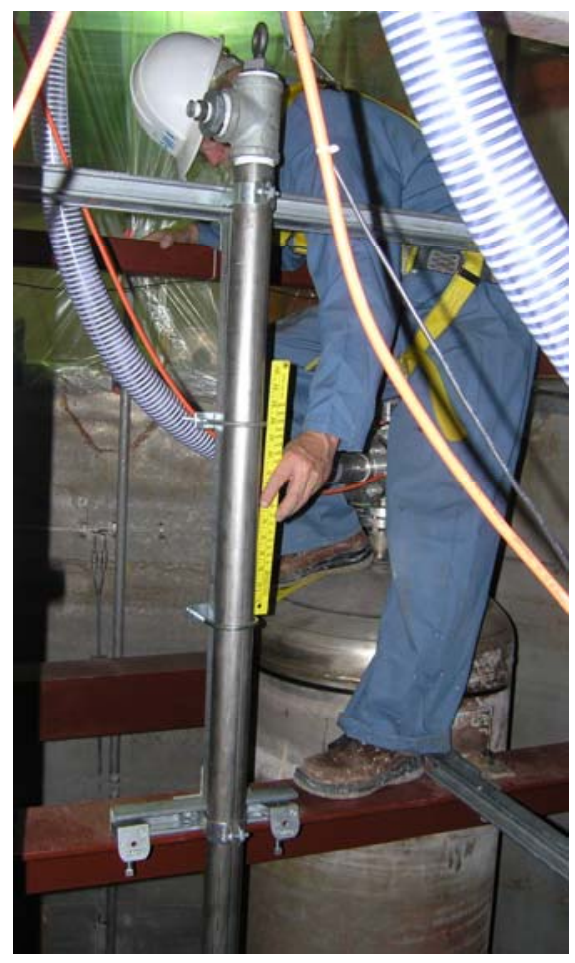

Figure 5.8. The Mount for the Accelerometer Mast

\subsection{Laser Levels}

The locations of the laser beam strike points are illustrated with red stars in Figure 5.9. They were positioned to provide at least one measurement near the tank center and near any operating PJM (L2 and L3) and one more peripheral measurement (L4). Additional measurements of beam locations are listed in Table 5.3. 


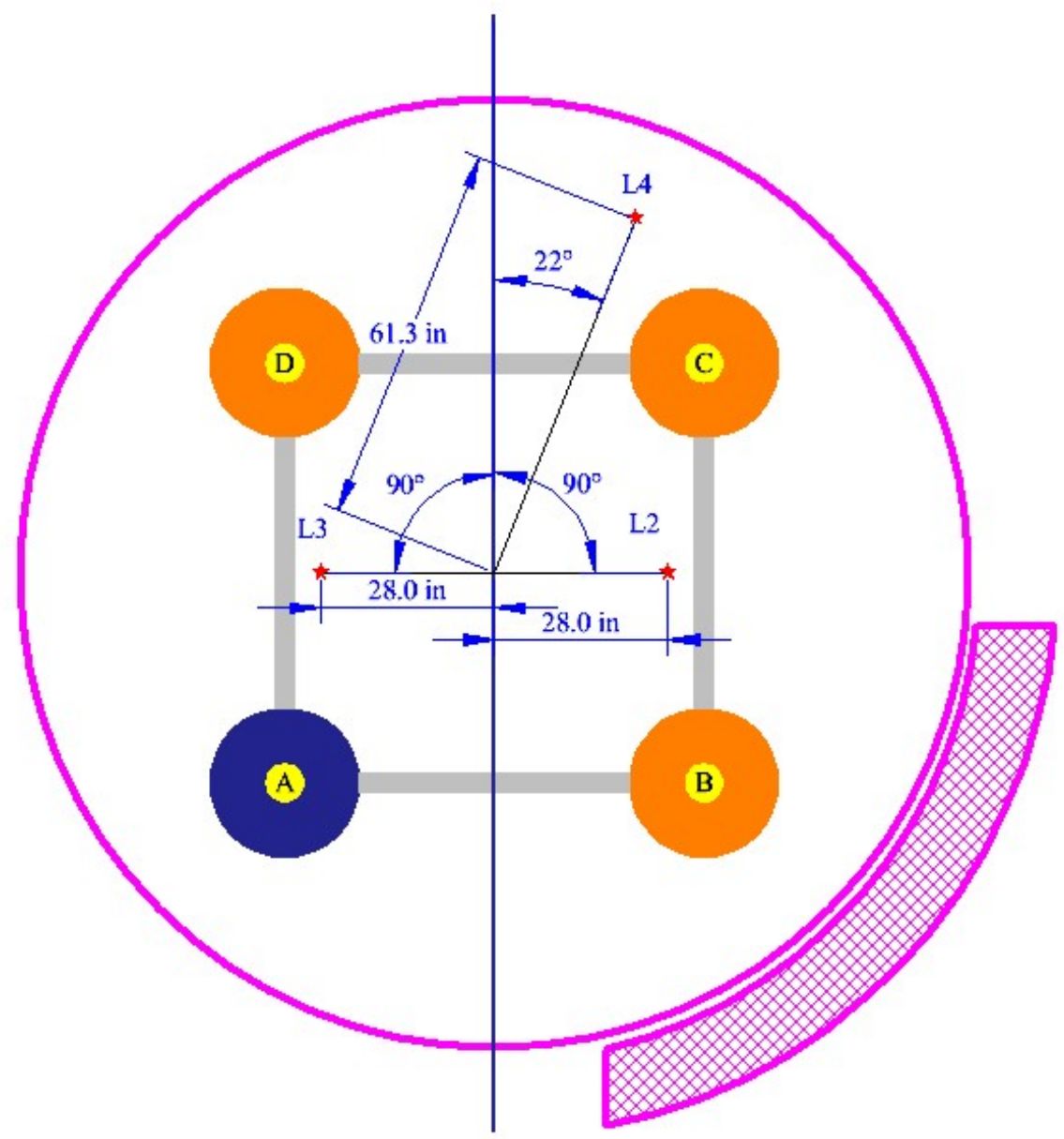

Figure 5.9. Location of the Laser Levels, 4-PJM Configuration 



\subsection{8-PJM Overblow Test Matrix}

For each simulant, the various single and multiple overblow tests that were performed with the 8-PJM test configuration are shown in Tables 6.1, 6.2, and 6.3. Most of the overblow tests with the 8-PJM system were primarily concentrated around PJM\#5. The tests were conducted with an overblow duration that typically ranged from 1.5 to as high as 7.5 seconds.

The tests required to assess the effect of simultaneous overblows on the loads inside the vessel are shown in Table 6.1. Simultaneous overblow tests were conducted at a simulant H/D $=0.8$ (and also at 0.96 in water) and the hydrophones located at the low, mid, and high positions. Preliminary tests with two pulse tubes have shown that there is considerable variability in the times at which each PJM starts to overblow, with differences in the start times being as high as $300 \mathrm{~ms}$. In this work, overblow data were collected from two pulse tubes until a set of overblows was obtained with a start time difference less than $20 \mathrm{~ms}$. In the laboratory the time difference was estimated from plots of the conductivity probe data recorded on DAS-2 (at a rate of $10.24 \mathrm{kHz}$ ).

The tests required to assess the effect of Reynolds number on the loads inside the vessel are listed in Table 6.2. During these tests, one or two PJMs were overblown at varying nozzle velocities. Three repetitions were performed at each velocity. These tests were conducted in triplicate at each of the three target hydrophone levels. These tests were done with both water and clay simulants. Surface videos were made at each nozzle velocity and liquid level. Subsurface, high-speed videos of an overblow jet were made at each nozzle velocity and each level of water.

The tests required to assess the effect of multiple (three and four) overblows on loadings are listed in Table 6.3. These tests were conducted at only one nozzle velocity but were performed at all three hydrophone levels and all three liquid levels for each simulant. Surface videos were made of these tests at each liquid level. Subsurface high-speed videos were made at each level in water.

Most of the tests listed in Tables 6.2 and 6.3 were conducted without air sparging. A few selected tests were repeated with the air spargers turned on. These tests are noted in the Master Run Log, Appendix A.

Table 6.1. Simultaneous Overblow Test Conditions for the 8-PJM Configuration

\begin{tabular}{|c|c|c|c|c|c|c|}
\hline $\begin{array}{l}\text { Test } \\
\text { Stand }\end{array}$ & $\begin{array}{c}\text { Simulant } \\
\text { Level } \\
\text { (H/D) }\end{array}$ & Simulant & $\begin{array}{l}\text { Target } \\
\text { Velocity }\end{array}$ & $\begin{array}{l}\text { No. of } \\
\text { PJMs }\end{array}$ & Repetitions & $\begin{array}{l}\text { Hydrophone } \\
\text { Levels }^{(a)}\end{array}$ \\
\hline 8-PJM & 0.96 & Water & $14 \pm 1 \mathrm{~m} / \mathrm{s}$ & $\begin{array}{c}2 \text { (PJMs } \\
\# 4 \text { and \#5) }\end{array}$ & $\begin{array}{l}\text { As many as needed to obtain } \\
\text { a data set with less than a } 20 \\
\text { ms difference }\end{array}$ & $\begin{array}{l}\text { Low, mid, } \\
\text { high }\end{array}$ \\
\hline 8-PJM & 0.8 & Clay & $14 \pm 1 \mathrm{~m} / \mathrm{s}$ & $\begin{array}{c}2 \text { (PJMs } \\
\# 4 \text { and \#5) }\end{array}$ & $\begin{array}{l}\text { As many as needed to obtain } \\
\text { a data set with less than a } 20 \\
\text { ms difference }\end{array}$ & $\begin{array}{l}\text { Low, mid, } \\
\text { high }\end{array}$ \\
\hline
\end{tabular}

(a) Low, medium and high hydrophone levels were 18”, 48” and 96” above the perimeter nozzles, respectively. 
Table 6.2. Single and Double Overblow Tests Performed to Investigate the Effect of Reynolds Number on Loadings in the 8-PJM Configuration

\begin{tabular}{ccccccc}
\hline & $\begin{array}{c}\text { Simulant } \\
\text { Level } \\
\text { Test Stand }\end{array}$ & Simulant & $\begin{array}{c}\text { Target Velocity } \\
(\mathrm{m} / \mathrm{s})\end{array}$ & PJMs & $\begin{array}{c}\text { Repetitions } \\
\text { Hydrophone } \\
\text { Levels }\end{array}$ \\
\hline \multirow{2}{*}{ 8-PJM } & 0.31 & & $8 \pm 1$ & $\# 5$ & & $\begin{array}{c}\text { Low } \\
\text { Mid }^{(\mathrm{b})} \\
\end{array}$ \\
8-PJM & 0.55 & Water/Clay & $12 \pm 1$ & & 3 & High $^{(\mathrm{b})}$ \\
& 0.8 & $14 \pm 1$ & $\# 4$ and \#5 & & \\
\hline
\end{tabular}

(a) Low, medium and high hydrophone levels were 18, 48 and 96 inches above the perimeter nozzles, respectively.

(b) Hydrophone measurements at the mid and high levels were not obtained at the low simulant fill level $(\mathrm{H} / \mathrm{D}=0.31)$ because the hydrophones would be above the simulant surface. Hydrophone measurements at the high level were not obtained at the mid simulant fill level $(\mathrm{H} / \mathrm{D}=0.55)$ because the hydrophones would be above the simulant surface.

(c) This level was used only in tests with water.

Table 6.3. Tests Performed to Investigate the Effect of Multiple Overblows on Loadings in the 8-PJM Configuration

\begin{tabular}{|c|c|c|c|c|c|c|}
\hline Test Stand & $\begin{array}{c}\text { Simulant } \\
\text { Level } \\
(\mathrm{H} / \mathrm{D}) \\
\end{array}$ & Simulants & $\begin{array}{c}\text { Target } \\
\text { Velocity }\end{array}$ & PJMs & Repetitions & $\begin{array}{l}\text { Hydrophone } \\
\text { Elevations }^{(\mathrm{a})}\end{array}$ \\
\hline 8-PJM & 0.31 & & & $\# 4,5,6$ & & Low \\
\hline 8-PJM & $\begin{array}{c}0.55 \\
0.8 \\
0.96^{(\mathrm{c})}\end{array}$ & Water/Clay & $14 \pm 1 \mathrm{~m} / \mathrm{s}$ & $\# 4,5,6,7$ & 3 & $\begin{array}{l}\operatorname{Mid}^{(\mathrm{b})} \\
\operatorname{High}^{(\mathrm{b})}\end{array}$ \\
\hline
\end{tabular}

(a) Low, medium, and high hydrophone levels were 18, 48, and 96 in. above the perimeter nozzles, respectively.

(b) Hydrophone measurements at the mid and high levels were not obtained at the low simulant fill level $(\mathrm{H} / \mathrm{D}=0.31)$ because the hydrophones would be above the simulant surface. Hydrophone measurements at the high level were not obtained at the mid simulant fill level $(\mathrm{H} / \mathrm{D}=0.55)$ because the hydrophones would be located above the simulant surface.

(c) This level was used only in tests with water. 


\subsection{4-PJM Overblow Test Matrix}

For each simulant, the various single and multiple overblow tests that were performed with the 4-PJM test configuration are shown in Tables 7.1, 7.2, and 7.3. Most of the overblow tests with the 4-PJM system were primarily concentrated around PJM A. The tests were conducted with overblow durations that ranged from 2.5 and 7.5 seconds, most being 4 to 5 seconds long. A list of the tests performed is given in Appendix B, Master Run Log.

Many of the desired tests were to be performed at a target velocity of $12 \mathrm{~m} / \mathrm{s}$. Because of air flow limitations through the regulators on the JPP skids, ${ }^{(a)}$ the value of $12 \mathrm{~m} / \mathrm{s}$ is a nominal figure that may not have been reached under some conditions with more than one PJM operating. For all runs with a nominal target velocity of $12 \mathrm{~m} / \mathrm{s}$, the relevant supply regulators on both JPP skids were set at $100 \%$ open. No tolerance on the target velocity is shown here for the $12 \mathrm{~m} / \mathrm{s}$ runs.

The tests required to assess the effect of simultaneous overblows in-tank loadings are shown in Table 7.1. Preliminary tests with two pulse tubes have shown that there is considerable variability in the times at which the overblows start, with differences as high as $300 \mathrm{~ms}$. In this work, overblow data were collected from two pulse tubes until a set of overblows was obtained with a start time difference less than $20 \mathrm{~ms}$. In the laboratory, the time difference was estimated from plots of the conductivity probe data recorded on DAS-2. In water these tests were performed using PJMs A and C. The conductivity probe on PJM C failed (showing evidence of a short circuit to ground) during the time the simultaneous overblow tests were to be performed with the clay simulant. Simultaneous overblow tests with clay were performed using PJMs A and B. Simultaneous overblow tests in clay were also attempted using a simultaneity criterion based PJM inlet pressures (instead of nozzle area conductivity). These latter tests were conducted using PJMs A and C, and the results are presented for information only.

The tests required to assess the effect of Reynolds number on the in-tank loadings are listed in Table 7.2. During these tests, one or two PJMs were overblown at four different target nozzle velocities. Three repetitions were performed at each velocity. The tests were conducted at each of the four target hydrophone levels and were repeated at each of the three target liquid levels. The whole series was done with both water and clay simulants. Surface videos were made at each nozzle velocity and liquid level. Subsurface, high-speed videos of an overblow jet were made at each nozzle velocity and each water level.

The tests required to assess the effect of multiple (three and four) overblows on loadings are listed in Table 7.3. These tests were conducted at only one nozzle velocity but were performed at all four hydrophone levels and all three liquid levels for each simulant. Surface videos were made of these tests at each liquid level. Subsurface high-speed videos were made at each level in water. There were no air spargers installed in the 4-PJM configuration.

(a) To achieve target velocities of $>10 \mathrm{~m} / \mathrm{s}$ with the 4-PJM configuration, two JPPs were combined to supply the required air flow to each pulse tube. This is sometimes referred to as the 2-rack configuration. 
Table 7.1. Simultaneous Overblow Test Conditions for the 4-PJM Configuration

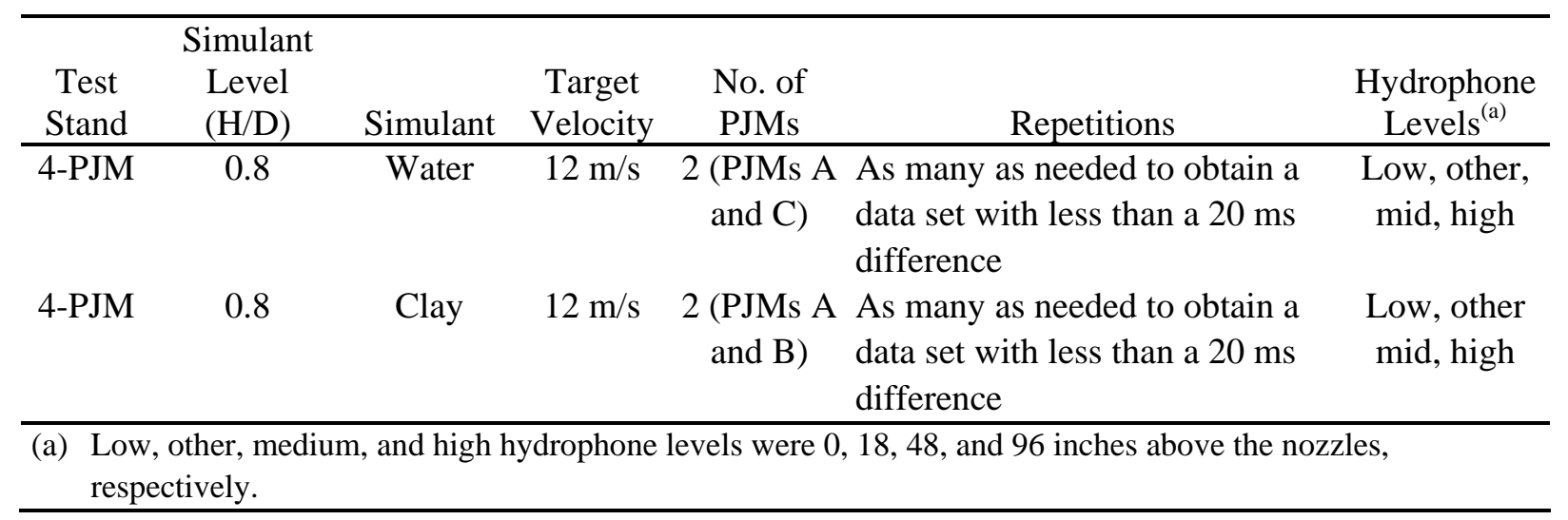

Table 7.2. Single and Double Overblow Tests Performed to Investigate the Effect of Reynolds Number on Loadings in the 4-PJM Configuration

\begin{tabular}{|c|c|c|c|c|c|c|}
\hline Test Stand & $\begin{array}{c}\text { Simulant } \\
\text { Level } \\
\text { (H/D) }\end{array}$ & Simulant & $\begin{array}{l}\text { Target Velocity } \\
(\mathrm{m} / \mathrm{s})\end{array}$ & PJMs & Repetitions & $\begin{array}{l}\text { Hydrophone } \\
\text { Levels }^{(a)}\end{array}$ \\
\hline $\begin{array}{l}\text { 4-PJM } \\
\text { 4-PJM }\end{array}$ & $\begin{array}{c}0.31 \\
0.55 \\
0.8\end{array}$ & Water/Clay & $\begin{array}{c}6 \pm 1 \\
8 \pm 1 \\
10 \pm 1 \\
12\end{array}$ & $\begin{array}{c}\mathrm{A} \\
\mathrm{A} \text { and } \mathrm{B}\end{array}$ & 3 & $\begin{array}{c}\text { Low } \\
\text { Other } \\
\text { Mid }^{(b)} \\
\text { High }^{(b)}\end{array}$ \\
\hline
\end{tabular}

(a) Low, other, medium and high hydrophone levels were 0, 18, 48, and 96 inches above the nozzles, respectively.

(b) Hydrophone measurements at the mid and high levels were not obtained at the low simulant fill level $(\mathrm{H} / \mathrm{D}=0.31)$ because the hydrophones would be located above the simulant surface. Hydrophone measurements at the high level were not obtained at the mid simulant fill level $(\mathrm{H} / \mathrm{D}=0.55)$ because the hydrophones would be located above the simulant surface.

Table 7.3. Tests Performed to Investigate the Effect of Multiple Overblows on Loadings in the 4-PJM Configuration

\begin{tabular}{|c|c|c|c|c|c|c|}
\hline Test Stand & $\begin{array}{c}\text { Simulant } \\
\text { Level } \\
(\mathrm{H} / \mathrm{D})\end{array}$ & Simulants & $\begin{array}{c}\text { Target } \\
\text { Velocity }\end{array}$ & PJMs & Repetitions & $\begin{array}{l}\text { Hydrophone } \\
\text { Elevations }^{(a)}\end{array}$ \\
\hline 4-PJM & 0.31 & & & $\mathrm{~A}, \mathrm{~B}, \mathrm{C}$ & & Low \\
\hline 4-PJM & $\begin{array}{c}0.55 \\
0.8\end{array}$ & Water/Clay & $12 \mathrm{~m} / \mathrm{s}$ & A,B,C,D & 3 & $\begin{array}{l}\text { Other } \\
\text { Mid }^{\left({ }^{b}\right)} \\
\text { High }^{(b)}\end{array}$ \\
\hline
\end{tabular}

(a) Low, other, medium, and high hydrophone levels were 0, 18, 48, and 96 inches above the nozzles, respectively.

(b) Hydrophone measurements at the mid and high levels were not obtained at the low simulant fill level $(\mathrm{H} / \mathrm{D}=0.31)$ because the hydrophones would be located above the simulant surface. Hydrophone measurements at the high level were not obtained at the mid simulant fill level $(\mathrm{H} / \mathrm{D}=0.55)$ because the hydrophones would be located above the simulant surface. 


\subsection{Run Logs and Data Files}

\subsection{Master Run Logs}

The master run logs for the water and clay runs are provided as Appendices A and B of this report. These master run log sheets summarize the test conditions and provide the file names for the data recorded on DAS-1, DAS-2, DAS-4, and the surface video recording. The entries in each column of the master run log are described below.

- Column A provides a sequential numbering of each test. The format is E\#\#\#, where \#\#\#\# is the sequential experiment number.

- Column B indicates the PJM configuration. An "8” denotes the 8-PJM cluster configuration, a "4" denotes the 4-PJM configuration.

- Column C indicates the simulant used, which is either water or clay.

- Column D provides the simulant height in inches, as measured from the tank rim. The simulant depth may be determined by subtracting the simulant distance from the tank rim from the total tank height of 178.2 inches. The total tank height is the distance from the inner bottom center of the tank to the tank rim.

- Column E provides the simulant height-to-diameter (H/D) ratio. The tank diameter is 153 inches.

- Column F provides the Bingham plastic yield stress $\left(\tau_{\mathrm{ys}}\right)$ in Pa. This does not apply to water.

- Column G provide the Bingham plastic consistency ( $\kappa)$ in $\mathrm{cP}$. This does not apply to water.

- Column H provides the total number of PJMs that are overblowing.

- Column I provides the pulse tube numbers for the PJMs that are being subjected to an overblow. See Figure 4.1 for the locations of the pulse tubes in the 8-PJM configuration. See Figure 5.1 for the locations of the pulse tubes in the 4-PJM configuration.

- Column J provides an estimate of the duration of the overblow. The values shown were estimated by eye from a computer display using the output from the conductivity probes. These values are presented for information only. The actual duration of a PJM overblow should be obtained from electronic data recorded during the testing (for example, from the pressure transmitter data recorded on DAS-1 or the conductivity probe data recorded on DAS-2).

- Columns K-O provide the drive pressure settings for each PJM in the 8-PJM configuration. These values are obtained from pressure transmitters on the PJM air supply racks and are for presented information only. A dash indicates that the PJM was not being tested.

- Columns K-N provide the drive pressure settings for each PJM in the 4-PJM configuration. If two pressures appear in a column in the master run log (Appendix B) for a PJM drive pressure, the values separated by a slash, this means that two JPP racks were used to supply drive air to the PJM during the experiment. The drive pressure values are obtained from pressure transmitters on the PJM air supply racks and are for presented information only. A dash indicates that the PJM was not being tested. 
- Columns P-T provide the PJM operating settings for each PJM being tested in the 8-PJM configuration. The numbers provided are the times in milliseconds of the four steps in the PJM cycle in the format: vacuum/delay/drive/vent. These values are presented for information only.

- Columns O-R provide the PJM operating settings for each PJM being tested in the 4-PJM configuration.

- Column U in the 8-PJM configuration or column S in the 4-PJM configuration provides the target nominal peak average nozzle velocity. The values presented are for information only.

- Columns V-Y in the 8-PJM configuration indicate the level of each of the hydrophones during the test. Refer to Section 3 for the actual elevations and locations of the hydrophones at each level.

- Columns T-W in the 4-PJM configuration indicate the level of each of the hydrophones during the test. Refer to Section 4 for the actual elevations and locations of the hydrophones at each level.

- Column Z indicates whether spargers were on or off in the 8-PJM configuration

- Column AA in the 8-PJM configuration or column X in the 4-PJM configuration indicates whether any videos (surface or subsurface) were recorded.

- Column AB in the 8-PJM configuration or column Y in the 4-PJM configuration gives an index of which repeat the experiment corresponds in a set done at equivalent conditions. Most tests were done in triplicate.

- Column AC in the 8-PJM configuration or column Z in the 4-PJM configuration contains the DAS-1 (DASYLAB) file name.

- Column AD in the 8-PJM configuration or column AA in the 4-PJM configuration contains the DAS2 (DACTRON) file name.

- Column AE in the 8-PJM configuration or column AB in the 4-PJM configuration contains the DAS4 file name (high speed video file name). Note that the frame rate used is stamped on the recorded video along with time and frame step data.

\subsection{DAS-1 (DASYLAB) File Naming Convention and Description of File Contents}

The data files saved from DAS-1 were named as E\#-D1-YYMMDD.ASC, where:

- \# = 4-digit cumulative running value of the experiment starting at 0001

- $\mathrm{D} 1=\mathrm{DAS}-1$

- $\mathrm{YY} \quad=2$-digit extension of the year

- $\mathrm{MM} \quad=2$-digit extension of the month

- $\mathrm{DD} \quad=2$-digit extension of the day.

The DAS-1 files were multicolumn ASCI format where data for each channel were recorded in separate columns, as described in Table 8.1 (for data taken in the 8-PJM equipment configuration) or Table 8.2 (for the 4-PJM configuration). 
Table 8.1. Channel Names as Used in the DAS-1 Log Files with a Brief Description (8-PJM Configuration)

\begin{tabular}{|c|c|}
\hline $\begin{array}{c}\text { Channel Name } \\
\text { Date (month/day/year) } \\
\end{array}$ & Description (units) \\
\hline Time & $\begin{array}{l}\text { Run clock (minutes past the hour:sec.decimal). Wall clock time appears in } \\
\text { the file header. }\end{array}$ \\
\hline PJM Level 1 & PJM 1 level probe data (inches) \\
\hline PJM Level 2 & PJM 2 level probe data (inches) \\
\hline PJM Level 3 & PJM 3 level probe data (inches) \\
\hline PJM Level 4 & PJM 4 level probe data (inches) \\
\hline PJM Level 5 & PJM 5 level probe data (inches) \\
\hline PJM Level 6 & PJM 6 level probe data (inches) \\
\hline PJM Level 7 & PJM 7 level probe data (inches) \\
\hline PJM Level 8 & PJM 8 level probe data (inches) \\
\hline PJM Pres 1 & Top of PJM 1 pressure transducer data (psia) \\
\hline PJM Pres 2 & Top of PJM 2 pressure transducer data (psia) \\
\hline PJM Pres 3 & Top of PJM 3 pressure transducer data (psia) \\
\hline PJM Pres 4 & Top of PJM 4 pressure transducer data (psia) \\
\hline PJM Pres 5 & Top of PJM 5 pressure transducer data (psia) \\
\hline PJM Pres 6 & Top of PJM 6 pressure transducer data (psia) \\
\hline PJM Pres 7 & Top of PJM 7 pressure transducer data (psia) \\
\hline PJM Pres 8 & Top of PJM 8 pressure transducer data (psia) \\
\hline PJM 5 Manif Temp & PJM 5 air temperature measured at manifold $\left({ }^{\circ} \mathrm{C}\right)$ \\
\hline PJM 5 Temp & PJM 5 air temperature measured on top of PJM $5\left({ }^{\circ} \mathrm{C}\right)$ \\
\hline Time Sync & $\begin{array}{l}\text { Time synchronization switch signal to determine and correct for logged time } \\
\text { difference between DAS-1 and DAS-2 (volts) }\end{array}$ \\
\hline Vel Vert 18 & Vertical velocity component measured 18 inches above nozzle (m/s) \\
\hline Vel Rad 18 & Radial velocity component measured 18 inches above nozzle (m/s) \\
\hline Vel Vert 48 & Vertical velocity component measured 48 inches above nozzle $(\mathrm{m} / \mathrm{s})$ \\
\hline Vel Rad 48 & Radial velocity component measured 48 inches above nozzle (m/s) \\
\hline Vel Vert 96 & Vertical velocity component measured 96 inches above nozzle $(\mathrm{m} / \mathrm{s})$ \\
\hline Vel Rad 96 & Radial velocity component measured 96 inches above nozzle (m/s) \\
\hline Tk Sur Level 1 & Tank surface level reading at position 1 (m) \\
\hline Tk Sur Level 2 & Tank surface level reading at position $2(\mathrm{~m})$ \\
\hline Tk Sur Level 3 & This instrument was not operational. \\
\hline Tk Sur Level 4 & Tank surface level reading at position $4(\mathrm{~m})$ \\
\hline $\begin{array}{l}\text { TK Sur Level } 1 \text { - error } \\
\text { code }\end{array}$ & $\begin{array}{l}\text { Error code signal for measured tank surface level reading at position } 1 \\
\text { ( } 1 \text { = measurement without error signal, } 0=\text { error signal sent by instrument) } \\
\text { Not verified; for information only. }\end{array}$ \\
\hline $\begin{array}{l}\text { TK Sur Level } 2 \text { - error } \\
\text { code }\end{array}$ & $\begin{array}{l}\text { Error code signal for measured tank surface level reading at position } 2 \\
\text { ( } 1 \text { = measurement without error signal, } 0=\text { error signal sent by instrument). } \\
\text { Not verified; for information only. }\end{array}$ \\
\hline $\begin{array}{l}\text { TK Sur Level } 3 \text { - error } \\
\text { code }\end{array}$ & This instrument was not operational. \\
\hline $\begin{array}{l}\text { TK Sur Level } 4 \text { - error } \\
\text { code }\end{array}$ & $\begin{array}{l}\text { Error code signal for measured tank surface level reading at position } 4 \\
\text { ( } 1 \text { = measurement without error signal, } 0=\text { error signal sent by instrument). } \\
\text { Not verified; for information only. }\end{array}$ \\
\hline
\end{tabular}


Table 8.2. Channel Names as Used in the DAS-1 Log Files with a Brief Description (4-PJM Configuration)

\begin{tabular}{|c|c|}
\hline Channel Name & Description (units) \\
\hline Date & Date (month/day/year) \\
\hline Time & $\begin{array}{l}\text { Run clock (minutes past the hour:sec.decimal). Wall clock time appears in } \\
\text { the file header. }\end{array}$ \\
\hline PJM Lvl A & PJM A level probe data (inches) \\
\hline PJM Lvl B & PJM B level probe data (inches) \\
\hline PJM Lvl C & PJM C level probe data (inches) \\
\hline PJM Lvl D & PJM D level probe data (inches) \\
\hline PJM Pres A & Top of PJM A pressure transducer data (psia) \\
\hline PJM Pres B & Top of PJM B pressure transducer data (psia) \\
\hline PJM Pres C & Top of PJM C pressure transducer data (psia) \\
\hline PJM Pres D & Top of PJM D pressure transducer data (psia) \\
\hline PJM A Manif Temp & PJM A air temperature measured at manifold $\left({ }^{\circ} \mathrm{C}\right)$ \\
\hline PJM A Temp & PJM A air temperature measured on top of PJM $5\left({ }^{\circ} \mathrm{C}\right)$ \\
\hline Time Sync & $\begin{array}{l}\text { Time synchronization switch signal to determine and correct for logged time } \\
\text { difference between DAS-1 and DAS-2 (volts) }\end{array}$ \\
\hline Vel Vert 18 & Vertical velocity component measured 18 inches above nozzle $(\mathrm{m} / \mathrm{s})$ \\
\hline Vel Rad 18 & Radial velocity component measured 18 inches above nozzle (m/s) \\
\hline Vel Vert 48 & Vertical velocity component measured 48 inches above nozzle $(\mathrm{m} / \mathrm{s})$ \\
\hline Vel Rad 48 & Radial velocity component measured 48 inches above nozzle $(\mathrm{m} / \mathrm{s})$ \\
\hline Vel Vert 96 & Vertical velocity component measured 96 inches above nozzle $(\mathrm{m} / \mathrm{s})$ \\
\hline Vel Rad 96 & Radial velocity component measured 96 inches above nozzle $(\mathrm{m} / \mathrm{s})$ \\
\hline Tk Sur Level 1 & This instrument was not operational. \\
\hline Tk Sur Level 2 & Tank surface level reading at position 2 (m). \\
\hline Tk Sur Level 3 & $\begin{array}{l}\text { Tank surface level reading at position } 3(\mathrm{~m}) \text {. Laser sensor \#1 was installed in } \\
\text { this position instead of sensor \#3. }\end{array}$ \\
\hline Tk Sur Level 4 & Tank surface level reading at position 4 (m). \\
\hline TK Sur Lvl 1 - error code & This instrument was not operational. \\
\hline TK Sur Lvl 2 - error code & $\begin{array}{l}\text { Error code signal for measured tank surface level reading at position } 2 \\
\text { ( } 1 \text { = measurement without error signal, } 0=\text { error signal sent by instrument). } \\
\text { Not verified; for information only. }\end{array}$ \\
\hline TK Sur Lvl 3 - error code & $\begin{array}{l}\text { Error code signal for measured tank surface level reading at position } 3 \\
\text { ( } 1 \text { = measurement without error signal, } 0=\text { error signal sent by instrument). } \\
\text { Not verified; for information only. }\end{array}$ \\
\hline TK Sur Lvl 4 - error code & $\begin{array}{l}\text { Error code signal for measured tank surface level reading at position } 4 \\
(1=\text { measurement without error signal, } 0=\text { error signal sent by instrument). } \\
\text { Not verified; for information only. }\end{array}$ \\
\hline
\end{tabular}

Data were taken periodically when the PJMs were not operating. These baseline data provided information about instrument offsets, drifts and noise levels. The resulting data files were saved with the same naming convention except that the letters BL (indicates baseline) have been added to the file names. For example, the files containing baseline data have the format E\#-D1-BL-YYMMDD.ASC. These baseline data files were generally recorded at the start and finish of testing each day. 


\subsection{DAS-2 (DACTRON) File Naming Nomenclature}

All data files saved from DAS-2 files have names that began with E\#-D2-Channel\# (or E\#-D2-C\#). Here, D2 stands for DAS-2 and Channel\# (or C\#) stands for the channel number. Refer to Table 8.3 for an explanation of these channel numbers in the 8-PJM configuration. Refer to Table 8.4 for an explanation of the DAS-2 channel numbers in the 4-PJM configuration. All DAS-2 data file names ended with date and time stamps. For example, the file name E0017-D2-Channel 3 Feb 13, 2007 15-26-32.TXT represents the test file for Channel 3 (conductivity probe on PJM \#4), created on February 13, 2007, at 15:26:32.

Data were taken periodically when the PJMs were not operating. These baseline data provided information about instrument offsets, drifts and noise levels. The resulting data files were saved with the same naming convention except that the letters BL (indicates baseline) have been added to the file names. For example, the files containing baseline data have the format E\#-D2-BL-Channel\#. These baseline data files were recorded at the start and finish of testing each day and often during testing, at approximately 1 hour intervals. Frequent baseline data were obtained on DAS 2 because the output from the in-tank pressure sensors drifted.

Table 8.3. Channel Numbers and Names as Used in the DAS-2 Log Files with a Brief Description (8-PJM Configuration)

\begin{tabular}{cl}
\hline $\begin{array}{c}\text { Channel } \\
\text { Number }\end{array}$ & \multicolumn{1}{c}{ Description (units) } \\
\hline 1 & $\begin{array}{l}\text { Time synchronization switch signal to determine and correct for logged time } \\
\text { difference between DAS-1 and DAS-2 (volts) }\end{array}$ \\
\hline 2 & $\begin{array}{l}\text { Time synchronization signal between DAS-2 and DAS-4 (high-speed video) that } \\
\text { gets activated when the subsurface camera starts recording. (volts) }\end{array}$ \\
\hline 3 & PJM 4 conductivity probe overblow signal (volts) \\
\hline 4 & PJM 5 conductivity probe overblow signal (volts) \\
\hline 5 & PJM 6 conductivity probe overblow signal (volts) \\
\hline 6 & PJM 7 conductivity probe overblow signal (volts) \\
\hline 8 & PJM 8 conductivity probe overblow signal (volts) \\
\hline 9 & Measurements obtained from Hydrophone 1 (Pa) \\
10 & Measurements obtained from Hydrophone 2 (Pa) \\
11 & Measurements obtained from Hydrophone 4 (Pa) \\
12 & Top level pressure transducer 'TA' (Pa) \\
13 & Top level pressure transducer 'TT' (Pa) \\
14 & Top level pressure transducer 'TD' (Pa) \\
15 & Middle level pressure transducer 'MA' (Pa) \\
\hline 16 & Middle level pressure transducer 'MT' (Pa) \\
17 & Middle level pressure transducer 'MD' (Pa) \\
18 & Lower level pressure transducer 'BT' (Pa) \\
19 & Lower level pressure transducer 'BAU' (Pa) \\
20 & Low level pressure transducer 'BAD' (Pa) \\
\hline
\end{tabular}


Table 8.4. Channel Numbers and Names as Used in the DAS-2 Log Files with a Brief Description (4-PJM Configuration)

\begin{tabular}{cl}
\hline $\begin{array}{c}\text { Channel } \\
\text { Number }\end{array}$ & \multicolumn{1}{c}{ Description (units) } \\
\hline A1 & $\begin{array}{l}\text { Time synchronization switch signal to determine and correct for logged time } \\
\text { difference between DAS-1 and DAS-2 (volts) }\end{array}$ \\
A2 & $\begin{array}{l}\text { Time synchronization signal between DAS-2 and DAS-4 (high-speed video) that } \\
\text { gets activated when the subsurface camera starts recording. (volts) }\end{array}$ \\
A3 & PJM A conductivity probe overblow signal (volts) \\
A4 & PJM B conductivity probe overblow signal (volts) \\
A5 & PJM C conductivity probe overblow signal (volts) \\
A6 & PJM D conductivity probe overblow signal (volts) \\
A7 & Channel not used \\
A8 & Measurements obtained from Hydrophone 1 (Pa) \\
A9 & Measurements obtained from Hydrophone 2 (Pa) \\
A10 & Measurements obtained from Hydrophone 3 (Pa) \\
A11 & Measurements obtained from Hydrophone 4 (Pa) \\
A12 & Top level pressure transducer 'TA' (Pa) \\
A13 & Top level pressure transducer 'TT' (Pa) \\
A14 & Top level pressure transducer 'TD' (Pa) \\
A15 & Middle level pressure transducer 'MA' (Pa) \\
A16 & Middle level pressure transducer 'MT' (Pa) \\
A17 & Middle level pressure transducer 'MD' (Pa) \\
A18 & Lower level pressure transducer 'BT' (Pa) \\
A19 & Lower level pressure transducer 'BAU' (Pa) \\
A20 & Low level pressure transducer 'BAD' (Pa) \\
B1 & Accelerometer x-axis (points straight down) \\
B2 & Accelerometer y-axis (orthogonal to the other two) \\
B3 & Accelerometer z-axis (points toward the tank center) \\
\hline
\end{tabular}

\subsection{Description of DVDs Containing 8-PJM data}

Several duplicate sets of DVD's containing the 8-PJM test data was provided to BNI. Test files included on DVDs were organized by the day the tests were conducted. The DVD name convention is YYMMDD_Data Acquisition System. On occasion, the DAS-2 runs were copied onto two DVDs due to the large number of files. These sets included an A and B extension to the DVD name. In addition, multiple DVDs were used to copy the high speed video (DAS-4) generated on February 23, 2007 and February 26, 2007. These DVDs included the run numbers on the DVD labels. Each DVD also has files with data taken with no tank activity to provide baseline data. These files used the file naming convention discussed earlier in this section except that the letters BL (indicates baseline) were added to the file names.

There was a separate DVD labeled “Water_Surface_Video” containing files of surface video for each test, corresponding to three different camera viewing angles. For example, for E0025, files included were

• 070219_E0025_run1_pjm4over.avi

- 070219_E0025_run1_pjm7over.avi

• 070219_E0025_run1_pjm4surf.avi. 
These corresponded to the three camera positions:

- pjm4over: a fixed camera over PJM\#4 and looking vertically downward

- pjm7over: a hand-held camera over PJM\#7 looking vertically downward

- pjm7surf: a hand-held camera at the tank rim adjacent to PJM\#7, looking across the tank surface.

The overhead camera positions were used for all of the video tests and the tank rim camera was used in most cases.

\subsection{Description of the Portable Hard Disk Drives Containing 4-PJM Data}

Triplicate copies 4-PJM test data were provided to BNI on three 1TB portable hard drives. Each of the 1TB drives contained copies of all of the electronic data files generated during 4-PJM testing. At the top level the files were grouped under directories "4PJM Clay" and "4PJM Water." Each of these in turn had subdirectories "DAS-1," "DAS-2," "Surface Video," and (in the case of 4PJM water) "DAS-4." The DAS-4 subdirectory contained the subsurface video files. Within the subdirectories were dated folders, named according to the 'YYMMDD' convention that contained the individual data files.

The surface videos taken during 4-PJM testing had their own particular naming convention. The "E\#” experiment number was followed by the characters "SV" (for surface video) and then by either "O" (for overhead) or "S" (for surface or side or south). The O videos were taken from the overhead walkway above the tank; the $\mathrm{S}$ videos were taken from the observation deck at the south rim of the tank. O video files with "PJMAD" in the name were taken from the overhead walkway with a camera aimed down between PJM A and PJM D. O video files with PJMBC in the name were taken from the walkway with a camera aimed down between PJM B and PJM C. In the S videos the camera looked from the south rim toward the tank center and across the tank. In these latter $\mathrm{S}$ videos the camera sometimes panned up and down or zoomed in or out. 



\subsection{Data Discussion}

\subsection{Nozzle Velocity Settings}

This section discusses the determination of the JPP settings required to produce the desired PJM nozzle velocities in both the 8- and 4-PJM configurations. Shakedown tests were performed before beginning the formal test series to determine the JPP drive pressure values needed to achieve the targeted peak average PJM nozzle velocities. ${ }^{(a)}$ These target velocities were 8, 12, 14, $15 \pm 1 \mathrm{~m} / \mathrm{s}$ in the 8-PJM configuration and 6, 8, 10, and $12 \pm 1 \mathrm{~m} / \mathrm{s}$ in the 4-PJM configuration. All runs for determining the JPP rack pressures were performed at an H/D of 0.94 to 0.96 , which was slightly greater than the maximum H/D of 0.8 for the overblow tests. High H/D or fill levels ensured that the PJMs were sufficiently full before starting the drive phase and eliminated the need for suction to fill up the tubes. This simplified subsequent calculations for the nozzle velocity because the velocity could be calculated either from changes in the simulant level in the PJMs or changes in the bulk tank surface level. For a given rack pressure, nozzle velocity increases as the fill level is decreased.

\subsubsection{Peak Average Nozzle Velocity Settings}

The peak average nozzle velocity versus JPP rack pressure curves for water and clay simulants in the 8-PJM configuration are plotted in Figure 9.1. All reported JPP rack pressures are based on gauge values and identified by bar-g units. The rack pressures shown were obtained from sensors on the JPP skids that had expired calibrations. Rack pressures were used only as operational indicators of the drive regulator settings, not as actual pressure measurements, and the values were not used in calculations. All runs were performed at $\mathrm{H} / \mathrm{D}=0.96$. For water simulant, 15 to 20 cycles of PJM level probe data were averaged to obtain the nozzle velocities. On the other hand, for the clay simulant, 5 to 6 cycles of laser-level data were used to obtain the nozzle velocities.

\subsubsection{Rack Pressure Settings for 4-PJM Configuration}

For a given nozzle velocity, a factor of four increase in the volumetric flow rate out of the 4-inch diameter nozzle as compared to the 2-inch diameter nozzle resulted in considerably higher drive air flow requirements for the 4-PJM configuration than those for the 8-PJM configuration. To maximize the drive air flow in the 4-PJM configuration, the supply piping was rearranged so that two drive regulators/JPP combinations (one regulator on each JPP skid) were available to supply air in parallel to each PJM if desired. To enable a further increase in the air flow to the PJMs, modifications were made to the JPP vent system to throttle the flow if needed.

(a). The definition of peak average nozzle velocity can be found in Section 3.2.2 of Meyer et al. (2005). 


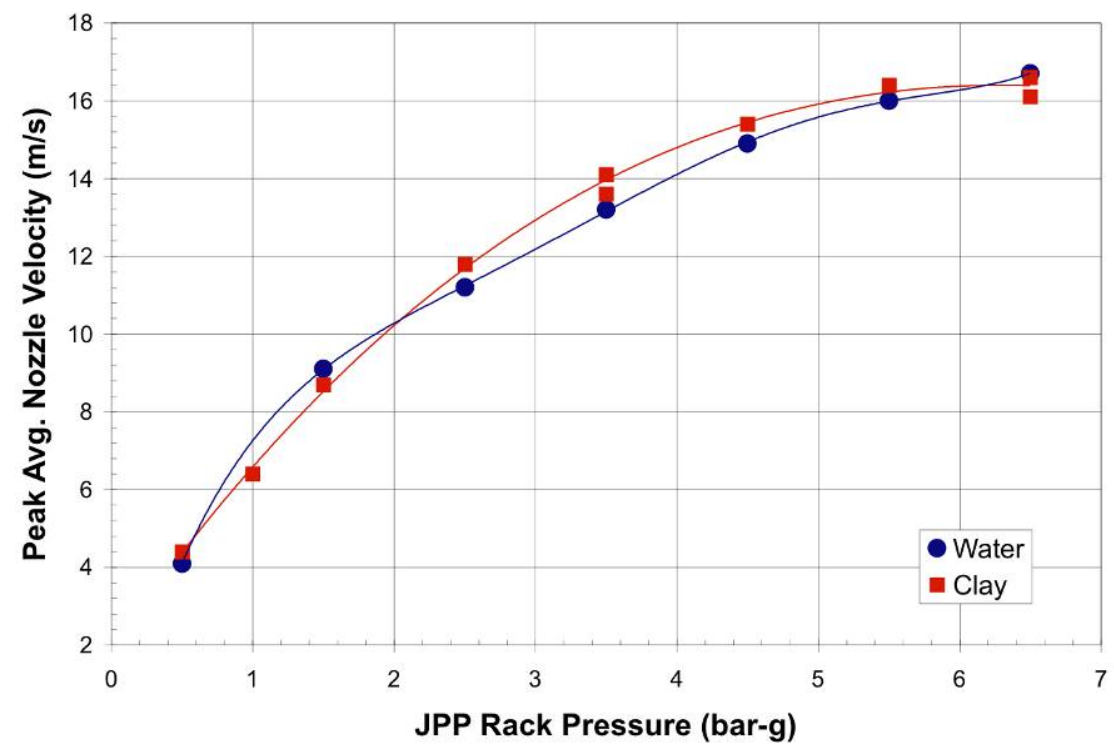

Figure 9.1. Nozzle Velocity Versus Rack Pressure, 8-PJM Configuration (values from Tables 9.1 and 9.2)

All rack pressure versus nozzle velocity determination runs with water were performed at an $\mathrm{H} / \mathrm{D}=0.96$. The peak average nozzle velocities for water were determined in the same way as in the 8PJM testing by averaging 15 to 20 cycles of PJM level probe data. The nozzle velocity versus rack pressure for water using the one and two JPP rack configurations is plotted in Figure 9.2, where blue circles identify water tests in which each PJM was driven with one drive regulator on one JPP rack/skid. For PJMs driven using 1 JPP rack, the vent flow was not throttled to increase the pressure in the PJM. The red circles show the data when the PJMs were driven with two racks and a 3:1 reducer on the JPP vents to choke the vent flow. The last data point for this series was performed at maximum air flow by operating both regulators fully open (RFO) (this data point is labeled on Figure 9.2). ${ }^{\text {(a) }}$ Also shown in Figure 9.2 is one data point (green square) obtained with from a single test conducted by driving each PJM at maximum air flow (i.e., RFO) and without the 3:1 reducer on the JPP vent.

It can be seen from the data in Figure 9.2 that 1) for the same rack pressure, driving with two regulators in parallel resulted in significantly higher velocities than those observed when driving with one regulator and 2) when driving the PJMs with both racks going from an unthrottled vent to a throttled vent resulted in only a marginal increase peak velocity $(12.0 \mathrm{~m} / \mathrm{s}$ for the un-throttled versus $12.2 \mathrm{~m} / \mathrm{s}$ for the throttled vent). Also, during the runs with a 3:1 reducer on the JPP vent, it was observed that throttling the vent flow resulted in a significant backflow of air into off-PJMs through the common vent header when fewer than 4 PJMs were being operated. Because of the marginal benefit and the backflow disadvantage, the approach to increasing the drive velocities by throttling the vent flow was abandoned.

(a) The rack pressure under the RFO condition varies from 7.2 bar-g at the start of the drive phase to $\sim 6.5$ bar-g at the end of the drive phase. Therefore, this point is represented by a nominal 6.8 bar-g on the plots. 


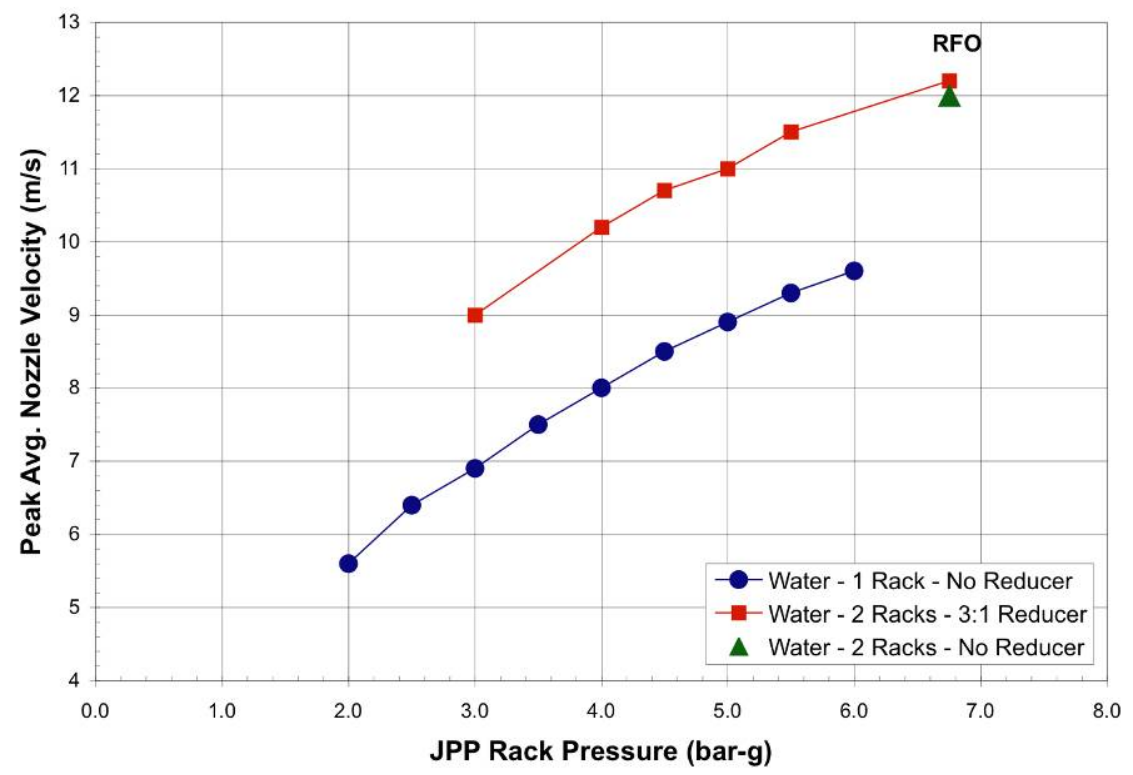

Figure 9.2. Nozzle Velocity Versus Rack Pressure, 4-PJM Configuration, Water Simulant (driving all four PJMs; values from Table 9.3)

At the start of the 4-PJM clay testing, not enough clay was available to accurately calibrate nozzle velocities to drive pressures. On agreement with BNI and DEI, the drive pressures for achieving the target nozzle velocities of 6,8 , and 10 were estimated by matching the slopes of the PJM level probe data versus time during the drive phase using clay simulant with the corresponding slopes obtained during testing of the 4-PJM system with water. In this approach, the slopes were matched to within $\pm 0.25 \mathrm{~m} / \mathrm{s}$. The drive pressures estimated for target velocities of 6 , 8, and $10 \mathrm{~m} / \mathrm{s}$ were 2.6 bar driving with one JPP rack, 4.6 bar driving with one JPP rack, and 4.8 bar driving with both JPP racks, respectively. The tests with the maximum drive velocity, which was presumed to be very close to the target of $12 \mathrm{~m} / \mathrm{s}$, were carried out by driving the PJMs with both JPP racks with drive regulators fully open.

More accurate estimates of the nozzle velocity versus rack pressure in the 4-PJM system with clay were made later after the receipt of more clay. These runs were performed at a simulant level of $\mathrm{H} / \mathrm{D}=0.94$. The rack pressure versus nozzle velocity data is shown in Figure 9.3 for driving the PJMs with one JPP rack (blue circles) and two JPP racks (red circles). Also shown in Figure 9.3 are the estimated pressures (green squares) at the target velocities of 6,8 , and $10 \mathrm{~m} / \mathrm{s}$ obtained by matching slopes discussed above. Unlike the 8-PJM case with clay, the peak average nozzle velocities shown in Figure 9.3 were determined from the PJM level probe data instead of the tank laser-level data because the tank laser level data for the 4-PJM case was found to be extremely noisy and finding 5 to 6 cycles of good noise-free data to average was not possible. It can be seen from the data in Figure 9.3 that the estimated values for $6,8,10 \mathrm{~m} / \mathrm{s}$ fall very close (within $\pm 0.2 \mathrm{~m} / \mathrm{s}$ ) to actual values, and the maximum achievable velocity (i.e., at RFO with two racks) was only $11 \mathrm{~m} / \mathrm{s}$ as opposed to the nominal target of $12 \mathrm{~m} / \mathrm{s}$. 


\subsection{K Value Calculations for Water and Clay}

In tests where PJMs are used in a cycle to mix tank contents, nozzle velocities can be inferred by several methods. Measurements of liquid levels in the tank or in the PJMs can be used, assuming conservation of volume and validity of finite differencing to obtain velocities from successive liquid levels. Alternatively, the pressure in the PJM headspace as a function of time can be used to calculate changing nozzle velocities during the cycle. Finite differencing of liquid levels can result in noisy inferred velocities, though the liquid level behavior is quantitatively correct on the time scale of a pulse. Calculating nozzle velocity from pressure is a simpler and more noise-free, but some calibration is required to determine the contribution of friction to the energy balance (i.e., nozzle loss coefficients).

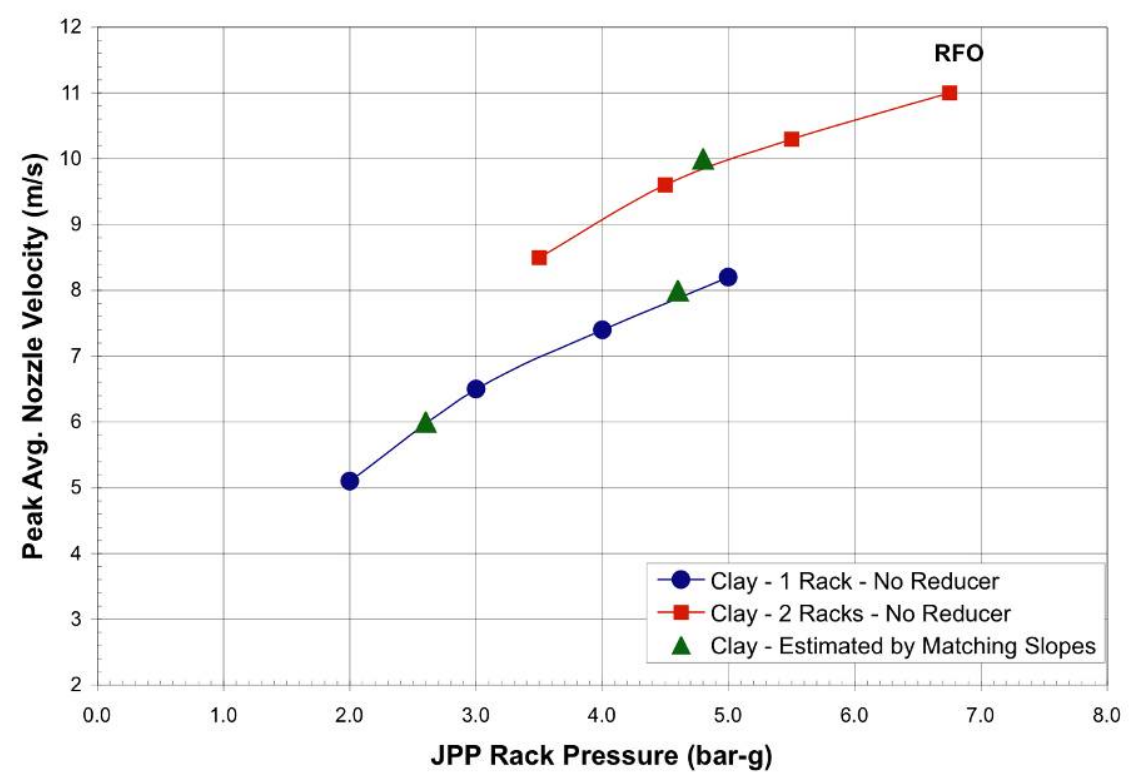

Figure 9.3. Nozzle Velocity Versus Rack Pressure, 4-PJM Configuration, Clay Simulant (driving all four PJMs; values from Tables 9.4)

Bontha et al. (2005) presented a calibration procedure for determining PJM nozzle loss coefficients. Using that approach, nozzle loss coefficients were calculated from the velocity and pressure data. The approach is presented in detail in Appendix C. The nozzle loss coefficients (K values) calculated from level and pressure for water and clay simulants using the 8- and 4-PJM systems are shown in Tables 9.1 through 9.4. The K values listed are based on the velocity at the nozzle exit diameter. It can be seen from the data in Tables 9.1 to 9.4, the loss coefficients for the 4PJM are significantly greater than those for the 8PJM. The larger k-value for the 4-PJM setup is attributed to the vena contracta effect of the free jet emerging from the 4-inch nozzle. In the 8-PJM setup, the $45^{\circ}$ bend at the end of the contraction plus the 12-inch angled pipe appears to prevent the vena contracta effect (flow streamlines re-attach to the pipe in the 12-inch long pipe before emerging into the tank). 
Table 9.1. Peak Average Nozzle Velocities and Loss Coefficients with Water, 8-PJM Configuration

\begin{tabular}{lccc}
\hline \multicolumn{1}{c}{ Test Run Title } & $\begin{array}{c}\text { Peak Average Velocity } \\
\text { from PJM Level }^{(\mathrm{b})} \\
(\mathrm{m} / \mathrm{s})\end{array}$ & $\begin{array}{c}\text { Peak Average } \\
\text { Velocity }^{(\mathrm{a})} \text { from } \\
\text { PJM Pressure } \\
(\mathrm{m} / \mathrm{s})\end{array}$ & $\begin{array}{c}\text { Nozzle Loss } \\
\text { Coefficient for }^{(\mathrm{c})} \\
\text { Forward Flow }^{(\mathrm{c})} \\
(\mathrm{kf})\end{array}$ \\
\hline NV0.5bar-070122-1 & 4.1 & 4.3 & 0.27 \\
\hline NV1.5bar-070119-1 & 9.1 & 9.1 & 0.215 \\
\hline NV2.5bar-070117-1 & 11.2 & 11.2 & 0.273 \\
\hline NV3.5bar-070117-1 & 13.2 & 13.2 & 0.25 \\
\hline NV4.5bar-070117-1 & 14.9 & 14.9 & 0.245 \\
\hline NV5.5bar-070117-1 & 16 & 15.9 & 0.272 \\
\hline NV6.5bar-070117-1 & 16.7 & 16.7 & 0.278 \\
NV7.5bar-070119-1 & 17.6 & 17.5 & 0.22 \\
\hline Average & N/A & N/A & $0.253^{(\mathrm{d})}$ \\
\hline
\end{tabular}

(a) Peak average velocities for the forward flow (discharge process)

(b) PJM tube levels were obtained by the capacitance level probes.

(c) Used for peak average velocity calculations from PJM pressure data for the forward flow (discharge process).

(d) Average over eight test runs of the drag coefficients for the forward flow.

Table 9.2. Peak Average Velocities and Drag Loss Coefficients with Clay, 8-PJM Configuration

\begin{tabular}{|c|c|c|c|c|c|c|}
\hline Test Run Title & $\begin{array}{c}\text { Rack } \\
\text { Pressure } \\
\text { (bar) }\end{array}$ & $\begin{array}{c}\text { Peak Average } \\
\text { Velocity from } \\
\text { Tank Level } \\
\text { Data }^{(\mathrm{a})} \\
(\mathrm{m} / \mathrm{s}) \\
\end{array}$ & $\begin{array}{c}\text { Peak Average } \\
\text { Velocity from } \\
\text { Tank Level } \\
\text { Data }^{(\mathrm{b})} \\
(\mathrm{m} / \mathrm{s}) \\
\end{array}$ & $\begin{array}{c}\text { Peak Average } \\
\text { Velocity from } \\
\text { Pressure } \\
\text { Data }^{(a)} \\
(\mathrm{m} / \mathrm{s}) \\
\end{array}$ & $\begin{array}{c}\text { Peak Average } \\
\text { Velocity from } \\
\text { Pressure } \\
\text { Data }^{(\mathrm{b})} \\
(\mathrm{m} / \mathrm{s}) \\
\end{array}$ & $\mathrm{K}^{(\mathrm{c})}$ \\
\hline NV0.5bar-Clay-070327-1 & 0.5 & 4.4 & 3.9 & - & - & - \\
\hline NV1.0bar-Clay-070329-1 & 1.0 & 6.4 & 5.6 & 6.5 & 5.7 & 0.5 \\
\hline NV1.5bar-Clay-070327-1 & 1.5 & 8.7 & 7.7 & - & - & - \\
\hline NV2.5bar-Clay-070327-1 & 2.5 & 11.8 & 10.4 & - & - & - \\
\hline NV3.5bar-Clay-070326-1 & 3.5 & 14.1 & 12.4 & - & - & - \\
\hline NV_3.5bar-Clay-070423-1 & 3.5 & 13.6 & 12.0 & 13.3 & 12.0 & 0.25 \\
\hline NV4.5bar-Clay-070326-1 & 4.5 & 15.4 & 13.7 & - & - & - \\
\hline NV5.5bar-Clay-070326-1 & 5.5 & 16.4 & 14.5 & - & - & - \\
\hline NV6.5bar-Clay-070327-1 & 6.5 & 16.6 & 14.6 & - & - & - \\
\hline NV_6.5bar-Clay-070423-1 & 6.5 & 16.1 & 14.2 & 16.6 & 14.6 & 0.3 \\
\hline
\end{tabular}

(a) Four inoperative 4 PJM tubes were included into the tank fluid surface area.

(b) Four inoperative 4 PJM tubes were excluded from the tank fluid surface area.

(c) Nozzle loss coefficient in the discharge flow used for the peak average velocity calculation excluding the four inoperative 4 PJM tubes from the tank fluid surface area. Values estimated for $\mathrm{K}$ based on including the four inoperative PJMs into the tank surface area calculation were essentially zero. 
Table 9.3. Peak Average Nozzle Velocities and Loss Coefficients with Water, 4-PJM Configuration

\begin{tabular}{|c|c|c|c|c|}
\hline Test Run Title & $\begin{array}{c}\text { Peak Average } \\
\text { Velocity }^{(\mathrm{a})} \text { from } \\
\text { PJM Level }^{(\mathrm{b})} \\
(\mathrm{m} / \mathrm{s})\end{array}$ & $\begin{array}{c}\text { Peak Average } \\
\text { Velocity }{ }^{(\mathrm{a})} \text { from } \\
\text { PJM Pressure } \\
(\mathrm{m} / \mathrm{s})\end{array}$ & $\begin{array}{c}\text { Nozzle Loss } \\
\text { Coefficient for } \\
\text { Forward Flow }^{(\mathrm{c})} \\
(\mathrm{kf}) \\
\end{array}$ & $\begin{array}{c}\text { Nozzle Loss } \\
\text { Coefficient for } \\
\text { Backward Flow }{ }^{(\mathrm{d})} \\
(\mathrm{kb})\end{array}$ \\
\hline 070709-4PJM-NV 2.0 Bar $^{(\mathrm{e})}$ & 5.6 & 5.6 & 0.850 & 1.8 \\
\hline 070709-4PJM-NV 2.5 Bar $^{(\mathrm{e})}$ & 6.4 & 6.4 & 0.875 & 1.8 \\
\hline 070709-4PJM-NV 3.0 Bar $^{(\mathrm{e})}$ & 6.9 & 7.0 & 0.875 & 1.8 \\
\hline 070709-4PJM-NV 3.5 Bar ${ }^{(\mathrm{e})}$ & 7.5 & 7.5 & 0.875 & 1.8 \\
\hline 070709-4PJM-NV 4.0 Bar $^{(\mathrm{e})}$ & 8.0 & 8.0 & 0.875 & 1.8 \\
\hline 070709-4PJM-NV 4.5 Bar ${ }^{(\mathrm{e})}$ & 8.5 & 8.5 & 0.875 & 1.8 \\
\hline 070709-4PJM-NV 5.0 Bar ${ }^{(\mathrm{e})}$ & 8.9 & - & - & - \\
\hline 070711-4PJM-NV 5.5 Bar $^{(\mathrm{e})}$ & 9.3 & - & - & - \\
\hline 070711-4PJM-NV 6.0 Bar $^{(\mathrm{e})}$ & 9.6 & - & - & - \\
\hline 070803-4PJM-NV 3.0 Bar 3 to $1 \operatorname{Red}^{(\mathrm{f})}$ & 9.0 & 9.0 & 1.000 & 1.9 \\
\hline 070803-4PJM-NV 4.0 Bar 3 to 1 Red $^{(\mathrm{f})}$ & 10.2 & 10.2 & 1.020 & 1.7 \\
\hline 070803-4PJM-NV 4.5 Bar 3 to $1 \operatorname{Red}^{(\mathrm{f})}$ & 10.7 & 10.7 & 1.030 & 1.7 \\
\hline 070803-4PJM-NV 5.0 Bar 3 to $1 \operatorname{Red}^{(\mathrm{f})}$ & 11.0 & 11.1 & 1.040 & 1.7 \\
\hline 070803-4PJM-NV 5.5 Bar 3 to $1 \operatorname{Red}^{(\mathrm{f})}$ & 11.5 & 11.5 & 1.050 & 1.8 \\
\hline 070802-4PJM-NV 6.0 Bar 3 to 1 Red $^{(\mathrm{f})}$ & 12.2 & 12.2 & 1.125 & 1.6 \\
\hline 070802-4PJM-NV 6.0 Bar ${ }^{(\mathrm{g})}$ & 11.98 & 11.95 & 1.05 & 1.8 \\
\hline Average driving with $1 \mathrm{JPP}$ rack & N/A & N/A & 0.871 & 1.8 \\
\hline Average driving with 2 JPP racks & N/A & N/A & 1.045 & 1.74 \\
\hline \multicolumn{5}{|c|}{$\begin{array}{l}\text { (a) Peak average velocities for the forward flow (discharge process). } \\
\text { (b) PJM tube levels were obtained by the capacitance level probes. } \\
\text { (c) Used for peak average velocity calculations from PJM pressure data for the forward flow (disch } \\
\text { (d) Peak average velocities for the backward flow (refill process) are not reported. } \\
\text { (e) Driving all } 4 \text { PJMs with one JPP rack. } \\
\text { (f) Driving all } 4 \text { PJMs with two JPP racks. The JPP vent outlet was throttled with at 3x1 reducer. } \\
\text { (g) Driving all } 4 \text { PJMs with two JPP racks, no throttling of vent outlets. }\end{array}$} \\
\hline
\end{tabular}


Table 9.4. Peak Average Velocities and Nozzle Loss Coefficients with Clay, 4-PJM Configuration

\begin{tabular}{|c|c|c|c|c|}
\hline Test Run Title & $\begin{array}{c}\text { Peak Average } \\
\text { Velocity }^{(\mathrm{a})} \text { from } \\
\text { PJM Level }^{(\mathrm{b})} \\
(\mathrm{m} / \mathrm{s})\end{array}$ & $\begin{array}{c}\text { Peak Average } \\
\text { Velocity }{ }^{(\mathrm{a})} \text { from } \\
\text { PJM Pressure } \\
(\mathrm{m} / \mathrm{s})\end{array}$ & $\begin{array}{c}\text { Nozzle Loss } \\
\text { Coefficient for } \\
\text { Forward Flow } \\
(\mathrm{kf}) \\
\end{array}$ & $\begin{array}{c}\text { Nozzle Loss } \\
\text { Coefficient for } \\
\text { Backward Flow }^{(\mathrm{d})} \\
(\mathrm{kb}) \\
\end{array}$ \\
\hline 070927-PJM-L\&P 2.0 Bar-1 Rack ${ }^{(\mathrm{e})}$ & 5.1 & 5.2 & 1.11 & 1.8 \\
\hline 070927-PJM-L\&P 3.0 Bar-1 Rack ${ }^{(\mathrm{e})}$ & 6.5 & 6.5 & 1.05 & 1.7 \\
\hline 070927-PJM-L\&P 4.0 Bar-1 Rack ${ }^{(\mathrm{e})}$ & 7.4 & 7.4 & 1.06 & 1.65 \\
\hline 070927-PJM-L\&P 5.0 Bar-1 Rack ${ }^{(\mathrm{e})}$ & 8.2 & 8.2 & 1.08 & 1.75 \\
\hline 070928-PJM-L\&P 3.5 Bar-2 Racks ${ }^{(f)}$ & 8.5 & 8.5 & 1.09 & 1.8 \\
\hline 070928-PJM-L\&P 4.5 Bar-2 Racks ${ }^{(f)}$ & 9.6 & 9.6 & 1.1 & 1.6 \\
\hline 070928-PJM-L\&P 5.5 Bar-2 Racks ${ }^{(f)}$ & 10.3 & 10.4 & 1.13 & 1.6 \\
\hline 070927-PJM-L\&P RFO-2 Racks ${ }^{(\mathrm{f}, \mathrm{g})}$ & 11 & 11 & 1.12 & 1.75 \\
\hline Average driving with $1 \mathrm{JPP}$ rack & N/A & N/A & 1.08 & 1.73 \\
\hline Average driving with 2 JPP racks & N/A & N/A & 1.11 & 1.69 \\
\hline \multicolumn{5}{|c|}{$\begin{array}{l}\text { (a) Peak average velocities for the forward flow (discharge process). } \\
\text { (b) PJM tube levels were obtained with the laser level probes. } \\
\text { (c) Used for peak average velocity calculations from PJM pressure data for the forward flow (discharge process). } \\
\text { (d) Peak average velocities for the backward flow (refill process) are not reported. } \\
\text { (e) Driving all } 4 \text { PJMs with one JPP rack. } \\
\text { (f) Driving all } 4 \text { PJMs with two JPP racks. } \\
\text { (g) RFO - drive regulators fully open. }\end{array}$} \\
\hline
\end{tabular}

\subsection{Clay Property Measurements}

\subsubsection{Density}

Seven density measurements of the clay slurry were made using pycnometers during the course of the 8-PJM clay testing. Thirty density measurements on nine samples of the clay slurry were made during the course of the 4-PJM clay testing. Density measurements were made whenever clay, water or make-up slurry were added to the tank, as required by the Test Specifications. No deviations in the density from Test Specification requirements were noted.

\subsubsection{Rheology}

Rheological measurements on 12 grab samples of the clay slurry were made during the course of the 8-PJM overblow testing with clay. Measurements on 13 grab samples of clay were made during the course of the 4-PJM overblow testing. Samples were taken daily and rheology measurements were made at a minimum frequency of once every three days, as required by the Test Specifications. Samples were also taken and measurements made whenever clay, water or make-up slurry were added to the tank. No deviations in the slurry rheology from Test Specification requirements were noted.

Rheological measurements (i.e., yield stress and viscosity) were made using a TA Instruments AR2000 rheometer. Stainless steel sample cups and recessed-end concentric cylinder geometry were used for the measurements. The sample cup used with the rheometer maintained the sample temperature at 
$25^{\circ} \mathrm{C}$. The rheometer was verified every 30 days with a Brookfield standard fluid to ensure that it measured the standard fluid to within $10 \%$ of stated value.

The measurement procedure adhered to the standard Guidelines for Performing Chemical, Physical and Rheological Properties Measurements, 24590-WTP-GPG-RTD-001 Rev. 0. In this procedure the properties of each sample were measured with three different shear rate programs:

- Shear rate ramps up from 0 to $1000 \mathrm{~s}^{-1}$ over 5 minutes

- Shear rate is held at $1000 \mathrm{~s}^{-1}$ for 1 minute

- Shear rate ramps down from 1000 to $0 \mathrm{~s}^{-1}$ over 5 minutes.

Three such measurements were performed on each grab sample from the tank:

- Fresh run-a fresh volume from the grab sample was placed in the cup

- Rerun-a repeat test of the existing volume in cup

- Repeat fresh run-the cup is cleaned and a new volume from the same grab sample was placed in cup.

Using the TA Instruments Rheology Advantage data analysis software, the down ramp data were fit to a Bingham plastic model over a range of shear rates from 50 to $1000 \mathrm{~s}^{-1}$,

$$
\tau=\kappa \dot{\gamma}+\tau_{\mathrm{y}}
$$

where $\tau=$ shear stress $(\mathrm{Pa})$

$\kappa=$ consistency factor or Bingham viscosity (Pa-s; reported in $\mathrm{cP})$

$\hat{\gamma}=$ shear rate or strain rate (per second, $1 / \mathrm{s}$ )

$\tau_{\mathrm{y}}=$ Bingham yield stress, the assumed minimum stress required to initiate fluid movement as determined by a flow curve obtained by fitting rheological data using a Bingham plastic rheological model $(\mathrm{Pa})$.

The Bingham model parameters fit to the down ramp data were used to verify that the yield stress of the clay simulant was within the target range. The Bingham yield stress parameter $\tau_{\mathrm{y}}$ averaged over the fresh run, rerun, and repeat fresh runs was required to be $30 \pm 5 \mathrm{~Pa}$.

\subsection{General Comments on Overblow Experiments}

The laser level probes did not measure water levels reliably. That medium did not reflect enough laser probe beam power from the liquid surface back to the receiver. DAS-1 data on channels "Tk Sur Lvl 1,” “Tk Sur Lvl 2,” “Tk Sur Lvl 3,” and “Tk Sur Lvl 4” were used with caution when the working fluid was water. These data are provided for BNI's information only and are not considered to be of high quality. Laser levels taken when the working fluid was clay are considered to be high-quality data, provided that no error codes (as listed in Tables 8.1 and 8.2) of 0 were recorded for the sensor and time of interest and provided the sensor was operational (again as listed in Tables 8.1 and 8.2). 
Baseline (with the PJMs off) hydrostatic pressure measurements from the in-tank sensors drifted. These sensors were calibrated after installation in the tank to take into account offset shifts during installation. Even so, these offset values were not constant and changed on an hourly time scale. Calibration re-checks verified that the instruments remained linear, with constant psi/volt slopes, after the offset changes occurred. So, dynamic pressure measurements made during overblows were not compromised by the offset shifts. Frequent (roughly hourly) baseline hydrostatic pressure measurements were recorded on DAS-2 to track the changes. Total pressures during an overblow experiment can be estimated by subtracting the mean of the most recent baseline (at the same tank level) from the time series of interest and adding the known hydrostatic head (at that tank level) above the sensor.

The in-tank pressure transmitter in the top position facing down (labeled TD) was calibrated with a non-zero offset. Data from this sensor were recorded on channel 14 of DAS-2. The offset output with 0 psig applied to the sensor during calibration was $-0.75 \mathrm{~V}$ (which drifted subsequently). It was not feasible, because of software limitations and the need for high rates of data acquisition, to remove the offset in real time at DAS-2. Because of this negative voltage offset the recorded gauge pressure values from channel 14 were negative much of the time. As above, dynamic pressure measurements were not compromised by the negative offset. Such offset can be removed to calculate the total pressure, if desired, by subtracting the baseline and adding the hydrostatic head above the sensor as discussed above.

As noted above, the in-tank pressure transducers were calibrated in place in the field. The field pressure source had very small fluctuations that determined the ultimate precision of the calibration. The resulting calibration curves determined individual pressure values to no worse than $\pm 0.027 \mathrm{psi}( \pm 190 \mathrm{~Pa}$ ) Such uncertainty estimates varied from transducer to transducer with factors, such as the tightness of the gas fittings used during calibration, in some cases being an order of magnitude lower than the values listed above.

A QA surveillance of the vendor providing the calibration services for the velocity probes revealed that the vendor did not correct the reported velocities for wall effects arising from the use of an 8-inch pipe diameter for the tow vessel during the probe calibration. For water simulant, the wall correction can be determined theoretically, and the inaccuracy of the reported velocities is estimated to be $+6 \%$ (i.e., the fluid velocities measured by the Valeport velocity probes were $6 \%$ more than the actual velocities). For the clay simulant, however, the determination of the wall effect correction was complicated by the nonNewtonian nature of the simulant and the unknown effect of the viscosity on the Valeport velocity probe performance. Based on the deviation of the probe response from a 1:1 correspondence with the tow velocity, it is estimated this error could be as high as $+25 \%$ (i.e., the fluid velocities measured by the Valeport velocity probes were $25 \%$ more than the actual velocities.

Occasionally, a nozzle conductivity probe short-circuited during clay experiments, making the probe temporarily useless for estimating overblow start times and durations. Our speculation is that this shorting was related to clay deposits on the electrodes. When this was observed is noted below.

\subsection{Notes on 8-PJM Water Data}

When 8-PJM water tests began, nozzle velocity calibration data at low drive pressures ( $0.5 \mathrm{bar})$ had not yet been evaluated. The drive pressure needed to achieve a nozzle velocity of $8 \mathrm{~m} / \mathrm{s}$ was estimated to be 0.9 bar, based on extrapolation of data taken at 1.5, 2.5, 3.5, and 4.5 bar to lower pressures. This drive 
pressure was too low to obtain the target $8( \pm 1) \mathrm{m} / \mathrm{s}$. The actual nozzle velocity during overblow experiments at 0.9 bar drive pressure was roughly $6.5 \mathrm{~m} / \mathrm{s}$.

For tests E0001-E0185, the data obtained by the velocity probe in the lower position should be used with caution. This includes data on channels "Vel Vert 18" and "Vel Rad 18" on DAS-1. Examination of the baseline data indicates that the zero offset increased steadily during testing. From test E0185 onward, the lower velocity probe (sensor S/N 20557) was replaced (with sensor S/N 21073), and the data are considered to be of good quality.

The thermocouple installed near the top of PJM 5 failed starting with run E0029 on 2/20/07 due to a loose connection. The failure is evident from a questionable high or low temperature spike. Starting with run E0072 the thermocouple reading was 300, which means the connection failed completely. Some subsequent temperatures during 8-PJM water runs may appear to have reasonable values, but values from runs after E0028 should not be considered reliable.

\subsection{Notes on 8-PJM Clay Data}

The vertical velocity probe (sensor S/N 21073) at the lowest (18-inch) level exhibited substantial drift during clay testing. Its baseline value drifted from an average (over 30,000 points) of $0.022 \mathrm{~m} / \mathrm{s}$ at the beginning of the clay testing (March 30, 2007) to approximately 0.2 on April 24 (three baselines taken that day within a 4-hour period had average values of $0.20,0.17$, and 0.15 ). A comparison of overblow runs before the baseline shift (E0481-E0483) with comparable runs after the shift (E0731-E0733) showed the same dynamic response in the vertical component of the velocity at 18 inches during the overblow. This suggests the probe was still functioning but with an offset of $\sim 0.15 \mathrm{~m} / \mathrm{s}$.

When the clay was drained from the tank, a significant amount of clay was found adhering to the hydrophones and their masts. The adhered clay was fairly soft and appeared to be a thicker version of the clay in the tank. The adhered clay had a thickness estimated to be about 3-4 inches and formed spherical clumps centered on each hydrophone (the total diameter of a clump was about 6-8 inches). Other equipment in the tank also was observed to have an adhered layer of clay, but the amount on the hydrophones was significantly greater. PNNL and DEI examined the output from the hydrophones over time, over the course of the 8-PJM experiments with clay. They were unable to detect a significant reduction in hydrophone output caused by clay accumulation.

Clay did not adhere to the velocity probe sensors, although it did adhere to the mast holding the sensors. The in-tank pressure sensor tree had clay on the mast and the horizontal portions of the tubes holding the pressure sensors. However, the faces of the sensors appeared free of significant clay buildup. Examination of pressure data for two sets of plotted data taken 12 days apart (runs E0416 and E0578 which done were under equivalent experimental conditions) indicated that the pressure responses were remarkably similar, indicating that the sensors were not affected by clay buildup.

The PJM 8 conductivity probe intermittently produced an abnormally low voltage. Intermittent shorting could have caused this low voltage across the electrodes. However, the mechanism or location of the short circuit was unknown. Researchers at DEI said they observed other instances of low voltages from conductivity probes in some of the other pulse tubes when operating with clay. While the 
conductivity probes clearly provide a different type of signal with clay than with water, they were deemed suitable (by BNI and DEI) for indicating when the overblow starts.

Runs E0731 through E0739 were repetitions of various earlier experiments, but using a higher laser level sampling rate than normal $(10 \mathrm{~Hz}$ instead of the usual $2 \mathrm{~Hz})$. These extra experiments were performed at the request of BNI and DEI.

\subsection{Notes on 4-PJM Water Data}

The elevations of the middle in-tank pressure transducers were set approximately 6 inches lower than originally specified (24 inches instead of 30 inches above the PJM nozzles). The sensors were lowered to position them below an interfering cross beam. The spacing between the middle and upper levels of pressure sensors was maintained at 48 inches. Upper pressure sensors were also lowered 6 inches (to 72 inches above the nozzles). The lower pressure sensors remained at the originally specified 18 inches above the nozzle. Refer to section 5 of this report for more measurements.

The velocity probes were not operating during runs E0778 through E0795 due to a power interruption prior to the start of these runs. To replace the missing data the experiments were repeated with the probes on in runs E0796 through E0814. It should be noted that the video recordings made during runs E0778 through E0795 were not repeated during runs E0796 through E0814.

\subsection{Notes on 4-PJM Clay Data}

Valeport velocity probe at the lower level, sensor S/N 21073, was removed after the water testing and replaced with spare sensor S/N 21077 for the clay testing. This was done because sensor S/N 21073 was only recalibrated in water after the end of the 8-PJM testing, when a baseline drift was noted.

The conductivity probe on PJM C failed sometime after run E1236, during downtime while awaiting a new shipment of clay. Probe output went down to nearly $0 \mathrm{~V}$, indicating a short to ground. Routine tests demonstrated that the problem was not in the signal conditioning electronics but somewhere in the sensor or cabling. The probe operated briefly and intermittently after that, but was essentially dead for runs E1237 through E1378. As with the low probe voltages noticed during the 8-PJM experiments with clay, the failure was attributed to shorting of the probe electrodes with clay deposits.

The simultaneous overblow tests were conducted with PJMs A and B instead of the planned PJMs A and $\mathrm{C}$ because of the failure of the conductivity probe on PJM C. PJM A was always used during simultaneous overblow testing because most of the instrumentation was clustered around it.

Extra simultaneous overblow tests were conducted with PJMs A and C using a simultaneity criterion based on PJM inlet pressures instead of nozzle conductivity. The PJM pressure criterion was tried because of the inability to apply the conductivity criterion used in all other tests (because of the failure of the conductivity probe on PJM C). The pressure criterion used during these runs (E1366 through E1378) was not approved in the Test Plan, evaluated during scoping tests or considered in detail by BNI or DEI. We present these data for BNI's and DEI's information only. 


\subsection{Video Camera Time Synchronization}

Early scoping test data submitted to DEI suggested there was a roughly 200 ms delay between the time overblow was indicated from conductivity probe data and the time it was apparent in the high speed video images. An effort was undertaken by PNNL to quantify purported delays in the transmission of the camera sync pulse from DAS-4 to DAS-2 with bench tests using an oscilloscope to display the pulse. These crude tests estimated an average delay (from 10 determinations) of only $4 \mathrm{~ms}$, but particular delays could have been between a 32-ms lead to a 40-ms lag. There was no indication of a $200 \mathrm{~ms}$ delay in these bench tests. Subsequent evaluation of test results by DEI indicated that the large purported delay was an outcome of the overblow detection thresholding algorithm being used, and the delay was greatly reduced after tuning that algorithm. PNNL made no additional estimates of the possible camera sync pulse delays. The estimates given were from scoping tests and are considered to be "For Information Only."

\subsection{Linear Approximation for Nozzle Velocity Determination}

In this section, we present a simple approach to approximately estimate the peak average nozzle velocities from the PJM level probe data of the overblow runs. It should be noted that the approach presented in this section is only an approximation and the approach presented in Appendix $\mathrm{C}$ along with the loss coefficient data presented in Tables 9.1 to 9.4 represents the best method for determination of the peak average nozzle velocities from the pressure data.

The approach involves performing a linear regression fit of the level probe data during the drive phase in the region where the pulse tube pressure is constant. Because the slope determined from the PJM level probe data represents the average fluid velocity in the pulse tube, it can be converted to the velocity in the nozzle using the PJM/nozzle area ratio and a conversion factor to convert the velocity from "inches/sec" to "m/s" as shown below:

$$
\text { Peak Avg. Noz.Vel. }(\mathrm{m} / \mathrm{sec})=\text { Slope }(\text { inch } / \mathrm{sec}) *\left[\frac{\text { Area PJM }}{\text { Area Nozzle }}\right] * 0.0254(\mathrm{~m} / \text { inch })
$$

For the 8-PJM configuration with a 23.5-inch-ID pulse tube containing a 0.75-inch-OD level probe and 2-inch ID nozzle, the area ratio is 137.92. Similarly, for the 4-PJM configuration with a 23.5-inch-ID pulse tube containing a 0.75 -inch-OD level probe and 4-inch-ID nozzle, the area ratio is 34.48 .

Using the linear approximation outlined here requires some user judgment, particularly in identifying the region of the level probe data to use in the regression due to acceleration effects and because the pressure in the PJM is not truly constant. The following recommendations are a guide:

- When a full set of PJM level data is available, it is recommended that the upper region of the level probe used in the regression be no greater than 50 inches because acceleration effects become important above this point.

- Level probe data below 10 inches for the 8-PJM tests and 15 inches for the 4-PJM runs should not be used in the regression because the portion of the probe near the end penetrates the PJM cone.

Typical examples demonstrating the use of linear approximation at the low and high target velocities for the 8-PJM and 4-PJM configuration are illustrated in Figures 9.4 to 9.7, respectively. In addition to 
the level probe and pressure data, the region of the level probe data used in the regression fit is also shown on the graphs as dashed lines. The estimated velocities from the slope of the linear regression fit and target velocities are shown in Table 9.5.

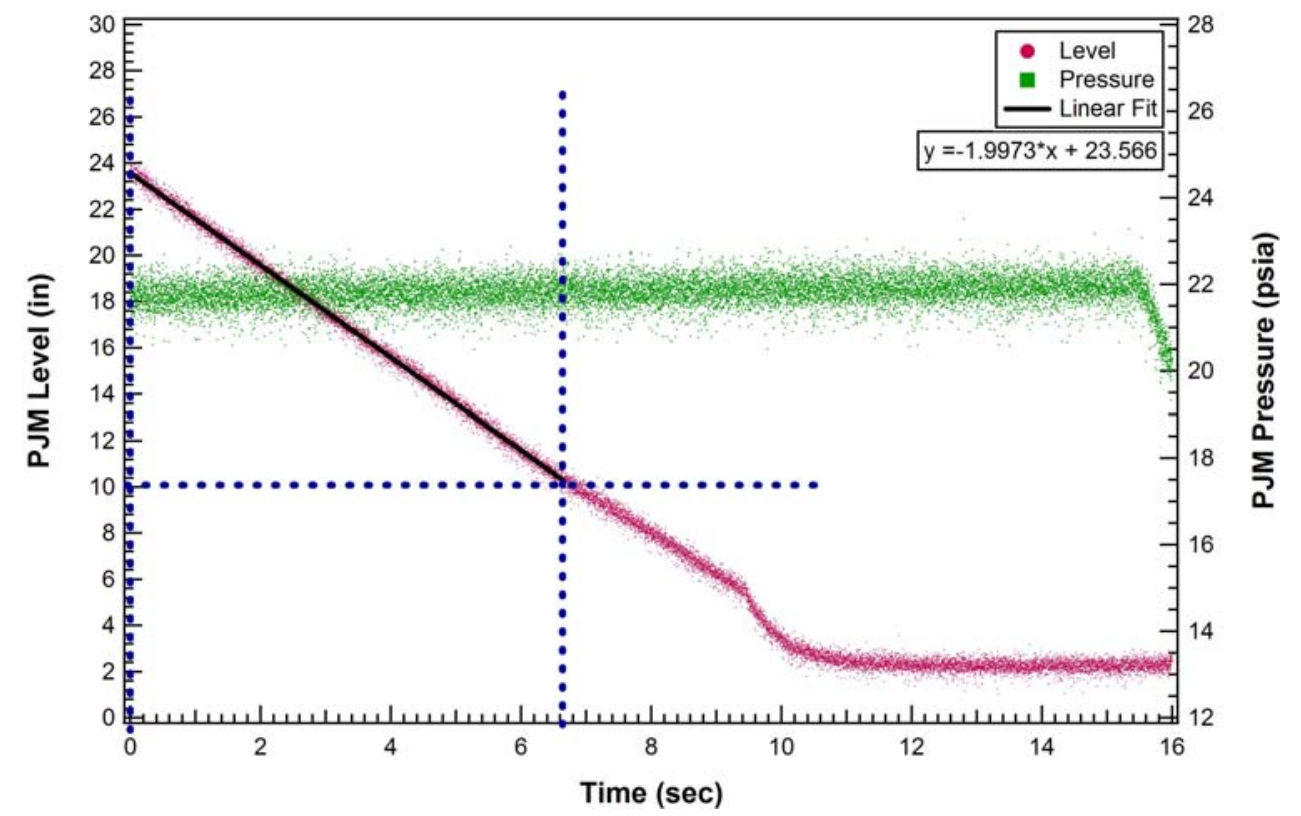

Figure 9.4. Illustration of Linear Approximation for Nozzle Velocity Determination for 8-PJM LowVelocity Case (8 m/s) Using DAS-1 Data from Run E0515

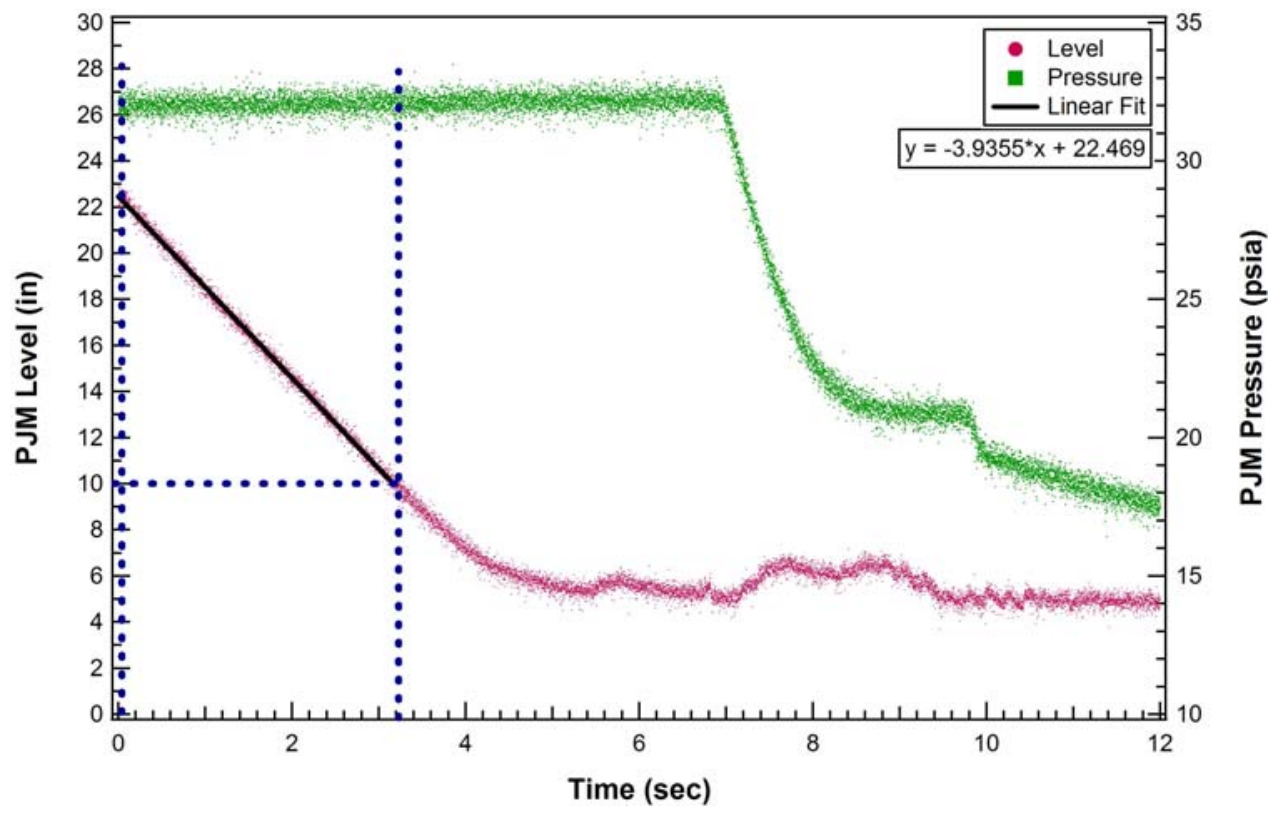

Figure 9.5. Illustration of the Linear Approximation for Nozzle Velocity Determination for the 8PJM High-Velocity Case (14 m/s) Using DAS-1 Data from Run E0481 


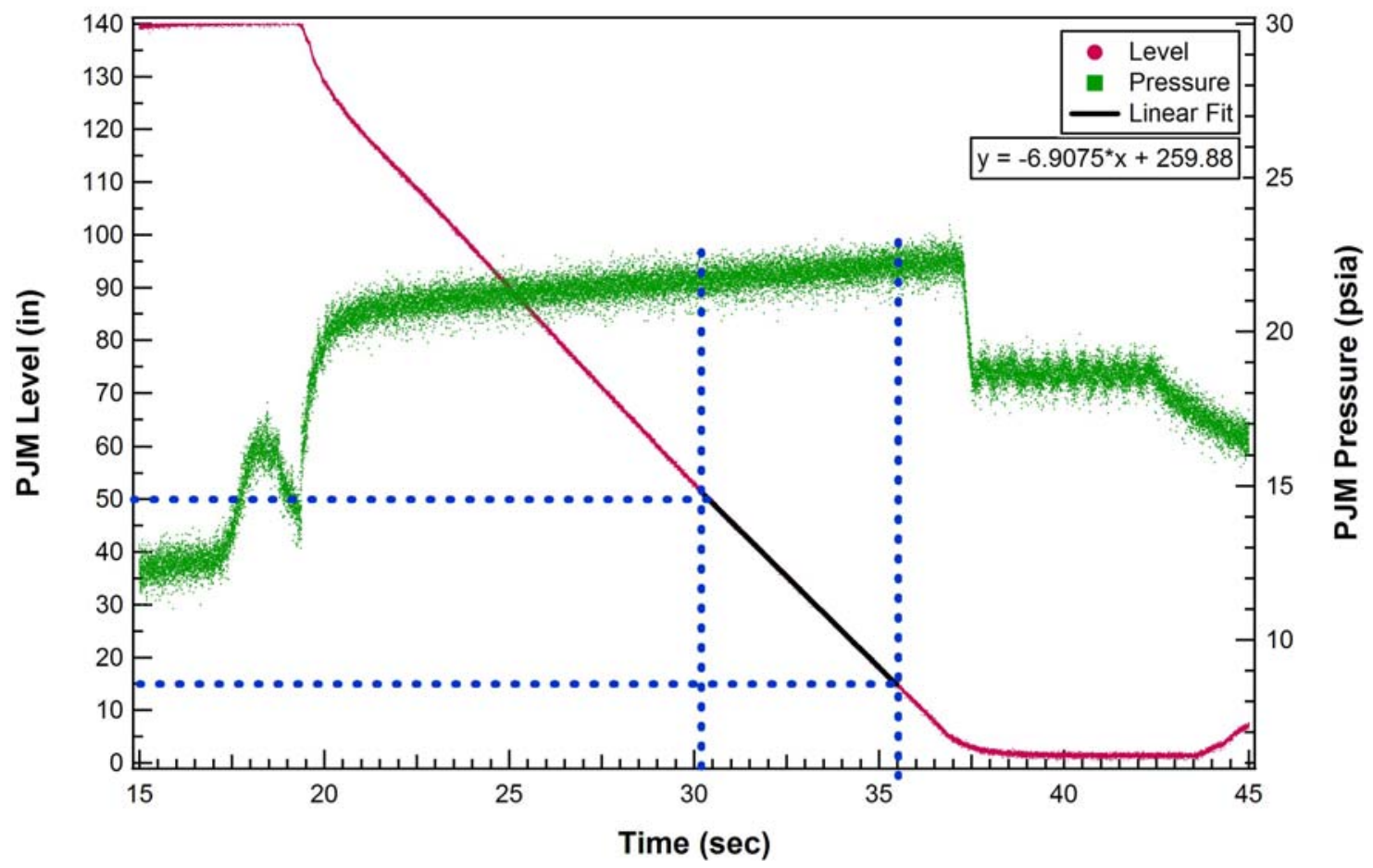

Figure 9.6. Illustration of the Linear Approximation for Nozzle Velocity Determination for the 4-PJM Low-Velocity Case (6 m/s) Using DAS-1 Data from Run E0875

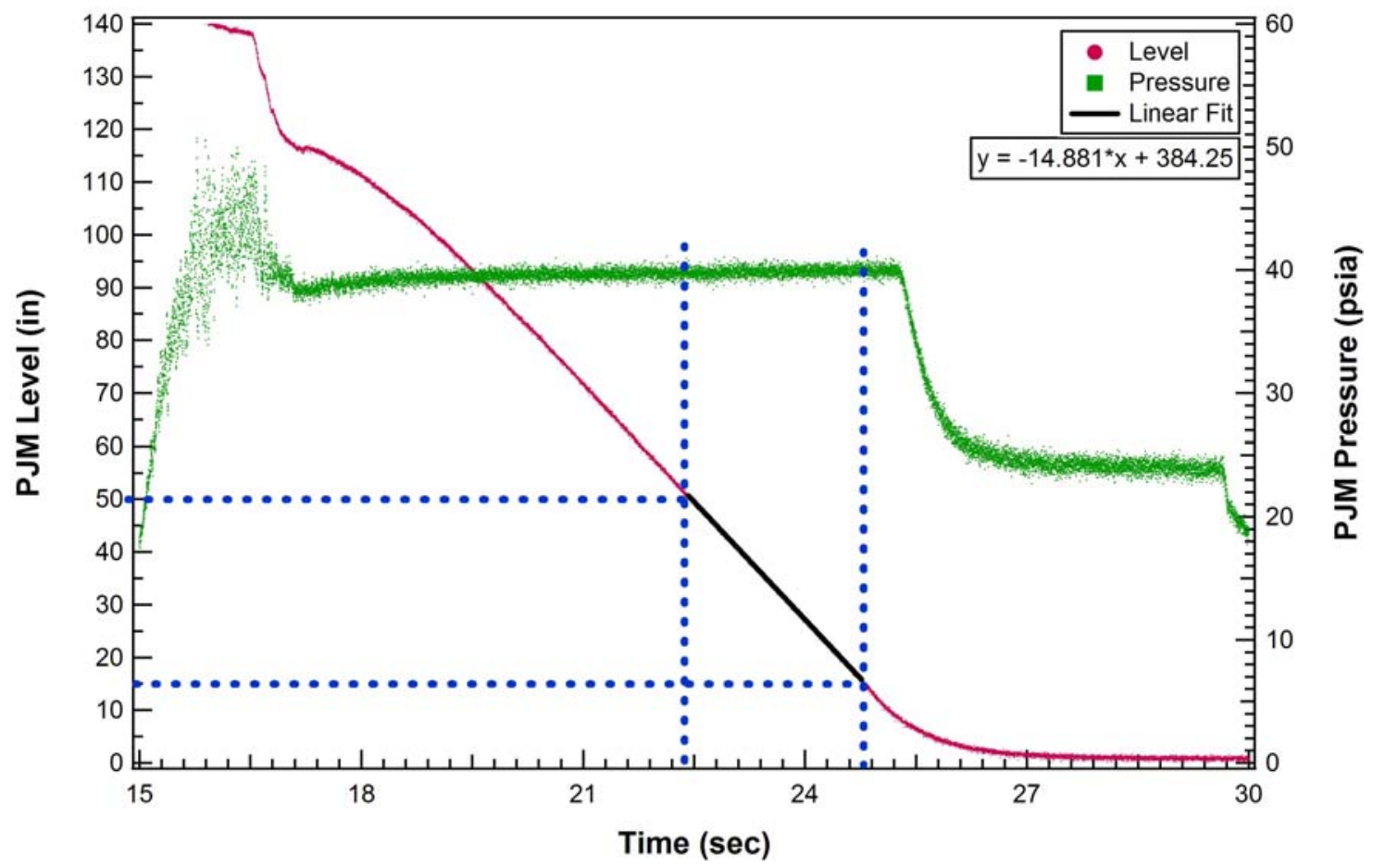

Figure 9.7. Illustration of the Linear Approximation for Nozzle Velocity Determination for the 4-PJM High-Velocity Case (12 m/s) Using DAS-1 Data from Run E0896 
Table 9.5. Target and Estimated Peak Average Nozzle Velocities Using the Linear Approximation

\begin{tabular}{lccc}
\hline & & \multicolumn{2}{c}{ Nozzle Velocity $(\mathrm{m} / \mathrm{s})$} \\
Run No. & Slope & Target & Estimated \\
\hline E0515 & -1.9973 & 8.0 & 7.0 \\
E0481 & -3.9355 & 14.0 & 13.8 \\
E0875 & -6.9075 & 6.0 & 6.0 \\
E0896 & -14.881 & 12.0 & 13.0 \\
\hline
\end{tabular}

\subsection{Example Data}

The volume of data obtained in this project was much too large to allow a complete presentation in this report. Example 8-PJM data from run E0530 and 4-PJM data from run E1302 are provided in plots in Appendixes D and E, respectively. These data are presented for BNI and DEI to aid in the testing of their data preprocessing computer software.

Example runs E0530 and E1302 were both done with clay, so no subsurface videos could be taken. For those runs, the camera synchronization pulse was absent and DAS-2 channel 2 recorded only baseline noise. Additional camera synchronization pulse data from DAS-2 channel 2 are included in Appendixes D and E from runs E0110 and E0781. These were runs with water where subsurface videos were taken and DAS-2 channel 2 records a $5 \mathrm{~V}$ rectangular pulse. 



\subsection{References}

Poloski AP, PA Meyer, LK Jagoda, and PR Hrma. 2004. Non-Newtonian Slurry Simulant Development and Selection for Pulse Jet Mixer Testing. WTP-RPT-111 Rev. 0 (PNWD-3495), Battelle-Pacific Northwest Division, Richland, Washington.

Poloski AP, ST Arm, OP Bredt, TB Calloway, Y Onishi, RA Peterson, GL Smith, and HD Smith. 2006. Final Report: Technical Basis for HLW Vitrification Stream Physical and Rheological Property Bounding Conditions. WTP-RPT-112 Rev. 0 (PNWD-3675), Battelle-Pacific Northwest Division, Richland, Washington.

Bamberger JA, PA Meyer, and JR Bontha. 2005. Technical Basis for Testing Scaled Pulse Jet Mixing Systems for Non-Newtonian Slurries. PNWD-3551 (WTP-RPT-113 Rev. 0), Battelle-Pacific Northwest Division, Richland, Washington.

Bontha JR, DS Trent, MD Johnson, TE Michener, and JM Bates. 2003a. Development and Assessment of the TEMPEST CFD Model of the Pulsed Jet Mixing Systems. PNWD-3261 (WTP-RTP-061), Battelle-Pacific Northwest Division, Richland, Washington.

Bontha JR, JM Bates, CW Enderlin, and MG Dodson. 2003b. Large Tank Experimental Data for Validation of the FLUENT CFD Model of Pulse Jet Mixers. PNWD-3303 (WTP-RTP-081), BattellePacific Northwest Division, Richland, Washington.

Bontha JR, CW Stewart, and DE Kurath. 2005. Technical Basis for Predicting Mixing and Flammable Gas Behavior in the Ultrafiltration Feed Process and High-Level Waste Lag Storage Vessels with NonNewtonian Slurries. PNWD-3676 (WTP-RPT-132 Rev. 0), Battelle-Pacific Northwest Division, Richland, Washington.

Meyer PA, DE Kurath, and CW Stewart. 2005. Overview of the Pulse Jet Mixer Non-Newtonian Scaled Test Program. PNWD-3677 (WTP-RPT-127 Rev. 0), Battelle-Pacific Northwest Division, Richland, Washington. 

Appendix A

\section{Master Run Log, 8-PJM Configuration}



Table A.1. Master Run Log, 8-PJM Configuration

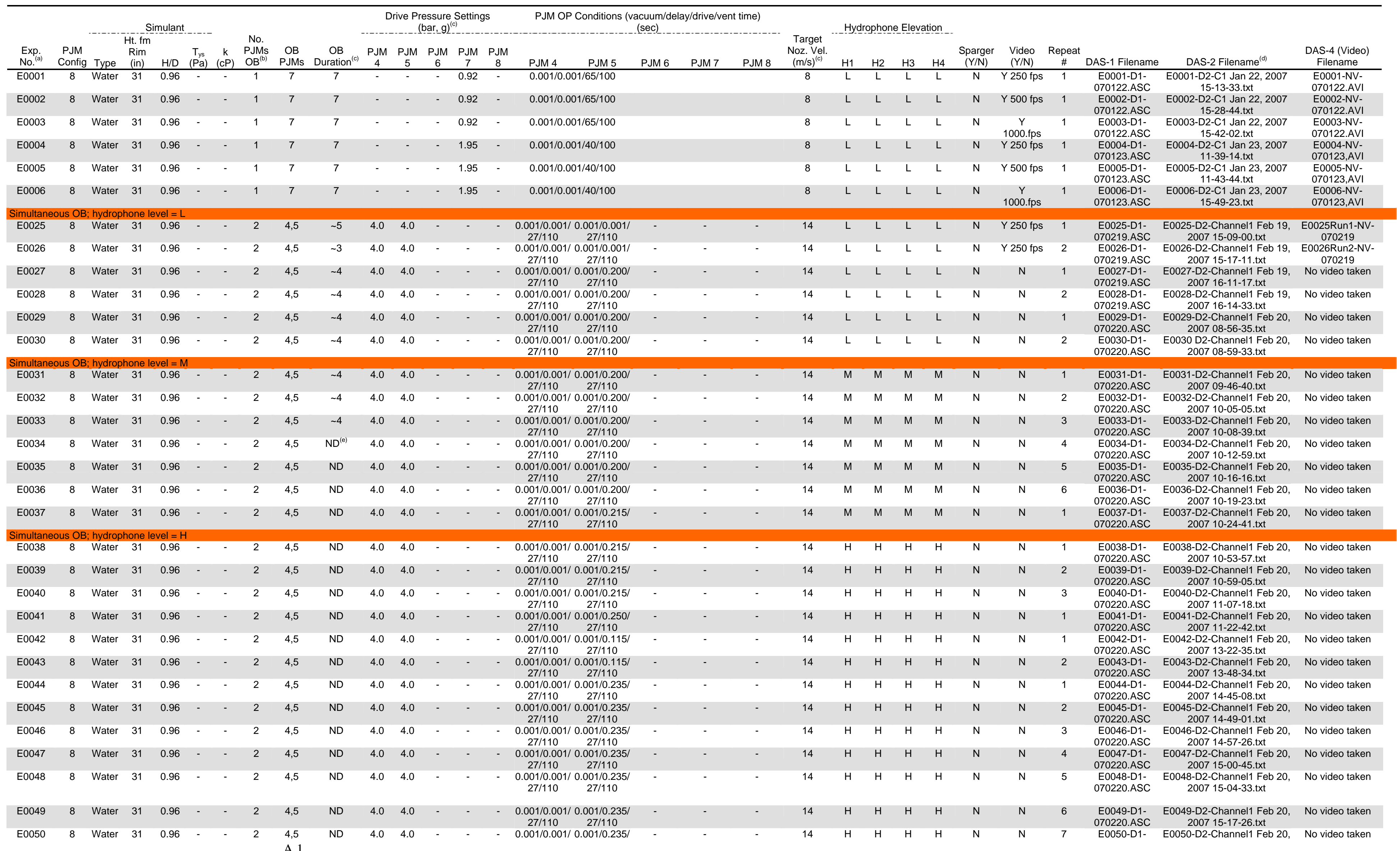




\begin{tabular}{|c|c|c|c|c|c|c|c|c|c|c|c|c|c|c|c|c|c|c|c|c|c|c|c|c|c|c|c|c|c|c|}
\hline \multirow[b]{2}{*}{$\begin{array}{l}\text { Exp. } \\
\text { No.(a) } \\
\end{array}$} & \multirow[b]{2}{*}{$\begin{array}{l}\text { PJM } \\
\text { Config } \\
\end{array}$} & \multicolumn{5}{|c|}{ Simulant } & \multirow[b]{2}{*}{$\begin{array}{c}\text { No. } \\
\text { PJMs } \\
\mathrm{OB}^{(0)} \\
\end{array}$} & \multirow[b]{2}{*}{$\begin{array}{l}\text { OB } \\
\text { PJMs } \\
\end{array}$} & \multirow[b]{2}{*}{$\begin{array}{c}\text { OB } \\
\text { Duration } \\
\end{array}$} & \multicolumn{5}{|c|}{$\begin{array}{l}\text { Drive Pressure Settings } \\
\quad\left(b_{a r}-g\right)^{(c)}\end{array}$} & \multicolumn{5}{|c|}{$\begin{array}{l}\text { PJM OP Conditions (vacuum/delay/drive/vent time) } \\
\text { (sec) }\end{array}$} & \multirow[b]{2}{*}{$\begin{array}{c}\text { Target } \\
\text { Noz Vel. } \\
(\mathrm{m} / \mathrm{s})^{(\mathrm{c})}\end{array}$} & \multicolumn{4}{|c|}{ Hydrophone Elevation } & \multirow[b]{2}{*}{$\begin{array}{c}\text { Sparger } \\
(Y / N)\end{array}$} & \multirow[b]{2}{*}{$\begin{array}{l}\text { Video } \\
(\mathrm{Y} / \mathrm{N})\end{array}$} & \multirow[b]{2}{*}{$\begin{array}{c}\text { Repeat } \\
\#\end{array}$} & \multirow[b]{2}{*}{ DAS-1 Filename } & \multirow{2}{*}{ DAS-2 Filename ${ }^{(d)}$} & \multirow[b]{2}{*}{$\begin{array}{l}\text { DAS-4 (Video } \\
\text { Filename }\end{array}$} \\
\hline & & Type & $\begin{array}{l}\text { Ht. ffm } \\
\text { Rim } \\
\text { (in) }\end{array}$ & $H / D$ & $\begin{array}{c}T_{y s} \\
(P a)\end{array}$ & $\begin{array}{c}k \\
(\mathrm{cP})\end{array}$ & & & & PJM & $\begin{array}{c}\text { PJM } \\
5\end{array}$ & $\begin{array}{c}\text { PJM } \\
6\end{array}$ & $\begin{array}{l}\text { PJM } \\
7\end{array}$ & $\begin{array}{c}\text { PJM } \\
8\end{array}$ & PJM 4 & PJM 5 & PJM 6 & PJM 7 & PJM 8 & & $\mathrm{H} 1$ & $\mathrm{H} 2$ & H3 & $\mathrm{H}_{4}$ & & & & & & \\
\hline E0051 & 8 & Water & 31 & 0.96 & & & 2 & 4,5 & ND & 4.0 & 4.0 & 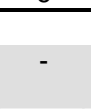 & & 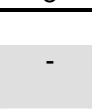 & $\begin{array}{l}27 / 110 \\
0.001 / 0.001 \\
27 / 110\end{array}$ & $\begin{array}{l}27 / 110 \\
10.001 / 0.235 / \\
27 / 110\end{array}$ & & & & 14 & $\mathrm{H}$ & $\mathrm{H}$ & $\mathrm{H}$ & $\mathrm{H}$ & $\mathrm{N}$ & $\mathrm{N}$ & 8 & $\begin{array}{l}\text { 070220.ASC } \\
\text { E0051-D1- } \\
\text { 070220.ASC }\end{array}$ & $\begin{array}{c}\text { 2007 15-19-43.txt } \\
\text { E0051-D2-Channel Fep 20, } \\
\text { 2007 15-22-49.txt 20, }\end{array}$ & No video taken \\
\hline E0052 & 8 & Water & 31 & 0.96 & & - & 2 & 4,5 & ND & 4.0 & 4.0 & - & - & - & $\begin{array}{c}0.001 / 0.001 \\
27 / 110\end{array}$ & 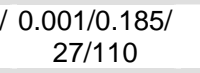 & & - & - & 14 & $\mathrm{H}$ & $\mathrm{H}$ & $\mathrm{H}$ & $\mathrm{H}$ & $\mathrm{N}$ & $\mathrm{N}$ & 1 & $\begin{array}{l}\text { E0052-D1- } \\
\text { 070220.ASC }\end{array}$ & $\begin{array}{l}\text { E0052-D2-Channel1 Feb 20, } \\
\text { 2007 15-30-15.txt }\end{array}$ & No video taken \\
\hline E0053 & 8 & Water & 31 & 0.96 & & - & 2 & 4,5 & ND & 4.0 & 4.0 & - & & - & $\begin{array}{c}0.001 / 0.001 \\
27 / 110\end{array}$ & $\begin{array}{l}\text { / } 0.001 / 0.185 / \\
27 / 110\end{array}$ & & & & 14 & $\mathrm{H}$ & $\mathrm{H}$ & $\mathrm{H}$ & $\mathrm{H}$ & $\mathrm{N}$ & $\mathrm{N}$ & 2 & $\begin{array}{l}\text { E0053-D1- } \\
\text { 070220.ASC }\end{array}$ & $\begin{array}{l}\text { E0053-D2-Channel1 Feb 20, } \\
\text { 2007 15-33-14.txt }\end{array}$ & No video taken \\
\hline E0054 & 8 & Water & 31 & 0.96 & - & - & 2 & 4,5 & ND & 4.0 & 4.0 & - & - & - & $\begin{array}{l}0.001 / 0.001 \\
27 / 110\end{array}$ & $\begin{array}{l}\text { / } 0.001 / 0.185 / \\
27 / 110\end{array}$ & - & - & - & 14 & $\mathrm{H}$ & $\mathrm{H}$ & H & $\mathrm{H}$ & $\mathrm{N}$ & $\mathrm{N}$ & 3 & $\begin{array}{l}\text { E0054-D1- } \\
\text { 077222.0SC }\end{array}$ & $\begin{array}{l}\text { E0054-D2-Channel1 Feb 20, } \\
\text { 2007 15-43-32.xt }\end{array}$ & No video taken \\
\hline E0055 & 8 & Water & 31 & 0.96 & - & - & 2 & 4,5 & ND & 4.0 & 4.0 & - & - & - & $\begin{array}{l}0.001 / 10.001 \\
27 / 110\end{array}$ & $\begin{array}{l}/ 0.001 / 0.150 / \\
27 / 110\end{array}$ & - & - & - & 14 & $\mathrm{H}$ & $\mathrm{H}$ & H & H & $\mathrm{N}$ & $\mathrm{N}$ & 1 & $\begin{array}{l}\text { E0055-D1- } \\
\text { 070220.ASC }\end{array}$ & $\begin{array}{l}\text { E0055-D2-Chanel1 Feb 20, } \\
\text { 2007 15-48-27.txt }\end{array}$ & No video taken \\
\hline E0056 & 8 & Water & 31 & 0.96 & - & - & 2 & 4,5 & ND & 4.0 & 4.0 & - & - & - & $\begin{array}{l}0.001 / 0.001 \\
27 / 110\end{array}$ & $\begin{array}{l}\text { / 0.001/0.160/ } \\
27 / 110\end{array}$ & - & - & - & 14 & $\mathrm{H}$ & $\mathrm{H}$ & H & $\mathrm{H}$ & $\mathrm{N}$ & $\mathrm{N}$ & 1 & $\begin{array}{l}\text { E0056-D1- } \\
\text { 0772221.1SC }\end{array}$ & $\begin{array}{l}\text { E0056-D2-Channel1 Feb 21, } \\
\text { 2007 10-05-10.txt }\end{array}$ & No video taken \\
\hline E0057 & 8 & Water & 31 & 0.96 & - & - & 2 & 4,5 & $\mathrm{ND}$ & 4.0 & 4.0 & - & - & - & $\begin{array}{l}0.001 / 10.001 \\
27 / 110\end{array}$ & $\begin{array}{l}/ 0.001 / 10.160 / \\
27 / 110\end{array}$ & - & - & - & 14 & H & $\mathrm{H}$ & H & $\mathrm{H}$ & $\mathrm{N}$ & $\mathrm{N}$ & 2 & $\begin{array}{l}\text { E0057-D1- } \\
\text { 070221.ASC }\end{array}$ & $\begin{array}{l}\text { E0057-D2-Chanell Feb 21, } \\
\text { 2007 10-25-40.txt }\end{array}$ & No video taken \\
\hline E0058 & 8 & Water & 31 & 0.96 & & - & 2 & 4,5 & ND & 4.0 & 4.0 & - & - & - & $\begin{array}{c}0.001 / 0.001 \\
27 / 110\end{array}$ & $\begin{array}{l}\text { / } 0.001 / 0.110 / \\
27 / 110\end{array}$ & & - & 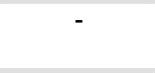 & 14 & $\mathrm{H}$ & $\mathrm{H}$ & $\mathrm{H}$ & $\mathrm{H}$ & $\mathrm{N}$ & $\mathrm{N}$ & 1 & $\begin{array}{l}\text { E0058-D1- } \\
\text { 070221.ASC }\end{array}$ & $\begin{array}{l}\text { E0058-D2-Channel1 Feb 21, } \\
\text { 2007 10-33-15.txt }\end{array}$ & No video taken \\
\hline E0059 & 8 & Water & 31 & 0.96 & & - & 2 & 4,5 & ND & 4.0 & 4.0 & - & & - & $\begin{array}{c}0.001 / 0.001 \\
27 / 110\end{array}$ & $\begin{array}{l}\text { / } 0.001 / 0.110 / \\
27 / 110\end{array}$ & & & & 14 & $\mathrm{H}$ & $\mathrm{H}$ & $\mathrm{H}$ & $\mathrm{H}$ & $\mathrm{N}$ & $\mathrm{N}$ & 2 & $\begin{array}{l}\text { E0059-D1- } \\
\text { 070221.ASC }\end{array}$ & $\begin{array}{l}\text { E0059-D2-Channel1 Feb 21, } \\
\text { 2007 10-42-05.txt }\end{array}$ & No video taken \\
\hline E0060 & 8 & Water & 31 & 0.96 & & - & 2 & 4,5 & ND & 4.0 & 4.0 & - & & - & $\begin{array}{c}0.001 / 0.001 \\
27 / 110\end{array}$ & $\begin{array}{l}\text { / } 0.001 / 0.110 / \\
27 / 110\end{array}$ & & & & 14 & $\mathrm{H}$ & $\mathrm{H}$ & $\mathrm{H}$ & $\mathrm{H}$ & $\mathrm{N}$ & $\mathrm{N}$ & 3 & $\begin{array}{l}\text { E0060-D1- } \\
\text { 070221.ASC }\end{array}$ & $\begin{array}{l}\text { E0060-D2-Channel1 Feb 21, } \\
\text { 2007 10-52-50.txt }\end{array}$ & No video taken \\
\hline E0061 & 8 & Water & 31 & 0.96 & & - & 2 & 4,5 & ND & 4.0 & 4.0 & - & - & - & $\begin{array}{l}0.000 / 10.001 \\
27 / 110\end{array}$ & $\mid$ & - & - & - & 14 & $\mathrm{H}$ & $\mathrm{H}$ & $\mathrm{H}$ & $\mathrm{H}$ & $\mathrm{N}$ & $\mathrm{N}$ & 4 & $\begin{array}{l}\text { E0061-D1- } \\
\text { 070221.ASC }\end{array}$ & $\begin{array}{l}\text { E0061-D2-Channel1 Feb 21, } \\
\text { 2007 11-02-56.txt }\end{array}$ & No video taken \\
\hline E0062 & 8 & Water & 31 & 0.96 & - & - & 2 & 4,5 & ND & 4.0 & 4.0 & - & - & - & $\begin{array}{l}0.001 / 0.001 \\
27 / 110\end{array}$ & $\begin{array}{l}\text { / 0.001/0.110/ } \\
27 / 110\end{array}$ & - & - & - & 14 & H & $\mathrm{H}$ & H & $\mathrm{H}$ & $\mathrm{N}$ & $\mathrm{N}$ & 5 & $\begin{array}{l}\text { E0062-D1- } \\
\text { 077222.1.SAC }\end{array}$ & $\begin{array}{l}\text { E0062-D2-Channel1 Feb 21, } \\
\text { 20707 11-16-29 ty }\end{array}$ & No video taken \\
\hline E0063 & 8 & Water & 31 & 0.96 & - & - & 2 & 4,5 & ND & 4.0 & 4.0 & - & - & - & $\begin{array}{c}0.001 / 0.001 \\
27 / 110\end{array}$ & $\begin{array}{l}\text { / } 0.001 / 0.110 / \\
27 / 110\end{array}$ & - & - & - & 14 & $\mathrm{H}$ & $\mathrm{H}$ & $\mathrm{H}$ & $\mathrm{H}$ & N & $\mathrm{N}$ & 6 & $\begin{array}{l}\text { E0063-D1- } \\
\text { 070221.ASC }\end{array}$ & $\begin{array}{l}\text { E0063-D2-Channel Feb 21, } \\
\text { 2007 11-26-57.txt }\end{array}$ & No video taken \\
\hline E0064 & 8 & Water & 31 & 0.96 & - & - & 2 & 4,5 & ND & 4.0 & 4.0 & - & - & - & $\begin{array}{c}0.001 / 0.001 \\
27 / 110\end{array}$ & $\begin{array}{l}\text { / } 0.001 / 0.110 / \\
27 / 110\end{array}$ & - & - & - & 14 & $\mathrm{H}$ & $\mathrm{H}$ & $\mathrm{H}$ & $\mathrm{H}$ & $\mathrm{N}$ & $\mathrm{N}$ & 7 & $\begin{array}{l}\text { E0064-D1- } \\
\text { 070221.ASC }\end{array}$ & $\begin{array}{l}\text { E0064-D2-Channel1 Feb 21, } \\
\text { 2007 11-39-29.txt }\end{array}$ & No video taken \\
\hline E0065 & 8 & Water & 31 & 0.96 & - & - & 2 & 4,5 & ND & 4.0 & 4.0 & - & - & - & $\begin{array}{l}0.001 / / 0.001 \\
27 / 110\end{array}$ & $\mid \begin{array}{l}0.001 / 0.110 / \\
27 / 110\end{array}$ & - & - & - & 14 & H & $\mathrm{H}$ & H & $\mathrm{H}$ & $\mathrm{N}$ & $\mathrm{N}$ & 1 & $\begin{array}{l}\text { E0065-D1- } \\
\text { 070222.ASC }\end{array}$ & $\begin{array}{l}\text { E0065-D2-Channel1 Feb 21, } \\
\text { 2007 11-48-54.4xt }\end{array}$ & No video taken \\
\hline E0066 & 8 & Water & 31 & 0.96 & - & - & 2 & 4,5 & ND & 4.0 & 4.0 & - & - & - & $\begin{array}{c}0.001 / 0.001 \\
27 / 110\end{array}$ & $\begin{array}{l}\text { / } 0.001 / 0.110 / \\
27 / 110\end{array}$ & - & - & - & 14 & $\mathrm{H}$ & $\mathrm{H}$ & $\mathrm{H}$ & $\mathrm{H}$ & $\mathrm{N}$ & $\mathrm{N}$ & 2 & $\begin{array}{l}\text { E0066-D1- } \\
\text { 070221.ASC }\end{array}$ & $\begin{array}{l}\text { E0066-D2-Channel1 Feb 21, } \\
2007 \text { 13-39-56.txt }\end{array}$ & No video taken \\
\hline E0067 & 8 & Water & 31 & 0.96 & & & 2 & 4,5 & ND & 4.0 & 4.0 & - & 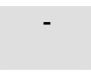 & - & $\begin{array}{c}0.001 / 0.001 \\
27 / 110\end{array}$ & $\begin{array}{l}\text { / } 0.001 / 0.020 / \\
27 / 110\end{array}$ & & - & - & 14 & $\mathrm{H}$ & $\mathrm{H}$ & $\mathrm{H}$ & $\mathrm{H}$ & $\mathrm{N}$ & $\mathrm{N}$ & 1 & $\begin{array}{l}\text { E0067-D1- } \\
\text { 070221.ASC }\end{array}$ & $\begin{array}{l}\text { E0067-D2-Channel1 Feb 21, } \\
\text { 2007 13-51-58.txt }\end{array}$ & No video taken \\
\hline E0068 & 8 & Water & 31 & 0.96 & & - & 2 & 4,5 & ND & 4.0 & 4.0 & - & - & - & $\begin{array}{c}0.001 / 0.001 \\
27 / 110\end{array}$ & $\begin{array}{l}\text { / } 0.001 / 0.001 / / \\
27 / 110\end{array}$ & & - & - & 14 & $\mathrm{H}$ & $\mathrm{H}$ & $\mathrm{H}$ & $\mathrm{H}$ & $\mathrm{N}$ & $\mathrm{N}$ & 1 & $\begin{array}{l}\text { E0068-D1- } \\
\text { 070221.ASC }\end{array}$ & $\begin{array}{l}\text { E0068-D2-Channel1 Feb 21, } \\
2007 \text { 14-01-41.txt }\end{array}$ & No video taken \\
\hline E0069 & 8 & Water & 31 & 0.96 & - & - & 2 & 4,5 & ND & 3.9 & 4.0 & - & - & - & $\begin{array}{c}0.001 / 0.001 \\
27 / 110\end{array}$ & $\begin{array}{l}\text { / } 0.001 / 0.001 / \\
27 / 110\end{array}$ & - & - & - & 14 & H & H & H & H & $\mathrm{N}$ & $\mathrm{N}$ & 1 & $\begin{array}{l}\text { E0069-D1- } \\
\text { 0772221.1SC }\end{array}$ & $\begin{array}{l}\text { E00069-D2-Channe } \\
\text { 2007 14-21- }\end{array}$ & No video taken \\
\hline E0070 & 8 & Water & 31 & 0.96 & - & - & 2 & 4,5 & ND & 3.9 & 4.0 & - & - & - & $\begin{array}{c}0.001 / 0.001 \\
27 / 110\end{array}$ & $\begin{array}{l}\text { / } 0.001 / 0.001 / \\
27 / 110\end{array}$ & - & - & - & 14 & $\mathrm{H}$ & $\mathrm{H}$ & $\mathrm{H}$ & $\mathrm{H}$ & $\mathrm{N}$ & $\mathrm{N}$ & 2 & $\begin{array}{l}\text { E00070-D1- } \\
\text { 070221.ASC }\end{array}$ & $\begin{array}{r}\text { E0070-D2-Char } \\
2007 \text { 14-3 }\end{array}$ & No video taken \\
\hline E0071 & 8 & Water & 31 & 0.96 & - & - & 2 & 4,5 & ND & 3.9 & 4.0 & - & - & - & $\begin{array}{c}0.001 / 0.001 \\
07 / 110\end{array}$ & $/ 0.001 / 0.001 /$ & - & - & - & 14 & $\mathrm{H}$ & $\mathrm{H}$ & $\mathrm{H}$ & $\mathrm{H}$ & N & N & 3 & $\begin{array}{l}\text { E0071-D1- } \\
\text { 070221.ASC }\end{array}$ & $\begin{array}{l}\text { E0071-D2-Channel1 Feb 21, } \\
\text { 2007 14-38-04.txt }\end{array}$ & No video taken \\
\hline E0072 & 8 & Water & 31 & 0.96 & - & - & 2 & 4,5 & ND & 3.9 & 4.0 & - & - & - & $\begin{array}{c}0.001 / 0.001 \\
27 / 110\end{array}$ & $\begin{array}{l}/ 0.001 / 0.100 / \\
27 / 110\end{array}$ & - & - & - & 14 & $\mathrm{H}$ & $\mathrm{H}$ & $\mathrm{H}$ & $\mathrm{H}$ & $\mathrm{N}$ & $\mathrm{N}$ & 1 & $\begin{array}{l}\text { E0072-D1- } \\
\text { 070221.ASC }\end{array}$ & $\begin{array}{l}\text { E0072-D2-Channel1 Feb 21, } \\
\text { 2007 14-43-45.txt }\end{array}$ & No video taken \\
\hline $\begin{array}{l}\text { High wate } \\
\text { E0073 }\end{array}$ & $\begin{array}{l}\text { evel. } \\
8\end{array}$ & $\begin{array}{l}\text { hydroph } \\
\text { Water }\end{array}$ & $\begin{array}{l}\text { lone lev } \\
31\end{array}$ & $\begin{array}{l}\text { el }=\mathrm{H} \\
0.96\end{array}$ & & & 1 & 5 & ND & & 4.0 & & & & & $\begin{array}{r}0.001 / \\
27 !\end{array}$ & & & & 14 & $\mathrm{H}$ & $\mathrm{H}$ & $\mathrm{H}$ & $\mathrm{H}$ & $\mathrm{N}$ & $\mathrm{N}$ & 1 & & E0073 & No video taken \\
\hline E0074 & 8 & Water & 31 & 0.96 & - & - & 1 & 5 & ND & & 4.0 & - & - & - & - & $\begin{array}{l}0.001 / 0.001 / \\
27 / 110\end{array}$ & & - & - & 14 & $\mathrm{H}$ & $\mathrm{H}$ & $\mathrm{H}$ & $\mathrm{H}$ & $\mathrm{N}$ & $\mathrm{N}$ & 2 & -AS1- & $\begin{array}{r}E 0074-D 2 \\
200\end{array}$ & No video taken \\
\hline E0075 & 8 & Water & 31 & 0.96 & - & - & 1 & 5 & ND & - & 4.0 & - & - & - & - & $\begin{array}{l}0.001 / 0.001 / \\
27 / 110\end{array}$ & - & - & - & 14 & $\mathrm{H}$ & $\mathrm{H}$ & H & H & $\mathrm{N}$ & $\mathrm{N}$ & 3 & $\begin{array}{l}\text { E0075-D1- } \\
\text { 070222.ASC }\end{array}$ & $\begin{array}{r}\text { E0075-D2-Chan } \\
200709-3\end{array}$ & No video taken \\
\hline E0076 & 8 & Water & 31 & 0.96 & - & - & 1 & 8 & ND & - & - & - & - & 4.0 & - & & - & & $\begin{array}{l}0.001 / \\
0.0011 \\
31 / 110\end{array}$ & 14 & $\mathrm{H}$ & $\mathrm{H}$ & H & $\mathrm{H}$ & N & N & 1 & $\begin{array}{l}\text { E0076-D1- } \\
\text { 070222.ASC }\end{array}$ & $\begin{array}{l}\text { E0076-D2-Channel1 Feb 22, } \\
\text { 2007 09-45-49.txt }\end{array}$ & No video taken \\
\hline E0077 & 8 & Water & 31 & 0.96 & - & - & 1 & 8 & ND & - & - & - & - & 4.0 & - & - & - & - & $\begin{array}{l}0.001 / \\
0.001 / \\
31 / 110\end{array}$ & 14 & H & $\mathrm{H}$ & $\mathrm{H}$ & $\mathrm{H}$ & $\mathrm{N}$ & $\mathrm{N}$ & 2 & $\begin{array}{l}\text { E0077-D1- } \\
\text { 070222.ASC }\end{array}$ & $\begin{array}{l}\text { E0077-D2-Channel1 Feb 22, } \\
\text { 2007 09-48-29.txt }\end{array}$ & No video taken \\
\hline E0078 & 8 & Water & 31 & 0.96 & & & 1 & 8 & ND & & & & & 4.0 & & & & & $\begin{array}{l}0.001 / 10.00 \\
1 / 31 / 110\end{array}$ & 14 & H & $\mathrm{H}$ & $\mathrm{H}$ & $\mathrm{H}$ & N & N & 3 & $\begin{array}{l}\text { E0078-D1- } \\
\text { 070222.ASC }\end{array}$ & $\begin{array}{l}\text { E0078-D2-Channel1 Feb 22, } \\
\text { 2007 09-51-03.txt }\end{array}$ & No video taken \\
\hline E0079 & 8 & Water & 31 & 0.96 & & & 2 & 4,5 & $\mathrm{ND}$ & 4.0 & 4.0 & & & & $\begin{array}{l}0.001 / 0.001 \\
27 / 110\end{array}$ & $\begin{array}{l}/ 0.001 / 0.001 / \\
27 / 110\end{array}$ & & & & 14 & $\mathrm{H}$ & $\mathrm{H}$ & $\mathrm{H}$ & $H$ & $\mathrm{~N}$ & $\mathrm{~N}$ & 1 & $\begin{array}{l}\text { E0079-D1- } \\
\text { 070222.ASC }\end{array}$ & $\begin{array}{l}\text { E0079-D2-Channel1 Feb 22, } \\
2007 \text { 10-01-42.txt }\end{array}$ & No video taken \\
\hline E0080 & 8 & Water & 31 & 0.96 & & - & 2 & 4,5 & ND & 4.0 & 4.0 & & & - & $\begin{array}{c}0.001 / 0.001 \\
27 / 110\end{array}$ & $\begin{array}{l}\text { / } 0.001 / 0.001 / \\
27 / 110\end{array}$ & & & - & 14 & $\mathrm{H}$ & $\mathrm{H}$ & $\mathrm{H}$ & $\mathrm{H}$ & $\mathrm{N}$ & $\mathrm{N}$ & 2 & $\begin{array}{l}\text { E0080-D1- } \\
\text { 070222.ASC }\end{array}$ & $\begin{array}{l}\text { E0080-D2-Channel1 Feb 22, } \\
2007 \text { 10-05-21.txt }\end{array}$ & No video taken \\
\hline E0081 & 8 & Water & 31 & 0.96 & - & - & 2 & 4,5 & ND & 4.0 & 4.0 & - & - & - & $\begin{array}{c}0.001 / 0.001 \\
27 / 110\end{array}$ & $\begin{array}{l}\text { / } 0.001 / 0.001 / \\
27 / 110\end{array}$ & & & & 14 & $\mathrm{H}$ & $\mathrm{H}$ & $\mathrm{H}$ & $\mathrm{H}$ & $\mathrm{N}$ & N & 3 & $\begin{array}{l}\text { E0081-D1- } \\
\text { 070222.ASC }\end{array}$ & $\begin{array}{l}\text { E0081-D2-Channel1 Feb 22, } \\
\text { 2007 10-07-55.txt }\end{array}$ & No video taken \\
\hline
\end{tabular}


Table A.1. Master Run Log, 8-PJM Configuration

\begin{tabular}{|c|c|c|c|c|c|c|c|c|c|c|c|c|c|c|c|c|c|c|c|c|c|c|c|c|c|c|c|c|c|c|}
\hline \multirow[b]{2}{*}{$\begin{array}{c}\text { Exp. } \\
\text { No.(i) }\end{array}$} & \multirow[b]{2}{*}{$\begin{array}{l}\text { PJM } \\
\text { Config }\end{array}$} & \multicolumn{4}{|c|}{ Simulant } & \multirow{2}{*}{\multicolumn{2}{|c|}{$\begin{array}{l}\text { No. } \\
\text { PJMS } \\
\mathrm{OB}^{(b)}\end{array}$}} & \multirow[b]{2}{*}{$\begin{array}{l}\text { OB } \\
\text { PJMS }\end{array}$} & \multirow[b]{2}{*}{$\begin{array}{c}\mathrm{OB} \\
\text { Duration }\end{array}$} & \multicolumn{5}{|c|}{$\begin{array}{l}\text { Drive Pressure Settings } \\
\quad(\text { bar, }- \text { g) })^{(c)}\end{array}$} & \multicolumn{5}{|c|}{$\begin{array}{r}\text { PJM OP Conditions (vacuum/delay/drive/vent time) } \\
\text { (sec) }\end{array}$} & \multirow[b]{2}{*}{$\begin{array}{l}\text { Target } \\
\text { Noz. Vel. } \\
(\mathrm{m} / \mathrm{s})^{(\mathrm{col})}\end{array}$} & \multicolumn{4}{|c|}{ Hydrophone Elevation } & \multirow{2}{*}{$\begin{array}{c}\text { Sparger } \\
(\mathrm{Y} / \mathbb{N})\end{array}$} & \multirow[b]{2}{*}{$\begin{array}{l}\text { Video } \\
\text { (Y/N) }\end{array}$} & \multirow[b]{2}{*}{$\underset{\#}{\text { Repeat }}$} & \multirow[b]{2}{*}{ DAS-1 Filename } & \multirow[b]{2}{*}{ DAS-2 Filename ${ }^{(\mathrm{d})}$} & \multirow[b]{2}{*}{$\begin{array}{l}\text { DAS-4 (Video) } \\
\text { Filename }\end{array}$} \\
\hline & & Type & 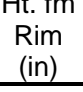 & $\mathrm{H} / \mathrm{D}$ & $\begin{array}{l}\mathrm{T}_{\mathrm{ys}} \\
(\mathrm{Pa})\end{array}$ & & & & & $\begin{array}{c}\text { PJM } \\
4\end{array}$ & $\begin{array}{c}\text { PJM } \\
5\end{array}$ & $\begin{array}{l}\text { PJM } \\
6 \\
\end{array}$ & $\begin{array}{l}\text { PJM } \\
7\end{array}$ & $\begin{array}{c}\text { PJM } \\
8\end{array}$ & PJM 4 & PJM 5 & PJM 6 & PJM 7 & PJM 8 & & $\mathrm{H} 1$ & $\mathrm{H} 2$ & $\mathrm{H} 3$ & $\mathrm{H} 4$ & & & & & & \\
\hline E0082 & & Water & 31 & 0.96 & & & & $4,5,6$ & & 4.0 & & & & & $\begin{array}{c}0.001 / 0.001 / \\
27 / 110\end{array}$ & $\begin{array}{c}0.001 / 0.001 / \\
27 / 110\end{array}$ & $\begin{array}{l}0.001 / 1 \\
0.001 / 271 \\
110\end{array}$ & 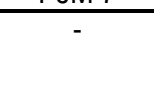 & & & $\mathrm{H}$ & $\mathrm{H}$ & $\mathrm{H}$ & $\mathrm{H}$ & & $\mathrm{N}$ & 1 & $\begin{array}{l}\text { E0082-D1- } \\
\text { 070222.ASC }\end{array}$ & $\begin{array}{l}\text { E0082-D2-Channel1 Feb 22, } \\
\text { 2007 10-31-59.txt }\end{array}$ & \\
\hline E0083 & 8 & Water & 31 & 0.96 & 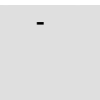 & - & 3 & $4,5,6$ & ND & 4.0 & 4.0 & 4.0 & - & - & $\begin{array}{c}0.001 / 0.001 / \\
27 / 110\end{array}$ & $\begin{array}{l}0.001 / 0.001 / \\
27 / 110\end{array}$ & $\begin{array}{l}1 \\
0.001 / \\
0.001 / 27 / \\
110\end{array}$ & 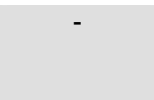 & - & 14 & $\mathrm{H}$ & $\mathrm{H}$ & H & $\mathrm{H}$ & $\mathrm{N}$ & $\mathrm{N}$ & 2 & $\begin{array}{l}\text { E0083-D1- } \\
\text { 070222.ASC }\end{array}$ & $\begin{array}{l}\text { E0083-D2-Channel1 Feb 22, } \\
\text { 2007 10-34-03.txt }\end{array}$ & No video taken \\
\hline E0084 & 8 & Water & 31 & 0.96 & - & - & 3 & $4,5,6$ & ND & 4.0 & 4.0 & 4.0 & - & - & $\begin{array}{c}0.001 / 0.001 / \\
27 / 110\end{array}$ & $\begin{array}{c}0.001 / 0.001 / \\
27 / 110\end{array}$ & $\begin{array}{l}0.001 / \\
0.00127 / 1 \\
110\end{array}$ & - & - & 14 & $\mathrm{H}$ & $\mathrm{H}$ & $\mathrm{H}$ & $\mathrm{H}$ & $\mathrm{N}$ & $\mathrm{N}$ & 3 & $\begin{array}{l}\text { E0084-D1- } \\
\text { 070222.ASC }\end{array}$ & $\begin{array}{l}\text { E0084-D2-Channel1 Feb 22, } \\
\text { 2007 10-37-06.txt }\end{array}$ & No video taken \\
\hline E0085 & 8 & Water & 31 & 0.96 & & & 4 & $4,5,6,7$ & ND & 4.0 & 4.0 & 4.0 & 4.0 & & $\begin{array}{l}0.001 / 0.001 / \\
27 / 110\end{array}$ & $\begin{array}{c}0.001 / 0.001 / \\
27 / 110\end{array}$ & $\begin{array}{l}0.001 / \\
0.001 / 271 \\
110\end{array}$ & $\begin{array}{l}0.001 / \\
0.001 / 271 \\
110\end{array}$ & & 14 & $\mathrm{H}$ & $\mathrm{H}$ & $\mathrm{H}$ & $\mathrm{H}$ & $\mathrm{N}$ & $\mathrm{N}$ & 1 & $\begin{array}{l}\text { E0085-D1- } \\
\text { 070222.ASC }\end{array}$ & $\begin{array}{l}\text { E0085-D2-Channel1 Feb 22, } \\
\text { 2007 10-47-19.txt }\end{array}$ & No video taken \\
\hline E0086 & 8 & Water & 31 & 0.96 & 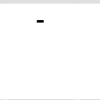 & - & 4 & $4,5,6,7$ & ND & 4.0 & 4.0 & 4.0 & 4.0 & & $\begin{array}{c}0.001 / 0.001 / \\
27 / 110\end{array}$ & $\begin{array}{l}0.001 / 0.001 / \\
27 / 110\end{array}$ & 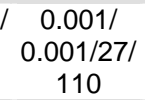 & $\begin{array}{l}0.001 / \\
0.001 / 271 \\
110\end{array}$ & & 14 & $\mathrm{H}$ & $\mathrm{H}$ & $\mathrm{H}$ & $\mathrm{H}$ & $\mathrm{N}$ & $\mathrm{N}$ & 2 & $\begin{array}{l}\text { E0086-D1- } \\
\text { 070222.ASC }\end{array}$ & $\begin{array}{l}\text { E0086-D2-Channel1 Feb 22, } \\
\text { 2007 10-50-25.txt }\end{array}$ & No video taken \\
\hline E0087 & 8 & Water & 31 & 0.96 & - & - & 4 & $4,5,6,7$ & ND & 4.0 & 4.0 & 4.0 & 4.0 & - & $\begin{array}{l}0.001 / 0.001 / \\
27 / 110\end{array}$ & $\begin{array}{c}0.001 / 0.001 / \\
27 / 110\end{array}$ & $\begin{array}{c}10.001 / 1 \\
0.001 / 27 / \\
110\end{array}$ & $\begin{array}{l}0.001 / 1 \\
0.001 / 271 \\
110\end{array}$ & - & 14 & $\mathrm{H}$ & $\mathrm{H}$ & $\mathrm{H}$ & $\mathrm{H}$ & $\mathrm{N}$ & $\mathrm{N}$ & 3 & $\begin{array}{l}\text { E0087-D1- } \\
\text { 070222.ASC }\end{array}$ & $\begin{array}{l}\text { E0087-D2-Channel1 Feb 22, } \\
\text { 2007 10-53-25.txt }\end{array}$ & No video taken \\
\hline E0088 & 8 & Water & 31 & 0.96 & - & - & 1 & 5 & ND & - & 5.0 & - & - & - & - & $\begin{array}{l}0.001 / 0.001 / \\
27 / 110\end{array}$ & 1 & - & - & $>15$ & $\mathrm{H}$ & $\mathrm{H}$ & $\mathrm{H}$ & $\mathrm{H}$ & $\mathrm{N}$ & $\mathrm{N}$ & 1 & $\begin{array}{l}\text { EE0088-D1- } \\
\text { 07022.ASC }\end{array}$ & $\begin{array}{l}\text { E0088-D2-Channell Feb 22, } \\
\text { 2007 11-07-35.txt }\end{array}$ & No video taken \\
\hline E0089 & 8 & Water & 31 & 0.96 & - & - & 1 & 5 & ND & - & 5.0 & - & - & - & - & $\begin{array}{l}0.001 / 0.001 / \\
27 / 110\end{array}$ & - & - & - & $>15$ & $\mathrm{H}$ & $\mathrm{H}$ & $\mathrm{H}$ & H & $\mathrm{N}$ & $\mathrm{N}$ & 2 & $\begin{array}{l}\text { E0089-D1- } \\
\text { 077222.2SC }\end{array}$ & $\begin{array}{l}\text { E0089-D2-Channel1 Feb 22, } \\
\text { 2007 11-11-54.t.te }\end{array}$ & No video taken \\
\hline E0090 & 8 & Water & 31 & 0.96 & - & - & 1 & 5 & ND & - & 5.0 & - & - & - & $\cdot$ & $\begin{array}{c}0.001 / 0.001 / \\
27 / 110\end{array}$ & I & - & - & $>15$ & $\mathrm{H}$ & $\mathrm{H}$ & $\mathrm{H}$ & $\mathrm{H}$ & $\mathrm{N}$ & $\mathrm{N}$ & 3 & $\begin{array}{l}\text { E0009-D1- } \\
\text { 070222.ASC }\end{array}$ & $\begin{array}{l}\text { E0090-D2-Channel1 Feb 22, } \\
\text { 2007 11-13-32.txt }\end{array}$ & No video taken \\
\hline E0091 & 8 & Water & 31 & 0.96 & & & 2 & 4,5 & ND & 5.0 & 5.0 & - & - & & $\begin{array}{c}0.001 / 0.001 / \\
27 / 110\end{array}$ & $\begin{array}{l}0.001 / 0.001 / \\
27 / 110\end{array}$ & & & & $>15$ & $\mathrm{H}$ & $\mathrm{H}$ & $\mathrm{H}$ & $\mathrm{H}$ & $\mathrm{N}$ & $\mathrm{N}$ & 1 & $\begin{array}{l}\text { E0091-D1- } \\
\text { 070222.ASC }\end{array}$ & $\begin{array}{l}\text { E0091-D2-Channel1 Feb 22, } \\
\text { 2007 11-23-07.txt }\end{array}$ & No video taken \\
\hline E0092 & 8 & Water & 31 & 0.96 & ( & & 2 & 4,5 & ND & 5.0 & 5.0 & - & - & & $\begin{array}{c}0.001 / 0.001 / \\
27 / 110\end{array}$ & $\begin{array}{c}0.001 / 0.001 / \\
27 / 110\end{array}$ & & - & - & $>15$ & $\mathrm{H}$ & $\mathrm{H}$ & $\mathrm{H}$ & $\mathrm{H}$ & $\mathrm{N}$ & $\mathrm{N}$ & 2 & $\begin{array}{l}\text { E0092-D1- } \\
\text { 070222.ASC }\end{array}$ & $\begin{array}{l}\text { E0092-D2-Channel1 Feb 22, } \\
\text { 2007 11-25-52.txt }\end{array}$ & No video taken \\
\hline E0094 & 8 & Water & 31 & 0.96 & - & - & 1 & 5 & ND & - & 3.0 & - & - & - & 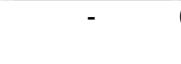 & $\begin{array}{l}0.001 / 0.001 / \\
27 / 110\end{array}$ & - & - & - & 12 & $\mathrm{H}$ & $\mathrm{H}$ & $\mathrm{H}$ & $\mathrm{H}$ & $\mathrm{N}$ & $\mathrm{N}$ & 1 & $\begin{array}{l}\text { EE0094-DI- } \\
\text { 070222.ASC }\end{array}$ & $\begin{array}{l}\text { E0094-D2-Channell Feb 22, } \\
\text { 2007 13-03-44.txt }\end{array}$ & No video taken \\
\hline E0095 & 8 & Water & 31 & 0.96 & - & - & 1 & 5 & ND & - & 3.0 & - & - & - & - & $\begin{array}{c}0.001 / 0.001 / \\
27 / 110\end{array}$ & - & - & - & 12 & $\mathrm{H}$ & $\mathrm{H}$ & $\mathrm{H}$ & $\mathrm{H}$ & $\mathrm{N}$ & $\mathrm{N}$ & 2 & $\begin{array}{l}\text { E0095-D1- } \\
\text { 070222.ASC }\end{array}$ & $\begin{array}{l}\text { E0095-D2-Channel1 Feb 22, } \\
\text { 2007 13-06-22.txt }\end{array}$ & No video taken \\
\hline E0096 & 8 & Water & 31 & 0.96 & - & - & 1 & 5 & ND & - & 3.0 & - & - & - & - & $\begin{array}{c}0.001 / 0.001 / \\
27 / 110\end{array}$ & - & - & - & 12 & $\mathrm{H}$ & $\mathrm{H}$ & $\mathrm{H}$ & $\mathrm{H}$ & $\mathrm{N}$ & $\mathrm{N}$ & 3 & $\begin{array}{l}\text { E0096-D1- } \\
\text { 070222.ASC }\end{array}$ & $\begin{array}{l}\text { E0096-D2-Channel1 Feb 22, } \\
\text { 2007 13-09-17.txt }\end{array}$ & No video taken \\
\hline E0097 & 8 & Water & 31 & 0.96 & 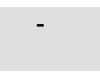 & - & 1 & 5 & -2.5 & - & 3.0 & - & - & & - & $\begin{array}{c}0.001 / 0.001 / \\
30 / 110\end{array}$ & - & - & - & 12 & $\mathrm{H}$ & $\mathrm{H}$ & $\mathrm{H}$ & $\mathrm{H}$ & $\mathrm{N}$ & $\mathrm{N}$ & 1 & $\begin{array}{l}\text { E0097-D1- } \\
\text { 070222.ASC }\end{array}$ & $\begin{array}{l}\text { E0097-D2-Channel1 Feb 22, } \\
\text { 2007 13-33-35.txt }\end{array}$ & No video taken \\
\hline E0098 & 8 & Water & 31 & 0.96 & - & - & 1 & 5 & $\sim 2.5$ & 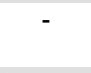 & 3.0 & - & - & & & $\begin{array}{c}0.001 / 0.001 / \\
30 / 110\end{array}$ & & - & 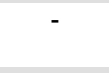 & 12 & $\mathrm{H}$ & $\mathrm{H}$ & $\mathrm{H}$ & $\mathrm{H}$ & $\mathrm{N}$ & $\mathrm{N}$ & 2 & $\begin{array}{l}\text { E0098-D1- } \\
\text { 070222.ASC }\end{array}$ & $\begin{array}{l}\text { E00098-D2-Channel1 Feb 22, } \\
\text { 2007 13-36-54.txt }\end{array}$ & No video taken \\
\hline E0099 & 8 & Water & 31 & 0.96 & & & 1 & 5 & -2.5 & - & 3.0 & - & - & & & $\begin{array}{c}0.001 / 0.001 / \\
30 / 110\end{array}$ & & & & 12 & $\mathrm{H}$ & H & H & $\mathrm{H}$ & $\mathrm{N}$ & $\mathrm{N}$ & 3 & $\begin{array}{l}\text { E0099-D1- } \\
\text { 070222.ASC }\end{array}$ & $\begin{array}{l}\text { E00099-D2-Channel1 Feb 22, } \\
\text { 2007 13-39-38.txt }\end{array}$ & No video taken \\
\hline E0100 & 8 & Water & 31 & 0.96 & - & - & 2 & 4,5 & $\sim 2.5$ & 3.0 & 3.0 & - & - & - & $\begin{array}{c}0.001 / 0.001 / \\
30 / 110\end{array}$ & $\begin{array}{c}0.001 / 0.001 / \\
30 / 110\end{array}$ & I & - & - & 12 & $\mathrm{H}$ & $\mathrm{H}$ & $\mathrm{H}$ & $\mathrm{H}$ & $\mathrm{N}$ & $\mathrm{N}$ & 1 & $\begin{array}{l}\text { E0100-D1- } \\
\text { 070222.ASC }\end{array}$ & $\begin{array}{l}\text { E0100-D2-Channel1 Feb 22, } \\
2007 \text { 13-50-51.txt }\end{array}$ & No video taken \\
\hline E0101 & 8 & Water & 31 & 0.96 & - & - & 2 & 4,5 & -2.5 & 3.0 & 3.0 & - & - & $-c$ & $\begin{array}{l}0.001 / 0.001 / \\
30 / 110\end{array}$ & $\begin{array}{c}0.001 / 0.001 / \\
30 / 110\end{array}$ & - & - & - & 12 & $H$ & $\mathrm{H}$ & $\mathrm{H}$ & $\mathrm{H}$ & $\mathrm{N}$ & N & 2 & $\begin{array}{l}\text { E0101-D1- } \\
\text { 070222.ASC }\end{array}$ & $\begin{array}{l}\text { E0101-D2-Channel1 Feb 22, } \\
\text { 2007 13-53-30.txt }\end{array}$ & No video taken \\
\hline E0102 & 8 & Water & 31 & 0.96 & - & - & 2 & 4,5 & $\sim 2.5$ & 3.0 & 3.0 & - & - & & $\begin{array}{c}0.001 / 0.001 / \\
30 / 110\end{array}$ & $\begin{array}{l}0.001 / 0.001 / \\
30 / 110\end{array}$ & & - & - & 12 & $\mathrm{H}$ & $\mathrm{H}$ & $\mathrm{H}$ & $\mathrm{H}$ & $\mathrm{N}$ & $\mathrm{N}$ & 3 & $\begin{array}{l}\text { E0102-D1- } \\
\text { 070222.ASC }\end{array}$ & $\begin{array}{l}\text { E0102-D2-Channel1 Feb 22, } \\
\text { 2007 13-56-11.txt }\end{array}$ & No video taken \\
\hline E0103 & 8 & Water & 31 & 0.96 & - & 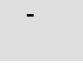 & 1 & 5 & $\sim 4.5$ & - & 0.9 & & - & & & $\begin{array}{l}0.001 / .0 .001 / \\
60 / 1110\end{array}$ & & - & & 8 & $\mathrm{H}$ & $\mathrm{H}$ & $\mathrm{H}$ & $\mathrm{H}$ & $\mathrm{N}$ & $\mathrm{N}$ & 1 & $\begin{array}{l}\text { EE10103-1- } \\
\text { 070222.ASC }\end{array}$ & $\begin{array}{l}\text { E0103-D2-Channel1 Feb 22, } \\
\text { 2007 14-25-13.txt }\end{array}$ & No video taken \\
\hline E0104 & 8 & Water & 31 & 0.96 & & & 1 & 5 & $\sim 4.5$ & & 0.9 & & & & & $\begin{array}{c}0.001 / 0.001 / \\
60 / 110\end{array}$ & & & & 8 & $\mathrm{H}$ & $\mathrm{H}$ & $\mathrm{H}$ & $\mathrm{H}$ & $\mathrm{N}$ & $\mathrm{N}$ & 2 & $\begin{array}{l}\text { E0104-D1- } \\
\text { 070222.ASC }\end{array}$ & $\begin{array}{l}\text { E0104-D2-Channel1 Feb 22, } \\
\text { 2007 14-28-44.txt }\end{array}$ & No video taken \\
\hline E0105 & 8 & Water & 31 & 0.96 & - & & 1 & 5 & $\sim 4.5$ & & 0.9 & & & & & $\begin{array}{c}0.001 / 0.001 / \\
60 / 110\end{array}$ & & & & 8 & $\mathrm{H}$ & $\mathrm{H}$ & $\mathrm{H}$ & $\mathrm{H}$ & $\mathrm{N}$ & $\mathrm{N}$ & 3 & $\begin{array}{l}\text { E0105-D1- } \\
\text { 070222.ASC }\end{array}$ & $\begin{array}{l}\text { E0105-D2-Channel1 Feb 22, } \\
2007 \text { 14-31-41.txt }\end{array}$ & No video taken \\
\hline E0106 & 8 & Water & 31 & 0.96 & & & 2 & 4,5 & $\sim 5$ & 1.0 & 0.9 & & & & $\begin{array}{c}0.001 / 0.001 / \\
60 / 110\end{array}$ & $\begin{array}{c}0.001 / 0.001 / \\
60 / 110\end{array}$ & & & & 8 & $\mathrm{H}$ & H & H & $\mathrm{H}$ & $\mathrm{N}$ & $\mathrm{N}$ & 1 & $\begin{array}{l}\text { E0106-D1- } \\
\text { 070222.ASC }\end{array}$ & $\begin{array}{l}\text { E0106-D2-Channel1 Feb 22, } \\
\text { 2007 14-43-17.txt }\end{array}$ & No video taken \\
\hline E0107 & 8 & Water & 31 & 0.96 & - & - & 2 & 4,5 & -5 & 1.0 & 0.9 & - & - & - & $\begin{array}{l}0.001 / 0.001 / \\
60 / 110\end{array}$ & $\mid \begin{array}{l}0.001 / 0.001 / \\
60 / 110\end{array}$ & I & - & - & 8 & $\mathrm{H}$ & $\mathrm{H}$ & $\mathrm{H}$ & $\mathrm{H}$ & $\mathrm{N}$ & $\mathrm{N}$ & 2 & $\begin{array}{l}\text { EE1010-D1- } \\
\text { 070222.ASC }\end{array}$ & $\begin{array}{l}\text { E0107-D2-Channell Feb 22, } \\
\text { 2007 14-47-06.txt }\end{array}$ & No video taken \\
\hline E0108 & 8 & Water & 31 & 0.96 & - & - & 2 & 4,5 & $\sim 5$ & 1.0 & 0.9 & - & - & ( & $\begin{array}{c}0.001 / 0.001 / \\
60 / 110\end{array}$ & $\begin{array}{l}0.001 / 0.001 / \\
60 / 110\end{array}$ & I & - & & 8 & $\mathrm{H}$ & H & $\mathrm{H}$ & $\mathrm{H}$ & $\mathrm{N}$ & $\mathrm{N}$ & 3 & $\begin{array}{l}\text { E0108-D1- } \\
\text { 070222.ASC }\end{array}$ & $\begin{array}{l}\text { E0108-D2-Channel1 Feb 22, } \\
\text { 2007 14-50-27.txt }\end{array}$ & No video taken \\
\hline $\begin{array}{l}\text { High wate } \\
\text { E0109 }\end{array}$ & 8 & $\begin{array}{l}\text { hydroph } \\
\text { Water }\end{array}$ & $\begin{array}{l}\text { one lev } \\
31\end{array}$ & $\begin{array}{l}\text { el }=\mathrm{M} \\
0.96\end{array}$ & & & 1 & 5 & $\sim 4$ & & 0.9 & & & & & $\begin{array}{c}0.001 / 0.001 / \\
60 / 110\end{array}$ & & & & 8 & M & M & M & M & $\mathrm{N}$ & $\begin{array}{l}Y \text { Y butt } \\
\text { bad) }\end{array}$ & 1 & $\begin{array}{l}\text { E01099-11- } \\
\text { 07023.ASC }\end{array}$ & $\begin{array}{l}\text { E0109-D2-Channel1 Feb 23, } \\
2007 \text { 10-00-22.txt }\end{array}$ & $\begin{array}{l}\text { E0100Runi-NV- } \\
070223\end{array}$ \\
\hline
\end{tabular}


Table A.1. Master Run Log, 8-PJM Configuration

\begin{tabular}{|c|c|c|c|c|c|c|c|c|c|c|c|c|c|c|c|c|c|c|c|c|c|c|c|c|c|c|c|c|c|c|}
\hline \multirow[b]{2}{*}{$\begin{array}{l}\operatorname{Exp}_{\text {(a) }} \\
\text { Noo. }\end{array}$} & \multirow[b]{2}{*}{$\begin{array}{c}\text { PJM } \\
\text { Config }\end{array}$} & \multicolumn{5}{|c|}{ Simulant } & \multirow[b]{2}{*}{$\begin{array}{l}\text { No. } \\
\text { PJMS } \\
\mathrm{OB}^{()^{(1)}}\end{array}$} & \multirow[b]{2}{*}{$\begin{array}{l}\text { OB } \\
\text { PJMs }\end{array}$} & \multirow[b]{2}{*}{$\begin{array}{c}\mathrm{OB} \\
\text { Duration }\end{array}$} & \multicolumn{5}{|c|}{$\begin{array}{l}\text { Drive Pressure Settings } \\
\left({ }^{(b a r}, 2\right)^{(c)}\end{array}$} & \multicolumn{5}{|c|}{ PJM OP Conditions (vacuum/delay/drive/vent time) } & \multirow[b]{2}{*}{$\begin{array}{l}\text { Target } \\
\text { Noz. Vel. } \\
(\mathrm{m} / \mathrm{s})^{(\mathrm{c})}\end{array}$} & \multicolumn{4}{|c|}{ Hydrophone Elevation } & \multirow[b]{2}{*}{$\begin{array}{l}\text { Sparger } \\
(Y / N)\end{array}$} & \multirow[b]{2}{*}{$\begin{array}{l}\text { Video } \\
\text { (YIN) }\end{array}$} & \multirow[b]{2}{*}{$\begin{array}{c}\text { Repeat } \\
\#\end{array}$} & \multirow[b]{2}{*}{ DAS-1 Filename } & \multirow[b]{2}{*}{ DAS-2 Filename $\mathrm{e}^{(\mathrm{d})}$} & \multirow[b]{2}{*}{$\begin{array}{l}\text { DAS-4 (Video) } \\
\text { Filename }\end{array}$} \\
\hline & & Type & $\begin{array}{l}\text { H. fm } \\
\text { Rim } \\
\text { (in) }\end{array}$ & $H / D$ & $\begin{array}{l}T_{y s} \\
(P a)\end{array}$ & $\begin{array}{c}\mathrm{k} \\
(\mathrm{cP})\end{array}$ & & & & $\begin{array}{c}\text { PJM } \\
4\end{array}$ & $\begin{array}{c}\text { PJM } \\
5\end{array}$ & $\begin{array}{c}\text { PJM } \\
6\end{array}$ & $\begin{array}{c}\text { PJM } \\
7\end{array}$ & $\begin{array}{c}\text { PJM } \\
8\end{array}$ & PJM 4 & PJM 5 & PJM 6 & PJM 7 & PJM 8 & & $\mathrm{H} 1$ & $\mathrm{H} 2$ & H3 & $\mathrm{H} 4$ & & & & & & \\
\hline E0112 & 8 & Water & 31 & 0.96 & - & - & 2 & 4,5 & $\sim 1.5, \sim 5$ & 0.9 & 0.9 & 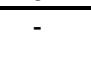 & - & - & $\begin{array}{l}0.001 / 0.001 / \\
6\end{array}$ & $\begin{array}{l}0.001 / 0.001 / \\
60 / 110\end{array}$ & & 1 & sinc & 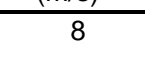 & $\mathrm{M}$ & $\mathrm{M}$ & M & $\mathrm{M}$ & $\mathrm{N}$ & yes & 1 & $\begin{array}{l}\text { E0112-D1- } \\
070223 \text { ASC }\end{array}$ & E0112-D2-Channel1 Feb 23, & $\begin{array}{l}\text { E0112Run4-NV- } \\
070233\end{array}$ \\
\hline E0113 & 8 & Water & 31 & 0.96 & - & - & 2 & 4,5 & $\begin{array}{l}-2.5, \sim \\
4.5\end{array}$ & 0.9 & 0.9 & - & - & - & $\begin{array}{l}0.001 / 0.001 / \\
60 / 110\end{array}$ & $\begin{array}{l}0.001 / 0.001 / \\
60 / 110\end{array}$ & - & - & - & 8 & M & M & M & M & $\mathrm{N}$ & $\begin{array}{l}Y(\text { sub } \\
\text { surf)/N(s }\end{array}$ & 1 & $\begin{array}{l}\text { E0113-D1- } \\
\text { 070223.ASC }\end{array}$ & $\begin{array}{l}\text { E0113-D2-Channel1 Feb 23, } \\
2007 \text { 10-54-18.txt }\end{array}$ & $\begin{array}{l}\text { E0113Runs-NV- } \\
070223\end{array}$ \\
\hline E0114 & 8 & Water & 31 & 0.96 & - & - & 2 & 4,5 & $\begin{array}{r}-1.5, \sim \\
4.5\end{array}$ & 0.9 & 0.9 & - & - & - & $\begin{array}{l}0.001 / 0.001 / \\
60 / 110\end{array}$ & $\begin{array}{c}0.001 / 0.001 / \\
60 / 110\end{array}$ & - & - & - & 8 & M & M & M & M & $\mathrm{N}$ & yes & 1 & $\begin{array}{l}\text { E0114-D1- } \\
\text { 070223.ASC }\end{array}$ & $\begin{array}{l}\text { E0114-D2-Channel1 Feb 23, } \\
2007 \text { 11-02-51.txt }\end{array}$ & $\begin{array}{l}\text { E0114Run6-NV- } \\
070223\end{array}$ \\
\hline E0115 & 8 & Water & 31 & 0.96 & - & & 2 & 4,5 & $-2.5, \sim 5$ & 0.9 & 0.9 & - & & 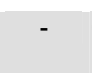 & $\begin{array}{l}0.001 / 0.001 / 1 \\
60 / 110\end{array}$ & $\begin{array}{l}0.001 / / .001 / \\
60 / 110\end{array}$ & & - & - & 8 & M & M & M & M & $\mathrm{N}$ & yes & 1 & $\begin{array}{l}\text { E0115-D1- } \\
\text { 070223.ASC }\end{array}$ & $\begin{array}{l}\text { E0115-D-Channel1 Feb 23, } \\
\text { 2007 11-15-04.txt }\end{array}$ & $\begin{array}{l}\text { E0115Run7-NV- } \\
070223\end{array}$ \\
\hline E0116 & 8 & Water & 31 & 0.96 & - & - & 2 & 4,5 & $\sim 4, \sim 5$ & 1.0 & 0.9 & - & - & - & $\begin{array}{l}0.001 / 0.001 / 1 \\
60 / 110\end{array}$ & $\begin{array}{l}0.001 / / .001 / \\
60 / 110\end{array}$ & & - & - & 8 & M & M & M & M & $\mathrm{N}$ & yes & 2 & $\begin{array}{l}\text { E0116-D1- } \\
\text { 070223.ASC }\end{array}$ & $\begin{array}{l}\text { E016-D2-Channel1 Feb 23, } \\
\text { 2007 11-31-51.txt }\end{array}$ & $\begin{array}{l}\text { E0116Runs-NV- } \\
070223\end{array}$ \\
\hline E0117 & 8 & Water & 31 & 0.96 & - & - & 1 & 5 & -2.5 & - & 3.0 & - & - & - & & $\begin{array}{l}0.001 / 1 / 001 / \\
30 / 110\end{array}$ & & - & - & 12 & M & M & M & M & $\mathrm{N}$ & yes & 1 & $\begin{array}{l}\text { E0117-D1- } \\
\text { 070223.ASC }\end{array}$ & $\begin{array}{l}\text { E0117-D2-Channel1 Feb 23, } \\
\text { 2007 11-48-03.txt }\end{array}$ & $\begin{array}{l}\text { E0117Rung-NV- } \\
070223\end{array}$ \\
\hline E0118 & 8 & Water & 31 & 0.96 & - & - & 1 & 5 & -2.5 & - & 3.0 & - & - & - & - & $\begin{array}{l}0.001 / / .001 / / \\
30 / 110\end{array}$ & - & - & - & 12 & $\mathrm{M}$ & M & M & M & $\mathrm{N}$ & yes & 2 & $\begin{array}{l}\text { E0118-D1- } \\
\text { O07023 ASC }\end{array}$ & $\begin{array}{l}\text { E0118-D2-Channel1 Feb 23, } \\
\text { 2007 11-53-43 txt }\end{array}$ & $\begin{array}{l}\text { E0118Run10-NV- } \\
07023\end{array}$ \\
\hline E0119 & 8 & Water & 31 & 0.96 & - & - & 1 & 5 & -2.5 & - & 3.0 & - & - & - & - & $\begin{array}{l}0.001 / 1 / 001 / \\
3 / 110\end{array}$ & - & - & - & 12 & M & M & M & M & $\mathrm{N}$ & No & 3 & $\begin{array}{l}\text { E0119-D1- } \\
\text { 070223.ASC }\end{array}$ & $\begin{array}{l}\text { E0119-D2-Channel1 Feb 23, } \\
\text { 2007 11-57-27.txt }\end{array}$ & No video taken \\
\hline E0120 & 8 & Water & 31 & 0.96 & - & - & 2 & 4,5 & $\sim 2$ & 3.0 & 3.0 & - & - & - & $\begin{array}{l}0.001 / 0.001 / \\
30 / 110\end{array}$ & $\begin{array}{l}0.001 / 10.001 / \\
30 / 110\end{array}$ & - & - & - & 12 & M & M & M & M & $\mathrm{N}$ & Yes & 1 & $\begin{array}{l}\text { E0120-D1- } \\
\text { 070223.ASC }\end{array}$ & $\begin{array}{l}\text { E0120-D2-Channel1 Feb 23, } \\
\text { 2007 13-09-11.txt }\end{array}$ & $\begin{array}{l}\text { E0120Run12-NV- } \\
070223\end{array}$ \\
\hline E0121 & 8 & Water & 31 & 0.96 & - & - & 2 & 4,5 & -2 & 3.0 & 3.0 & - & - & - & $\begin{array}{l}0.001 / 0.001 / \\
30 / 110\end{array}$ & $\begin{array}{l}0.001 / 1 / 001 / \\
30 / 110\end{array}$ & - & - & - & 12 & M & M & M & M & $\mathrm{N}$ & Yes & 2 & $\begin{array}{l}\text { E0121-D1- } \\
\text { 070223.ASC }\end{array}$ & $\begin{array}{l}\text { E0121-D2-Channell Feb 23, } \\
\text { 2007 13-17-02.xt }\end{array}$ & $\begin{array}{l}\text { E01212un13-NV- } \\
070223\end{array}$ \\
\hline E0122 & 8 & Water & 31 & 0.96 & - & & 2 & 4,5 & $\sim 2$ & 3.0 & 3.0 & - & - & & $\begin{array}{l}0.001 / 0.001 / \\
30 / 110\end{array}$ & $\begin{array}{l}0.001 / 10.001 / \\
30 / 110\end{array}$ & & - & - & 12 & M & M & M & M & $\mathrm{N}$ & No & 3 & $\begin{array}{l}\text { E0122-D1- } \\
07023 \text {. }\end{array}$ & $\begin{array}{l}\text { E0122-D2-Channell Feb 23, } \\
\text { 2007 13-23-45.txt }\end{array}$ & No video taken \\
\hline E0123 & 8 & Water & 31 & 0.96 & - & & 1 & 5 & $>4$ & & 5.1 & - & - & & & $\begin{array}{l}0.001 / 10.001 / \\
271110\end{array}$ & & - & - & $>15$ & M & M & M & M & $\mathrm{N}$ & Yes & 1 & $\begin{array}{l}\text { E0123-D1- } \\
070223 \text { ASC }\end{array}$ & $\begin{array}{l}\text { E0123-D2-Channell Feb 23, } \\
\text { 2007 13-39-35. fxt }\end{array}$ & $\begin{array}{l}\text { E0123Run15-NV- } \\
070223\end{array}$ \\
\hline E0124 & 8 & Water & 31 & 0.96 & 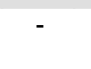 & & 1 & 5 & $>4.5$ & & 5.0 & - & - & & & $0.001 / 0.001 /$ & & - & - & $>15$ & M & M & M & M & $\mathrm{N}$ & Yes & 1 & E0124-D1- & E0124-D2-Channel1 Feb 23, & E0124Run16-NV- \\
\hline E0125 & 8 & Water & 31 & 0.96 & - & - & 1 & 5 & $>5$ & - & 5.0 & - & - & - & - & $\begin{array}{c}0.001 / 0.001 / \\
27 / 110\end{array}$ & - & - & - & $>15$ & M & M & M & M & $\mathrm{N}$ & Yes & 2 & $\begin{array}{l}\text { E0125-D1- } \\
\text { 070223.ASC }\end{array}$ & $\begin{array}{l}\text { E0125-D2-Channel1 Feb 23, } \\
2007 \text { 13-55-42.txt }\end{array}$ & $\begin{array}{l}\text { E0125Run17-NV- } \\
070223\end{array}$ \\
\hline E0126 & 8 & Water & 31 & 0.96 & - & - & 1 & 5 & $\sim 5$ & - & 5.0 & - & - & - & - & $0.001 / / 0.001 /$ & - & - & - & $>15$ & M & M & M & M & N & No & 3 & $\begin{array}{l}\text { E0126-D1- } \\
\text { E01- }\end{array}$ & $\begin{array}{l}\text { E0126-D2-Chan } \\
\text {-D07 }\end{array}$ & No video taken \\
\hline E0127 & 8 & Water & 31 & 0.96 & - & - & 2 & 4,5 & $>5$ & 5.0 & 5.0 & - & - & - & $\begin{array}{l}0.001 / 0.001 / \\
27 / 110\end{array}$ & $\begin{array}{l}0.001 / 1 / 001 / \\
27 / 110\end{array}$ & - & - & - & $>15$ & M & M & M & M & N & Yes & 1 & $\begin{array}{l}\text { E0127-D1- } \\
070223 \text { ASC }\end{array}$ & E0127-D2-Channel1 Feb 23, & $\begin{array}{l}\text { E0127Run19-NV- } \\
070233\end{array}$ \\
\hline E0128 & 8 & Water & 31 & 0.96 & - & - & 2 & 4,5 & $>5$ & 5.0 & 5.0 & - & - & - & $\begin{array}{l}0.001 / 0.001 / 1 \\
27 / 110\end{array}$ & $\begin{array}{l}0.001 / / 0.001 / \\
27 / 110\end{array}$ & & - & - & $>15$ & M & M & M & M & $\mathrm{N}$ & Yes & 2 & $\begin{array}{l}\text { E0128-D1- } \\
\text { 070223.ASC }\end{array}$ & $\begin{array}{l}\text { E0128-D2-Chanr } \\
200714-22\end{array}$ & $\begin{array}{l}\text { E0128Run20-NV- } \\
070223\end{array}$ \\
\hline E0129 & 8 & Water & 31 & 0.96 & - & - & 2 & 4,5 & -5 & 5.0 & 5.0 & - & - & - & $\begin{array}{c}0.001 / 0.001 / \\
27 / 110\end{array}$ & $\begin{array}{l}0.001 / 0.001 / \\
27 / 110\end{array}$ & - & - & - & $>15$ & M & M & M & M & $\mathrm{N}$ & No & 3 & si- & $\begin{aligned} \text { E0129-D2 } & \text { 200 }\end{aligned}$ & No video taken \\
\hline E0130 & 8 & Water & 31 & 0.96 & - & & 1 & 8 & $>5$ & 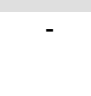 & $\therefore$ & - & - & 4.0 & & & & - & $\begin{array}{l}0.001 / \\
0.001 / \\
311110\end{array}$ & 14 & M & M & M & M & $\mathrm{N}$ & Yes & 1 & $\begin{array}{l}\text { E0130-D1- } \\
\text { 070223.ASC }\end{array}$ & $\begin{array}{l}\text { E0130-D2-Channel1 Feb 23, } \\
\text { 2007 14-41-25.txt }\end{array}$ & $\begin{array}{l}\text { E0130Run22-NV- } \\
070223\end{array}$ \\
\hline E0131 & 8 & Water & 31 & 0.96 & . & & 1 & 8 & $\sim 5$ & & & 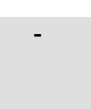 & & 4.0 & & & & & $\begin{array}{l}-1 \\
0.0011 \\
0.0011 \\
31110\end{array}$ & 14 & M & M & M & M & $\mathrm{N}$ & Yes & 2 & $\begin{array}{l}\text { E0131-D1- } \\
\text { 070223.ASC }\end{array}$ & $\begin{array}{l}\text { E0131-D2-Channel1 Feb 23, } \\
\text { 2007 14-49-50.txt }\end{array}$ & $\begin{array}{l}\text { E0131Run23-NV- } \\
070223\end{array}$ \\
\hline E0132 & 8 & Water & 31 & 0.96 & - & - & 1 & 8 & $\sim 5$ & - & - & - & - & 4.0 & - & - & - & - & $\begin{array}{l}0.001 / \\
0.001 / \\
31110\end{array}$ & 14 & M & M & M & M & N & No & 3 & $\begin{array}{l}\text { E0132-D1- } \\
\text { 070223.ASC }\end{array}$ & $\begin{array}{l}\text { E0132-D2-Channel1 Feb 23, } \\
\text { 2007 15-00-21.txt }\end{array}$ & No video taken \\
\hline E0133 & 8 & Water & 31 & 0.96 & - & - & 1 & 5 & $\sim 3.5$ & - & 4.01 & - & - & - & - & $\begin{array}{l}0.001 / 0.001 / \\
27 / 110\end{array}$ & - & - & 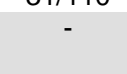 & 14 & M & M & M & M & N & Yes & 1 & ic & $\begin{aligned} E 0133-D \\
20\end{aligned}$ & $\begin{array}{l}\text { E0133Run1-NV- } \\
070226\end{array}$ \\
\hline E0134 & 8 & Water & 31 & 0.96 & - & - & 1 & 5 & -3.5 & - & 4.01 & - & - & - & - & $\begin{array}{r}0.0011 \\
271\end{array}$ & & - & - & 14 & M & M & M & M & $\mathrm{N}$ & Yes & 2 & & E0134-D & E0134 \\
\hline E0135 & 8 & Water & 31 & 0.96 & - & - & 1 & 5 & -3.5 & - & 4.01 & - & - & - & - & $0.001 / 1 /$ & & - & - & 14 & M & M & M & M & N & No & 3 & & E0135-D2-Ch & No video taken \\
\hline E0136 & 8 & Water & 31 & 0.96 & - & - & 2 & 4,5 & $\sim 3.5$ & 3.99 & 4.01 & - & - & & $\begin{array}{l}0.001 / 0.001 / \\
27 / 110\end{array}$ & $\begin{array}{l}0.001 / 0.001 / \\
27 / 110\end{array}$ & & - & - & 14 & M & M & M & M & $\mathrm{N}$ & Yes & 1 & $\begin{array}{l}\text { E0136--11- } \\
\text { 070226.ASC }\end{array}$ & $\begin{array}{l}\text { E0136-DQ-Channeli Feb 26, } \\
\text { 2007 10-45-50.txt }\end{array}$ & $\begin{array}{l}\text { E0136Run4-NV- } \\
070226\end{array}$ \\
\hline E0137 & 8 & Water & 31 & 0.96 & - & 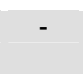 & 2 & 4,5 & -3.5 & 3.99 & 4.01 & - & - & - & $\begin{array}{l}0.001 / 0.001 / \\
27 / 110\end{array}$ & $\begin{aligned} 0.001 / C \\
27 / 1\end{aligned}$ & 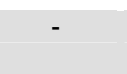 & - & - & 14 & M & M & M & M & $\mathrm{N}$ & Yes & 2 & $\begin{array}{l}\text { E0137-D1- } \\
\text { 070226.ASC }\end{array}$ & $\begin{array}{l}\text { E0137-D2-Channel1 Feb 26, } \\
2007 \text { 10-53-29.txt }\end{array}$ & $\begin{array}{l}\text { E0137Run5-NV- } \\
070226\end{array}$ \\
\hline E0138 & 8 & Water & 31 & 0.96 & & - & 2 & 4,5 & $\sim 3$. & 3.99 & 4.01 & - & & - & $0.001 / /$ & $0.001 /$ & - & - & - & 14 & $\mathrm{M}$ & M & M & M & $\mathrm{N}$ & No & 3 & & E0138-D & No video taken \\
\hline E0139 & 8 & Water & 31 & 0.96 & - & - & 3 & $4,5,6$ & -3. & 3.96 & 4.07 & 3.95 & - & - & $\begin{array}{l}0.001 / 0.001 / \\
27 / 110\end{array}$ & $\begin{array}{l}0.001 / 0.001 / \\
27 / 110\end{array}$ & $\begin{array}{l}0.001 / \\
0.001 / 271 \\
110\end{array}$ & - & - & 14 & M & M & M & M & $\mathrm{N}$ & Yes & 1 & $\begin{array}{l}\text { E0139-D1- } \\
\text { 070226.ASC }\end{array}$ & $\begin{array}{l}\text { E0139-D2-Channel1 Feb 26, } \\
\text { 2007 11.14.05.txt }\end{array}$ & $\begin{array}{l}\text { E0139Run7-NV- } \\
070226\end{array}$ \\
\hline E0140 & 8 & Water & 31 & 0.96 & - & & 3 & $4,5,6$ & $\sim 3$. & 4.01 & 4.08 & 4.01 & & & $\begin{array}{c}0.001 / 0.001 / \\
27 / 110\end{array}$ & $\begin{array}{c}0.001 / 0.001 / \\
27 / 110\end{array}$ & $\begin{array}{l}110 \\
0.001 / \\
0.001 / 27 / \\
110\end{array}$ & & & 14 & $\mathrm{M}$ & M & M & M & $\mathrm{N}$ & Yes & 1 & $\begin{array}{l}\text { E0140-D1- } \\
\text { 070226.ASC }\end{array}$ & $\begin{array}{l}\text { E0140-D2-Channel1 Feb 26, } \\
\text { 2007 13-13-51.txt }\end{array}$ & $\begin{array}{l}\text { E0140Run8-NV- } \\
070226\end{array}$ \\
\hline E0141 & 8 & Water & 31 & 0.96 & & & 3 & $4,5,6$ & $\sim 3$. & 4.01 & 4.08 & 4.01 & & & $\begin{array}{l}0.001 / 0.001 / \\
27 / 110\end{array}$ & $\begin{array}{l}0.001 / / 0.001 / \\
27 / 110\end{array}$ & $\begin{array}{l}1.001 / \\
0.001 / 271\end{array}$ & & & 14 & M & $\mathrm{M}$ & M & M & $\mathrm{N}$ & Yes & 2 & $\begin{array}{l}\text { E0141-D1- } \\
\text { 070226.ASC }\end{array}$ & $\begin{array}{l}\text { E0141-D2-Channel1 Feb 26, } \\
2007 \text { 13-21-56.txt }\end{array}$ & $\begin{array}{l}\text { E0141Run9-NV- } \\
070226\end{array}$ \\
\hline
\end{tabular}


Table A.1. Master Run Log, 8-PJM Configuration

\begin{tabular}{|c|c|c|c|c|c|c|c|c|c|c|c|c|c|c|c|c|c|c|c|c|c|c|c|c|c|c|c|c|c|c|}
\hline \multirow[b]{2}{*}{$\begin{array}{l}\text { Exp } \\
\text { No. }\end{array}$} & \multirow[b]{2}{*}{$\begin{array}{l}\text { PJM } \\
\text { Config }\end{array}$} & \multirow[b]{2}{*}{ Type } & \multicolumn{3}{|c|}{ Simulant } & \multirow{2}{*}{\multicolumn{2}{|c|}{$\begin{array}{l}\text { No. } \\
\text { KJ) } \\
\text { PJM } \\
\mathrm{OB}^{(0)}\end{array}$}} & \multirow[b]{2}{*}{$\begin{array}{c}\mathrm{OB} \\
\mathrm{PJMS} \\
\end{array}$} & \multirow[b]{2}{*}{$\begin{array}{c}\mathrm{OB} \\
\text { Duration } \\
(c)\end{array}$} & \multicolumn{5}{|c|}{$\begin{array}{l}\text { Drive Pressure Settings } \\
\text { (bar,-g9) }\end{array}$} & \multicolumn{5}{|c|}{ PJM OP Conditions (vacuum/delay/drive/vent time) } & \multirow[b]{2}{*}{$\begin{array}{c}\text { Target } \\
\text { Noz. Vel. } \\
(\mathrm{m} / \mathrm{s})^{(\mathrm{cl})}\end{array}$} & \multicolumn{4}{|c|}{ Hydrophone Elevation } & \multirow[b]{2}{*}{$\begin{array}{c}\text { Sparger } \\
(\mathrm{Y} / \mathrm{N})\end{array}$} & \multirow[b]{2}{*}{$\begin{array}{l}\text { Video } \\
(\mathrm{Y} / \mathrm{N})\end{array}$} & \multirow[b]{2}{*}{$\underset{\#}{\substack{\text { Repeat } \\
\#}}$} & \multirow[b]{2}{*}{ DAS-1 Filename } & \multirow[b]{2}{*}{ DAS-2 Filename $\mathrm{e}^{(\mathrm{d})}$} & \multirow[b]{2}{*}{$\begin{array}{l}\text { DAS-4 (Video) } \\
\text { Filename }\end{array}$} \\
\hline & & & $\begin{array}{l}\text { Ht. fm } \\
\text { Rim } \\
\text { (in) }\end{array}$ & $H / D$ & $\begin{array}{c}T_{\text {ys }} \\
(\mathrm{Pa})\end{array}$ & & & & & PJM & $\begin{array}{c}\text { PJM } \\
5\end{array}$ & $\underset{6}{\mathrm{PJM}}$ & PJM & $\begin{array}{l}\text { PJM } \\
8\end{array}$ & PJM 4 & PJM 5 & PJM 6 & PJM 7 & PJM 8 & & $\mathrm{H} 1$ & H2 & $\mathrm{H} 3$ & $\mathrm{H} 4$ & & & & & & \\
\hline E0142 & 8 & Water & 31 & 0.96 & & & 3 & $4,5,6$ & -3. & 4.01 & 4.08 & 4.01 & 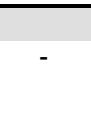 & & $\begin{array}{c}0.001 / 0.001 / \\
27 / 110\end{array}$ & $\begin{array}{l}0.001 / 0.001 / \\
27 / 110\end{array}$ & $\begin{array}{c}110 \\
0.001 / \\
0.001 / 271 \\
110\end{array}$ & 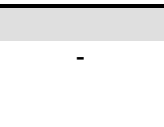 & 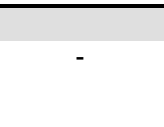 & 14 & M & M & M & M & $\mathrm{N}$ & No & 3 & $\begin{array}{l}\text { E0142-D1- } \\
\text { 070226.ASC }\end{array}$ & $\begin{array}{l}\text { E0142-D2-Channel1 Feb 26, } \\
\text { 2007 13-29-03.txt }\end{array}$ & No video taken \\
\hline E0143 & 8 & Water & 31 & 0.96 & & & 4 & $4,5,6,7$ & -3 & 3.98 & 4.01 & 3.99 & 4.04 & & $\begin{array}{l}0.001 / 0.001 / \\
27 / 110\end{array}$ & $\begin{array}{l}0.001 / 0.001 / \\
27 / 110\end{array}$ & $\begin{array}{r}0.001 / \\
0.001 / 271 \\
110\end{array}$ & $\begin{array}{l}0.001 / \\
0.001 / 271 \\
110\end{array}$ & & 14 & M & M & M & M & $\mathrm{N}$ & Yes & 1 & $\begin{array}{l}\text { E0143-D1- } \\
\text { 070226.ASC }\end{array}$ & $\begin{array}{l}\text { E0143-D2-Channel1 Feb 26, } \\
\text { 2007 13-40-01.txt }\end{array}$ & $\begin{array}{l}\text { E0143Run11-NV- } \\
\quad 070226\end{array}$ \\
\hline E0144 & 8 & Water & 31 & 0.96 & - & - & 4 & $4,5,6,7$ & -3 & 3.98 & 4.01 & 3.99 & 4.04 & - & $\begin{array}{c}0.001 / 0.001 / \\
27 / 110\end{array}$ & $\begin{array}{l}0.001 / 0.001 / \\
27 / 110\end{array}$ & $\begin{array}{c}110 / \\
0.001 / \\
0.001 / 27 / \\
110\end{array}$ & $\begin{array}{c}0.001 / 1 \\
0.001 / 271 \\
110\end{array}$ & - & 14 & M & M & M & M & $\mathrm{N}$ & Yes & 2 & $\begin{array}{l}\text { E0144-D1- } \\
\text { 070226.ASC }\end{array}$ & $\begin{array}{l}\text { E0144-D2-Channel1 Feb 26, } \\
\text { 2007 13-48-32.txt }\end{array}$ & $\begin{array}{l}\text { E0144Run12-NV- } \\
070226\end{array}$ \\
\hline E0145 & 8 & Water & 31 & 0.96 & - & - & 4 & $4,5,6,7$ & -3. & 3.98 & 4.01 & 3.99 & 4.04 & - & $\begin{array}{c}0.001 / 0.001 / \\
27 / 110\end{array}$ & $\begin{array}{c}0.001 / 0.001 / \\
27 / 110\end{array}$ & $\begin{array}{c}0.001 / \\
0.001 / 27 / \\
110\end{array}$ & $\begin{array}{c}0.001 / 0.00 \\
1 / 27 / 110\end{array}$ & - & 14 & M & M & M & M & $\mathrm{N}$ & No & 3 & $\begin{array}{l}\text { E0145-D1- } \\
\text { 070226.ASC }\end{array}$ & $\begin{array}{l}\text { E0145-D2-Channel1 Feb 26, } \\
\text { 2007 13-56-30.txt }\end{array}$ & No video taken \\
\hline $\begin{array}{l}\text { High water } \\
\text { E0146 }\end{array}$ & $\begin{array}{l}\text { rlevel, } \\
8\end{array}$ & $\begin{array}{l}\text { hydroph } \\
\text { Water }\end{array}$ & one le & $\begin{array}{ll}e l=L \\
0.96\end{array}$ & & & 1 & 8 & -4.5 & & & & - & 4.02 & & & & & $0.001 / 0.00$ & 14 & L & L & L & L & $\mathrm{N}$ & No & 1 & E0146-D1- & E0146-D2-Channel1 Feb 26, & No video taken \\
\hline E0147 & 8 & Water & 31 & 0.96 & & & 1 & 8 & $>5$ & - & - & - & - & 4.02 & - & & - & - & $\begin{array}{l}0.001 / 10.00 \\
1 / 31 / 110\end{array}$ & 14 & L & L & L & $\mathrm{L}$ & $\mathrm{N}$ & No & 2 & $\begin{array}{l}\text { E0147--D1- } \\
\text { 070226.ASC }\end{array}$ & $\begin{array}{l}\text { E0147-D2-Channeli Feb 26, } \\
\text { 2007 14-25-47.txt }\end{array}$ & No video taken \\
\hline E0148 & 8 & Water & 31 & 0.96 & & - & 1 & 8 & $>5$ & -5 & - & - & - & 4.02 & - & & - & - & $\begin{array}{c}0.001 / 0.00 \\
1 / 31 / 110\end{array}$ & 14 & L & L & L & $\mathrm{L}$ & $\mathrm{N}$ & No & 3 & $\begin{array}{l}\text { E0148-D1- } \\
\text { 070226.ASC }\end{array}$ & $\begin{array}{l}\text { E0148-D2-Channel1 Feb 26, } \\
\text { 2007 14-28-19.txt }\end{array}$ & No video taken \\
\hline E0149 & 8 & Water & 31 & 0.96 & - & - & 1 & 5 & -3 & - & 3.99 & - & - & - & - & $\begin{array}{c}0.001 / 0.001 / \\
27 / 110\end{array}$ & - & - & - & 14 & L & L & L & $\mathrm{L}$ & $\mathrm{N}$ & No & 1 & $\begin{array}{l}\text { E0149-D1- } \\
\text { 070226.ASC }\end{array}$ & $\begin{array}{l}\text { E0149-D2-Channel1 Feb 26, } \\
2007 \text { 14-35-57.txt }\end{array}$ & No video taken \\
\hline E0150 & 8 & Water & 31 & 0.96 & - & - & 1 & 5 & -3 & - & 3.99 & - & - & - & - & $\begin{array}{l}0.001 / 10.001 / \\
27110\end{array}$ & - & - & - & 14 & L & L & L & $\mathrm{L}$ & $\mathrm{N}$ & No & 2 & $\begin{array}{l}\text { E0150-D1- } \\
\text { 07720 ASC }\end{array}$ & $\begin{array}{l}\text { E0150-D2-Channeli Feb 26, } \\
\text { 2007 }\end{array}$ & No video taken \\
\hline E0151 & 8 & Water & 31 & 0.96 & - & - & 1 & 5 & -3.5 & - & 3.99 & - & - & - & - & $\begin{array}{l}0.00110 .001 / \\
27 / 1110\end{array}$ & - & - & - & 14 & L & L & L & $\mathrm{L}$ & $\mathrm{N}$ & No & 3 & $\begin{array}{l}\text { E0151-D1- } \\
\text { 070226.ASC }\end{array}$ & $\begin{array}{l}\text { E0151-D2-Channel1 Feb 26, } \\
\text { 2007 14-41-08.txt }\end{array}$ & No video taken \\
\hline E0152 & 8 & Water & 31 & 0.96 & & & 2 & 4,5 & -3. & 4 & 4.07 & ( & - & & $\begin{array}{c}0.001 / 0.001 / \\
27 / 110\end{array}$ & $\begin{array}{c}0.001 / 0.001 / \\
27 / 110\end{array}$ & & - & - & 14 & L & $\mathrm{L}$ & L & L & $\mathrm{N}$ & No & 1 & $\begin{array}{l}\text { E0152-D1- } \\
\text { 070226.ASC }\end{array}$ & $\begin{array}{l}\text { E0152-D2-Channel1 Feb 26, } \\
\text { 2007 14-51-16.txt }\end{array}$ & No video taken \\
\hline E0154 & 8 & Water & 31 & 0.96 & & & 2 & 4,5 & -3. & 4 & 4.07 & - & - & & $\begin{array}{c}0.001 / 0.001 / \\
27 / 110\end{array}$ & $\begin{array}{c}0.001 / 0.001 / \\
27 / 110\end{array}$ & I & - & - & 14 & L & $\mathrm{L}$ & $\mathrm{L}$ & L & $\mathrm{N}$ & No & 3 & $\begin{array}{l}\text { E0154-D1- } \\
\text { 070226.ASC }\end{array}$ & $\begin{array}{l}\text { E0154-D2-Channel1 Feb 26, } \\
\text { 2007 14-56-00.txt }\end{array}$ & No video taken \\
\hline E0155 & 8 & Water & 31 & 0.96 & - & - & 3 & $4,5,6$ & -3. & 3.98 & 3.99 & 3.97 & - & - & $\begin{array}{l}0.001 / 0.001 / \\
27 / 110\end{array}$ & $\begin{array}{l}0.001 / 0.001 / \\
27 / 110\end{array}$ & $\begin{array}{l}0.001 / \\
0.001 / 27 / \\
110\end{array}$ & - & - & 14 & L & L & L & L & $\mathrm{N}$ & No & 1 & $\begin{array}{l}\text { E0155-D1- } \\
\text { 070226.ASC }\end{array}$ & $\begin{array}{l}\text { E0155-D2-Channel1 Feb 26, } \\
\text { 2007 15-05-19.txt }\end{array}$ & No video taken \\
\hline E0156 & 8 & Water & 31 & 0.96 & - & - & 3 & $4,5,6$ & -3. & 3.98 & 3.99 & 3.97 & - & - & $\begin{array}{l}0.001 / 0.001 / \\
27 / 110\end{array}$ & $\begin{array}{l}0.001 / 0.001 / \\
27 / 110\end{array}$ & $\mid \begin{array}{c}0.001 / \\
0.001 / 27 / \\
110\end{array}$ & - & - & 14 & L & L & L & L & $\mathrm{N}$ & No & 2 & $\begin{array}{l}\text { E0156-D1- } \\
\text { 070226.ASC }\end{array}$ & $\begin{array}{l}\text { E0156-D2-Channel1 Feb 26, } \\
\text { 2007 15-07-37.txt }\end{array}$ & No video taken \\
\hline E0157 & 8 & Water & 31 & 0.96 & & - & 3 & $4,5,6$ & $\sim 2.5$ & 3.98 & 3.99 & 3.97 & - & & $\begin{array}{c}0.001 / 0.001 / \\
27 / 110\end{array}$ & $\begin{array}{c}0.001 / 0.001 / \\
27 / 110\end{array}$ & $\begin{array}{l}0.001 / \\
0.001 / 271 \\
110\end{array}$ & 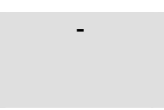 & - & 14 & L & L & L & L & N & No & 3 & $\begin{array}{l}\text { E0157-D1- } \\
\text { 070226.ASC }\end{array}$ & $\begin{array}{l}\text { E0157-D2-Channel1 Feb 26, } \\
\text { 2007 15-09-59.txt }\end{array}$ & No video taken \\
\hline E0158 & 8 & Water & 31 & 0.96 & & & 4 & $4,5,6,7$ & -3 & 4 & 3.98 & 3.98 & 3.97 & & $\begin{array}{c}0.001 / 0.001 / \\
27 / 110\end{array}$ & $\begin{array}{l}0.001 / 0.001 / \\
27 / 110\end{array}$ & $\begin{array}{c}0.001 / \\
0.001 / 271 \\
110\end{array}$ & $\begin{array}{l}0.001 / \\
0.001 / 27 / 1 \\
10\end{array}$ & & 14 & L & L & L & L & $\mathrm{N}$ & No & 1 & $\begin{array}{l}\text { E0158-D1- } \\
\text { 070227.ASC }\end{array}$ & $\begin{array}{l}\text { E0158-D2-Channel1 Feb 27, } \\
\text { 2007 09-21-04.txt }\end{array}$ & No video taken \\
\hline E0159 & 8 & Water & 31 & 0.96 & & & 4 & $4,5,6,7$ & -3 & 4 & 3.98 & 3.98 & 3.97 & & $\begin{array}{c}0.001 / 0.001 / \\
27 / 110\end{array}$ & $\begin{array}{c}0.001 / 0.001 / \\
27 / 110\end{array}$ & $\begin{array}{l}0.001 / \\
0.001 / 271 \\
110\end{array}$ & $\begin{array}{l}0.001 / 1 \\
0.001 / 271 \\
110\end{array}$ & & 14 & L & L & L & L & $\mathrm{N}$ & No & 2 & $\begin{array}{l}\text { E0159-D1- } \\
\text { 070227.ASC }\end{array}$ & $\begin{array}{l}\text { E0159-D2-Channel1 Feb 27, } \\
\text { 2007 09-24-02.txt }\end{array}$ & No video taken \\
\hline E0160 & 8 & Water & 31 & 0.96 & - & - & 4 & $4,5,6,7$ & -3 & 4 & 3.98 & 3.98 & 3.97 & - & $\begin{array}{c}0.001 / 0.001 / \\
27 / 110\end{array}$ & $\begin{array}{c}0.001 / 0.001 / \\
27 / 110\end{array}$ & $\begin{array}{l}0.001 / \\
0.001 / 27 \\
110\end{array}$ & $\begin{array}{l}0.001 / 1 \\
0.001 / 271 \\
110\end{array}$ & - & 14 & L & L & L & L & $\mathrm{N}$ & No & 3 & $\begin{array}{l}\text { E0160-D1- } \\
\text { 070227.ASC }\end{array}$ & $\begin{array}{l}\text { E0160-D2-Channel1 Feb 27, } \\
2007 \text { 09-26-41.txt }\end{array}$ & No video taken \\
\hline E0161 & 8 & Water & 31 & 0.96 & & - & 4 & $4,5,6,7$ & -3 & 4.01 & 4.01 & 3.96 & 4 & & $\begin{array}{c}0.001 / 0.001 / \\
27 / 110\end{array}$ & $\begin{array}{l}0.001 / 0.001 / \\
27 / 110\end{array}$ & $\begin{array}{l}0.001 / \\
0.001 / 271 \\
110\end{array}$ & $\begin{array}{l}0.001 / \\
0.001 / 271 \\
110\end{array}$ & - & 14 & L & L & L & L & Y & No & 1 & $\begin{array}{l}\text { E0161-D1- } \\
\text { 070227.ASC }\end{array}$ & $\begin{array}{c}\text { E0161-D2-Channel1 Feb 27, } \\
\text { 2007 09-57-17.txt }\end{array}$ & No video taken \\
\hline E0162 & 8 & Water & 31 & 0.96 & & - & 4 & $4,5,6,7$ & -3 & 4.01 & 4.01 & 3.96 & 4 & & $\begin{array}{l}0.001 / 0.001 / \\
27 / 110\end{array}$ & $\begin{array}{l}0.001 / 0.001 / \\
27 / 110\end{array}$ & $\begin{array}{l}0.001 / \\
0.001 / 27 / \\
110\end{array}$ & $\begin{array}{l}0.001 / 1 \\
0.001 / 271 \\
110\end{array}$ & - & 14 & L & L & L & L & $\mathrm{Y}$ & No & 2 & $\begin{array}{l}\text { E0162-D1- } \\
\text { 070227.ASC }\end{array}$ & $\begin{array}{l}\text { E0162-D2-Channel1 Feb 27, } \\
\text { 2007 10-01-07.txt }\end{array}$ & No video taken \\
\hline E0163 & 8 & Water & 31 & 0.96 & & & 4 & $4,5,6,7$ & -3 & 4.01 & 4.01 & 3.96 & 4 & & $\begin{array}{l}0.001 / 0.001 / \\
27 / 110\end{array}$ & $\begin{array}{l}0.001 / 0.001 / \\
27 / 110\end{array}$ & $\begin{array}{l}0.001 / \\
0.001 / 271 \\
110\end{array}$ & $\begin{array}{l}0.001 / 1 \\
0.001 / 271 \\
110\end{array}$ & & 14 & L & L & L & L & $Y$ & No & 3 & $\begin{array}{l}\text { E0163-D1- } \\
\text { 070227.ASC }\end{array}$ & $\begin{array}{c}\text { E0163-D2-Channel1 Feb 27, } \\
\text { 2007 10-04-06.txt }\end{array}$ & No video taken \\
\hline E0164 & 8 & Water & 31 & 0.96 & & - & 1 & 5 & $>5$ & - & 5.02 & - & - & - & - & $\begin{array}{c}0.001 / 0.001 / \\
27 / 110\end{array}$ & & & - & $>15$ & L & L & L & L & $\mathrm{N}$ & No & 1 & $\begin{array}{l}\text { E0164-D1- } \\
\text { 070227.ASC }\end{array}$ & $\begin{array}{l}\text { E0164-D2-Channel1 Feb 27, } \\
\text { 2007 10-18-38.txt }\end{array}$ & No video taken \\
\hline E0165 & 8 & Water & 31 & 0.96 & - & - & 1 & 5 & $>5$ & - & 5.02 & - & - & - & - & $\begin{array}{l}0.001 / 0.001 / \\
27 / 110\end{array}$ & - & - & - & $>15$ & L & L & L & L & $\mathrm{N}$ & No & 2 & $\begin{array}{l}\text { E0165-D1- } \\
\text { 070227.ASC }\end{array}$ & $\begin{array}{l}\text { E0165-D2-Channel1 Feb 27, } \\
\text { 2007 10-20-47.txt }\end{array}$ & No video taken \\
\hline
\end{tabular}


Table A.1. Master Run Log, 8-PJM Configuration

\begin{tabular}{|c|c|c|c|c|c|c|c|c|c|c|c|c|c|c|c|c|c|c|c|c|c|c|c|c|c|c|c|c|c|c|}
\hline \multirow[b]{2}{*}{$\begin{array}{l}\text { Exp } \\
\text { No. }\end{array}$} & \multirow[b]{2}{*}{$\begin{array}{l}\text { PJM } \\
\text { Config }\end{array}$} & \multicolumn{4}{|c|}{ Simulant } & & \multirow[b]{2}{*}{$\begin{array}{l}\text { No. } \\
\text { PJMs } \\
\mathrm{OB}^{()^{()}}\end{array}$} & \multirow[b]{2}{*}{$\begin{array}{l}\text { OB } \\
\text { PJMs }\end{array}$} & \multirow[b]{2}{*}{$\begin{array}{c}\mathrm{OB} \\
\text { Duration }^{(o)} \\
\end{array}$} & \multicolumn{5}{|c|}{$\begin{array}{l}\text { Drive Pressure Settings } \\
(\text { barrgg) }\end{array}$} & \multicolumn{5}{|c|}{ PJM OP Conditions (vacuum/delay/drive/vent time) } & \multirow[b]{2}{*}{$\begin{array}{c}\text { Target } \\
\text { Noz. Vel. } \\
\left(\mathrm{m} / \mathrm{s}^{(0)}\right.\end{array}$} & \multicolumn{4}{|c|}{...Hydrophone Elevation } & \multirow[b]{2}{*}{$\begin{array}{l}\text { Sparger } \\
(\mathrm{Y} / \mathrm{N})\end{array}$} & \multirow[b]{2}{*}{$\begin{array}{l}\text { Video } \\
(Y / N)\end{array}$} & \multirow[b]{2}{*}{$\underset{\#}{\text { Repeat }}$} & \multirow[b]{2}{*}{ DAS-1 Filename } & \multirow[b]{2}{*}{ DAS-2 Filename $e^{(d)}$} & \multirow[b]{2}{*}{$\begin{array}{l}\text { DAS-4 (Video) } \\
\text { Filename }\end{array}$} \\
\hline & & Type & $\begin{array}{l}\text { Ht. fm } \\
\text { Rim } \\
\text { (in) }\end{array}$ & $H / D$ & $\begin{array}{c}\mathrm{T}_{\mathrm{ys}} \\
(\mathrm{Pa})(\mathrm{C}\end{array}$ & $\begin{array}{c}\mathrm{k} \\
(\mathrm{CP})\end{array}$ & & & & $\stackrel{\mathrm{PJM}}{4}$ & $\begin{array}{c}\text { PJM } \\
5\end{array}$ & $\underset{6}{\mathrm{PJM}}$ & $\begin{array}{l}\text { PJM } \\
7\end{array}$ & $\begin{array}{l}\text { PJM } \\
8\end{array}$ & PJM 4 & PJM 5 & PJM 6 & PJM 7 & PJM 8 & & $\mathrm{H} 1$ & $\mathrm{H} 2$ & H3 & $\mathrm{H} 4$ & & & & & & \\
\hline E0168 & 8 & Water & 31 & 0.96 & - & - & 2 & 4,5 & $>5$ & 5 & 4.99 & & $i$ & $-c$ & $\begin{array}{l}0.001 / 0.001 / \\
271101\end{array}$ & $10.001 / 0.001 /$ & & 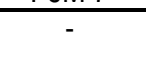 & 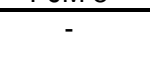 & $>15$ & $\mathrm{~L}$ & $\mathrm{~L}$ & $\mathrm{~L}$ & $\mathrm{~L}$ & $\mathrm{~N}$ & No & 2 & $\begin{array}{l}\text { E0168-D1- } \\
\text { 07727 ASC }\end{array}$ & E0168-D2-Channel1 Feb 27, & No video taken \\
\hline E0169 & 8 & Water & 31 & 0.96 & & - & 2 & 4,5 & $>5$ & 5 & 4.99 & - & & c & $\begin{array}{l}0.00110 .001 / \\
27110\end{array}$ & $\begin{array}{l}\text { / } 0.001 / 0.001 / \\
27 / 110\end{array}$ & & & & $>15$ & L & L & L & L & N & No & 3 & $\begin{array}{l}\text { E0169-D1- } \\
07027 \text { ASC }\end{array}$ & $\begin{array}{l}\text { E0169-D2-Channel1 Feb 27, } \\
2007 \text { 10-42-14.xt }\end{array}$ & No video taken \\
\hline E0170 & 8 & Water & 31 & 0.96 & & & 2 & 4,5 & $>5$ & 5 & 4.99 & & & 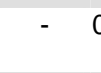 & $\begin{array}{c}0.001 / 0.001 / \\
27 / 110\end{array}$ & $\begin{array}{l}\text { / } 0.001 / 0.001 / \\
27 / 110\end{array}$ & & & & $>15$ & L & $\mathrm{L}$ & L & L & $\mathrm{Y}$ & No & 1 & $\begin{array}{l}\text { E0170-D1- } \\
\text { 070227.ASC }\end{array}$ & $\begin{array}{l}\text { E0170-D2-Channel1 Feb 27, } \\
2007 \text { 10-46-35.txt }\end{array}$ & No video taken \\
\hline E0171 & 8 & Water & 31 & 0.96 & & & 2 & 4,5 & $>5$ & 5 & 4.99 & - & & c & $\begin{array}{c}0.001 / 0.001 / \\
271110\end{array}$ & $\mid \begin{array}{l}0.001 / 0.001 / \\
27 / 110\end{array}$ & & & & $>15$ & L & L & L & $\mathrm{L}$ & $\mathrm{Y}$ & No & 2 & $\begin{array}{l}\text { E0171-D1- } \\
\text { 007027.ASC }\end{array}$ & $\begin{array}{l}\text { E0171-D2-Channel1 Feb 27, } \\
\text { 2007 10-48-52.txt }\end{array}$ & No video taken \\
\hline E0172 & 8 & Water & 31 & 0.96 & - & - & 2 & 4,5 & $>5$ & 5 & 4.99 & - & - & $-c$ & $\begin{array}{l}0.001 / 0.001 / \\
27 / 110\end{array}$ & $\begin{array}{l}\text { / } 0.001 / 0.001 / \\
27 / 110\end{array}$ & 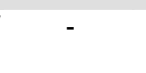 & - & - & $>15$ & L & L & L & L & $\mathrm{Y}$ & No & 3 & $\begin{array}{l}\text { E0172-D1- } \\
\text { 070227.ASC }\end{array}$ & $\begin{array}{l}\text { E0172-D2-Channel1 Feb 27, } \\
2007 \text { 10-50-58.txt }\end{array}$ & No video taken \\
\hline E0173 & 8 & Water & 31 & 0.96 & - & - & 1 & 5 & -2.5 & - & 2.97 & - & - & - & - & $\begin{array}{c}0.001 / 0.001 / \\
30 / 110\end{array}$ & - & - & - & 12 & $\mathrm{~L}$ & L & L & $\mathrm{L}$ & $\mathrm{N}$ & No & 1 & $\begin{array}{l}\text { E0173-D1- } \\
\text { 070227.ASC }\end{array}$ & $\begin{array}{l}\text { E0173-D2-Channel1 Feb 27, } \\
\text { 2007 11-14-09.txt }\end{array}$ & No video taken \\
\hline E0175 & 8 & Water & 31 & 0.96 & - & - & 1 & 5 & -2.5 & - & 2.97 & - & - & - & - & $\begin{array}{l}0.001 / 0.001 / \\
30 / 110\end{array}$ & 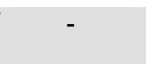 & - & - & 12 & L & L & L & $\mathrm{L}$ & $\mathrm{N}$ & No & 3 & $\begin{array}{l}\text { E0175-D1- } \\
\text { 007027.ASC }\end{array}$ & $\begin{array}{l}\text { E0175-D2-Channell Feb 27, } \\
\text { 2007 11-11-199t trt }\end{array}$ & No video taken \\
\hline E0176 & 8 & Water & 31 & 0.96 & - & - & 2 & 4,5 & -2.5 & 2.99 & 2.99 & - & - & c & $\begin{array}{l}0.001 / 0.001 / \\
30 / 110\end{array}$ & $\begin{array}{l}\text { / 0.001/0.001/ } \\
30 / 110\end{array}$ & & - & - & 12 & L & $\mathrm{L}$ & L & L & $\mathrm{N}$ & No & 1 & $\begin{array}{l}\text { E0176--11- } \\
\text { 070227.ASC }\end{array}$ & $\begin{array}{c}\text { E0176-D2-Channel1 Feb 27, } \\
\text { 2007 11-27-57.txt }\end{array}$ & No video taken \\
\hline E0177 & 8 & Water & 31 & 0.96 & & & 2 & 4,5 & -2.5 & 2.99 & 2.99 & - & & $-c$ & $\begin{array}{c}0.001 / 0.001 / \\
30 / 110\end{array}$ & 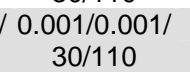 & & - & . & 12 & L & L & L & $\mathrm{L}$ & $\mathrm{N}$ & No & 2 & $\begin{array}{l}\text { E0177-D1- } \\
\text { 070227.ASC }\end{array}$ & $\begin{array}{l}\text { E0177-D2-Channel1 Feb 27, } \\
2007 \text { 11-30-28.txt }\end{array}$ & No video taken \\
\hline E0178 & 8 & Water & 31 & 0.96 & - & - & 2 & 4,5 & -2.5 & 2.99 & 2.99 & - & - & c & $\begin{array}{c}0.001 / 0.001 / \\
30 / 110\end{array}$ & 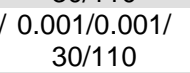 & & - & - & 12 & L & $\mathrm{L}$ & $\mathrm{L}$ & L & $\mathrm{N}$ & No & 3 & $\begin{array}{l}\text { E0178-D1- } \\
\text { 070227.ASC }\end{array}$ & $\begin{array}{l}\text { E0178-D2-Channel1 Feb 27, } \\
\text { 2007 11-33-13.txt }\end{array}$ & No video taken \\
\hline E0179 & 8 & Water & 31 & 0.96 & - & - & 1 & 5 & -5 & - & 0.92 & - & - & - & ofrat & $\begin{array}{c}0.001 / 0.001 / \\
60 / 110\end{array}$ & 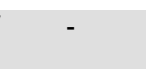 & - & - & 8 & L & L & L & L & $\mathrm{N}$ & No & 1 & $\begin{array}{l}\text { E0179-D1- } \\
\text { 00727 ASC }\end{array}$ & $\begin{array}{l}\text { E0179-D2-Channel1 Feb 27, } \\
\text { 2007 13-12-17 tyx }\end{array}$ & No video taken \\
\hline E0180 & 8 & Water & 31 & 0.96 & - & - & 1 & 5 & -5 & - & 0.92 & - & - & - & - & $\begin{array}{l}0.001 / 0.001 / \\
60 / 110\end{array}$ & - & - & - & 8 & L & L & L & L & $\mathrm{N}$ & No & 2 & $\begin{array}{l}\text { E0180-D1- } \\
\text { 070227.ASC }\end{array}$ & $\begin{array}{l}\text { E0180-D2-Channel1 Feb 27, } \\
\text { 2007 13-21-17.txt }\end{array}$ & No video taken \\
\hline E0181 & 8 & Water & 31 & 0.96 & - & - & 1 & 5 & -5 & - & 0.92 & - & - & - & & $\begin{array}{l}0.001 / 0.001 / \\
60 / 110\end{array}$ & & - & - & 8 & L & L & L & L & $\mathrm{N}$ & No & 3 & $\begin{array}{l}\text { E0181-D1- } \\
\text { 070?27 ASC }\end{array}$ & E0181-D2-Channel1 Feb 27, & No video taken \\
\hline E0182 & 8 & Water & 31 & 0.96 & - & - & 2 & 4,5 & -4 & 0.93 & 0.94 & - & & c & $\begin{array}{c}0.001 / 0.001 / \\
60 / 110\end{array}$ & $\begin{array}{l}\text { / 0.001/0.001/ } \\
60 / 110\end{array}$ & & & & 8 & L & L & L & L & $\mathrm{N}$ & No & 1 & $\begin{array}{l}\text { E0182-D1- } \\
07027 \text {. }\end{array}$ & $\begin{array}{l}\text { E0182-D2-Channel1 Feb } 27, \\
\text { 2007 13-31-29.txt }\end{array}$ & No video taken \\
\hline E0184 & 8 & Water & 31 & 0.96 & 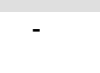 & & 2 & 4,5 & $\sim 4$ & 0.89 & 0.93 & - & & c & $\begin{array}{l}0.001 / 0.001 / \\
60 / 110\end{array}$ & $\begin{array}{l}/ 0.001 / 0.001 / \\
60 / 110\end{array}$ & & & & 8 & L & L & L & L & $\mathrm{N}$ & No & 1 & $\begin{array}{l}\text { E0184--11- } \\
\text { 070227.ASC }\end{array}$ & $\begin{array}{l}\text { E0184-D2-Channel1 Feb 27, } \\
\text { 2007 13-50-01.txt }\end{array}$ & No video taken \\
\hline E0185 & 8 & Water & 31 & 0.96 & & & 2 & 4,5 & -3.5 & 0.93 & 0.91 & - & & c & $\begin{array}{c}0.001 / 0.001 / \\
60 / 110\end{array}$ & 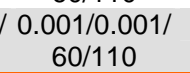 & & & & 8 & L & L & L & L & $\mathrm{N}$ & No & 2 & $\begin{array}{l}\text { E0185-D1- } \\
\text { 070227.ASC }\end{array}$ & $\begin{array}{l}\text { E0185-D2-Channel1 Feb 27, } \\
\text { 2007 13-56-33.txt }\end{array}$ & No video taken \\
\hline $\begin{array}{l}\text { Low wate: } \\
\text { E0186 }\end{array}$ & $\begin{array}{l}\text { vel, } \\
8\end{array}$ & $\begin{array}{l}\text { Iydropho } \\
\text { Water }\end{array}$ & $\begin{array}{l}\text { one leve } \\
130\end{array}$ & 0.31 & - & - & 1 & 8 & $>5$ & & & - & & 4.02 & & & & & $\begin{array}{l}45 / 0.001 / \\
31 / 110\end{array}$ & 14 & L & L & L & L & $\mathrm{N}$ & Y & 1 & $\begin{array}{l}\text { E0186-D1- } \\
\text { 070305.ASC }\end{array}$ & $\begin{array}{l}\text { E0186-D2-Channel1 March } \\
5,2007 \text { 10-01-34.txt }\end{array}$ & $\begin{array}{l}\text { E0186-RUN1-NV- } \\
\text { 070305.AVI }\end{array}$ \\
\hline E0187 & 8 & Water & 130 & 0.31 & - & & 1 & 5 & -4 & & 3.96 & - & & - & & $45 / 0.001 / 27 /$ & & & & 14 & L & L & L & L & $\mathrm{N}$ & No & 1 & $\begin{array}{l}\text { E0187-D1- } \\
\text { 07005.ASC }\end{array}$ & $\begin{array}{l}\text { E0187-D2-Channel March } \\
5,207 \text { 10-28-20.txt }\end{array}$ & No video taken \\
\hline E0188 & 8 & Water & 130 & 0.31 & 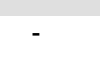 & & 1 & 5 & $\sim 4$ & & 3.96 & - & & - & & $\begin{array}{l}45 / 0.001 / 27 / \\
110\end{array}$ & & & & 14 & L & L & L & L & $\mathrm{N}$ & No & 2 & $\begin{array}{l}\text { E0138-D1- } \\
\text { 07005.ASC }\end{array}$ & $\begin{array}{l}\text { E0188-D2-Channel1 March } \\
5,207 \text { 10-31-46.txt }\end{array}$ & No video taken \\
\hline E0189 & 8 & Water & 130 & 0.31 & & & 1 & 5 & -4 & & 3.96 & - & & - & & $45 / 0.0001 / 271$ & & & & 14 & L & L & L & L & $\mathrm{N}$ & No & 3 & $\begin{array}{l}\text { E0189-D1- } \\
\text { E01- }\end{array}$ & $\begin{array}{l}\text { E0189-D2-Channel1 March } \\
\text { 5-D07 }\end{array}$ & No video taken \\
\hline E0190 & 8 & Water & 130 & 0.31 & & & 2 & 4,5 & $\sim 4$ & 4 & 3.95 & - & & 4 & $\begin{array}{l}45 / 0.001 / 271 \\
110\end{array}$ & / 45/0.001/27/ & & & & 14 & L & L & L & L & $\mathrm{N}$ & No & 1 & $\begin{array}{l}\text { E0190-D1- } \\
\text { 07005.ASC }\end{array}$ & $\begin{array}{l}\text { E0190-D2-Channell March } \\
5,2007 \text { 10-50-37 txt }\end{array}$ & No video taken \\
\hline E0191 & 8 & Water & 130 & 0.31 & - & - & 2 & 4,5 & $\sim 4$ & 4 & 3.95 & - & - & - & $\begin{array}{l}45 / 0.001 / 271 \\
110\end{array}$ & $|45 / 0.001 / 27|$ & 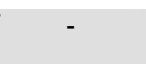 & - & - & 14 & L & L & L & L & $\mathrm{N}$ & No & 2 & $\begin{array}{l}\text { E0191-D1- } \\
07035 \text { ASC }\end{array}$ & $\begin{array}{l}\text { E0191-D2-Channel1 March } \\
\text { 5 2007 } 200-55-05 t x t\end{array}$ & No video taken \\
\hline E0192 & 8 & Water & 130 & 0.31 & - & - & 2 & 4,5 & -3.5 & 4 & 3.95 & - & - & -2 & $45 / 0.001 / 27$ & $\mid 45 / 0.001 / 27 /$ & - & - & - & 14 & L & L & L & L & $\mathrm{N}$ & No & 3 & E0192-D1- & $E 0192-5$ & No video taken \\
\hline E0193 & 8 & Water & 130 & 0.31 & - & - & 3 & $4,5,6$ & -3.5 & 3.97 & 3.92 & 3.99 & & -4 & $45 / 0.001 / 27$ & $\mid 45 / 0.001 / 271$ & $45 / 0.001 /$ & - & - & 14 & L & L & L & L & $\mathrm{N}$ & No & 1 & $\begin{array}{l}\text { E0193-D1- } \\
\text { 07730 ASC }\end{array}$ & $\begin{array}{l}\text { E0193-D2-Channel1 March } \\
\text { 5 }\end{array}$ & No video taken \\
\hline E0194 & 8 & Water & 130 & 0.31 & - & & 3 & $4,5,6$ & -3.5 & 3.97 & 3.92 & 3.99 & & - & $\begin{array}{l}45 / 0.001 / 271 \\
110\end{array}$ & / 45/0.001/27/ & $\begin{array}{l}45 / 0.001 / \\
27 / 110\end{array}$ & & & 14 & L & L & L & L & $\mathrm{N}$ & No & 2 & $\begin{array}{l}\text { E0194-D1- } \\
\text { 070305.ASC }\end{array}$ & $\begin{array}{r}\text { E0194- } \\
5,2\end{array}$ & No video taken \\
\hline E0195 & 8 & Water & 130 & 0.31 & & & 3 & $4,5,6$ & $\sim 3.5$ & 3.91 & 3.92 & 3.99 & - & - & $\begin{array}{l}45 / 0.001 / 27 / \\
110\end{array}$ & / 45/0.001/27/ & $\begin{array}{l}45 / 0.001 / \\
27 / 110\end{array}$ & & & 14 & L & $\mathrm{L}$ & $\mathrm{L}$ & L & $\mathrm{N}$ & No & 3 & $\begin{array}{l}\text { E0195--11- } \\
\text { 070305.ASC }\end{array}$ & $\begin{array}{l}\text { E0195-D-Channel March } \\
\text { 5, 2007 11-22-30.txt }\end{array}$ & No video taken \\
\hline E0196 & 8 & Water & 130 & 0.31 & - & & 1 & 8 & $>5$ & & - & & & 4.05 & & & & & $\begin{array}{l}45 / 0.001 / \\
31 / 110\end{array}$ & 14 & L & L & $\mathrm{L}$ & L & $\mathrm{N}$ & Y & 1 & $\begin{array}{l}\text { E0196-D1- } \\
\text { 070305.ASC }\end{array}$ & $\begin{array}{l}\text { E0196-D2-Channell March } \\
5,2007 \text { 13-12-38 txt }\end{array}$ & $\begin{aligned} E 0196- \\
070\end{aligned}$ \\
\hline E0197 & 8 & Water & 130 & 0.31 & 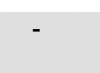 & & 1 & 8 & $>5$ & & - & & & 4.05 & & & & & $\begin{array}{l}45 / 0.001 / 1 \\
31 / 110\end{array}$ & 14 & L & L & $\mathrm{L}$ & $\mathrm{L}$ & $\mathrm{N}$ & $\mathrm{Y}$ & 2 & $\begin{array}{l}\text { E0197--1D- } \\
\text { 070305.ASC }\end{array}$ & $\begin{array}{l}\text { E0197-D2-Channeli March } \\
\text { 5, 2007 13-23-36.txt }\end{array}$ & $\begin{aligned} & \text { E0197-RUI } \\
& 070305\end{aligned}$ \\
\hline E0198 & 8 & Water & 130 & 0.31 & - & - & 1 & 8 & $>5$ & 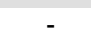 & - & - & - & 4.05 & - & - & - & - & $\begin{array}{l}45 / 0.001 / \\
3 / 1110\end{array}$ & 14 & L & L & L & L & $\mathrm{N}$ & $\mathrm{N}$ & 3 & $\begin{array}{l}\text { E0198-D1- } \\
\text { E7 }\end{array}$ & E0198-D2-Channel1 March & No video taken \\
\hline
\end{tabular}


Table A.1. Master Run Log, 8-PJM Configuration

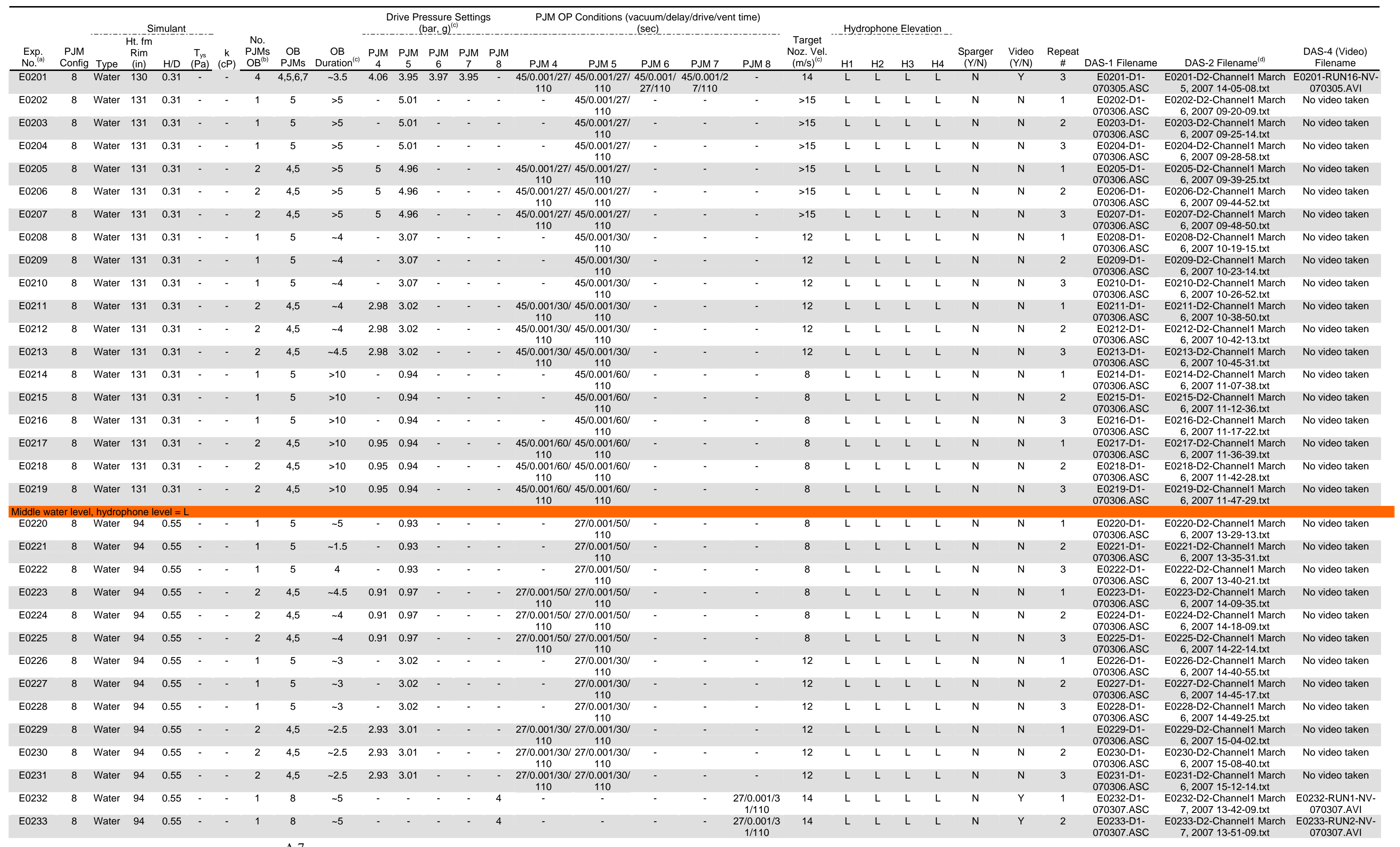


Table A.1. Master Run Log, 8-PJM Configuration

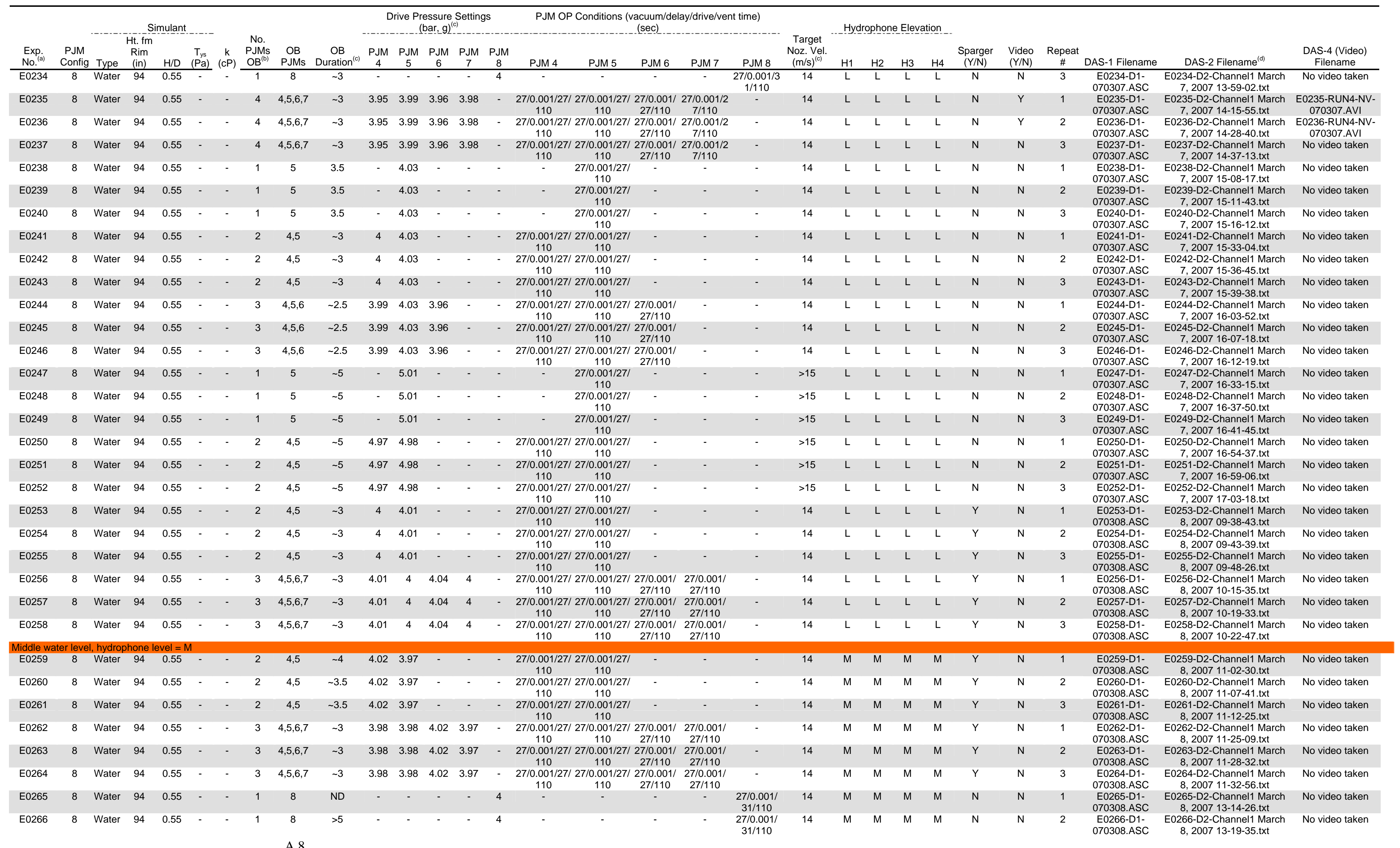


Table A.1. Master Run Log, 8-PJM Configuration

\begin{tabular}{|c|c|c|c|c|c|c|c|c|c|c|c|c|c|c|c|c|c|c|c|c|c|c|c|c|c|c|c|c|c|c|}
\hline \multirow[b]{2}{*}{$\begin{array}{c}\text { Exp. } \\
\text { No.(a) }\end{array}$} & \multirow[b]{2}{*}{$\begin{array}{l}\text { PJM } \\
\text { Config }\end{array}$} & \multicolumn{5}{|c|}{ Simulant } & \multirow[b]{2}{*}{$\begin{array}{c}\text { No. } \\
\text { PJMs } \\
\mathrm{OB}^{(\text {) }}\end{array}$} & \multirow[b]{2}{*}{$\begin{array}{c}\text { OB } \\
\text { PJMS } \\
\end{array}$} & \multirow[b]{2}{*}{$\begin{array}{c}\mathrm{OB} \\
\text { Duration } \\
\text { (c) }\end{array}$} & \multicolumn{5}{|c|}{$\begin{array}{l}\text { Drive Pressure Settings } \\
\left(\text { barar.g }^{(c)}\right)^{(0)}\end{array}$} & \multicolumn{5}{|c|}{ PJM OP Conditions (vacuum/delay/drive/vent time) } & \multirow[b]{2}{*}{$\begin{array}{l}\text { Target } \\
\text { Noz. Vel. } \\
(\mathrm{m} /)^{\left({ }^{(c)}\right.}\end{array}$} & \multicolumn{4}{|c|}{ Hydrophone Elevation } & \multirow[b]{2}{*}{$\begin{array}{c}\text { Sparger } \\
(\mathrm{Y} / \mathrm{N})\end{array}$} & \multirow[b]{2}{*}{$\begin{array}{l}\text { Video } \\
(Y / N)\end{array}$} & \multirow[b]{2}{*}{ 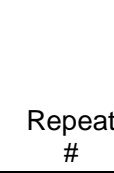 } & \multirow[b]{2}{*}{ DAS-1 Filename } & \multirow[b]{2}{*}{ DAS-2 Filename ${ }^{(\mathrm{d})}$} & \multirow[b]{2}{*}{$\begin{array}{c}\text { DAS-4 (Video) } \\
\text { Filename }\end{array}$} \\
\hline & & Type & $\begin{array}{l}\text { Ht. fm } \\
\text { Rim } \\
\text { (in) }\end{array}$ & $H / D$ & $\begin{array}{l}\mathrm{T}_{\mathrm{ys}} \\
(\mathrm{Pa})\end{array}$ & $\begin{array}{c}\mathrm{k} \\
(\mathrm{cP})\end{array}$ & & & & $\underset{4}{\mathrm{PJM}}$ & $\begin{array}{c}\text { PJM } \\
5\end{array}$ & $\begin{array}{c}\text { PJM } \\
6\end{array}$ & $\begin{array}{c}\text { PJM } \\
7\end{array}$ & $\begin{array}{c}\text { PJM } \\
8\end{array}$ & PJM 4 & PJM 5 & PJM 6 & PJM 7 & PJM 8 & & $\mathrm{H} 1$ & $\mathrm{H} 2$ & H3 & $\mathrm{H} 4$ & & & & & & \\
\hline E0267 & 8 & Water & 94 & 0.55 & & - & 1 & 8 & $>5$ & & - & - & - & 4 & & - & - & & $\begin{array}{l}27 / 0.001 / \\
31 / 110\end{array}$ & & $\mathrm{M}$ & $\mathrm{M}$ & $\mathrm{M}$ & M & $\mathrm{N}$ & $\mathrm{N}$ & 3 & $\begin{array}{l}\text { E0267-D1- } \\
\text { 070083ASC }\end{array}$ & $\begin{array}{l}\text { E0267-D2-Channel1 March } \\
8 \text { 82007 13-23-302 }\end{array}$ & No video taker \\
\hline E0268 & 8 & Water & 94 & 0.55 & & - & 1 & 5 & -3 & - & 4.01 & - & - & - & - & $\begin{array}{l}27 / 0.001 / 27 / \\
110\end{array}$ & - & - & & 14 & M & M & M & M & N & N & 1 & $\begin{array}{l}\text { E0268-D1- } \\
070308 \text {.ASC }\end{array}$ & $\begin{array}{l}\text { E0268-20-Channeli March } \\
\text { 8, 2007 13-33-14.txt }\end{array}$ & No video taker \\
\hline E0269 & 8 & Water & 94 & 0.55 & & & 1 & 5 & -3 & & 4.01 & - & & & & $2710.001 / 271$ & & & & 14 & M & $\mathrm{M}$ & M & M & $\mathrm{N}$ & $\mathrm{N}$ & 2 & $\begin{array}{l}\text { E0269-D1- } \\
070308 \text { ASC }\end{array}$ & $\begin{array}{l}\text { E0269-D2-Channel1 March } \\
8 \text { 2007 13-3-313 trt }\end{array}$ & No video taker \\
\hline E0270 & 8 & Water & 94 & 0.55 & & - & 1 & 5 & -3 & - & 4.01 & - & - & - & & $\begin{array}{l}27 / 0.001 / 27 / \\
110\end{array}$ & - & - & & 14 & $\mathrm{M}$ & M & M & M & $\mathrm{N}$ & $\mathrm{N}$ & 3 & $\begin{array}{l}\text { E0270-D1- } \\
\text { 070308.ASC }\end{array}$ & $\begin{array}{l}\text { E0270-D2-Channel1 March } \\
\text { 8, 2007 13-41-47.txt }\end{array}$ & No video taker \\
\hline E0271 & 8 & Water & 94 & 0.55 & 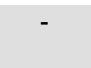 & - & 2 & 4,5 & -3.5 & 4.01 & 4.01 & - & - & - & $\begin{array}{c}27 / 0.001 / 27 / \\
110\end{array}$ & $\begin{array}{l}27 / 0.001 / 27 / \\
110\end{array}$ & - & - & - & 14 & M & M & M & M & $\mathrm{N}$ & $\mathrm{N}$ & 1 & $\begin{array}{l}\text { E0271-D1- } \\
\text { 0700808.ASC }\end{array}$ & $\begin{array}{l}\text { E0271-D2-Channel1 March } \\
\text { 8. 2007 13-57-22.ttx }\end{array}$ & No video taker \\
\hline E0272 & 8 & Water & 94 & 0.55 & - & - & 2 & 4,5 & -3 & 4.01 & 4.01 & - & - & - & $\begin{array}{c}27 / 0.001 / 27 / \\
110\end{array}$ & $\begin{array}{l}27 / 0.001 / 27 / \\
110\end{array}$ & - & - & - & 14 & M & M & M & M & $\mathrm{N}$ & N & 2 & $\begin{array}{l}\text { E0272-D1- } \\
070308 \text { ASC }\end{array}$ & $\begin{array}{l}\text { E0272-D2-Channel1 March } \\
\text { 8, 2007 14-01-33.txt }\end{array}$ & No video taker \\
\hline E0273 & 8 & Water & 94 & 0.55 & - & - & 2 & 4,5 & -3 & 4.01 & 4.01 & - & - & - & $27 / 0.001 / 271$ & $712710.001 / 271$ & - & - & - & 14 & M & M & M & M & $\mathrm{N}$ & $\mathrm{N}$ & 3 & $\begin{array}{l}\text { E0273-D1- } \\
\text { 07008 ASC }\end{array}$ & $\begin{array}{l}\text { E0273-D2-Channel1 March } \\
\text { 8.2007 74-06-33 }\end{array}$ & No video taken \\
\hline E0274 & 8 & Water & 94 & 0.55 & - & - & 3 & $4,5,6$ & -3 & 4.01 & 4.01 & 4.03 & - & - & $\begin{array}{c}27 / 0.001 / 27 / \\
110\end{array}$ & $\begin{array}{l}27 / 0.001 / 27 / 2 \\
110\end{array}$ & $\begin{array}{l}27 / 0.001 / \\
27 / 110\end{array}$ & - & - & 14 & M & M & M & M & $\mathrm{N}$ & $\mathrm{N}$ & 1 & $\begin{array}{l}\text { E0274-D1- } \\
070308 \text { ASC }\end{array}$ & $\begin{array}{l}\text { E0274-D2-Channel1 March } \\
\text { 8. 2007 14-28-36 txt }\end{array}$ & No video taken \\
\hline E0275 & 8 & Water & 94 & 0.55 & & - & 3 & $4,5,6$ & -3 & 4.01 & 4.01 & 4.03 & - & - & $27 / 0.001 / 271$ & $7127 / 0.001 / 2712$ & $\begin{array}{l}27 / 0.001 / \\
27110\end{array}$ & & 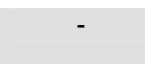 & 14 & M & M & M & M & $\mathrm{N}$ & $\mathrm{N}$ & 2 & $\begin{array}{l}\text { E0275-D1- } \\
\text { O700308 ASC }\end{array}$ & $\begin{array}{l}\text { E0275-D2-Channel March } \\
8 \text { 2007 14-32-206 trt }\end{array}$ & No video taken \\
\hline E0276 & 8 & Water & 94 & 0.55 & & - & 3 & $4,5,6$ & -3 & 4.01 & 4.01 & 4.03 & - & - & $\begin{array}{c}27 / 0.001 / 27 / \\
110\end{array}$ & / 27/0.001/27/ & $\begin{array}{l}27 / 0.001 / 1 \\
27 / 110\end{array}$ & & - & 14 & M & M & M & M & $\mathrm{N}$ & $\mathrm{N}$ & 3 & $\begin{array}{l}\text { E0276-D1- } \\
\text { 0700808 ASC }\end{array}$ & $\begin{array}{l}\text { E0276-D2-Channel March } \\
8 \text { 8007 14-35-44t大t }\end{array}$ & No video taken \\
\hline E0277 & 8 & Water & 94 & 0.55 & & 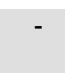 & 4 & $4,5,6,7$ & -3 & 3.99 & 4.02 & 4 & 4.03 & - & $\begin{array}{c}27 / 0.001 / 27 / \\
110\end{array}$ & $7 / 27 / 0.001 / 27 / 2$ & $\begin{array}{l}27 / 0.001 / 1 \\
27 / 110\end{array}$ & $\begin{array}{c}27 / 0.001 / \\
27 / 110\end{array}$ & & 14 & M & M & M & M & $\mathrm{N}$ & $\mathrm{N}$ & 1 & $\begin{array}{l}\text { E0277-D1- } \\
\text { 070308.ASC }\end{array}$ & $\begin{array}{l}\text { E0277-D2-Channel1 March } \\
\text { 8, 2007 14-56-32.txt }\end{array}$ & No video taken \\
\hline E0278 & 8 & Water & 94 & 0.55 & & - & 4 & $4,5,6,7$ & -3 & 3.99 & 4.02 & 4 & 4.03 & - & $27 / 0.001 / 271$ & $71 / 27 / 0.001 / 27 / 2$ & $\begin{array}{l}27 / 0.001 / \\
27110\end{array}$ & $\begin{array}{l}27 / 10.001 / \\
27110\end{array}$ & - & 14 & M & M & M & M & $\mathrm{N}$ & $\mathrm{N}$ & 2 & $\begin{array}{l}\text { E0278-D1- } \\
\text { 07008 ASC }\end{array}$ & $\begin{array}{l}\text { E0278-D2-Channel1 March } \\
8 \text { - 2007 15-02-28 }\end{array}$ & No video taken \\
\hline E0279 & 8 & Water & 94 & 0.55 & - & - & 4 & $4,5,6,7$ & -3 & 3.99 & 4.02 & 4 & 4.03 & - & $\begin{array}{l}27 / 0.001 / 27 / \\
110\end{array}$ & $7 / 27 / 0.001 / 27 / 2$ & $\begin{array}{l}27 / 10.001 / 1 \\
27 / 110\end{array}$ & $\begin{array}{c}27 / 0.001 / \\
27 / 110\end{array}$ & - & 14 & M & M & M & M & $\mathrm{N}$ & $\mathrm{N}$ & 3 & $\begin{array}{l}\text { E0279-D1- } \\
\text { 070308.ASC }\end{array}$ & $\begin{array}{l}\text { E0279-D2-Channel1 March } \\
\text { 8, 2007 15-05-48.txt }\end{array}$ & No video taken \\
\hline E0280 & 8 & Water & 94 & 0.55 & & - & 1 & 5 & $>5$ & - & 5.02 & - & - & - & & $\begin{array}{l}27 / 0.001 / 27 / \\
110\end{array}$ & t. & & - & 15 & M & M & M & M & $\mathrm{N}$ & $\mathrm{N}$ & 1 & $\begin{array}{l}\text { E0280-D1- } \\
\text { 070309.ASC }\end{array}$ & $\begin{array}{l}\text { E0280-D2-Channel1 March } \\
\text { 9, 2007 10-11-14.txt }\end{array}$ & No video taken \\
\hline E0281 & 8 & Water & 94 & 0.55 & & & 1 & 5 & $>5$ & - & 5.02 & - & - & & & $\begin{array}{l}27 / 0.001 / 271 \\
110\end{array}$ & - & & & 15 & $\mathrm{M}$ & M & M & M & $\mathrm{N}$ & $\mathrm{N}$ & 2 & $\begin{array}{l}\text { E0281-D1- } \\
\text { 070309.ASC }\end{array}$ & $\begin{array}{l}\text { E0281-D2-Channel1 March } \\
\text { 9, 2007 10-14-40.txt }\end{array}$ & No video taken \\
\hline E0282 & 8 & Water & 94 & 0.55 & & & 1 & 5 & $>5$ & & 5.02 & - & & & & $27 / 0.001 / 27 /$ & ( & & & 15 & M & M & M & M & $\mathrm{N}$ & $\mathrm{N}$ & 3 & $\begin{array}{l}\text { E0282-D1- } \\
\text { ON0200 }\end{array}$ & $\begin{array}{l}\text { E0282-D2-Channel1 March } \\
\text { o- }\end{array}$ & No video taken \\
\hline E0283 & 8 & Water & 94 & 0.55 & & & 2 & 4,5 & $>5$ & 4.98 & 4.99 & - & & & $\begin{array}{l}27 / 0.001 / 27 / \\
110\end{array}$ & $7 / 27 / 0.001 / 271$ & & & & 15 & M & M & M & M & $\mathrm{N}$ & $\mathrm{N}$ & 1 & $\begin{array}{l}\text { E0283-D1- } \\
\text { 070309.ASC }\end{array}$ & $\begin{array}{l}\text { E0283-D2-Channel1 March } \\
\text { 9, 2007 10-24-33.txt }\end{array}$ & No video taken \\
\hline E0284 & 8 & Water & 94 & 0.55 & & & 2 & 4,5 & $>5$ & 4.98 & 4.99 & - & & & $\begin{array}{l}27 / 0.001 / 27 / \\
110\end{array}$ & $7 / 27 / 0.001 / 271$ & - & & & 15 & $\mathrm{M}$ & M & M & M & $\mathrm{N}$ & $\mathrm{N}$ & 2 & $\begin{array}{l}\text { E0284-D1- } \\
070309 \text { ASC }\end{array}$ & $\begin{array}{l}\text { E0284-D2-Channel1 March } \\
\text { 9.2007 10-27-24 txt }\end{array}$ & No video taken \\
\hline E0285 & 8 & Water & 94 & 0.55 & & - & 2 & 4,5 & $>5$ & 4.98 & 4.99 & - & - & - & $\begin{array}{c}27 / 0.001 / 27 / \\
110\end{array}$ & $7 / 27 / 0.001 / 27 /$ & - & - & - & 15 & M & M & M & M & $\mathrm{N}$ & $\mathrm{N}$ & 3 & $\begin{array}{l}\text { E0285-D1- } \\
\text { 070309.ASC }\end{array}$ & $\begin{array}{l}\text { E0285-D2-Channel1 March } \\
\text { 9, 2007 10-30-10.txt }\end{array}$ & No video taken \\
\hline E0286 & 8 & Water & 94 & 0.55 & - & - & 1 & 5 & -3 & - & 2.99 & - & - & - & & $\begin{array}{l}27 / 0.001 / 30 / \\
110\end{array}$ & - & - & - & 12 & M & M & M & M & $\mathrm{N}$ & $\mathrm{N}$ & 1 & $\begin{array}{l}\text { E0286-D1- } \\
070309 \text { ASC }\end{array}$ & $\begin{array}{l}\text { E0286-D2-Channel1 March } \\
\text { o }\end{array}$ & No video taken \\
\hline E0287 & 8 & Water & 94 & 0.55 & - & - & 1 & 5 & -3 & - & 2.99 & - & - & - & - & $\begin{array}{l}2710.001 / 30 / \\
110\end{array}$ & - & - & - & 12 & M & M & M & M & $\mathrm{N}$ & $\mathrm{N}$ & 2 & $\begin{aligned} E 028 \\
07030\end{aligned}$ & $\begin{array}{l}\text { E0287-D2-Channel1 March } \\
\text { 9, 2007 10-51-37.txt }\end{array}$ & No video taken \\
\hline E0288 & 8 & Water & 94 & 0.55 & & 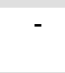 & 1 & 5 & -3 & - & 2.99 & - & - & . & & $\begin{array}{c}27 / 0.001 / 30 / \\
110\end{array}$ & - & & & 12 & M & M & M & M & $\mathrm{N}$ & $\mathrm{N}$ & 3 & $\begin{array}{l}\text { E0288-D1- } \\
\text { 070309.ASC }\end{array}$ & $\begin{array}{l}\text { E0288-D2-Channel1 March } \\
\text { 9, 2007 10-55-01.txt }\end{array}$ & No video taken \\
\hline E0289 & 8 & Water & 94 & 0.55 & & & 2 & 4,5 & -3 & 3.01 & 2.98 & - & & 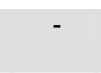 & $\begin{array}{c}27 / 0.001 / 30 / \\
110\end{array}$ & $\begin{array}{l}27 / 0.0 \\
1\end{array}$ & - & & & 12 & M & M & M & M & $\mathrm{N}$ & $\mathrm{N}$ & 1 & $\begin{array}{l}\text { E02 } \\
070\end{array}$ & $\begin{array}{r}E 0289- \\
9,2\end{array}$ & No video taken \\
\hline E0290 & 8 & Water & 94 & 0.55 & & & 2 & 4,5 & -3 & 3.01 & 2.98 & - & & & $\begin{array}{c}27 / 0.001 / 30 / \\
110\end{array}$ & / $27 / 0.001 / 30 /$ & - & & & 12 & M & M & M & M & $\mathrm{N}$ & $\mathrm{N}$ & 2 & $\begin{array}{l}\text { E0290-D1- } \\
\text { 070309.ASC }\end{array}$ & $\begin{array}{l}\text { E0290-D2-Channel1 March } \\
\text { 9, 2007 11-09-44.txt }\end{array}$ & No video taken \\
\hline E0291 & 8 & Water & 94 & 0.55 & - & - & 2 & 4,5 & -3 & 3.01 & 2.98 & - & - & - & $\begin{array}{l}27 / 0.001 / 30 / \\
110\end{array}$ & D/ 27/0.001/30/ & - & - & - & 12 & M & M & M & M & $\mathrm{N}$ & $\mathrm{N}$ & 3 & $\begin{array}{l}\text { E0291-D1- } \\
\text { 0700909.ASC }\end{array}$ & $\begin{array}{l}\text { E0291-D2-Channel1 March } \\
9200711-12-35 t \times t\end{array}$ & No video taken \\
\hline E0292 & 8 & Water & 94 & 0.55 & & - & 1 & 5 & $\sim 4$ & - & 0.91 & - & - & - & & $\begin{array}{c}27 / 0.001 / 50 / \\
110\end{array}$ & - & - & - & 8 & M & M & M & M & $\mathrm{N}$ & $\mathrm{N}$ & 1 & DASC & $\begin{array}{r}E 0292-D \\
9,20\end{array}$ & No video taken \\
\hline E0293 & 8 & Water & 94 & 0.55 & - & - & 1 & 5 & -4.5 & - & 0.91 & - & - & - & - & $2710.001 / 50 /$ & - & - & - & 8 & M & M & M & M & $\mathrm{N}$ & $\mathrm{N}$ & 2 & $\begin{array}{c}E 02 \\
003\end{array}$ & $\begin{array}{l}\text { E0293-D2-Channel1 March } \\
\text { o } 2007 \text { 11-25-31 ty }\end{array}$ & No video taken \\
\hline E0294 & 8 & Water & 94 & 0.55 & - & - & 1 & 5 & -4 & - & 0.91 & - & - & - & & $\begin{array}{r}27 / 0 . C \\
1\end{array}$ & - & - & - & 8 & M & M & M & M & $\mathrm{N}$ & $\mathrm{N}$ & 3 & -ASC & $\begin{array}{l}\text { E0294-D2-Channel1 March } \\
\text { 9, 2007 11-28-38.txt }\end{array}$ & No video taken \\
\hline E0295 & 8 & Water & 94 & 0.55 & & & 2 & 4,5 & -4 & 0.93 & 0.91 & - & & & $27 / 0.001 / 50 /$ & / $2710.001 / 50 /$ & - & & & 8 & M & M & M & M & $\mathrm{N}$ & $\mathrm{N}$ & 1 & $\begin{array}{l}\text { E0295-D1- } \\
\text { O700909 ASC }\end{array}$ & $\begin{array}{l}\text { E0295-D2-Channel March } \\
\text { 92007 11-35-33 }\end{array}$ & No video taken \\
\hline E0296 & 8 & Water & 94 & 0.55 & & & 2 & 4,5 & -3.5 & 0.93 & 0.91 & 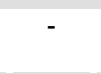 & & & $\begin{array}{c}27 / 0.001 / 50 / \\
110\end{array}$ & $\begin{array}{l}27 / 0.001 / 50 / \\
110\end{array}$ & 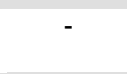 & & & 8 & M & M & M & M & $\mathrm{N}$ & $\mathrm{N}$ & 2 & $\begin{array}{l}\text { E0296-D1- } \\
\text { 070309.ASC }\end{array}$ & $\begin{array}{r}\text { E0296-D2-Chann } \\
9,2007 \text { 11-47 }\end{array}$ & No video taken \\
\hline E0297 & 8 & Water & 94 & 0.55 & & & 2 & 4,5 & -3 & 0.93 & 0.91 & & & & $\begin{array}{c}27 / 0.001 / 50 / \\
110\end{array}$ & $\begin{array}{l}27 / 0.001 / 50 / \\
110\end{array}$ & & & & 8 & $\mathrm{M}$ & M & M & M & $\mathrm{N}$ & $\mathrm{N}$ & 3 & $\begin{array}{l}\text { E0297-D1- } \\
\text { 070309.ASC }\end{array}$ & $\begin{array}{l}\text { E0297-D2-Channel1 March } \\
\text { 9, 2007 11-52-58.txt }\end{array}$ & No video taken \\
\hline E0298 & 8 & Water & 56 & 0.8 & & & 1 & 5 & $>5$ & 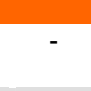 & 0.9 & - & - & - & - & $\begin{array}{c}10 / 0.001 / 57 / \\
110\end{array}$ & - & - & - & 8 & $\mathrm{M}$ & M & M & $\mathrm{M}$ & $\mathrm{N}$ & $\mathrm{N}$ & 1 & $\begin{array}{l}\text { E0298-D1- } \\
\text { 070309.ASC }\end{array}$ & $\begin{array}{l}\text { E0298-D2-Channel1 Mar 9, } \\
\text { 2007 14-31-42.txt }\end{array}$ & No video taken \\
\hline E0299 & 8 & Water & 56 & 0.8 & & 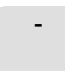 & 1 & 5 & $>5$ & - & 0.9 & - & - & - & & $\begin{array}{c}10 / 0.001 / 571 \\
110\end{array}$ & - & - & - & 8 & M & M & M & M & $\mathrm{N}$ & $\mathrm{N}$ & 2 & $\begin{array}{l}\text { E0299-D1- } \\
\text { 070309.ASC }\end{array}$ & $\begin{array}{l}\text { E0299-D2-Channel1 Mar 9, } \\
2007 \text { 14-34-41.txt }\end{array}$ & No video taken \\
\hline
\end{tabular}




\begin{tabular}{|c|c|c|c|c|c|c|c|c|c|c|c|c|c|c|c|c|c|c|c|c|c|c|c|c|c|c|c|c|c|c|}
\hline \multirow[b]{2}{*}{$\begin{array}{l}\operatorname{Exp}_{\left({ }_{0}\right.} \\
\text { No. }\end{array}$} & \multirow[b]{2}{*}{$\begin{array}{c}\text { PJM } \\
\text { Config }\end{array}$} & \multicolumn{4}{|c|}{ Simulant } & \multirow{2}{*}{\multicolumn{2}{|c|}{$\begin{array}{cc}\text { No. } \\
k \\
\text { PJMs } \\
c P) & \mathrm{OB}^{(0)}\end{array}$}} & \multirow[b]{2}{*}{$\begin{array}{l}\text { OB } \\
\text { PJMs }\end{array}$} & \multirow[b]{2}{*}{$\begin{array}{c}\mathrm{OB} \\
\text { Duration }{ }^{(\mathrm{c})}\end{array}$} & \multicolumn{5}{|c|}{$\begin{array}{l}\text { Drive Pressure Settings } \\
(\text { bar,_gg }\end{array}$} & \multicolumn{5}{|c|}{ PJM OP Conditions (vacuum/delay/drive/vent time) } & \multirow[b]{2}{*}{$\begin{array}{l}\text { Target } \\
\text { Noz. Vel. } \\
\left(\mathrm{m} / \mathrm{s}^{(\mathrm{c})}\right.\end{array}$} & \multicolumn{4}{|c|}{ Hydrophone Elevation } & \multirow[b]{2}{*}{$\begin{array}{l}\text { Sparger } \\
(\mathrm{Y} / \mathrm{N})\end{array}$} & \multirow[b]{2}{*}{$\begin{array}{l}\text { Video } \\
\text { (Y/N) }\end{array}$} & \multirow[b]{2}{*}{$\begin{array}{l}\text { Repeat } \\
\#\end{array}$} & \multirow[b]{2}{*}{ DAS-1 Filename } & \multirow[b]{2}{*}{ DAS-2 Filename ${ }^{(\mathrm{d})}$} & \multirow[b]{2}{*}{$\begin{array}{l}\text { DAS-4 (Video) } \\
\text { Filename }\end{array}$} \\
\hline & & Type & $\begin{array}{l}\text { Ht. fm } \\
\text { Rim } \\
\text { (in) }\end{array}$ & $H / D$ & 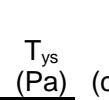 & & & & & $\underset{4}{\mathrm{PJM}}$ & $\underset{5}{\mathrm{PJM}}$ & $\begin{array}{c}\text { PJM } \\
6\end{array}$ & $\begin{array}{l}\text { PJM } \\
7\end{array}$ & $\begin{array}{c}\text { PJM } \\
8\end{array}$ & PJM 4 & PJM & PJM 6 & PJM 7 & PJM 8 & & $\mathrm{H} 1$ & $\mathrm{H}_{2}$ & H3 & a & & & & & & \\
\hline E0300 & & Water & 56 & 0.8 & & & & 5 & $>5$ & & 0.9 & & & & & $\begin{array}{l}10 / 0.001 / 57 / \\
110\end{array}$ & & & & & $\mathrm{M}$ & $\mathrm{M}$ & $\mathrm{M}$ & $\mathrm{M}$ & $\mathrm{N}$ & $\mathrm{N}$ & 3 & $\begin{array}{l}\text { E0300-D1- } \\
\text { 070309.ASC }\end{array}$ & $\begin{array}{c}\text { E0300-D2-Channel1 Mar 9, } \\
2007 \text { 14-40-31.txt }\end{array}$ & No video taken \\
\hline E0301 & 8 & Water & 56 & 0.8 & & & 2 & 4,5 & -3.5 & 0.9 & 0.9 & - & & & $\begin{array}{l}10 / 0.001 / 57 \\
110\end{array}$ & $\begin{array}{l}7 / 10 / 0.001 / 57 / \\
110\end{array}$ & & & & 8 & M & M & M & M & $\mathrm{N}$ & $\mathrm{N}$ & 1 & $\begin{array}{l}\text { E0301-D1- } \\
\text { 070309.ASC }\end{array}$ & $\begin{array}{l}\text { E0301-D2-Channel1 Mar 9, } \\
2007 \text { 14-56-01.txt }\end{array}$ & No video taken \\
\hline E0302 & 8 & Water & 56 & 0.8 & & & 2 & 4,5 & -4 & 0.9 & 0.9 & - & - & & $\begin{array}{l}10 / 0.001 / 57 \\
110\end{array}$ & $7 / 10 / 0.001 / 57 /$ & - & & & 8 & $\mathrm{M}$ & M & M & M & $\mathrm{N}$ & $\mathrm{N}$ & 2 & $\begin{array}{l}\text { E0302-D1- } \\
\text { 070309.ASC }\end{array}$ & $\begin{array}{l}\text { E0302-D2-Channel1 Mar 9, } \\
\text { 2007 14-59-131.txt }\end{array}$ & No video taken \\
\hline E0303 & 8 & Water & 56 & 0.8 & - & - & 2 & 4,5 & -4 & 0.9 & 0.9 & - & - & - & $\begin{array}{c}10 / 0.001 / 57 \\
110\end{array}$ & $\begin{array}{l}7 / 10 / 0.001 / 57 / \\
110\end{array}$ & - & - & - & 8 & M & M & M & M & $\mathrm{N}$ & $\mathrm{N}$ & 3 & $\begin{array}{l}\text { E0303-D1- } \\
\text { 070309.ASC }\end{array}$ & $\begin{array}{l}\text { E0303-D2-Channel1 Mar 9, } \\
2007 \text { 15-02-43.txt }\end{array}$ & No video taken \\
\hline E0304 & 8 & Water & 56 & 0.8 & - & - & 1 & 5 & -2.5 & - & 3.02 & - & - & - & - & $\begin{array}{l}10 / 0.001 / 31 / \\
110\end{array}$ & - & - & - & 12 & M & M & M & M & $\mathrm{N}$ & $\mathrm{N}$ & 1 & $\begin{array}{l}\text { E00304-D1- } \\
\text { 070312.ASC }\end{array}$ & $\begin{array}{l}\text { E0304-D2-Channel1 Mar 12, } \\
\text { 2007 09-36-43, }\end{array}$ & No video taken \\
\hline E0305 & 8 & Water & 56 & 0.8 & $\begin{array}{l}- \\
-\end{array}$ & - & 1 & 5 & -2.5 & - & 3.02 & - & - & - & - & $\begin{array}{l}10 / 0.001 / 31 / \\
110\end{array}$ & - & - & - & 12 & M & M & M & M & $\mathrm{N}$ & $\mathrm{N}$ & 2 & $\begin{array}{l}\text { EO305-D1- } \\
\text { O07031- ASC }\end{array}$ & $\begin{array}{l}\text { E0305-D2-Channel1 Mar 12, } \\
\text { 2007 09-39-4. }\end{array}$ & No video taken \\
\hline E0306 & 8 & Water & 56 & 0.8 & - & - & 1 & 5 & -2.5 & - & 3.03 & - & - & - & - & $\begin{array}{l}10 / 0.001 / 31 / \\
110\end{array}$ & - & - & - & 12 & M & M & M & M & $\mathrm{N}$ & $\mathrm{N}$ & 3 & $\begin{array}{l}\text { EO306-D1- } \\
\text { 070312DAC }\end{array}$ & $\begin{array}{l}\text { E0306-D2-Channel1 Mar 12, } \\
\text { 2007 09-42-2 }\end{array}$ & No video taken \\
\hline E0307 & 8 & Water & 56 & 0.8 & & & 2 & 4,5 & -2.5 & 2.99 & 3.01 & - & - & - & $10 / 0.001 / 31$ & $1 / 10 / 0.001 / 31 /$ & - & - & - & 12 & M & M & M & M & N & N & 1 & E0307-D1- & E0307-D2-Channel1 Mar 12, & No video taken \\
\hline E0308 & 8 & Water & 56 & 0.8 & & & 2 & 4,5 & -2.5 & 2.95 & 3.01 & - & - & & $\begin{array}{l}10 / 0.001 / 31 \\
110\end{array}$ & $\begin{array}{l}1 / 10 / 0.001 / 31 / \\
110\end{array}$ & - & - & $-x_{2}$ & 12 & M & M & M & M & $\mathrm{N}$ & $\mathrm{N}$ & 2 & $\begin{array}{l}\text { E0308-D1- } \\
\text { 070312.ASC }\end{array}$ & $\begin{array}{c}\text { E0308-D2-Channel1 Mar 12, } \\
\text { 2007 09-52-50.txt }\end{array}$ & No video taken \\
\hline E0309 & 8 & Water & 56 & 0.8 & & & 2 & 4,5 & -2.5 & 3.03 & 3.02 & - & - & & $\begin{array}{l}10 / 0.001 / 31 \\
110\end{array}$ & $1 / 10 / 0.001 / 31 /$ & - & & & 12 & M & M & M & M & $\mathrm{N}$ & $\mathrm{N}$ & 3 & $\begin{array}{l}\text { E0309-D1- } \\
\text { 070312.ASC }\end{array}$ & $\begin{array}{l}\text { E0309-D2-Channel1 Mar 12, } \\
2007 \text { 09-58-08.txt }\end{array}$ & No video taken \\
\hline E0310 & 8 & Water & 56 & 0.8 & - & - & 1 & 8 & -4 & - & - & - & - & 4.00 & & - & - & - & $\begin{array}{c}10 / 0.001 / \\
311110\end{array}$ & 14 & $\mathrm{M}$ & M & M & M & $\mathrm{N}$ & $\mathrm{N}$ & 1 & $\begin{array}{l}\text { EO310-D1- } \\
\text { 070312ASC }\end{array}$ & $\begin{array}{l}\text { E0310-D2-Channel1 Mar 12, } \\
\text { 2007 }\end{array}$ & No video taken \\
\hline E0311 & 8 & Water & 56 & 0.8 & - & - & 1 & 8 & -3.5 & - & - & - & - & 4.00 & - & - & - & - & $\begin{array}{c}10 / 0.001 / \\
31 / 110\end{array}$ & 14 & M & M & M & M & $\mathrm{N}$ & $\mathrm{N}$ & 2 & $\begin{array}{l}\text { E0011-D1- } \\
\text { 070312.ASC }\end{array}$ & $\begin{array}{l}\text { E0311-D2-Channel1 Mar 12, } \\
\text { 2007 10-12-39.txt }\end{array}$ & No video taken \\
\hline E0312 & 8 & Water & 56 & 0.8 & & - & 1 & 8 & -4 & - & - & - & - & 4.00 & - & & - & - & $\begin{array}{c}10 / 0.001 / \\
31 / 110\end{array}$ & 14 & $\mathrm{M}$ & M & M & M & $\mathrm{N}$ & $\mathrm{N}$ & 3 & $\begin{array}{l}\text { E0312-D1- } \\
\text { 070312.ASC }\end{array}$ & $\begin{array}{l}\text { E0312-D2-Channel1 Mar 12, } \\
2007 \text { 10-15-03.txt }\end{array}$ & No video taken \\
\hline E0313 & 8 & Water & 56 & 0.8 & & & 1 & 5 & $>5$ & & 4.00 & - & & & & $\begin{array}{c}10 / 0.001 / 31 / \\
110\end{array}$ & & & & 14 & M & M & M & M & $\mathrm{N}$ & $\mathrm{N}$ & 1 & $\begin{array}{l}\text { E0313-D1- } \\
\text { 070312.ASC }\end{array}$ & $\begin{array}{l}\text { E0313-D2-Channel1 Mar 12, } \\
2007 \text { 10-35-30.txt }\end{array}$ & No video taken \\
\hline E0314 & 8 & Water & 56 & 0.8 & & & 1 & 5 & $>5$ & & 4.03 & - & - & & & $\begin{array}{c}10 / 0.001 / 31 / \\
110\end{array}$ & - & & & 14 & M & M & M & M & $\mathrm{N}$ & $\mathrm{N}$ & 2 & $\begin{array}{l}\text { E0314-D1- } \\
\text { 070312.ASC }\end{array}$ & $\begin{array}{l}\text { E0314-D2-Channel1 Mar 12, } \\
\text { 200710-38-00.txt }\end{array}$ & No video taken \\
\hline E0315 & 8 & Water & 56 & 0.8 & & & 1 & 5 & $>5$ & - & 4.03 & - & - & & & $\begin{array}{l}10 / 0.001 / 31 / \\
110\end{array}$ & ( & & & 14 & M & M & M & M & $\mathrm{N}$ & $\mathrm{N}$ & 3 & $\begin{array}{l}\text { E0315-D1- } \\
\text { 070312.ASC }\end{array}$ & $\begin{array}{l}\text { E0315-D2-Channel1 Mar 12, } \\
\text { 2007 10-42-56.t.txt }\end{array}$ & No video taken \\
\hline E0316 & 8 & Water & 56 & 0.8 & & & 2 & 4,5 & $>5$ & 4.03 & 4.03 & - & - & & $\begin{array}{l}10 / 0.001 / 3 \\
110\end{array}$ & $\begin{array}{l}1 / 10 / 0.001 / 31 / \\
110\end{array}$ & - & - & - & 14 & M & M & M & M & $\mathrm{N}$ & $\mathrm{N}$ & 1 & $\begin{array}{l}\text { E0316-D1- } \\
\text { 07032ASC }\end{array}$ & E0316-D2-Channel1 Mar 12, & No video taken \\
\hline E0317 & 8 & Water & 56 & 0.8 & & & 2 & 4,5 & $>5$ & 4.02 & 4.03 & - & - & & $\begin{array}{l}10 / 0.001 / 31 \\
110\end{array}$ & $\begin{array}{l}1 / 10 / 0.001 / 31 / \\
110\end{array}$ & - & - & - & 14 & M & M & M & M & $\mathrm{N}$ & $\mathrm{N}$ & 2 & $\begin{array}{l}\text { E0317-D1- } \\
\text { 070312.ASC }\end{array}$ & $\begin{array}{l}\text { E0317-D2-Channel1 Mar 12, } \\
\text { 200710-59-01.txt }\end{array}$ & No video taken \\
\hline E0318 & 8 & Water & 56 & 0.8 & & - & 2 & 4,5 & $>5$ & 4.02 & 4.03 & - & - & & $\begin{array}{l}10 / 0.001 / 31 \\
110\end{array}$ & $\begin{array}{l}10 / 0.001 / 31 / \\
110\end{array}$ & - & - & - & 14 & M & M & M & M & $\mathrm{N}$ & $\mathrm{N}$ & 3 & $\begin{array}{l}\text { E0318-D1- } \\
\text { 070312.ASC }\end{array}$ & $\begin{array}{l}\text { E0318-D2-Channel1 Mar 12, } \\
2007 \text { 11-02-12.txt }\end{array}$ & No video taken \\
\hline E0319 & 8 & Water & 56 & 0.8 & & & 3 & $4,5,6$ & $>5$ & 4.07 & 4.01 & 4.01 & & & $\begin{array}{c}10 / 0.001 / \\
110\end{array}$ & $\begin{array}{l}1 / 10 / 0.001 / 31 / \\
110\end{array}$ & $\begin{array}{c}10 / 0.001 / \\
31 / 110\end{array}$ & & & & $\mathrm{M}$ & M & M & M & $\mathrm{N}$ & $\mathrm{N}$ & 1 & $\begin{array}{l}\text { D1- } \\
\text { ASC }\end{array}$ & $\begin{array}{r}\text { E0319-D } \\
20 \mathrm{C}\end{array}$ & No video taken \\
\hline E0320 & 8 & Water & 56 & 0.8 & & & 3 & $4,5,6$ & $>5$ & 3.95 & 4.01 & 4.01 & & & $10 / 0.001 / 31$ & $1 / 10 / 0.001 / 31 /$ & $\begin{array}{l}10 / 0.001 / \\
31 / 110\end{array}$ & & - & 14 & M & M & M & M & $\mathrm{N}$ & $\mathrm{N}$ & 2 & $\begin{array}{l}\text { EO320-D1- } \\
\text { 077312ASC }\end{array}$ & $\begin{array}{l}\text { E0320-D2-Channel1 Mar 12, } \\
\text { 2007 }\end{array}$ & No video taken \\
\hline E0321 & 8 & Water & 56 & 0.8 & & & 3 & $4,5,6$ & $>5$ & 3.95 & 4.01 & 4.01 & & & $10 / 0.001 / 31$ & $\begin{array}{l}1 / 10 / 0.001 / 31 / \\
110\end{array}$ & $\begin{array}{l}10 / 0.001 / \\
31 / 110\end{array}$ & & & 14 & M & M & M & M & $\mathrm{N}$ & $\mathrm{N}$ & 3 & $\begin{array}{l}\text { E0321-D1- } \\
\text { 070312.ASC }\end{array}$ & $\begin{aligned} E 0321-D \\
200\end{aligned}$ & No video taken \\
\hline E0322 & 8 & Water & 56 & 0.8 & - & & 4 & $4,5,6,7$ & $>5$ & 3.98 & 4.00 & 3.99 & 4.00 & - & $10 / 0.001 / 31$ & $1 / 10 / 0.001 / 31 /$ & $\begin{array}{l}10 / 0.001 / \\
31 / 110\end{array}$ & $\begin{array}{c}10 / 0.001 / \\
311110\end{array}$ & - & 14 & M & M & M & M & $\mathrm{N}$ & $\mathrm{N}$ & 1 & $\begin{array}{l}\text { E0322-D1- } \\
\text { O7021- }\end{array}$ & $\begin{array}{l}\text { E0322-D2-Channel1 Mar 12, } \\
\text { 2007 }\end{array}$ & No video taken \\
\hline Е0323 & 8 & Water & 56 & 0.8 & - & - & 4 & $4,5,6,7$ & $>5$ & 3.99 & 4.00 & 4.00 & 3.99 & - & $\begin{array}{l}10 / 0.001 / 31 \\
110\end{array}$ & $\begin{array}{l}1 / 10 / 0.001 / 31 / \\
110\end{array}$ & $\begin{array}{l}10 / 0.001 / \\
31 / 110\end{array}$ & $\begin{array}{c}10 / 0.001 / \\
31 / 110\end{array}$ & - & 14 & M & M & M & M & $\mathrm{N}$ & $\mathrm{N}$ & 2 & $\begin{array}{l}\text { E0323-D1- } \\
070312 \text { ASC }\end{array}$ & $\begin{aligned} E 0323-D \\
20\end{aligned}$ & No video taken \\
\hline E0324 & 8 & Water & 56 & 0.8 & & - & 4 & $4,5,6,7$ & $>5$ & 4.00 & 4.00 & 3.99 & 3.95 & - & $\begin{array}{l}10 / 0.001 / 31 \\
110\end{array}$ & $\begin{array}{l}1 / 10 / 0.001 / 31 / \\
110\end{array}$ & $\begin{array}{c}10 / 0.001 / \\
31 / 110\end{array}$ & $\begin{array}{c}10 / 0.001 / \\
31 / 110\end{array}$ & - & 14 & M & M & M & M & $\mathrm{N}$ & $\mathrm{N}$ & 3 & $\begin{array}{l}\text { E0324-D1- } \\
\text { 070312.ASC }\end{array}$ & $\begin{array}{l}\text { E0324-D2-Channel1 Mar 12, } \\
\text { 2007 11-34-06.txt }\end{array}$ & No video taken \\
\hline E0325 & 8 & Water & 56 & 0.8 & & & 1 & 5 & $\sim 4.5$ & & 4.99 & & & & & $\begin{array}{c}10 / 0.001 / 27 / \\
110\end{array}$ & & & & $>15$ & M & M & M & M & $\mathrm{N}$ & $\mathrm{N}$ & 1 & D1- & $\begin{array}{ll}E 0325-I \\
2 C\end{array}$ & No video taken \\
\hline E0326 & 8 & Water & 56 & 0.8 & & & 1 & 5 & $\sim 4.5$ & & 4.99 & - & & & & $\begin{array}{c}10 / 0.001 / 27 / \\
110\end{array}$ & & & & $>15$ & M & M & M & M & $\mathrm{N}$ & $\mathrm{N}$ & 2 & $\begin{array}{l}\text { E0326-D1- } \\
\text { 070312.ASC }\end{array}$ & $\begin{aligned} E 0326-D \\
20\end{aligned}$ & No video taken \\
\hline E0327 & 8 & Water & 56 & 0.8 & & & 1 & 5 & $\sim 4.5$ & & 4.99 & & & & & $\begin{array}{c}10 / 0.001 / 27 / \\
110\end{array}$ & & & & $>15$ & M & M & M & M & $N$ & $\mathrm{~N}$ & 3 & $\begin{array}{l}\text { D1- } \\
\text { ASC }\end{array}$ & $\begin{array}{r}\text { E0327-D2-Char } \\
200713-2\end{array}$ & No video taken \\
\hline E0328 & 8 & Water & 56 & 0.8 & - & - & 2 & 4,5 & $\sim 4.5$ & 4.98 & 4.96 & - & - & - & $10 / 0.00$ & $\begin{array}{c}7 / 10 / 0.001 / 27 / \\
110\end{array}$ & - & - & - & $>15$ & M & $\mathrm{M}$ & M & M & $\mathrm{N}$ & $\mathrm{N}$ & 1 & $\begin{array}{l}\text { D1- } \\
\text { ASC }\end{array}$ & $\begin{array}{l}\text { E0328-D2-Channel1 Mar 12, } \\
\text { 2007 13-34-36.txt }\end{array}$ & No video taken \\
\hline E0329 & 8 & Water & 56 & 0.8 & - & - & 2 & 4,5 & -4.5 & 4.98 & 4.96 & - & - & - & $\begin{array}{l}10 / 0.001 / 27 \\
110\end{array}$ & $\begin{array}{c}7 / 10 / 0.001 / 27 / \\
110\end{array}$ & - & - & - & $>15$ & M & M & M & M & $\mathrm{N}$ & $\mathrm{N}$ & 2 & $\begin{array}{l}\text { E0329-D1- } \\
\text { 070312.ASC }\end{array}$ & $\begin{array}{l}\text { E0329-D2-Channel1 Mar 12, } \\
2007 \text { 13-38-47.txt }\end{array}$ & No video taken \\
\hline Е0330 & 8 & Water & 56 & 0.8 & - & - & 2 & 4,5 & $\sim 4.0$ & 4.98 & 4.96 & - & - & - & $\begin{array}{c}10 / 0.001 / 2 \\
110\end{array}$ & $\begin{array}{c}10 / 0.001 / 27 / \\
110\end{array}$ & - & & & $>15$ & M & M & M & M & $\mathrm{N}$ & $\mathrm{N}$ & 3 & $\begin{array}{l}\text { E0330-D1- } \\
\text { 070312.ASC }\end{array}$ & $\begin{array}{l}\text { E0330-D2-Channel1 Mar 12, } \\
\text { 2007 13-41-42.txt }\end{array}$ & No video taken \\
\hline $\begin{array}{l}\text { h wate } \\
0331\end{array}$ & evel & Water & 56 & 0.8 & & & 1 & 5 & 4.5 & & 4.97 & & & & & $10 / 0.001 / 271$ & & & & 15 & $\Pi$ & $\mathrm{H}$ & $\mathrm{H}$ & $\mathrm{H}$ & $\mathrm{N}$ & $\mathrm{N}$ & 1 & & Mar 1 & Jo video tak \\
\hline
\end{tabular}

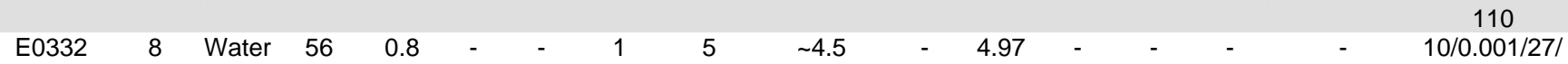




\begin{tabular}{|c|c|c|c|c|c|c|c|c|c|c|c|c|c|c|c|c|c|c|c|c|c|c|c|c|c|c|c|c|c|c|}
\hline \multirow[b]{2}{*}{$\begin{array}{l}\text { Exp. } \\
\text { Noo. }\end{array}$} & \multirow[b]{2}{*}{$\begin{array}{c}\text { PJM } \\
\text { Config }\end{array}$} & \multirow[b]{2}{*}{ Type } & \multicolumn{4}{|c|}{ Simulant } & \multirow[b]{2}{*}{$\begin{array}{c}\text { No. } \\
\text { PJMS } \\
\text { PJB(b) } \\
\end{array}$} & \multirow[b]{2}{*}{$\begin{array}{l}\text { OB } \\
\text { PJMs }\end{array}$} & \multirow[b]{2}{*}{$\begin{array}{c}\mathrm{OB} \\
\text { Duration } \\
\end{array}$} & \multicolumn{5}{|c|}{$\begin{array}{l}\text { Drive Pressure Settings } \\
\quad\left(\text { bar,_ga }{ }^{(c)}\right)^{-}\end{array}$} & \multicolumn{5}{|c|}{$\begin{array}{l}\text { PJM OP Conditions (vacuum/delay/drive/vent time) } \\
\text { (sec) }\end{array}$} & \multirow[b]{2}{*}{$\begin{array}{c}\text { Target } \\
\text { Noz. Vel. } \\
(\mathrm{m} / \mathrm{s})^{(\mathrm{c})}\end{array}$} & \multicolumn{4}{|c|}{ Hydrophone Elevation } & \multirow[b]{2}{*}{$\begin{array}{c}\text { Sparger } \\
(\mathrm{Y} / \mathrm{N})\end{array}$} & \multirow[b]{2}{*}{$\begin{array}{l}\text { Video } \\
\text { (Y/N) }\end{array}$} & \multirow[b]{2}{*}{$\begin{array}{c}\text { Repeat } \\
\# \\
\end{array}$} & \multirow[b]{2}{*}{ DAS-1 Filename } & \multirow[b]{2}{*}{ DAS-2 Filename $e^{(d)}$} & \\
\hline & & & $\begin{array}{l}\text { Hit. fm } \\
\text { Rim } \\
\text { (in) }\end{array}$ & H/D & $\begin{array}{c}T_{\text {Tys }} \\
(\mathrm{Pa})\end{array}$ & $\begin{array}{c}k \\
(\mathrm{CP})\end{array}$ & & & & $\begin{array}{c}\text { PJM } \\
4\end{array}$ & $\begin{array}{c}\text { PJM } \\
5\end{array}$ & $\begin{array}{c}\text { PJM } \\
6\end{array}$ & $\begin{array}{c}\text { PJM } \\
7\end{array}$ & $\begin{array}{c}\text { PJM } \\
8\end{array}$ & PJM 4 & PJM 5 & PJM 6 & PJM 7 & PJM 8 & & $\mathrm{H} 1$ & $\mathrm{H} 2$ & $\mathrm{H} 3$ & $\mathrm{H} 4$ & & & & & & $\begin{array}{l}\text { DAS-4 (Video) } \\
\text { Filename }\end{array}$ \\
\hline Еозз3 & 8 & Water & 56 & 0.8 & & & 1 & 5 & $\sim 4.5$ & - & 4.97 & 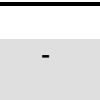 & 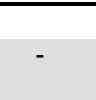 & & & $\begin{array}{l}110 \\
10 / 0.001 / 27 / \\
110\end{array}$ & & & & $>15$ & $\mathrm{H}$ & $\mathrm{H}$ & H & $\mathrm{H}$ & $\mathrm{N}$ & $\mathrm{N}$ & 3 & $\begin{array}{l}070312 . A S C \\
\text { E033-D1- } \\
\text { 070312.ASC }\end{array}$ & $\begin{array}{l}\text { 2007 14-13-29.txt } \\
\text { E0333-D2-Channel1 Mar 12, } \\
\text { 2007 14-16-33.txx }\end{array}$ & No video taken \\
\hline E0334 & 8 & Water & 56 & 0.8 & - & - & 2 & 4,5 & $\sim .5$ & 5.01 & 4.97 & - & - & - & $\begin{array}{l}10 / 0.001 / 27 / \\
110\end{array}$ & $\begin{array}{c}10 / 0.001 / 27 / \\
110\end{array}$ & - & - & - & $>15$ & $\mathrm{H}$ & $\mathrm{H}$ & H & $\mathrm{H}$ & $\mathrm{N}$ & $\mathrm{N}$ & 1 & $\begin{array}{l}\text { EO334-D1- } \\
\text { 0030312ASC }\end{array}$ & $\begin{array}{l}\text { E0334-D2-Channel1 Mar 12, } \\
\text { 2007 14-28-51 trt }\end{array}$ & No video taken \\
\hline Е0335 & 8 & Water & 56 & 0.8 & - & - & 2 & 4,5 & -4.5 & 5.01 & 4.97 & - & - & - & $\begin{array}{l}10 / 0.001 / 27 / \\
110\end{array}$ & $\begin{array}{l}10 / 0.001 / 27 / \\
110\end{array}$ & - & - & - & $>15$ & H & H & $\mathrm{H}$ & $\mathrm{H}$ & $\mathrm{N}$ & N & 2 & $\begin{array}{l}\text { E0035--D1- } \\
\text { 070312.ASC }\end{array}$ & $\begin{array}{l}\text { E0335-D2-Channel1 Mar 12, } \\
\text { 2007 14-33-19.txt }\end{array}$ & No video taken \\
\hline Е0336 & 8 & Water & 56 & 0.8 & - & - & 2 & 4,5 & $\sim 4.5$ & 5.01 & 4.97 & - & - & - & $\begin{array}{l}10 / 0.001 / 27 / \\
110\end{array}$ & $\begin{array}{c}10 / 0.001 / 27 / \\
110\end{array}$ & - & - & - & $>15$ & $\mathrm{H}$ & $\mathrm{H}$ & $\mathrm{H}$ & $\mathrm{H}$ & $\mathrm{N}$ & $\mathrm{N}$ & 3 & $\begin{array}{l}\text { EO336-D1- } \\
\text { O030312 ASC }\end{array}$ & $\begin{array}{l}\text { E0336-D2-Channel1 Mar 12, } \\
\text { 2007 19-36-30 tyt }\end{array}$ & No video taken \\
\hline E0337 & 8 & Water & 56 & 0.8 & - & - & 1 & 5 & $>5$ & - & 3.98 & - & - & - & - & $\begin{array}{l}10 / 0.001 / 31 / \\
110\end{array}$ & - & - & - & 14 & $\mathrm{H}$ & $\mathrm{H}$ & $\mathrm{H}$ & $\mathrm{H}$ & $\mathrm{N}$ & $\mathrm{N}$ & 1 & $\begin{array}{l}\text { E0037--D1- } \\
\text { 070312.ASC }\end{array}$ & $\begin{array}{l}\text { E0337-D2-Channel1 Mar 12, } \\
\text { 2007 14-46-42.txt }\end{array}$ & No video taken \\
\hline E0338 & 8 & Water & 56 & 0.8 & - & - & 1 & 5 & $>5$ & - & 3.98 & - & - & - & - & $10 / 0.001 / 31 /$ & - & - & - & 14 & $\mathrm{H}$ & $\mathrm{H}$ & $\mathrm{H}$ & $\mathrm{H}$ & $\mathrm{N}$ & $\mathrm{N}$ & 2 & $\begin{array}{l}\text { EO338-D1- } \\
\text { O0312 ASC }\end{array}$ & $\begin{array}{l}\text { E0338-D2-Channel1 Mar 12, } \\
\text { 2007 14-50-52 tyt }\end{array}$ & No video taken \\
\hline Е0339 & 8 & Water & 56 & 0.8 & & & 1 & 5 & $>5$ & - & 3.98 & 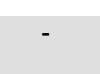 & - & - & - & $\begin{array}{l}10 / 0.001 / 31 / \\
110\end{array}$ & & - & - & 14 & $\mathrm{H}$ & $\mathrm{H}$ & $\mathrm{H}$ & $\mathrm{H}$ & $\mathrm{N}$ & $\mathrm{N}$ & 3 & $\begin{array}{l}\text { E0339-D1- } \\
\text { 070312.ASC }\end{array}$ & $\begin{array}{l}\text { E0339-D2-Channel1 Mar 12, } \\
\text { 2007 14-54-29.txt }\end{array}$ & No video taken \\
\hline E0340 & 8 & Water & 56 & 0.8 & & & 2 & 4,5 & $>5$ & 4.04 & 3.98 & & - & & $10 / 0.001 / 31 /$ & $10 / 0.001 / 31 /$ & & - & - & 14 & $\mathrm{H}$ & $\mathrm{H}$ & $\mathrm{H}$ & $\mathrm{H}$ & N & $\mathrm{N}$ & 1 & $\begin{array}{l}\text { E0340-D1- } \\
\text { E031- } \\
07031 \text { ASC }\end{array}$ & $\begin{array}{l}\text { E0340-D2-Channeli Mar 12, } \\
\text { E0307 }\end{array}$ & No video taken \\
\hline E0341 & 8 & Water & 56 & 0.8 & & & 2 & 4,5 & $>5$ & 4.04 & 3.98 & - & - & - & $10 / 0.001 / 31 /$ & $\begin{array}{l}10 / 0.001 / 31 / \\
110\end{array}$ & & - & - & 14 & $\mathrm{H}$ & $\mathrm{H}$ & $\mathrm{H}$ & $\mathrm{H}$ & $\mathrm{N}$ & $\mathrm{N}$ & 2 & $\begin{array}{l}\text { E0341-D1- } \\
\text { 0700312ASC }\end{array}$ & $\begin{array}{l}\text { E0341-D2-Channel1 Mar 12, } \\
2000 \text { 15-07-39, txt }\end{array}$ & No video taken \\
\hline E0342 & 8 & Water & 56 & 0.8 & - & - & 2 & 4,5 & $>5$ & 4.04 & 3.98 & - & - & - & $\begin{array}{l}10 / 0.0001 / 31 / \\
110\end{array}$ & $10 / 0.001 / 31 /$ & - & - & - & 14 & $\mathrm{H}$ & $\mathrm{H}$ & $\mathrm{H}$ & $\mathrm{H}$ & $\mathrm{N}$ & $\mathrm{N}$ & 3 & $\begin{array}{l}\text { E0342-D1- } \\
\text { 070312ASC }\end{array}$ & $\begin{array}{l}\text { E0342-D2-Channel1 Mar 12, } \\
\text { 2007 15-11-188 trt }\end{array}$ & No video taken \\
\hline E0343 & 8 & Water & 56 & 0.8 & - & - & 3 & $4,5,6$ & $>5$ & 3.96 & 3.99 & 3.97 & - & - & $10 / 0.001 / 31 /$ & $10 / 0.001 / 31 / 10$ & $\begin{array}{l}10 / 0.001 / \\
311110\end{array}$ & - & - & 14 & $\mathrm{H}$ & $\mathrm{H}$ & $\mathrm{H}$ & $\mathrm{H}$ & $\mathrm{N}$ & $\mathrm{N}$ & 1 & $\begin{array}{l}\text { E0343-D1- } \\
07033 \text { ASC }\end{array}$ & E0343-D2-Channel1 Mar 13, & No video taken \\
\hline E0344 & 8 & Water & 56 & 0.8 & - & - & 3 & $4,5,6$ & $>5$ & 3.96 & 3.99 & 3.97 & - & - & $\begin{array}{l}10 / 0.001 / 31 / \\
110\end{array}$ & $10 / 0.001 / 31 / 16$ & $\begin{array}{l}1010.001 / \\
31 / 110\end{array}$ & - & - & 14 & $\mathrm{H}$ & $\mathrm{H}$ & $\mathrm{H}$ & $\mathrm{H}$ & $\mathrm{N}$ & $\mathrm{N}$ & 2 & $\begin{array}{l}\text { E0344-D1- } \\
\text { 070313 ASC }\end{array}$ & $\begin{array}{l}\text { E0344-D2-Channel1 Mar 13, } \\
\text { 2007 13-55-08 trt }\end{array}$ & No video taken \\
\hline E0345 & 8 & Water & 56 & 0.8 & - & - & 3 & $4,5,6$ & $>5$ & 3.96 & 3.99 & 3.97 & - & - & $10 / 0.001 / 31 /$ & $10 / 0.001 / 31 / 1 \mathrm{c}$ & $\begin{array}{l}5100.001 / \\
311110\end{array}$ & - & - & 14 & $\mathrm{H}$ & $\mathrm{H}$ & $\mathrm{H}$ & $\mathrm{H}$ & $\mathrm{N}$ & $\mathrm{N}$ & 3 & E0345-D1- & E0345-D2-Channel1 Mar 13, & No video taken \\
\hline Е0346 & 8 & Water & 56 & 0.8 & - & & 4 & $4,5,6,7$ & $>5$ & 3.95 & 4.00 & 3.98 & 3.96 & - & $\begin{array}{l}10 / 0.001 / 31 / \\
110\end{array}$ & $10 / 0.001 / 31 / 10$ & $\begin{array}{l}10 / 0.001 / 1 \\
31 / 110\end{array}$ & $\begin{array}{c}10 / 0.001 / \\
31 / 110\end{array}$ & - & 14 & $\mathrm{H}$ & $\mathrm{H}$ & $\mathrm{H}$ & $\mathrm{H}$ & $\mathrm{N}$ & $\mathrm{N}$ & 1 & $\begin{array}{l}\text { E0346-D1- } \\
\text { 070313.ASC }\end{array}$ & $\begin{array}{l}\text { E0346-D2-Channel1 Mar 13, } \\
2007 \text { 11-04-16.txt }\end{array}$ & No video taken \\
\hline E0347 & 8 & Water & 56 & 0.8 & & & 4 & $4,5,6,7$ & $>5$ & 3.99 & 4.00 & 3.98 & 3.96 & & $\begin{array}{ll}10 / 0.001 / 31 / \\
110\end{array}$ & $10 / 0.001 / 31 / 1 \mathrm{c}$ & $\begin{array}{l}10 / 0.001 / \\
31 / 110\end{array}$ & $\begin{array}{l}10 / 0.001 / \\
33 / 110\end{array}$ & - & 14 & $\mathrm{H}$ & $\mathrm{H}$ & H & $\mathrm{H}$ & $\mathrm{N}$ & $\mathrm{N}$ & 2 & $\begin{array}{l}\text { E0347-D1- } \\
\text { 070313.ASC }\end{array}$ & 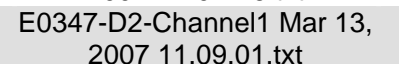 & No video taken \\
\hline E0348 & 8 & Water & 56 & 0.8 & & & 4 & $4,5,6,7$ & $>5$ & 3.99 & 4.00 & 3.98 & 3.96 & - & $\begin{array}{l}10 / 0.001 / 31 / \\
110\end{array}$ & $\begin{array}{c}10 / 0.001 / 31 / 10 \\
110\end{array}$ & $\begin{array}{l}10 / 0.001 / \\
31 / 110\end{array}$ & $\begin{array}{l}10 / 0.001 / \\
31 / 110\end{array}$ & - & 14 & $\mathrm{H}$ & $\mathrm{H}$ & $\mathrm{H}$ & $\mathrm{H}$ & $\mathrm{N}$ & $\mathrm{N}$ & 3 & $\begin{array}{l}\text { E0348-D1- } \\
\text { 070313.ASC }\end{array}$ & $\begin{array}{l}\text { E0348-D2-Channel1 Mar 13, } \\
\text { 200711-11-32.txt }\end{array}$ & No video taken \\
\hline E0349 & 8 & Water & 56 & 0.8 & - & - & 1 & 8 & -4 & - & - & - & - & 3.99 & - & - & - & - & $\begin{array}{l}10 / 0.001 / \\
3 / 1 / 110\end{array}$ & 14 & H & $\mathrm{H}$ & $\mathrm{H}$ & $\mathrm{H}$ & $\mathrm{N}$ & $\mathrm{N}$ & 1 & $\begin{array}{l}\text { E0349-D1- } \\
07313 \text { SC }\end{array}$ & $\begin{array}{l}\text { E0349-D2-Channel1 Mar 13, } \\
\text { 2007 11-19-12 }\end{array}$ & No video taken \\
\hline E0350 & 8 & Water & 56 & 0.8 & - & - & 1 & 8 & $\sim 4$ & - & - & - & - & 3.99 & - & - & - & - & $\begin{array}{l}10 / 0.001 / \\
3 / 1110\end{array}$ & 14 & $\mathrm{H}$ & $\mathrm{H}$ & $\mathrm{H}$ & $\mathrm{H}$ & $\mathrm{N}$ & $\mathrm{N}$ & 2 & $\begin{array}{l}\text { E0350-D1- } \\
\text { 070313ASC }\end{array}$ & $\begin{array}{l}\text { E0350-D2-Channel1 Mar 13, } \\
\text { 2007 11-21-50 tyt }\end{array}$ & No video taken \\
\hline E0351 & 8 & Water & 56 & 0.8 & - & - & 1 & 8 & -4 & - & - & - & - & 3.99 & - & - & - & - & $10 / 0.001 /$ & 14 & $\mathrm{H}$ & $\mathrm{H}$ & $\mathrm{H}$ & $\mathrm{H}$ & N & $\mathrm{N}$ & 3 & $\begin{array}{l}\text { E0351-D1- } \\
\text { 070313ASC }\end{array}$ & $\begin{array}{l}\text { E0351-D2-Chan } \\
200711-2\end{array}$ & No video taken \\
\hline E0352 & 8 & Water & 56 & 0.8 & & & 1 & 5 & $\sim 2.5$ & - & 2.98 & & - & & - & $\begin{array}{l}10 / 0.001 / 31 / \\
110\end{array}$ & - & - & & 12 & $\mathrm{H}$ & $\mathrm{H}$ & $\mathrm{H}$ & $\mathrm{H}$ & $\mathrm{N}$ & $\mathrm{N}$ & 1 & $\begin{array}{l}\text { E0352-D1- } \\
\text { 070313.ASC }\end{array}$ & $\begin{array}{l}\mathrm{E} 0352-\mathrm{D} 2 \\
2007\end{array}$ & No video taken \\
\hline E0353 & 8 & Water & 56 & 0.8 & & & 1 & 5 & $\sim 2.5$ & & 3.01 & & - & & & $\begin{array}{l}10 / 0.001 / 31 / \\
110\end{array}$ & & - & - & 12 & $\mathrm{H}$ & $\mathrm{H}$ & $\mathrm{H}$ & $\mathrm{H}$ & $\mathrm{N}$ & N & 2 & Asc & $\begin{array}{l}\text { E0353-D2-Cha } \\
\text { 2007 11- }\end{array}$ & No video taken \\
\hline E0354 & 8 & Water & 56 & 0.8 & & & 1 & 5 & $\sim 2.5$ & - & 3.02 & - & - & - & - & $\begin{array}{l}10 / 0.001 / 31 / \\
110\end{array}$ & - & - & - & 12 & $\mathrm{H}$ & $\mathrm{H}$ & $\mathrm{H}$ & $\mathrm{H}$ & $\mathrm{N}$ & N & 3 & $\begin{array}{l}\text { E0354-D1- } \\
\text { 070313.ASC }\end{array}$ & $\begin{array}{l}\text { E0354-D2-Chan } \\
\text { 2007 11-43 }\end{array}$ & No video taken \\
\hline E0355 & 8 & Water & 56 & 0.8 & - & - & 2 & 4,5 & -2.5 & 3.01 & 3.00 & - & - & - & $10 / 0.001 / 3$ & $\begin{array}{l}10 / 0.001 / 31 / \\
110\end{array}$ & - & - & - & 12 & $\mathrm{H}$ & $\mathrm{H}$ & $\mathrm{H}$ & $\mathrm{H}$ & $\mathrm{N}$ & $\mathrm{N}$ & 1 & $\begin{array}{l}\text { E03 } \\
0703\end{array}$ & $\begin{array}{l}\text { E0355-D2-Chann } \\
\text { 20007 711-51 }\end{array}$ & No video taken \\
\hline E0356 & 8 & Water & 56 & 0.8 & - & - & 2 & 4,5 & $\sim 2.5$ & 3.01 & 3.00 & - & - & - & $10 / 10.001 / 31 /$ & $\begin{array}{l}10 / 0.001 / 31 / \\
110\end{array}$ & - & - & - & 12 & $\mathrm{H}$ & $\mathrm{H}$ & $\mathrm{H}$ & $\mathrm{H}$ & $\mathrm{N}$ & $\mathrm{N}$ & 2 & $\begin{aligned} E 0 \\
070\end{aligned}$ & $\begin{array}{l}\mathrm{E} 0356-\mathrm{D} 2 \\
200\end{array}$ & No video taken \\
\hline E0357 & 8 & Water & 56 & 0.8 & - & & 2 & 4,5 & -2.5 & 3.00 & 3.02 & - & - & - & $10 / 0.001 / 31 /$ & $10 / 0.001 / 31 /$ & - & - & - & 12 & $\mathrm{H}$ & $\mathrm{H}$ & $\mathrm{H}$ & H & $\mathrm{N}$ & $\mathrm{N}$ & 3 & $\begin{array}{l}\text { E0357-D1- } \\
070313 \text { ASC }\end{array}$ & $\begin{array}{l}\text { E0357-D2-Channel1 Mar 13, } \\
2000 \text { 11-59-46 txt }\end{array}$ & No video taken \\
\hline E0358 & 8 & Water & 56 & 0.8 & - & & 1 & 5 & -5 & - & 0.94 & - & - & - & & $\begin{array}{l}10 / 0.001 / 57 / \\
110\end{array}$ & - & - & - & 8 & $\mathrm{H}$ & $\mathrm{H}$ & $\mathrm{H}$ & $\mathrm{H}$ & $\mathrm{N}$ & $\mathrm{N}$ & 1 & $\begin{aligned} E 0 \\
070\end{aligned}$ & $\begin{array}{l}\mathrm{E} 0358-\mathrm{D} 2 \\
200\end{array}$ & No video taken \\
\hline Е0359 & 8 & Water & 56 & 0.8 & & & 1 & 5 & -4 & & 0.90 & & & & & $\begin{array}{l}10 / 0.001 / 57 / \\
110\end{array}$ & & - & - & 8 & H & $\mathrm{H}$ & $\mathrm{H}$ & $\mathrm{H}$ & N & $\mathrm{N}$ & 2 & $\begin{array}{l}\text { E03 } \\
0703\end{array}$ & $\begin{array}{l}\text { E0359-D2-Channe } \\
\text { O070 }\end{array}$ & No video taken \\
\hline E0360 & 8 & Water & 56 & 0.8 & & & 1 & 5 & -5 & & 0.94 & & & & & $\begin{array}{l}10 / 0.001 / 57 / \\
110\end{array}$ & & - & - & 8 & $\mathrm{H}$ & $\mathrm{H}$ & $\mathrm{H}$ & $\mathrm{H}$ & $\mathrm{N}$ & $\mathrm{N}$ & 3 & $\begin{array}{l}\text { E0360-D1- } \\
\text { 070313.ASC }\end{array}$ & $\begin{array}{l}\text { E0360-D2-Chan } \\
200713-30\end{array}$ & No video taken \\
\hline E0361 & 8 & Water & 56 & 0.8 & & & 2 & 4,5 & -3.5 & 0.90 & 0.90 & & & & $10 / 0.001 / 571$ & $10 / 0.001 / 571$ & & - & - & 8 & $\mathrm{H}$ & $\mathrm{H}$ & $\mathrm{H}$ & H & $\mathrm{N}$ & $\mathrm{N}$ & 1 & $1-$ & E0361-D2-Channel1 Mar 13, & No video taken \\
\hline E0362 & 8 & Water & 56 & 0.8 & - & & 2 & 4,5 & $\sim 3.5$ & 0.89 & 0.93 & - & - & - & $\begin{array}{l}10 / 0.00 \\
11\end{array}$ & $\begin{array}{l}10 / 0.001 / 57 / \\
110\end{array}$ & - & - & - & 8 & $\mathrm{H}$ & $\mathrm{H}$ & $\mathrm{H}$ & $\mathrm{H}$ & N & $\mathrm{N}$ & 2 & $\begin{array}{l}\text { E0362-D1- } \\
07313 \text { ASC }\end{array}$ & $\begin{array}{l}\text { E0362-D2-Chan } \\
200713-4 \mathrm{C}\end{array}$ & No video taken \\
\hline E0363 & 8 & Water & 56 & 0.8 & - & - & 2 & 4,5 & -4 & 0.92 & 0.93 & - & - & - & $10 / 0.001 / 571$ & $10 / 0.001 / 571$ & - & - & - & 8 & $\mathrm{H}$ & $\mathrm{H}$ & $\mathrm{H}$ & $\mathrm{H}$ & N & N & 3 & $1-$ & $\begin{array}{l}\text { E0363-D2-Chanr } \\
\text { DO-C }\end{array}$ & No video taken \\
\hline E0364 & 8 & Water & 56 & 0.8 & - & - & 2 & 4,5 & -3 & 0.89 & 0.93 & - & - & - & $\begin{array}{l}10 / 0.001 / 57 / \\
110\end{array}$ & $\begin{array}{l}10 / 0.001 / 57 / \\
110\end{array}$ & - & - & - & 8 & $\mathrm{H}$ & $H$ & $\mathrm{H}$ & $\mathrm{H}$ & $\mathrm{N}$ & $\mathrm{N}$ & 4 & $\begin{array}{l}\text { E03646-D1- } \\
\text { 070313.ASC }\end{array}$ & $\begin{array}{l}\text { E0364--D2-Channell Mar 13, } \\
\text { 2007 13-55-53.txt }\end{array}$ & No video taken \\
\hline 0365 & 8 & ater & 56 & 0.8 & & & & & -5 & & 0.94 & & & & & & & & & & & & & & & & & & D2-Channel1 Mar 13, & No video taken \\
\hline
\end{tabular}


Table A.1. Master Run Log, 8-PJM Configuration

\begin{tabular}{|c|c|c|c|c|c|c|c|c|c|c|c|c|c|c|c|c|c|c|c|c|c|c|c|c|c|c|c|c|c|c|}
\hline \multirow[b]{2}{*}{$\begin{array}{l}\text { Exp. } \\
\text { No. }{ }^{(a)}\end{array}$} & \multirow[b]{2}{*}{$\begin{array}{l}\text { PJM } \\
\text { Config }\end{array}$} & \multirow[b]{2}{*}{ Type } & \multicolumn{4}{|c|}{ simulant } & \multirow{2}{*}{$\begin{array}{c}\text { No. } \\
\text { PJMS } \\
\text { OB } \\
\end{array}$} & \multirow[b]{2}{*}{$\begin{array}{l}\text { OB } \\
\text { PJMs } \\
\end{array}$} & \multirow[b]{2}{*}{$\begin{array}{c}\text { OB } \\
\text { Duration } \\
\end{array}$} & \multicolumn{5}{|c|}{$\begin{array}{l}\text { Drive Pressure Settings } \\
\quad(\text { bar._gg) }\end{array}$} & \multicolumn{5}{|c|}{$\begin{array}{l}\text { PJM OP Conditions (vacuum/delay/drive/vent time) } \\
\text { (sec) }\end{array}$} & \multirow[b]{2}{*}{$\begin{array}{c}\text { Target } \\
\text { Noz. Vel. } \\
\left(\mathrm{m} / \mathrm{s}^{(\mathrm{c})}\right.\end{array}$} & \multicolumn{4}{|c|}{ Hydrophone Elevation } & \multirow{2}{*}{$\begin{array}{c}\text { Sparger } \\
(\mathrm{Y} / \mathrm{N})\end{array}$} & \multirow[b]{2}{*}{$\begin{array}{l}\text { Video } \\
(\mathrm{Y} / \mathrm{N})\end{array}$} & \multirow[b]{2}{*}{$\underset{\#}{\text { Repeat }}$} & \multirow[b]{2}{*}{ DAS-1 Filename } & \multirow[b]{2}{*}{ DAS-2 Filename ${ }^{(())}$} & \\
\hline & & & $\begin{array}{l}\text { Ht. fm } \\
\text { Rim } \\
\text { (in) }\end{array}$ & $H / D$ & $\begin{array}{c}\mathrm{T}_{\mathrm{ys}} \\
(\mathrm{Pa})\end{array}$ & $\begin{array}{c}k \\
(\mathrm{CP})\end{array}$ & & & & $\underset{4}{\mathrm{PJM}}$ & $\underset{5}{\mathrm{PJM}}$ & $\underset{6}{\text { PJM }}$ & $\begin{array}{c}\text { PJM } \\
7\end{array}$ & $\begin{array}{c}\text { PJM } \\
8\end{array}$ & PJM 4 & PJM 5 & PJM 6 & PJM 7 & PJM 8 & & $\mathrm{H} 1$ & $\mathrm{H} 2$ & $\mathrm{H} 3$ & $\mathrm{H} 4$ & & & & & & $\begin{array}{c}\text { DAS-4 (Video) } \\
\text { Filename }\end{array}$ \\
\hline E0366 & 8 & Water & 56 & 0.8 & & & 1 & 5 & -5 & & 0.94 & & & & & $\begin{array}{l}110 \\
10 / 0.001 / 57 / \\
110\end{array}$ & & & & 8 & L & L & L & L & $\mathrm{N}$ & $\mathrm{N}$ & 2 & $\begin{array}{l}\text { E0366-D1- } \\
\text { 070313.ASC }\end{array}$ & $\begin{array}{l}\text { 2007 14-27-13.txt } \\
\text { E0366-D2-Channel1 Mar 13, } \\
\text { 2007 14-30-06.txt }\end{array}$ & No video taken \\
\hline E0367 & 8 & Water & 56 & 0.8 & & & 1 & 5 & -5 & & 0.92 & & - & & & $\begin{array}{l}10 / 0.001 / 57 / \\
110\end{array}$ & & & & 8 & L & L & $\mathrm{L}$ & L & N & N & 3 & $\begin{array}{l}\text { E0367-D1- } \\
\text { 070313ASC }\end{array}$ & $\begin{array}{l}\text { E0367-D2-Channel1 Mar 13, } \\
\text { 2007 14-32-57 txt }\end{array}$ & No video taken \\
\hline E0368 & 8 & Water & 56 & 0.8 & - & - & 2 & 4,5 & $\sim 4$ & 0.94 & 0.97 & - & - & 1 & $\begin{array}{c}10 / 0.001 / 57 \\
110\end{array}$ & / $10 / 0.001 / 57 /$ & - & - & - & 8 & L & $\mathrm{L}$ & L & $\mathrm{L}$ & $\mathrm{N}$ & $\mathrm{N}$ & 1 & $\begin{array}{l}\text { E0368-D1- } \\
\text { 070313.ASC }\end{array}$ & $\begin{array}{l}\text { E0368-D2-Channel1 Mar 13, } \\
\text { 2007 14-40-12.txt }\end{array}$ & No video taken \\
\hline E0369 & 8 & Water & 56 & 0.8 & - & - & 2 & 4,5 & -3 & 0.96 & 0.89 & - & - & 1 & $10 / 0.001 / 57$ & $10 / 0.001 / 57 /$ & - & - & - & 8 & L & L & L & L & $\mathrm{N}$ & $\mathrm{N}$ & 2 & $\begin{array}{l}\text { E0369-D1- } \\
\text { 070313ASC }\end{array}$ & $\begin{array}{l}\text { E0369-D2-Channel1 Mar 13, } \\
\text { 2007 14-46-47 txt }\end{array}$ & No video taken \\
\hline E0370 & 8 & Water & 56 & 0.8 & - & - & 2 & 4,5 & -3 & 0.90 & 0.88 & - & - & -1 & $\begin{array}{l}10 / 0.001 / 57 \\
110\end{array}$ & $\begin{array}{l}\mid 10 / 0.001 / 57 / \\
110\end{array}$ & - & - & - & 8 & L & $\mathrm{L}$ & L & L & $\mathrm{N}$ & N & 3 & $\begin{array}{l}\text { E0370-D1- } \\
070313 \text { ASC }\end{array}$ & $\begin{array}{l}\text { E0370-D2-Channel1 Mar 13, } \\
2000 \text { 14-50-29: }\end{array}$ & No video taken \\
\hline E0372 & 8 & Water & 56 & 0.8 & - & - & 1 & 5 & -2.5 & - & 3.01 & - & - & - & & $10 / 0.001 / 31 /$ & - & - & - & 12 & L & $\mathrm{L}$ & $\mathrm{L}$ & $\mathrm{L}$ & $\mathrm{N}$ & $\mathrm{N}$ & 1 & $\begin{array}{l}\text { E0372-D1- } \\
\text { 07013.ASC }\end{array}$ & $\begin{array}{l}\text { E0372-D2-Channel1 Mar 13, } \\
\text { 2007 15-45-34.txt }\end{array}$ & No video taken \\
\hline E0373 & 8 & Water & 56 & 0.8 & 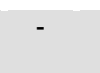 & - & 1 & 5 & -3 & - & 3.04 & - & - & & & $\begin{array}{l}10 / 0.001 / 31 / \\
110\end{array}$ & & - & 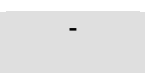 & 12 & L & $\mathrm{L}$ & L & $\mathrm{L}$ & $\mathrm{N}$ & $\mathrm{N}$ & 2 & $\begin{array}{l}\text { E0373-D1- } \\
\text { 070313.ASC }\end{array}$ & $\begin{array}{l}\text { E0373-D2-Channel1 Mar 13, } \\
2007 \text { 15-06-56.txt }\end{array}$ & No video taken \\
\hline E0374 & 8 & Water & 56 & 0.8 & - & - & 1 & 5 & -3 & - & 3.04 & - & - & & & $\begin{array}{l}10 / 0.001 / 31 / \\
110\end{array}$ & & - & - & 12 & L & L & $\mathrm{L}$ & L & $\mathrm{N}$ & $\mathrm{N}$ & 3 & $\begin{array}{l}\text { E0374-D1- } \\
\text { 070313.ASC }\end{array}$ & $\begin{array}{l}\text { E0374-D2-Channel1 Mar 13, } \\
2007 \text { 15-09-25.txt }\end{array}$ & No video taken \\
\hline E0375 & 8 & Water & 56 & 0.8 & 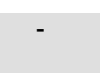 & - & 2 & 4,5 & -3 & 3.05 & 3.01 & - & - & 1 & $10 / 0.001 / 31$ & $/ 10 / 0.001 / 31 /$ & 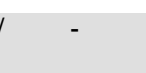 & - & - & 12 & L & $\mathrm{L}$ & L & L & $\mathrm{N}$ & $\mathrm{N}$ & 1 & $\begin{array}{l}\text { E0375-D1- } \\
\text { 070313.ASC }\end{array}$ & $\begin{array}{l}\text { E0375-D2-Channel1 Mar 13, } \\
\text { 2007 15-21-10.txt }\end{array}$ & No video taken \\
\hline E0376 & 8 & Water & 56 & 0.8 & - & - & 2 & 4,5 & -3 & 3.02 & 3.00 & - & - & 1 & $10 / 0.001 / 31$ & / 10/0.001/31/ & - & - & - & 12 & L & L & L & L & $\mathrm{N}$ & $\mathrm{N}$ & 2 & $\begin{array}{l}\text { E0376-D1- } \\
\text { 070313ASC }\end{array}$ & $\begin{array}{l}\text { E0376-D2-Channel1 Mar 13, } \\
\text { 2007 15-2-23 }\end{array}$ & No video taken \\
\hline E0377 & 8 & Water & 56 & 0.8 & - & - & 2 & 4,5 & -3 & 3.02 & 3.02 & - & - & -1 & $10 / 0.001 / 31$ & $/ 10 / 0.001 / 31 /$ & - & - & - & 12 & L & $\mathrm{L}$ & L & L & $\mathrm{N}$ & $\mathrm{N}$ & 3 & $\begin{array}{l}\text { EO377-D1- } \\
\text { 070313.ASC }\end{array}$ & $\begin{array}{l}\text { E0377-D2-Channel1 Mar 13, } \\
\text { 2007 15-39-42.txt }\end{array}$ & No video taken \\
\hline E0378 & 8 & Water & 56 & 0.8 & - & - & 1 & 8 & $\sim 4$ & - & - & - & - & 4.00 & - & tro & - & - & $\begin{array}{l}10 / 0.001 / \\
31 / 110\end{array}$ & 14 & L & L & L & L & N & $\mathrm{N}$ & 1 & $\begin{array}{l}\text { E0378-D1- } \\
\text { 070314ASC }\end{array}$ & $\begin{array}{l}\text { E0378-D2-Channel1 Mar 14, } \\
\text { 2000 09-12-31 txt }\end{array}$ & No video taken \\
\hline E0379 & 8 & Water & 56 & 0.8 & - & - & 1 & 8 & $\sim 4$ & - & - & - & - & 4.00 & - & - & - & - & $\begin{array}{l}10 / 0.001 / \\
31 / 110\end{array}$ & 14 & L & L & L & L & $\mathrm{N}$ & $\mathrm{N}$ & 2 & $\begin{array}{l}\text { E0379-D1- } \\
\text { 070314.ASC }\end{array}$ & $\begin{array}{l}\text { E0379-D2-Channel1 Mar 14, } \\
\text { 2007 09-15-32.txt }\end{array}$ & No video taken \\
\hline E0381 & 8 & Water & 56 & 0.8 & & & 1 & 5 & -2.5 & & 4.04 & - & - & & & $\begin{array}{l}10 / 0.001 / 27 / \\
110\end{array}$ & & & & 14 & L & L & L & L & $\mathrm{N}$ & N & 1 & $\begin{array}{l}\text { E0381-D1- } \\
\text { 070314.ASC }\end{array}$ & $\begin{array}{l}\text { E0381-D2-Channel1 Mar 14, } \\
\text { 2000 09-25-32.txt }\end{array}$ & No video taken \\
\hline E0382 & 8 & Water & 56 & 0.8 & & & 1 & 5 & -2.5 & & 4.05 & - & - & & & $10 / 0.001 / 27 /$ & & - & & 14 & L & L & L & L & $\mathrm{N}$ & $\mathrm{N}$ & 2 & E0382-D1- E & E0382-D2-Channel1 Mar 14, & No video taken \\
\hline E0383 & 8 & Water & 56 & 0.8 & - & - & 1 & 5 & -2.5 & - & 4.05 & - & - & - & - & $10 / 0.001 / 271$ & - & - & - & 14 & L & L & L & L & N & N & 3 & $\begin{array}{l}\text { E0383-D1- } \\
070314 \text { ASC }\end{array}$ & $\begin{array}{l}\text { E0383-D2-Channel1 Mar 14, } \\
2000 \text { 90-3-00 }\end{array}$ & No video taken \\
\hline E0384 & 8 & Water & 56 & 0.8 & - & - & 2 & 4,5 & -2 & 3.97 & 4.00 & - & - & - & $10 / 0.001 / 271$ & / 10/0.001/27/ & - & - & - & 14 & L & L & L & L & $\mathrm{N}$ & $\mathrm{N}$ & 1 & $\begin{array}{l}\text { E03844-D1- } \\
\text { E7.- }\end{array}$ & $\begin{array}{l}\text { E0384-D2-Channeli Mar 14, } \\
\text { E038- }\end{array}$ & No video taken \\
\hline E0385 & 8 & Water & 56 & 0.8 & - & - & 2 & 4,5 & $\sim 4$ & 3.96 & 4.00 & - & - & - & $10 / 0.001 / 29 /$ & $/ 10 / 0.001 / 29 /$ & - & - & - & 14 & L & L & L & L & N & $\mathrm{N}$ & 1 & $\begin{array}{l}\text { E0385-D1- } \\
\text { O70314 ASC }\end{array}$ & E0385-D2-Channel1 Mar 14, & No video taken \\
\hline E0386 & 8 & Water & 56 & 0.8 & - & & 2 & 4,5 & -4 & 4.04 & 4.01 & - & - & & $\begin{array}{l}10 / 0.001 / 29 / \\
110\end{array}$ & $/ 10 / 0.001 / 29 /$ & 1 & - & - & 14 & L & $\mathrm{L}$ & $\mathrm{L}$ & L & $\mathrm{N}$ & $\mathrm{N}$ & 2 & $\begin{array}{l}\text { E0386-D1- } \\
\text { 070314.ASC }\end{array}$ & $\begin{array}{l}\text { E0386-D2-Channel1 Mar 14, } \\
\text { 2007 09-54-04.txt }\end{array}$ & No video taken \\
\hline E0387 & 8 & Water & 56 & 0.8 & - & - & 2 & 4,5 & -4 & 3.96 & 4.00 & - & - & se & $\begin{array}{l}10 / 0.001 / 29 / \\
110\end{array}$ & / 10/0.001/29/ & 1 & - & - & 14 & L & L & $\mathrm{L}$ & $\mathrm{L}$ & $\mathrm{N}$ & $\mathrm{N}$ & 3 & $\begin{array}{l}\text { E0387-D1- } \\
\text { 07014.ASC }\end{array}$ & $\begin{array}{l}\text { E0387-D2-Channel1 Mar 14, } \\
\text { 2007 009-56-39.txt }\end{array}$ & No video taken \\
\hline E0388 & 8 & Water & 56 & 0.8 & & & 3 & $4,5,6$ & $\sim 4$ & 3.96 & 3.99 & 3.99 & - & & $\begin{array}{l}10 / 0.001 / 29 / \\
110\end{array}$ & $\begin{array}{l}/ 10 / 0.001 / 29 / \\
110\end{array}$ & $\begin{array}{c}10 / 0.001 / \\
29 / 110\end{array}$ & 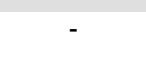 & & 14 & L & $\mathrm{L}$ & L & $\mathrm{L}$ & $\mathrm{N}$ & $\mathrm{N}$ & 1 & $\begin{array}{l}\text { E0388-D1- } \\
\text { 070314.ASC }\end{array}$ & $\begin{array}{l}\text { E0388-D2-Channel1 Mar 14, } \\
2007 \text { 10-05-06.txt }\end{array}$ & No video taken \\
\hline E0389 & 8 & Water & 56 & 0.8 & & & 3 & $4,5,6$ & -4 & 3.99 & 3.98 & 3.99 & & & $\begin{array}{l}10 / 0.001 / 29 / \\
110\end{array}$ & / 10/0.001/29/ & $\begin{array}{l}10 / 0.001 / \\
2 / 110\end{array}$ & & & 14 & L & L & L & L & $\mathrm{N}$ & $\mathrm{N}$ & 2 & $\begin{array}{l}\text { E0389-D1- } \\
\text { 070314ASC }\end{array}$ & $\begin{array}{l}\text { E0389-D2-Channel1 Mar 14, } \\
\text { 2007 10-11-43 tyt }\end{array}$ & No video taken \\
\hline E0390 & 8 & Water & 56 & 0.8 & & & 3 & $4,5,6$ & $\sim 4$ & 3.95 & 3.99 & 3.99 & & & $10 / 0.001 / 29 /$ & $/ 10 / 0.001 / 29 /$ & $\begin{array}{l}10 / 0.001 / \\
29 / 110\end{array}$ & & & 14 & L & L & L & L & $\mathrm{N}$ & $\mathrm{N}$ & 3 & $\begin{array}{l}\text { E0390-D1- } \\
\text { 070314.ASC }\end{array}$ & $\begin{array}{l}\text { E0390-D2-Channel1 Mar 14, } \\
\text { 2007 10-16-27 txt }\end{array}$ & No video taken \\
\hline E0391 & 8 & Water & 56 & 0.8 & - & - & 4 & $4,5,6,7$ & -3.5 & 3.97 & 3.96 & 3.97 & 3.96 & - & $\begin{array}{l}10 / 0.001 / 29 / \\
110\end{array}$ & / 10/0.001/29/ & $\begin{array}{l}10 / 0.001 / \\
29 / 110\end{array}$ & $\begin{array}{l}10 / 0.001 / \\
29 / 110\end{array}$ & - & 14 & L & L & L & L & $\mathrm{N}$ & $\mathrm{N}$ & 1 & $\begin{array}{l}\text { E0391-D1- } \\
\text { 070314ASC }\end{array}$ & $\begin{array}{l}\text { E0391-D2-Channel1 Mar 14, } \\
\text { 2007 10-30-31 }\end{array}$ & No video taken \\
\hline E0392 & 8 & Water & 56 & 0.8 & - & - & 4 & $4,5,6,7$ & $\sim 4$ & 3.95 & 3.96 & 3.97 & 4.01 & - & $10 / 0.001 / 29 /$ & $/ 10 / 0.001 / 29 /$ & $\begin{array}{l}10 / 0.001 / \\
29 / 110\end{array}$ & $\begin{array}{l}10 / 0.001 / \\
29 / 110\end{array}$ & - & 14 & L & L & L & L & $\mathrm{N}$ & N & 2 & $\begin{array}{l}\text { E0392-D1- } \\
\text { 070314.ASC }\end{array}$ & $\begin{array}{l}\text { E0392-D2-Channel1 Mar 14, } \\
\text { 2007 10-35-19.txt }\end{array}$ & No video taken \\
\hline E0393 & 8 & Water & 56 & 0.8 & - & & 4 & $4,5,6,7$ & -4 & 3.95 & 3.96 & 3.97 & 3.98 & - & $10 / 0.001 / 29 /$ & / 10/0.001/29/ & $\mid \begin{array}{l}10 / 0.001 / \\
20110\end{array}$ & $\begin{array}{l}10 / 0.001 / \\
20 / 10\end{array}$ & & 14 & L & L & L & L & $\mathrm{N}$ & $\mathrm{N}$ & 3 & $\begin{array}{l}\text { EO393-D1- } \\
\text { E70314ASC }\end{array}$ & $\begin{array}{l}\text { E0393-D2-Channel1 Mar 14, } \\
\text { 2007 10-3-30? }\end{array}$ & No video taken \\
\hline E0394 & 8 & Water & 56 & 0.8 & & & 1 & 5 & -5 & & 5.04 & & & & & $\begin{array}{l}10 / 0.001 / 27 / \\
110\end{array}$ & & & & $>15$ & L & L & L & L & $\mathrm{N}$ & $\mathrm{N}$ & 1 & $\begin{array}{l}\text { E0394-D1- } \\
\text { 070314.ASC }\end{array}$ & $\begin{array}{l}\text { E0394-D2-Chann } \\
\text { 2007 10-47- }\end{array}$ & No video taken \\
\hline E0395 & 8 & Water & 56 & 0.8 & & & 1 & 5 & -5 & & 5.04 & & & & & $10 / 0.001 / 271$ & & & & $>15$ & L & L & L & L & $\mathrm{N}$ & $\mathrm{N}$ & 2 & $\begin{array}{l}\text { EO395-D1- } \\
\text { E7034- }\end{array}$ & $\begin{array}{l}\text { E0395-D2-Channeli Mar 14, } \\
\text {-DOt }\end{array}$ & No video taken \\
\hline E0396 & 8 & Water & 56 & 0.8 & & & 1 & 5 & -5 & & 5.04 & & & & & $\begin{array}{c}10 / 0.001 / 27 / \\
110\end{array}$ & & & & $>15$ & L & L & L & L & $\mathrm{N}$ & $\mathrm{N}$ & 3 & $\begin{array}{l}\text { E0396-D1- } \\
\text { 070314.ASC }\end{array}$ & $\begin{array}{l}\text { E0396-D2-Channel1 Mar 14, } \\
2007 \text { 10-52-39.txt }\end{array}$ & No video taken \\
\hline
\end{tabular}


Table A.1. Master Run Log, 8-PJM Configuration

\begin{tabular}{|c|c|c|c|c|c|c|c|c|c|c|c|c|c|c|c|c|c|c|c|c|c|c|c|c|c|c|c|c|c|}
\hline \multirow[b]{2}{*}{ 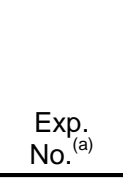 } & \multirow[b]{2}{*}{$\begin{array}{l}\text { PJM } \\
\text { Config }\end{array}$} & \multicolumn{5}{|c|}{ Simulant } & \multirow[b]{2}{*}{$\begin{array}{l}\text { No. } \\
\text { PJMS } \\
\mathrm{OB}^{()^{()}}\end{array}$} & \multirow[b]{2}{*}{$\begin{array}{l}\text { OB } \\
\text { PJMs }\end{array}$} & \multirow[b]{2}{*}{$\begin{array}{c}\mathrm{OB} \\
\text { Duration }^{(o)} \\
\end{array}$} & \multicolumn{5}{|c|}{$\begin{array}{l}\text { Drive Pressure Settings } \\
\text { Dbaurgg } c^{(c)}\end{array}$} & \multicolumn{4}{|c|}{ PJM OP Conditions (vacuum/delay/drive/vent time) } & \multirow[b]{2}{*}{$\begin{array}{c}\text { Target } \\
\text { Noz. Vel. } \\
(\mathrm{m} / \mathrm{s})^{(\mathrm{c})}\end{array}$} & \multicolumn{4}{|c|}{ Hydrophone Elevation } & \multirow[b]{2}{*}{$\begin{array}{l}\text { Sparger } \\
(\mathrm{Y} / \mathrm{N})\end{array}$} & \multirow[b]{2}{*}{$\begin{array}{l}\text { Video } \\
\text { (Y/N) }\end{array}$} & \multirow[b]{2}{*}{$\begin{array}{c}\text { Repeat } \\
\#\end{array}$} & \multirow[b]{2}{*}{ DAS-1 Filename } & \multirow[b]{2}{*}{ DAS-2 Filename $\mathrm{e}^{(\mathrm{d})}$} & \multirow[b]{2}{*}{$\begin{array}{l}\text { DAS-4 (Video) } \\
\text { Filename }\end{array}$} \\
\hline & & Type & $\begin{array}{l}\text { Ht. fm } \\
\text { Rim } \\
\text { (in) }\end{array}$ & $\mathrm{H} / \mathrm{D}$ & $\begin{array}{c}T_{y s} \\
(P a)\end{array}$ & $\underset{c}{k}$ & & & & $\stackrel{\mathrm{PJM}}{4}$ & $\begin{array}{l}\text { PJM } \\
5\end{array}$ & $\begin{array}{c}\text { PJM } \\
6\end{array}$ & $\begin{array}{l}\text { PJM } \\
7\end{array}$ & $\begin{array}{l}\text { PJM } \\
8\end{array}$ & PJM 4 & PJM 6 & PJM 7 & PJM 8 & & $\mathrm{H} 1$ & $\mathrm{H} 2$ & H3 & $\mathrm{H} 4$ & & & & & & \\
\hline E0399 & 8 & Water & 56 & 0.8 & $x_{1}$ & - & 2 & 4,5 & -4.5 & 5.03 & 5.01 & 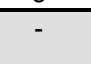 & 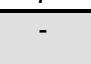 & - & $\begin{array}{l}10 / 0.001 / 27 / 10 / 0.001 / 271 \\
110\end{array}$ & $\mathrm{~T}$ & Tour & - & $>15$ & $\frac{m}{L}$ & L & L & $\frac{74}{L}$ & $N$ & $\mathrm{~N}$ & 3 & E0399-D1- & E0399-D2-Channel1 Mar 14, & No video taken \\
\hline E0400 & 8 & Water & 132 & 0.31 & & - & 2 & 4,5 & -4 & 4.00 & 3.98 & - & - & - & $\begin{array}{l}45 / 0.001 / 27 / 45 / 0.001 / 27 / \\
110 \\
110\end{array}$ & 1 & - & - & 14 & L & L & L & L & Y & N & 1 & $\begin{array}{l}\text { E0400-D1- } \\
\text { 070315.ASC }\end{array}$ & $\begin{array}{l}\text { E0400-D2-Channell Mar 15, } \\
\text { 2007 14-41-40.xt }\end{array}$ & No video taken \\
\hline E0401 & 8 & Water & 132 & 0.31 & & & 2 & 4,5 & -4 & 3.95 & 3.99 & - & & & $\begin{array}{l}45 / 0.001 / 27 / 45 / 0.001 / 27 / \\
110 \\
110\end{array}$ & & & & 14 & $\mathrm{~L}$ & L & L & $\mathrm{L}$ & $\mathrm{Y}$ & $\mathrm{N}$ & 2 & $\begin{array}{l}\text { E0401-D1- } \\
070315 \text { ASC }\end{array}$ & $\begin{array}{l}\text { E0401-D2-Channeli Mar 15, } \\
\text { DOD7 }\end{array}$ & No video taken \\
\hline E0402 & 8 & Water & 132 & 0.31 & & & 2 & 4,5 & $\sim 4$ & 4.01 & 3.99 & - & - & & $45 / 0.001 / 27 / 45 / 0.001 / 27 /$ & & - & - & 14 & L & L & L & L & Y & N & 3 & $\begin{array}{l}\text { E0402-D1- } \\
\text { O70315ASC }\end{array}$ & $\begin{array}{l}\text { E0402-D2-Channell Mar 15, } \\
\text { 2007 14-47-24 txt }\end{array}$ & No video taken \\
\hline E0403 & 8 & Water & 132 & 0.31 & & & 4 & $4,5,6,7$ & -4 & 4.00 & 3.96 & 3.97 & 3.95 & & $45 / 0.001 / 27 / 45 / 0.001 / 27 / 4$ & | 45/0.001/ & $45 / 0.001 /$ & - & 14 & $\mathrm{~L}$ & L & L & L & $\mathrm{Y}$ & $\mathrm{N}$ & 1 & $\begin{array}{l}\text { E0403-D1- } \\
\text { E7) }\end{array}$ & $\begin{array}{l}\text { E0403-D2-Channel1 Mar 15, } \\
\text {-DOF }\end{array}$ & No video taken \\
\hline E0404 & 8 & Water & 132 & 0.31 & - & - & 4 & $4,5,6,7$ & -4 & 4.05 & 3.96 & 3.97 & 4.03 & - & $45 / 0.001 / 27 / 45 / 0.001 / 27 / 4$ & / $45 / 1 / 0.001 /$ & $\begin{array}{l}25 / 110 \\
45001 /\end{array}$ & - & 14 & L & L & L & L & Y & N & 2 & E0404-D1- & 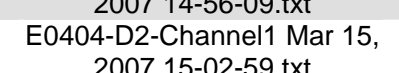 & No video taken \\
\hline E0405 & 8 & Water & 132 & 0.31 & 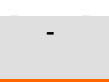 & - & 4 & $4,5,6,7$ & -4 & 4.05 & 3.96 & 3.97 & 3.97 & - & $\begin{array}{l}45 / 0.001 / 27 / 45 / / 0.001 / 27 / 4 \\
110 \\
110\end{array}$ & $\begin{array}{l}45 / 1.001 / \\
27 / 110\end{array}$ & $\begin{array}{l}45 / 0.001 / \\
27 / 110\end{array}$ & - & 14 & L & $\mathrm{L}$ & L & L & $\mathrm{Y}$ & $\mathrm{N}$ & 3 & $\begin{array}{l}\text { E0405-D1- } \\
\text { 070315.ASC }\end{array}$ & $\begin{array}{l}\text { E0405-D2-Channel1 Mar 15, } \\
2007 \text { 15-05-33.txt }\end{array}$ & No video taken \\
\hline $\begin{array}{l}\text { Simultane } \\
\text { E00406BL }\end{array}$ & & & ; & & & & & & & & & & & & & & - & 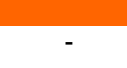 & & & & & & , & & & E0406-D1-BL- & E0406-D2-BL-Channel\# & \\
\hline E0406 & 8 & Clay & 55 & 0.8 & 34.82 & 29.3 & 2 & 4,5 & -3.5 & 3.46 & 3.54 & - & & & $12 / 0.001 / 34 / 12 / 0.001 / 34 /$ & 1 & - & - & 14 & L & L & L & L & N & $\mathrm{N}$ & 1 & $\begin{array}{l}\text { 070330.ASC } \\
\text { E0406-D1- }\end{array}$ & $\begin{array}{l}\text { Mar30, 2007 14-08-05.txt } \\
\text { E0406-D2-Channel1 Mar 30, }\end{array}$ & No video taken \\
\hline E0407 & 8 & Clay & 55 & 0.8 & 34.82 & 29.3 & 2 & 4,5 & -3 & 3.47 & 3.45 & - & - & & $\begin{array}{c}12 / 0.001 / 34 / 12 / 0.001 / 34 / \\
110 \\
110\end{array}$ & 1 & - & - & 14 & L & L & L & L & $\mathrm{N}$ & $\mathrm{N}$ & 1 & $\begin{array}{l}\text { E0407-D1- } \\
\text { 07030.ASC }\end{array}$ & $\begin{array}{l}\text { E0407-D2-Channel1 Mar 30, } \\
\text { 2007 14-27-44.txt }\end{array}$ & No video taken \\
\hline E0408 & 8 & Clay & 55 & 0.8 & 34.82 & 29.3 & 2 & 4,5 & -3 & 3.52 & 3.44 & - & - & & $\begin{array}{c}12 / 0.001 / 34 / 12 / 0.100 / 34 / \\
110 \\
110\end{array}$ & 1 & - & - & 14 & L & L & L & L & N & $\mathrm{N}$ & 1 & $\begin{array}{l}\text { EO408-D1- } \\
\text { 070330 ASC }\end{array}$ & $\begin{array}{l}\text { E0408-D2-Channel1 Mar 30, } \\
\text { 2007 }\end{array}$ & No video taken \\
\hline E0409 & 8 & Clay & 55 & 0.8 & 34.82 & 29.3 & 2 & 4,5 & -3 & 3.47 & 3.42 & - & - & - & $\begin{array}{c}12 / 0.001 / 34 / 12 / 0.100 / 34 / \\
110 \\
110\end{array}$ & - & - & - & 14 & L & L & L & L & $\mathrm{N}$ & $\mathrm{N}$ & 1 & E0409-D1- & $\begin{array}{l}\text { E0409-D2-Channell Mar 30, } \\
\text { 2007 14-55-41 Mt }\end{array}$ & No video taken \\
\hline E0410 & 8 & Clay & 55 & 0.8 & 34.82 & 29.3 & 2 & 4,5 & -3 & 3.47 & 3.47 & - & - & - & $12 / 0.001 / 34 / 12 / 0.090 / 34 /$ & - & - & - & 14 & L & L & L & L & $\mathrm{N}$ & $\mathrm{N}$ & 1 & $\begin{array}{l}\text { E0410-D1- } \\
\text { E70 }\end{array}$ & E0410-D2-Channel1 Mar 30, & No video taken \\
\hline E0411 & 8 & Clay & 55 & 0.8 & 34.82 & 29.3 & 2 & 4,5 & -3 & 3.47 & 3.44 & - & - & - & $\begin{array}{c}12 / 0.001 / 34 / 12 / 0.090 / 34 / \\
110 \\
110\end{array}$ & - & - & - & 14 & $\mathrm{~L}$ & $\mathrm{~L}$ & L & L & $\mathrm{N}$ & $\mathrm{N}$ & 1 & $\begin{array}{l}\text { E0411-D1- } \\
\text { 070330.ASC }\end{array}$ & $\begin{array}{l}\text { E0411-D2-Channel1 Mar 30, } \\
\text { 2007 15-15-26.txt }\end{array}$ & No video taken \\
\hline E0412 & 8 & Clay & 55 & 0.8 & 34.82 & 29.3 & 2 & 4,5 & -3 & 3.47 & 3.44 & - & - & - & $\begin{array}{c}12 / 0.001 / 34 / 12 / 0.150 / 34 / \\
110 \\
110\end{array}$ & - & - & - & 14 & L & L & L & L & $\mathrm{N}$ & $\mathrm{N}$ & 1 & $\begin{array}{l}\text { E0412-D1- } \\
\text { 070330.ASC }\end{array}$ & $\begin{array}{l}\text { E0412-D2-Channel1 Mar 30, } \\
\text { 2007 15-22-25.txt }\end{array}$ & No video taken \\
\hline E0413 & 8 & Clay & 55 & 0.8 & 34.82 & 29.3 & 2 & 4,5 & -3 & 3.46 & 3.54 & - & - & - & $\begin{array}{c}12 / 0.001 / 34 / 12 / 0.200 / 34 / \\
110 \\
110\end{array}$ & - & - & - & 14 & L & $\mathrm{L}$ & L & L & $\mathrm{N}$ & $\mathrm{N}$ & 1 & $\begin{array}{l}\text { E0413-D1- } \\
\text { 070330.ASC }\end{array}$ & $\begin{array}{l}\text { E0413-D2-Channel1 Mar 30, } \\
\text { 2007 15-26-28.txt }\end{array}$ & No video taken \\
\hline E0414 & 8 & Clay & 55 & 0.8 & 34.82 & 29.3 & 2 & 4,5 & -3 & 3.47 & 3.43 & - & . & & $\begin{array}{c}12 / 0.001 / 34 / 12 / 0.200 / 34 / \\
110 \\
110\end{array}$ & 1 & - & - & 14 & L & L & L & L & $\mathrm{N}$ & $\mathrm{N}$ & 1 & $\begin{array}{l}\text { E0414-D1- } \\
\text { 07030.ASC }\end{array}$ & $\begin{array}{l}\text { E0414-D2-Channel1 Mar 30, } \\
\text { 2007 15-32-08.txt }\end{array}$ & No video taken \\
\hline E0415 & 8 & Clay & 55 & 0.8 & 34.82 & 29.3 & 2 & 4,5 & -3 & 3.48 & 3.44 & - & - & - & $12 / 0.001 / 34 / 12 / 0.200 / 34 /$ & 1 & - & - & 14 & $\mathrm{~L}$ & L & L & L & $\mathrm{N}$ & $\mathrm{N}$ & 1 & $\begin{array}{l}\text { E0415-D1- } \\
07033 \text { ASC }\end{array}$ & E0415-D2-Channel1 Mar 30, & No video taken \\
\hline E0416 & 8 & Clay & 55 & 0.8 & 34.82 & 29.3 & 2 & 4,5 & -3 & 3.46 & 3.43 & - & - & - & $\begin{array}{c}12 / 0.001 / 34 / 12 / 0.200 / 34 / \\
110 \\
110\end{array}$ & - & - & - & 14 & L & $\mathrm{L}$ & L & L & $\mathrm{N}$ & $\mathrm{N}$ & 1 & $\begin{array}{l}\text { E0416-D1- } \\
\text { 07030.ASC }\end{array}$ & $\begin{array}{l}\text { E0416-D2-Channel1 Mar 30, } \\
\text { 2007 15-45-20.txt }\end{array}$ & No video taken \\
\hline E0416BL & - & - & - & - & - & - & - & - & - & - & - & - & - & - & & - & - & - & - & - & - & - & - & - & - & - & $\begin{array}{l}\text { E0416-D1-BL- } \\
070330 \text {.ASC }\end{array}$ & $\begin{array}{l}\text { E0416-D2-BL-Channel\# } \\
\text { Mar30, 2007 15-54-35.txt }\end{array}$ & - \\
\hline E0417a & & & & & & & & & & & - & - & & & & & & & & & & & & & & & & E0417. & \\
\hline E0417 & 8 & Clay & 55 & 0.8 & 33.42 & 28.6 & 2 & 4,5 & -3 & 3.49 & 3.48 & - & - & - & $1 / 12 / 0.001 / 34 /$ & 1 & - & - & 14 & $\mathrm{H}$ & $\mathrm{H}$ & $\mathrm{H}$ & $\mathrm{H}$ & $\mathrm{N}$ & $\mathrm{N}$ & 1 & S1- & $E_{20} 0417-1$ & No video taken \\
\hline E0418 & 8 & Clay & 55 & 0.8 & 33.42 & 28.6 & 2 & 4,5 & -3 & 3.49 & $3.60^{(1)}$ & - & & & $\begin{array}{c}12 / 0.001 / 34 / 12 / 0.200 / 34 / \\
110 \\
110\end{array}$ & l & - & - & 14 & H & $\mathrm{H}$ & $\mathrm{H}$ & H & $\mathrm{N}$ & $\mathrm{N}$ & 1 & $\begin{array}{l}\text { E0418-D1- } \\
\text { 070402.ASC }\end{array}$ & $\begin{array}{l}\text { E0418-D2-Channel1 Apr 02, } \\
\text { 2007 12-57-10.txt }\end{array}$ & No video taken \\
\hline E0419 & 8 & Clay & 55 & 0.8 & 33.42 & 28.6 & 2 & 4,5 & -3 & 3.48 & 3.49 & - & & - & $\begin{array}{c}12 / 0.001 / 34 / 12 / 0.200 / 34 / \\
110 \\
110\end{array}$ & 1 & - & - & 14 & $\mathrm{H}$ & $\mathrm{H}$ & $\mathrm{H}$ & $\mathrm{H}$ & $\mathrm{N}$ & $\mathrm{N}$ & 1 & DI- & E0419-D & No video taken \\
\hline E0420 & 8 & Clay & 55 & 0.8 & 33.42 & 28.6 & 2 & 4,5 & -3 & 3.48 & 3.61 & - & - & - & $\begin{array}{c}12 / 0.001 / 34 / 12 / 0.300 / 34 / \\
110 \\
110\end{array}$ & - & - & - & 14 & $\mathrm{H}$ & $\mathrm{H}$ & $\mathrm{H}$ & $\mathrm{H}$ & N & $\mathrm{N}$ & 1 & $\begin{array}{l}\text { E0420-D1- } \\
\text { 070402.ASC }\end{array}$ & ell Apr 02, & No video taken \\
\hline E0421 & 8 & Clay & 55 & 0.8 & 33.42 & 28.6 & 2 & 4,5 & -3 & 3.48 & 3.52 & - & - & - & $\begin{array}{c}12 / 0.001 / 34 / 12 / 0.300 / 34 / \\
110 \\
110\end{array}$ & 1 & - & - & 14 & $\mathrm{H}$ & $\mathrm{H}$ & H & $\mathrm{H}$ & $\mathrm{N}$ & $\mathrm{N}$ & 1 & $\begin{array}{l}\text { E0421-D1- } \\
\text { 070402.ASC }\end{array}$ & $\begin{array}{l}\text { E0421-D2-Channel1 Apr 02, } \\
\text { 200713-11-07.txt }\end{array}$ & No video taken \\
\hline E0422 & 8 & Clay & 55 & 0.8 & 33.42 & 28.6 & 2 & 4,5 & -3 & 3.50 & 3.52 & - & - & - & $\begin{array}{c}12 / 0.001 / 34 / 12 / 0.300 / 34 / \\
110 \\
110\end{array}$ & - & - & - & 14 & $\mathrm{H}$ & $\mathrm{H}$ & $\mathrm{H}$ & $\mathrm{H}$ & $\mathrm{N}$ & $\mathrm{N}$ & 1 & $\begin{array}{l}\text { E0422-D1- } \\
\text { 070402.ASC }\end{array}$ & $\begin{array}{l}\mathrm{E} 0422-\mathrm{D} \\
200\end{array}$ & No video taken \\
\hline E0423 & 8 & Clay & 55 & 0.8 & 33.42 & 28.6 & 2 & 4,5 & -3 & 3.49 & 3.46 & - & & & $\begin{array}{l}12 / 0.001 / 34 / 12 / 0.300 / 34 / \\
110 \\
110\end{array}$ & 1 & - & - & 14 & $\mathrm{H}$ & $\mathrm{H}$ & $\mathrm{H}$ & $\mathrm{H}$ & $\mathrm{N}$ & $\mathrm{N}$ & 1 & $\begin{array}{l}\text { EO423-D1- } \\
\text { E7201- }\end{array}$ & $\begin{array}{l}\text { E0423-D2-Channeli Apr 02, } \\
\text { E042-Ch }\end{array}$ & No video taken \\
\hline E0424 & 8 & Clay & 55 & 0.8 & 33.42 & 28.6 & 2 & 4,5 & -3 & 3.54 & 3.59 & - & & & $12 / 0.001 / 34 / 12 / 0.300 / 34 /$ & 1 & - & - & 14 & $\mathrm{H}$ & $\mathrm{H}$ & $\mathrm{H}$ & $\mathrm{H}$ & N & $\mathrm{N}$ & 1 & E0424-D1- & E0424-D & No video taken \\
\hline E0425 & 8 & Clay & 55 & 0.8 & 33.42 & 28.6 & 2 & 4,5 & -3 & 3.49 & 3.52 & & & & $\begin{array}{l}12 / 0.001 / 34 / 12 / 0.300 / 34 / \\
111 /\end{array}$ & & & & 14 & H & $\mathrm{H}$ & H & $\mathrm{H}$ & $\mathrm{N}$ & $\mathrm{N}$ & 1 & E0425 & $\begin{array}{l}\text { E0425-D2-Channeli Apr 02, } \\
\text { E045 }\end{array}$ & No video taken \\
\hline E0426 & 8 & Clay & 55 & 0.8 & 33.42 & 28.6 & 2 & 4,5 & -3 & 3.49 & 3.56 & & & & $\begin{array}{c}12 / 0.001 / 34 / 12 / 0.400 / 34 / \\
110 \\
110\end{array}$ & & & & 14 & $\mathrm{H}$ & $\mathrm{H}$ & $H$ & $H$ & $\mathrm{~N}$ & $\mathrm{~N}$ & 1 & $\begin{array}{l}\text { E0426-D1- } \\
\text { 070402.ASC }\end{array}$ & $\begin{array}{l}\text { E0426-D2-Channel1 Apr 02, } \\
\text { 2007 13-38-07.txt }\end{array}$ & No video taken \\
\hline E0427 & 8 & Clay & 55 & 0.8 & 33.42 & 28.6 & 2 & 4,5 & -3 & 3.49 & 3.44 & & - & & $\begin{array}{c}12 / 0.001 / 34 / 12 / 0.400 / 34 / \\
110 \\
110\end{array}$ & 1 & - & & 14 & $\mathrm{H}$ & $\mathrm{H}$ & H & $\mathrm{H}$ & $\mathrm{N}$ & $\mathrm{N}$ & 1 & $\begin{array}{l}\text { E0427-D1- } \\
\text { 070402.ASC }\end{array}$ & $\begin{array}{l}\text { E0427-D2-Channel1 Apr 02, } \\
2007 \text { 13-43-07.txt }\end{array}$ & No video taken \\
\hline E0428 & 8 & Clay & 55 & 0.8 & 33.42 & 28.6 & 2 & 4,5 & $\sim 3$ & 3.49 & 3.55 & - & & & $12 / 0.001 / 34 / 12 / 0.400 / 34 /$ & & & & 14 & $\mathrm{H}$ & $\mathrm{H}$ & $\mathrm{H}$ & $\mathrm{H}$ & $\mathrm{N}$ & TV & 1 & E0428-D1- & E0428-D2-Channel1 Apr 02, & No video taken \\
\hline
\end{tabular}




\begin{tabular}{|c|c|c|c|c|c|c|c|c|c|c|c|c|c|c|c|c|c|c|c|c|c|c|c|c|c|c|c|c|c|c|}
\hline \multirow[b]{2}{*}{$\begin{array}{l}\operatorname{Exp}_{\text {No. }} \\
\text { Noo. }\end{array}$} & \multirow[b]{2}{*}{$\begin{array}{l}\text { PJM } \\
\text { Config }\end{array}$} & \multicolumn{5}{|c|}{ Simulant } & \multirow[b]{2}{*}{$\begin{array}{r}\text { No. } \\
\text { PJMs } \\
\text { P) } \\
\mathrm{OB}^{(t)} \\
\end{array}$} & \multirow[b]{2}{*}{$\begin{array}{l}\text { OB } \\
\text { PJMs } \\
\end{array}$} & \multirow[b]{2}{*}{$\begin{array}{c}\mathrm{OB} \\
\text { Duration } \\
\end{array}$} & \multicolumn{5}{|c|}{$\begin{array}{l}\text { Drive Pressure Settings } \\
(\text { bar.,glc) }\end{array}$} & \multicolumn{5}{|c|}{ PJM OP Conditions (vacuum/delay/drive/vent time) } & \multirow[b]{2}{*}{$\begin{array}{c}\text { Target } \\
\text { Noz. Vel. } \\
\left(\mathrm{m} / \mathrm{s}^{(\mathrm{c})}\right.\end{array}$} & \multicolumn{4}{|c|}{ Hydrophone Elevation } & \multirow[b]{2}{*}{$\begin{array}{c}\text { Sparger } \\
\text { (Y/N) }\end{array}$} & \multirow[b]{2}{*}{$\begin{array}{l}\text { Video } \\
(\mathrm{Y} / \mathrm{N})\end{array}$} & \multirow[b]{2}{*}{$\begin{array}{c}\text { Repeat } \\
\#\end{array}$} & \multirow[b]{2}{*}{ DAS-1 Filename } & \multirow[b]{2}{*}{ DAS-2 Filename } & \multirow[b]{2}{*}{$\begin{array}{c}\text { DAS-4 (Video) } \\
\text { Filename }\end{array}$} \\
\hline & & Type & $\begin{array}{l}\text { Het. } \\
\text { Rim } \\
\text { (in) }\end{array}$ & $H / D$ & $\begin{array}{l}\mathrm{T}_{\mathrm{ys}} \\
(\mathrm{Pa})\end{array}$ & $\begin{array}{c}k \\
(\mathrm{CP})\end{array}$ & & & & $\begin{array}{c}\text { PJM } \\
4\end{array}$ & $\begin{array}{c}\text { PJM } \\
5\end{array}$ & $\begin{array}{c}\text { PJM } \\
6\end{array}$ & $\begin{array}{c}\text { PJM } \\
7 \\
\end{array}$ & $\begin{array}{c}\text { PJM } \\
8\end{array}$ & PJM 4 & PJM 5 & PJM 6 & PJM 7 & PJM 8 & & $\mathrm{H} 1$ & $\mathrm{H} 2$ & H3 & $\mathrm{H} 4$ & & & & & & \\
\hline E0429 & 8 & Clay & 55 & 0.8 & 33.4 & 28.6 & 2 & 4,5 & -3 & 3.50 & 3.41 & & 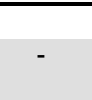 & & $\begin{array}{l}110 \\
110.001 / 34 \\
110\end{array}$ & $\begin{array}{l}110 \\
12 / 0.400 / 34 / \\
110\end{array}$ & & & & 14 & $\mathrm{H}$ & $\mathrm{H}$ & $\mathrm{H}$ & $\mathrm{H}$ & $\mathrm{N}$ & $\mathrm{N}$ & 1 & $\begin{array}{l}\text { 070402.ASC } \\
\text { E0429-D1- } \\
\text { 070492.ASC }\end{array}$ & $\begin{array}{c}\text { 2007 13-46-26.txt } \\
\text { E0429-D2-Channel Apr 02, } \\
\text { 2007 13-52-38.txt }\end{array}$ & No video taken \\
\hline E0430 & 8 & Clay & 55 & 0.8 & 33.4 & 28.6 & 2 & 4,5 & -3 & 3.50 & 3.52 & - & - & - & $\begin{array}{l}12 / 0.001 / 341 \\
110\end{array}$ & $\begin{array}{c}12 / 0.400 / 34 / \\
110\end{array}$ & - & - & - & 14 & $\mathrm{H}$ & $\mathrm{H}$ & $\mathrm{H}$ & $\mathrm{H}$ & $\mathrm{N}$ & $\mathrm{N}$ & 1 & $\begin{array}{l}\text { E0430-D1- } \\
\text { 0770402ASC }\end{array}$ & $\begin{array}{l}\text { E0430-D2-Channel1 Apr 02, } \\
\text { 2007 13-56-57t trt }\end{array}$ & No video taken \\
\hline E0431 & 8 & Clay & 55 & 0.8 & 33.4 & 28.6 & 2 & 4,5 & -3 & 3.49 & 3.42 & - & - & - & $\begin{array}{l}12 / 0.001 / 34 / \\
110\end{array}$ & $\begin{array}{l}12 / 0.500 / 34 / \\
110\end{array}$ & - & - & - & 14 & $\mathrm{H}$ & $\mathrm{H}$ & $\mathrm{H}$ & $\mathrm{H}$ & $\mathrm{N}$ & $\mathrm{N}$ & 1 & $\begin{array}{l}\text { E0431-D1- } \\
\text { 070402.ASC }\end{array}$ & $\begin{array}{l}\text { E0431-D2-Channel1 Apr 02, } \\
2007 \text { 14-09-17.txt }\end{array}$ & No video taken \\
\hline E0432 & 8 & Clay & 55 & 0.8 & 33.4 & 28.6 & 2 & 4,5 & -3 & 3.49 & 3.54 & - & - & - & $12 / 0.001 / 34 /$ & $\begin{array}{l}12 / 0.500 / 34 / \\
110\end{array}$ & - & - & - & 14 & $\mathrm{H}$ & $\mathrm{H}$ & $\mathrm{H}$ & $\mathrm{H}$ & $\mathrm{N}$ & $\mathrm{N}$ & 1 & $\begin{array}{l}\text { E0432-D1- } \\
07040 \text { ASC }\end{array}$ & $\begin{array}{l}\text { E0432-D2-Channel1 Apr 02, } \\
\text { 2007 14-13-04 4xt }\end{array}$ & No video taken \\
\hline E0433 & 8 & Clay & 55 & 0.8 & 33.4 & 28.6 & 2 & 4,5 & -3 & 3.49 & 3.41 & - & - & - & $\begin{array}{l}12 / 0.001 / 34 / \\
110\end{array}$ & $\begin{array}{l}12 / 0.600 / 34 / \\
110\end{array}$ & - & - & - & 14 & $\mathrm{H}$ & $\mathrm{H}$ & $\mathrm{H}$ & $\mathrm{H}$ & $\mathrm{N}$ & $\mathrm{N}$ & 1 & $\begin{array}{l}\text { E0433-D1- } \\
\text { 070402.ASC }\end{array}$ & $\begin{array}{l}\text { E0433-D2-Channel1 Apr 02, } \\
\text { 2007 14-25-09.txt }\end{array}$ & No video taken \\
\hline E0434 & 8 & Clay & 55 & 0.8 & 33.4 & 28.6 & 2 & 4,5 & -3 & 3.49 & 3.51 & - & - & & $\begin{array}{c}12 / 0.001 / 34 / \\
110\end{array}$ & $\begin{array}{l}12 / 0.600 / 34 / \\
110\end{array}$ & - & & & 14 & $\mathrm{H}$ & $\mathrm{H}$ & $\mathrm{H}$ & $\mathrm{H}$ & $\mathrm{N}$ & $\mathrm{N}$ & 1 & $\begin{array}{l}\text { E0434-D1- } \\
\text { 070402.ASC }\end{array}$ & $\begin{array}{l}\text { E0434-D2-Channel1 Apr 02, } \\
2007 \text { 14-28-45.txt }\end{array}$ & No video taken \\
\hline E0435 & 8 & Clay & 55 & 0.8 & 33.4 & 28.6 & 2 & 4,5 & -3 & 3.50 & 3.41 & - & - & & $\begin{array}{l}12 / 0.001 / 341 \\
110\end{array}$ & $\begin{array}{l}12 / 0.600 / 34 / \\
110\end{array}$ & - & & & 14 & $\mathrm{H}$ & $\mathrm{H}$ & $\mathrm{H}$ & $\mathrm{H}$ & $\mathrm{N}$ & $\mathrm{N}$ & 1 & $\begin{array}{l}\text { E0433-D1- } \\
\text { 070402.ASC }\end{array}$ & $\begin{array}{l}\text { E0435-D2-Channel1 Apr 02, } \\
\text { 2007 14-35-28.txt }\end{array}$ & No video taken \\
\hline E0436 & 8 & Clay & 55 & 0.8 & 33.4 & 28.6 & 2 & 4,5 & -3 & 3.48 & 3.43 & - & - & & $12 / 0.001 / 34 /$ & $12 / 0.600 / 34 /$ & - & & & 14 & $\mathrm{H}$ & $\mathrm{H}$ & $\mathrm{H}$ & $\mathrm{H}$ & $\mathrm{N}$ & $\mathrm{N}$ & 1 & $\begin{array}{l}\text { E0436-D1- } \\
07002 A S C\end{array}$ & $\begin{array}{l}\text { E0436-D2-Channel1 Apr 02, } \\
\text { 207 }\end{array}$ & No video taken \\
\hline E0437 & 8 & Clay & 55 & 0.8 & 33.4 & 28.6 & 2 & 4,5 & -3 & 3.48 & 3.43 & - & - & - & $\begin{array}{l}12 / 0.001 / 341 \\
110\end{array}$ & $\begin{array}{l}12 / 0.600 / 34 / \\
110\end{array}$ & - & - & - & 14 & $\mathrm{H}$ & $\mathrm{H}$ & $\mathrm{H}$ & $\mathrm{H}$ & $\mathrm{N}$ & $\mathrm{N}$ & 1 & $\begin{array}{l}\text { E0437-D1- } \\
\text { 070402ASC }\end{array}$ & $\begin{array}{l}\text { E0437-D2-Channel1 Apr 02, } \\
\text { 2007 14-45-01.tt }\end{array}$ & No video taken \\
\hline E0438 & 8 & Clay & 55 & 0.8 & 33.4 & 28.6 & 2 & 4,5 & $\sim^{3}$ & 3.49 & 3.49 & - & - & - & $12 / 0.001 / 341$ & $\begin{array}{c}12 / 0.600 / 34 / \\
110\end{array}$ & - & - & - & 14 & $\mathrm{H}$ & $\mathrm{H}$ & $\mathrm{H}$ & $\mathrm{H}$ & $\mathrm{N}$ & $\mathrm{N}$ & 1 & $\begin{array}{l}\text { E0438-D1- } \\
\text { 0700202 ASC }\end{array}$ & $\begin{array}{l}\text { E0438-D2-Channel1 Apr 02, } \\
\text { 2007 14-54-5 txt }\end{array}$ & No video taken \\
\hline E0439 & 8 & Clay & 55 & 0.8 & 33.4 & 28.6 & 2 & 4,5 & -3 & 3.48 & 3.49 & - & - & - & $\begin{array}{l}12 / 0.001 / 34 / \\
110\end{array}$ & $\begin{array}{l}12 / 0.400 / 34 / \\
110\end{array}$ & - & - & - & 14 & $\mathrm{H}$ & $\mathrm{H}$ & $\mathrm{H}$ & $\mathrm{H}$ & $\mathrm{N}$ & $\mathrm{N}$ & 1 & $\begin{array}{l}\text { E0439-D1- } \\
\text { 070402.ASC }\end{array}$ & $\begin{array}{l}\text { E0439-D2-Channel1 Apr 02, } \\
\text { 2007 15-01-36.txt }\end{array}$ & No video taken \\
\hline E0440 & 8 & Clay & 55 & 0.8 & 33.4 & 28.6 & 2 & 4,5 & -3 & 3.48 & 3.43 & - & - & & $12 / 0.001 / 341$ & $\begin{array}{l}12 / 0.400 / 34 / \\
110\end{array}$ & - & - & - & 14 & $\mathrm{H}$ & $H$ & $\mathrm{H}$ & H & $\mathrm{N}$ & $\mathrm{N}$ & 1 & $\begin{array}{l}\text { E0440-D1- } \\
\text { 070402.ASC }\end{array}$ & $\begin{array}{l}\text { E0440-D2-Channell Apr 02, } \\
2007 \text { 15-06-04.txt }\end{array}$ & No video taken \\
\hline E0441 & 8 & Clay & 55 & 0.8 & 33.4 & 28.6 & 2 & 4,5 & -3 & 3.49 & 3.54 & - & - & & $\begin{array}{l}12 / 0.001 / 341 \\
110\end{array}$ & $\begin{array}{c}12 / 0.400 / 34 / \\
110\end{array}$ & - & 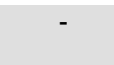 & & 14 & $\mathrm{H}$ & $\mathrm{H}$ & $\mathrm{H}$ & $\mathrm{H}$ & $\mathrm{N}$ & $\mathrm{N}$ & 1 & $\begin{array}{l}\text { E0441-D1- } \\
\text { 070402.ASC }\end{array}$ & $\begin{array}{l}\text { E0441-D2-Channel1 Apr 02, } \\
2007 \text { 15-09-29.txt }\end{array}$ & No video taken \\
\hline E0442 & 8 & Clay & 55 & 0.8 & 33.4 & 28.6 & 2 & 4,5 & -3 & 3.49 & 3.42 & - & - & & $12 / 0.001 / 341$ & $\begin{array}{l}12 / 0.400 / 34 / \\
110\end{array}$ & - & - & - & 14 & H & $\mathrm{H}$ & $\mathrm{H}$ & H & $\mathrm{N}$ & $\mathrm{N}$ & 1 & $\begin{array}{l}\text { E0442-D1- } \\
\text { 070402.ASC }\end{array}$ & $\begin{array}{l}\text { E0442-D2-Channel1 Apr 02, } \\
\text { 2007 15-13-46.txt }\end{array}$ & No video taken \\
\hline E0443 & 8 & Clay & 55 & 0.8 & 33.4 & 28.6 & 2 & 4,5 & -3 & 3.50 & 3.54 & - & & & $\begin{array}{l}12 / 0.001 / 34 / \\
110\end{array}$ & $\begin{array}{l}12 / 0.400 / 34 / \\
110\end{array}$ & - & & & 14 & H & $\mathrm{H}$ & $\mathrm{H}$ & H & $\mathrm{N}$ & $\mathrm{N}$ & 1 & $\begin{array}{l}\text { E0443-D1- } \\
\text { 070402.ASC }\end{array}$ & $\begin{array}{l}\text { E0443-D2-Channell Apr 02, } \\
\text { 2007 15-18-59.txt }\end{array}$ & No video taken \\
\hline E0444 & 8 & Clay & 55 & 0.8 & 33.4 & 28.6 & 2 & 4,5 & -3 & 3.49 & 3.42 & - & - & - & $\begin{array}{l}12 / 0.001 / 34 / \\
110\end{array}$ & $\begin{array}{l}12 / 0.400 / 34 / \\
110\end{array}$ & - & - & - & 14 & H & $\mathrm{H}$ & $\mathrm{H}$ & $\mathrm{H}$ & $\mathrm{N}$ & $\mathrm{N}$ & 1 & $\begin{array}{l}\text { E0444--11- } \\
\text { 070402.ASC }\end{array}$ & $\begin{array}{l}\text { E0444-D2-Channeli Apr 02, } \\
\text { 2007 15-26-34.txt }\end{array}$ & No video taken \\
\hline E0445 & 8 & Clay & 55 & 0.8 & 33.4 & 28.6 & 2 & 4,5 & -3 & 3.49 & 3.54 & - & - & - & $\begin{array}{c}12 / 0.001 / 34 / \\
110\end{array}$ & $\begin{array}{l}12 / 0.000 / 34 / \\
110\end{array}$ & - & - & - & 14 & $\mathrm{H}$ & H & $\mathrm{H}$ & H & $\mathrm{N}$ & N & 1 & $\begin{array}{l}\text { E0445-D1- } \\
\text { 070402.ASC }\end{array}$ & $\begin{array}{l}\text { E0445-D2-Channel1 Apr 02, } \\
\text { 2007 15-31-27.txt }\end{array}$ & No video taken \\
\hline E0445BL & - & - & - & - & 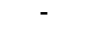 & - & - & - & - & - & 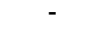 & - & - & 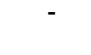 & $-a_{-1}$ & & - & 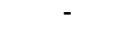 & 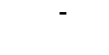 & - & - & - & - & - & - & - & - & $\begin{array}{l}\text { D1-BL- } \\
\text { 2.ASC }\end{array}$ & $\begin{aligned} E 0445-L \\
2,2\end{aligned}$ & \\
\hline E0446BL & - & & - & & & & & & & & & & & & & & - & & & - & & -7 & - & - & - & - & - & $\begin{array}{l}\text { E0446-D1-BL- } \\
\text { 070403.ASC }\end{array}$ & $\begin{array}{r}\text { E0446-D2- } \\
3,200\end{array}$ & \\
\hline E0446 & 8 & Clay & 54 & 0.8 & 31.6 & 26.5 & 2 & 4,5 & -3 & 3.51 & 3.46 & - & - & & $\begin{array}{r}12 / 0.001 \\
110\end{array}$ & $\begin{array}{c}12 / 0.001 / 34 / \\
110\end{array}$ & - & & 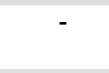 & 14 & $\mathrm{H}$ & $\mathrm{H}$ & $\mathrm{H}$ & $\mathrm{H}$ & $\mathrm{N}$ & $\mathrm{N}$ & 1 & $\begin{array}{l}\text { E0446-D1- } \\
\text { 070403.ASC }\end{array}$ & $\begin{array}{l}\text { E0446-D2-Channel1 Apr 03, } \\
2007 \text { 10-34-28.txt }\end{array}$ & No video taken \\
\hline E0447 & 8 & Clay & 54 & 0.8 & 31.6 & 26.5 & 2 & 4,5 & -3 & 3.51 & 3.46 & - & & & $\begin{array}{c}12 / 0.001 / 34 \mid \\
110\end{array}$ & $12210.250 / 341$ & - & & & 14 & $\mathrm{H}$ & H & $\mathrm{H}$ & H & $\mathrm{N}$ & $\mathrm{N}$ & 1 & $\begin{array}{l}\text { E0447-D1- } \\
07003 \text { ASC }\end{array}$ & E0447-D2-Channel1 Apr 03, & No video taken \\
\hline E0448 & 8 & Clay & 54 & 0.8 & 31.6 & 26.5 & 2 & 4,5 & -3 & 3.49 & 3.60 & - & - & & $\begin{aligned} 12 / 0.001 / 34 / \\
110\end{aligned}$ & $\begin{array}{l}12 / 0.250 / 34 / \\
110\end{array}$ & - & & $x^{-5}+2$ & 14 & $\mathrm{H}$ & $\mathrm{H}$ & $\mathrm{H}$ & $\mathrm{H}$ & $\mathrm{N}$ & $\mathrm{N}$ & 1 & $\begin{array}{l}\text { E0448-D1- } \\
\text { 070403.ASC }\end{array}$ & $\begin{array}{l}\text { E0448-D2-Channell Apr 03, } \\
\text { 2007 10-54-55.txt }\end{array}$ & No video taken \\
\hline E0449 & 8 & Clay & 54 & 0.8 & 31.6 & 26.5 & 2 & 4,5 & -3 & 3.49 & 3.46 & - & - & ( & $12 / 0.001 / 341$ & $12 / 0.250 / 341$ & - & - & - & 14 & $\mathrm{H}$ & $\mathrm{H}$ & $\mathrm{H}$ & $\mathrm{H}$ & $\mathrm{N}$ & $\mathrm{N}$ & 1 & $\begin{array}{l}\text { E0449-D1- } \\
\text { E7003 }\end{array}$ & E0449-D2-Channel1 Apr 03, & No video taken \\
\hline E0450 & 8 & Clay & 54 & 0.8 & 31.6 & 26.5 & 2 & 4,5 & -3 & 3.49 & 3.45 & - & - & - & $\begin{array}{l}12 / 0.001 / 34 / \\
110\end{array}$ & $\begin{array}{l}12 / 0.200 / 34 / \\
110\end{array}$ & - & - & - & 14 & $\mathrm{H}$ & H & $\mathrm{H}$ & $\mathrm{H}$ & $\mathrm{N}$ & $\mathrm{N}$ & 1 & $\begin{array}{l}\text { E0450-D1- } \\
\text { 070403.ASC }\end{array}$ & $\begin{array}{l}\text { E0450-D2-Channel1 Apr 03, } \\
\text { 2007 11-09-27.tx }\end{array}$ & No video taken \\
\hline E0451 & 8 & Clay & 54 & 0.8 & 31.6 & 26.5 & 2 & 4,5 & -3 & 3.49 & 3.45 & - & & & $\begin{aligned} 12 / 0.001 / 34 / \\
110\end{aligned}$ & $\begin{array}{l}12 / 0.200 / 34 / \\
110\end{array}$ & - & & & 14 & $\mathrm{H}$ & $\mathrm{H}$ & $\mathrm{H}$ & $\mathrm{H}$ & $\mathrm{N}$ & $\mathrm{N}$ & 1 & $\begin{array}{l}\text { E0451-D1- } \\
\text { 070403.ASC }\end{array}$ & $\begin{array}{l}\text { E0451-D2-Channel1 Apr 03, } \\
\text { 2007 11-17-00.txt }\end{array}$ & No video taken \\
\hline E0452 & 8 & Clay & 54 & 0.8 & 31.6 & 26.5 & 2 & 4,5 & -3 & 3.49 & 3.52 & - & & & $\begin{array}{l}12 / 0.001 / 34 / \\
110\end{array}$ & $\begin{array}{c}12 / 0.200 / 34 / \\
110\end{array}$ & - & & & 14 & $\mathrm{H}$ & $\mathrm{H}$ & $\mathrm{H}$ & $\mathrm{H}$ & $\mathrm{N}$ & $\mathrm{N}$ & 1 & $\begin{array}{r}\text { E04 } \\
0704\end{array}$ & $\begin{array}{r}\text { E0452-[ } \\
20\end{array}$ & No video taken \\
\hline E0453 & 8 & Clay & 54 & 0.8 & 31.6 & 26.5 & 2 & 4,5 & -3 & 3.49 & 3.48 & - & & & $\begin{array}{c}12 / 0.001 / 3 \\
110\end{array}$ & $\begin{array}{l}12 / 0.600 / 34 / \\
110\end{array}$ & & & & 14 & $\mathrm{H}$ & $\mathrm{H}$ & $\mathrm{H}$ & $\mathrm{H}$ & $\mathrm{N}$ & $\mathrm{N}$ & 1 & $\begin{array}{l}\text { E0453-D1- } \\
\text { 070403.ASC }\end{array}$ & $\begin{array}{l}\text { E0453-D2-Channel1 Apr 03, } \\
\text { 2007 11-39-57.txt }\end{array}$ & No video taken \\
\hline E04 & $\begin{array}{l}\mathrm{scl} \\
8\end{array}$ & Clay & $\begin{array}{ll}\text { w; hy } \\
54\end{array}$ & 0.8 & $\begin{array}{l}\text { ne level } \\
31.6\end{array}$ & $\begin{array}{c}\mathrm{el}=\mathrm{M} \\
26.5\end{array}$ & 2 & 4, & -3 & 3.51 & 3.43 & - & - & & $12 / 0.001 / 34 /$ & $\begin{array}{l}12 / 0.600 / 34 / \\
110\end{array}$ & - & & & 14 & $M$ & M & M & M & $\mathrm{N}$ & $\mathrm{N}$ & 1 & $\begin{array}{l}\text { E0454-D1- } \\
\text { 070403ASC }\end{array}$ & $\begin{array}{l}\text { E0454-D2-Channel1 Apr 03, } \\
\text { 2007 13-52-35.txt }\end{array}$ & No video taken \\
\hline E0455 & 8 & Clay & 54 & 0.8 & 31.6 & 26.5 & 2 & 4,5 & -3 & 3.50 & 3.46 & - & - & - & $12 / 0.001 / 3$ & $12 / 0.600 / 341$ & - & -5 & & 14 & M & M & M & M & $\mathrm{N}$ & $\mathrm{N}$ & 1 & $\begin{array}{l}\text { E0455-D1- } \\
070403 \text { ASC }\end{array}$ & E0455-D2-Channel1 Apr 03, & No video taken \\
\hline E0456 & 8 & Clay & 54 & 0.8 & 31.6 & 26.5 & 2 & 4,5 & -3 & 3.50 & 3.46 & - & & & $\begin{array}{l}12 / 0.001 \\
110\end{array}$ & $\begin{array}{l}12 / 0.600 / 341 \\
110\end{array}$ & - & - & - & 14 & M & M & M & M & $\mathrm{N}$ & N & 1 & $\begin{array}{l}\text { E0456-D1- } \\
\text { 070403.ASC }\end{array}$ & $\begin{array}{l}\text { E0456-D2-Cha } \\
\text { 2007 14-- }\end{array}$ & No video taken \\
\hline E0457 & 8 & Clay & 54 & 0.8 & 31.6 & 26.5 & 2 & 4,5 & -3 & 3.50 & 3.48 & & & & $\begin{array}{l}12 / 0.001 / 3 \\
110\end{array}$ & $\begin{array}{l}12 / 0.000 / 34 / \\
110\end{array}$ & & & & 14 & $\mathrm{M}$ & M & $\mathrm{M}$ & $\mathrm{M}$ & $\mathrm{N}$ & $\mathrm{N}$ & 1 & $\begin{array}{l}\text { E0457-D1- } \\
\text { 070403.ASC }\end{array}$ & $\begin{array}{l}\text { E0457-D2-Channel1 Apr 03, } \\
\text { 2007 14-07-34.txt }\end{array}$ & No video taken \\
\hline E0458 & 8 & Clay & 54 & 0.8 & 31.6 & 26.5 & 2 & 4,5 & -3 & 3.49 & 3.45 & & & & $\begin{array}{l}12 / 0.001 / 34 / \\
110\end{array}$ & $\begin{array}{l}12 / 0.600 / 34 / \\
110\end{array}$ & & & & 14 & M & M & M & $\mathrm{M}$ & $\mathrm{N}$ & $\mathrm{N}$ & 1 & $\begin{array}{l}\text { E0458-D1- } \\
\text { 070403.ASC }\end{array}$ & $\begin{array}{l}\text { E0458-D2-Channel1 Apr 03, } \\
2007 \text { 14-12-48.txt }\end{array}$ & No video taken \\
\hline E0459 & 8 & Clay & 54 & 0.8 & 31.6 & 26.5 & 2 & 4,5 & -3 & 3.49 & 3.51 & & & & 12 & $12 / 0610$ & & & & & & $\mathrm{M}$ & & & & & & E0459-D1- & 0459-D2-Channel1 Apr 03, & No video taken \\
\hline
\end{tabular}




\begin{tabular}{|c|c|c|c|c|c|c|c|c|c|c|c|c|c|c|c|c|c|c|c|c|c|c|c|c|c|c|c|c|c|c|}
\hline \multirow[b]{2}{*}{$\begin{array}{l}\text { Exp. } \\
\text { Noo. }\end{array}$} & \multirow[b]{2}{*}{$\begin{array}{l}\text { PJM } \\
\text { Config }\end{array}$} & \multirow{2}{*}{ Type } & \multicolumn{4}{|c|}{ Simulant } & \multirow[b]{2}{*}{$\begin{array}{c}\text { No. } \\
\text { PJM( } \\
\text { OB }\end{array}$} & \multirow[b]{2}{*}{$\begin{array}{c}\text { OB } \\
\text { PJMs }\end{array}$} & \multirow[b]{2}{*}{$\begin{array}{c}\mathrm{OB} \\
\text { Duration } \\
(\mathrm{c}) \\
\end{array}$} & \multicolumn{5}{|c|}{$\begin{array}{l}\text { Drive Pressure Settings } \\
\left(\text { barar.g }^{(c)}\right)^{(0)}\end{array}$} & \multicolumn{5}{|c|}{ PJM OP Conditions (vacuum/delay/drive/vent time) } & \multirow[b]{2}{*}{$\begin{array}{c}\text { Target } \\
\text { Noz. Vel. } \\
\left(\mathrm{m} / \mathrm{s}^{(\mathrm{c})}\right.\end{array}$} & \multicolumn{4}{|c|}{ Hydrophone Elevation } & \multirow[b]{2}{*}{$\begin{array}{c}\text { Sparger } \\
(Y / N)\end{array}$} & \multirow[b]{2}{*}{$\begin{array}{l}\text { Video } \\
(Y / N)\end{array}$} & \multirow[b]{2}{*}{$\underset{\#}{\text { Repeat }}$} & \multirow[b]{2}{*}{ DAS-1 Filename } & \multirow[b]{2}{*}{ DAS-2 Filename ${ }^{(\mathrm{d})}$} & \\
\hline & & & $\begin{array}{l}\text { Ht. fm } \\
\text { Rim } \\
\text { (in) }\end{array}$ & $\mathrm{H} / \mathrm{D}$ & $\begin{array}{l}\mathrm{T}_{\mathrm{ys}} \\
(\mathrm{Pa})\end{array}$ & $\begin{array}{c}k \\
(C P)\end{array}$ & & & & $\underset{4}{\mathrm{PJM}}$ & $\begin{array}{c}\text { PJM } \\
5\end{array}$ & $\begin{array}{c}\text { PJM } \\
6\end{array}$ & $\underset{7}{\mathrm{PJM}}$ & $\begin{array}{c}\text { PJM } \\
8\end{array}$ & PJM 4 & PJM 5 & РJM 6 & PJM 7 & PJM 8 & & $\mathrm{H} 1$ & $\mathrm{H} 2$ & H3 & $\mathrm{H} 4$ & & & & & & $\begin{array}{l}\text { DAS-4 (Video) } \\
\text { Filename }\end{array}$ \\
\hline E0460 & 8 & Clay & 54 & 0.8 & 31.6 & 26.5 & 2 & 4,5 & -3 & 3.49 & 3.45 & 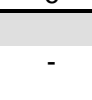 & & & $\begin{array}{c}110 \\
12 / 0.001 / 34 / \\
110\end{array}$ & $\begin{array}{c}110 \\
12 / 0.610 / 34 / \\
110\end{array}$ & & & & 14 & M & M & $\mathrm{M}$ & M & $\mathrm{N}$ & $\mathrm{N}$ & 1 & $\begin{array}{l}\text { 070403.ASC } \\
\text { E0460-D1- } \\
0070403 \text { SSC }\end{array}$ & $\begin{array}{c}2007 \text { 14-21-40.txt } \\
\text { E0460-D2-Channel1 Apr 03, } \\
\text { 2007 14-28-14txt }\end{array}$ & No video taken \\
\hline E0461 & 8 & Clay & 54 & 0.8 & 31.6 & 26.5 & 2 & 4,5 & -3 & 3.49 & 3.45 & - & - & & $\begin{array}{l}12 / 0.001 / 34 / \\
110\end{array}$ & $12 / 0.610 / 34 /$ & - & - & - & 14 & M & M & M & M & $\mathrm{N}$ & $\mathrm{N}$ & 1 & $\begin{array}{l}\text { E0461-D1- } \\
070403 \text { ASC }\end{array}$ & $\begin{array}{l}\text { E0461-D2-Channel1 Apr 03, } \\
\text { E02 }\end{array}$ & No video taken \\
\hline E0462 & 8 & Clay & 54 & 0.8 & 31.6 & 26.5 & 2 & 4,5 & -3 & 3.49 & 3.45 & - & - & - & $\begin{array}{l}12 / 0.001 / 34 / \\
110\end{array}$ & $\begin{array}{l}12 / 0.580 / 34 / \\
110\end{array}$ & - & - & - & 14 & M & M & $\mathrm{M}$ & M & $\mathrm{N}$ & $\mathrm{N}$ & 1 & $\begin{array}{l}\text { E0462-D1- } \\
\text { 070403.ASC }\end{array}$ & $\begin{array}{l}\text { E0462-D2-Channel1 Apr 03, } \\
\text { 2007 14-42-15 txt }\end{array}$ & No video taken \\
\hline E0463 & 8 & Clay & 54 & 0.8 & 31.6 & 26.5 & 2 & 4,5 & -3 & 3.49 & 3.46 & - & - & - & $\begin{array}{l}12 / 0.001 / 34 / \\
110\end{array}$ & $1210.580 / 341$ & - & - & - & 14 & M & M & M & M & $\mathrm{N}$ & $\mathrm{N}$ & 1 & $\begin{array}{l}\text { E0463-D1- } \\
\text { 077430 ASC }\end{array}$ & $\begin{array}{l}\text { E0463-D2-Channel1 Apr 03, } \\
\text { 2007 14-47-3t }\end{array}$ & No video taken \\
\hline E0464 & 8 & Clay & 54 & 0.8 & 31.6 & 26.5 & 2 & 4,5 & -3 & 3.54 & 3.58 & - & - & - & $\begin{array}{l}12 / 0.001 / 34 / \\
110\end{array}$ & $\begin{array}{l}12 / 10.580 / 34 / \\
110\end{array}$ & - & - & - & 14 & M & M & M & M & $\mathrm{N}$ & $\mathrm{N}$ & 1 & $\begin{array}{l}\text { E0464-D1- } \\
\text { 070403.ASC }\end{array}$ & $\begin{array}{l}\text { E0464-D2-Channell Apr 03, } \\
\text { 2007 14-58-25.txt }\end{array}$ & No video taken \\
\hline E0465 & 8 & Clay & 54 & 0.8 & 31.6 & 26.5 & 2 & 4,5 & -3 & 3.49 & 3.46 & - & - & - & $\begin{array}{l}12 / 0.001 / 34 / \\
110\end{array}$ & $\begin{array}{l}12 / 0.580 / 34 / \\
110\end{array}$ & - & & - & 14 & M & M & M & M & $\mathrm{N}$ & $\mathrm{N}$ & 1 & $\begin{array}{l}\text { E0465-D1- } \\
\text { E701- }\end{array}$ & 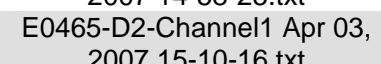 & No video taken \\
\hline E0466 & 8 & Clay & 54 & 0.8 & 31.6 & 26.5 & 2 & 4,5 & -3 & 3.47 & 3.43 & - & - & - & $\begin{array}{l}12 / 0.001 / 34 / \\
110\end{array}$ & $\begin{array}{l}12 / 0.550 / 34 / \\
110\end{array}$ & - & - & - & 14 & M & M & $\mathrm{M}$ & M & $\mathrm{N}$ & $\mathrm{N}$ & 1 & $\begin{array}{l}\text { E0466-D1- } \\
\text { 070403ASC }\end{array}$ & $\begin{array}{l}\text { E0466-D2-Channel1 Apr 03, } \\
\text { 2007 15-21-01.tt }\end{array}$ & No video taken \\
\hline E0467 & 8 & Clay & 54 & 0.8 & 31.6 & 26.5 & 2 & 4,5 & -3 & 3.52 & 3.45 & - & - & - & $\begin{array}{l}12 / 0.001 / 34 / \\
110\end{array}$ & $12 / 0.550 / 34 /$ & - & & & 14 & M & M & M & M & N & N & 1 & $\begin{array}{l}\text { E0467-D1- } \\
070403 \text { ASC }\end{array}$ & $\begin{array}{l}\text { E0467-D2-Channeli Apr 03, } \\
\text { 2007 }\end{array}$ & No video taken \\
\hline E0467BL & - & - & - & - & & - & - & - & - & - & - & - & - & - & & & - & - & - & - & - & - & - & - & - & - & - & $\begin{array}{l}\text { E0467-D1-BL- } \\
\text { E04-1- }\end{array}$ & 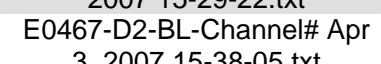 & \\
\hline E0468BL & - & - & - & - & 30.8 & 26.0 & - & - & - & - & - & - & - & - & - & - & - & - & - & - & - & - & - & - & - & - & - & E0468-D1-BL- & E0468-D2-BL-Channel\# Apr & - \\
\hline E0468 & 8 & Clay & 54 & 0.8 & 30.8 & 26.0 & 2 & 4,5 & -3 & 3.50 & 3.45 & - & - & - & $12 / 0.001 / 34 /$ & $12 / 0.550 / 34 /$ & - & - & - & 14 & M & M & M & M & $\mathrm{N}$ & N & 1 & E0468-D1- & E0468-D2-Channel1 Apr 04, & No video taken \\
\hline E0469 & 8 & Clay & 54 & 0.8 & 30.8 & 26.0 & 2 & 4,5 & -3 & 3.50 & 3.49 & - & - & - & $\begin{array}{l}12 / 0.001 / 34 / \\
110\end{array}$ & $\begin{array}{l}12 / 0.550 / 34 / \\
110\end{array}$ & - & - & - & 14 & M & M & M & M & $\mathrm{N}$ & $\mathrm{N}$ & 1 & $\begin{array}{l}\text { E0469-D1- } \\
\text { 070404.ASC }\end{array}$ & $\begin{array}{l}\text { E0469-D2-Channel1 Apr 04, } \\
\text { 2007 11-25-06.tx }\end{array}$ & No video taken \\
\hline E0470 & 8 & Clay & 54 & 0.8 & 30.8 & 26.0 & 2 & 4,5 & -3 & 3.53 & 3.49 & - & - & - & $\begin{array}{l}12 / 0.001 / 34 / \\
110\end{array}$ & $\begin{array}{l}12 / 0.550 / 34 / \\
110\end{array}$ & - & - & - & 14 & M & M & M & M & $\mathrm{N}$ & $\mathrm{N}$ & 1 & E0470-D1- & E0470-D2-Channel1 Apr 04, & No video taken \\
\hline E0471 & 8 & Clay & 54 & 0.8 & 30.8 & 26.0 & 2 & 4,5 & -3 & 3.50 & 3.49 & - & - & & $\begin{array}{l}12 / 0.001 / 34 / \\
110\end{array}$ & $\begin{array}{l}12 / 0.250 / 34 / \\
110\end{array}$ & - & & & 14 & M & M & M & M & $\mathrm{N}$ & $\mathrm{N}$ & 1 & $\begin{array}{l}\text { E0471-D1- } \\
\text { 070404.ASC }\end{array}$ & $\begin{array}{l}\text { E0471-D2-Channel1 Apr 04, } \\
\text { 2007 11-37-37 txt }\end{array}$ & No video taken \\
\hline E0472 & 8 & Clay & 54 & 0.8 & 30.8 & 26.0 & 2 & 4,5 & -3 & 3.49 & 3.50 & - & & & $12 / 0.001 / 34 /$ & $1210.250 / 341$ & - & & - & 14 & M & M & M & M & $\mathrm{N}$ & $\mathrm{N}$ & 1 & $\begin{array}{l}\text { E0472-D1- } \\
\text { E701- } \\
07019 \text { ASC }\end{array}$ & $\begin{array}{l}\text { E0472-D2-Channeli Apr 04, } \\
\text { 2077 }\end{array}$ & No video taken \\
\hline E0473 & 8 & Clay & 54 & 0.8 & 30.8 & 26.0 & 2 & 4,5 & -3 & 3.50 & 3.49 & - & & & $\begin{array}{l}12 / 0.001 / 34 / \\
110\end{array}$ & $\begin{array}{l}12 / 0.50 / 34 / 1 \\
10\end{array}$ & - & & & 14 & M & M & M & M & $\mathrm{N}$ & $\mathrm{N}$ & 1 & $\begin{array}{l}\text { E047-D1- } \\
\text { 070404.ASC }\end{array}$ & $\begin{array}{l}\text { E0473-D2-Channel1 Apr 04, } \\
\text { 2007 11-49-54.txt }\end{array}$ & No video taken \\
\hline E0474BL & - & - & - & - & 30.8 & 26.0 & - & - & - & & & - & - & & & & - & & & - & - & - & - & - & - & - & - & E0474-D1-BL- & E0474-D2-BL-Channel/A Apr & \\
\hline E0474 & 8 & Clay & 54 & 0.8 & 30.8 & 26.0 & 2 & 4,5 & -3 & 3.49 & 3.52 & - & - & - & $\begin{array}{l}12 / 0.001 / 34 / \\
110\end{array}$ & $\begin{array}{l}12 / 0.50 / 34 / 1 \\
10\end{array}$ & - & - & - & 14 & M & M & M & M & N & N & 1 & E0474-D1- & E0474-D2-Channel1 Apr 04, & No video taken \\
\hline E0475 & 8 & Clay & 54 & 0.8 & 30.8 & 26.0 & 2 & 4,5 & -3 & 3.50 & 3.49 & - & - & - & $12 / 0.001 / 34 /$ & $12 / 0.55 / 34 / 1$ & - & - & - & 14 & M & M & M & M & $\mathrm{N}$ & $\mathrm{N}$ & 1 & $\begin{array}{l}\text { E0475-D1- } \\
\text { E075 }\end{array}$ & E0475-D2-Channel1 Apr 04, & No video taken \\
\hline E0476 & 8 & Clay & 54 & 0.8 & 30.8 & 26.0 & 2 & 4,5 & -3 & 3.47 & 3.50 & - & - & - & $12 / 0.001 / 34 /$ & $12 / 0.55 / 34 / 1$ & - & - & - & 14 & M & M & M & M & $\mathrm{N}$ & $\mathrm{N}$ & 1 & $\begin{array}{l}\text { E0476-D1- } \\
\text { E0404 } \\
07004 \text { ASC }\end{array}$ & E0476-D2-Channel1 Apr 04, & No video taken \\
\hline E0477 & 8 & Clay & 54 & 0.8 & 30.8 & 26.0 & 2 & 4,5 & -3 & 3.51 & 3.52 & - & & 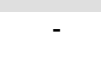 & $12 / 0.001 / 34 /$ & $12 / 0.55 / 34 / 1$ & - & & & 14 & M & M & M & M & $\mathrm{N}$ & $\mathrm{N}$ & 1 & D1- & E0477-D & No video taken \\
\hline E0478 & 8 & Clay & 54 & 0.8 & 30.8 & 26.0 & 2 & 4,5 & -3 & 3.50 & 3.52 & - & - & - & $\begin{array}{l}12 / 0.001 / 34 / \\
110\end{array}$ & $12 / 0.54 / 34 / 1$ & - & - & - & 14 & M & M & M & M & $\mathrm{N}$ & $\mathrm{N}$ & 1 & $\begin{array}{l}\text { EO } \\
070\end{array}$ & E0478-D & No video taken \\
\hline E0479 & 8 & Clay & 54 & 0.8 & 30.8 & 26.0 & 2 & 4,5 & -3 & 3.53 & 3.48 & - & & & $\begin{array}{l}12 / 0.001 / 34 / \\
110\end{array}$ & $\begin{array}{l}12 / 0.54 / 34 / 1 \\
10\end{array}$ & - & & & 14 & M & M & M & M & $\mathrm{N}$ & $\mathrm{N}$ & 1 & $\begin{array}{l}\text { E0479-1D- } \\
\text { 070404.ASC }\end{array}$ & $\begin{array}{l}\text { E0479-D2-Channell Apr 04, } \\
\text { 2007 13-49-50.txt }\end{array}$ & No video taken \\
\hline E0480 & 8 & Clay & 54 & 0.8 & 30.8 & 26.0 & 2 & 4,5 & -3 & 3.48 & 3.48 & - & & & $\begin{array}{c}12 / 0.001 / 34 / \\
110\end{array}$ & $\begin{array}{l}12 / 0.54 / 34 / 1 \\
10\end{array}$ & & & & 14 & M & M & M & M & $\mathrm{N}$ & $\mathrm{N}$ & 1 & $\begin{array}{l}\text { E0480-D1- } \\
\text { 070404.ASC }\end{array}$ & $\begin{array}{l}\text { E0480-D2-Channel1 Apr 04, } \\
\text { 2007 13-54-43.txt }\end{array}$ & No video taken \\
\hline $\begin{array}{l}\text { High clé } \\
\text { E048. }\end{array}$ & $\begin{array}{l}\text { el, } \\
8\end{array}$ & $\begin{array}{l}\text { dropho } \\
\text { Clay }\end{array}$ & $\begin{array}{l}\text { e lev } \\
54\end{array}$ & $\begin{array}{l}=\mathrm{M} \\
0.8\end{array}$ & 30.8 & 26.0 & 1 & 5 & -3 & & 3.48 & & & & & $\begin{array}{c}12 / 0.001 / 34 / \\
110\end{array}$ & & & & 14 & M & M & M & M & $\mathrm{N}$ & $\mathrm{N}$ & 1 & $\begin{array}{l}\text { E0481-D1- } \\
\text { 070404.ASC }\end{array}$ & $\begin{array}{l}\text { E0481-D2-Channel1 Apr 04, } \\
\text { 2007 14-35-40.txt }\end{array}$ & No video taken \\
\hline E0482 & 8 & Clay & 54 & 0.8 & 30.8 & 26.0 & 1 & 5 & -3 & - & 3.53 & - & - & - & - & $1210.001 / 341$ & - & - & - & 14 & M & M & M & M & $\mathrm{N}$ & $\mathrm{N}$ & 2 & $\begin{array}{l}\text { E0482-D1- } \\
\text { 0070404.ASC }\end{array}$ & $\begin{array}{l}\text { nell Apr 04, } \\
\text { B-5.2.txt }\end{array}$ & No video taken \\
\hline E0483 & 8 & Clay & 54 & 0.8 & 30.8 & 26.0 & 1 & 5 & -3 & - & 3.49 & - & - & - & - & $12 / 0.001 / 34 /$ & - & - & - & 14 & M & M & M & M & N & N & 3 & E0483-D1- & $\begin{array}{l}\text { E0483-D2-Channel1 Apr 04, } \\
\text {-D7 }\end{array}$ & No video taken \\
\hline E0484 & 8 & Clay & 54 & 0.8 & 30.8 & 26.0 & 2 & 4,5 & -3 & 3.49 & 3.49 & - & & - & $\begin{array}{l}12 / 0.001 / 34 / \\
110\end{array}$ & $\begin{array}{l}12 / 0.001 / 34 / \\
110\end{array}$ & - & & & 14 & M & M & M & M & $\mathrm{N}$ & $\mathrm{N}$ & 1 & $\begin{array}{l}\text { D1- } \\
\text { ASC }\end{array}$ & E0484- & No video taken \\
\hline E0485 & 8 & Clay & 54 & 0.8 & 30.8 & 26.0 & 2 & 4,5 & -3 & 3.49 & 3.54 & - & & & $\begin{array}{l}12 / 0.001 / 34 / \\
110\end{array}$ & $12 / 0.001 / 34 /$ & - & & & 14 & M & M & M & M & $\mathrm{N}$ & $\mathrm{N}$ & 2 & DSC & $\mathrm{E} 0485-\mathrm{D} 2$ & No video taken \\
\hline E0486 & 8 & Clay & 54 & 0.8 & 30.8 & 26.0 & 2 & 4,5 & -3 & 3.48 & 3.48 & 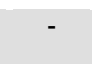 & & & $12 / 0.001 / 34 /$ & $1210.001 / 341$ & & & & 14 & M & M & M & M & $\mathrm{N}$ & $\mathrm{N}$ & 3 & $\begin{array}{l}\text { E0486-D1- } \\
\text { 077404ASC }\end{array}$ & $\begin{array}{l}\text { E0486-D2-Channeli Apr 04, } \\
\text { ED7 }\end{array}$ & No video taken \\
\hline E0486BL & - & - & - & - & 30.8 & 26.0 & - & - & - & & - & - & & & & & - & & & - & - & - & - & & - & - & - & $\begin{array}{l}\text { E0486-D1-BL- } \\
070404 . A S C\end{array}$ & $\begin{array}{l}\text { LL-Channel\# Apr } \\
\text { 15-16-56.txt }\end{array}$ & \\
\hline E0487BL & - & - & - & - & 30.8 & 26.0 & - & - & - & - & - & - & - & - & - & 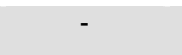 & - & - & - & - & - & - & - & - & - & - & - & E0487-D1-BL- & BL-Channel|lt Apr & \\
\hline E0487 & 8 & Clay & 54 & 0.8 & 30.8 & 26.0 & 3 & $4,5,6$ & -3 & 3.51 & 3.53 & 3.48 & - & - & $12 / 0.001 / 34 /$ & $12 / 0.001 / 34 / 1$ & /0.001/ & & & 14 & M & M & $\mathrm{N}$ & $\mathrm{M}$ & & $\mathrm{N}$ & & $87-\mathrm{D1}-$ & nel1 Apr 05, & ker \\
\hline
\end{tabular}




\begin{tabular}{|c|c|c|c|c|c|c|c|c|c|c|c|c|c|c|c|c|c|c|c|c|c|c|c|c|c|c|c|c|c|c|}
\hline \multirow[b]{2}{*}{$\begin{array}{l}\text { Exp. } \\
\text { No. }{ }^{(i)} \\
\end{array}$} & \multirow[b]{2}{*}{$\begin{array}{c}\text { PJM } \\
\text { Config } \\
\end{array}$} & \multicolumn{4}{|c|}{ Simulant } & & \multirow[b]{2}{*}{$\begin{array}{l}\text { No. } \\
\text { PJMS } \\
\text { PB(t) } \\
\end{array}$} & \multirow[b]{2}{*}{$\begin{array}{c}\text { OB } \\
\text { PJMs } \\
\end{array}$} & \multirow[b]{2}{*}{$\begin{array}{c}\mathrm{OB} \\
\text { Duration } \\
\text { (c) } \\
\end{array}$} & \multicolumn{5}{|c|}{ 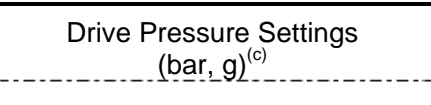 } & \multicolumn{5}{|c|}{ PJM OP Conditions (vacuum/delay/drive/vent time) } & \multirow[b]{2}{*}{$\begin{array}{c}\text { Target } \\
\text { Noz. Vel. } \\
(\mathrm{m} / \mathrm{s})^{(c)}\end{array}$} & \multicolumn{4}{|c|}{ Hydrophonone Elevevation } & \multirow[b]{2}{*}{$\begin{array}{c}\text { Sparger } \\
(\mathrm{Y} / \mathrm{N})\end{array}$} & \multirow[b]{2}{*}{$\begin{array}{l}\text { Video } \\
\text { (YIN) }\end{array}$} & \multirow[b]{2}{*}{ 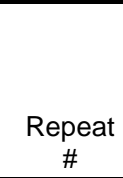 } & \multirow[b]{2}{*}{ DAS-1 Filename } & \multirow[b]{2}{*}{ DAS-2 Filename $\mathrm{e}^{(\mathrm{d})}$} & \multirow[b]{2}{*}{$\begin{array}{l}\text { DAS-4 (Video) } \\
\text { Filename }\end{array}$} \\
\hline & & Type & $\begin{array}{l}\text { Ht. ffm } \\
\text { Rim } \\
\text { (in) }\end{array}$ & H/D & $\begin{array}{l}T_{y s} \\
(\mathrm{~Pa})\end{array}$ & $\begin{array}{c}k \\
(\mathrm{CP})\end{array}$ & & & & $\begin{array}{c}\text { PJM } \\
4\end{array}$ & $\begin{array}{c}\text { PJM } \\
5\end{array}$ & $\begin{array}{c}\text { PJM } \\
6\end{array}$ & $\begin{array}{c}\text { PJM } \\
7\end{array}$ & $\begin{array}{c}\text { PJM } \\
8\end{array}$ & & PJM 5 & $P \mathrm{PJ}$ & JM 7 & PJM \& & & $\mathrm{H} 1$ & $\mathrm{H} 2$ & H3 & $\mathrm{H} 4$ & & & & & & \\
\hline E0488 & 8 & Clay & 54 & 0.8 & 30.8 & 26.0 & 3 & $4,5,6$ & -3 & 3.47 & 3.48 & 3.49 & & & $\begin{array}{l}110 \\
12 / 0.001 / 34 \\
110\end{array}$ & $\frac{110}{1 / 12 / 0.001 / 34 /}$ & $\begin{array}{l}34 / 110 \\
12 / 10.001 / 1 \\
34 / 1110\end{array}$ & & & 14 & M & M & M & M & $\mathrm{N}$ & $\mathrm{N}$ & 2 & $\begin{array}{l}\text { 070405.ASC } \\
\text { E0488-D1- } \\
\text { 070405.ASC }\end{array}$ & $\begin{array}{l}\text { 2007 10-25-05.txt } \\
\text { E0488-D2-Channel Apr 05, } \\
\text { 2007 10-29-13.txt }\end{array}$ & No video taken \\
\hline E0489 & 8 & Clay & 54 & 0.8 & 30.8 & 26.0 & 3 & $4,5,6$ & -3 & 3.46 & 3.51 & 3.49 & & & $\begin{array}{r}12 / 0.001 / 34 \mid \\
110\end{array}$ & $12 / 0.001 / 34 /$ & $\begin{array}{l}\text { / 12/0.001/ } \\
34 / 110\end{array}$ & & 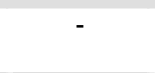 & 14 & $\mathrm{M}$ & M & M & M & $\mathrm{N}$ & $\mathrm{N}$ & 3 & $\begin{array}{l}\text { E0489-D1- } \\
\text { 070405.ASC }\end{array}$ & $\begin{array}{l}\text { E0489-D2-Channell Apr 05, } \\
2007 \text { 10-33-10.txt }\end{array}$ & No video taken \\
\hline E0490 & 8 & Clay & 54 & 0.8 & 30.8 & 26.0 & 4 & $4,5,6,7$ & -3 & 3.49 & 3.54 & 3.48 & 3.45 & & $\begin{array}{l}12 / 0.001 / 34 \\
110\end{array}$ & / 12/0.001/34/ & $\begin{array}{c}112 / 0.001 / 1 \\
34 / 110\end{array}$ & $\begin{array}{c}12 / 0.001 / \\
34 / 110\end{array}$ & & 14 & M & M & M & M & $\mathrm{N}$ & $\mathrm{N}$ & 1 & $\begin{array}{l}\text { E0490--DD- } \\
\text { 070405.ASC }\end{array}$ & $\begin{array}{l}\text { E0490-D2-Channell Apr 05, } \\
\text { 2007 10-47-30.txt }\end{array}$ & No video taken \\
\hline E0491 & 8 & Clay & 54 & 0.8 & 30.8 & 26.0 & 4 & $4,5,6,7$ & -3 & 3.49 & 3.45 & 3.48 & 3.52 & - & $\begin{array}{l}12 / 0.001 / 34 \\
110\end{array}$ & / $12 / 0.001 / 34 /$ & $\begin{array}{c}12 / 0.001 / \\
34 / 110\end{array}$ & $\begin{array}{c}12 / 0.001 / \\
34 / 110\end{array}$ & - & 14 & M & M & M & M & $\mathrm{N}$ & $\mathrm{N}$ & 2 & $\begin{array}{l}\text { E0491-D1- } \\
\text { 0070450.ASC }\end{array}$ & $\begin{array}{l}\text { E0491-D2-Channel1 Apr 05, } \\
\text { 2007 10-53-19.txt }\end{array}$ & No video taken \\
\hline E0492 & 8 & Clay & 54 & 0.8 & 30.8 & 26.0 & 4 & $4,5,6,7$ & $\sim 3$ & 3.49 & 3.45 & 3.48 & 3.54 & - & $\begin{array}{r}12 / 0.001 / 34 \mid \\
110\end{array}$ & $1 / 12 / 0.001 / 34 /$ & $\begin{array}{l}\text { / 12/0.001/ } \\
34 / 110\end{array}$ & $\begin{array}{c}12 / 0.001 / \\
34 / 110\end{array}$ & - & 14 & M & M & M & M & $\mathrm{N}$ & $\mathrm{N}$ & 3 & $\begin{array}{l}\text { E0492-D1- } \\
\text { 070405.ASC }\end{array}$ & $\begin{array}{l}\text { E0492-D2-Channell Apr 05, } \\
2007 \text { 10-57-38.txt }\end{array}$ & No video taken \\
\hline E0493 & 8 & Clay & 54 & 0.8 & 30.8 & 26.0 & 4 & $4,5,6,7$ & $\sim 3$ & 3.49 & 3.52 & 3.48 & 3.45 & - & $\begin{array}{l}12 / 0.001 / 34 \mid \\
110\end{array}$ & / 12/0.001/34/ & $\begin{array}{c}12 / 0.001 / \\
34 / 110\end{array}$ & $\begin{array}{c}12 / 0.001 / \\
34 / 110\end{array}$ & - & 14 & $\mathrm{M}$ & M & M & M & $\mathrm{N}$ & $\mathrm{N}$ & 4 & $\begin{array}{l}\text { E0493-D1- } \\
\text { 0070405.ASC }\end{array}$ & $\begin{array}{l}\text { E0493-D2-Channel1 Apr 05, } \\
\text { 2007 11-03-37.txt }\end{array}$ & No video taken \\
\hline E0494 & 8 & Clay & 54 & 0.8 & 30.8 & 26.0 & 1 & 8 & $\sim 4$ & - & - & - & - & 3.50 & & - & - & 2 & $\begin{array}{c}12 / 0.001 / \\
38 / 110\end{array}$ & 14 & M & M & M & M & $\mathrm{N}$ & $\mathrm{N}$ & 1 & $\begin{array}{l}\text { E0494-D1- } \\
\text { 070405.ASC }\end{array}$ & $\begin{array}{l}\text { E0494-D2-Channel1 Apr 05, } \\
\text { 2007 11-19-24.txt }\end{array}$ & No video taken \\
\hline E0495 & 8 & Clay & 54 & 0.8 & 30.8 & 26.0 & 1 & 8 & $\sim 4$ & & - & - & & 3.50 & & - & - & - & $\begin{array}{c}12 / 0.001 / \\
38110\end{array}$ & 14 & M & M & M & M & $\mathrm{N}$ & $\mathrm{N}$ & 2 & $\begin{array}{l}\text { E0495-D1- } \\
\text { 070005 ASC }\end{array}$ & $\begin{array}{l}\text { E0495-D2-Channel1 Apr 05, } \\
\text { 2007 11-26-19 }\end{array}$ & No video taken \\
\hline E0496 & 8 & Clay & 54 & 0.8 & 30.8 & 26.0 & 1 & 8 & $\sim 4$ & & & - & ( & 3.51 & & & - & & $\begin{array}{l}12 / 10.001 / \\
38 / 110\end{array}$ & 14 & M & M & M & M & $\mathrm{N}$ & $\mathrm{N}$ & 3 & $\begin{array}{l}\text { E0496-D1- } \\
\text { 070405.ASC }\end{array}$ & $\begin{array}{l}\text { E0496-D2-Channel1 Apr 05, } \\
\text { 2007 11-30-11.txt }\end{array}$ & No video taken \\
\hline E0497 & 8 & Clay & 54 & 0.8 & 30.8 & 26.0 & 2 & 4,5 & -12 & 3.50 & 3.53 & 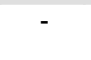 & & & $\begin{array}{l}12 / 0.001 / 43 \mid \\
110\end{array}$ & $3 / 12 / 0.001 / 43 /$ & ' & 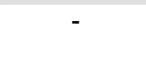 & & 14 & $\mathrm{M}$ & M & M & M & $\mathrm{N}$ & $\mathrm{N}$ & 1 & $\begin{array}{l}\text { E0497-D1- } \\
\text { 070005 ASC }\end{array}$ & $\begin{array}{l}\text { E0497-D2-Channel1 Apr 05, } \\
\text { 20007 14-07.05 }\end{array}$ & No video taken \\
\hline E0498 & 8 & Clay & 54 & 0.8 & 30.8 & 26.0 & 2 & 4,5 & -12 & 3.51 & 3.52 & - & - & & $\begin{array}{r}12 / 0.001 / 43 / \\
110\end{array}$ & $3 / 12 / 0.001 / 43 /$ & I & & & 14 & M & M & M & M & $\mathrm{N}$ & $\mathrm{N}$ & 2 & $\begin{array}{l}\text { E0498-D1- } \\
\text { 070405.ASC }\end{array}$ & $\begin{array}{l}\text { E0498-D2-Channel1 Ap 05, } \\
\text { 200714-10-13.txt }\end{array}$ & No video taken \\
\hline E0499 & 8 & Clay & 54 & 0.8 & 30.8 & 26.0 & 2 & 4,5 & -12 & 3.49 & 3.51 & - & - & - & $12 / 0.001 / 43$ & $3 / 12 / 0.001 / 431$ & - & - & - & 14 & $\mathrm{M}$ & M & M & M & $\mathrm{N}$ & $\mathrm{N}$ & 3 & $\begin{array}{l}\text { EO499-D1- } \\
\text { 07740 ASC }\end{array}$ & $\begin{array}{l}\text { E0499-D2-Channel1 Apr 05, } \\
\text { 20007 14-16-10 }\end{array}$ & No video taken \\
\hline E0500 & 8 & Clay & 54 & 0.8 & 30.8 & 26.0 & 2 & 4,5 & -3 & 3.49 & 3.45 & - & - & - & $\begin{array}{l}12 / 0.001 / 34 \\
110\end{array}$ & $1 / 12 / 0.001 / 34 /$ & - & - & - & 14 & M & M & M & M & $\mathrm{Y}$ & $\mathrm{N}$ & 1 & $\begin{array}{l}\text { E0500-D1- } \\
\text { 070405.ASC }\end{array}$ & $\begin{array}{l}\text { E0500-D2-Channel1 Apr 05, } \\
\text { 2007 14-25-15.txt }\end{array}$ & No video taken \\
\hline E0501 & 8 & Clay & 54 & 0.8 & 30.8 & 26.0 & 2 & 4,5 & $\sim 3$ & 3.48 & 3.49 & - & - & - & $12 / 0.001 / 34$ & H/ 12/0.001/34/ & - & - & - & 14 & M & M & M & M & Y & $\mathrm{N}$ & 2 & $\begin{array}{l}\text { E0501-D1- } \\
\text { E01- }\end{array}$ & E0501-D2-Channeli Ap Ap 05, & No video taken \\
\hline E0502 & 8 & Clay & 54 & 0.8 & 30.8 & 26.0 & 2 & 4,5 & -3 & 3.50 & 3.48 & - & - & - & $\begin{array}{l}12 / 0.001 / 34 / \\
110\end{array}$ & / 12/0.001/34/ & - & - & - & 14 & $\mathrm{M}$ & M & M & M & $\mathrm{Y}$ & $\mathrm{N}$ & 3 & $\begin{array}{l}\text { E0502-D1- } \\
\text { 070405.ASC }\end{array}$ & $\begin{array}{l}\text { E0502-D2-Channel1 Apr 05, } \\
\text { 2007 14-40-12.txt }\end{array}$ & No video taken \\
\hline E0503 & 8 & Clay & 54 & 0.8 & 30.8 & 26.0 & 1 & 5 & -4.5 & - & 4.04 & - & - & - & & $12 / 0.001 / 34 /$ & - & - & - & 15 & M & M & M & M & $\mathrm{N}$ & $\mathrm{N}$ & 1 & $\begin{array}{l}\text { E0503-D1- } \\
\text { 0070400.ASC }\end{array}$ & E0503-D2-Channel1 Apr 05, & No video taken \\
\hline E0504 & 8 & Clay & 54 & 0.8 & 30.8 & 26.0 & 1 & 5 & -4.5 & & 4.05 & 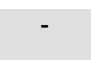 & - & & & $12 / 0.001 / 341$ & - & & - & 15 & M & M & M & M & $\mathrm{N}$ & N & 2 & $\begin{array}{l}\text { E0504-D1- } \\
07045 \text { ASC }\end{array}$ & $\begin{array}{l}\text { E0504-D2-Channel1 Apr 05, } \\
2007 \text { 15-01-34 tx }\end{array}$ & No video taken \\
\hline E0505 & 8 & Clay & 54 & 0.8 & 30.8 & 26.0 & 1 & 5 & -4.5 & & 4.05 & - & - & - & & $\begin{array}{l}12 / 0.001 / 34 / \\
110\end{array}$ & 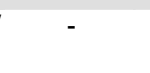 & - & - & 15 & M & M & M & M & $\mathrm{N}$ & $\mathrm{N}$ & 3 & $\begin{array}{l}\text { E0505-D1- } \\
\text { 070405.ASC }\end{array}$ & $\begin{array}{l}\text { E0505-D2-Channell Apr 05, } \\
2007 \text { 15-05-43.txt }\end{array}$ & No video taken \\
\hline E0506 & 8 & Clay & 54 & 0.8 & 30.8 & 26.0 & 2 & 4,5 & -4.5 & 4.01 & 4.04 & - & - & - & $\begin{array}{c}12 / 0.001 / 34 / \\
110\end{array}$ & $\begin{array}{l}12 / 0.001 / 34 / \\
110\end{array}$ & 1 & - & - & 15 & M & M & M & M & $\mathrm{N}$ & $\mathrm{N}$ & 1 & $\begin{array}{l}\text { E0506-D1- } \\
\text { 0070405.ASC }\end{array}$ & $\begin{array}{l}\text { E0506-D2-Channel1 Apr 05, } \\
\text { 2007 15-12-23.txt }\end{array}$ & No video taken \\
\hline E0507 & 8 & Clay & 54 & 0.8 & 30.8 & 26.0 & 2 & 4,5 & -4.5 & 4.01 & 4.00 & - & - & - & $\begin{array}{l}12 / 0.001 / 34 / \\
110\end{array}$ & / 12/0.001/34/ & - & - & - & 15 & M & M & M & M & $\mathrm{N}$ & $\mathrm{N}$ & 2 & $\begin{array}{l}\text { E0507-D1- } \\
\text { 070405.ASC }\end{array}$ & $\begin{array}{l}\text { E0507-D2-Ch } \\
200715-\end{array}$ & No video taken \\
\hline E0508 & 8 & Clay & 54 & 0.8 & 30.8 & 26.0 & 2 & 4,5 & -4.5 & 4.00 & 4.02 & - & - & - & $\begin{array}{l}12 / 0.001 / 34 / \\
110\end{array}$ & $\mid 12 / 0.001 / 34 /$ & - & - & - & 15 & M & M & M & M & $\mathrm{N}$ & $\mathrm{N}$ & 3 & $\begin{array}{l}\text { E0508-D1- } \\
\text { 070405.ASC }\end{array}$ & $\begin{array}{l}\text { E0508-D2-Channell Apr 05, } \\
\text { 2007 15-19-37.txt }\end{array}$ & No video taken \\
\hline E0509 & 8 & Clay & 54 & 0.8 & 30.8 & 26.0 & 1 & 5 & -4.5 & - & 2.52 & - & - & - & 10 & $\begin{array}{l}12 / 0.001 / 41 / \\
110\end{array}$ & - & - & - & 12 & M & M & M & M & $\mathrm{N}$ & $\mathrm{N}$ & 1 & $\begin{array}{l}\text { E0509-D1- } \\
\text { 070405.ASC }\end{array}$ & $\begin{aligned} E 0509-D 2 \\
200\end{aligned}$ & No video taken \\
\hline E0510 & 8 & Clay & 54 & 0.8 & 30.8 & 26.0 & 1 & 5 & -4 & - & 2.54 & - & - & - & - & $\begin{array}{l}12 / 0.001 / 41 / \\
110\end{array}$ & - & - & - & 12 & M & M & M & M & $\mathrm{N}$ & $\mathrm{N}$ & 2 & $\begin{array}{l}\text { E05 } \\
0004-204\end{array}$ & $\begin{array}{l}\text { E0510-D2-Channel1 Apr 05, } \\
\text { 2007 15-39-21 trt }\end{array}$ & No video taken \\
\hline E0511 & 8 & Clay & 54 & 0.8 & 30.8 & 26.0 & 1 & 5 & -4 & & 2.55 & - & & & & $12 / 0.001 / 41 /$ & 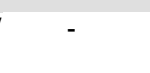 & - & & 12 & $\mathrm{M}$ & M & M & M & N & N & 3 & $\begin{array}{l}\text { EO } \\
070\end{array}$ & $\begin{array}{r}E 0511-D \\
200\end{array}$ & No video taken \\
\hline E0512 & 8 & Clay & 54 & 0.8 & 30.8 & 26.0 & 2 & 4,5 & -4 & 2.48 & 2.53 & & & & $\begin{array}{l}12 / 0.001 / 41 / \\
110\end{array}$ & / 12/0.001/41/ & & & & 12 & M & M & M & M & $\mathrm{N}$ & N & 1 & $\begin{aligned} E 05 \\
0702\end{aligned}$ & $\begin{array}{l}\text { E0512-D2-Chan } \\
200715-56\end{array}$ & No video taken \\
\hline E0513 & 8 & Clay & 54 & 0.8 & 30.8 & 26.0 & 2 & 4,5 & -4 & 2.54 & 2.48 & & & & $12 / 1.001 / 41 /$ & $\begin{array}{l}/ 12 / 0.001 / 41 / \\
110\end{array}$ & - & - & & 12 & $\mathrm{M}$ & M & M & M & $\mathrm{N}$ & $\mathrm{N}$ & 2 & $\begin{aligned} E 05 \\
0702\end{aligned}$ & $\begin{array}{l}\text { E0513-D2-Ch } \\
200715\end{array}$ & No video taken \\
\hline E0514 & 8 & Clay & 54 & 0.8 & 30.8 & 26.0 & 2 & 4,5 & $\sim 4$ & 2.46 & 2.46 & - & - & - & $\begin{array}{l}12 / 0.001 / 41 / \\
110\end{array}$ & $\begin{array}{l}\text { / 12/0.001/41/ } \\
110\end{array}$ & 1 & - & & 12 & M & M & M & M & $\mathrm{N}$ & $\mathrm{N}$ & 3 & $\begin{array}{l}\text { E0514-D1- } \\
\text { 070405.ASC }\end{array}$ & $\begin{array}{l}\text { E0514-D2-Channel1 Apr 05, } \\
2007 \text { 16-06-45.txt }\end{array}$ & No video taken \\
\hline E0514BL & - & & - & - & 30.8 & 26.0 & & & - & - & - & & - & - & & & & - & - & & - & - & - & - & & - & - & $\begin{array}{l}\text { E0514-D1-BL- } \\
\text { 070405.ASC }\end{array}$ & $\begin{array}{r}E 0514-I \\
5,2\end{array}$ & - \\
\hline E0515BL & - & - & - & - & 30.8 & 26.0 & - & - & - & - & - & - & - & - & - & - & - & - & - & - & - & - & - & - & - & - & - & E0515-D1-BL- & E0515-D & - \\
\hline E0515 & 8 & Clay & 54.5 & 0.8 & 30.8 & 26.0 & 1 & 5 & -3 & - & 1.28 & - & - & - & - & $12 / 0.001 / 60 /$ & - & - & - & 8 & M & M & M & M & $\mathrm{N}$ & N & 1 & $\begin{array}{l}\text { E05 } \\
0704\end{array}$ & $\begin{array}{l}\mathrm{E} 0515-\mathrm{D} 2 \\
200\end{array}$ & No video taken \\
\hline E0516 & 8 & Clay & 54.5 & 0.8 & 30.8 & 26.0 & 1 & 5 & -3 & & 1.26 & - & & & & $\begin{array}{l}12 / 0.001 / 60 / \\
110\end{array}$ & - & & & 8 & $\mathrm{M}$ & M & M & M & $\mathrm{N}$ & $\mathrm{N}$ & 2 & $\begin{array}{l}\text { E0516--11- } \\
\text { 070406.ASC }\end{array}$ & $\begin{array}{l}\text { E0516-D2-Chann } \\
200709-56 \text { - }\end{array}$ & No video taken \\
\hline E0517 & 8 & Clay & 54.5 & 0.8 & 30.8 & 26.0 & 1 & 5 & -3 & & 1.27 & & & & & $12 / 0.001 / 62 /$ & - & & & 8 & M & M & M & M & $\mathrm{N}$ & $\mathrm{N}$ & 1 & $\begin{array}{l}\text { E0517-D1- } \\
\text { 070406ASC }\end{array}$ & $\begin{array}{l}\text { E0517-D2 } \\
2007\end{array}$ & No video taken \\
\hline E0518 & 8 & Clay & 54.5 & 0.8 & 30.8 & 26.0 & 1 & 5 & -3 & & 1.28 & & & & & $\begin{array}{l}12 / 0.001 / 621 \\
110\end{array}$ & & & & 8 & M & M & M & M & $\mathrm{N}$ & $\mathrm{N}$ & 2 & $\begin{array}{l}\text { E0518-D1- } \\
\text { 070406.ASC }\end{array}$ & $\begin{array}{l}\text { E0518-D2-Channel1 Apr 06, } \\
\text { 2007 10-06-05.txt }\end{array}$ & No video taken \\
\hline
\end{tabular}


Table A.1. Master Run Log, 8-PJM Configuration

\begin{tabular}{|c|c|c|c|c|c|c|c|c|c|c|c|c|c|c|c|c|c|c|c|c|c|c|c|c|c|c|c|c|c|c|}
\hline \multirow[b]{2}{*}{$\begin{array}{l}\text { Exp. } \\
\text { Noo. }\end{array}$} & \multirow[b]{2}{*}{$\begin{array}{c}\text { PJM } \\
\text { Config }\end{array}$} & \multicolumn{4}{|c|}{ Simulant } & \multirow{2}{*}{\multicolumn{2}{|c|}{ 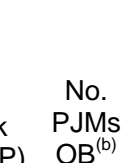 }} & \multirow[b]{2}{*}{$\begin{array}{l}\text { OB } \\
\text { PJMs }\end{array}$} & \multirow[b]{2}{*}{$\underset{\text { Duration }}{\mathrm{OB}}$} & \multicolumn{5}{|c|}{$\begin{array}{l}\text { Drive Pressure Settings } \\
\text { (bar,gg }{ }^{(0)}\end{array}$} & \multicolumn{5}{|c|}{$\begin{array}{l}\text { PJM OP Conditions (vacuum/delay/drive/vent time) } \\
\text { (sec) }\end{array}$} & \multirow[b]{2}{*}{$\begin{array}{c}\text { Target } \\
\text { Noz Vel. } \\
(\mathrm{m} / \mathrm{s})^{(\mathrm{c})}\end{array}$} & \multicolumn{4}{|c|}{ Hydrophone Elevation } & \multirow[b]{2}{*}{$\begin{array}{l}\text { Sparger } \\
(\mathrm{Y} / \mathrm{N})\end{array}$} & \multirow[b]{2}{*}{$\begin{array}{l}\text { Video } \\
\text { (Y/N) }\end{array}$} & \multirow[b]{2}{*}{$\begin{array}{c}\text { Repeat } \\
\#\end{array}$} & \multirow[b]{2}{*}{ DAS-1 Filename } & \multirow[b]{2}{*}{ DAS-2 Filename $\mathrm{e}^{(\mathrm{d})}$} & \multirow[b]{2}{*}{$\begin{array}{l}\text { DAS-4 (Video) } \\
\text { Filename }\end{array}$} \\
\hline & & Type & $\begin{array}{l}\text { tht.fm } \\
\text { Rim } \\
\text { (in) }\end{array}$ & H/D & $\begin{array}{c}T_{y s} \\
(P a)\end{array}$ & $\begin{array}{c}k \\
(\mathrm{CP})\end{array}$ & & & & $\begin{array}{c}\text { PJM } \\
4\end{array}$ & $\begin{array}{c}\text { PJM } \\
5\end{array}$ & $\begin{array}{c}\text { PJM } \\
6\end{array}$ & $\underset{7}{\mathrm{PJM}}$ & $\begin{array}{c}\text { PJM } \\
8\end{array}$ & PJM 4 & PJM 5 & PJM 6 & PJM 7 & PJM 8 & & $\mathrm{H} 1$ & $\mathrm{H} 2$ & нз & $\mathrm{H} 4$ & & & & & & \\
\hline $\begin{array}{l}\text { E0519 } \\
\end{array}$ & & Clay & 54.5 & 0.8 & 30.8 & & 1 & 5 & $\sim 3$ & 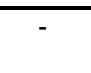 & 1.28 & & - & - & 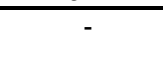 & $\begin{array}{c}12 / 0.001 / 62 / \\
110\end{array}$ & . & - & - & & $\mathrm{M}$ & $M$ & M & M & $\mathrm{N}$ & $\mathrm{N}$ & 3 & $\begin{array}{l}\text { E0519-D1- } \\
\text { 070406.ASC }\end{array}$ & $\begin{array}{l}\text { E0519-D2-Channel1 Apr 06, } \\
\text { 2007 10-10-32.txt }\end{array}$ & No video taken \\
\hline E0520 & 8 & Clay & 54.5 & 0.8 & 30.8 & 26.0 & 2 & 4,5 & -3 & 1.26 & 1.28 & 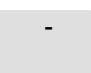 & - & - & $\begin{array}{l}12 / 0.001 / 62 / \\
110\end{array}$ & $\begin{array}{c}|12 / 0.001 / 62| \\
110\end{array}$ & - & - & - & 8 & M & M & M & M & $\mathrm{N}$ & $\mathrm{N}$ & 1 & $\begin{array}{l}\text { E0520-D1- } \\
\text { 070406.ASC }\end{array}$ & $\begin{array}{l}\text { E0520-D2-Channell Apr 06, } \\
\text { 2007 10-19-50.txt }\end{array}$ & No video taken \\
\hline E0521 & 8 & Clay & 54.5 & 0.8 & 30.8 & 26.0 & 2 & 4,5 & -3 & 1.28 & 1.28 & & - & - & $12 / 0.001 / 621$ & $|12 / 0.001 / 62|$ & - & - & - & 8 & $\mathrm{M}$ & M & M & M & $\mathrm{N}$ & $\mathrm{N}$ & 2 & $\begin{array}{l}\text { E0521-D1- } \\
\text { 070406.ASC }\end{array}$ & $\begin{array}{l}\text { E0521-D2-Channel1 Apr 06, } \\
\text { 2007 10-26-29.txt }\end{array}$ & No video taken \\
\hline E0522 & 8 & Clay & 54.5 & 0.8 & 30.8 & 26.0 & 2 & 4,5 & -3 & 1.29 & 1.28 & & - & - & $\begin{array}{c}12 / 0.001 / 62 / \\
110\end{array}$ & 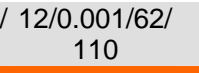 & & & & 8 & M & M & M & M & $\mathrm{N}$ & $\mathrm{N}$ & 3 & $\begin{array}{l}\text { E0522-D1- } \\
\text { 070406.ASC }\end{array}$ & $\begin{array}{l}\text { E0522-D2-Channel1 Apr 06, } \\
2007 \text { 10-30-58.txt }\end{array}$ & No video taken \\
\hline $\begin{array}{l}\text { High clay } \\
\text { E0523BL }\end{array}$ & el,, & dropho & one leve & $=\mathrm{H}$ & 30.8 & & - & - & - & & - & & - & - & & 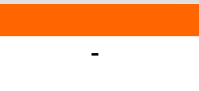 & - & - & - & - & - & - & - & & - & - & t & $\begin{array}{l}\text { E0523-D1-BL- } \\
\text { 0040406AC }\end{array}$ & 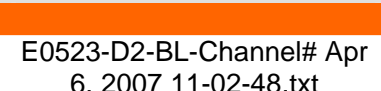 & \\
\hline E0524 & 8 & Clay & 54.5 & 0.8 & 30.8 & 26.0 & 1 & 5 & -3 & - & 1.28 & - & - & - & - & $12 / 0.001 / 621$ & - & - & - & 8 & $\mathrm{H}$ & $\mathrm{H}$ & $\mathrm{H}$ & $\mathrm{H}$ & $\mathrm{N}$ & $\mathrm{N}$ & 2 & $\begin{array}{l}\text { E0524-D1- } \\
\text { 070406.ASC }\end{array}$ & $\begin{array}{l}\text { E0524-D2-Channel1 Apr 06, } \\
\text { 2007 11-1-16-.txt }\end{array}$ & No video taken \\
\hline E0525 & 8 & Clay & 54.5 & 0.8 & 30.8 & 26.0 & 1 & 5 & -3 & - & 1.27 & - & - & - & - & $\begin{array}{l}12 / 0.001 / 62 / \\
110\end{array}$ & - & - & - & 8 & $\mathrm{H}$ & $\mathrm{H}$ & $H$ & $\mathrm{H}$ & $\mathrm{N}$ & $\mathrm{N}$ & 3 & $\begin{array}{l}\text { E0525-D1- } \\
\text { 070406.ASC }\end{array}$ & $\begin{array}{l}\text { E0525-D2-Channell Apr 06, } \\
\text { 2007 11-20-43.txt }\end{array}$ & No video taken \\
\hline E0526 & 8 & Clay & 54.5 & 0.8 & 30.8 & 26.0 & 2 & 4,5 & -3.5 & 1.30 & 1.27 & & - & - & $\begin{array}{c}12 / 0.001 / 62 / \\
110\end{array}$ & $\begin{array}{l}\text { / 12/0.001/62/ } \\
110\end{array}$ & - & - & - & 8 & $\mathrm{H}$ & $\mathrm{H}$ & $\mathrm{H}$ & $\mathrm{H}$ & $\mathrm{N}$ & $\mathrm{N}$ & 1 & $\begin{array}{l}\text { E0526-D1- } \\
\text { 070406.ASC }\end{array}$ & $\begin{array}{l}\text { E0526-D2-Channel1 Apr 06, } \\
\text { 2007 11-25-52.txt }\end{array}$ & No video taken \\
\hline E0527 & 8 & Clay & 54.5 & 0.8 & 30.8 & 26.0 & 2 & 4,5 & -3.5 & 1.27 & 1.27 & & - & - & $\begin{array}{c}12 / 0.001 / 62 / \\
110\end{array}$ & $\mid \begin{array}{l}|12 / 0.001 / 62| \\
110\end{array}$ & & - & - & 8 & $\mathrm{H}$ & $\mathrm{H}$ & $\mathrm{H}$ & $\mathrm{H}$ & $\mathrm{N}$ & $\mathrm{N}$ & 2 & $\begin{array}{l}\text { E0527-D1- } \\
\text { 070406.ASC }\end{array}$ & $\begin{array}{l}\text { E0527-D2-Channel1 Apr 06, } \\
\text { 2007 11-32-03.txt }\end{array}$ & No video taken \\
\hline E0528 & 8 & Clay & 54.5 & 0.8 & 30.8 & 26.0 & 2 & 4,5 & -3.5 & 1.27 & 1.27 & - & - & - & $\begin{array}{c}12 / 0.001 / 621 \\
110\end{array}$ & $\begin{array}{c}\text { / 12/0.001/62/ } \\
110\end{array}$ & - & - & - & 8 & $\mathrm{H}$ & $\mathrm{H}$ & $\mathrm{H}$ & $\mathrm{H}$ & $\mathrm{N}$ & $\mathrm{N}$ & 3 & $\begin{array}{l}\text { E0528-D1- } \\
\text { 070406.ASC }\end{array}$ & $\begin{array}{l}\text { E0528-D2-Channel1 Apr 06, } \\
2007 \text { 11-36-46.txt }\end{array}$ & No video taken \\
\hline E0529 & 8 & Clay & 54.5 & 0.8 & 30.8 & 26.0 & 1 & 5 & 4 & - & 2.57 & - & - & - & - & $\begin{array}{l}12 / 0.001 / 41 / \\
110\end{array}$ & - & - & - & 12 & $\mathrm{H}$ & $\mathrm{H}$ & $\mathrm{H}$ & $\mathrm{H}$ & $\mathrm{N}$ & $\mathrm{N}$ & 1 & $\begin{array}{l}\text { E0529-D1- } \\
\text { 070406.ASC }\end{array}$ & $\begin{array}{l}\text { E0529-D2-Channel1 A Apr 06, } \\
\text { 2007 13-00-02.txt }\end{array}$ & No video taken \\
\hline E0530 & 8 & Clay & 54.5 & 0.8 & 30.8 & 26.0 & 1 & 5 & 4 & - & 2.53 & - & - & - & - & $\begin{array}{l}12 / 0.001 / 41 / \\
110\end{array}$ & - & - & - & 12 & $\mathrm{H}$ & $\mathrm{H}$ & $\mathrm{H}$ & $\mathrm{H}$ & $\mathrm{N}$ & $\mathrm{N}$ & 1 & $\begin{array}{l}\text { E0530-D1- } \\
\text { 070406.ASC }\end{array}$ & $\begin{array}{l}\text { E0530-D2-Channel1 Apr 06, } \\
2007 \text { 13-03-43.txt }\end{array}$ & No video taken \\
\hline E0531 & 8 & Clay & 54.5 & 0.8 & 30.8 & 26.0 & 1 & 5 & 4 & - & 2.53 & - & - & - & - & $\begin{array}{l}12 / 0.001 / 41 / \\
110\end{array}$ & - & - & - & 12 & $\mathrm{H}$ & $\mathrm{H}$ & $\mathrm{H}$ & $\mathrm{H}$ & $\mathrm{N}$ & $\mathrm{N}$ & 2 & $\begin{array}{l}\text { E0531-D1- } \\
\text { 070406.ASC }\end{array}$ & $\begin{array}{l}\text { E0531-D2-Channel1 A Apr 06, } \\
\text { 2007 13-07-44.txt }\end{array}$ & No video taken \\
\hline E0533 & 8 & Clay & 54.5 & 0.8 & 30.8 & 26.0 & 2 & 4,5 & 3 & 2.46 & 2.54 & & & - & $\begin{array}{c}12 / 0.001 / 41 / \\
110\end{array}$ & / 12/0.001/41/ & & & & 12 & $\mathrm{H}$ & $\mathrm{H}$ & $\mathrm{H}$ & $\mathrm{H}$ & $\mathrm{N}$ & $\mathrm{N}$ & 1 & $\begin{array}{l}\text { E0533-D1- } \\
\text { 070406.ASC }\end{array}$ & $\begin{array}{l}\text { E0533-D2-Channel1 Apr 06, } \\
\text { 2007 13-21-54.txt }\end{array}$ & No video taken \\
\hline E0534 & 8 & Clay & 54.5 & 0.8 & 30.8 & 26.0 & 2 & 4,5 & 3.5 & 2.51 & 2.51 & & - & - & $\begin{array}{c}12 / 0.001 / 41 / \\
110\end{array}$ & $\begin{array}{l}\text { / 12/0.001/41/ } \\
110\end{array}$ & - & - & & 12 & $\mathrm{H}$ & $\mathrm{H}$ & $\mathrm{H}$ & $\mathrm{H}$ & $\mathrm{N}$ & $\mathrm{N}$ & 2 & $\begin{array}{l}\text { E0534-D1- } \\
\text { 070406.ASC }\end{array}$ & $\begin{array}{l}\text { E0534-D2-Channel1 Apr 06, } \\
\text { 2007 13-27-09.txt }\end{array}$ & No video taken \\
\hline E0535 & 8 & Clay & 54.5 & 0.8 & 30.8 & 26.0 & 2 & 4,5 & 3 & 2.51 & 2.54 & - & - & - & $\begin{array}{c}12 / 0.001 / 41 / \\
110\end{array}$ & $\begin{array}{l}\text { / 12/0.001/41/ } \\
110\end{array}$ & - & - & - & 12 & $\mathrm{H}$ & $\mathrm{H}$ & $\mathrm{H}$ & $\mathrm{H}$ & $\mathrm{N}$ & $\mathrm{N}$ & 3 & $\begin{array}{l}\text { E0535-D1- } \\
\text { 070406.ASC }\end{array}$ & $\begin{array}{c}\text { E0535-D2-Channel1 Apr 06, } \\
\text { 2007 13-31-33.txt }\end{array}$ & No video taken \\
\hline E0535BL & - & - & - & - & 30.8 & 26.0 & - & - & - & - & - & - & - & - & - & $\begin{array}{ll}20 \\
-\end{array}$ & - & - & - & - & - & - & - & - & - & - & - & $\begin{array}{l}\text { E0535-D1-BL- } \\
070406 . A S C\end{array}$ & $\begin{array}{l}\text { E0535-D2-BL-Channel\# Apr } \\
6,2007 \text { 13-44-20.txt }\end{array}$ & - \\
\hline E0536BL & - & - & - & - & 30.6 & 26.2 & - & - & - & - & - & - & - & - & - & - & - & - & - & - & - & - & - & - & - & - & - & $\begin{array}{l}\text { E0536-D1-BL- } \\
070410 \text { ASC }\end{array}$ & $\begin{array}{l}\text { E0536-D2-BL-Channel\# Apr } \\
10 \text { 2007 13-42-40.txt }\end{array}$ & - \\
\hline E0536 & 8 & Clay & 53.4 & 0.8 & 30.6 & 26.2 & 1 & 8 & $>3$ & - & - & & - & 3.50 & - & - & - & - & $\begin{array}{c}12 / 0.001 / \\
38 / 110\end{array}$ & 14 & H & $\mathrm{H}$ & $\mathrm{H}$ & $\mathrm{H}$ & $\mathrm{N}$ & $\mathrm{N}$ & 1 & $\begin{array}{l}\text { E0536-D1- } \\
\text { 070410.ASC }\end{array}$ & $\begin{array}{l}\text { E0536-D2-Channell Apr 10, } \\
\text { 2007 13-50-49.txt }\end{array}$ & No video taken \\
\hline E0537 & 8 & Clay & 53.4 & 0.8 & 30.6 & 26.2 & 1 & 8 & $>3$ & - & - & & - & 3.50 & ( & - & - & - & $\begin{array}{c}12 / 0.001 / \\
38 / 110\end{array}$ & 14 & $\mathrm{H}$ & $\mathrm{H}$ & $\mathrm{H}$ & $\mathrm{H}$ & $\mathrm{N}$ & $\mathrm{N}$ & 2 & $\begin{array}{l}\text { E0537-D1- } \\
\text { 070410.ASC }\end{array}$ & $\begin{array}{l}\text { E0537-D2-Channel1 Apr 10, } \\
2007 \text { 13-54-24.txt }\end{array}$ & No video taken \\
\hline E0538 & 8 & Clay & 53.4 & 0.8 & 30.6 & 26.2 & 1 & 8 & $>3$ & - & - & & & 3.50 & & - & - & - & $\begin{array}{c}12 / 0.001 / \\
38 / 110\end{array}$ & 14 & $\mathrm{H}$ & $\mathrm{H}$ & $\mathrm{H}$ & $\mathrm{H}$ & $\mathrm{N}$ & $\mathrm{N}$ & 3 & $\begin{array}{l}\text { E0538-D1- } \\
\text { 070410.ASC }\end{array}$ & $\begin{array}{l}\text { E0538-D2-Channel1 Apr 10, } \\
\text { 2007 13-59-17.txt }\end{array}$ & No video taken \\
\hline E0539 & 8 & Clay & 53.4 & 0.8 & 30.6 & 26.2 & 1 & 5 & $>3$ & - & 3.55 & & - & - & - & $\begin{array}{l}12 / 0.001 / 34 / \\
110\end{array}$ & & - & & 14 & $\mathrm{H}$ & $\mathrm{H}$ & $\mathrm{H}$ & $\mathrm{H}$ & $\mathrm{N}$ & $\mathrm{N}$ & 1 & $\begin{array}{l}\text { E0539-D1- } \\
\text { 070410.ASC }\end{array}$ & $\begin{array}{l}\text { E0539-D2-Channel1 Apr 10, } \\
2007 \text { 14-07-18.txt }\end{array}$ & No video taken \\
\hline E0540 & 8 & Clay & 53.4 & 0.8 & 30.6 & 26.2 & 1 & 5 & -3 & - & 3.54 & - & - & - & - & $\begin{array}{c}12 / 0.001 / 34 / \\
110\end{array}$ & - & - & - & 14 & $\mathrm{H}$ & $\mathrm{H}$ & $\mathrm{H}$ & $\mathrm{H}$ & $\mathrm{N}$ & N & 2 & $\begin{array}{l}\text { E0540-D1- } \\
\text { 070410.ASC }\end{array}$ & $\begin{array}{l}\text { E0540-D2-Channell Apr 10, } \\
2007 \text { 14-10-29.txt }\end{array}$ & No video taken \\
\hline E0541 & 8 & Clay & 53.4 & 0.8 & 30.6 & 26.2 & 1 & 5 & $>3$ & - & 3.52 & - & - & - & - & $\begin{array}{c}12 / 0.001 / 34 / \\
110\end{array}$ & - & - & - & 14 & $\mathrm{H}$ & $\mathrm{H}$ & $\mathrm{H}$ & $\mathrm{H}$ & $\mathrm{N}$ & $\mathrm{N}$ & 3 & $\begin{array}{l}\text { E0541-D1- } \\
\text { 070410.ASC }\end{array}$ & $\begin{array}{l}\text { E0541-D2-Channel1 Apr 10, } \\
\text { 2007 14-13-57.txt }\end{array}$ & No video taken \\
\hline E0542 & 8 & Clay & 53.4 & 0.8 & 30.6 & 26.2 & 2 & 4,5 & 3 & 3.53 & 3.48 & & - & - & $\begin{array}{l}12 / 0.001 / 34 \\
110\end{array}$ & $\begin{array}{l}/ 12 / 1 / 0.001 / 34 / \\
110\end{array}$ & - & 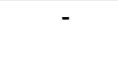 & - & 14 & $\mathrm{H}$ & $\mathrm{H}$ & $\mathrm{H}$ & $\mathrm{H}$ & $\mathrm{N}$ & $\mathrm{N}$ & 1 & $\begin{array}{l}\text { E0542-D1- } \\
\text { 070410.ASC }\end{array}$ & $\begin{array}{l}\text { E0542-D2-Channell Apr 10, } \\
\text { 2007 14-22-53.txt }\end{array}$ & No video taken \\
\hline E0543 & 8 & Clay & 53.4 & 0.8 & 30.6 & 26.2 & 2 & 4,5 & 3 & 3.50 & 3.47 & & & - & $\begin{array}{c}12 / 0.001 / 34 \\
110\end{array}$ & $\begin{array}{l}\text { / 12/0.001/34/ } \\
110\end{array}$ & & & & 14 & $\mathrm{H}$ & $\mathrm{H}$ & $\mathrm{H}$ & $\mathrm{H}$ & $\mathrm{N}$ & $\mathrm{N}$ & 2 & $\begin{array}{l}\text { E0543-D1- } \\
\text { 070410.ASC }\end{array}$ & $\begin{array}{l}\text { E0543-D2-Channel1 Apr 10, } \\
\text { 2007 14-26-29.txt }\end{array}$ & No video taken \\
\hline E0544 & 8 & Clay & 53.4 & 0.8 & 30.6 & 26.2 & 2 & 4,5 & 3 & 3.51 & 3.46 & & & - & $\begin{array}{l}12 / 0.001 / 3 \\
110\end{array}$ & $\begin{array}{c}\mid \begin{array}{c}12 / 0.001 / 34 / \\
110\end{array} \\
\text { | }\end{array}$ & & & & 14 & $\mathrm{H}$ & $\mathrm{H}$ & $\mathrm{H}$ & $\mathrm{H}$ & $\mathrm{N}$ & $\mathrm{N}$ & 3 & $\begin{array}{l}\text { E0544-D1- } \\
\text { 070410.ASC }\end{array}$ & $\begin{array}{l}\text { E0544-D2-Channel1 Apr 10, } \\
2007 \text { 14-29-39.txt }\end{array}$ & No video taken \\
\hline E0545 & 8 & Clay & 53.4 & 0.8 & 30.6 & 26.2 & 2 & 4,5 & 3 & 3.49 & 3.47 & & & - & $\begin{array}{c}12 / 0.001 / 34 \\
110\end{array}$ & $\begin{array}{l}|12 / 0.001 / 34| \\
110\end{array}$ & & & & 14 & $\mathrm{H}$ & $\mathrm{H}$ & $\mathrm{H}$ & $H$ & $Y$ & $\mathrm{~N}$ & 1 & $\begin{array}{l}\text { E0545-D1- } \\
\text { 070410.ASC }\end{array}$ & $\begin{array}{l}\text { E0545-D2-Channel1 Apr 10, } \\
\text { 2007 14-36-23.txt }\end{array}$ & No video taken \\
\hline E0546 & 8 & Clay & 53.4 & 0.8 & 30.6 & 26.2 & 2 & 4,5 & 2.5 & 3.48 & 3.46 & & - & - & $\begin{array}{c}12 / 0.001 / 34 \\
110\end{array}$ & $\mid \begin{array}{l}122 / 0.001 / 34 / \\
110\end{array}$ & - & - & - & 14 & $\mathrm{H}$ & $\mathrm{H}$ & $\mathrm{H}$ & $\mathrm{H}$ & Y & N & 2 & $\begin{array}{l}\text { E0546-D1- } \\
\text { 070410.ASC }\end{array}$ & $\begin{array}{l}\text { E0546-D2-Channel1 Apr 10, } \\
\text { 2007 14-39-46.txt }\end{array}$ & No video taken \\
\hline
\end{tabular}


Table A.1. Master Run Log, 8-PJM Configuration

\begin{tabular}{|c|c|c|c|c|c|c|c|c|c|c|c|c|c|c|c|c|c|c|c|c|c|c|c|c|c|c|c|c|c|c|}
\hline \multirow[b]{2}{*}{$\begin{array}{l}\operatorname{Exp}_{\left({ }^{\prime}\right.} \\
\text { Noo. }\end{array}$} & \multirow[b]{2}{*}{$\begin{array}{l}\text { PJM } \\
\text { Config }\end{array}$} & \multicolumn{4}{|c|}{ Simulant } & \multirow{2}{*}{\multicolumn{2}{|c|}{$\begin{array}{ll} & \text { No. } \\
\text { K } & \text { PJMs } \\
P & \mathrm{OB}^{(b)}\end{array}$}} & \multirow[b]{2}{*}{$\begin{array}{l}\text { OB } \\
\text { PJMs }\end{array}$} & \multirow[b]{2}{*}{$\begin{array}{c}\mathrm{OB} \\
\text { Duration }\end{array}$} & \multicolumn{5}{|c|}{$\begin{array}{l}\text { Drive Pressure Settings } \\
\quad\left(b_{\text {bar_ag }}\right)^{(0)}\end{array}$} & \multicolumn{5}{|c|}{ PJM OP Conditions (vacuum/delay/drive/vent time) } & \multirow[b]{2}{*}{$\begin{array}{l}\text { Target } \\
\text { Noz. Vel. } \\
(\mathrm{m} / \mathrm{s})^{()^{(c)}}\end{array}$} & \multicolumn{4}{|c|}{ Hydrophone Elevation } & \multirow[b]{2}{*}{$\begin{array}{c}\text { Sparger } \\
(\mathrm{Y} / \mathrm{N})\end{array}$} & \multirow[b]{2}{*}{$\begin{array}{l}\text { Video } \\
(\mathrm{Y} / \mathrm{N})\end{array}$} & \multirow[b]{2}{*}{$\begin{array}{c}\text { Repeat } \\
\#\end{array}$} & \multirow[b]{2}{*}{ DAS-1 Filename } & \multirow[b]{2}{*}{ DAS-2 Filename ${ }^{(d)}$} & \multirow[b]{2}{*}{$\begin{array}{l}\text { DAS-4 (Video) } \\
\text { Filename }\end{array}$} \\
\hline & & pe & $\begin{array}{l}\text { Ht. fm } \\
\text { Rim } \\
\text { (in) }\end{array}$ & $H / D$ & $\begin{array}{c}T_{y s} \\
(\mathrm{~Pa})\end{array}$ & & & & & $\begin{array}{c}\text { PJM } \\
4\end{array}$ & $\begin{array}{c}\text { PJM } \\
5\end{array}$ & $\begin{array}{c}\text { PJM } \\
6\end{array}$ & $\begin{array}{c}\text { PJM } \\
7\end{array}$ & $\begin{array}{c}\text { PJM } \\
8\end{array}$ & PJM 4 & PJM & PJM 6 & PJM 7 & PJM 8 & & $\mathrm{H} 1$ & $\mathrm{H}_{2}$ & H3 & $\mathrm{H} 4$ & & & & & & \\
\hline E0549 & & Clay & 53.4 & 0.8 & 30.6 & & $\frac{2}{2}$ & 4,5 & 12 & 3.51 & 3.48 & & & & $\begin{array}{l}12 / 0.001 / 43 \\
110\end{array}$ & $3 / 12 / 0.001 / 43 /$ & & & & 14 & $\mathrm{H}$ & $\mathrm{H}$ & $\mathrm{H}$ & $\mathrm{H}$ & $N$ & $\mathrm{~N}$ & 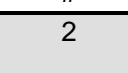 & $\begin{array}{l}\text { E5049-D1- } \\
\text { 070410.ASC }\end{array}$ & $\begin{array}{l}\text { E0549-D2-Channel1 Apr 10, } \\
\text { 2007 14-59-48.tpt }\end{array}$ & No video taken \\
\hline E0550 & 8 & Clay & 53.4 & 0.8 & 30.6 & 26.2 & 2 & 4,5 & 12 & 3.52 & 3.48 & - & & & $\begin{array}{c}12 / 0.001 / 43 \\
110\end{array}$ & $\begin{array}{l}3 / 12 / 0.001 / 43 / \\
110\end{array}$ & & & & 14 & $\mathrm{H}$ & H & $\mathrm{H}$ & $\mathrm{H}$ & $\mathrm{N}$ & $\mathrm{N}$ & 3 & $\begin{array}{l}\text { E0550-D1- } \\
\text { 070410.ASC }\end{array}$ & $\begin{array}{l}\text { E0550-D2-Channel1 Apr 10, } \\
2007 \text { 15-04-09.txt }\end{array}$ & No video taken \\
\hline E0551 & 8 & Clay & 53.4 & 0.8 & 30.6 & 26.2 & 3 & $4,5,6$ & 3 & 3.48 & 3.52 & 3.51 & & & $\begin{array}{l}12 / 0.001 / 34 \\
110\end{array}$ & 4/ 12/0.001//34/ 1 & $\begin{array}{l}12 / 0.001 / \\
3 / 110\end{array}$ & & & 14 & $\mathrm{H}$ & H & $\mathrm{H}$ & $\mathrm{H}$ & $\mathrm{N}$ & $\mathrm{N}$ & 1 & $\begin{array}{l}\text { E0551-D1- } \\
\text { 070410.ASC }\end{array}$ & $\begin{array}{l}\text { E0551-D2-Channel1 Apr 10, } \\
\text { 2007 15-14-18.txt }\end{array}$ & No video taken \\
\hline E0552 & 8 & Clay & 53.4 & 0.8 & 30.6 & 26.2 & 3 & $4,5,6$ & 2.5 & 3.49 & 3.47 & 3.51 & - & 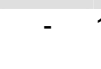 & $\begin{array}{r}12 / 0.001 / 34 \\
110\end{array}$ & 4/ 12/0.001/34/ 1 & $\begin{array}{c}12 / 0.001 / \\
34 / 110\end{array}$ & - & - & 14 & $\mathrm{H}$ & H & $\mathrm{H}$ & $\mathrm{H}$ & $\mathrm{N}$ & N & 2 & $\begin{array}{l}\text { E0552-D1- } \\
\text { 070410.ASC }\end{array}$ & $\begin{array}{l}\text { E0552-D2-Chanell Apr 10, } \\
\text { 2007 15-18-09 txt }\end{array}$ & No video taken \\
\hline E0553 & 8 & Clay & 53.4 & 0.8 & 30.6 & 26.2 & 3 & $4,5,6$ & 2.5 & 3.48 & 3.46 & 3.51 & - & : & $\begin{array}{l}12 / 0.001 / 34 \\
110\end{array}$ & 4/ 12/0.001/34/ 1 & $\begin{array}{c}12 / 0.001 / \\
34 / 110\end{array}$ & 1 & - & 14 & $\mathrm{H}$ & H & $\mathrm{H}$ & $\mathrm{H}$ & $\mathrm{N}$ & N & 3 & $\begin{array}{l}\text { E0553-D1- } \\
\text { 070410ASC }\end{array}$ & E0553-D2-Channel1 Apr 10, & No video taken \\
\hline E0554 & 8 & Clay & 53.4 & 0.8 & 30.6 & 26.2 & 4 & $4,5,6,7$ & 2.5 & 3.54 & 3.48 & 3.51 & 3.47 & - & $\begin{array}{c}12 / 0.001 / 34 \\
110\end{array}$ & $\begin{array}{l}4 / 12 / 0.001 / 34 / 1 \\
110\end{array}$ & $\begin{array}{l}12 / 0.001 / \\
34 / 110\end{array}$ & $\begin{array}{c}12 / 0.001 / \\
34 / 110\end{array}$ & - & 14 & $\mathrm{H}$ & $\mathrm{H}$ & $\mathrm{H}$ & $\mathrm{H}$ & $\mathrm{N}$ & $\mathrm{N}$ & 1 & $\begin{array}{l}\text { E0554-D1- } \\
\text { 070410.ASC }\end{array}$ & $\begin{array}{l}\text { E0554-D2-Channel1 Apr 10, } \\
\text { 2007 15-33-19.txt }\end{array}$ & No video taken \\
\hline E0555 & 8 & Clay & 53.4 & 0.8 & 30.6 & 26.2 & 4 & $4,5,6,7$ & 2.5 & 3.46 & 3.52 & 3.50 & 3.48 & & $\begin{array}{c}12 / 0.001 / \\
34 / 110\end{array}$ & $\begin{array}{l}12 / 0.001 / 1 \\
34 / 110\end{array}$ & $\begin{array}{c}12 / 0.001 / \\
34 / 110\end{array}$ & $\begin{array}{c}12 / 0.001 / \\
34 / 110\end{array}$ & & 14 & $\mathrm{H}$ & H & $\mathrm{H}$ & $\mathrm{H}$ & $\mathrm{N}$ & $\mathrm{N}$ & 2 & $\begin{array}{l}\text { E0555-D1- } \\
\text { 070410.ASC }\end{array}$ & $\begin{array}{l}\text { E0555-D2-Channel1 Apr 10, } \\
2007 \text { 15-36-51.txt }\end{array}$ & No video taken \\
\hline E0556 & 8 & Clay & 53.4 & 0.8 & 30.6 & 26.2 & 4 & $4,5,6,7$ & 2.5 & 3.49 & 3.46 & 3.50 & 3.46 & & $\begin{array}{c}12 / 0.001 / \\
34 / 110\end{array}$ & $\begin{array}{l}12 / 10.001 / 1 \\
34 / 110\end{array}$ & $\begin{array}{c}12 / 0.001 / \\
34 / 110\end{array}$ & $\begin{array}{c}12 / 0.001 / \\
34 / 110\end{array}$ & & 14 & $\mathrm{H}$ & $\mathrm{H}$ & $\mathrm{H}$ & $\mathrm{H}$ & $\mathrm{N}$ & $\mathrm{N}$ & 3 & $\begin{array}{l}\text { E0556-D1- } \\
\text { 070410.ASC }\end{array}$ & $\begin{array}{l}\text { E0556-D2-Channel1 Apr 10, } \\
2007 \text { 15-41-24.txt }\end{array}$ & No video taken \\
\hline E0556BL & - & - & - & - & 30.6 & 26.2 & - & - & - & - & - & - & - & - & & & - & & - & - & - & - & - & - & - & - & - & $\begin{array}{l}\text { E0556-D1-BL- } \\
\text { 070410.ASC }\end{array}$ & $\begin{array}{l}\text { E0556-D2-BL-Channel\# Apr } \\
10,2007 \text { 15-48-09.txt }\end{array}$ & \\
\hline E0557BL & - & - & - & - & 30.4 & 26.1 & - & - & - & - & - & - & - & - & - & - & - & - & - & - & - & - & - & - & - & - & - & E0557-D1-BL- & E0557-D2-BL-Channel\# Apr & - \\
\hline E0557 & 8 & Clay & 53.5 & 0.8 & 30.4 & 26.1 & 1 & 5 & 4.5 & - & 3.96 & - & - & - & - & $12 / 0.001 / 34 /$ & - & - & - & 15 & $\mathrm{H}$ & $\mathrm{H}$ & $\mathrm{H}$ & $\mathrm{H}$ & $\mathrm{N}$ & $\mathrm{N}$ & 1 & $\begin{array}{l}\text { E557-D1- } \\
070411 \text { ASC }\end{array}$ & $\begin{array}{l}\text { E0557-D2-Channell Apr 11, } \\
\text { 2007 09-51-48 txt }\end{array}$ & No video taken \\
\hline E0558 & 8 & Clay & 53.5 & 0.8 & 30.4 & 26.1 & 1 & 5 & 4.5 & - & 4.03 & - & - & 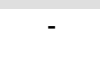 & - & $\begin{array}{l}12 / 0.001 / 34 / \\
110\end{array}$ & - & - & - & 15 & $\mathrm{H}$ & H & $\mathrm{H}$ & $\mathrm{H}$ & $\mathrm{N}$ & $\mathrm{N}$ & 2 & $\begin{array}{l}\text { E0558-D1- } \\
\text { 070411.ASC }\end{array}$ & $\begin{array}{l}\text { E0558-D2-Channell Apr 11, } \\
\text { 2007 09-55-38.txt }\end{array}$ & No video taken \\
\hline E0559 & 8 & Clay & 53.5 & 0.8 & 30.4 & 26.1 & 1 & 5 & 4.5 & - & 3.96 & - & - & . & & $\begin{array}{l}12 / 0.001 / 34 / \\
110\end{array}$ & - & & & 15 & $\mathrm{H}$ & $\mathrm{H}$ & $\mathrm{H}$ & $\mathrm{H}$ & $\mathrm{N}$ & $\mathrm{N}$ & 3 & $\begin{array}{l}\text { E0559-D1- } \\
\text { 070411.ASC }\end{array}$ & $\begin{array}{l}\text { E0559-D2-Channell Apr 11, } \\
2007 \text { 09-58-40.txt }\end{array}$ & No video taken \\
\hline E0560 & 8 & Clay & 53.5 & 0.8 & 30.4 & 26.1 & 2 & 4,5 & $>5$ & 4.02 & 3.96 & - & - & ( & $\begin{array}{l}12 / 0.001 / 34 \\
110\end{array}$ & 4/ 12/0.001/34/ & - & & - & 15 & $\mathrm{H}$ & H & $\mathrm{H}$ & $\mathrm{H}$ & $\mathrm{N}$ & $\mathrm{N}$ & 1 & $\begin{array}{l}\text { E0560-D1- } \\
\text { 070411.ASC }\end{array}$ & $\begin{array}{l}\text { E0560-D2-Channell Apr 11, } \\
\text { 2007 10-12-09.txt }\end{array}$ & No video taken \\
\hline E0561 & 8 & Clay & 53.5 & 0.8 & 30.4 & 26.1 & 2 & 4,5 & 4.5 & 4.01 & 3.97 & - & & & $12210.001 / 34$ & 4/ $12 / 0.001 / 34 /$ & 1 & & & 15 & $\mathrm{H}$ & H & $\mathrm{H}$ & H & $\mathrm{N}$ & $\mathrm{N}$ & 2 & $\begin{array}{l}\text { E0561-D1- } \\
\text { 070411.ASC }\end{array}$ & E0561-D2-Channel1 Apr 11, & No video taken \\
\hline E0562 & 8 & Clay & 53.5 & 0.8 & 30.4 & 26.1 & 2 & 4,5 & 4.5 & 3.95 & 3.98 & - & - & $\cdot$ & $\begin{array}{c}12 / 0.001 / 34 \\
110\end{array}$ & $\begin{array}{l}4 / 12 / 0.001 / 34 / \\
110\end{array}$ & - & - & - & 15 & $\mathrm{H}$ & $\mathrm{H}$ & $\mathrm{H}$ & $\mathrm{H}$ & $\mathrm{N}$ & $\mathrm{N}$ & 3 & $\begin{array}{l}\text { E0562-D1- } \\
\text { 070411.ASC }\end{array}$ & $\begin{array}{l}\text { E0562-D2-Channel1 Apr 11, } \\
\text { 2007 10-18-56.txt }\end{array}$ & No video taken \\
\hline $\begin{array}{l}\text { High clay I } \\
\text { E0563BL }\end{array}$ & - & Irophe & & L & 30.4 & 26.1 & & - & - & 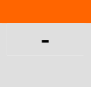 & - & - & - & - & 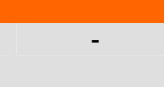 & 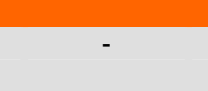 & - & & 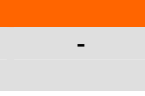 & - & - & - & - & 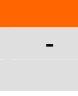 & - & - & - & 1-BL- & $\begin{array}{l}\text { E0563- } \\
\quad 11,\end{array}$ & \\
\hline E0563 & 8 & Clay & 53.5 & 0.8 & 30.4 & 26.1 & 1 & 5 & 4.5 & - & 4.01 & - & - & - & - & $\begin{array}{l}12 / 0.001 / 34 / \\
110\end{array}$ & - & - & - & 15 & $\mathrm{~L}$ & $\mathrm{~L}$ & $\mathrm{~L}$ & L & $\mathrm{N}$ & $\mathrm{Y}$ & 1 & $\begin{array}{l}\text { E0563-D1- } \\
\text { 070411.ASC }\end{array}$ & $\begin{array}{l}\text { E0563-D2-Channell Apr 11, } \\
\text { 2007 11-15-05.txt }\end{array}$ & No video taken \\
\hline E0564 & 8 & Clay & 53.5 & 0.8 & 30.4 & 26.1 & 1 & 5 & 4.5 & & 4.02 & - & & & & $\begin{array}{c}12 / 0.001 / 34 / \\
110\end{array}$ & - & & & 15 & $\mathrm{~L}$ & L & $\mathrm{L}$ & $\mathrm{L}$ & $\mathrm{N}$ & Y & 2 & $\begin{array}{l}\text { E056 } \\
007041\end{array}$ & $\begin{array}{l}\text { E0564-D2-Channel1 Apr 11, } \\
\text { 2007 11-19-27.txt }\end{array}$ & No video taken \\
\hline E0565 & 8 & Clay & 53.5 & 0.8 & 30.4 & 26.1 & 1 & 5 & 4.5 & 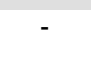 & 4.02 & - & - & - & & $\begin{array}{l}12 / 0.001 / 34 / \\
110\end{array}$ & - & & - & 15 & $\mathrm{~L}$ & $\mathrm{~L}$ & $\mathrm{~L}$ & $\mathrm{~L}$ & $\mathrm{~N}$ & $\mathrm{Y}$ & 3 & $\begin{array}{l}\text { E0565-D1- } \\
\text { 070411.ASC }\end{array}$ & $\begin{array}{l}\text { E0565-D2-Channel1 Apr 11, } \\
\text { 2007 11-24-53.txt }\end{array}$ & No video taken \\
\hline E0566 & 8 & Clay & 53.5 & 0.8 & 30.4 & 26.1 & 2 & 4,5 & 4.5 & 3.96 & 4.04 & - & - & 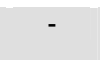 & $\begin{array}{l}12 / 0.001 / 34 \\
110\end{array}$ & $4 / 12 / 0.001 / 34 /$ & - & - & - & 15 & $\mathrm{~L}$ & L & $\mathrm{L}$ & L & $\mathrm{N}$ & $\mathrm{Y}$ & 1 & $\begin{array}{l}\text { E0566-D1- } \\
\text { 070411.ASC }\end{array}$ & $\begin{array}{l}\text { E0566-D2-Channel1 Apr 11, } \\
\text { 2007 }\end{array}$ & No video taken \\
\hline E0567 & 8 & Clay & 53.5 & 0.8 & 30.4 & 26.1 & 2 & 4,5 & 4.5 & 3.95 & 4.03 & - & - & - & $\begin{array}{c}12 / 0.001 / 34 \\
110\end{array}$ & $4 / 12 / 0.001 / 34 /$ & - & - & - & 15 & $\mathrm{~L}$ & L & L & $\mathrm{L}$ & $\mathrm{N}$ & $\mathrm{Y}$ & 2 & $\begin{array}{l}\text { E0567-D1- } \\
\text { 070411.ASC }\end{array}$ & $\begin{array}{l}\text { E0567-D2-Chan } \\
200711-35\end{array}$ & No video taken \\
\hline E0568 & 8 & Clay & 53.5 & 0.8 & 30.4 & 26.1 & 2 & 4,5 & 4.5 & 4.05 & 4.04 & - & & & $1220.001 / 34$ & $4 / 12 / 0.001 / 34 /$ & - & & - & 15 & $\mathrm{~L}$ & L & $\mathrm{L}$ & L & $\mathrm{N}$ & Y & 3 & $\begin{array}{l}\text { E0568-D1- } \\
\text { 070411 ASC }\end{array}$ & $\begin{array}{l}\text { E0568-D2-Channel1 Apr 11, } \\
\text { 2007 11-39-19txt }\end{array}$ & No video taken \\
\hline E0569 & 8 & Clay & 53.5 & 0.8 & 30.4 & 26.1 & 2 & 4,5 & 4.5 & 3.99 & 4.02 & - & - & & $\begin{array}{c}12 / 0.001 / 34 \\
110\end{array}$ & $\begin{array}{l}4 / 12 / 0.001 / 34 / \\
110\end{array}$ & - & - & & 15 & L & L & L & $\mathrm{L}$ & $\mathrm{N}$ & $\mathrm{Y}$ & 4 & $\begin{array}{l}\text { E0569-D1- } \\
\text { 070411.ASC }\end{array}$ & $\begin{array}{r}\text { E0569-D } \\
200\end{array}$ & No video taken \\
\hline E0570 & 8 & Clay & 53.5 & 0.8 & 30.4 & 26.1 & 1 & 8 & $>3$ & & & & & 3.50 & & & - & & $\begin{array}{c}12 / 0.001 / \\
381110\end{array}$ & 14 & L & L & L & L & $\mathrm{N}$ & Y & 1 & $\begin{array}{l}\text { E057 } \\
07041\end{array}$ & $\begin{array}{l}\text { E0570-D2-Chann } \\
200713-53-\end{array}$ & No video taken \\
\hline E0571 & 8 & Clay & 53.5 & 0.8 & 30.4 & 26.1 & 1 & 8 & $>3$ & & & - & & 3.49 & & & - & & $\begin{array}{c}12 / 0.001 / \\
38 / 110\end{array}$ & 14 & L & L & $\mathrm{L}$ & L & $\mathrm{N}$ & $\mathrm{Y}$ & 2 & $\begin{array}{l}\text { E0571-D1- } \\
\text { 070411.ASC }\end{array}$ & $\begin{array}{l}\text { E0571-D2-Chan } \\
200713-58\end{array}$ & No video taken \\
\hline E0572 & 8 & Clay & 53.5 & 0.8 & 30.4 & 26.1 & 1 & 8 & $>3$ & & & & & 3.49 & & & & & $\begin{array}{c}12 / 0.001 / \\
38 / 110\end{array}$ & 14 & L & L & L & L & $\mathrm{N}$ & $\mathrm{Y}$ & 3 & $\begin{array}{l}\text { E0572-D1- } \\
\text { 070411.ASC }\end{array}$ & $\begin{array}{l}\text { E0572-D2-Channel1 Apr 11, } \\
\text { 2007 14-02-17.txt }\end{array}$ & No video taken \\
\hline E0573 & 8 & Clay & 53.5 & 0.8 & 30.4 & 26.1 & 1 & 5 & 2.5 & - & 3.52 & - & - & - & - & $\begin{array}{l}12 / 0.001 / 34 / \\
110\end{array}$ & - & - & & 14 & L & L & $\mathrm{L}$ & L & $\mathrm{N}$ & $\mathrm{Y}$ & 1 & $\begin{array}{l}\text { E0573-D1- } \\
\text { 070411.ASC }\end{array}$ & $\begin{array}{ll}E 0573-\mathrm{D} \\
200\end{array}$ & No video taken \\
\hline E0574 & 8 & Clay & 53.5 & 0.8 & 30.4 & 26.1 & 1 & 5 & 3 & - & 3.53 & - & - & - & - & $\begin{array}{l}12 / 0.001 / 34 / \\
110\end{array}$ & - & - & 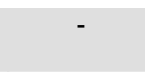 & 14 & L & L & L & L & $\mathrm{N}$ & Y & 2 & $\begin{array}{l}\text { E0574-D1- } \\
\text { 070411.ASC }\end{array}$ & $\begin{array}{l}\text { E0574-D2-Channel1 Apr 11, } \\
\text { 2007 14-11-38.txt }\end{array}$ & No video taken \\
\hline E0575 & 8 & Clay & 53.5 & 0.8 & 30.4 & 26.1 & 1 & 5 & 3 & - & 3.54 & - & & - & - & $\begin{array}{c}12 / 0.001 / 34 / \\
110\end{array}$ & - & & - & 14 & L & L & L & L & N & Y & 3 & $\begin{array}{l}\text { E0575-D1- } \\
\text { 070411.ASC }\end{array}$ & $\begin{array}{l}\text { E0575-D2-C } \\
20071\end{array}$ & No video taken \\
\hline E0576 & 8 & Clay & 53.5 & 0.8 & 30.4 & 26.1 & 2 & 4,5 & 3 & 3.49 & 3.52 & & & & $\begin{array}{l}12 / 0.001 / 3 \\
110\end{array}$ & $4 / 12 / 0.001 / 34 /$ & & & & 14 & $\mathrm{~L}$ & L & $\mathrm{L}$ & $\mathrm{L}$ & $\mathrm{N}$ & $Y$ & 1 & $\begin{array}{l}\text { E0576-D1- } \\
\text { 070411.ASC }\end{array}$ & $\begin{array}{l}\text { E0576-D2-Channel1 Apr 11, } \\
\text { 2007 14-41-47.txt }\end{array}$ & No video taken \\
\hline E0577 & 8 & Clay & 53.5 & 0.8 & 30.4 & 26.1 & 2 & 4,5 & 3 & 3.52 & 3.52 & & & & $\begin{array}{l}12 / 0.001 / 34 \\
110\end{array}$ & $\begin{array}{c}4 / 12 / 0.001 / 34 / \\
110\end{array}$ & & & & 14 & L & L & $\mathrm{L}$ & $\mathrm{L}$ & & $Y$ & 2 & $\begin{array}{l}\text { E0577-D1- } \\
\text { 070411.ASC }\end{array}$ & $\begin{array}{c}\text { E0577-D2-Channel1 Apr 11, } \\
\text { 2007 14-48-01.txt }\end{array}$ & No video taken \\
\hline 578 & 8 & Clay & 53.5 & 0.8 & 30.4 & 26.1 & 2 & 4,5 & & 3.52 & 3.52 & & & & $01 / 3$ & $4 / 12 / 0.001 / 34 /$ & & & & & & & & & & & & E0578-D1- & 0578-D2-Channel1 Apr 11, & No video taken \\
\hline
\end{tabular}




\begin{tabular}{|c|c|c|c|c|c|c|c|c|c|c|c|c|c|c|c|c|c|c|c|c|c|c|c|c|c|c|c|c|c|c|}
\hline \multirow[b]{2}{*}{$\begin{array}{l}\operatorname{Exp}_{(i)} \\
\text { No. }\end{array}$} & \multirow[b]{2}{*}{$\begin{array}{l}\text { PJM } \\
\text { Config }\end{array}$} & \multirow{2}{*}{ Type } & \multicolumn{4}{|c|}{ Simulant } & \multirow{2}{*}{$\begin{array}{c}\text { No. } \\
\text { PJMs } \\
\text { ) } \mathrm{OB}^{(b)} \\
\end{array}$} & \multirow{2}{*}{$\begin{array}{c}\text { OB } \\
\text { PJMS } \\
\end{array}$} & \multirow[b]{2}{*}{$\begin{array}{c}\mathrm{OB} \\
\text { Duration } \\
\end{array}$} & \multicolumn{5}{|c|}{$\begin{array}{l}\text { Drive Pressure Settings } \\
\text { (bar.__a })_{2}^{(c)}\end{array}$} & \multicolumn{5}{|c|}{ PJM OP Conditions (vacuum/delay/drive/vent time) } & \multirow{2}{*}{$\begin{array}{c}\text { Target } \\
\text { Noz. Vel. } \\
\left(\mathrm{m} / \mathrm{s}^{(\mathrm{c})}\right.\end{array}$} & \multicolumn{4}{|c|}{ Hydrophone Elevation } & \multirow[b]{2}{*}{$\begin{array}{c}\text { Sparger } \\
(\mathrm{Y} / \mathrm{N})\end{array}$} & \multirow[b]{2}{*}{$\begin{array}{l}\text { Video } \\
(Y / N)\end{array}$} & \multirow[b]{2}{*}{ 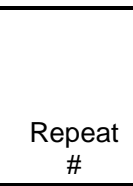 } & \multirow[b]{2}{*}{ DAS-1 Filename } & \multirow[b]{2}{*}{ DAS-2 Filename ${ }^{(\mathrm{d})}$} & \\
\hline & & & $\begin{array}{l}\text { HH. } \mathrm{fim} \\
\text { Rim } \\
\text { (in) }\end{array}$ & H/D & $\begin{array}{c}\mathrm{T}_{\mathrm{ys}} \\
(\mathrm{Pa})\end{array}$ & $\begin{array}{c}\mathrm{k} \\
(\mathrm{cP})\end{array}$ & & & & PJM & PJM & PJM & PJM & $\begin{array}{l}\text { PJM } \\
8\end{array}$ & PJM 4 & PJM 5 & PJM 6 & PJM 7 & PJM 8 & & $\mathrm{H} 1$ & $\mathrm{H} 2$ & $\mathrm{H} 3$ & $\mathrm{H} 4$ & & & & & & $\begin{array}{l}\text { DAS-4 (Video) } \\
\text { Filename }\end{array}$ \\
\hline & & & & & & & & & & & & & & & $\frac{1104}{110}$ & 110 & & & & & & & & & & & & 070411.ASC & 2007 14-52-21.txt & \\
\hline E0579 & 8 & Clay & 53.5 & 0.8 & 30.4 & 26.1 & 3 & $4,5,6$ & 3 & 3.50 & 3.50 & 3.50 & & - & $\begin{array}{l}12 / 0.001 / 34 \\
110\end{array}$ & / 12/0.001/34/ & $\begin{array}{c}12 / 0.001 / \\
34 / 110\end{array}$ & & & 14 & $\mathrm{~L}$ & $\mathrm{~L}$ & L & $\mathrm{L}$ & $\mathrm{N}$ & $\mathrm{Y}$ & 1 & $\begin{array}{l}\text { E0579-D1- } \\
\text { 070411.ASC }\end{array}$ & $\begin{array}{l}\text { E0579-D2-Channel1 Apr 11, } \\
2007 \text { 15-02-03.txt }\end{array}$ & No video taken \\
\hline E0580 & 8 & Clay & 53.5 & 0.8 & 30.4 & 26.1 & 3 & $4,5,6$ & 3 & 3.45 & 3.51 & 3.50 & - & - & $12 / 0.001 / 34$ & t/ $12 / 0.001 / 34 /$ & $\begin{array}{l}12 / 0.001 / \\
34110\end{array}$ & - & - & 14 & $\mathrm{~L}$ & $\mathrm{~L}$ & L & L & $\mathrm{N}$ & $\mathrm{Y}$ & 2 & $\begin{array}{l}\text { E0580-D1- } \\
\text { 0070411.ASC }\end{array}$ & $\begin{array}{l}\text { E0580-D2-Channel1 Apr 11, } \\
\text { 2007 15-75-37.t.te }\end{array}$ & No video taken \\
\hline E0581 & 8 & Clay & 53.5 & 0.8 & 30.4 & 26.1 & 3 & $4,5,6$ & 3 & 3.48 & 3.51 & 3.50 & - & - & $12 / 0.001 / 34$ & / 12/0.001/34/ & 1 $12 / 0.001 /$ & - & - & 14 & L & $\mathrm{L}$ & L & L & $\mathrm{N}$ & Y & 3 & $\begin{array}{l}\text { E0581-D1- } \\
07041 \text { ASC }\end{array}$ & E0581-D2-Channel1 Apr 11, & No video taken \\
\hline E0582 & 8 & Clay & 53.5 & 0.8 & 30.4 & 26.1 & 4 & $4,5,6,7$ & 3 & 3.50 & 3.51 & 3.49 & 3.48 & - & $\begin{array}{l}12 / 0.001 / 34 \\
110\end{array}$ & $\begin{array}{l}12 / 0.001 / 34 / \\
110\end{array}$ & $\begin{array}{l}34 / 110 \\
12 / 0.001 / \\
34 / 110\end{array}$ & $\begin{array}{c}12 / 0.001 / \\
34 / 110\end{array}$ & - & 14 & L & L & L & L & $\mathrm{N}$ & Y & 1 & $\begin{array}{l}\text { E0582-D1- } \\
\text { 070411.ASC }\end{array}$ & $\begin{array}{l}\text { E0582-D2-Channel1 Apr } 11 \\
2007 \text { 15-17-55.txt }\end{array}$ & No video taken \\
\hline E0583 & 8 & Clay & 53.5 & 0.8 & 30.4 & 26.1 & 4 & $4,5,6,7$ & 3 & 3.49 & 3.49 & 3.49 & 3.49 & & $\begin{array}{l}12 / 0.001 / 34 \\
110\end{array}$ & // 12/0.001/34/ & $\begin{array}{l}12 / 0.001 / \\
34 / 110\end{array}$ & $\begin{array}{l}12 / 0.001 / \\
34 / 110\end{array}$ & & 14 & L & L & L & L & $\mathrm{N}$ & Y & 2 & $\begin{array}{l}\text { E0583-D1- } \\
\text { 070411.ASC }\end{array}$ & $\begin{array}{l}\text { E0583-D2-Channel1 Apr 11, } \\
\text { 2007 15-22-51.txt }\end{array}$ & No video taken \\
\hline E0584 & 8 & Clay & 53.5 & 0.8 & 30.4 & 26.1 & 4 & $4,5,6,7$ & 3 & 3.50 & 3.54 & 3.49 & 3.47 & - & $\begin{array}{l}12 / 0.001 / 34 \\
110\end{array}$ & $\begin{array}{l}/ / 12 / 0.001 / 34 / \\
110\end{array}$ & $\begin{array}{c}12 / 0.001 / \\
34 / 110\end{array}$ & $\begin{array}{l}12 / 0.001 / 3 \\
4 / 110\end{array}$ & & 14 & $\mathrm{~L}$ & $\mathrm{~L}$ & $\mathrm{~L}$ & L & $\mathrm{N}$ & $\mathrm{Y}$ & 3 & $\begin{array}{l}\text { E0584-D1- } \\
\text { 070411.ASC }\end{array}$ & $\begin{array}{l}\text { E0584-D2-Channel1 Apr 11, } \\
\text { 2007 15-27-39.txt }\end{array}$ & No video taken \\
\hline E0584BL & - & - & - & - & 30.4 & 26.1 & - & - & - & - & - & - & - & - & & & & & - & - & - & - & - & - & - & - & - & $\begin{array}{l}\text { E0584-D1-BL- } \\
\text { 070411.ASC }\end{array}$ & $\begin{array}{l}\text { E0584-D2-BL-Channel\# Apr } \\
\text { 11, } 2007 \text { 15-33-52.txt }\end{array}$ & \\
\hline E0585BL & - & - & - & - & 30.9 & 26.7 & - & - & - & - & - & - & & - & & & - & & & - & - & - & - & - & - & - & - & $\begin{array}{l}\text { E0585-D1-BL1- } \\
\text { 070412ASC }\end{array}$ & $\begin{array}{l}\text { E0585-D2-BL1-Channel\# } \\
\text { Ant 12 2007 79-50-20 }\end{array}$ & \\
\hline $\mathrm{E} 0585 \mathrm{BL}$ & - & - & - & - & 30.9 & 26.7 & - & - & - & - & - & - & - & - & - & - & - & - & - & - & - & - & - & - & Y & - & - & E0585-D1-BL2- & - E0585-D2-BL2-Channel\# & - \\
\hline E0585 & 8 & Clay & 54.0 & 0.8 & 30.9 & 26.7 & 2 & 4,5 & 3 & 3.46 & 3.53 & - & - & - & $\begin{array}{l}12 / 0.001 / 34 \\
110\end{array}$ & / 12/0.001/34/ & - & - & - & 14 & L & L & L & L & $\mathrm{Y}$ & $\mathrm{Y}$ & 1 & $\begin{array}{l}\text { E0585-D1- } \\
\text { 070412.ASC }\end{array}$ & E0585-D2-Channel1 Apr 12, & No video taken \\
\hline E0586 & 8 & Clay & 54.0 & 0.8 & 30.9 & 26.7 & 2 & 4,5 & 3 & 3.53 & 3.54 & - & - & - & $\begin{array}{l}12 / 0.001 / 34 \\
110\end{array}$ & $\begin{array}{l}1 / 12 / 0.001 / 34 / \\
110\end{array}$ & s & - & - & 14 & L & L & L & L & Y & $\mathrm{Y}$ & 2 & $\begin{array}{l}\text { E0566-D1- } \\
\text { 070412.ASC }\end{array}$ & $\begin{array}{l}\text { E0586-D2-Channel1 Apr 12, } \\
\text { 2007 10-15-48.txt }\end{array}$ & No video taken \\
\hline E0587 & 8 & Clay & 54.0 & 0.8 & 30.9 & 26.7 & 2 & 4,5 & 3 & 3.46 & 3.54 & - & - & - & $12 / 0.001 / 34$ & 1/ $12 / 0.001 / 34 /$ & te & - & - & 14 & L & $\mathrm{L}$ & $\mathrm{L}$ & L & Y & $\mathrm{Y}$ & 3 & $\begin{array}{l}\text { EO587-D1- } \\
\text { 077412 ASC }\end{array}$ & $\begin{array}{l}\text { E0587-D2-Channel1 Apr 12, } \\
\text { 2007 10-21-12 trt }\end{array}$ & No video taken \\
\hline E0588 & 8 & Clay & 54.0 & 0.8 & 30.9 & 26.7 & 2 & 4,5 & 11.5 & 3.51 & 3.50 & - & - & - & $\begin{array}{l}12 / 0.001 / 43 \\
110\end{array}$ & $\begin{array}{l}3 / 12 / 0.001 / 43 / \\
110\end{array}$ & & - & - & 14 & L & L & L & L & $\mathrm{N}$ & Y & 1 & $\begin{array}{l}\text { E0588-D1- } \\
\text { 070412.ASC }\end{array}$ & $\begin{array}{l}\text { E0588-D2-Channel1 Apr 12, } \\
\text { 2007 10-27-49.txt }\end{array}$ & No video taken \\
\hline E0589 & 8 & Clay & 54.0 & 0.8 & 30.9 & 26.7 & 2 & 4,5 & 11.5 & 3.57 & 3.53 & - & - & - & $12 / 0.001 / 43$ & $3 / 12 / 0.001 / 43 /$ & & - & - & 14 & L & L & L & L & $\mathrm{N}$ & Y & 2 & $\begin{array}{l}\text { EO589-D1- } \\
\text { 077412ASC }\end{array}$ & $\begin{array}{l}\text { E0589-D2-Channel1 Apr 12, } \\
\text { 2007 10-3-34 }\end{array}$ & No video taken \\
\hline E0590 & 8 & Clay & 54.0 & 0.8 & 30.9 & 26.7 & 2 & 4,5 & 11.5 & 3.51 & 3.51 & - & - & - & $12 / 10.001 / 43$ & $\begin{array}{l}3 / 12 / 0.001 / 43 / \\
110\end{array}$ & - & - & - & 14 & L & $\mathrm{L}$ & L & L & $\mathrm{N}$ & Y & 3 & $\begin{array}{l}\text { E0590-D1- } \\
\text { 070412.ASC }\end{array}$ & $\begin{array}{l}\text { E0590-D2-Channell Apr 12, } \\
\text { 2000 10-36-43.txt }\end{array}$ & No video taken \\
\hline E0591 & 8 & Clay & 54.0 & 0.8 & 30.9 & 26.7 & 2 & 4,5 & 11.5 & 3.52 & 3.54 & - & - & - & $12 / 0.001 / 43$ & $3 / 12 / 0.001 / 43 /$ & - & - & - & 14 & L & L & L & L & $\mathrm{N}$ & Y & 4 & $\begin{array}{l}\text { EO591-D1- } \\
\text { O72011 ASC }\end{array}$ & $\begin{array}{l}\text { E0591-D2-Channel1 App 12, }\end{array}$ & No video taken \\
\hline E0592 & 8 & Clay & 54.0 & 0.8 & 30.9 & 26.7 & 1 & 5 & 3.5 & - & 2.49 & - & - & - & 110 & $\begin{array}{l}12 / 0.001 / 41 / \\
110\end{array}$ & - & - & - & 12 & L & L & L & L & $\mathrm{N}$ & Y & 1 & $\begin{array}{l}\text { E0592-D1- } \\
\text { 07042.ASC }\end{array}$ & $\begin{array}{l}\text { E0592-D2-Char } \\
200710-5\end{array}$ & No video taken \\
\hline E0593 & 8 & Clay & 54.0 & 0.8 & 30.9 & 26.7 & 1 & 5 & 4 & - & 2.55 & - & - & - & - & $12 / 0.001 / 41 /$ & - & - & - & 12 & L & L & L & L & $\mathrm{N}$ & $\mathrm{Y}$ & 2 & $\begin{array}{l}\text { EO593-D1- } \\
\text { O711- }\end{array}$ & E0593-D2-Chanr & No video taken \\
\hline E0594 & 8 & Clay & 54.0 & 0.8 & 30.9 & 26.7 & 1 & 5 & 4 & & 2.52 & - & & - & & $\begin{array}{l}12 / 0.001 / 41 / \\
110\end{array}$ & & & & 12 & L & L & L & L & $\mathrm{N}$ & Y & 3 & E0594-D1- & $\begin{aligned} E 0594-D 2 \\
2007\end{aligned}$ & No video taken \\
\hline E0595 & 8 & Clay & 54.0 & 0.8 & 30.9 & 26.7 & 2 & 4,5 & & 2.69 & 2.37 & - & & - & $12 / 0.001 / 41$ & / 12/0.001/41/ & & & & 12 & L & L & L & L & $\mathrm{N}$ & Y & 1 & $\begin{array}{l}\text { E055 } \\
\text { E7na }\end{array}$ & $\begin{array}{l}\text { E0595-D2-Cha } \\
\text { D027 }\end{array}$ & No video taken \\
\hline E0596 & 8 & Clay & 54.0 & 0.8 & 30.9 & 26.7 & 2 & 4,5 & & 2.57 & 2.49 & - & & - & $\begin{array}{l}12 / 0.001 / 41 \\
110\end{array}$ & $\begin{array}{l}/ 12 / 0.001 / 41 / \\
110\end{array}$ & & & & 12 & L & L & L & L & $\mathrm{N}$ & Y & 2 & $\begin{array}{l}\text { E0596-D1- } \\
07041 \text { ASC }\end{array}$ & E0596-D & No video taken \\
\hline E0597 & 8 & Clay & 54.0 & 0.8 & 30.9 & 26.7 & 2 & 4,5 & 3.5 & 2.48 & 2.55 & - & - & - & $12 / 0.001 / 41$ & $/ 12 / 0.001 / 41 /$ & - & - & - & 12 & L & $\mathrm{L}$ & L & L & $\mathrm{N}$ & Y & 3 & $\begin{array}{l}\text { E057--D1- } \\
\text { E017- }\end{array}$ & E0597-D2-Chanr & No video taken \\
\hline E0598 & 8 & Clay & 54.0 & 0.8 & 30.9 & 26.7 & 2 & 4,5 & 3.5 & 2.47 & 2.56 & - & - & - & $12 / 0.001 / 41$ & $/ 12 / 0.001 / 41 /$ & - & - & - & 12 & L & L & L & L & N & Y & 4 & $\begin{array}{l}\text { ASC } \\
\text { D1- }\end{array}$ & E0598- & No video taken \\
\hline E0599 & 8 & Clay & 54.0 & 0.8 & 30.9 & 26.7 & 2 & 4,5 & 3.5 & 2.52 & 2.50 & - & - & - & $12 / 0.001 / 41$ & $1 / 12 / 0.001 / 41 /$ & - & - & - & 12 & L & L & L & L & $\mathrm{N}$ & Y & 5 & $\begin{array}{l}\text { E0599-D1- } \\
\text { 070412.ASC }\end{array}$ & $\begin{array}{l}\text { E0599-D2-Chan } \\
\text { 2007 11-34 }\end{array}$ & No video taken \\
\hline E0600 & 8 & Clay & 54.0 & 0.8 & 30.9 & 26.7 & 2 & 4,5 & 3 & 2.55 & 2.46 & - & - & - & $\begin{aligned} 12 / 0.001 / 41 \\
110\end{aligned}$ & / 12/0.001/41/ & & - & - & 12 & L & L & L & L & $\mathrm{N}$ & $\mathrm{Y}$ & 6 & D1- & $\begin{aligned} E 0600-D \\
200\end{aligned}$ & No video taken \\
\hline E0601 & 8 & Clay & 54.0 & 0.8 & 30.9 & 26.7 & 1 & 5 & 3 & - & 1.29 & - & - & - & & $\begin{array}{l}12 / 0.001 / 62 / \\
110\end{array}$ & & - & - & 8 & L & L & L & L & $\mathrm{N}$ & $\mathrm{Y}$ & 1 & $\begin{array}{l}\text { E0601-D1- } \\
\text { 070412.ASC }\end{array}$ & $\begin{array}{l}\mathrm{E} 06011 \mathrm{D} \\
200\end{array}$ & No video taken \\
\hline E0602 & 8 & Clay & 54.0 & 0.8 & 30.9 & 26.7 & 1 & 5 & 3 & & 1.33 & - & & & & $\begin{array}{l}12 / 0.00 \\
11\end{array}$ & & & & 8 & L & L & L & L & $\mathrm{N}$ & $\mathrm{Y}$ & 2 & & $\begin{array}{l}E 0602-D \\
200\end{array}$ & No video taken \\
\hline E0603 & 8 & Clay & 54.0 & 0.8 & 30.9 & 26.7 & 1 & 5 & 3 & & 1.30 & - & & - & & $\begin{array}{l}12 / 0.001 / 62 / \\
110\end{array}$ & & & & 8 & $\mathrm{~L}$ & L & L & L & $\mathrm{N}$ & Y & 3 & DASC & $\begin{aligned} E 0603-D \\
200\end{aligned}$ & No video taken \\
\hline E0604 & 8 & Clay & 54.0 & 0.8 & 30.9 & 26.7 & 2 & 4,5 & 3 & 1.30 & 1.31 & - & & - & $12 / 0.001$ & $12 / 0.001 / 62 /$ & & - & & 8 & L & $\mathrm{L}$ & $\mathrm{L}$ & L & $\mathrm{N}$ & Y & 1 & $\begin{array}{l}\text { E0604-D1- } \\
07042 \text { ASC }\end{array}$ & $\begin{array}{ll}E 0604-D \\
200\end{array}$ & No video taken \\
\hline E0605 & 8 & Clay & 54.0 & 0.8 & 30.9 & 26.7 & 2 & 4,5 & 3 & 1.31 & 1.30 & - & - & - & $12 / 0.0$ & $\begin{array}{l}12 / 0.001 / 62 / \\
110\end{array}$ & - & - & - & 8 & L & L & L & $\mathrm{L}$ & $\mathrm{N}$ & $\mathrm{Y}$ & 2 & $\begin{array}{l}\text { E0605-D1- } \\
\text { 07042.ASC }\end{array}$ & $\begin{array}{l}\text { E0605-D2-Channel1 Apr 12, } \\
\text { 2000 13-46-49.xt }\end{array}$ & No video taken \\
\hline E0606 & 8 & Clay & 54.0 & 0.8 & 30.9 & 26.7 & 2 & 4,5 & 3 & 1.32 & 1.32 & - & & & $\begin{array}{l}12 / 0.001 / 62 \\
110\end{array}$ & $12 / 0.001 / 62 /$ & s & - & & 8 & L & $\mathrm{L}$ & L & $\mathrm{L}$ & $\mathrm{N}$ & $\mathrm{Y}$ & 3 & $\begin{array}{l}\text { not recorded by } \\
\text { error }\end{array}$ & $\begin{array}{l}\text { y E0606-D2-Chaneli Apr 12, } \\
\text { 2007 13-51-24.txt }\end{array}$ & No video taken \\
\hline E0607 & 8 & Clay & 54.0 & 0.8 & 30.9 & 26.7 & 2 & 4,5 & 3 & 1.32 & 1.34 & - & & - & $\begin{array}{l}12 / 0.001 / \\
110\end{array}$ & $\begin{array}{l}12 / 0.001 / 62 / \\
110\end{array}$ & & & & 8 & $\mathrm{~L}$ & L & L & L & $\mathrm{N}$ & Y & 4 & $\begin{array}{l}\text { E0607-D1- } \\
\text { 070412.ASC }\end{array}$ & $\begin{array}{l}\text { E0607-D2-Channel1 Apr 12, } \\
2007 \text { 13-57-36.txt }\end{array}$ & No video taken \\
\hline O7BL & - & - & - & - & 30.9 & 26.7 & - & & & & & & & & & & & & & & & & & & & & & E0607-D1-BL- & E0607-D2-BL-Channel\# Apr & \\
\hline
\end{tabular}


Table A.1. Master Run Log, 8-PJM Configuration

\begin{tabular}{|c|c|c|c|c|c|c|c|c|c|c|c|c|c|c|c|c|c|c|c|c|c|c|c|c|c|c|c|c|c|c|}
\hline \multirow[b]{2}{*}{$\begin{array}{l}\text { Exp. } \\
\text { No. }\end{array}$} & \multirow[b]{2}{*}{$\begin{array}{l}\text { PJM } \\
\text { Config }\end{array}$} & \multicolumn{5}{|c|}{ Simulant } & \multirow[b]{2}{*}{$\begin{array}{l}\text { No. } \\
\text { PJMs } \\
\mathrm{OB}^{(0)}\end{array}$} & \multirow[b]{2}{*}{$\begin{array}{c}\text { OB } \\
\text { PJMS }\end{array}$} & \multirow[b]{2}{*}{$\begin{array}{c}\mathrm{OB} \\
\text { Duration }{ }^{(c)} \\
\end{array}$} & \multicolumn{5}{|c|}{ 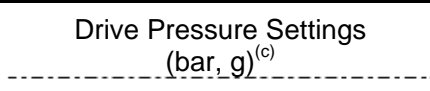 } & \multicolumn{5}{|c|}{ PJM OP Conditions (vacuum/delay/drive/vent time) } & \multirow{3}{*}{$\begin{array}{c}\text { Target } \\
\text { Noz. Vel. } \\
(\mathrm{m} / \mathrm{s})^{()^{\circ)}}\end{array}$} & \multicolumn{4}{|c|}{ Hydrophone Elevation } & \multirow{3}{*}{$\begin{array}{c}\text { Sparger } \\
(Y / N)\end{array}$} & \multirow{3}{*}{$\begin{array}{l}\text { Video } \\
(\mathrm{Y} / \mathrm{N})\end{array}$} & \multirow{3}{*}{$\begin{array}{c}\text { Repeat } \\
\#\end{array}$} & \multirow[b]{2}{*}{ DAS-1 Filename } & \multirow[b]{2}{*}{ DAS-2 Filename ${ }^{(\mathrm{d})}$} & \multirow[b]{2}{*}{$\begin{array}{c}\text { DAS-4 (Video) } \\
\text { Filename }\end{array}$} \\
\hline & & Type & $\begin{array}{l}\text { Ht. fm } \\
\text { Rim } \\
\text { (in) }\end{array}$ & H/D & $\begin{array}{c}T_{\mathrm{ys}} \\
(\mathrm{Pa})\end{array}$ & $\begin{array}{c}k \\
(\mathrm{CP})\end{array}$ & & & & $\begin{array}{r}\text { PJM } \\
4\end{array}$ & $\begin{array}{c}\text { PJM } \\
5\end{array}$ & $\begin{array}{c}\text { PJM } \\
6\end{array}$ & $\begin{array}{c}\text { PJM } \\
7\end{array}$ & $\begin{array}{c}\text { PJM } \\
8\end{array}$ & PJM 4 & PJM 5 & PJM 6 & PJM 7 & PJM 8 & & $\mathrm{H} 1$ & $\mathrm{H} 2$ & H3 & $\mathrm{H} 4$ & & & & & & \\
\hline & & & & & & & & & & & & & & & & & & & & & & & & & & & & 070412.ASC & 12,2007 14-07-35.txt & \\
\hline $\begin{array}{l}\text { ealum } C \\
0608 \mathrm{BL}\end{array}$ & & & & - & $\begin{array}{l}\mathrm{L} \\
31.02\end{array}$ & 27.0 & & - & - & & - & - & & & & & - & & & - & & - & & & N & - & 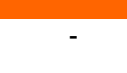 & $\begin{array}{l}\text { E0608-D1-BL- } \\
070416 \text { ASC }\end{array}$ & E0608-D2-BL-Channel\# Apr & \\
\hline E0608 & 8 & Clay & 94.9 & 0.55 & 31.0 & 27.0 & 1 & 5 & 4 & - & 1.29 & - & & & & $\begin{array}{l}30 / 0.001 / 521 \\
110\end{array}$ & & & & 8 & $\mathrm{~L}$ & L & L & $\mathrm{L}$ & $\mathrm{N}$ & $\mathrm{N}$ & 1 & $\begin{array}{l}\text { E0608-D1- } \\
\text { 070416.ASC }\end{array}$ & $\begin{array}{c}\text { E0608-D2-Channel1 Apr 16, } \\
\text { 2007 10-27-59.txt }\end{array}$ & No video taken \\
\hline E0609 & 8 & Clay & 94.9 & 0.55 & 31.0 & 27.0 & 1 & 5 & 4 & - & 1.30 & - & - & - & - & $30 / 0.001 / 521$ & - & - & - & 8 & L & L & L & L & N & N & 2 & $\begin{array}{l}\text { E0609-D1- } \\
\text { 070416.ASC }\end{array}$ & $\begin{array}{l}\text { E0609-D2-Channel1 Apr 16, } \\
\text { 2007 10-32-08.tpt }\end{array}$ & No video taken \\
\hline E0610 & 8 & Clay & 94.9 & 0.55 & 31.02 & 27.0 & 1 & 5 & 4 & - & 1.33 & - & - & - & - & $30 / 0.001 / 521$ & - & - & - & 8 & $\mathrm{~L}$ & L & L & $\mathrm{L}$ & $\mathrm{N}$ & $\mathrm{N}$ & 3 & $\begin{array}{l}\text { E0610-D1- } \\
\text { 07016 ASC }\end{array}$ & E0610-D2-Channel1 Apr 16, & No video taken \\
\hline E0611 & 8 & Clay & 94.9 & 0.55 & 31.02 & 27.0 & 2 & 4,5 & 4 & 1.32 & 1.30 & - & - & - & $30 / 0.001 / 52$ & $/ 30 / 0.001 / 52 /$ & - & - & - & 8 & $\mathrm{~L}$ & L & L & L & N & N & 1 & $\begin{array}{l}\text { OV0416.ASC } \\
\text { E0611-D1- }\end{array}$ & $\begin{array}{l}200 / 10-36-50 . t \mathrm{tt} \\
\text { E0611-D2-Channel1 Apr 16, }\end{array}$ & No video taken \\
\hline E0612 & 8 & Clay & 94.9 & 0.55 & 31.02 & 27.0 & 2 & 4,5 & 4 & 1.32 & 1.29 & - & - & - & $\begin{array}{l}30 / 0.001 / 52 \\
110\end{array}$ & 30/0.001/52/ & - & - & - & 8 & L & L & L & $\mathrm{L}$ & $\mathrm{N}$ & N & 2 & $\begin{array}{l}\text { E0612-D1- } \\
\text { E7016 }\end{array}$ & E0612-D2-Channel1 Apr 16, & No video taken \\
\hline E0613 & 8 & Clay & 94.9 & 0.55 & 31.02 & 27.0 & 2 & 4,5 & 4 & 1.33 & 1.29 & - & - & - & $\begin{array}{l}30 / 0.001 / 52 \\
110\end{array}$ & $\begin{array}{l}/ 30 / 0.001 / 52 / \\
110\end{array}$ & - & & 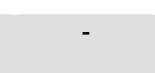 & 8 & L & L & L & L & $\mathrm{N}$ & $\mathrm{N}$ & 3 & $\begin{array}{l}\text { E0613-D1- } \\
\text { 070416.ASC }\end{array}$ & $\begin{array}{l}\text { E0613-D2-Channel1 Apr 16, } \\
\text { 2007 10-53-42.txt }\end{array}$ & No video taken \\
\hline E0614 & 8 & Clay & 94.9 & 0.55 & 31.02 & 27.0 & 1 & 5 & 4 & - & 2.51 & - & - & - & & $\begin{array}{l}30 / 0.001 / 39 / \\
110\end{array}$ & - & - & - & 12 & $\mathrm{~L}$ & L & $\mathrm{L}$ & $\mathrm{L}$ & $\mathrm{N}$ & $\mathrm{N}$ & 1 & $\begin{array}{l}\text { E0614-D1- } \\
\text { 070416.ASC }\end{array}$ & $\begin{array}{l}\text { E0614-D2-Channel1 Apr 16, } \\
\text { 2007 11-08-48.txt }\end{array}$ & No video taken \\
\hline E0615 & 8 & Clay & 94.9 & 0.55 & 31.02 & 27.0 & 1 & 5 & 4 & & 2.49 & - & - & & & $\begin{array}{l}30 / 0.001 / 39 / \\
110\end{array}$ & & & & 12 & L & L & L & L & $\mathrm{N}$ & $\mathrm{N}$ & 2 & $\begin{array}{l}\text { E0615-D1- } \\
\text { 070416.ASC }\end{array}$ & $\begin{array}{l}\text { E0615-D2-Channel1 Apr 16, } \\
\text { 2007 11-14-0.1.txt }\end{array}$ & No video taken \\
\hline E0616 & 8 & Clay & 94.9 & 0.55 & 31.02 & 27.0 & 1 & 5 & 4 & - & 2.51 & - & - & - & - & $\begin{array}{l}30 / 0.001 / 39 / \\
110\end{array}$ & - & - & - & 12 & $\mathrm{~L}$ & L & $\mathrm{L}$ & $\mathrm{L}$ & $\mathrm{N}$ & $\mathrm{N}$ & 3 & $\begin{array}{l}\text { E0616--11- } \\
\text { 070416.ASC }\end{array}$ & $\begin{array}{l}\text { E0616-D2-Channel Apr 16, } \\
\text { 2007 11-18-02.txt }\end{array}$ & No video taken \\
\hline E0617 & 8 & Clay & 94.9 & 0.55 & 31.02 & 27.0 & 2 & 4,5 & 4.5 & 2.46 & 2.51 & - & - & - & $\begin{array}{r}30 / 0.001 / 39 \\
110\end{array}$ & / 30/0.001/39/ & - & - & - & 12 & $\mathrm{~L}$ & L & L & L & $\mathrm{N}$ & $\mathrm{N}$ & 1 & $\begin{array}{l}\text { E0617-D1- } \\
\text { 070016 ASC }\end{array}$ & $\begin{array}{l}\text { E0617-D2-Channel1 Apr 16, } \\
\text { 2007 11-24.3t txt }\end{array}$ & No video taken \\
\hline E0618 & 8 & Clay & 94.9 & 0.55 & 31.02 & 27.0 & 2 & 4,5 & 4.5 & 2.45 & 2.50 & - & - & - & $\begin{array}{l}30 / 0.001 / 39 \\
110\end{array}$ & $/ / 30 / 0.001 / 39 /$ & - & - & - & 12 & $\mathrm{~L}$ & L & $\mathrm{L}$ & $\mathrm{L}$ & $\mathrm{N}$ & $\mathrm{N}$ & 2 & $\begin{array}{l}\text { E0618-D1- } \\
\text { 070416.ASC }\end{array}$ & $\begin{array}{l}\text { E0618-D2-Channel1 Apr 16, } \\
\text { 2007 11-28-35.txt }\end{array}$ & No video taken \\
\hline E0619 & 8 & Clay & 94.9 & 0.55 & 31.02 & 27.0 & 2 & 4,5 & 4.5 & 2.45 & 2.46 & - & - & 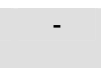 & $\begin{array}{r}30 / 0.001 / 39 \\
110\end{array}$ & / 30/0.001/39/ & - & & & 12 & $\mathrm{~L}$ & L & L & L & $\mathrm{N}$ & $\mathrm{N}$ & 3 & $\begin{array}{l}\text { E0619-D1- } \\
\text { 07016 ASC }\end{array}$ & $\begin{array}{l}\text { E0619-D2-Channel1 Apr 16, } \\
\text { 2007 11-32-0 txt }\end{array}$ & No video taken \\
\hline E0620 & 8 & Clay & 94.9 & 0.55 & 31.0 & 27.0 & 1 & 8 & 4 & & & - & - & 3.52 & & & - & - & $\begin{array}{l}35 / 0.001 / \\
35 / 110\end{array}$ & 14 & $\mathrm{~L}$ & L & L & L & $\mathrm{N}$ & $\mathrm{N}$ & 1 & $\begin{array}{l}\text { EO620-D1- } \\
\text { 070416.ASC }\end{array}$ & $\begin{array}{l}\text { E0620-D2-Channell Apr 16, } \\
\text { 2007 13-05-36.txt }\end{array}$ & No video taken \\
\hline E0621 & 8 & Clay & 94.9 & 0.55 & 31.02 & 27.0 & 1 & 8 & 4 & & & - & & 3.51 & & & - & & $\begin{array}{l}35 / 0.001 / \\
35 / 110\end{array}$ & 14 & $\mathrm{~L}$ & L & L & L & $\mathrm{N}$ & $\mathrm{N}$ & 2 & $\begin{array}{l}\text { E0621-D1- } \\
\text { E7016 ASC }\end{array}$ & $\begin{array}{l}\text { E0621-D2-Channel1 Apr 16, } \\
\text { 2007 } 13 \text { - } 09 \text {-38t }\end{array}$ & No video taken \\
\hline E0622 & 8 & Clay & 94.9 & 0.55 & 31.02 & 27.0 & 1 & 8 & 4 & - & - & - & - & 3.52 & - & & - & - & $\begin{array}{c}35 / 0.001 / \\
35 / 110\end{array}$ & 14 & $\mathrm{~L}$ & L & $\mathrm{L}$ & L & $\mathrm{N}$ & $\mathrm{N}$ & 3 & $\begin{array}{l}\text { E0622-D1- } \\
\text { 070416.ASC }\end{array}$ & $\begin{array}{l}\text { E0622-D2-Channel1 Apr 16, } \\
\text { 2007 13-15-43.txt }\end{array}$ & No video taken \\
\hline E0623 & 8 & Clay & 94.9 & 0.55 & 31.02 & 27.0 & 1 & 5 & 2.5 & - & 3.48 & - & - & - & - & $30 / 0.001 / 321$ & - & - & - & 14 & $\mathrm{~L}$ & L & L & $\mathrm{L}$ & $\mathrm{N}$ & $\mathrm{N}$ & 1 & $\begin{array}{l}\text { E0623-D1- } \\
\text { 070416.ASC }\end{array}$ & $\begin{array}{l}\text { E0623-D2-Channel1 Apr 16, } \\
\text { 2007 13-22-38 8xt }\end{array}$ & No video taken \\
\hline E0624 & 8 & Clay & 94.9 & 0.55 & 31.02 & 27.0 & 1 & 5 & 2.5 & - & 3.54 & - & - & - & - & $\begin{array}{l}30 / 0.001 / 32 / \\
110\end{array}$ & - & - & - & 14 & $L$ & L & $\mathrm{L}$ & $\mathrm{L}$ & $\mathrm{N}$ & $\mathrm{N}$ & 2 & $\begin{array}{l}\text { E0624-D1- } \\
\text { 070416.ASC }\end{array}$ & $\begin{array}{l}\text { E0624-D2-Channeli Apr 16, } \\
\text { 2007 13-28-48.txt }\end{array}$ & No video taken \\
\hline E0625 & 8 & Clay & 94.9 & 0.55 & 31.02 & 27.0 & 1 & 5 & 2.5 & - & 3.54 & - & - & - & - & $\begin{array}{l}30 / 0.001 / 32 / \\
110\end{array}$ & - & - & - & 14 & $\mathrm{~L}$ & L & L & L & $\mathrm{N}$ & $\mathrm{N}$ & 3 & 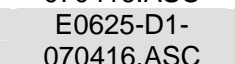 & $\begin{array}{l}\text { E0625-D2-Channel1 Apr 16, } \\
\text { 2007 13-34-53txt }\end{array}$ & No video taken \\
\hline E0626 & 8 & Clay & 94.9 & 0.55 & 31.02 & 27.0 & 2 & 4,5 & 2.5 & 3.46 & 3.49 & - & - & - & $30 / 0.001 / 32$ & / 30/0.001/321 & - & - & - & 14 & $\mathrm{~L}$ & L & L & L & $\mathrm{N}$ & $\mathrm{N}$ & 1 & E0626-D1- & E0626-D2-Channel1 Apr 16, & No video taken \\
\hline E0627 & 8 & Clay & 94.9 & 0.55 & 31.02 & 27.0 & 2 & 4,5 & 2.5 & 3.52 & 3.49 & - & . & & $\begin{array}{l}30 / 10.001 / 3 \\
110\end{array}$ & $\begin{array}{l}130 / 0.001 / 321 \\
110\end{array}$ & 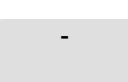 & & & 14 & $\mathrm{~L}$ & L & L & L & $\mathrm{N}$ & $\mathrm{N}$ & 2 & $\begin{array}{l}\text { E0627-D1- } \\
\text { 070416.ASC }\end{array}$ & $\begin{array}{l}\text { E0627-D2-Channel Apr 16, } \\
\text { 2007 13-58-15.txt }\end{array}$ & No video taken \\
\hline E0628 & 8 & Clay & 94.9 & 0.55 & 31.02 & 27.0 & 2 & 4,5 & 2.5 & 3.52 & 3.48 & - & & & $30 / 0.001 / 32$ & / 30/0.001/32/ & - & - & - & 14 & $\mathrm{~L}$ & L & L & $\mathrm{L}$ & $N$ & $N$ & 3 & $\begin{array}{l}\text { E0628-D1- } \\
\text { 070016.ASC }\end{array}$ & $\begin{array}{l}\text { E0628-D2-Channel1 Apr 16, } \\
\text { 2007 14-04-11 }\end{array}$ & No video taken \\
\hline E0629 & 8 & Clay & 94.9 & 0.55 & 31.0 & 27.0 & 3 & $4,5,6$ & 2.5 & 3.48 & 3.47 & 3.49 & - & 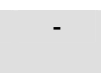 & $\begin{array}{l}30 / 0.001 / 32 \\
110\end{array}$ & $/ 30 / 0.001 / 32 /$ & $\begin{array}{l}30 / 0.001 / \\
32 / 110\end{array}$ & - & - & 14 & $\mathrm{~L}$ & L & L & $\mathrm{L}$ & $\mathrm{N}$ & $\mathrm{N}$ & 1 & $\begin{array}{l}\text { E0629-D1- } \\
\text { 070416.ASC }\end{array}$ & $\begin{array}{l}\text { E0629-D2-Chanell Apr 16, } \\
\text { 2007 14-19-00.txt }\end{array}$ & No video taken \\
\hline E0630 & 8 & Clay & 94.9 & 0.55 & 31.02 & 27.0 & 3 & $4,5,6$ & 2.5 & 3.48 & 3.47 & 3.49 & - & - & $30 / 0.001 / 32$ & / 30/0.001/32/ & $\begin{array}{l}30 / 0.001 / \\
32 / 110\end{array}$ & - & - & 14 & $\mathrm{~L}$ & L & L & L & $\mathrm{N}$ & $\mathrm{N}$ & 2 & $\begin{array}{l}\text { E0630-D1- } \\
\text { 070416.ASC }\end{array}$ & $\begin{array}{l}\text { E0630-D2-Channel1 Apr 16, } \\
\text { 2007 }\end{array}$ & No video taken \\
\hline E0631 & 8 & Clay & 94.9 & 0.55 & 31.0 & 27.0 & 3 & $4,5,6$ & 2.5 & 3.48 & 3.46 & 3.49 & - & & $\begin{array}{r}30 / 0.001 / 32 \\
110\end{array}$ & $/ 30 / 0.001 / 32 /$ & $\begin{array}{l}30 / 0.001 / \\
32 / 1110\end{array}$ & & - & 14 & $\mathrm{~L}$ & L & L & L & $\mathrm{N}$ & $\mathrm{N}$ & 3 & $\begin{array}{l}\text { E0631-D1- } \\
\text { 070416.ASC }\end{array}$ & $\begin{array}{l}\text { E0631-D2-Chan } \\
\text { 2007 14-2! }\end{array}$ & No video taken \\
\hline E0632 & 8 & Clay & 94.9 & 0.55 & 31.02 & 27.0 & 4 & $4,5,6,7$ & 2.5 & 3.47 & 3.46 & 3.48 & 3.53 & & $30 / 0.001 / 32$ & / 30/0.001/32/ & $\begin{array}{l}30 / 0.001 / \\
2 / 2110 \\
3\end{array}$ & | $30 / 0.001 /$ & & 14 & $\mathrm{~L}$ & L & L & $\mathrm{L}$ & $\mathrm{N}$ & $\mathrm{N}$ & 1 & $\begin{array}{l}\text { E0632-D1- } \\
\text { 070016 ASC }\end{array}$ & E0632-D2-Channel1 Apr 16, & No video taken \\
\hline E0633 & 8 & Clay & 94.9 & 0.55 & 31.0 & 27.0 & 4 & $4,5,6,7$ & 2.5 & 3.48 & 3.47 & 3.48 & 3.48 & & $\begin{array}{l}30 / 0.001 / 32 \\
110\end{array}$ & $/ 30 / 0.001 / 32 /$ & $\begin{array}{l}30 / 11001 / \\
32 / 1110\end{array}$ & $\begin{array}{l}30 / 1.001 / \\
32 / 110\end{array}$ & & 14 & $\mathrm{~L}$ & L & L & $\mathrm{L}$ & $\mathrm{N}$ & $\mathrm{N}$ & 2 & $\begin{array}{l}\text { E6633-D1- } \\
\text { 070416.ASC }\end{array}$ & $\begin{array}{l}\text { E0633-D2-Channel A Apr 16, } \\
\text { 2007 14-47-42.txt }\end{array}$ & No video taken \\
\hline E0634 & 8 & Clay & 94.9 & 0.55 & 31.02 & 27.0 & 4 & $4,5,6,7$ & 2.5 & 3.48 & 3.55 & 3.48 & 3.48 & & $\begin{array}{l}30 / 0.001 / 32 \\
110\end{array}$ & 30/0.001/32/ & $30 / 1.001 /$ & | $30 / 2.001 /$ & & 14 & $\mathrm{~L}$ & L & L & L & $\mathrm{N}$ & $\mathrm{N}$ & 3 & $\begin{array}{l}\text { E0634-D1- } \\
\text { 070416.ASC }\end{array}$ & $\begin{array}{l}\text { E0634-D2-Channel1 Apr 16, } \\
\text { E07 }\end{array}$ & No video taken \\
\hline $\begin{array}{l}\mathrm{E} \\
\mathrm{E}\end{array}$ & . & & & & 31 & & & & & & & & & & & & & & & & & & & & $\mathrm{~N}$ & & & $\begin{array}{l}E 0635-1 \\
07041\end{array}$ & Apr & \\
\hline $\begin{array}{l}\mathrm{E} 0635 \mathrm{BL} \\
2\end{array}$ & - & - & - & - & 31.02 & 27.0 & - & - & - & 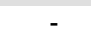 & - & - & - & - & - & & 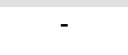 & 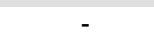 & - & - & 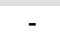 & - & - & - & $\mathrm{Y}$ & - & - & $\begin{array}{ll}0,106 \\
\text { E067 } \\
070\end{array}$ & I\# & \\
\hline E0635 & 8 & Clay & 94.9 & 0.55 & 31.02 & 27.0 & 2 & 4,5 & 2.5 & 3.45 & 3.49 & - & - & - & $\begin{array}{l}30 / 0.001 / \\
110\end{array}$ & 30/0.001/32/ & - & - & - & 14 & L & L & L & $\mathrm{L}$ & Y & N & 1 & $\begin{array}{l}\text { E0635-D1- } \\
\text { 070416.ASC }\end{array}$ & $\begin{array}{l}\text { Apr 1, 20-Dannel1 Apr 16, } \\
\text { E0635-D2-Chant } \\
2007 \text { 15-16-26.tt }\end{array}$ & No video taken \\
\hline E0636 & 8 & Clay & 94.9 & 0.55 & 31.02 & 27.0 & 2 & 4,5 & 2.5 & 3.52 & 3.47 & - & & & $\begin{array}{l}30 / 0.001 / 32 \\
110\end{array}$ & / 30/0.001/32/ & & & & 14 & $\mathrm{~L}$ & $\mathrm{~L}$ & L & L & $Y$ & $\mathrm{~N}$ & 2 & $\begin{array}{l}\text { E0636-D1- } \\
\text { 070416.ASC }\end{array}$ & $\begin{array}{l}\text { E0636-D2-Channel1 Apr 16, } \\
2007 \text { 15-20-40.txt }\end{array}$ & No video taken \\
\hline
\end{tabular}


Table A.1. Master Run Log, 8-PJM Configuration

\begin{tabular}{|c|c|c|c|c|c|c|c|c|c|c|c|c|c|c|c|c|c|c|c|c|c|c|c|c|c|c|c|c|c|c|}
\hline \multirow[b]{2}{*}{$\begin{array}{l}\text { Exp. } \\
\text { No. }{ }^{(a)} \\
\end{array}$} & \multirow[b]{2}{*}{$\begin{array}{l}\text { PJM } \\
\text { Config } \\
\end{array}$} & \multicolumn{5}{|c|}{ Simulant } & \multirow[b]{2}{*}{$\begin{array}{l}\text { No. } \\
\text { PJMs } \\
\mathrm{OB}^{()^{()}}\end{array}$} & \multirow[b]{2}{*}{$\begin{array}{c}\text { OB } \\
\text { PJMS }\end{array}$} & \multirow[b]{2}{*}{$\begin{array}{c}\text { OB } \\
\text { Duration } \\
\text { (c) }\end{array}$} & \multicolumn{5}{|c|}{$\begin{array}{l}\text { Drive Pressure Settings } \\
(\text { bar,_g( }) 2_{c}^{(c)}\end{array}$} & \multicolumn{5}{|c|}{ PJM OP Conditions (vacuum/delay/drive/vent time) } & \multirow[b]{2}{*}{$\begin{array}{c}\text { Target } \\
\text { Noz. Vel. } \\
(\mathrm{m} / \mathrm{s})^{(\mathrm{c})}\end{array}$} & \multicolumn{4}{|c|}{...Hydrophone Elevation } & \multirow[b]{2}{*}{$\begin{array}{c}\text { Sparger } \\
(\mathrm{Y} / \mathrm{N})\end{array}$} & \multirow[b]{2}{*}{$\begin{array}{l}\text { Video } \\
(\mathrm{Y} / \mathrm{N})\end{array}$} & \multirow[b]{2}{*}{$\begin{array}{c}\text { Repeat } \\
\#\end{array}$} & \multirow[b]{2}{*}{ DAS-1 Filename } & \multirow[b]{2}{*}{ DAS-2 Filename ${ }^{(\mathrm{d})}$} & \multirow[b]{2}{*}{$\begin{array}{l}\text { DAS-4 (Video) } \\
\text { Filename }\end{array}$} \\
\hline & & Type & $\begin{array}{l}\text { Ht. fm } \\
\text { Rim } \\
\text { (in) }\end{array}$ & $H / D$ & $\begin{array}{c}T_{y s} \\
(\mathrm{~Pa})\end{array}$ & $\begin{array}{c}\mathrm{k} \\
(\mathrm{CP})\end{array}$ & & & & $\underset{4}{\mathrm{PJM}}$ & $\begin{array}{c}\text { PJM } \\
5\end{array}$ & $\underset{6}{\text { PJM }}$ & $\underset{7}{\text { PJM }}$ & $\begin{array}{c}\text { PJM } \\
8\end{array}$ & PJM & PJM 5 & PJM 6 & PJM 7 & PJM 8 & & $\mathrm{H} 1$ & $\mathrm{H} 2$ & H3 & $\mathrm{H} 4$ & & & & & & \\
\hline E0637 & 8 & Clay & 94.9 & 0.55 & 31.02 & & 2 & 4,5 & 2.5 & 3.48 & 3.48 & & & & $\begin{array}{l}30 / 0.001 / 321 \\
110\end{array}$ & $|30 / 0.001 / 32|$ & & & & 14 & $\mathrm{~L}$ & $\mathrm{~L}$ & $\mathrm{~L}$ & $\mathrm{~L}$ & 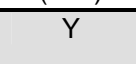 & $\mathrm{N}$ & 3 & $\begin{array}{ll}\text { E0637-D1- } \\
07016 \text { ASC }\end{array}$ & E0637-D2-Channel1 Apr 16, & No video taker \\
\hline E0638 & 8 & Clay & 94.9 & 0.55 & 31.02 & 27.0 & 2 & 4,5 & 12.5 & 3.46 & 3.49 & & I. & - & $\begin{array}{l}30 / 0.001 / 421 \\
110\end{array}$ & / 30/0.001/42/ & & & & 14 & $\mathrm{~L}$ & L & L & L & $\mathrm{N}$ & $\mathrm{N}$ & 1 & $\begin{array}{l}\text { E014038-D1- } \\
\text { 070416.ASC }\end{array}$ & $\begin{array}{l}\text { E0638-D2-Channel1 Apr 16, } \\
\text { 2007 15-33-51.txt }\end{array}$ & No video taker \\
\hline E0639 & 8 & Clay & 94.9 & 0.55 & 31.02 & 27.0 & 2 & 4,5 & 12.5 & 3.46 & 3.49 & & & & $\begin{array}{ll}30 / 0.001 / 42 / \\
110\end{array}$ & $\mid 30 / 0.001 / 421$ & & & & 14 & L & L & L & $\mathrm{L}$ & $\mathrm{N}$ & $\mathrm{N}$ & 2 & $\begin{array}{l}\text { E0639-D1- } \\
07016 \text { ASC }\end{array}$ & $\begin{array}{l}\text { E0639-D2-Channel1 Apr 16, } \\
\text { 2007 }\end{array}$ & No video taker \\
\hline E0640 & 8 & Clay & 94.9 & 0.55 & 31.02 & 27.0 & 2 & 4,5 & 13 & 3.51 & 3.52 & - & - & - & $\begin{array}{l}30 / 0.001 / 42 / \\
110\end{array}$ & / 30/0.001/42/ & - & - & - & 14 & L & L & L & $\mathrm{L}$ & $\mathrm{N}$ & $\mathrm{N}$ & 3 & $\begin{array}{l}\text { E0640-D1- } \\
070416 \text { ASC }\end{array}$ & $\begin{array}{l}\text { E0640-D2-Channel1 Apr 16, } \\
\text { 2007 15-41-43.ttt }\end{array}$ & No video taker \\
\hline E0641 & 8 & Clay & 94.9 & 0.55 & 31.02 & 27.0 & 1 & 5 & 4.5 & - & 3.99 & - & - & - & & $30 / 0.001 / 321$ & - & - & - & 15 & L & L & L & L & $\mathrm{N}$ & $\mathrm{N}$ & 1 & $\begin{array}{l}\text { E0641-D1- } \\
\text { 077416 ASC }\end{array}$ & $\begin{array}{l}\text { E0641-D2-Channel1 Apr 16, } \\
\text { 2007 15-53-07 }\end{array}$ & No video taker \\
\hline E0642 & 8 & Clay & 94.9 & 0.55 & 31.02 & 27.0 & 1 & 5 & 4.5 & - & 3.99 & - & - & - & - & $30 / 0.001 / 321$ & - & - & - & 15 & $\mathrm{~L}$ & L & L & $\mathrm{L}$ & $\mathrm{N}$ & $\mathrm{N}$ & 2 & $\begin{array}{l}\text { E0642-D1- } \\
\text { E70416 ASC }\end{array}$ & $\begin{array}{c}\text { E0642-D2-Channel1 Apr 16, } \\
200715-56-19\end{array}$ & No video taker \\
\hline E0643 & 8 & Clay & 94.9 & 0.55 & 31.02 & 27.0 & 1 & 5 & 4.5 & - & 4.00 & - & - & - & - & 30/0.0001/321 & & & & 15 & L & L & L & L & $\mathrm{N}$ & $\mathrm{N}$ & 3 & $\begin{array}{l}\text { E0643-D1- } \\
\text { 07016 }\end{array}$ & $\begin{array}{l}\text { E0643-D2-Channel1 Apr 16, } \\
\text { 2007 }\end{array}$ & No video taker \\
\hline E0644 & 8 & Clay & 94.9 & 0.55 & 31.02 & 27.0 & 2 & 4,5 & 4.5 & 4.00 & 4.01 & - & - & - & $30 / 0.001 / 32$ & / 30/0.001/32/ & - & - & - & 15 & L & L & L & L & $\mathrm{N}$ & $\mathrm{N}$ & 1 & 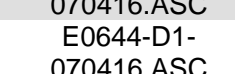 & E0644-D2-Channel1 Apr 16, & No video taker \\
\hline E0645 & 8 & Clay & 94.9 & 0.55 & 31.02 & 27.0 & 2 & 4,5 & 4.5 & 4.01 & 3.99 & & & - & $\begin{array}{l}30 / 0.001 / 321 \\
110\end{array}$ & / 30/0.001/32/ & - & & & 15 & L & $\mathrm{L}$ & $\mathrm{L}$ & $\mathrm{L}$ & $\mathrm{N}$ & $\mathrm{N}$ & 2 & $\begin{array}{l}\text { E0645-D1- } \\
\text { 070416.ASC }\end{array}$ & $\begin{array}{l}\text { E0645-D2-Channel1 Apr 16, } \\
\text { 2007 16-08-33.txt }\end{array}$ & No video taker \\
\hline E0646 & 8 & Clay & 94.9 & 0.55 & 31.02 & 27.0 & 2 & 4,5 & 4.5 & 4.01 & 3.99 & - & & - & $\begin{array}{l}30 / 0.001 / 321 \\
110\end{array}$ & $\begin{array}{l}\text { / 30/0.001/32/ } \\
110\end{array}$ & & & & 15 & L & $\mathrm{L}$ & $\mathrm{L}$ & L & $\mathrm{N}$ & $\mathrm{N}$ & 3 & $\begin{array}{l}\text { E0646-D1- } \\
\text { 070416.ASC }\end{array}$ & $\begin{array}{l}\text { E0646-D2-Channel1 Apr 16, } \\
2007 \text { 16-13-47.txt }\end{array}$ & No video taker \\
\hline E0646BL & - & - & - & - & 31.02 & 27.0 & - & - & - & - & - & - & - & - & & & - & - & - & - & - & - & - & - & $\mathrm{N}$ & - & - & $\begin{array}{l}\text { E0646-D1-BL- } \\
\text { 070416.ASC }\end{array}$ & $\begin{array}{l}\text { E0646-2D-2LL-Channel|I Apr } \\
16 \text {, 2007 16-21-47.txt }\end{array}$ & - \\
\hline $\begin{array}{l}\text { Medium c } \\
\text { E0647BL }\end{array}$ & clay leve & I, hydrol & phone I & evel = 1 & 28.82 & & & & - & & - & & & & & & & & & & & & & & $N$ & & 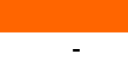 & & E064 & \\
\hline E0647 & 8 & Clay & 95.5 & 0.55 & 28.82 & 25.7 & 1 & 5 & 4.5 & - & 4.00 & . & - & - & & $\begin{array}{c}30 / 0.001 / 32 / \\
110\end{array}$ & - & - & - & 15 & $\mathrm{M}$ & M & M & M & $\mathrm{N}$ & $Y$ & 1 & $\begin{array}{l}\text { 070417.ASC } \\
\text { E0647-D1- } \\
\text { 070417.ASC }\end{array}$ & $\begin{array}{l}\text { 17, 2007 09-44-51.txt } \\
\text { E0647-D2-Channel1 Apr 17, } \\
2007 \text { 09-53-35.txt }\end{array}$ & No video taker \\
\hline E0648 & 8 & Clay & 95.5 & 0.55 & 28.82 & 25.7 & 1 & 5 & 4.5 & & 4.01 & - & - & - & & $30 / 0.001 / 321$ & & & & 15 & M & M & M & M & $\mathrm{N}$ & $\mathrm{Y}$ & 2 & $\begin{array}{l}\text { E0648-D1- } \\
\text { 0070417.ASC }\end{array}$ & $\begin{array}{l}\text { E0648-D2-Channel1 Apr 17, } \\
\text { 2007 09-58-06.txt }\end{array}$ & No video taker \\
\hline E0649 & 8 & Clay & 95.5 & 0.55 & 28.82 & 25.7 & 1 & 5 & 4.5 & - & 4.02 & - & - & - & & $\begin{array}{l}30 / 0.001 / 32 / \\
110\end{array}$ & & & & 15 & M & M & M & M & $\mathrm{N}$ & Y & 3 & $\begin{array}{l}\text { E0649-D1- } \\
\text { 070417.ASC }\end{array}$ & $\begin{array}{l}\text { E064-D2-Channel1 Apr 17, } \\
2007 \text { 10-01-36.txt }\end{array}$ & No video taker \\
\hline E0650 & 8 & Clay & 95.5 & 0.55 & 28.82 & 25.7 & 2 & 4,5 & 4.5 & 4.04 & 4.02 & - & - & - & $30 / 0.001 / 32$ & $\mid \begin{array}{l}\mid 30 / 0.000 / 321 \\
110\end{array}$ & - & - & - & 15 & $\mathrm{M}$ & M & M & M & $\mathrm{N}$ & Y & 1 & $\begin{array}{l}\text { E0650-D1- } \\
070417 \text { ASC }\end{array}$ & $\begin{array}{l}\text { E0650-D2-Channel1 Apr 17, } \\
\text { 2007 10-7-73- }\end{array}$ & No video taker \\
\hline E0651 & 8 & Clay & 95.5 & 0.55 & 28.82 & 25.7 & 2 & 4,5 & 4.5 & 4.02 & 4.02 & - & - & - & $\begin{array}{l}30 / 0.001 / 32 \\
110\end{array}$ & / 30/0.001/32/ & - & - & - & 15 & M & M & M & M & $\mathrm{N}$ & Y & 2 & $\begin{array}{l}\text { E0651-D1- } \\
\text { 070417.ASC }\end{array}$ & $\begin{array}{c}\text { E0651-D2-Channel1 Apr 17, } \\
\text { 2007 10-12-05.txt }\end{array}$ & No video taker \\
\hline E0652 & 8 & Clay & 95.5 & 0.55 & 28.82 & 25.7 & 2 & 4,5 & 4.5 & 4.02 & 4.01 & - & - & - & $30 / 0.001 / 32$ & $\mid$ 30/0.000/321 & - & - & - & 15 & M & M & M & M & $\mathrm{N}$ & $\mathrm{Y}$ & 3 & $\begin{array}{l}\text { E0652-D1- } \\
070417 \text { ASC }\end{array}$ & $\begin{array}{l}\text { E0652-D2-Channel1 Apr 17, } \\
\text { 2007 10.1-5-56 }\end{array}$ & No video taker \\
\hline E0653 & 8 & Clay & 95.5 & 0.55 & 28.82 & 25.7 & 1 & 5 & 3 & & 3.52 & & & - & & $\begin{array}{l}30 / 0.001 / 32 / \\
110\end{array}$ & & & & 14 & M & M & M & M & $\mathrm{N}$ & $\mathrm{Y}$ & 1 & $\begin{array}{l}\text { E0653-D1- } \\
\text { 070417.ASC }\end{array}$ & $\begin{array}{l}\text { E0653-D } \\
200\end{array}$ & No video taker \\
\hline E0654 & 8 & Clay & 95.5 & 0.55 & 28.82 & 25.7 & 1 & 5 & 3 & & 3.48 & & & - & & $30 / 0.001 / 321$ & & & & 14 & M & M & M & M & N & Y & 2 & $\begin{array}{l}\text { E0654-D1- } \\
\text { O70417 ASC }\end{array}$ & $\begin{array}{l}\text { E0654-D2-C } \\
20071\end{array}$ & No video taker \\
\hline E0655 & 8 & Clay & 95.5 & 0.55 & 28.82 & 25.7 & 1 & 5 & 3 & - & 3.48 & - & - & - & & $\begin{array}{l}30 / 0.001 / 32 / \\
110\end{array}$ & & - & - & 14 & M & M & M & M & $\mathrm{N}$ & Y & 3 & $\begin{array}{l}\text { E0655-D1- } \\
\text { 070417.ASC }\end{array}$ & $\begin{array}{l}\mathrm{E} 0655-\mathrm{D} \\
200\end{array}$ & No video taker \\
\hline E0656 & 8 & Clay & 95.5 & 0.55 & 28.82 & 25.7 & 2 & 4,5 & 2.5 & 3.45 & 3.50 & & & - & $30 / 0.001 / 32$ & $\mid \begin{array}{l}30 / 0.001 / 321 \\
110\end{array}$ & & & & 14 & M & M & M & M & $\mathrm{N}$ & Y & 1 & $\begin{array}{l}\text { E0656-D1- } \\
07047 \text { ASC }\end{array}$ & $\begin{array}{l}\text { E0656-D2-C } \\
20071\end{array}$ & No video taker \\
\hline E0657 & 8 & Clay & 95.5 & 0.55 & 28.82 & 25.7 & 2 & 4,5 & 3 & 3.55 & 3.48 & - & - & - & $\begin{array}{l}30 / 0.001 / 321 \\
110\end{array}$ & $\mid$ / 30/0.001/32/ & - & - & - & 14 & $M$ & M & M & M & N & $Y$ & 2 & $\begin{array}{l}\text { E06 } \\
0704\end{array}$ & $\begin{aligned} E 0657-\mathrm{L} \\
20\end{aligned}$ & No video taker \\
\hline E0658 & 8 & Clay & 95.5 & 0.55 & 28.82 & 25.7 & 2 & 4,5 & 2.5 & 3.52 & 3.48 & - & - & - & 30/0.001/32 & $\mid \begin{array}{l}30 / 0.000 / 321 \\
110\end{array}$ & - & - & - & 14 & M & M & M & M & N & Y & 3 & $\begin{array}{l}\text { E0658-D1- } \\
\text { 070417 ASC }\end{array}$ & $\begin{array}{l}\text { E0058-D2-Chan } \\
\text { 2007 10-5 }\end{array}$ & No video taker \\
\hline E0659 & 8 & Clay & 95.5 & 0.55 & 28.82 & 25.7 & 3 & $4,5,6$ & 2.5 & 3.45 & 3.46 & 3.49 & - & - & $\begin{array}{l}30 / 0.001 / 32 \\
110\end{array}$ & $\mid \begin{array}{l}30 / 0.0001 / 32 \mid \\
110\end{array}$ & $\begin{array}{l}30 / 0.001 / / \\
32 / 1110\end{array}$ & - & - & 14 & M & M & M & M & $\mathrm{N}$ & $\mathrm{Y}$ & 1 & EC & $\begin{aligned} E 0659-1 \\
20\end{aligned}$ & No video taker \\
\hline E0660 & 8 & Clay & 95.5 & 0.55 & 28.82 & 25.7 & 3 & $4,5,6$ & 2.5 & 3.46 & 3.47 & 3.49 & & - & $\begin{array}{c}30 / 0.001 / \\
110\end{array}$ & $\mid \begin{array}{l}30 / 0.001 / 32 / \\
110\end{array}$ & $\begin{array}{l}30 / 0.001 / \\
32 / 110\end{array}$ & & & 14 & M & M & M & M & $\mathrm{N}$ & $\mathrm{Y}$ & 2 & $\begin{array}{l}\text { E0660-D1- } \\
\text { 070417.ASC }\end{array}$ & $\begin{aligned} E 0660-D \\
20\end{aligned}$ & No video taker \\
\hline E0661 & 8 & Clay & 95.5 & 0.55 & 28.82 & 25.7 & 3 & $4,5,6$ & 3 & 3.54 & 3.46 & 3.49 & & . & $\begin{array}{l}30 / 0.001 / 321 \\
110\end{array}$ & $\mid \begin{array}{l}30 / 0.001 / 321 \\
110\end{array}$ & $\begin{array}{l}30 / 0.001 / \\
32 / 110\end{array}$ & & & 14 & $M$ & M & M & M & $\mathrm{N}$ & Y & 3 & $\begin{array}{l}\text { E0661-D1- } \\
\text { 070417.ASC }\end{array}$ & E0661-I & No video taker \\
\hline E0662 & 8 & Clay & 95.5 & 0.55 & 28.82 & 25.7 & 4 & $4,5,6,7$ & 2.5 & 3.51 & 3.50 & 3.48 & 3.55 & - & $\begin{array}{l}30 / 0.001 / 321 \\
110\end{array}$ & / 30/0.001/32/ & $\begin{array}{l}30 / 0.001 / \\
32 / 110\end{array}$ & $\begin{array}{c}30 / 0.001 / \\
32 / 110\end{array}$ & - & 14 & M & M & M & M & $\mathrm{N}$ & $\mathrm{Y}$ & 1 & $\begin{array}{l}\text { E0662-D1- } \\
\text { 070417.ASC }\end{array}$ & $\begin{array}{l}\text { E0662-D2-Chan } \\
2007 \text { 11-3! }\end{array}$ & No video taker \\
\hline E0663 & 8 & Clay & 95.5 & 0.55 & 28.82 & & 4 & $4,5,6,7$ & 2.5 & 3.52 & 3.46 & 3.50 & 3.43 & - & $\begin{array}{l}30 / 0.001 / 321 \\
110\end{array}$ & / 30/0.001/32/ & $\begin{array}{l}30 / 0.001 / \\
32 / 110\end{array}$ & $\begin{array}{c}30 / 0.001 / \\
32 / 110\end{array}$ & - & 14 & M & M & M & M & $\mathrm{N}$ & Y & 1 & $\begin{array}{l}\text { not recorded by } \\
\text { error }\end{array}$ & $\begin{array}{l}\text { y E0663-D2-Channell Apr 17, } \\
\text { 2007 13-38-38.txt }\end{array}$ & No video taker \\
\hline E0664 & 8 & Clay & 95.5 & 0.55 & 28.82 & 25.7 & 4 & $4,5,6,7$ & 3 & 3.51 & 3.46 & 3.49 & 3.55 & - & $\begin{array}{l}30 / 0.001 / 321 \\
110\end{array}$ & / 30/0.001/32/ & $\begin{array}{l}321101 / \\
30 / 0.1110 \\
32 / 110\end{array}$ & $\begin{array}{l}30 / 1.001 / 1 \\
32 / 110\end{array}$ & - & 14 & M & M & M & M & $\mathrm{N}$ & $\mathrm{Y}$ & 2 & $\begin{array}{l}\text { E0664-D1- } \\
\text { 070417.ASC }\end{array}$ & $\begin{aligned} E 0664-D \\
200\end{aligned}$ & No video taker \\
\hline E0665 & 8 & Clay & 95.5 & 0.55 & 28.82 & & 4 & $4,5,6,7$ & 3 & 3.52 & 3.46 & 3.49 & 3.48 & - & $\begin{array}{l}30 / 0.001 / 321 \\
110\end{array}$ & $\mid \begin{array}{c}30 / 0.001 / 32 / \\
110\end{array}$ & $\begin{array}{l}30 / 0.001 / \\
32 / 110\end{array}$ & $\begin{array}{c}30 / 0.001 / \\
32 / 110\end{array}$ & - & 14 & M & M & M & M & $\mathrm{N}$ & Y & 3 & $\begin{array}{l}\text { E0665-D1- } \\
\text { 070417.ASC }\end{array}$ & $\begin{array}{l}\text { E0665-D2-Chan } \\
2007 \text { 13-51 }\end{array}$ & No video taker \\
\hline E0666 & 8 & Clay & 95.5 & 0.55 & 28.82 & 25.7 & 4 & $4,5,6,7$ & 3 & 3.51 & 3.46 & 3.49 & 3.48 & - & $\begin{array}{l}30 / 0.001 / 32 \\
110\end{array}$ & $\mid \begin{array}{l}30 / 0.001 / 32 / \\
110\end{array}$ & $\begin{array}{l}30 / 0.001 / \\
32 / 110\end{array}$ & $\begin{array}{c}30 / 0.001 / \\
32 / 110\end{array}$ & & 14 & $\mathrm{~N}$ & M & M & M & $\mathrm{N}$ & $\mathrm{Y}$ & 4 & $\begin{array}{l}\text { DI- } \\
\text { ASC }\end{array}$ & Apr 17, & No video taker \\
\hline E0667 & 8 & Clay & 95.5 & 0.55 & 28.82 & 25.7 & 1 & 8 & 3 & & & & & 3.49 & & & & & $\begin{array}{c}35 / 0.001 / \\
35 / 110\end{array}$ & 14 & M & M & M & M & $\mathrm{N}$ & Y & 1 & $\begin{array}{l}\text { E0667-D1- } \\
\text { 070417.ASC }\end{array}$ & $\begin{array}{l}\text { E0667-D2-Channel1 Apr 17, } \\
2007 \text { 14-05-29.txt }\end{array}$ & No video taker \\
\hline
\end{tabular}


Table A.1. Master Run Log, 8-PJM Configuration

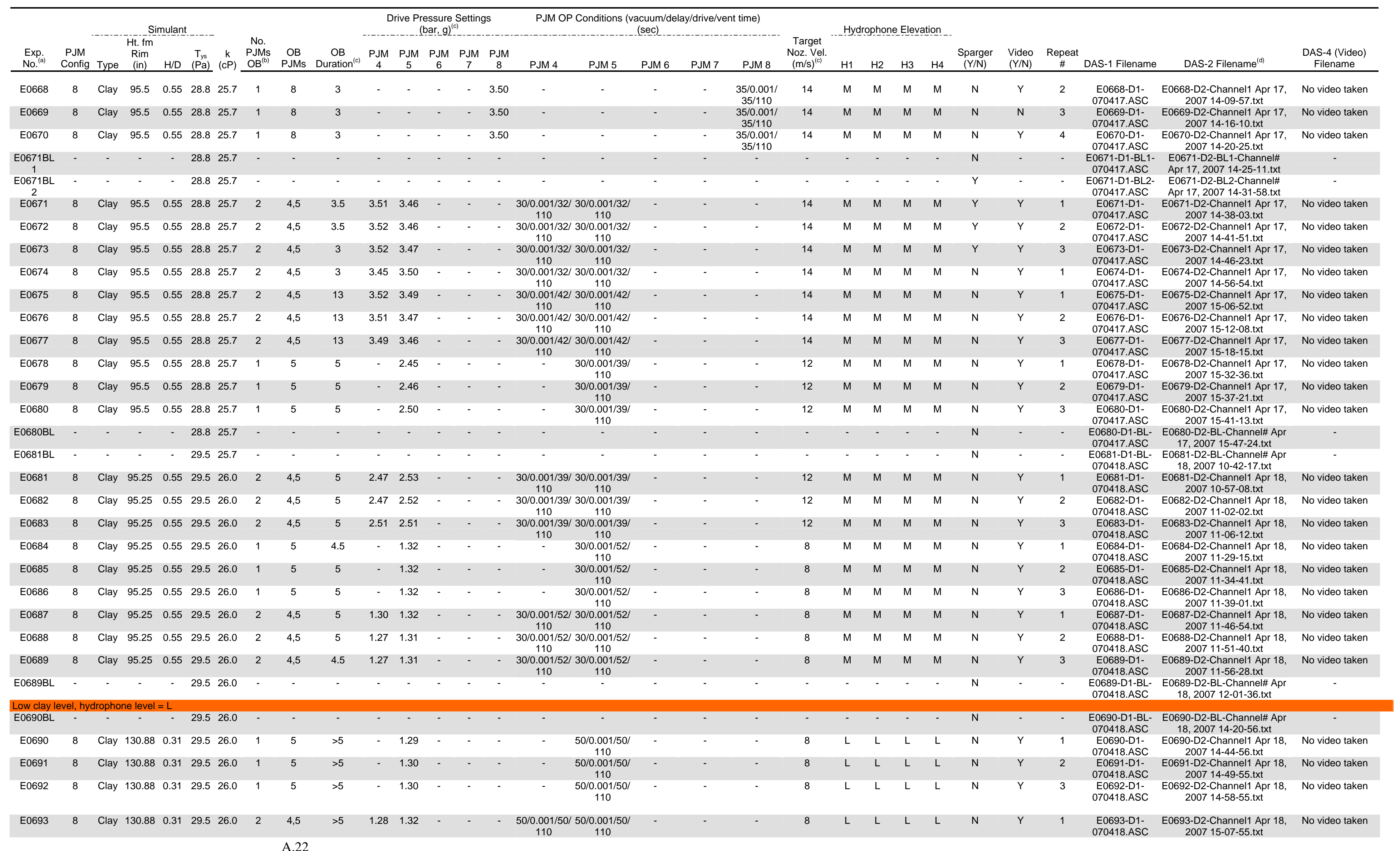


Table A.1. Master Run Log, 8-PJM Configuration

\begin{tabular}{|c|c|c|c|c|c|c|c|c|c|c|c|c|c|c|c|c|c|c|c|c|c|c|c|c|c|c|c|c|c|c|}
\hline \multirow[b]{2}{*}{ 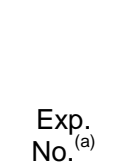 } & \multirow[b]{2}{*}{$\begin{array}{l}\text { PJM } \\
\text { Config }\end{array}$} & \multirow{2}{*}{ Type } & \multicolumn{4}{|c|}{ Simulant } & \multirow[b]{2}{*}{$\begin{array}{l}\text { No. } \\
\text { PJMS } \\
\mathrm{OB}^{(b)}\end{array}$} & \multirow[b]{2}{*}{$\begin{array}{l}\text { OB } \\
\text { PJMs }\end{array}$} & \multirow[b]{2}{*}{$\begin{array}{l}\mathrm{OB} \\
\text { Duration }{ }^{(\mathrm{c})}\end{array}$} & \multicolumn{5}{|c|}{$\begin{array}{l}\text { Drive Pressure Settings } \\
\quad(\text { (bar,_gl })_{-}^{(c)}\end{array}$} & \multicolumn{5}{|c|}{ PJM OP Conditions (vacuum/delay/drive/vent time) } & \multirow[b]{2}{*}{$\begin{array}{l}\text { Target } \\
\text { Noz. Vel. } \\
(\mathrm{m} / \mathrm{s})^{(\mathrm{c})}\end{array}$} & \multicolumn{4}{|c|}{ Hydrophone Elevation } & \multirow[b]{2}{*}{$\begin{array}{l}\text { Sparger } \\
(\text { Y } / N)\end{array}$} & \multirow[b]{2}{*}{$\begin{array}{l}\text { Video } \\
(\mathrm{Y} / \mathrm{N})\end{array}$} & \multirow[b]{2}{*}{$\begin{array}{c}\text { Repeat } \\
\#\end{array}$} & \multirow[b]{2}{*}{ DAS-1 Filename } & \multirow[b]{2}{*}{ DAS-2 Filename } & \\
\hline & & & $\begin{array}{l}\text { Ht. fm } \\
\text { Rim } \\
\text { (in) }\end{array}$ & $H / D$ & $\begin{array}{c}T_{y s} \\
(P a)\end{array}$ & $\begin{array}{c}k \\
(C P)\end{array}$ & & & & PJM & $\underset{5}{\mathrm{PJM}}$ & $\underset{6}{\mathrm{PJM}}$ & $\underset{7}{\mathrm{PJM}}$ & $\begin{array}{c}\text { PJM } \\
8\end{array}$ & PJM 4 & PJM & PJM 6 & PJM 7 & PJM 8 & & $\mathrm{H} 1$ & $\mathrm{H} 2$ & H3 & $\mathrm{H} 4$ & & & & & & $\begin{array}{l}\text { DAS-4 (Video) } \\
\text { Filename }\end{array}$ \\
\hline E0694 & & & & & & & & 4,5 & $>5$ & 1.28 & & & & & $50 / 0.001 / 50 /$ & $\begin{array}{l}50 / 0.001 / 50 / \\
110\end{array}$ & & & & & $\frac{1}{L}$ & $\mathrm{~L}$ & $\mathrm{~L}$ & $\mathrm{~L}$ & $\mathrm{~N}$ & 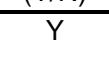 & 2 & $\begin{array}{l}\text { E0694-D1- } \\
\text { 070418.ASC }\end{array}$ & $\begin{array}{l}\text { E0694-D2-Channel1 Apr 18, } \\
\text { 2007 15-13-19.txt }\end{array}$ & No video taken \\
\hline E0695 & 8 & Clay & 130.88 & 0.31 & 29.5 & 26.0 & 2 & 4,5 & $>5$ & 1.29 & 1.28 & - & & & $\begin{array}{l}50 / 0.001 / 50 / \\
110\end{array}$ & $\begin{array}{l}50 / 0.001 / 50 / \\
110\end{array}$ & & & & 8 & L & L & L & $\mathrm{L}$ & $\mathrm{N}$ & Y & 3 & $\begin{array}{l}\text { E0695-D1- } \\
\text { 070418.ASC }\end{array}$ & $\begin{array}{l}\text { E0695-D2-Channel1 Apr 18, } \\
2007 \text { 15-18-49.txt }\end{array}$ & No video taken \\
\hline E0696 & 8 & Clay & 130.88 & 0.31 & 29.5 & 26.0 & 1 & 5 & 5 & - & 2.55 & - & - & - & - & $50 / 0.001 / 36 /$ & - & - & - & 12 & L & $\mathrm{L}$ & L & L & $\mathrm{N}$ & Y & 1 & $\begin{array}{l}\text { E0696-D1- } \\
\text { 07048.ASC }\end{array}$ & $\begin{array}{l}\text { E0696-D2-Channel1 Apr 18, } \\
\text { 2007 15-32-46.txt }\end{array}$ & No video taken \\
\hline E0697 & 8 & Clay & 130.88 & 0.31 & 29.5 & 26.0 & 1 & 5 & 4 & - & 2.48 & - & - & - & - & $\begin{array}{l}50 / 0.001 / 36 / \\
110\end{array}$ & - & - & - & 12 & L & L & L & L & N & Y & 2 & E0697-D1- & E0697-D2-Channel1 Apr 18, & No video taken \\
\hline E0698 & 8 & Clay & 130.88 & 0.31 & 29.5 & 26.0 & 1 & 5 & 4 & - & 2.46 & - & - & - & - & $\begin{array}{l}50 / 0.001 / 36 / \\
110\end{array}$ & - & - & - & 12 & L & L & L & L & $\mathrm{N}$ & Y & 3 & $\begin{array}{l}\text { E0698-D1- } \\
\text { 070418.ASC }\end{array}$ & $\begin{array}{l}\text { E0698-D2-Channel Apr 18, } \\
\text { 2007 15-42-26 txt }\end{array}$ & No video taken \\
\hline E0698BL & - & & & & 29.5 & 26.0 & - & - & - & - & - & - & - & - & - & & & - & - & & - & & & - & $\mathrm{N}$ & & & $\begin{array}{l}\text { E0698-D1-BL- } \\
\text { 070418.ASC }\end{array}$ & $\begin{array}{l}\text { E0698-D2-BL-Channel\# Apr } \\
\text { 18, } 2007 \text { 15-47-34.txt }\end{array}$ & \\
\hline E0699BL & - & - & - & & 29.5 & 26.0 & - & - & - & - & - & - & - & - & - & & - & - & - & - & - & - & - & - & $\mathrm{N}$ & - & - & E0699-D1-BL- & E0699-D2-BL-Channel\# Apr & \\
\hline E0699 & 8 & Clay & 131.00 & 0.31 & 29.5 & 26.0 & 2 & 4,5 & 4 & 2.51 & 2.46 & - & - & - & $\begin{array}{l}50 / 0.001 / 36 / \\
110\end{array}$ & $\begin{array}{l}50 / 0.001 / 36 / \\
110\end{array}$ & & - & - & 12 & L & L & L & L & $\mathrm{N}$ & Y & 1 & $\begin{array}{l}\text { E0699-DD- } \\
\text { 070419.ASC }\end{array}$ & $\begin{array}{l}\text { E0699-D2-Channel Apr 19, } \\
\text { 2007 09-46-10.txt }\end{array}$ & No video taken \\
\hline E0700 & 8 & Clay & 131.00 & 0.31 & 29.5 & 26.0 & 2 & 4,5 & 4.5 & 2.52 & 2.47 & - & - & & $\begin{array}{l}50 / 0.001 / 36 / \\
110\end{array}$ & $\begin{array}{l}\text { 50/0.001/36/ } \\
110\end{array}$ & & - & - & 12 & $\mathrm{~L}$ & L & L & L & $\mathrm{N}$ & Y & 2 & $\begin{array}{l}\text { E0700-D1- } \\
\text { 070419.ASC }\end{array}$ & $\begin{array}{l}\text { E0700-D2-Channel1 Apr 19, } \\
\text { 2007 09-50-45.txt }\end{array}$ & No video taken \\
\hline E0701 & 8 & Clay & 131.00 & 0.31 & 29.5 & 26.0 & 2 & 4,5 & 4 & 2.51 & 2.46 & - & - & - & $\begin{array}{l}50 / 0.001 / 36 / \\
110\end{array}$ & $\begin{array}{l}\text { | 50/0.001/36/ } \\
110\end{array}$ & - & - & - & 12 & L & L & L & L & $\mathrm{N}$ & Y & 3 & $\begin{array}{l}\text { E0701-D1- } \\
\text { 070419.ASC }\end{array}$ & $\begin{array}{l}\text { E0701-D2-Chaneli Apr 19, } \\
2007 \text { 09-55-02.txt }\end{array}$ & No video taken \\
\hline E0702 & 8 & Clay & 131.00 & 0.31 & 29.5 & 26.0 & 1 & 8 & 4.5 & - & - & - & - & 3.51 & -1 & 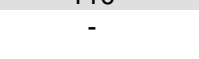 & - & - & $\begin{array}{l}50 / 0.001 / \\
35 / 110\end{array}$ & 14 & L & L & L & L & $\mathrm{N}$ & Y & 1 & $\begin{array}{l}\text { E0702-D1- } \\
\text { O07041- }\end{array}$ & $\begin{array}{l}\text { E0702-D2-Channel1 Apr 19, } \\
\text { D077 }\end{array}$ & No video taken \\
\hline E0703 & 8 & Clay & 131.00 & 0.31 & 29.5 & 26.0 & 1 & 8 & 4.5 & - & - & - & - & 3.51 & - & - & - & - & $\begin{array}{l}50 / 0.001 / \\
35 / 110\end{array}$ & 14 & L & L & L & L & $\mathrm{N}$ & Y & 2 & $\begin{array}{l}\text { E0703-D1- } \\
\text { 070419.ASC }\end{array}$ & $\begin{array}{l}\text { E0703-D2-Channel1 Apr 19, } \\
\text { 2007 10-12-16.txt }\end{array}$ & No video taken \\
\hline E0704 & 8 & Clay & 131.00 & 0.31 & 29.5 & 26.0 & 1 & 8 & 5 & - & - & - & - & 3.52 & - & & - & - & $\begin{array}{l}50 / 0.001 / \\
35 / 110\end{array}$ & 14 & L & L & L & $\mathrm{L}$ & $\mathrm{N}$ & Y & 3 & $\begin{array}{l}\text { E0704-D1- } \\
\text { 070419.ASC }\end{array}$ & $\begin{array}{l}\text { E0704-D2-Channel1 Apr 19, } \\
2007 \text { 10-16-19.txt }\end{array}$ & No video taken \\
\hline E0705 & 8 & Clay & 131.00 & 0.31 & 29.5 & 26.0 & 1 & 5 & 4.5 & & 3.46 & - & & & & $\begin{array}{c}50 / 0.001 / 32 / \\
110\end{array}$ & & - & & 14 & L & L & L & $\mathrm{L}$ & $\mathrm{N}$ & $y$ & 1 & $\begin{array}{l}\text { E0705-D1- } \\
\text { 070419.ASC }\end{array}$ & $\begin{array}{l}\text { E0705-D2-Cha } \\
2007 \text { 10- }\end{array}$ & No video taken \\
\hline E0706 & 8 & Clay & 131.00 & 0.31 & 29.5 & 26.0 & 1 & 5 & 4.5 & - & 3.47 & - & - & & - & $\begin{array}{l}50 / 0.001 / 32 / \\
110\end{array}$ & & - & - & 14 & L & L & L & L & $\mathrm{N}$ & Y & 2 & $\begin{array}{l}\text { E0706-D1- } \\
\text { 070419.ASC }\end{array}$ & $\begin{array}{l}\text { E0706-D2-Channel1 Apr 19, } \\
\text { 2007 10-25-04.txt }\end{array}$ & No video taken \\
\hline E0707 & 8 & Clay & 131.00 & 0.31 & 29.5 & 26.0 & 1 & 5 & 4.5 & - & 3.47 & - & - & & - & $50 / 0.001 / 321$ & & - & - & 14 & L & L & L & L & $\mathrm{N}$ & $\mathrm{Y}$ & 3 & $\begin{array}{l}\text { E0707-D1- } \\
\text { 07049.ASC }\end{array}$ & $\begin{array}{l}\text { E0707-D2-Channel1 Apr 19, } \\
2007 \text { 10-28-50.txt }\end{array}$ & No video taken \\
\hline E0708 & 8 & Clay & 131.00 & 0.31 & 29.5 & 26.0 & 2 & 4,5 & 4 & 3.48 & 3.47 & - & - & & $\begin{array}{l}50 / 0.001 / 321 \\
110\end{array}$ & $\begin{array}{l}50 / 0.001 / 32 / \\
110\end{array}$ & & - & - & 14 & L & L & L & L & $\mathrm{N}$ & Y & 1 & $\begin{array}{l}\text { E0708-D1- } \\
\text { E019 } \\
070419 \text { ASC }\end{array}$ & E0708-D2-Channel1 Apr 19, & No video taken \\
\hline E0709 & 8 & Clay & 131.00 & 0.31 & 29.5 & 26.0 & 2 & 4,5 & 4 & 3.55 & 3.48 & - & - & - & $50 / 0.001 / 321$ & $\begin{array}{l}50 / 0.001 / 32 / \\
110\end{array}$ & - & - & - & 14 & L & L & L & $\mathrm{L}$ & $\mathrm{N}$ & Y & 2 & $\begin{array}{l}\text { E0709-D1- } \\
\text { 070419.ASC }\end{array}$ & $\begin{array}{l}\text { E0709-D2-Char } \\
200710-4\end{array}$ & No video taken \\
\hline E0710 & 8 & Clay & 131.00 & 0.31 & 29.5 & 26.0 & 2 & 4,5 & 4 & 3.54 & 3.47 & - & - & - & $\begin{array}{l}50 / 0.001 / 321 \\
110\end{array}$ & | 50/0.0001/321 & - & - & - & 14 & L & L & L & L & $\mathrm{N}$ & Y & 3 & $\begin{array}{l}\text { E0710-D1- } \\
\text { E010 }\end{array}$ & $\begin{array}{l}\text { E0710-D2-Char } \\
\text { ODOT }\end{array}$ & No video taken \\
\hline E0711 & 8 & Clay & 131.00 & 0.31 & 29.5 & 26.0 & 3 & $4,5,6$ & 4.5 & 3.54 & 3.47 & 3.49 & - & - & $\begin{array}{l}50 / 0.001 / 321 \\
110\end{array}$ & $\begin{array}{l}50 / 0.001 / 32 / 5 \\
110\end{array}$ & $\begin{array}{l}5 / 0.001 / \\
32 / 110\end{array}$ & - & - & 14 & L & L & L & L & $\mathrm{N}$ & Y & 1 & ISC & $\begin{aligned} E 0711-D 2 \\
2007\end{aligned}$ & No video taken \\
\hline E0712 & 8 & Clay & 131.00 & 0.31 & 29.5 & 26.0 & 3 & $4,5,6$ & 4.5 & 3.53 & 3.46 & 3.49 & - & & $\begin{array}{l}50 / 0.001 / 321 \\
110\end{array}$ & $\begin{array}{l}50 / 0.001 / 32 / 5 \\
110\end{array}$ & $\begin{array}{l}50 / 1001 / \\
32 / 110\end{array}$ & - & - & 14 & L & L & L & L & $\mathrm{N}$ & $\mathrm{Y}$ & 2 & $\begin{array}{l}\text { E0172-12D- } \\
\text { 070419.ASC }\end{array}$ & $\begin{array}{l}\text { E0712-D2-Chan } \\
\text { 2007 11-03 }\end{array}$ & No video taken \\
\hline E0713 & 8 & Clay & 131.00 & 0.31 & 29.5 & 26.0 & 3 & $4,5,6$ & 4.5 & 3.52 & 3.46 & 3.49 & & & $\begin{array}{l}50 / 0.001 / 321 \\
110\end{array}$ & $\begin{array}{l}50 / 0.001 / 32 / 5 \\
110\end{array}$ & $\begin{array}{l}50 / 0.001 / \\
32 / 110\end{array}$ & & - & 14 & L & L & L & L & $\mathrm{N}$ & Y & 3 & ISC & $\begin{aligned} E 0713-D \\
20\end{aligned}$ & No video taken \\
\hline E0714 & 8 & Clay & 131.00 & 0.31 & 29.5 & 26.0 & 4 & $4,5,6,7$ & 4.5 & 3.53 & 3.51 & 3.49 & 3.60 & & $\begin{array}{l}50 / 0.001 / 321 \\
110\end{array}$ & $\begin{array}{l}50 / 0.001 / 32 / 5 \\
110\end{array}$ & $\begin{array}{l}5 / 1 / .001 / \\
32 / 110\end{array}$ & $\begin{array}{l}50 / 0.001 / \\
32 / 110\end{array}$ & - & 14 & L & L & L & L & $\mathrm{N}$ & Y & 1 & $\begin{array}{l}\text { D1- } \\
\text { ASC }\end{array}$ & $\begin{aligned} \text { E0714-D } & 20\end{aligned}$ & No video taken \\
\hline E0715 & 8 & Clay & 131.00 & 0.31 & 29.5 & 26.0 & 4 & $4,5,6,7$ & 4.5 & 3.45 & 3.46 & 3.49 & 3.48 & - & $\begin{array}{l}50 / 0.001 / 321 \\
110\end{array}$ & $\begin{array}{c}\text { 50/0.001/32/5 } \\
110\end{array}$ & $\begin{array}{l}50 / 0.001 / \\
32 / 110\end{array}$ & $\begin{array}{l}50 / 0.001 / \\
32 / 110\end{array}$ & - & 14 & L & L & L & L & $\mathrm{N}$ & Y & 1 & $\begin{array}{l}\text { E0715-D1- } \\
\text { 070419.ASC }\end{array}$ & $\begin{array}{r}\text { E0715-D } \\
200\end{array}$ & No video taken \\
\hline E0716 & 8 & Clay & 131.00 & 0.31 & 29.5 & 26.0 & 4 & $4,5,6,6$ & 4.5 & 3.52 & 3.46 & 3.49 & 3.50 & - & $50 / 0.001 / 321$ & /50/0.001/32/ 5 & $\begin{array}{l}50 / 0.001 / \\
321110\end{array}$ & $\begin{array}{l}50 / 0.001 / / \\
32 / 110\end{array}$ & - & 14 & L & L & L & $\mathrm{L}$ & N & Y & 2 & DI- & $\begin{array}{r}E 0716-D \\
200\end{array}$ & No video taken \\
\hline E0717 & 8 & Clay & 131.00 & 0.31 & 29.5 & 26.0 & 4 & $4,5,6,7$ & 4.5 & 3.51 & 3.45 & 3.48 & 3.55 & - & $\begin{array}{l}50 / 0.001 / 321 \\
110\end{array}$ & $\begin{array}{c}\text { / 50/0.001/32/5 } \\
110\end{array}$ & $\begin{array}{l}50 / 0.001 / \\
32 / 110\end{array}$ & $\begin{array}{l}50 / 0.001 / \\
32 / 110\end{array}$ & - & 14 & L & L & L & L & $\mathrm{N}$ & Y & 3 & $\begin{array}{l}\text { E0717-D1- } \\
\text { 070419.ASC }\end{array}$ & $\begin{array}{l}\text { E0717-D2-Channel1 Apr 19, } \\
\text { 2007 11-33-13.txt }\end{array}$ & No video taken \\
\hline E0718BL & - & - & - & & 29.5 & 26.0 & & - & - & - & - & - & - & & & & & & - & - & - & - & - & - & $\mathrm{N}$ & - & - & $\begin{array}{l}\text { E0718-D1-BL1- } \\
\text { 070419ASC }\end{array}$ & $\begin{array}{l}-\quad \text { E0718-D2 } \\
\text { Apr } 19,2\end{array}$ & \\
\hline E0718BL & & & & & 29.5 & 26.0 & - & & - & - & & & - & & & & & - & - & & & & - & - & r & - & & $\begin{array}{l}\text { E0718-D1-BL2- } \\
\text { OT7019-2- }\end{array}$ & 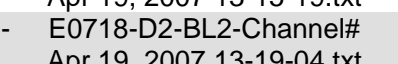 & \\
\hline E071 & 8 & Clay & 131.00 & 0.31 & 29.5 & 26.0 & 2 & 4,5 & 3 & 3.55 & 3.46 & & - & & $50 / 0.001$ & $\begin{array}{l}50 / 0.001 / 32 / \\
110\end{array}$ & & - & - & 14 & L & L & L & L & Y & Y & 1 & $\begin{array}{l}\text { D1- } \\
\text { ASC }\end{array}$ & $\begin{aligned} E 0718-D \\
20\end{aligned}$ & No video taken \\
\hline E0719 & 8 & Clay & 131.00 & 0.31 & 29.5 & 26.0 & 2 & 4,5 & 4 & 3.53 & 3.46 & & & & $\begin{array}{l}50 / 0.001 / 321 \\
110\end{array}$ & $\begin{array}{l}50 / 0.001 / 32 / \\
110\end{array}$ & & & & 14 & $\mathrm{~L}$ & $\mathrm{~L}$ & 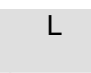 & L & Y & Y & 1 & $\begin{array}{l}\text { E0719-D1- } \\
\text { 070419.ASC }\end{array}$ & $\begin{array}{l}\text { E0719-D2-Channel1 Apr 19, } \\
\text { 2007 13-32-23.txt }\end{array}$ & No video taken \\
\hline E0720 & 8 & Clay & 131.00 & 0.31 & 29.5 & 26.0 & 2 & 4,5 & 4 & 3.54 & 3.46 & - & - & - & $50 / 0.001 / 321$ & $\begin{array}{l}50 / 0.001 / 32 / \\
110\end{array}$ & - & - & - & 14 & L & L & L & L & Y & Y & 2 & $\begin{array}{l}\text { E0720-D1- } \\
\text { 070419.ASC }\end{array}$ & $\begin{array}{l}\text { E0720-D2-Channel1 Apr 19, } \\
\text { 2007 13-36-51.txt }\end{array}$ & No video taken \\
\hline E0721 & 8 & Clay & 131.00 & 0.31 & 29.5 & 26.0 & 2 & 4,5 & 4 & 3.47 & 3.46 & - & - & - & $50 / 0.001 / 321$ & $\begin{array}{l}50 / 0.001 / 32 / \\
110\end{array}$ & - & - & - & 14 & L & L & L & L & Y & Y & 3 & $\begin{array}{l}\text { E0721-D1- } \\
\text { 070419.ASC }\end{array}$ & $\begin{array}{l}\text { E0721-D2-Channel1 Apr 19, } \\
\text { 2007 13-51-52.txt }\end{array}$ & No video taken \\
\hline E0722 & 8 & Clay & 131.00 & 0.31 & 29.5 & 26.0 & 2 & 4,5 & 12 & 3.47 & 3.47 & - & - & - & $\begin{array}{c}50 / 0.001 / 4 \\
110\end{array}$ & $\begin{array}{l}50 / 0.001 / 40 / \\
110\end{array}$ & - & - & - & 14 & L & L & $\mathrm{L}$ & L & $\mathrm{N}$ & $\mathrm{Y}$ & 1 & $\begin{array}{l}\text { E0722-D1- } \\
\text { 070419.ASC }\end{array}$ & $\begin{array}{l}\text { E0722-D2-Channel1 Apr 19, } \\
\text { 2007 14-00-13.txt }\end{array}$ & No video taken \\
\hline E0723 & 8 & Clay & 131.00 & 0.31 & 29.5 & 26.0 & 2 & 4,5 & 12 & 3.49 & 3.48 & & & & & | 50/0.001/40/ & & & & & & & & & & & & & 22-Channel1 Apr 19, & Jo video taken \\
\hline
\end{tabular}


Table A.1. Master Run Log, 8-PJM Configuration

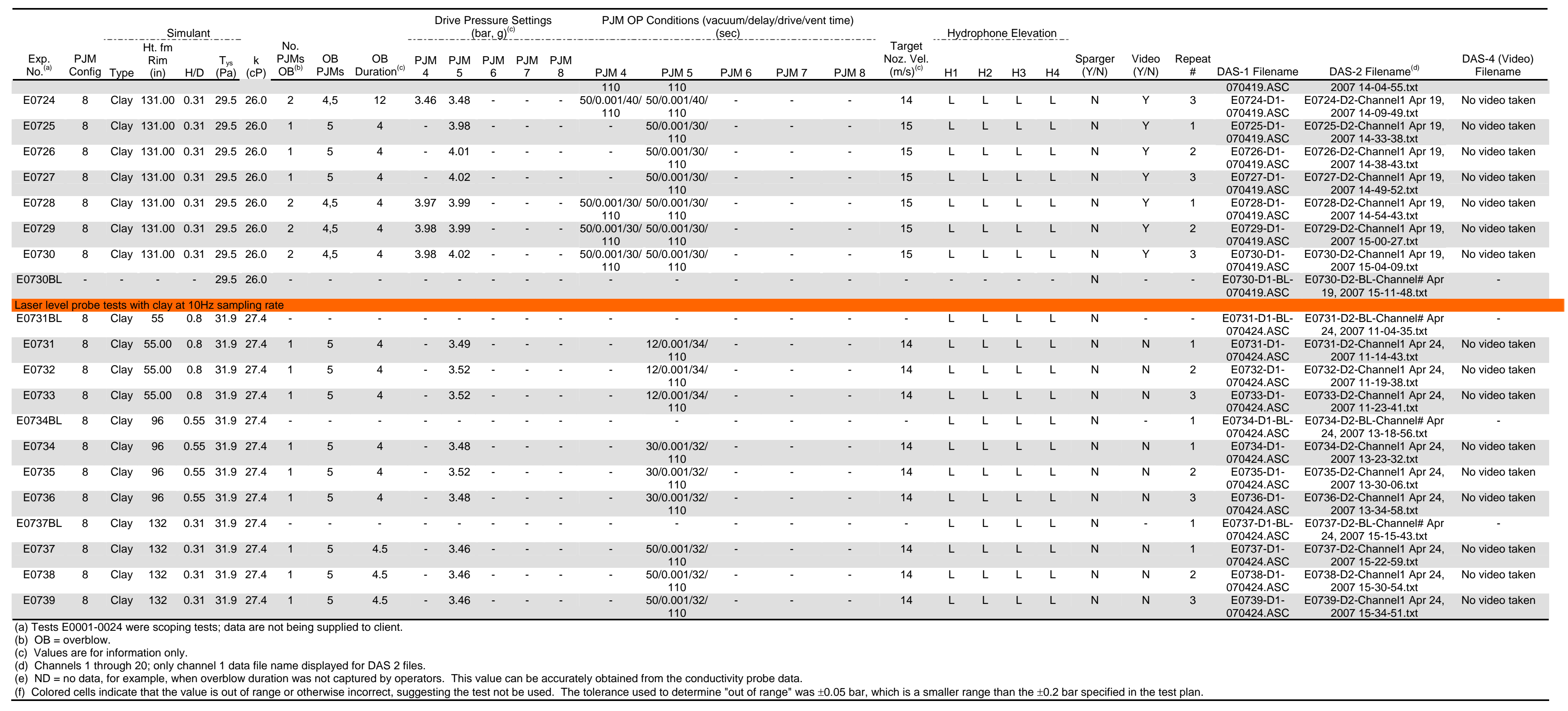


Appendix B

Master Run Log, 4-PJM Configuration 



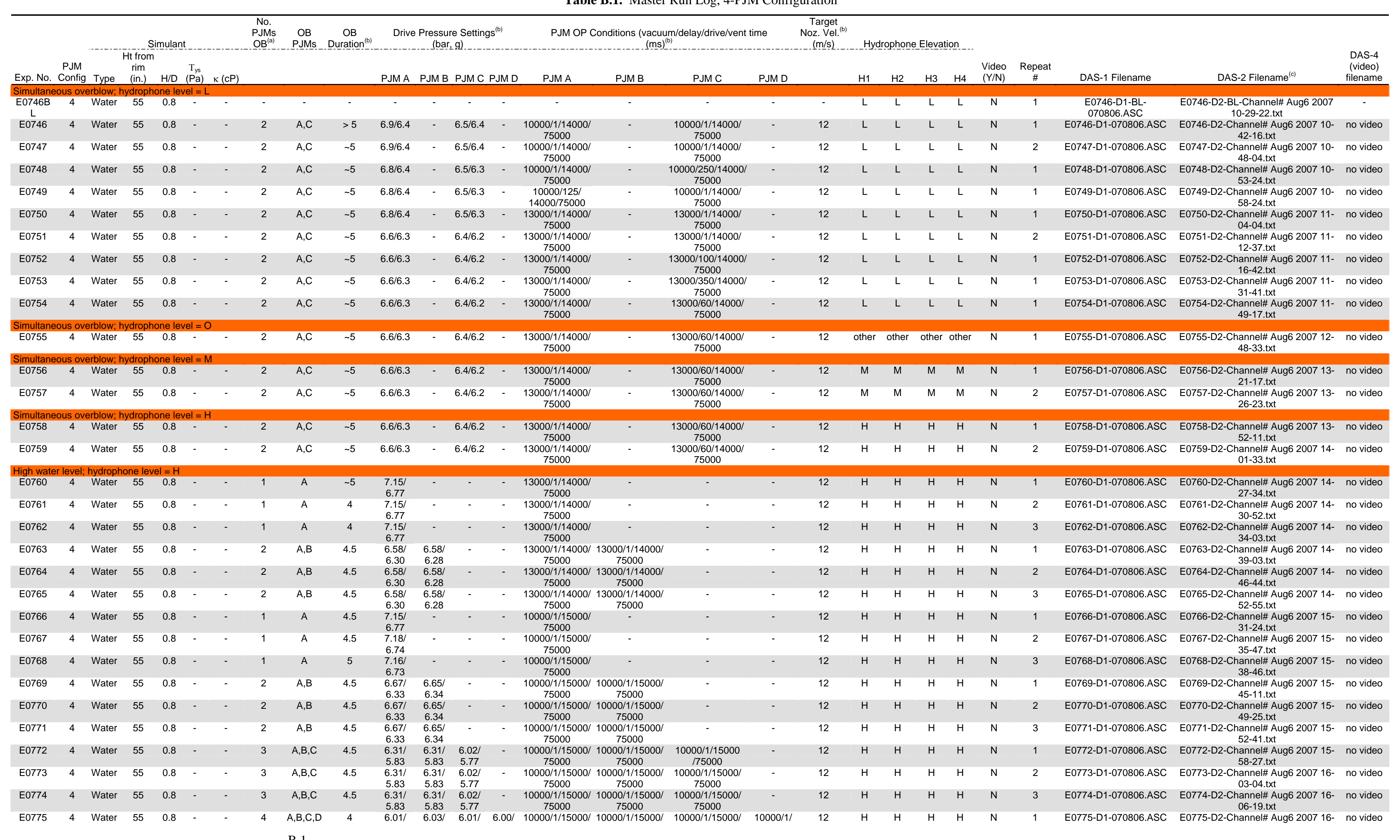


Table B.1. Master Run Log, 4-PJM Configuration

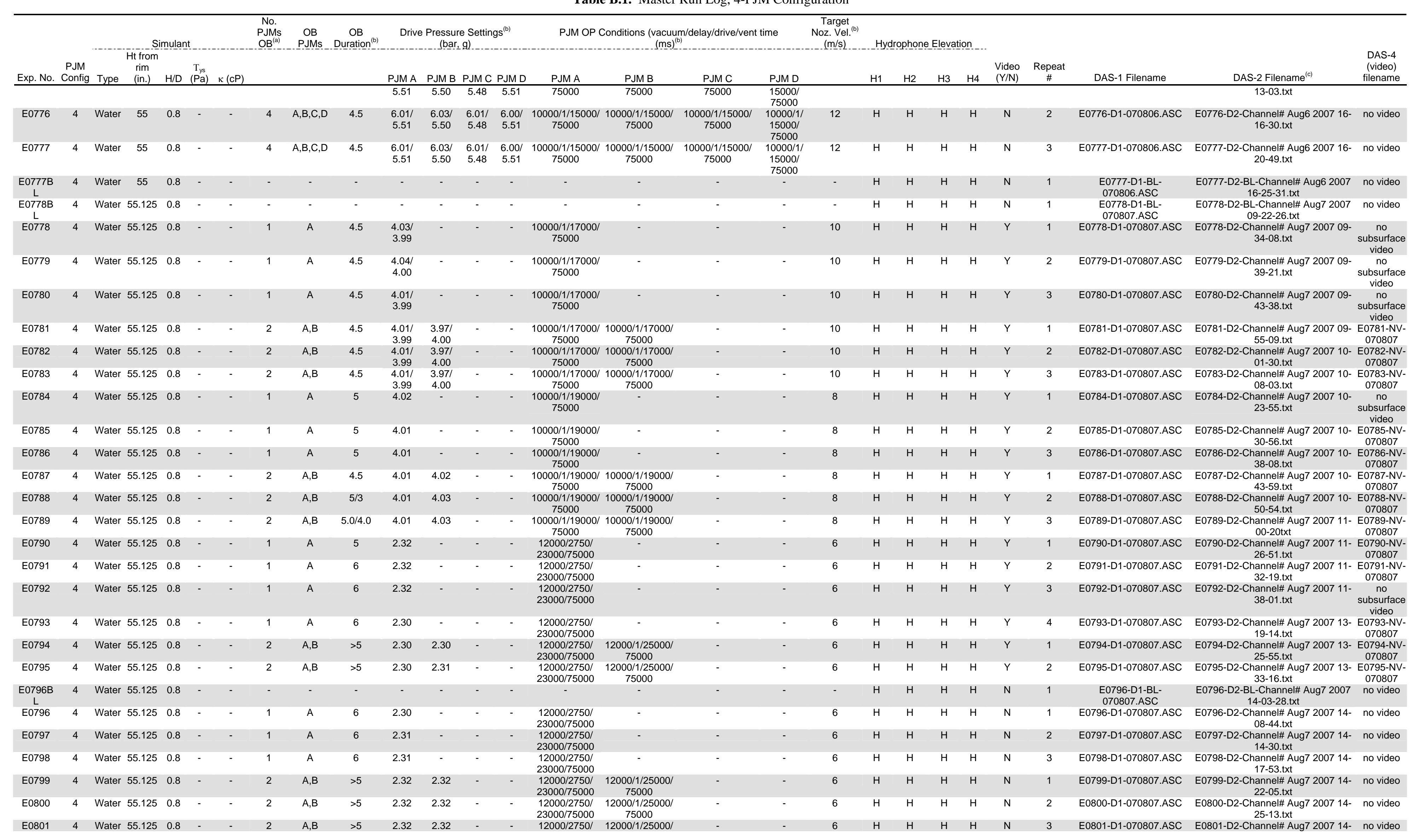


Table B.1. Master Run Log, 4-PJM Configuration

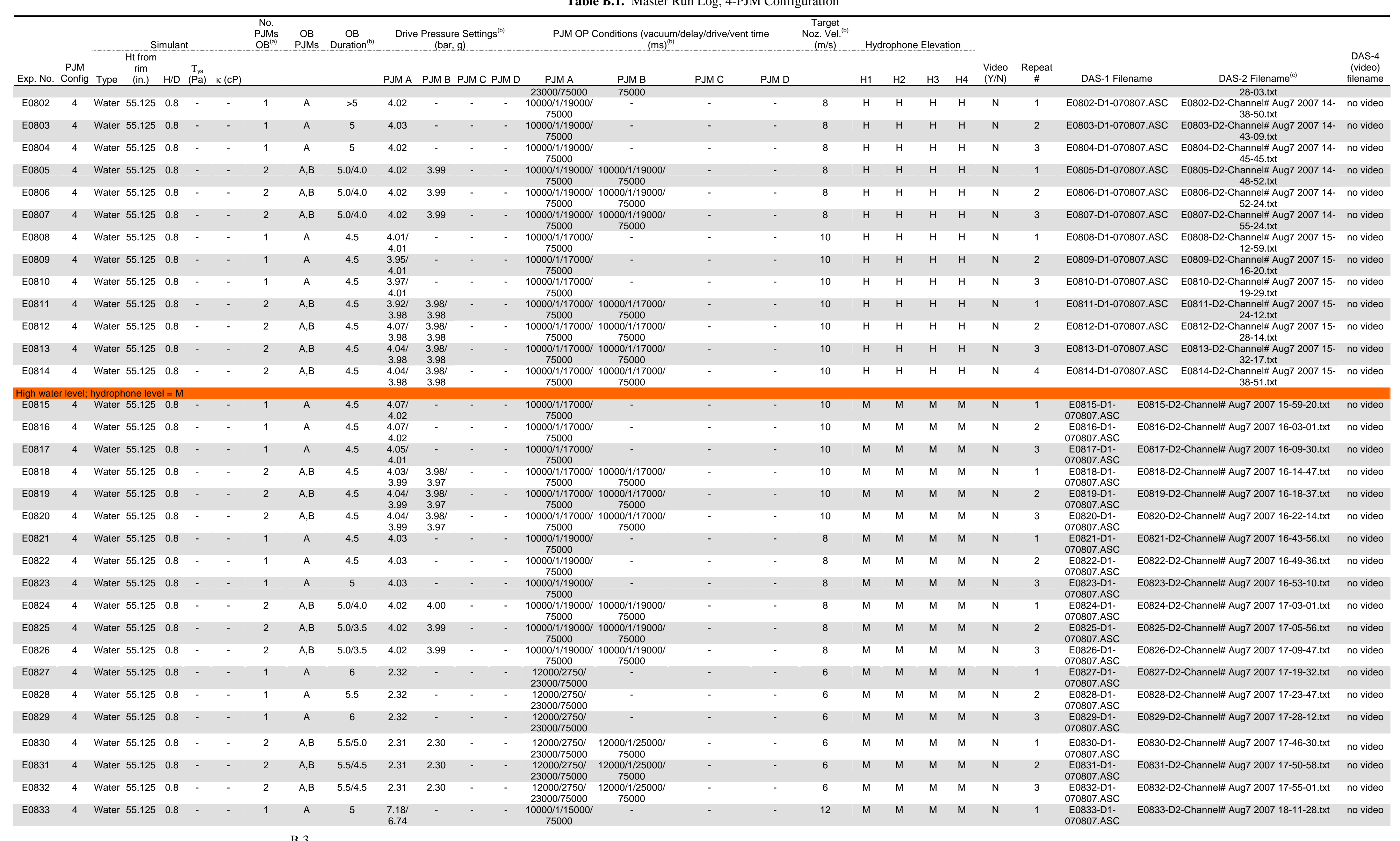


Table B.1. Master Run Log, 4-PJM Configuration

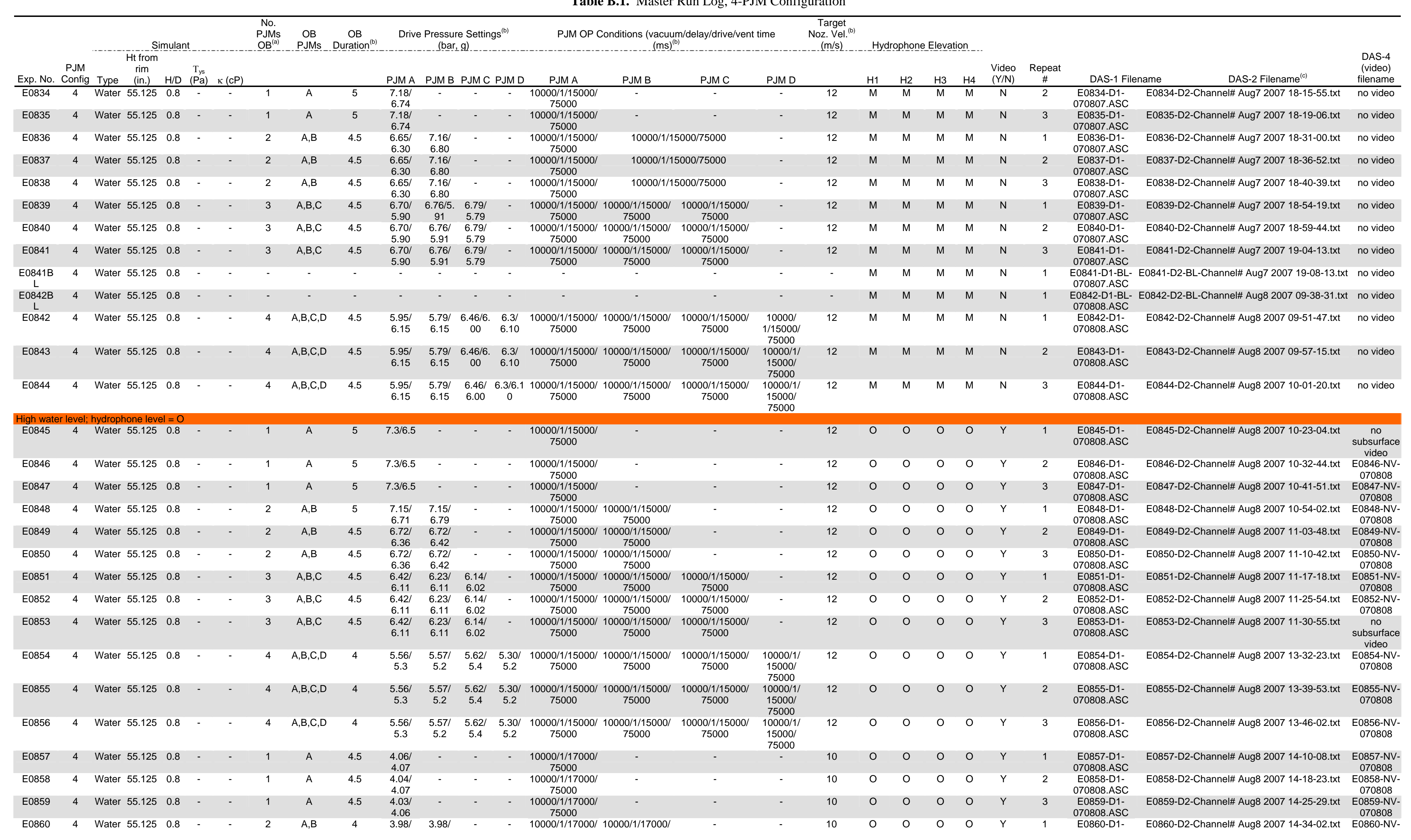


Table B.1. Master Run Log, 4-PJM Configuration

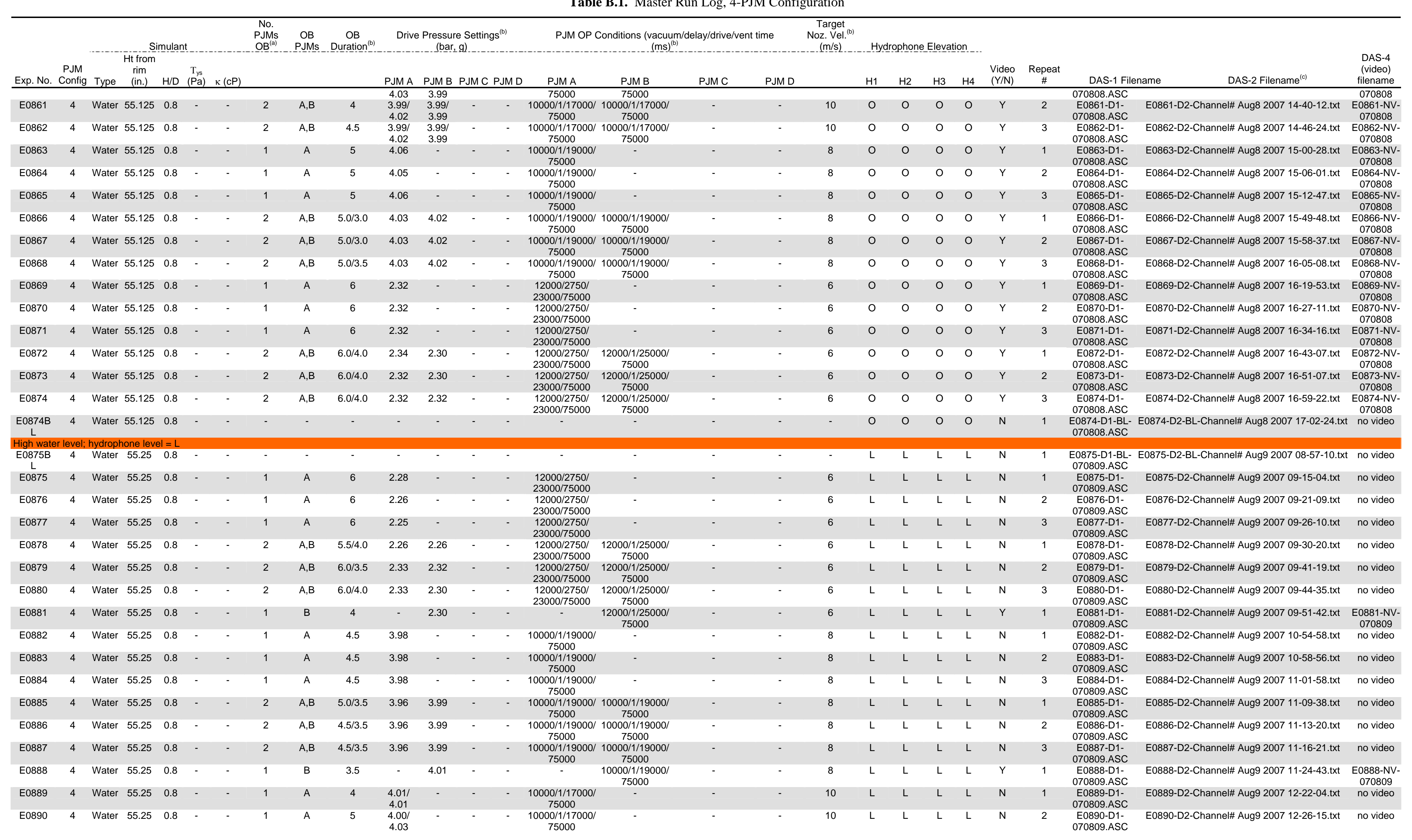


Table B.1. Master Run Log, 4-PJM Configuration

\begin{tabular}{|c|c|c|c|c|c|c|c|c|c|c|c|c|c|c|c|c|c|c|c|c|c|c|c|c|c|c|c|c|}
\hline \multirow{3}{*}{$\frac{\text { Exp. No. }}{\text { E0091 }}$} & \multirow[b]{2}{*}{$\begin{array}{l}\text { PJM } \\
\text { Config }\end{array}$} & \multicolumn{5}{|c|}{ Simulant } & \multirow[t]{2}{*}{$\begin{array}{l}\text { No. } \\
\text { PJMM } \\
\text { OB }^{(a)}\end{array}$} & \multirow[t]{2}{*}{$\begin{array}{c}\text { OB } \\
\text { PJMS }\end{array}$} & \multirow[t]{2}{*}{$\underset{\text { Durationon }}{\mathrm{OB}}$} & \multicolumn{4}{|c|}{$\begin{array}{l}\text { Drive Pressure Settings } \\
\text { (bar, g) }\end{array}$} & \multicolumn{4}{|c|}{$\begin{array}{l}\text { PJM OP Conditions (vacuum/delay/drive/vent time } \\
(\mathrm{ms})^{(0)}\end{array}$} & \multirow[t]{2}{*}{ 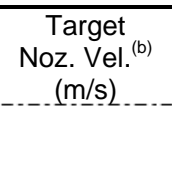 } & \multicolumn{5}{|c|}{ Hydrophone Elevation } & \multirow[b]{2}{*}{$\begin{array}{l}\text { Video } \\
(\mathrm{Y} / \mathrm{N})\end{array}$} & \multirow[b]{2}{*}{$\begin{array}{l}\text { Repeat } \\
\quad \#\end{array}$} & \multirow[b]{2}{*}{ DAS-1 Eilena } & \multirow[b]{2}{*}{ DAS-2 Filename ${ }^{(c)}$} & \multirow{2}{*}{$\begin{array}{c}\text { DAS-4 } \\
\text { (video) } \\
\text { filename } \\
\end{array}$} \\
\hline & & Type & $\begin{array}{l}\text { Ht from } \\
\text { rim } \\
\text { (in.) }\end{array}$ & H/D & & $\kappa(\mathrm{CP})$ & & & & PJM A & PJM B & PJM C & PJM D & PJN & PJM B & PJM C & PJM D & & $\mathrm{H} 1$ & $\mathrm{H} 2 \mathrm{C}$ & & $\mathrm{H}_{3}$ & $\mathrm{H} 4$ & & & & & \\
\hline & & Water & & & & & 1 & A & 4.5 & $4.01 /$ & & & & $\begin{array}{l}10000 / 1 / 17000 / \\
75000\end{array}$ & & & & 10 & $\mathrm{~L}$ & $\mathrm{~L}$ & & $\frac{T}{L}$ & $\frac{1}{\mathrm{~L}}$ & $\mathrm{~N}$ & 3 & $\begin{array}{l}\text { E0891-D1- } \\
\text { 070809.ASC }\end{array}$ & E0891-D2-Channel\# Aug9 2007 12-30-20.txt & \\
\hline E0892 & 4 & Water & 55.25 & 0.8 & & - & 2 & $A, B$ & 4 & $\begin{array}{l}4.00 / \\
4.00\end{array}$ & $\begin{array}{l}4.00 / \\
4.01\end{array}$ & & & $\begin{array}{l}10000 / 1 / 17000 / \\
75000\end{array}$ & $\begin{array}{l}10000 / 1 / 17000 / \\
75000\end{array}$ & & & 10 & $\mathrm{~L}$ & $\mathrm{~L}$ & & L & $\mathrm{L}$ & $\mathrm{N}$ & 1 & $\begin{array}{l}\text { E0892-D1- } \\
\text { 070809.ASC }\end{array}$ & E0892-D2-Channel\# Aug9 2007 12-37-22.txt & no video \\
\hline E0893 & 4 & Water & 55.25 & 0.8 & - & - & 2 & $A, B$ & 4 & $\begin{array}{l}4.001 \\
4.011 \\
4.01\end{array}$ & $\begin{array}{l}4.01 \\
4.011 \\
4.01\end{array}$ & - & - & $\begin{array}{l}10000 / 1 / 17000 / \\
75000\end{array}$ & / 10000/15/170000/ & - & - & 10 & L & L & & L & $\mathrm{L}$ & $\mathrm{N}$ & 2 & $\begin{array}{l}\text { E0893-D1- } \\
\text { 070809ASC }\end{array}$ & E0893-D2-Channel\# Aug9 2007 12-41-34.txt & no video \\
\hline E0894 & 4 & Water & 55.25 & 0.8 & - & - & 2 & $A, B$ & 4 & 4.001 & 4.001 & - & - & $10000 / 1 / 17000 /$ & / 10000/1/17000/ & - & - & 10 & $\mathrm{~L}$ & L & & L & L & $\mathrm{N}$ & 3 & 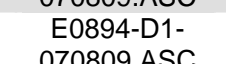 & E0894-D2-Channel\# Aug9 2007 12-45-33.txt & no video \\
\hline E0895 & 4 & Water & 55.25 & 0.8 & - & - & 1 & B & 4.5 & 4.00 & $\begin{array}{l}4.01 \\
4.041 \\
4.03\end{array}$ & - & - & 15000 & $10000 / 1 / 17000 /$ & - & - & 10 & L & L & & L & $\mathrm{L}$ & Y & 1 & $\begin{array}{l}\text { E0895-D1- } \\
\text { 078009ASC }\end{array}$ & E0895-D2-Channel\# Aug9 2007 13-02-46.txt & E0895-NV- \\
\hline E0896 & 4 & Water & 55.25 & 0.8 & - & - & 1 & A & 4.5 & 7.121 & & - & - & $\begin{array}{l}10000 / 1 / 15000 / \\
75000\end{array}$ & & - & - & 12 & L & L & & L & $\mathrm{L}$ & N & 1 & $\begin{array}{l}\text { E0896-D1- } \\
\text { 070809 ASC }\end{array}$ & E0896-D2-Channel\# Aug9 2007 13-16-03.txt & no video \\
\hline E0897 & 4 & Water & 55.25 & 0.8 & - & - & 1 & A & 4.5 & 7.121 & - & - & & $\begin{array}{l}10000 / 1 / 15000 / \\
75000\end{array}$ & & 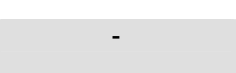 & - & 12 & L & $\mathrm{L}$ & & L & $\mathrm{L}$ & $\mathrm{N}$ & 2 & $\begin{array}{l}\text { E0897-D1- } \\
\text { 070809 ASC }\end{array}$ & E0897-D2-Channel\# Aug9 2007 13-20-39.txt & no video \\
\hline E0898 & 4 & Water & 55.25 & 0.8 & & - & 1 & A & 4.5 & $\begin{array}{l}0.121 \\
6.77\end{array}$ & - & - & & $\begin{array}{l}10000 / 1 / 15000 / \\
75000\end{array}$ & & & - & 12 & $\mathrm{~L}$ & $\mathrm{~L}$ & & L & $\mathrm{L}$ & $\mathrm{N}$ & 3 & $\begin{array}{l}\text { E0898-D1- } \\
\text { 070809.ASC }\end{array}$ & E0898-D2-Channel\# Aug9 2007 13-23-41.txt & no video \\
\hline E0899 & 4 & Water & 55.25 & 0.8 & & - & 2 & $A, B$ & 5 & $\mathrm{RFO}^{(d)}$ & RFO & - & & $\begin{array}{l}10000 / 1 / 15000 / \\
75000\end{array}$ & / 10000/1/150000/ & & - & 12 & L & L & & L & $\mathrm{L}$ & $\mathrm{N}$ & 1 & $\begin{array}{l}\text { EO899-D1- } \\
\text { 070809.ASC }\end{array}$ & E0899-D2-Channel\# Aug9 2007 13-29-04.txt & no video \\
\hline E0900 & 4 & Water & 55.25 & 0.8 & - & - & 2 & $A, B$ & 5 & RFO & RFO & - & - & $\begin{array}{l}10000 / 1 / 15000 / \\
75000\end{array}$ & / 10000/15/15000/ & - & - & 12 & L & L & & L & $\mathrm{L}$ & $\mathrm{N}$ & 2 & $\begin{array}{l}\text { E0900-D1- } \\
070809 \text { ASC }\end{array}$ & E0900-D2-Channel\# Aug9 2007 13-33-47.txt & no video \\
\hline E0901 & 4 & Water & 55.25 & 0.8 & - & - & 2 & $A, B$ & 5.5 & RFO & RFO & - & - & $\begin{array}{l}10000 / 1 / 15000 / \\
75000\end{array}$ & / 10000/15/15000/ & - & - & 12 & $\mathrm{~L}$ & L & & L & L & $\mathrm{N}$ & 3 & 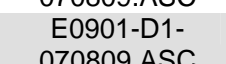 & E0901-D2-Channel|\# Aug9 2007 13-37-41.txt & no video \\
\hline E0902 & 4 & Water & 55.25 & 0.8 & - & - & 3 & $A, B, C$ & 4.5 & RFO & RFO & RFO & & $\begin{array}{l}10000 / 1 / 15000 / \\
75000\end{array}$ & / 10000/1/150000/ & $\begin{array}{l}10000 / 1 / 15000 / \\
75000\end{array}$ & - & 12 & $\mathrm{~L}$ & $\mathrm{~L}$ & & L & $\mathrm{L}$ & $\mathrm{N}$ & 1 & $\begin{array}{l}\text { E0902-D1- } \\
\text { 0070809ASC }\end{array}$ & E0902-D2-Channel\# Aug9 2007 13-44-59.txt & no video \\
\hline E0903 & 4 & Water & 55.25 & 0.8 & - & - & 3 & $A, B, C$ & 4.5 & RFO & RFO & RFO & - & $10000 / 1 / 15000 /$ & / 10000/1/15000/ & $10000 / 1 / 15000 /$ & - & 12 & L & L & & L & L & N & 2 & E0903-D1- & E0903-D2-Channel\# Aug9 2007 13-50-06.txt & no video \\
\hline E0904 & 4 & Water & 55.25 & 0.8 & - & - & 3 & $A, B, C$ & 4.5 & RFO & RFO & RFO & . & $\begin{array}{l}10000 / 1 / 15000 / \\
75000\end{array}$ & / 10000/1/15000/ & $10000 / 1 / 15000 /$ & . & 12 & L & $\mathrm{L}$ & & L & L & $\mathrm{N}$ & 3 & $\begin{array}{l}\text { E0904-D1- } \\
\text { O70809ASC }\end{array}$ & E0904-D2-Channel\# Aug9 2007 13-53-03.txt & no video \\
\hline E0905 & 4 & Water & 55.25 & 0.8 & - & - & 4 & $\mathrm{~A}, \mathrm{~B}, \mathrm{C}, \mathrm{D}$ & 4.5 & RFO & RFO & RFO & RFO & $\begin{array}{c}10000 / 1 / 15000 / \\
75000\end{array}$ & $\begin{array}{c}10000 / 1 / 1 / 5000 \\
75000\end{array}$ & $\begin{array}{c}10000 / 1 / 15000 / \\
75000\end{array}$ & $\begin{array}{c}10000 / 1 / \\
15000 /\end{array}$ & 12 & $\mathrm{~L}$ & $\mathrm{~L}$ & & L & $\mathrm{L}$ & $\mathrm{N}$ & 1 & $\begin{array}{l}\text { E0905-D1- } \\
\text { 070809.ASC }\end{array}$ & E0905-D2-Channel\# Aug9 2007 13-59-29.txt & no video \\
\hline E0906 & 4 & Water & 55.25 & 0.8 & - & - & 4 & $\mathrm{~A}, \mathrm{~B}, \mathrm{C}, \mathrm{D}$ & 4.5 & RFO & RFO & RFO & RFO & $\begin{array}{c}10000 / 1 / 15000 / \\
75000\end{array}$ & $\begin{array}{c}10000 / 1 / 15000 / \\
75000\end{array}$ & $\begin{array}{c}10000 / 1 / 15000 / \\
75000\end{array}$ & $\begin{array}{c}10000 / 1 / \\
15000 /\end{array}$ & 12 & L & $\mathrm{L}$ & & L & $\mathrm{L}$ & $\mathrm{N}$ & 2 & $\begin{array}{l}\text { E0906-D1- } \\
\text { 070809.ASC }\end{array}$ & E0906-D2-Channel\# Aug9 2007 14-02-22.txt & no video \\
\hline E0907 & 4 & Water & 55.25 & 0.8 & - & - & 4 & $A, B, C, D$ & 4.5 & RFO & RFO & RFO & RFO & $\begin{array}{c}10000 / 1 / 15000 / \\
75000\end{array}$ & $\begin{array}{c}10000 / 1 / 15000 / \\
75000\end{array}$ & $\begin{array}{c}10000 / 1 / 15000 / \\
75000\end{array}$ & $\begin{array}{l}150001 / 1 \\
1000000 / \\
15000 \\
75000\end{array}$ & 12 & $\mathrm{~L}$ & L & & L & $\mathrm{L}$ & $\mathrm{N}$ & 3 & $\begin{array}{l}\text { E0907-D1- } \\
\text { 070809.ASC }\end{array}$ & E0907-D2-Channel\# Aug9 2007 14-09-07.txt & no video \\
\hline E0908 & 4 & Water & 55.25 & 0.8 & & - & 1 & B & 4.5 & & RFO & & & & $\begin{array}{c}10000 / 1 / 15000 / \\
75000\end{array}$ & & & 12 & L & L & & L & $\mathrm{L}$ & $\mathrm{Y}$ & 1 & $\begin{array}{l}\text { E0908-D1- } \\
\text { 070809.ASC }\end{array}$ & E0908-D2-Channel\# Aug9 2007 14-15-28.txt & $\begin{array}{c}\text { no } \\
\text { subsurface }\end{array}$ \\
\hline E0909 & 4 & Water & 55.25 & 0.8 & - & - & 1 & B & 4.5 & - & RFO & - & & & $\begin{array}{l}10000 / 1 / 15000 / \\
75000\end{array}$ & & - & 12 & $\mathrm{~L}$ & $\mathrm{~L}$ & & L & $\mathrm{L}$ & $\mathrm{Y}$ & 2 & $\begin{array}{l}\text { E0909-D1- } \\
\text { 070809.ASC }\end{array}$ & E0909-D2-Channel\# Aug9 2007 14-19-16.txt & $\begin{array}{l}\text { E0909-NV- } \\
070809\end{array}$ \\
\hline $\begin{array}{l}\text { Middle we } \\
\text { EO910B }\end{array}$ & $\begin{array}{l}\text { er leve } \\
4\end{array}$ & $\begin{array}{l}\text { el; hydrc } \\
\text { Water }\end{array}$ & $\begin{array}{l}\text { ophone le } \\
94.25\end{array}$ & $\begin{array}{l}\text { evel }=\mathrm{L} \\
0.55\end{array}$ & & - & - & - & - & - & - & - & - & - & t. & - & - & - & $\mathrm{L}$ & L & & L & $\mathrm{L}$ & N & 1 & $\begin{array}{l}\text { E0910-D1-BL- } \\
\text { 070009ASC }\end{array}$ & E0910-D2-BL-Channel\# Aug9 2007 15-26-54.txt & $t$ no video \\
\hline E0910 & 4 & Water & 94.25 & 0.55 & - & - & 1 & A & 5 & RFO & - & - & - & $\begin{array}{l}16000 / 1 / 14750 / \\
75000\end{array}$ & - & - & - & 12 & $\mathrm{~L}$ & $\mathrm{~L}$ & & L & $\mathrm{L}$ & $\mathrm{Y}$ & 1 & $\begin{array}{l}\text { E0910-D1- } \\
\text { 070809.ASC }\end{array}$ & E0910-D2-Channel\# Aug9 2007 15-57-48.txt & $\begin{array}{c}\text { E0910-NV- } \\
070809\end{array}$ \\
\hline E0911 & 4 & Water & 94.25 & 0.55 & - & - & 1 & A & 5 & RFO & - & - & - & $\begin{array}{l}16000 / 1 / 14750 / \\
75000\end{array}$ & t & - & - & 12 & $\mathrm{~L}$ & $\mathrm{~L}$ & & L & $\mathrm{L}$ & $\mathrm{Y}$ & 2 & $\begin{array}{l}\text { E0911-D1- } \\
\text { 07009 ASC }\end{array}$ & E0911-D2-Channel\# Aug9 2007 16-08-26.txt & $\begin{array}{l}\text { E0911-NV- } \\
077809\end{array}$ \\
\hline E0912 & 4 & Water & 94.25 & 0.55 & - & - & 1 & A & 5 & RFO & - & - & - & $\begin{array}{l}16000 / 1 / 14750 / \\
75000\end{array}$ & - & - & - & 12 & $\mathrm{~L}$ & L & & L & $\mathrm{L}$ & $\mathrm{Y}$ & 3 & $\begin{array}{l}\text { E0912-D1- } \\
\text { 070809.ASC }\end{array}$ & E0912-D2-Channel\# Aug9 2007 16-18-31.txt & $\begin{array}{l}\text { E0912-NV- } \\
070809\end{array}$ \\
\hline E0912B & 4 & Water & 94.25 & 0.55 & & & & & & & & & & & & & - & 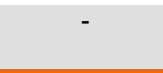 & $\mathrm{L}$ & $\mathrm{L}$ & & L & $\mathrm{L}$ & $\mathrm{N}$ & 1 & $\begin{array}{l}\text { E0912-D1-BL- } \\
\text { 070809.ASC }\end{array}$ & E0912-D2-BL-Channel\# Aug9 2007 16-29-38.txt & t no video \\
\hline $\begin{array}{l}\text { Middle we } \\
\text { EO913B } \\
\text { L }\end{array}$ & $\begin{array}{l}\text { ater leve } \\
4\end{array}$ & el; hydre & $\begin{array}{l}\text { ophone le } \\
94.75\end{array}$ & evel $=1$ & & & & & & & & & & & & & & & $\mathrm{O}$ & $\mathrm{O}$ & & 0 & $\mathrm{O}$ & $\mathrm{N}$ & 1 & $\begin{array}{l}\text { E0913-D1-BL- } \\
\text { 070812.ASC }\end{array}$ & $\begin{array}{l}\text { E0913-D2-BL-Channel\# Aug12 } 2007 \text { 08-42- } \\
\text { 58.txt }\end{array}$ & no video \\
\hline E0913 & 4 & Water & 94.75 & 0.55 & - & - & 1 & A & 5 & RFO & - & - & - & $\begin{array}{l}16000 / 1 / 14450 / \\
75000\end{array}$ & t & - & - & 12 & 0 & 0 & & 0 & 0 & $\mathrm{~N}$ & 1 & $\begin{array}{l}\text { E913-D1- } \\
\text { 070812.ASC }\end{array}$ & E0913-D2-Channel|\#A Aug12 2007 08-58-59.txt & no video \\
\hline E0914 & 4 & Water & 94.75 & 0.55 & - & - & 1 & A & 5 & RFO & - & - & - & $\begin{array}{l}16000 / 1 / 14750 / \\
75000\end{array}$ & - & - & - & 12 & 0 & 0 & & 0 & 0 & $\mathrm{~N}$ & 2 & $\begin{array}{l}\text { EO914-D1- } \\
\text { 070812.ASC }\end{array}$ & E0914-D2-Channel\# Aug12 2007 09-03-44.txt & no video \\
\hline E0915 & 4 & Water & 94.75 & 0.55 & - & - & 1 & A & 5 & RFO & - & - & - & $\begin{array}{l}16000 / 1 / 14750 / \\
75000\end{array}$ & - & - & - & 12 & 0 & 0 & & 0 & 0 & $\mathrm{~N}$ & 3 & $\begin{array}{l}\text { E0915-D1- } \\
\text { 070812.ASC }\end{array}$ & E0915-D2-Channel\#A Aug12 2007 09-07-04.txt & no video \\
\hline E0916 & 4 & Water & 94.75 & 0.55 & - & - & 2 & $A, B$ & 5.015 .0 & RFO & RFO & - & - & $\begin{array}{l}16000 / 1 / 14750 / \\
75000\end{array}$ & $\begin{array}{l}\text { 16000/1/14750/ } \\
75000\end{array}$ & - & - & 12 & 0 & 0 & & 0 & 0 & $\mathrm{~N}$ & 1 & $\begin{array}{l}\text { EO916-D1- } \\
\text { 070812.ASC }\end{array}$ & E0916-D2-Channel\# Aug12 2007 09-12-27.txt & no video \\
\hline E0917 & 4 & Water & 94.75 & 0.55 & & - & 2 & $A, B$ & $5.0 / 5.0$ & RFO & RFO & - & & $\begin{array}{c}16000 / 1 / 14750 / \\
75000\end{array}$ & $\begin{array}{l}16000 / 1 / 14750 / \\
75000\end{array}$ & & & 12 & 0 & 0 & & 0 & 0 & $\mathrm{~N}$ & 2 & $\begin{array}{l}\text { E0917-D1- } \\
\text { 070812.ASC }\end{array}$ & E0917-D2-Channel\# Aug12 2007 09-18-17.txt & no video \\
\hline
\end{tabular}


Table B.1. Master Run Log, 4-PJM Configuration

\begin{tabular}{|c|c|c|c|c|c|c|c|c|c|c|c|c|c|c|c|c|c|c|c|c|c|c|c|c|c|c|c|c|}
\hline \multirow{2}{*}{ Exp. №. } & \multirow[b]{2}{*}{$\begin{array}{c}\text { PJM } \\
\text { Contig }\end{array}$} & \multicolumn{5}{|c|}{ Simulant- } & \multirow[t]{2}{*}{$\begin{array}{l}\text { No. } \\
\text { PJMS } \\
\text { OBB }\end{array}$} & \multirow[t]{2}{*}{$\begin{array}{l}\text { OB } \\
\text { PJMs }\end{array}$} & \multirow[t]{2}{*}{$\begin{array}{l}\text { OB } \\
\text { Duration } \\
-(b)\end{array}$} & \multicolumn{4}{|c|}{$\begin{array}{l}\text { Drive Pressure Settings } \\
(b)\end{array}$} & \multicolumn{4}{|c|}{$\begin{array}{l}\text { PJM OP Conditions (vacuum/delay/drive/vent time } \\
(\mathrm{ms})^{(0)}\end{array}$} & \multirow[t]{2}{*}{$\begin{array}{c}\text { Target } \\
\text { Noz. Vel. }{ }^{(b)} \\
(\mathrm{m} / \mathrm{s})\end{array}$} & \multicolumn{5}{|c|}{ Hydrophone Elevation } & & \multirow[b]{2}{*}{$\begin{array}{l}\text { Repeat } \\
\#\end{array}$} & \multirow[b]{2}{*}{ DAS-1 Filenan } & \multirow{2}{*}{ ame $\quad$ DAS-2 Filename } & \multirow{2}{*}{$\begin{array}{c}\text { DAS-4 } \\
\text { (video) } \\
\text { filename }\end{array}$} \\
\hline & & Type & $\begin{array}{c}\text { Hetrim } \\
\text { rim. } \\
\text { (i.) }\end{array}$ & $H / D$ & $\begin{array}{c}\mathrm{T}_{\mathrm{Ys}} \\
(\mathrm{Pa})\end{array}$ & $\kappa(\mathrm{CP})$ & & & & PJM A & PJM B & PJM C & PJM D & PJM A & PJM B & PJMe & PJMD & & $\mathrm{H} 1$ & $\mathrm{H} 2$ & $H_{3}$ & & & & & & & \\
\hline $\begin{array}{c}\text { E0918 } \\
\end{array}$ & 4 & $\begin{array}{l}\text { Water } \\
\text {. }\end{array}$ & 94.75 & 0.55 & & & 2 & $A, B$ & $5.0 / 5.0$ & RFO & RFO & & & $\begin{array}{l}16000 / 1 / 147450 / \\
75000\end{array}$ & $\mid 16000 / 1 / 14750 /$ & & 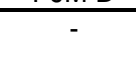 & 12 & 0 & 0 & $\bar{O}$ & & $\bar{o}$ & $\mathrm{~N}$ & 3 & $\begin{array}{l}\text { E0918-D1- } \\
\text { 07712 }\end{array}$ & E0918-D2-Channel\# Aug12 2007 09-21-39.txt & no video \\
\hline E0919 & 4 & Water & 94.75 & 0.55 & & & 3 & $A, B, C$ & $\begin{array}{l}4.5 / 4.51 \\
4.5\end{array}$ & RFO & RFO & RFO & & $\begin{array}{l}18000 / 1 / 14750 / \\
75000\end{array}$ & $\begin{array}{l}18000 / 1 / 14750 / \\
75000\end{array}$ & $\begin{array}{l}18000 / 1 / 14750 / \\
75000\end{array}$ & & 12 & 0 & o & o & & o & $\mathrm{N}$ & 1 & $\begin{array}{l}\text { E0919-D1- } \\
\text { 070812.ASC }\end{array}$ & E0919-D2-Channel\# Aug12 2007 09-32-29.txt & no video \\
\hline E0920 & 4 & Water & 94.75 & 0.55 & - & - & 3 & $A, B, C$ & 4.5/4.5/4.5 & RFO & RFO & RFO & - & $\begin{array}{ll}18000 / 1 / 14750 / \\
75000\end{array}$ & / 18000/1/14750/ & $\begin{array}{l}18000 / 1 / 14750 / \\
75500\end{array}$ & - & 12 & 0 & 0 & 0 & & o & $\mathrm{N}$ & 2 & $\begin{array}{l}\text { E0920-D1- } \\
\text { O70812 ASC }\end{array}$ & E0920-D2-Channel\# Aug12 2007 09-38-08.txt & no video \\
\hline E0921 & 4 & Water & 94.75 & 0.55 & - & - & 3 & $A, B, C$ & $\begin{array}{l}4.5 / 4.5 / \\
4.5\end{array}$ & RFO & RFO & RFO & - & $\begin{array}{l}18000 / 1 / 14750 / \\
75000\end{array}$ & $\begin{array}{l}18000 / 1 / 14750 / \\
75000\end{array}$ & $\begin{array}{l}18000 / 1 / 14750 / \\
75000\end{array}$ & - & 12 & 0 & o & 0 & & o & N & 3 & $\begin{array}{l}\text { EO921-D1- } \\
\text { 070812.ASC }\end{array}$ & E0921-D2-Channel\# Aug12 2007 09-41-07.txt & no video \\
\hline E0922 & 4 & Water & 94.75 & 0.55 & - & - & 4 & $\mathrm{~A}, \mathrm{~B}, \mathrm{C}, \mathrm{D}$ & $\begin{array}{l}4.5 / 4.5 / 4.5 \\
14.5\end{array}$ & RFO & RFO & RFO & RFO & $\begin{array}{c}18000 / 1 / 14750 / \\
75000\end{array}$ & $\begin{array}{c}18000 / 1 / 14750 / \\
75000\end{array}$ & $\begin{array}{c}18000 / 1 / 144750 / \\
75000\end{array}$ & $\begin{array}{c}18000 / 1 / \\
14750 / \\
7500\end{array}$ & 12 & 0 & 0 & 0 & & 0 & $\mathrm{~N}$ & 1 & $\begin{array}{l}\text { E0922-D1- } \\
\text { 070812.ASC }\end{array}$ & E0922-D2-Channel\# Aug12 2007 09-49-12.txt & no video \\
\hline E0923 & 4 & Water & 94.75 & 0.55 & - & - & 4 & $A, B, C, D$ & $\begin{array}{l}4.5 / 4.5 / 4.5 \\
14.5\end{array}$ & RFO & RFO & RFO & RFO & $\begin{array}{c}18000 / 1 / 14750 / \\
75000\end{array}$ & $\begin{array}{l}18000 / 1 / 14750 / \\
75000\end{array}$ & $\begin{array}{c}18000 / 1 / 14750 / \\
75000\end{array}$ & $\begin{array}{l}18000 / 1 / \\
14750 / \\
7500\end{array}$ & 12 & 0 & 0 & 0 & & o & $\mathrm{N}$ & 2 & $\begin{array}{l}\text { E0923-D1- } \\
\text { 070812.ASC }\end{array}$ & E0923-D2-Channel\# Aug12 2007 09-53-28.txt & no video \\
\hline E0924 & 4 & Water & 94.75 & 0.55 & - & - & 4 & $\mathrm{~A}, \mathrm{~B}, \mathrm{C}, \mathrm{D}$ & $\begin{array}{l}4.5 / 4.5 / 4.5 \\
14.5\end{array}$ & RFO & RFO & RFO & RFO & $\begin{array}{c}18000 / 1 / 14750 / \\
75000\end{array}$ & $\begin{array}{c}\text { 18000/1/144750/ } \\
75000\end{array}$ & $\begin{array}{l}18000 / 1 / 14750 / \\
75000\end{array}$ & $\begin{array}{l}18000 / 1 / \\
1450 / \\
75500\end{array}$ & 12 & 0 & 0 & $\mathrm{o}$ & & o & $\mathrm{N}$ & 3 & $\begin{array}{l}\text { E0924-D1- } \\
\text { 070812.ASC }\end{array}$ & E0924-D2-Channel\# Aug12 2007 09-56-46.txt & no video \\
\hline E0925 & 4 & Water & 94.75 & 0.55 & - & & 1 & A & 4.5 & $\begin{array}{l}4.00 / \\
4.00\end{array}$ & & & & $\begin{array}{l}18000 / 1 / 16750 / \\
75000\end{array}$ & & & & 10 & 0 & 0 & 0 & & o & $\mathrm{N}$ & 1 & $\begin{array}{l}\text { E0925-D1- } \\
\text { 070812.ASC }\end{array}$ & E0925-D2-Channel\# Aug12 2007 10-20-54.txt & no video \\
\hline E0926 & 4 & Water & 94.75 & 0.55 & - & - & 1 & A & 4.5 & $\begin{array}{l}4.001 \\
4.00\end{array}$ & - & - & & $\begin{array}{l}18000 / 1 / 16750 / \\
75000\end{array}$ & - & - & - & 10 & 0 & 0 & 0 & & o & $\mathrm{N}$ & 2 & $\begin{array}{l}\text { EOM26-D1- } \\
\text { 070812.ASC }\end{array}$ & E0926-D2-Channel\# Aug12 2007 10-25-30.txt & no video \\
\hline E0927 & 4 & Water & 94.75 & 0.55 & - & - & 1 & A & 4.5 & $\begin{array}{l}4.00 / \\
4.00\end{array}$ & - & & - & $\begin{array}{l}18000 / 1 / 16750 / \\
75000\end{array}$ & - & - & - & 10 & 0 & 0 & 0 & & 0 & $\mathrm{~N}$ & 3 & $\begin{array}{l}\text { E0927-D1- } \\
\text { O70812 ASC }\end{array}$ & E0927-D2-Channel\# Aug12 2007 10-28-29.txt & no video \\
\hline E0928 & 4 & Water & 94.75 & 0.55 & - & - & 2 & $A, B$ & 4.5 & $\begin{array}{l}3.99 / \\
3.98\end{array}$ & $\begin{array}{l}4.01 / \\
4.02\end{array}$ & - & - & $\begin{array}{l}18000 / 1 / 16750 / \\
75000\end{array}$ & $\begin{array}{l}18000 / 1 / 16750 / \\
75000\end{array}$ & - & - & 10 & 0 & 0 & 0 & & o & $\mathrm{N}$ & 1 & $\begin{array}{l}\text { E0928-D1- } \\
\text { 070812.ASC }\end{array}$ & E0928-D2-Channel\# Aug12 2007 10-34-40.txt & no video \\
\hline E0929 & 4 & Water & 94.75 & 0.55 & - & - & 2 & $A, B$ & 4.5 & 4.001 & 4.011 & - & - & $\begin{array}{l}18000 / 1 / 16750 / \\
75000\end{array}$ & / 18000/15/16750/ & - & - & 10 & 0 & 0 & 0 & & o & $\mathrm{N}$ & 2 & $\begin{array}{l}\text { E0929-D1- } \\
070812 \text { ASC }\end{array}$ & E0929-D2-Channel\# Aug12 2007 10-39-06.txt & no video \\
\hline E0930 & 4 & Water & 94.75 & 0.55 & - & - & 2 & $A, B$ & 4.5 & $\begin{array}{l}4.00 / \\
3.98\end{array}$ & $\begin{array}{l}4.01 / \\
4.02\end{array}$ & - & - & $\begin{array}{l}18000 / 1 / 16750 / \\
75000\end{array}$ & $\begin{array}{l}\text { / 18000/1/16750/ } \\
75000\end{array}$ & - & - & 10 & 0 & 0 & 0 & & 0 & $\mathrm{~N}$ & 3 & $\begin{array}{l}\text { E0930-D1- } \\
\text { 070812.ASC }\end{array}$ & E0930-D2-Channel\# Aug12 2007 10-43-13.txt & no video \\
\hline E0931 & 4 & Water & 94.75 & 0.55 & - & & 1 & A & 5 & 4.00 & & - & & $\begin{array}{l}23000 / 1 / 19000 / \\
75000\end{array}$ & & & - & 8 & 0 & 0 & 0 & & 0 & $\mathrm{~N}$ & 1 & $\begin{array}{l}\text { E0931-D1- } \\
\text { 070812.ASC }\end{array}$ & E0931-D2-Channel\# Aug12 2007 11-02-49.txt & no video \\
\hline E0932 & 4 & Water & 94.75 & 0.55 & - & & 1 & A & 5 & 4.01 & & - & & $\begin{array}{l}23000 / 1 / 19000 / \\
75000\end{array}$ & t & & - & 8 & 0 & 0 & 0 & & o & $\mathrm{N}$ & 2 & $\begin{array}{l}\text { E0932-D1- } \\
\text { 070812.ASC }\end{array}$ & E0932-D2-Channel\# Aug12 2007 11-07-10.txt & no video \\
\hline E0933 & 4 & Water & 94.75 & 0.55 & - & & 1 & A & 5 & 4.01 & & - & & $\begin{array}{l}23000 / 1 / 19000 / \\
75000\end{array}$ & & & - & 8 & 0 & 0 & 0 & & 0 & $\mathrm{~N}$ & 3 & $\begin{array}{l}\text { E0933-D1- } \\
\text { 070812.ASC }\end{array}$ & E0933-D2-Channel\# Aug12 2007 11-10-08.txt & no video \\
\hline E0934 & 4 & Water & 94.75 & 0.55 & - & - & 2 & $A, B$ & $5 / 3.5$ & 3.99 & 4.04 & - & - & $\begin{array}{l}23000 / 1 / 19000 / \\
75500\end{array}$ & $\begin{array}{l}\mid 23000 / 1 / 19000 / \\
75500\end{array}$ & - & - & 8 & 0 & $\mathrm{o}$ & $\mathrm{O}$ & & o & $\mathrm{N}$ & 1 & $\begin{array}{l}\text { E0934-D1- } \\
\text { 070812.ASC }\end{array}$ & E0934-D2-Channel\# Aug12 2007 11-16-44.txt & no video \\
\hline E0935 & 4 & Water & 94.75 & 0.55 & - & - & 2 & $A, B$ & $5 / 3.5$ & 3.99 & 4.04 & - & - & $23000 / 1 / 19000 /$ & $\begin{array}{l}23000 / 1 / 190000 / \\
75000\end{array}$ & - & - & 8 & 0 & o & o & & o & N & 2 & $\begin{array}{l}\text { E0935-D1- } \\
070812 \text { ASC }\end{array}$ & E0935-D2-Channel\# Aug12 2007 11-20-31.txt & no video \\
\hline E0936 & 4 & Water & 94.75 & 0.55 & - & - & 2 & $A, B$ & $5 / 3.5$ & 3.99 & 4.04 & - & - & $\begin{array}{l}23000 / 1 / 190000 / \\
75000\end{array}$ & $\begin{array}{l}23000 / 1 / 190000 / \\
75000\end{array}$ & - & - & 8 & 0 & o & 0 & & O & N & 3 & E0936-D1- & E0936-D2-Channel\# Aug12 2007 11-23-57.txt & no video \\
\hline E0937 & 4 & Water & 94.75 & 0.55 & - & - & 1 & A & 5 & 2.29 & - & - & & $\begin{array}{l}23000 / 1 / 22000 / \\
75000\end{array}$ & & - & - & 6 & 0 & 0 & 0 & & 0 & $\mathrm{~N}$ & 1 & $\begin{array}{l}\text { EO937-D1- } \\
\text { 070812.ASC }\end{array}$ & E0937-D2-Channel\# Aug12 2007 13-43-34.txt & no video \\
\hline E0938 & 4 & Water & 94.75 & 0.55 & - & - & 1 & A & 5 & 2.29 & & - & & $\begin{array}{l}23000 / 1 / 22000 / \\
75000\end{array}$ & t & - & - & 6 & 0 & 0 & 0 & & o & $\mathrm{N}$ & 2 & $\begin{array}{l}\text { E0938-D1- } \\
\text { 070812.ASC }\end{array}$ & E0938-D2-Channel\# Aug12 2007 13-47-33.txt & no video \\
\hline E0939 & 4 & Water & 94.75 & 0.55 & - & - & 1 & A & 5 & 2.29 & - & - & & $\begin{array}{l}23000 / 1 / 22000 / \\
75000\end{array}$ & & - & - & 6 & 0 & 0 & 0 & & o & $\mathrm{N}$ & 3 & $\begin{array}{l}\text { EOOM39-D1- } \\
\text { 070812.ASC }\end{array}$ & E0939-D2-Channel\# Aug12 2007 13-51-14.txt & no video \\
\hline E0940 & 4 & Water & 94.75 & 0.55 & - & - & 2 & $A, B$ & $4.0 / 2.0$ & 2.29 & 2.28 & - & & $\begin{array}{l}23000 / 1 / 22000 / \\
75000\end{array}$ & $\begin{array}{l}\text { 23000/1/22000/ } \\
75000\end{array}$ & - & - & 6 & 0 & 0 & 0 & & 0 & $\mathrm{~N}$ & 1 & $\begin{array}{l}\text { E0940-D1- } \\
\text { 070812.ASC }\end{array}$ & E0940-D2-Channel\#A Aug12 2007 13-57-29.txt & no video \\
\hline E0941 & 4 & Water & 94.75 & 0.55 & - & - & 2 & $A, B$ & $6.0 / 2.0$ & 2.29 & 2.28 & - & - & $23000 / 1000 /$ & $\begin{array}{l}23000 / 1 / 22000 / \\
75000\end{array}$ & - & - & 6 & 0 & 0 & o & & o & N & 2 & E0941-D1- & E0941-D2-Channel\# Aug12 2007 14-02-02.txt & no video \\
\hline E0942 & 4 & Water & 94.75 & 0.55 & - & - & 2 & $A, B$ & $6.0 / 2.0$ & 2.34 & 2.26 & - & - & $\begin{array}{l}23000 / 2000 / \\
23000 / 75000\end{array}$ & $\begin{array}{c}23000 / 1 / 122000 / \\
75000\end{array}$ & - & - & 6 & 0 & $\mathrm{o}$ & $\mathrm{o}$ & & o & $\mathrm{N}$ & 3 & $\begin{array}{l}\text { E0942-D1- } \\
\text { 070812.ASC }\end{array}$ & E0942-D2-Channel\# Aug12 2007 14-05-51.txt & no video \\
\hline $\begin{array}{l}\text { Middle We } \\
\text { E0943B } \\
\text { L }\end{array}$ & $\begin{array}{l}\text { Ileve } \\
4\end{array}$ & el: hydror & $\begin{array}{l}\text { phone } \\
94.7 !\end{array}$ & $\begin{array}{l}\text { level }=\mathrm{N} \\
0.55\end{array}$ & & & & & & & & & & & & & & & $\mathrm{M}$ & $\mathrm{M}$ & M & & M & $\mathrm{N}$ & 1 & $\begin{array}{r}\text { E09 } \\
070\end{array}$ & $\begin{array}{l}\text { E0943-D2-BL-Channel\#A Aug12 } 2007 \text { 14-25- } \\
\text { 32.txt }\end{array}$ & no video \\
\hline E0943 & 4 & Water & 94.75 & 0.55 & - & & 1 & A & 5 & 2.32 & & - & & $\begin{array}{l}23000 / 1 / 22000 / \\
75000\end{array}$ & & - & - & 6 & M & M & M & & M & $\mathrm{N}$ & 1 & $\begin{array}{l}\text { EO9943-D1- } \\
\text { 070812.ASC }\end{array}$ & E0943-D2-Channel\# Aug12 2007 14-29-30.txt & no video \\
\hline E0944 & 4 & Water & 94.75 & 0.55 & & & 1 & A & 5 & 2.28 & & & & $\begin{array}{l}23000 / 1 / 22000 / \\
75000\end{array}$ & & & - & 6 & M & M & M & & M & $\mathrm{N}$ & 2 & $\begin{array}{l}\text { E0944-D1- } \\
\text { 070812.ASC }\end{array}$ & E0944-D2-Channel\# Aug12 2007 14-32-32.txt & no video \\
\hline E0945 & 4 & Water & 94.75 & 0.55 & - & - & 1 & A & 5 & 2.25 & & - & & $\begin{array}{l}23000 / 1 / 1 / 22000 / \\
75000\end{array}$ & & - & - & 6 & M & M & M & & M & N & 3 & $\begin{array}{l}\text { E0945-D1- } \\
\text { E70812ASC }\end{array}$ & E0945-D2-Channel\# Aug12 2007 14-34-42.txt & no video \\
\hline E0946 & 4 & Water & 94.75 & 0.55 & - & - & 2 & $A, B$ & 5.015 .0 & 2.26 & 2.29 & - & - & $\begin{array}{l}23000 / 1 / 22000 / \\
75000\end{array}$ & $\begin{array}{l}21000 / 1 / 240000 \\
75000\end{array}$ & - & - & 6 & M & M & M & & M & $\mathrm{N}$ & 1 & $\begin{array}{l}\text { EO946-D1- } \\
\text { 070812.ASC }\end{array}$ & E0946-D2-Channel\# Aug12 2007 14-43-37.txt & no video \\
\hline E0947 & 4 & Water & 94.75 & 0.55 & - & - & 2 & $A, B$ & $5.0 / 5.0$ & 2.28 & 2.28 & - & - & $\begin{array}{l}23000 / 1 / 1 / 22000 / \\
75000\end{array}$ & $\begin{array}{l}21000 / 1 / 24000 / \\
75000\end{array}$ & - & - & 6 & M & M & M & & M & $\mathrm{N}$ & 2 & $\begin{array}{l}\text { E0147-D1- } \\
\text { 070812.ASC }\end{array}$ & E0947-D2-Channel\# Aug12 2007 14-47-08.txt & no video \\
\hline
\end{tabular}




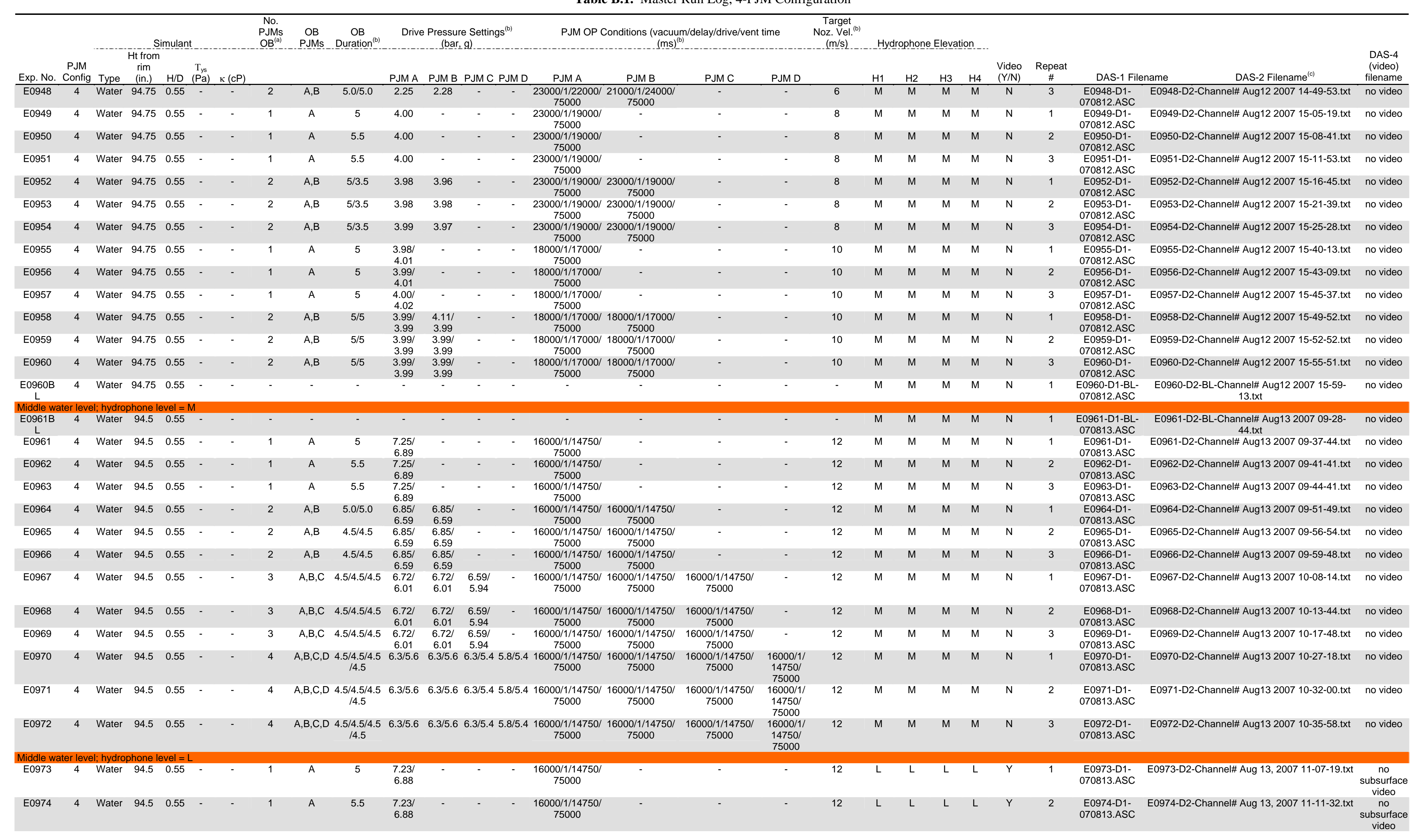


Table B.1. Master Run Log, 4-PJM Configuration

\begin{tabular}{|c|c|c|c|c|c|c|c|c|c|c|c|c|c|c|c|c|c|c|c|c|c|c|c|c|c|c|}
\hline \multirow[b]{2}{*}{ Exp. No. } & \multirow[b]{2}{*}{$\begin{array}{l}\text { PJM } \\
\text { Config }\end{array}$} & \multirow[b]{2}{*}{ Type } & \multicolumn{2}{|c|}{$\begin{array}{l}\text { Simulant } \\
\text { Ht from }\end{array}$} & \multirow[b]{2}{*}{$\mathrm{K}(\mathrm{CP})$} & \multirow{2}{*}{$\begin{array}{c}\text { No. } \\
\text { PMS } \\
\text { PJMB } \\
\mathrm{OB}^{(a)} \\
\end{array}$} & & \multirow{2}{*}{$\begin{array}{c}\mathrm{OB} \\
\text { Duration } \\
.\end{array}$} & \multicolumn{4}{|c|}{$\begin{array}{l}\text { Drive Pressure Settings }{ }^{(b)} \\
\text { (bar, } 9 \text { - }\end{array}$} & \multicolumn{4}{|c|}{$\begin{array}{l}\text { PJM OP Conditions (vacuum/delay/drive/vent time } \\
(\mathrm{ms})^{(0)}\end{array}$} & \multirow[t]{2}{*}{ 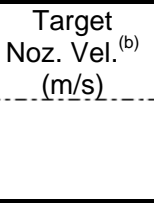 } & \multicolumn{4}{|c|}{ Hydrophone Elevation } & \multirow[b]{2}{*}{$\begin{array}{l}\text { Video } \\
(Y / N)\end{array}$} & \multirow[b]{2}{*}{$\underset{\#}{\text { Repeat }}$} & \multirow[b]{2}{*}{ DAS-1 Filenan } & \multirow{3}{*}{$\frac{\text { DAS-2 Filename }}{\text { nnel\# Aug 13, } 2007 \text { 11-19-17.txt }}$} & \multirow{2}{*}{$\begin{array}{r}\text { DAS-4 } \\
\text { (video) } \\
\text { filename } \\
\end{array}$} \\
\hline & & & $\begin{array}{l}\text { rim } \\
\text { (in.) }\end{array}$ & $\begin{array}{l}\mathrm{T}_{\mathrm{ys}} \\
\mathrm{H} / \mathrm{Pa})\end{array}$ & & & & & PJM A & PJM B & PJM C P. & JM D & PJMA & PJM B & PJM C & PJM D & & H1 & $\mathrm{H} 2$ & H3 & $\mathrm{H} 4$ & & & & & \\
\hline $\begin{array}{ll}\text { E0975 } \\
\end{array}$ & 4 & Water & 94.5 & 0.55 & & 1 & A & 5 & $\begin{array}{l}7.231 \\
6.88\end{array}$ & & & & $\begin{array}{l}16000 / 1 / 14750 / \\
75000\end{array}$ & & & & 12 & $\mathrm{~L}$ & $\mathrm{~L}$ & $\mathrm{~L}$ & $\mathrm{~L}$ & $\mathrm{~N}$ & & $\begin{array}{l}\text { E0975-D1- } \\
\text { 070813.ASC }\end{array}$ & & no video \\
\hline E0976 & 4 & Water & 94.5 & 0.55 & & 2 & $A, B$ & $4.5 / 4.5$ & $\begin{array}{l}6.981 \\
6.54\end{array}$ & $\begin{array}{l}6.96 / \\
6.45\end{array}$ & & & $\begin{array}{l}16000 / 1 / 14750 / \\
75000\end{array}$ & $\begin{array}{l}16000 / 1 / 14750 / \\
75000\end{array}$ & & & 12 & L & L & L & L & $\mathrm{Y}$ & 1 & $\begin{array}{l}\text { E0976-D1- } \\
\text { 070813.ASC }\end{array}$ & E0976-D2-Channel\# Aug 13, 2007 11-25-44.txt & $\begin{array}{l}\text { E0976-NV- } \\
070813\end{array}$ \\
\hline E0977 & 4 & Water & 94.5 & 0.55 & - & 2 & $A, B$ & $5 / 5$ & $\begin{array}{l}6.981 \\
6.54\end{array}$ & $6.96 /$ & - & - & $\begin{array}{l}16000 / 1 / 14750 / \\
75000\end{array}$ & 16000/1/14750/ & - & - & 12 & L & L & L & L & Y & 2 & $\begin{array}{l}\text { E0977-D1- } \\
\text { 0070813ASC }\end{array}$ & E0977-D2-Channel\# Aug 13, 2007 11-33-56.txt & $\begin{array}{l}\text { E0977-NV- } \\
0070813\end{array}$ \\
\hline E0978 & 4 & Water & 94.5 & $0.55-$ & - & 2 & $A, B$ & $4.5 / 4.5$ & $\begin{array}{l}6.981 \\
6.54\end{array}$ & $\begin{array}{l}6.96 / \\
6.45\end{array}$ & - & - & $\begin{array}{l}16000 / 1 / 14750 / \\
75000\end{array}$ & $\begin{array}{l}16000 / 1 / 14750 / \\
75000\end{array}$ & - & - & 12 & L & L & L & L & N & 3 & $\begin{array}{l}\text { E0978-D1- } \\
\text { 070813.ASC }\end{array}$ & E0978-D2-Channel\# Aug 13, 2007 11-37-17.txt & no video \\
\hline E0979 & 4 & Water & 94.5 & $0.55-$ & - & 3 & $\mathrm{~A}, \mathrm{~B}, \mathrm{C}$ & $4.5 / 4.5 / 4.5$ & $\begin{array}{l}0.321 \\
5.86\end{array}$ & $\begin{array}{l}6.321 \\
5.92\end{array}$ & $\begin{array}{l}6.19 / \\
5.84\end{array}$ & - & $\begin{array}{l}16000 / 1 / 14750 / \\
75000\end{array}$ & $\begin{array}{l}16000 / 1 / 14750 / 1 \\
75000\end{array}$ & $\begin{array}{l}16000 / 1 / 14750 / 75 \\
000\end{array}$ & - & 12 & $\mathrm{~L}$ & L & L & L & $\mathrm{Y}$ & 1 & $\begin{array}{l}\text { E0979-D1- } \\
\text { 070813.ASC }\end{array}$ & E0979-D2-Channel\# Aug 13, 2007 11-45-50.txt & $\begin{array}{l}\text { E0979-NV- } \\
070813\end{array}$ \\
\hline E0980 & 4 & Water & 94.5 & 0.55 & - & 3 & $\mathrm{~A}, \mathrm{~B}, \mathrm{C}$ & 4.5/4.5/4.5 & $\begin{array}{l}5.301 \\
5.86\end{array}$ & $\begin{array}{l}6.321 \\
5.92\end{array}$ & $\begin{array}{l}6.041 \\
5.84\end{array}$ & - & $\begin{array}{l}16000 / 1 / 1 / 14750 / \\
75000\end{array}$ & $\begin{array}{l}16000 / 1 / 144750 / 1 \\
75000\end{array}$ & $\begin{array}{l}16000 / 1 / 1 / 1450 / 75 \\
000\end{array}$ & - & 12 & $\mathrm{~L}$ & L & L & L & Y & 2 & $\begin{array}{l}\text { E0980-D1- } \\
\text { 07013.ASC }\end{array}$ & E0980-D2-Channel\# Aug 13, 2007 11-53-21.txt & E0980-NV- \\
\hline E0981 & 4 & Water & 94.5 & 0.55 & & 3 & $\mathrm{~A}, \mathrm{~B}, \mathrm{C}$ & $4.5 / 4.5 / 4.5$ & $\begin{array}{l}6.321 \\
5.86\end{array}$ & $\begin{array}{l}6.321 \\
5.92\end{array}$ & $\begin{array}{l}6.19 / \\
5.84\end{array}$ & & $\begin{array}{l}16000 / 1 / 14750 / \\
75000\end{array}$ & $\begin{array}{l}16000 / 1 / 14750 / 1 \\
75000\end{array}$ & $\begin{array}{l}16000 / 1 / 14750 / 75 \\
000\end{array}$ & & 12 & L & L & L & L & $\mathrm{N}$ & 3 & $\begin{array}{l}\text { E0981-D1- } \\
\text { 077812ASC }\end{array}$ & E0981-D2-Channel\# Aug 13, 2007 11-57-25.txt & no video \\
\hline E0982 & 4 & Water & 94.5 & 0.55 & - & 4 & $A, B, C, D$ & $\begin{array}{l}4.5 / 4.5 / 4.5 \\
14.5\end{array}$ & $6.01 / 5.5$ & 6.415 .5 & $6.4 / 5.56$. & $4 / 5.5$ & $\begin{array}{l}16000 / 1 / 14750 / \\
75000\end{array}$ & $\begin{array}{l}16000 / 1 / 147450 / 1 \\
75000\end{array}$ & $\begin{array}{l}16000 / 1 / 14750 / 75 \\
000\end{array}$ & $\begin{array}{l}16000 / 1 / \\
14500 / \\
75000\end{array}$ & 12 & $\mathrm{~L}$ & L & L & L & $\mathrm{Y}$ & 1 & $\begin{array}{l}\text { E0982-D1- } \\
\text { 070813.ASC }\end{array}$ & E0982-D2-Channel\# Aug 13, 2007 12-05-07.txt & $\begin{array}{l}\text { E0982-NV- } \\
070813\end{array}$ \\
\hline E0983 & 4 & Water & 94.5 & 0.55 & - & 4 & $\mathrm{~A}, \mathrm{~B}, \mathrm{C}, \mathrm{D}$ & $\begin{array}{l}4.5 / 4.5 / 4.5 \\
14.5\end{array}$ & $6.4 / 5.5$ & $6.4 / 5.5$ & 6.4/5.5 6. & $.4 / 5.5$ & $\begin{array}{c}16000 / 1 / 14750 / \\
75000\end{array}$ & $\begin{array}{c}16000 / 1 / 14750 / \\
75000\end{array}$ & $\begin{array}{c}16000 / 1 / 14750 / \\
75000\end{array}$ & $\begin{array}{l}16000 / 1 / \\
14750 / \\
75000\end{array}$ & 12 & $\mathrm{~L}$ & L & $\mathrm{L}$ & L & $\mathrm{Y}$ & 2 & $\begin{array}{l}\text { E0983-D1- } \\
\text { 070813.ASC }\end{array}$ & E0983-D2-Channel\# Aug 13, 2007 12-12-16.txt & $\begin{array}{l}\text { E0983-NV- } \\
070813\end{array}$ \\
\hline E0984 & 4 & Water & 94.5 & 0.55 & - & 4 & $A, B, C, D$ & $\begin{array}{l}4.5 / 4.5 / 4.5 \\
14.5\end{array}$ & $6.4 / 5.5$ & $6.4 / 5.5$ & $6.4 / 5.56$. & $4 / 5.5$ & $\begin{array}{l}16000 / 1 / 14750 / \\
75000\end{array}$ & $\begin{array}{l}16000 / 1 / 14750 / \\
75000\end{array}$ & $\begin{array}{c}16000 / 1 / 14750 / \\
75000\end{array}$ & $\begin{array}{l}16000 / 1 / \\
14750 / \\
75500\end{array}$ & 12 & $\mathrm{~L}$ & L & $\mathrm{L}$ & L & $\mathrm{N}$ & 3 & $\begin{array}{l}\text { E0984-D1- } \\
\text { 070813.ASC }\end{array}$ & E0984-D2-Channel\# Aug 13, 2007 12-16-02.txt & no video \\
\hline E0985 & 4 & Water & 94.5 & 0.55 & - & 1 & A & 5 & $\begin{array}{l}4.03 / 4.0 \\
3\end{array}$ & - & - & - & $\begin{array}{l}18000 / 1 / 17000 / \\
75000\end{array}$ & & - & & 10 & $\mathrm{~L}$ & L & L & L & $\mathrm{Y}$ & 1 & $\begin{array}{l}\text { E0985-D1- } \\
\text { 070813.ASC }\end{array}$ & E0985-D2-Channel\# Aug 13, 2007 13-36-53.txt & $\begin{array}{l}\text { E0985-NV- } \\
070813\end{array}$ \\
\hline E0986 & 4 & Water & 94.5 & 0.55 & & 1 & A & 5 & $\begin{array}{l}4.03 / 4.0 \\
3\end{array}$ & - & & - & $\begin{array}{c}18000 / 1 / 17000 / \\
75000\end{array}$ & & & & 10 & L & L & L & L & $\mathrm{Y}$ & 2 & $\begin{array}{l}\text { E0986-D1- } \\
\text { 070813.ASC }\end{array}$ & E0986-D2-Channel\# Aug 13, 2007 13-43-13.txt & $\begin{array}{l}\text { no } \\
\text { subsurface } \\
\text { video }\end{array}$ \\
\hline E0987 & 4 & Water & 94.5 & 0.55 & - & 1 & A & 5 & $\begin{array}{l}4.03 / 4.0 \\
3\end{array}$ & - & & - & $\begin{array}{l}18000 / 1 / 17000 / \\
75000\end{array}$ & & & & 10 & L & L & L & L & $\mathrm{N}$ & 3 & $\begin{array}{l}\text { E0987-D1- } \\
\text { 070813.ASC }\end{array}$ & E0987-D2-Channel\# Aug 13, 2007 13-49-34.txt & no video \\
\hline E0988 & 4 & Water & 94.5 & 0.55 & & 2 & $A, B$ & 5 & $4.0 / 3.99$ & $\begin{array}{c}3.95 / 4 . \\
02\end{array}$ & & & $\begin{array}{l}18000 / 1 / 17000 / \\
75000\end{array}$ & $\begin{array}{l}18000 / 1 / 17000 / \\
75000\end{array}$ & & & 10 & $\mathrm{~L}$ & L & $\mathrm{L}$ & L & Y & 1 & $\begin{array}{l}\text { E0988-D1- } \\
\text { 070813.ASC }\end{array}$ & E0988-D2-Channel\# Aug 13, 2007 13-58-05.txt & $\begin{array}{l}\text { E0988-NV- } \\
070813\end{array}$ \\
\hline E0989 & 4 & Water & 94.5 & 0.55 & - & 2 & $A, B$ & 5 & $4.0 / 3.99$ & $\begin{array}{l}3.95 / 4 . \\
02\end{array}$ & & - & $\begin{array}{l}18000 / 1 / 17000 / \\
75000\end{array}$ & $\begin{array}{l}18000 / 1 / 17000 / \\
75000\end{array}$ & & & 10 & L & L & $\mathrm{L}$ & L & $\mathrm{Y}$ & 2 & $\begin{array}{l}\text { E0989-D1- } \\
\text { 070813.ASC }\end{array}$ & E0989-D2-Channel\# Aug 13, 2007 14-05-56.txt & $\begin{array}{l}\text { E0989-NV- } \\
070813\end{array}$ \\
\hline E0990 & 4 & Water & 94.5 & 0.55 & - & 2 & $A, B$ & 5 & $4.0 / 3.99$ & $\begin{array}{l}3.95 / 4 . \\
02\end{array}$ & - & - & $\begin{array}{l}18000 / 1 / 17000 / \\
75000\end{array}$ & $\begin{array}{l}18000 / 1 / 170000 \\
75000\end{array}$ & - & - & 10 & L & L & L & L & $\mathrm{N}$ & 3 & $\begin{array}{l}\text { EO990-D1- } \\
\text { 077813.ASC }\end{array}$ & E0990-D2-Channel\# Aug 13, 2007 14-12-45.txt & no video \\
\hline E0991 & 4 & Water & 94.5 & 0.55 & - & 1 & B & 4.5 & - & $\begin{array}{l}3.98 / 4 . \\
05\end{array}$ & - & - & - & $\begin{array}{l}18000 / 1 / 17000 / \\
75000\end{array}$ & - & - & 10 & $\mathrm{~L}$ & L & L & L & Y & 1 & $\begin{array}{l}\text { E0991-D1- } \\
\text { 070813.ASC }\end{array}$ & E0991-D2-Channel\# Aug 13, 2007 14-25-05.txt & $\begin{array}{l}\text { E0991-NV- } \\
070813\end{array}$ \\
\hline E0992 & 4 & Water & 94.5 & 0.55 & - & 1 & A & 4.5 & 4.03 & & - & - & $\begin{array}{l}23000 / 1 / 19000 / \\
75000\end{array}$ & & - & & 8 & L & L & L & L & $\mathrm{Y}$ & 1 & $\begin{array}{l}\text { E0992-D1- } \\
\text { 070813.ASC }\end{array}$ & E0992-D2-Channel\# Aug 13, 2007 14-40-51.txt & $\begin{array}{l}\text { E0992-NV- } \\
070813\end{array}$ \\
\hline E0993 & 4 & Water & 94.5 & 0.55 & - & 1 & A & 5 & 4.03 & - & & & $\begin{array}{l}23000 / 1 / 19000 / \\
75000\end{array}$ & & & & 8 & $\mathrm{~L}$ & L & L & L & Y & 2 & $\begin{array}{l}\text { E0993-D1- } \\
\text { 070813.ASC }\end{array}$ & E0993-D2-Channel\# Aug 13, 2007 14-48-35.txt & $\begin{array}{l}\text { no } \\
\text { subsurface } \\
\text { video }\end{array}$ \\
\hline E0994 & 4 & Water & 94.5 & 0.55 & - & 1 & A & 5 & 4.04 & - & & & $\begin{array}{l}23000 / 1 / 19000 / \\
75000\end{array}$ & & & & 8 & L & L & L & $\mathrm{L}$ & $\mathrm{N}$ & 3 & $\begin{array}{l}\text { E0994-D1- } \\
\text { 070813.ASC }\end{array}$ & E0994-D2-Channel\# Aug 13, 2007 14-51-14.txt & no video \\
\hline E0995 & 4 & Water & 94.5 & 0.55 & & 2 & $A, B$ & $4.5 / 3.5$ & 4.01 & 3.99 & & & $\begin{array}{l}23000 / 1 / 19000 / \\
75000\end{array}$ & $\begin{array}{l}\text { 23000/1/19000/ } \\
75000\end{array}$ & & & 8 & $\mathrm{~L}$ & $\mathrm{~L}$ & $\mathrm{~L}$ & L & $\mathrm{Y}$ & 1 & $\begin{array}{l}\text { E0995-D1- } \\
\text { 070813.ASC }\end{array}$ & E0995-D2-Channel\# Aug 13, 2007 14-59-59.txt & $\begin{array}{l}\text { E0995-NV- } \\
070813\end{array}$ \\
\hline E0996 & 4 & Water & 94.5 & 0.55 & - & 2 & $A, B$ & $5 / 4$ & 4.02 & 3.99 & - & - & $\begin{array}{l}23000 / 1 / 19000 / \\
75000\end{array}$ & $\begin{array}{l}\text { 23000/1/19000/ } \\
75000\end{array}$ & - & - & 8 & $\mathrm{~L}$ & L & L & L & $\mathrm{Y}$ & 2 & $\begin{array}{l}\text { E0996-D1- } \\
\text { 070813.ASC }\end{array}$ & E0996-D2-Channel\# Aug 13, 2007 15-23-37.txt & $\begin{array}{l}\text { E0996-NV- } \\
070813\end{array}$ \\
\hline E0997 & 4 & Water & 94.5 & 0.55 & - & 2 & $A, B$ & $5 / 4$ & 4.02 & 3.99 & - & 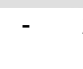 & $\begin{array}{l}23000 / 1 / 19000 / \\
75000\end{array}$ & $\begin{array}{l}23000 / 1 / 19000 / \\
75000\end{array}$ & - & - & 8 & L & L & L & L & $\mathrm{N}$ & 3 & $\begin{array}{l}\text { E0997-D1- } \\
\text { 070813ASC }\end{array}$ & E0997-D2-Channel\# Aug 13, 2007 15-28-39.txt & no video \\
\hline E0998 & 4 & Water & 94.5 & 0.55 & - & 1 & B & 3.5 & - & 4.00 & - & - & 70000 & $\begin{array}{l}23000 / 1 / 19000 / \\
75000\end{array}$ & - & - & 8 & $\mathrm{~L}$ & L & L & L & Y & 1 & $\begin{array}{l}\text { DAS } \\
\text { DASC }\end{array}$ & E0998-D2-Channel\# Aug 13, 2007 15-34-37.txt & $\begin{array}{l}\text { E0998-NV- } \\
070813\end{array}$ \\
\hline E0999 & 4 & Water & 94.5 & 0.55 & - & 1 & A & 4.5 & 2.30 & - & - & - & $\begin{array}{l}23000 / 1 / 22000 / \\
75000\end{array}$ & & - & & 6 & $\mathrm{~L}$ & L & L & L & $\mathrm{Y}$ & 1 & ASC & E0999-D2-Channel\# Aug 13, 2007 15-54-44.txt & $\begin{array}{l}\text { EO999-NV- } \\
070813\end{array}$ \\
\hline E1000 & 4 & Water & 94.5 & 0.55 & & 1 & A & 4.5 & 2.26 & - & & & $\begin{array}{l}23000 / 1 / 22000 / \\
75000\end{array}$ & & & & 6 & L & L & L & L & $\mathrm{Y}$ & 2 & $\begin{array}{l}\text { E1000-D1- } \\
\text { 070813.ASC }\end{array}$ & E1000-D2-Channel\# Aug 13, 2007 16-00-21.txt & $\begin{array}{l}\text { no } \\
\text { subsurface } \\
\text { video }\end{array}$ \\
\hline E1001 & 4 & Water & 94.5 & 0.55 & & 1 & A & 4.5 & 2.30 & - & & & $\begin{array}{l}23000 / 1 / 22000 / \\
75000\end{array}$ & & & & 6 & L & L & $\mathrm{L}$ & L & N & 3 & & E1001-D2-Channel\# Aug 13, 2007 16-03-49.txt & no video \\
\hline E1002 & 4 & Water & 94.5 & 0.55 & & 2 & $A, B$ & $4.5 / 4.5$ & 2.30 & 2.30 & & & $\begin{array}{l}23000 / 1 / 22000 / \\
75000\end{array}$ & $\begin{array}{l}\text { 21000/1/24000/ } \\
75000\end{array}$ & & & 6 & $\mathrm{~L}$ & L & L & L & 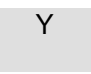 & 1 & $\begin{array}{l}\text { E1002-D1- } \\
\text { 070813.ASC }\end{array}$ & E1002-D2-Channel\# Aug 13, 2007 16-11-56.txt & $\begin{array}{l}\text { E1002-NV- } \\
070813\end{array}$ \\
\hline E1003 & 4 & Water & 94.5 & 0.55 & - & 2 & $A, B$ & 4.5/4.5 & 2.30 & 2.29 & - & - & $\begin{array}{l}23000 / 1 / 22000 / \\
75000\end{array}$ & $\begin{array}{l}21000 / 1 / 24000 / \\
75000\end{array}$ & - & & 6 & $\mathrm{~L}$ & L & L & L & $\mathrm{Y}$ & 2 & $\begin{array}{l}\text { E1003-D1- } \\
\text { 070813.ASC }\end{array}$ & E1003-D2-Channel\# Aug 13, 2007 16-20-33.txt & $\begin{array}{c}\text { E1003-NV- } \\
070813\end{array}$ \\
\hline E1004 & 4 & Water & 94.5 & $0.55-$ & 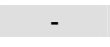 & 2 & $A, B$ & $4.5 / 4.5$ & 2.30 & 2.28 & - & - & 23000/1/22000/ & | 21000/1/24000/ & & 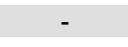 & 6 & & L & L & - & $\mathrm{N}$ & 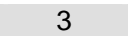 & E1004-D1- & E1004-D2-Channel\# Aug 13, 2007 16-26-26.txt & no video \\
\hline
\end{tabular}


Table B.1. Master Run Log, 4-PJM Configuration

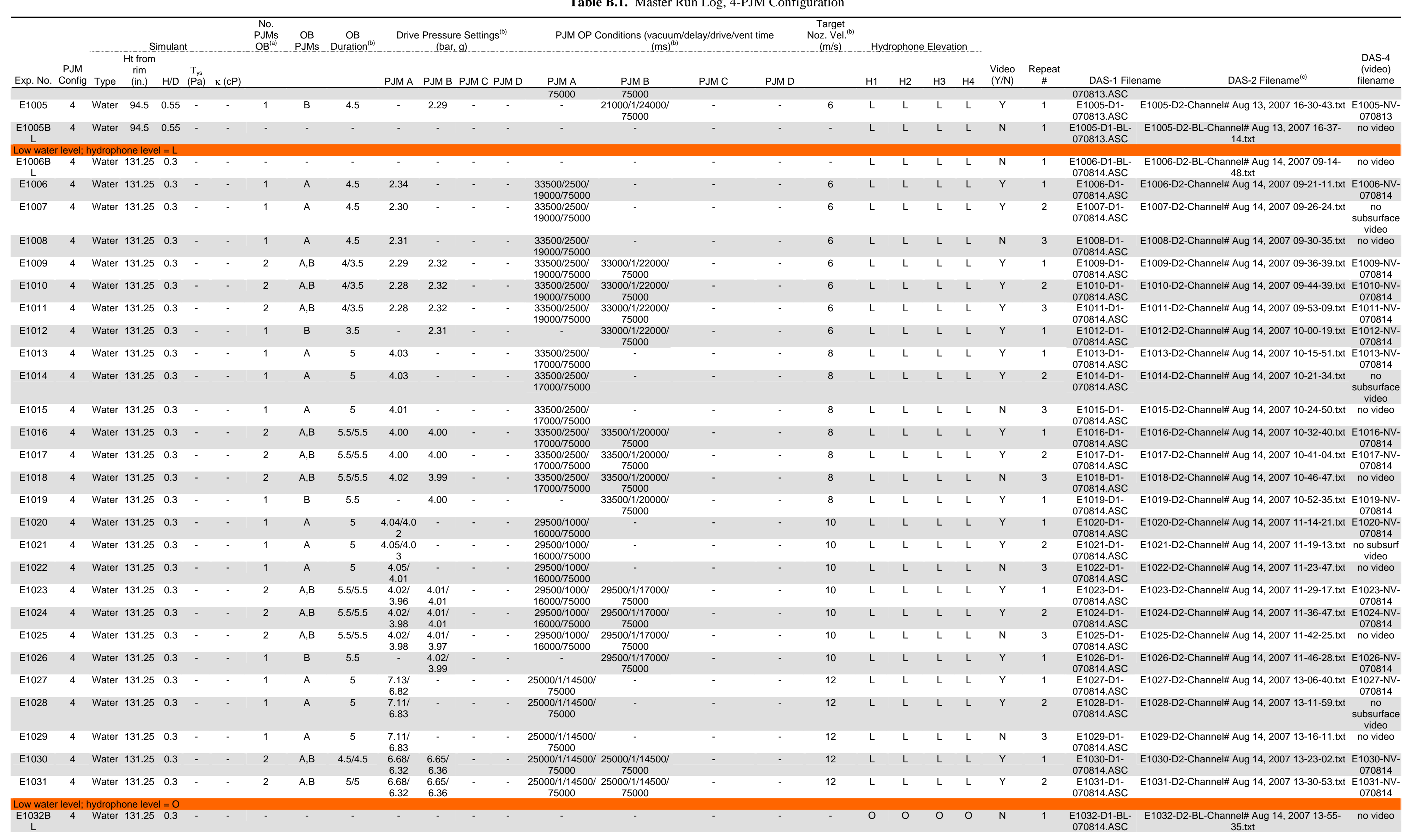


Table B.1. Master Run Log, 4-PJM Configuration

\begin{tabular}{|c|c|c|c|c|c|c|c|c|c|c|c|c|c|c|c|c|c|c|c|c|c|c|c|c|c|c|c|c|}
\hline \multirow[b]{2}{*}{ Exp. No. } & \multirow[b]{2}{*}{$\begin{array}{l}\text { PJM } \\
\text { Config }\end{array}$} & \multicolumn{5}{|c|}{ Simulant } & \multirow[t]{2}{*}{$\begin{array}{l}\text { No. } \\
\text { PJMs } \\
\text { OB (a) }\end{array}$} & \multirow[t]{2}{*}{$\begin{array}{c}\text { OB } \\
\text { PJMS }\end{array}$} & \multirow[t]{2}{*}{$\begin{array}{c}\mathrm{OB} \\
\text { Duration } \\
-(\text { (b) }\end{array}$} & \multicolumn{4}{|c|}{$\begin{array}{l}\text { Drive Pressure Settings } \\
\text { (b) }\end{array}$} & \multicolumn{4}{|c|}{$\begin{array}{l}\text { PJM OP Conditions (vacuum/delay/drive/vent time } \\
\qquad(\mathrm{ms})^{(0)}\end{array}$} & \multirow[t]{2}{*}{ 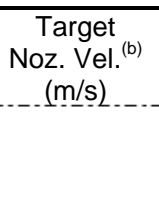 } & \multicolumn{5}{|c|}{ Hydrophone Elevation } & \multirow[b]{2}{*}{$\begin{array}{l}\text { Video } \\
(Y / N)\end{array}$} & \multirow[b]{2}{*}{$\begin{array}{l}\text { Repeat } \\
\#\end{array}$} & \multirow[b]{2}{*}{ DAS-1 Filenan } & \multirow{2}{*}{ ame $\quad$ DAS-2 Filename ${ }^{(c)}$} & \multirow[b]{2}{*}{$\begin{array}{c}\text { DAS-4 } \\
\text { (video) } \\
\text { filename }\end{array}$} \\
\hline & & Type & $\begin{array}{l}\text { Het from } \\
\text { rim } \\
\text { (in.) }\end{array}$ & $H / D$ & $\begin{array}{c}\mathrm{T}_{\mathrm{ys}} \\
(\mathrm{Pa})\end{array}$ & $\kappa(C P)$ & & & & PJM A & PJM B & PJM C & PJM D & PJM A & PJM B & PJM C & PJM D & & $\mathrm{H} 1$ & $\mathrm{H}_{2}$ & $\mathrm{H}$ & $13 \quad$ & $\mathrm{H} 4$ & & & & & \\
\hline E1032 & $\frac{4}{4}$ & Water & $\frac{131.25}{131.25}$ & 0.3 & & & 1 & A & 5 & 7.101 & & & & $25000 / 1 / 1 / 14500 /$ & & & & 12 & 0 & $\frac{16}{0}$ & c & & 0 & $\mathrm{~N}$ & & $\begin{array}{lll}\text { E1032-D1- } \\
\text { E7020 }\end{array}$ & E1032-D2-Channel/\# Aug 14, 2007 14-00-45.txt & no video \\
\hline E1033 & 4 & Water & 131.25 & 0.3 & & & 1 & A & 5 & $\begin{array}{l}6.85 \\
7.101 \\
6.85\end{array}$ & & & & $\begin{array}{l}75000 \\
25000 / 1 / 14500 / \\
75000\end{array}$ & & & & 12 & $\mathrm{o}$ & $\mathrm{o}$ & c & o & 0 & $\mathrm{~N}$ & 2 & $\begin{array}{l}\text { 070814.ASC } \\
\text { E1033-D1- } \\
070814 \text { ASC }\end{array}$ & E1033-D2-Channel\# Aug 14, 2007 14-03-51.txt & no video \\
\hline E1034 & 4 & Water & 131.25 & 0.3 & & & 1 & A & 5 & $\begin{array}{l}0.001 \\
6.83\end{array}$ & & - & & $\begin{array}{l}25000 / 1 / 14500 / \\
75000\end{array}$ & & & & 12 & $\mathrm{o}$ & $\mathrm{o}$ & c & o & 0 & $\mathrm{~N}$ & 3 & 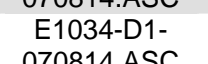 & E1034-D2-Channel\# Aug 14, 2007 14-06-53.txt & no video \\
\hline E1035 & 4 & Water & 131.25 & 0.3 & & & 2 & $A, B$ & $5 / 5$ & $\begin{array}{l}6.83 \\
6.94 / \\
6.40\end{array}$ & $6.94 /$ & & & $\begin{array}{l}25000 / 1 / 14500 / \\
75000\end{array}$ & 25000/1/14500/ & & & 12 & o & o & c & b & o & N & 1 & $\begin{array}{l}\text { E1035-D1- } \\
\text { E70814.ASC }\end{array}$ & E1035-D2-Channel\# Aug 14, 2007 14-12-22.txt & no video \\
\hline E1036 & 4 & Water & 131.25 & 0.3 & & & 2 & $A, B$ & $5 / 5$ & $\begin{array}{l}6.40 \\
6.941 \\
6.40\end{array}$ & $\begin{array}{l}0.944 \\
6.941 \\
6.34\end{array}$ & & & $25000 / 1 / 14500 /$ & / 25000/1/14500/ & & & 12 & o & o & $c$ & b & O & N & 2 & E1036-D1- & E1036-D2-Channel\# Aug 14, 2007 14-16-33.txt & no video \\
\hline E1037 & 4 & Water & 131.25 & 0.3 & - & - & 2 & $A, B$ & $5 / 5$ & $\begin{array}{l}6.941 \\
6.40\end{array}$ & $\begin{array}{l}6.941 \\
6.34\end{array}$ & - & & $\begin{array}{c}25000 / 1 / 14500 / \\
75000\end{array}$ & $\begin{array}{c}25000 / 1 / 1 / 4500 / \\
75000\end{array}$ & & - & 12 & $\mathrm{o}$ & $\mathrm{o}$ & c & o & 0 & $\mathrm{~N}$ & 3 & $\begin{array}{l}\text { E1037-D1- } \\
\text { 070814.ASC }\end{array}$ & E1037-D2-Channel/\# Aug 14, 2007 14-19-44.txt & no video \\
\hline E1038 & 4 & Water & 131.25 & 0.3 & - & - & 3 & $\mathrm{~A}, \mathrm{~B}, \mathrm{C}$ & 4.5/4.5/4.5 & $\begin{array}{l}0.40 \\
6.531 \\
6.09\end{array}$ & $\begin{array}{l}0.54 \\
6.541 \\
601\end{array}$ & 6.481 & & $25000 / 1 / 14500 /$ & / 25000/1/144500/ & $25000 / 1 / 14500 /$ & - & 12 & o & o & & O & O & $\mathrm{N}$ & 1 & E1038-D1- & E1038-D2-Channel\# Aug 14, 2007 14-25-26.txt & no video \\
\hline E1039 & 4 & Water & 131.25 & 0.3 & - & - & 3 & $A, B, C$ & 4.5/4.5/4.5 & $\begin{array}{l}6.531 \\
6.09\end{array}$ & $\begin{array}{l}6.541 \\
6.01\end{array}$ & $\begin{array}{l}6.481 \\
6.01\end{array}$ & & $\begin{array}{l}25000 / 1 / 14500 / \\
75000\end{array}$ & $\begin{array}{c}25000 / 1 / 145000 \\
75000\end{array}$ & $\begin{array}{l}25000 / 1 / 1 / 4500 / \\
75000\end{array}$ & - & 12 & $\mathrm{o}$ & $\mathrm{o}$ & & o & 0 & $\mathrm{~N}$ & 2 & $\begin{array}{l}\text { E1039-D1- } \\
\text { 070814.ASC }\end{array}$ & E1039-D2-Channel\# Aug 14, 2007 14-30-57.txt & no video \\
\hline E1040 & 4 & Water & 131.25 & 0.3 & - & - & 3 & $A, B, C$ & 4.5/4.5/4.5 & $\begin{array}{l}6.531 \\
650\end{array}$ & 6.541 & 6.481 & & $25000 / 1 / 145000 /$ & / 25000/1/1/14500/ & $25000 / 1 / 14500 /$ & - & 12 & $\mathrm{o}$ & $\mathrm{o}$ & & o & $\mathrm{o}$ & $\mathrm{N}$ & 3 & $\begin{array}{l}\text { E1040-D1- } \\
\text { E701- }\end{array}$ & E1040-D2-Channel\# Aug 14, 2007 14-36-24.txt & no video \\
\hline E1041 & 4 & Water & 131.25 & 0.3 & - & & 3 & $A, B, C$ & $4.5 / 4.5 / 4.5$ & $\begin{array}{l}0.531 \\
6.09\end{array}$ & $\begin{array}{l}6.01 / \\
6.01 /\end{array}$ & $\begin{array}{l}6.01 \\
6.01 \\
6.01\end{array}$ & & $\begin{array}{c}25000 / 1 / 14500 / \\
75000\end{array}$ & $\begin{array}{c}25000 / 1 / 145000 / 7000 \\
75000\end{array}$ & $\begin{array}{l}25000 / 1 / 14500 / \\
75000\end{array}$ & - & 12 & $\mathrm{o}$ & 0 & & o & 0 & $\mathrm{~N}$ & 4 & $\begin{array}{l}\text { E1041-D1- } \\
\text { 070814.ASC }\end{array}$ & E1041-D2-Channel\# Aug 14, 2007 14-41-51.txt & no video \\
\hline E1042 & 4 & Water & 131.25 & 0.3 & - & & 4 & $\mathrm{~A}, \mathrm{~B}, \mathrm{C}, \mathrm{D}$ & $\begin{array}{l}4.5 / 4.5 / 4.5 \\
14.5\end{array}$ & $5.9 / 5.2$ & $5.9 / 5.2$ & 5.015 .2 & $5.9 / 5.2$ & $\begin{array}{l}25000 / 1 / 14500 / \\
75000\end{array}$ & $\begin{array}{l}25000 / 1 / 145000 / \\
75000\end{array}$ & $\begin{array}{l}25000 / 1 / 144500 / \\
75000\end{array}$ & $\begin{array}{c}25000 / 1 / \\
14500 /\end{array}$ & 12 & $\mathrm{o}$ & $\mathrm{o}$ & & o & 0 & $\mathrm{~N}$ & 1 & $\begin{array}{l}\text { E1042-D1- } \\
\text { 070814.ASC }\end{array}$ & E1042-D2-Channel\# Aug 14, 2007 14-48-11.txt & no video \\
\hline E1043 & 4 & Water & 131.25 & 0.3 & - & - & 4 & $\mathrm{~A}, \mathrm{~B}, \mathrm{C}, \mathrm{D}$ & $\begin{array}{l}4.5 / 4.5 / 4.5 \\
14.5\end{array}$ & $5.9 / 5.2$ & $5.9 / 5.2$ & $5.9 / 5.2$ & $5.9 / 5.2$ & $\begin{array}{c}25000 / 1 / 14500 / \\
75000\end{array}$ & $\begin{array}{l}25000 / 1 / 145000 \\
75000\end{array}$ & $\begin{array}{l}25000 / 1 / 14500 / \\
75000\end{array}$ & $\begin{array}{l}25000 / 1 / \\
14000 /\end{array}$ & 12 & $\mathrm{o}$ & o & & o & o & $\mathrm{N}$ & 2 & $\begin{array}{l}\text { E1043-D1- } \\
\text { 070814.ASC }\end{array}$ & E1043-D2-Channel\# Aug 14, 2007 14-54-00.txt & no video \\
\hline E1044 & 4 & Water & 131.25 & 0.3 & - & - & 4 & $\mathrm{~A}, \mathrm{~B}, \mathrm{C}, \mathrm{D}$ & $\begin{array}{l}4.5 / 4.5 / 4.5 \\
14.5\end{array}$ & $5.9 / 5.2$ & $5.9 / 5.2$ & $5.9 / 5.2$ & $5.9 / 5.2$ & $\begin{array}{l}25000 / 1 / 14500 / \\
75000\end{array}$ & $\begin{array}{c}\text { / 2500/1/1/4500/ } \\
75000\end{array}$ & $\begin{array}{l}25000 / 1 / 145000 / \\
75000\end{array}$ & $\begin{array}{l}7500001 / \\
250001 / \\
14500 /\end{array}$ & 12 & $\mathrm{o}$ & 0 & & 0 & o & $\mathrm{N}$ & 3 & $\begin{array}{l}\text { E1044-D1- } \\
\text { 070814.ASC }\end{array}$ & E1044-D2-Channel\# Aug 14, 2007 14-58-37.txt & no video \\
\hline E1045 & 4 & Water & 131.25 & 0.3 & - & - & 1 & A & 5 & 4.011 & - & - & - & $29500 / 1000 /$ & - & - & - & 10 & $\mathrm{O}$ & O & $c$ & o & 0 & N & 1 & E1045-D1- & E1045-D2-Channel\# Aug 14, 2007 15-22-43.txt & no video \\
\hline E1046 & 4 & Water & 131.25 & 0.3 & - & - & 1 & A & 5 & $\begin{array}{l}3.09 \\
4.021 \\
.05\end{array}$ & - & - & - & $\begin{array}{l}160000 / 1 / 10000 \\
2950 / 1\end{array}$ & - & - & - & 10 & o & o & & o & 0 & N & 2 & $\begin{array}{l}\text { Oro814.ASC } \\
\text { E1046-D1- }\end{array}$ & E1046-D2-Channel\# Aug 14, 2007 15-26-16.txt & no video \\
\hline E1047 & 4 & Water & 131.25 & 0.3 & - & - & 1 & A & 5 & $\begin{array}{l}4.001 / \\
4.97\end{array}$ & & - & & $\begin{array}{l}19500 / 1000 / \\
16000 / 75000\end{array}$ & & - & - & 10 & 0 & 0 & & o & 0 & $\mathrm{~N}$ & 3 & $\begin{array}{l}\text { E1047-D1- } \\
\text { 070814.ASC }\end{array}$ & E1047-D2-Channel\# Aug 14, 2007 15-29-52.txt & no video \\
\hline E1048 & 4 & Water & 131.25 & 0.3 & - & - & 2 & $A, B$ & $5 / 5.5$ & $4.01 /$ & 3.991 & - & & $\begin{array}{l}29500 / 1000 / \\
16000 / 75000\end{array}$ & $\begin{array}{l}29500 / 1 / 17000 / \\
75000\end{array}$ & & - & 10 & 0 & $\mathrm{o}$ & & 0 & 0 & $\mathrm{~N}$ & 1 & $\begin{array}{l}\text { E1048-D1- } \\
\text { 070814ASC }\end{array}$ & E1048-D2-Channel\# Aug 14, 2007 15-35-07.txt & no video \\
\hline E1049 & 4 & Water & 131.25 & 0.3 & - & & 2 & $A, B$ & $5 / 5.5$ & $\begin{array}{l}4.011 \\
4.02\end{array}$ & $\begin{array}{l}4.041 \\
4.04\end{array}$ & & & $\begin{array}{l}29500 / 10000 / \\
16000 / 75000\end{array}$ & $\begin{array}{l}295000 / 1 / 17000 / \\
75000\end{array}$ & & - & 10 & o & 0 & & o & 0 & $\mathrm{~N}$ & 2 & $\begin{array}{l}\text { E1049-D1- } \\
\text { 070814.ASC }\end{array}$ & E1049-D2-Channel\# Aug 14, 2007 15-39-55.txt & no video \\
\hline E1050 & 4 & Water & 131.25 & 0.3 & - & - & 2 & $A, B$ & $5 / 5.5$ & $4.01 /$ & $\begin{array}{l}3.991 \\
4.04\end{array}$ & - & - & $\begin{array}{l}29500 / 1000 / \\
1600 / 75000\end{array}$ & $\begin{array}{l}29500 / 1 / 17000 / \\
75000\end{array}$ & - & - & 10 & $\mathrm{o}$ & $\mathrm{o}$ & & o & o & $\mathrm{N}$ & 3 & $\begin{array}{l}\text { E1050-D1- } \\
\text { 070814.ASC }\end{array}$ & E1050-D2-Channel\# Aug 14, 2007 15-43-11.txt & no video \\
\hline E1051 & 4 & Water & 131.25 & 0.3 & - & - & 1 & A & 5 & 4.03 & & - & - & $\begin{array}{l}33500 / 2500 / \\
17000 / 7500\end{array}$ & 70000 & - & - & 8 & $\mathrm{o}$ & $\mathrm{o}$ & & 0 & 0 & $\mathrm{~N}$ & 1 & $\begin{array}{l}\text { E1051-D1- } \\
\text { E701- }\end{array}$ & E1051-D2-Channel\# Aug 14, 2007 16-00-21.txt & no video \\
\hline E1052 & 4 & Water & 131.25 & 0.3 & - & - & 1 & A & 5.5 & 4.03 & - & - & - & $\begin{array}{l}17000 / 75000 \\
33500 / 2500 / \\
17000 / 75000\end{array}$ & - & - & - & 8 & o & o & & o & o & N & 2 & $\begin{array}{l}\text { 070814.ASC } \\
\text { E1052-D1- } \\
070814 \text { ASC }\end{array}$ & E1052-D2-Channel\# Aug 14, 2007 16-07-06.txt & no video \\
\hline E1053 & 4 & Water & 131.25 & 0.3 & - & - & 1 & A & 5.5 & 4.04 & - & - & - & $\begin{array}{l}33500 / 2500 / \\
17000 / 7500\end{array}$ & - & - & - & 8 & $\mathrm{o}$ & $\mathrm{o}$ & & o & 0 & $\mathrm{~N}$ & 3 & $\begin{array}{l}\text { E1053-D1- } \\
\text { E7051- }\end{array}$ & E1053-D2-Channel\# Aug 14, 2007 16-09-59.txt & no video \\
\hline E1054 & 4 & Water & 131.25 & 0.3 & - & - & 2 & $A, B$ & $5 / 5.5$ & 4.02 & 4.04 & - & - & $\begin{array}{l}170000 / 75000 \\
33500 / 2500 /\end{array}$ & $33500 / 1 / 20000 /$ & - & - & 8 & o & $\mathrm{o}$ & & o & 0 & N & 1 & $\begin{array}{l}\text { 0708144.ASC } \\
\text { E1054-D1- }\end{array}$ & E1054-D2-Channel\# Aug 14, 2007 16-22-25.txt & no video \\
\hline E1055 & 4 & Water & 131.25 & 0.3 & - & & 2 & $A, B$ & $5 / 5$ & 4.02 & 4.04 & - & & $\begin{array}{l}33500 / 2500 / \\
17000 / 75000\end{array}$ & $\begin{array}{l}33500 / 1 / 120000 / \\
75000\end{array}$ & - & - & 8 & $\mathrm{o}$ & o & & o & 0 & $\mathrm{~N}$ & 2 & $\begin{array}{l}\text { E1055-D1- } \\
\text { 070814.ASC }\end{array}$ & E1055-D2-Channel\# Aug 14, 2007 16-28-46.txt & no video \\
\hline E1056 & 4 & Water & 131.25 & 0.3 & - & - & 2 & $A, B$ & $5 / 5.5$ & 4.02 & 4.04 & - & & $\begin{array}{l}33500 / 2500 / \\
17000 / 75000\end{array}$ & $\begin{array}{l}33500 / 1 / 20000 / \\
75000\end{array}$ & - & - & 8 & $\mathrm{o}$ & $\mathrm{o}$ & & o & 0 & $\mathrm{~N}$ & 3 & $\begin{array}{l}\text { E1056-D1- } \\
\text { 070814.ASC }\end{array}$ & E1056-D2-Channel\# Aug 14, 2007 16-34-11.txt & no video \\
\hline E1057 & 4 & Water & 131.25 & 0.3 & - & - & 1 & A & 4.5 & 2.33 & - & - & - & $\begin{array}{l}33500 / 2500 / \\
19000 / 75000\end{array}$ & & - & - & 6 & o & o & & o & 0 & $\mathrm{~N}$ & 1 & $\begin{array}{l}\text { E1057-D1- } \\
\text { 070814.ASC }\end{array}$ & E1057-D2-Channel\# Aug 14, 2007 16-43-48.txt & no video \\
\hline E1058 & 4 & Water & 131.25 & 0.3 & - & - & 1 & A & 4.5 & 2.31 & - & - & - & 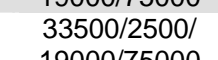 & - & - & - & 6 & o & $\mathrm{o}$ & & o & 0 & $\mathrm{~N}$ & 2 & E1058-D1- & E1058-D2-Channel\# Aug 14, 2007 16-47-29.txt & no video \\
\hline E1059 & 4 & Water & 131.25 & 0.3 & - & - & 1 & A & 4.5 & 2.31 & - & - & - & $\begin{array}{l}19000 / 2 \\
33500 / 2 \\
1900 / 7\end{array}$ & - & - & - & 6 & o & o & & o & 0 & $\mathrm{~N}$ & 3 & $\begin{array}{l}\text { E1059-D1- } \\
\text { 070814.ASC }\end{array}$ & E1059-D2-Channel\# Aug 14, 2007 16-51-21.txt & no video \\
\hline E1060 & 4 & Water & 131.25 & 0.3 & - & - & 2 & $A, B$ & $4 / 3.5$ & 2.29 & 2.31 & - & - & $\begin{array}{l}33500 / 2500 / \\
19000 / 75000\end{array}$ & $\begin{array}{c}33000 / 1 / 22000 / \\
75000\end{array}$ & - & - & 6 & $\mathrm{o}$ & $\mathrm{o}$ & & 0 & 0 & $\mathrm{~N}$ & 1 & $\begin{array}{l}\text { E1060-D1- } \\
\text { 070814.ASC }\end{array}$ & E1060-D2-Channel\# Aug 14, 2007 16-58-33.txt & no video \\
\hline E1061 & 4 & Water & 131.25 & 0.3 & - & - & 2 & $A, B$ & $4.5 / 4$ & 2.29 & 2.29 & - & & $\begin{array}{l}33500 / 25001 \\
19000 / 75000\end{array}$ & $\begin{array}{l}33000 / 1 / 122000 / \\
75000\end{array}$ & & - & 6 & $\mathrm{O}$ & $\mathrm{o}$ & & o & 0 & $\mathrm{~N}$ & 2 & $\begin{array}{l}\text { E1061-D1- } \\
\text { 070814ASC }\end{array}$ & E1061-D2-Channel\# Aug 14, 2007 17-03-29.txt & no video \\
\hline E1062 & 4 & Water & 131.25 & 0.3 & - & & 2 & $A, B$ & $4.5 / 4$ & 2.29 & 2.30 & & & $\begin{array}{l}33500 / 2500 / \\
19000 / 75000\end{array}$ & $\begin{array}{c}33000 / 1 / 22000 / \\
75000\end{array}$ & & & 6 & $\mathrm{o}$ & $\mathrm{o}$ & & 0 & $\mathrm{o}$ & $\mathrm{N}$ & 3 & $\begin{array}{l}\text { E1062-D1- } \\
\text { 070814.ASC }\end{array}$ & E1062-D2-Channel\# Aug 14, 2007 17-07-28.txt & no video \\
\hline
\end{tabular}


Table B.1. Master Run Log, 4-PJM Configuration

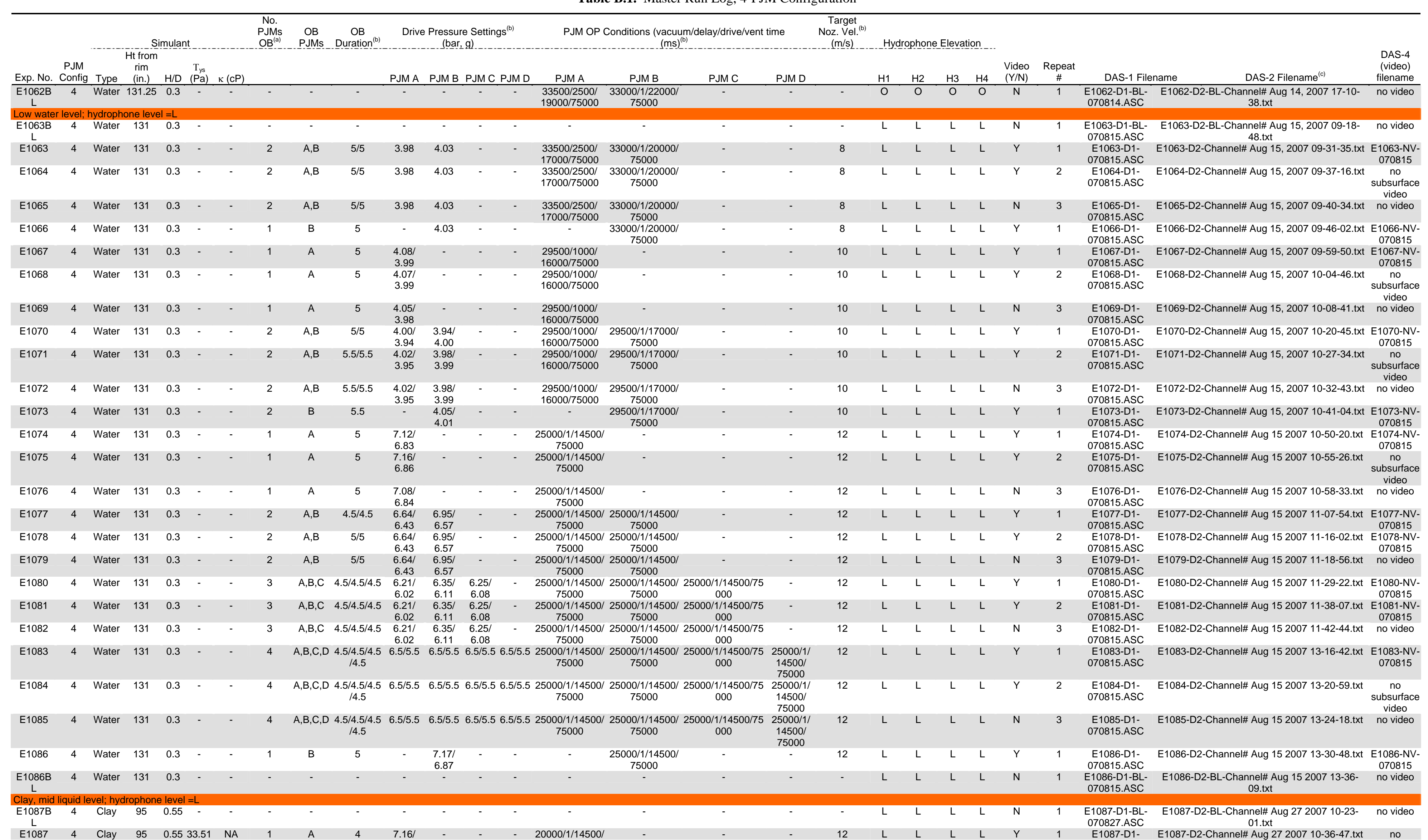


Table B.1. Master Run Log, 4-PJM Configuration

\begin{tabular}{|c|c|c|c|c|c|c|c|c|c|c|c|c|c|c|c|c|c|c|c|c|c|c|c|c|c|c|c|}
\hline \multirow{3}{*}{ Exp. №. } & \multirow{3}{*}{$\begin{array}{r}\text { PJM } \\
\text { Config }\end{array}$} & \multicolumn{4}{|c|}{ Simulant } & \multirow[t]{2}{*}{$\begin{array}{l}\text { No. } \\
\text { PJMS } \\
\text { OOB(a) }\end{array}$} & \multirow[t]{2}{*}{$\begin{array}{l}\text { OB } \\
\text { PJMS }\end{array}$} & \multirow[t]{2}{*}{$\begin{array}{c}\text { OB } \\
\text { Durationon } \\
\text { D(b) }\end{array}$} & \multicolumn{4}{|c|}{$\begin{array}{l}\text { Drive Pressure Settings } \\
\quad(\text { bar, }\end{array}$} & \multicolumn{4}{|c|}{$\begin{array}{l}\text { PJM OP Conditions (vacuum/delay/drive/vent time } \\
\text { (ms })^{(0)}\end{array}$} & \multirow[t]{2}{*}{ 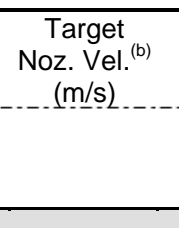 } & \multicolumn{5}{|c|}{ Hydrophone Elevation } & \multirow{3}{*}{$\begin{array}{l}\text { Video } \\
(Y / N)\end{array}$} & \multirow{3}{*}{$\underset{\substack{\text { Repeat } \\
\#}}{ }$} & \multirow{3}{*}{$\begin{array}{c}\text { DAS-1 Filena } \\
070827 . A S C\end{array}$} & \multirow{3}{*}{ DAS-2 Filename ${ }^{(c)}$} & \multirow[b]{2}{*}{$\begin{array}{c}\text { DAS-4 } \\
\text { (video) } \\
\text { filename } \\
\end{array}$} \\
\hline & & Type & $\begin{array}{l}\text { Hit from } \\
\text { rim } \\
\text { (in.) }\end{array}$ & $\begin{array}{c}\mathrm{T}_{\mathrm{ys}} \\
\mathrm{H} / \mathrm{D}(\mathrm{Pa}) \mathrm{k} \\
\end{array}$ & $\underline{k(C P)}$ & & & & PJM A & PJM B & PJMC F & PJM D & 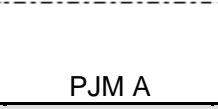 & PJM B & PJM C & PJM D & & $\mathrm{H} 1$ & $\mathrm{H} 2$ & $\mathrm{H} 3$ & & $\mathrm{H} 4$ & & & & & \\
\hline & & & & & & & & & 6.85 & & & & 75000 & & & & & & & & & & & & & & $\begin{array}{l}\text { subsurface } \\
\text { video }\end{array}$ \\
\hline E1088 & 4 & Clay & 95 & 0.5533 .51 & NA & 1 & A & 4 & $\begin{array}{l}7.16 / \\
6.85\end{array}$ & - & - & - & $\begin{array}{l}20000 / 1 / 14500 / \\
75000\end{array}$ & - & - & & 12 & $\mathrm{~L}$ & $\mathrm{~L}$ & L & & L & $\mathrm{Y}$ & 2 & $\begin{array}{l}\text { E1088-D1- } \\
\text { 070827.ASC }\end{array}$ & E1088-D2-Channel\# Aug 272007 10-43-34.txt & $\begin{array}{l}\text { no } \\
\text { subsurface } \\
\text { video }\end{array}$ \\
\hline E1089 & 4 & Clay & 95 & 0.5533 .51 & NA & 1 & A & 4 & $\begin{array}{l}7.161 \\
6.85\end{array}$ & & & - & $\begin{array}{l}20000 / 1 / 145000 / \\
75000\end{array}$ & & & & 12 & $\mathrm{~L}$ & L & L & & L & $\mathrm{Y}$ & 3 & $\begin{array}{l}\text { E1089-D1- } \\
\text { 070827.ASC }\end{array}$ & E1089-D2-Channel\# Aug 272007 10-49-10.txt & $\begin{array}{l}\text { no } \\
\text { subsurface } \\
\text { video }\end{array}$ \\
\hline E1090 & 4 & Clay & 95 & 0.5533 .51 & NA & 2 & $A, B$ & 4 & $\begin{array}{l}6.771 \\
6.41\end{array}$ & $\begin{array}{l}6.751 \\
6.42\end{array}$ & & & $\begin{array}{l}20000 / 1 / 14500 / \\
75000\end{array}$ & $\begin{array}{l}20000 / 1 / 14500 / \\
75000\end{array}$ & - & & 12 & $\mathrm{~L}$ & L & L & & L & $\mathrm{Y}$ & 1 & $\begin{array}{l}\text { E1090-D1- } \\
\text { 070827.ASC }\end{array}$ & E1090-D2-Channel\# Aug 272007 10-58-15.txt & $\begin{array}{l}\text { no } \\
\text { subsurface } \\
\text { video }\end{array}$ \\
\hline E1091 & 4 & Clay & 95 & 0.5533 .51 & NA & 2 & $A, B$ & 4.5 & $\begin{array}{l}6.771 \\
6.41\end{array}$ & $\begin{array}{l}6.751 \\
6.42\end{array}$ & & & $\begin{array}{l}20000 / 1 / 14500 / \\
75000\end{array}$ & $\begin{array}{l}20000 / 1 / 14500 / \\
75000\end{array}$ & & & 12 & $\mathrm{~L}$ & $\mathrm{~L}$ & L & & L & $\mathrm{Y}$ & 2 & $\begin{array}{l}\text { E1091-D1- } \\
\text { 070827.ASC }\end{array}$ & E1091-D2-Channel\# Aug 272007 11-03-54.txt & $\begin{array}{l}\text { no } \\
\text { subsurface } \\
\text { video }\end{array}$ \\
\hline E1092 & 4 & Clay & 95 & 0.5533 .51 & NA & 2 & $A, B$ & 4 & $\begin{array}{l}6.771 \\
6.41\end{array}$ & $\begin{array}{l}6.751 \\
6.42\end{array}$ & - & $\cdot$ & $\begin{array}{l}20000 / 1 / 14500 / \\
75000\end{array}$ & $\begin{array}{l}20000 / 1 / 14500 / \\
75000\end{array}$ & - & - & 12 & $\mathrm{~L}$ & L & L & & L & $\mathrm{Y}$ & 3 & $\begin{array}{l}\text { E1092-D1- } \\
\text { 070827.ASC }\end{array}$ & E1092-D2-Channel\# Aug 272007 11-11-33.txt & $\begin{array}{l}\text { no } \\
\text { subsurface } \\
\text { video }\end{array}$ \\
\hline E1093 & 4 & Clay & 95 & 0.5533 .51 & NA & 3 & $A, B, C$ & 3.5 & $\begin{array}{l}6.31 / \\
6.04\end{array}$ & $\begin{array}{l}6.31 / \\
6.01\end{array}$ & $\begin{array}{l}6.10 / \\
5.92\end{array}$ & - & $\begin{array}{l}20000 / 1 / 14500 / \\
75000\end{array}$ & $\begin{array}{l}\text { 20000/1/1/14500/ } \\
75000\end{array}$ & $\begin{array}{l}20000 / 1 / 14500 / \\
75000\end{array}$ & & 12 & $\mathrm{~L}$ & L & L & & L & Y & 1 & $\begin{array}{l}\text { E1093-D1- } \\
\text { 070827.ASC }\end{array}$ & E1093-D2-Channel\# Aug 272007 11-23-37.txt & $\begin{array}{l}\text { no } \\
\text { subsurface } \\
\text { video }\end{array}$ \\
\hline E1094 & 4 & Clay & 95 & 0.5533 .51 & NA & 3 & $A, B, C$ & 4 & $\begin{array}{l}6.31 / \\
6.04\end{array}$ & $\begin{array}{l}6.31 / \\
6.01\end{array}$ & $\begin{array}{l}6.10 / \\
5.92\end{array}$ & & $\begin{array}{l}20000 / 1 / 14500 / \\
75000\end{array}$ & $\begin{array}{l}20000 / 1 / 14500 / \\
75000\end{array}$ & $\begin{array}{l}20000 / 1 / 14500 / \\
75000\end{array}$ & & 12 & $\mathrm{~L}$ & L & $\mathrm{L}$ & & L & $\mathrm{Y}$ & 2 & $\begin{array}{l}\text { E1094-D1- } \\
\text { 070827.ASC }\end{array}$ & E1094-D2-Channel\# Aug 272007 11-32-03.txt & $\begin{array}{l}\text { no } \\
\text { subsurface } \\
\text { video }\end{array}$ \\
\hline E1095 & 4 & Clay & 95 & 0.5533 .51 & NA & 3 & $A, B, C$ & 3.5 & $\begin{array}{l}6.311 \\
6.04\end{array}$ & $\begin{array}{l}6.311 \\
6.01\end{array}$ & $\begin{array}{l}6.10 / \\
5.92\end{array}$ & & $\begin{array}{l}20000 / 1 / 14500 / \\
75000\end{array}$ & $\begin{array}{l}20000 / 1 / 145001 \\
75000\end{array}$ & $\begin{array}{l}20000 / 1 / 145001 \\
75000\end{array}$ & & 12 & $\mathrm{~L}$ & L & L & & L & $\mathrm{Y}$ & 3 & $\begin{array}{l}\text { E1095-D1- } \\
\text { 070827.ASC }\end{array}$ & E1095-D2-Channel\# Aug 272007 11-38-11.txt & $\begin{array}{l}\text { no } \\
\text { subsurface } \\
\text { video }\end{array}$ \\
\hline E1096 & 4 & Clay & 95 & 0.5533 .51 & NA & 4 & $\mathrm{~A}, \mathrm{~B}, \mathrm{C}, \mathrm{D}$ & 3.5 & $\begin{array}{l}6.41 / \\
5.32\end{array}$ & $\begin{array}{l}5.881 \\
5.64\end{array}$ & $\begin{array}{l}5.221 \\
5.53\end{array}$ & $\begin{array}{l}5.81 / \\
5.55\end{array}$ & $\begin{array}{l}20000 / 1 / 14500 / \\
75000\end{array}$ & $\begin{array}{l}20000 / 1 / 14500 / \\
75000\end{array}$ & $\begin{array}{l}20000 / 1 / 14500 / \\
75000\end{array}$ & $\begin{array}{l}20000 / 1 / \\
14500 / \\
75000\end{array}$ & 12 & $\mathrm{~L}$ & L & L & & L & $\mathrm{Y}$ & 1 & $\begin{array}{l}\text { E1096-D1- } \\
\text { 070827.ASC }\end{array}$ & E1096-D2-Channel\#A Aug 272007 11-49-34.txt & $\begin{array}{l}\text { no } \\
\text { subsurface } \\
\text { video }\end{array}$ \\
\hline E1097 & 4 & Clay & 95 & 0.5533 .51 & NA & 4 & $\mathrm{~A}, \mathrm{~B}, \mathrm{C}, \mathrm{D}$ & 3.5 & $\begin{array}{l}6.411 \\
5.32\end{array}$ & $\begin{array}{l}5.881 \\
5.64\end{array}$ & $\begin{array}{l}5.221 \\
5.53\end{array}$ & $\begin{array}{l}5.81 / \\
5.55\end{array}$ & $\begin{array}{l}20000 / 1 / 14500 / \\
75000\end{array}$ & $\begin{array}{l}20000 / 1 / 14500 / \\
75000\end{array}$ & $\begin{array}{l}20000 / 1 / 14500 / \\
75000\end{array}$ & $\begin{array}{l}20000 / 1 / \\
14500 / \\
75000\end{array}$ & 12 & $\mathrm{~L}$ & L & L & & L & $\mathrm{Y}$ & 2 & $\begin{array}{l}\text { E1097-D1- } \\
\text { 070827.ASC }\end{array}$ & E1097-D2-Channel\# Aug 272007 11-55-16.txt & $\begin{array}{l}\text { no } \\
\text { nubsurface } \\
\text { video }\end{array}$ \\
\hline E1098 & 4 & Clay & 95 & 0.5533 .51 & NA & 4 & $\mathrm{~A}, \mathrm{~B}, \mathrm{C}, \mathrm{D}$ & 3.5 & $\begin{array}{l}6.41 / \\
5.32\end{array}$ & $\begin{array}{l}5.881 \\
5.64\end{array}$ & $\begin{array}{l}5.221 \\
5.53\end{array}$ & $\begin{array}{l}5.81 / \\
5.55\end{array}$ & $\begin{array}{l}20000 / 1 / 14500 / \\
75000\end{array}$ & $\begin{array}{l}20000 / 1 / 14500 / \\
75000\end{array}$ & $\begin{array}{l}20000 / 1 / 14500 / \\
75000\end{array}$ & $\begin{array}{c}20000 / 1 / \\
14500 / \\
75000\end{array}$ & 12 & $\mathrm{~L}$ & L & L & & L & $\mathrm{Y}$ & 3 & $\begin{array}{l}\text { E1098-D1- } \\
\text { 070827.ASC }\end{array}$ & E1098-D2-Channel\# Aug 272007 12-01-12.txt & $\begin{array}{l}\text { no } \\
\text { subsurface } \\
\text { video }\end{array}$ \\
\hline$\underset{L}{E 1098 B}$ & 4 & Clay & 95 & 0.55 & - & & & & & & & & & & & & & $\mathrm{L}$ & $\mathrm{L}$ & L & & L & $\mathrm{N}$ & 1 & $\begin{array}{l}\text { E1098-D1-BL- } \\
\text { 070827.ASC }\end{array}$ & $\begin{array}{l}\text { E1098-D2-BL-Channel| Aug } 272007 \text { 12-05- } \\
\text { 11.txt }\end{array}$ & $\begin{array}{l}\text { no } \\
\text { subsurface } \\
\text { video }\end{array}$ \\
\hline $\begin{array}{c}\text { E1099B } \\
L\end{array}$ & 4 & Clay & 95.25 & 0.55 & 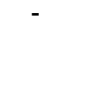 & - & - & - & & - & & - & & & & & & $\mathrm{L}$ & L & L & & L & $\mathrm{N}$ & 1 & $\begin{array}{l}\text { E1099-D1-BL- } \\
\text { 070828.ASC }\end{array}$ & $\begin{array}{l}\text { E1099-D2-BL-Channel\# Aug } 282007 \text { 10-32- } \\
\text { 29.txt }\end{array}$ & $\begin{array}{l}\text { no } \\
\text { subsurface } \\
\text { video }\end{array}$ \\
\hline E1099 & 4 & Clay & 95.25 & 0.5533 .51 & NA & 1 & A & 4 & $\begin{array}{l}4.81 / \\
4.81\end{array}$ & 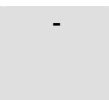 & & & $\begin{array}{l}20000 / 1 / 16000 / \\
75000\end{array}$ & & & & 10 & $\mathrm{~L}$ & L & L & & L & $\mathrm{Y}$ & 1 & $\begin{array}{l}\text { E1099-D1- } \\
\text { 070828.ASC }\end{array}$ & E1099-D2-Channel\# Aug 282007 10-41-16.txt & $\begin{array}{l}\text { no } \\
\text { subsurface } \\
\text { video }\end{array}$ \\
\hline E1100 & 4 & Clay & 95.25 & 0.5533 .51 & NA & 1 & A & 4 & $\begin{array}{l}4.81 / \\
4.81\end{array}$ & - & - & - & $\begin{array}{l}20000 / 1 / 16000 / \\
75000\end{array}$ & - & - & - & 10 & $\mathrm{~L}$ & L & L & & L & $\mathrm{Y}$ & 2 & $\begin{array}{l}\text { E1100-D1- } \\
\text { 070828.ASC }\end{array}$ & E1100-D2-Channel\# Aug 282007 10-46-27.txt & $\begin{array}{l}\text { no } \\
\text { subsurface } \\
\text { video }\end{array}$ \\
\hline E1101 & 4 & Clay & 95.25 & 0.5533 .51 & NA & 1 & A & 4 & $\begin{array}{l}4.81 / \\
4.81\end{array}$ & - & & - & $\begin{array}{l}20000 / 1 / 16000 / \\
75000\end{array}$ & & - & & 10 & L & $\mathrm{L}$ & $\mathrm{L}$ & & L & $\mathrm{Y}$ & 3 & $\begin{array}{l}\text { E1101-D1- } \\
\text { 070828.ASC }\end{array}$ & E1101-D2-Channel\# Aug 282007 10-51-27.txt & $\begin{array}{l}\text { no } \\
\text { subsurface } \\
\text { video }\end{array}$ \\
\hline E1102 & 4 & Clay & 95.25 & 0.5533 .51 & NA & 2 & $A, B$ & 4.5 & $\begin{array}{l}4.76 / \\
4.77\end{array}$ & $\begin{array}{l}4.781 \\
4.78\end{array}$ & & - & $\begin{array}{c}20000 / 1 / 16000 / \\
75000\end{array}$ & $\begin{array}{l}20000 / 1 / 160000 / \\
75000\end{array}$ & - & & 10 & $\mathrm{~L}$ & L & $\mathrm{L}$ & & L & $\mathrm{Y}$ & 1 & $\begin{array}{l}\text { E1102-D1- } \\
\text { 070828.ASC }\end{array}$ & E1102-D2-Channel\# Aug 282007 11-00-51.txt & $\begin{array}{l}\text { no } \\
\text { subsurface } \\
\text { video }\end{array}$ \\
\hline E1103 & 4 & Clay & 95.25 & 0.5533 .51 & NA & 2 & $A, B$ & 4.5 & $\begin{array}{l}4.761 \\
4.77\end{array}$ & $\begin{array}{l}4.781 \\
4.78\end{array}$ & & - & $\begin{array}{l}20000 / 1 / 16000 / \\
75000\end{array}$ & $\begin{array}{l}20000 / 1 / 160000 / \\
75000\end{array}$ & & & 10 & $\mathrm{~L}$ & $\mathrm{~L}$ & $\mathrm{~L}$ & & L & $\mathrm{Y}$ & 2 & $\begin{array}{l}\text { E1103-D1- } \\
\text { 070828.ASC }\end{array}$ & E1103-D2-Channel\# Aug 282007 11-07-42.txt & $\begin{array}{c}\text { no } \\
\text { subsurface } \\
\text { video }\end{array}$ \\
\hline E1104 & 4 & Clay & 95.25 & 0.5533 .51 & NA & 2 & $A, B$ & $4.5 / 4$ & $\begin{array}{l}4.761 \\
4.77\end{array}$ & $\begin{array}{l}4.781 \\
4.78\end{array}$ & - & - & $\begin{array}{l}20000 / 1 / 16000 / \\
75000\end{array}$ & $\begin{array}{c}20000 / 1 / 16000 / \\
75000\end{array}$ & - & - & 10 & $\mathrm{~L}$ & $\mathrm{~L}$ & $\mathrm{~L}$ & & L & $\mathrm{Y}$ & 3 & $\begin{array}{l}\text { E1104-D1- } \\
\text { 070828.ASC }\end{array}$ & E1104-D2-Channel\# Aug 282007 11-13-45.txt & $\begin{array}{l}\text { no } \\
\text { subsurface } \\
\text { video }\end{array}$ \\
\hline E1105 & 4 & Clay & 95.25 & 0.5533 .51 & NA & 1 & A & 4 & 4.63 & - & - & - & $\begin{array}{c}21000 / 1 / 177500 / \\
75000\end{array}$ & - & - & - & 8 & $\mathrm{~L}$ & L & $\mathrm{L}$ & & L & Y & 1 & $\begin{array}{l}\text { E1105-D1- } \\
\text { 070828.ASC }\end{array}$ & E1105-D2-Channel\# Aug 282007 11-42-57.txt & $\begin{array}{l}\text { no } \\
\text { subsurface } \\
\text { video }\end{array}$ \\
\hline E1106 & 4 & Clay & 95.25 & 0.5533 .51 & NA & 1 & A & 4.5 & 4.63 & - & & & $\begin{array}{c}21000 / 1 / 1 / 17500 / \\
75000\end{array}$ & & & & 8 & $\mathrm{~L}$ & L & $\mathrm{L}$ & & L & $\mathrm{Y}$ & 2 & $\begin{array}{l}\text { E1106-D1- } \\
\text { 070828.ASC }\end{array}$ & E1106-D2-Channel\# Aug 282007 11-48-42.txt & $\begin{array}{l}\text { no } \\
\text { subsurface } \\
\text { video }\end{array}$ \\
\hline
\end{tabular}




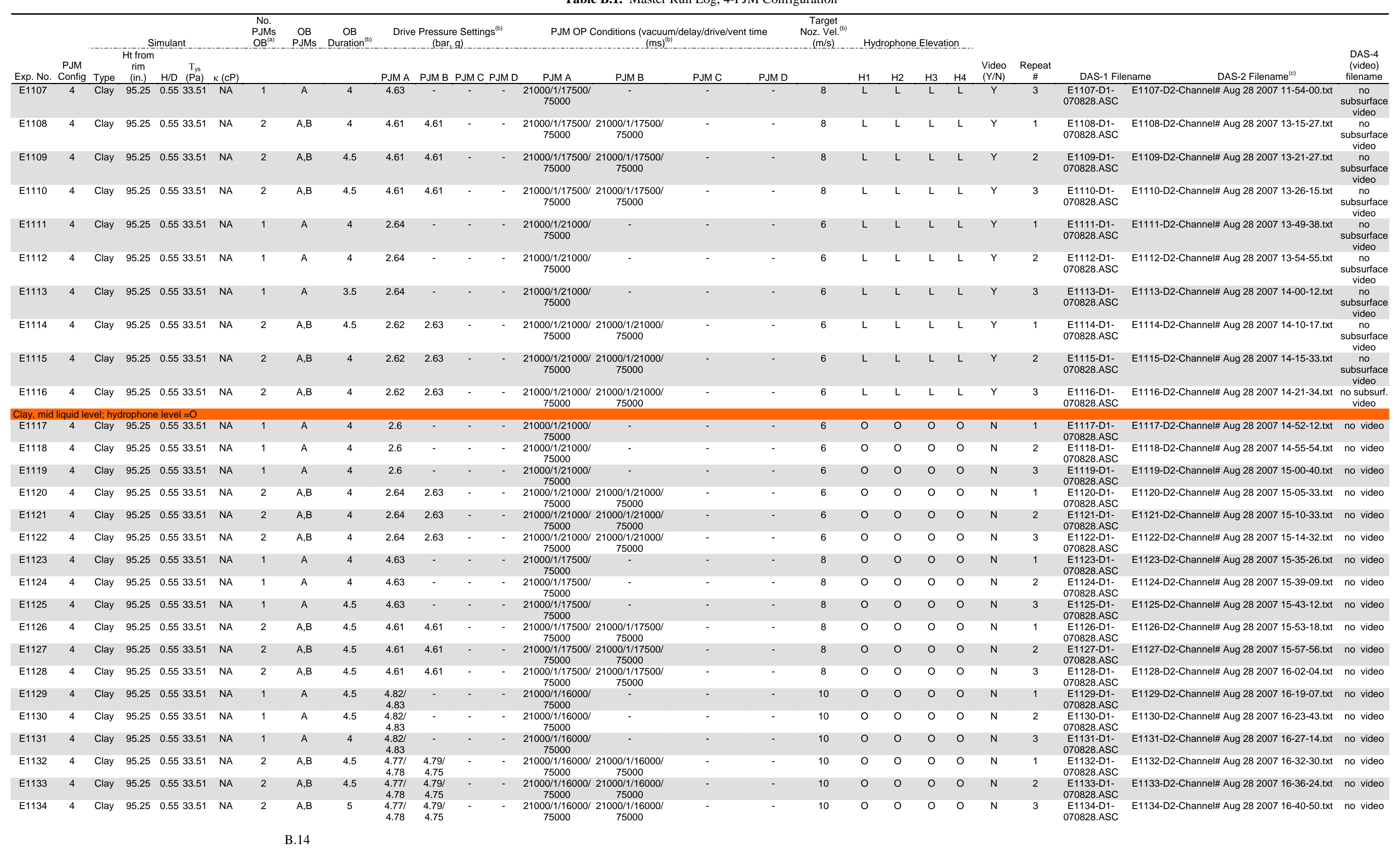




\begin{tabular}{|c|c|c|c|c|c|c|c|c|c|c|c|c|c|c|c|c|c|c|c|c|c|c|c|c|c|c|}
\hline \multirow[b]{2}{*}{ Exp. No. } & \multirow[b]{2}{*}{$\begin{array}{c}\text { PJM } \\
\text { Config }\end{array}$} & \multicolumn{4}{|c|}{ Simulant. } & \multirow[t]{2}{*}{$\begin{array}{l}\text { No. } \\
\text { PJMs } \\
\text { OB }\end{array}$} & \multirow[t]{2}{*}{$\begin{array}{l}\text { OB } \\
\text { PJMS D }\end{array}$} & \multirow[t]{2}{*}{ OB } & \multicolumn{4}{|c|}{$\begin{array}{l}\text { Drive Pressure Settings } \\
\text { (b) }\end{array}$} & \multicolumn{4}{|c|}{$\begin{array}{l}\text { PJM OP Conditions (vacuum/delay/drive/vent time } \\
(\mathrm{ms})^{(0)}\end{array}$} & \multirow[t]{2}{*}{ 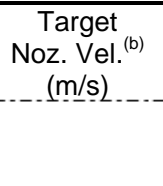 } & \multicolumn{4}{|c|}{ Hydrophone Elevation } & \multirow[b]{2}{*}{$\begin{array}{l}\text { Video } \\
(\mathrm{Y} / \mathrm{N})\end{array}$} & \multirow[b]{2}{*}{ 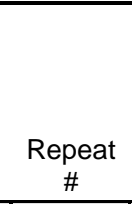 } & \multirow[b]{2}{*}{ DAS-1 Filena } & \multirow{3}{*}{ ame $\frac{\text { DAS-2 Filename }}{\left({ }^{(c)}\right.}$} & \multirow{2}{*}{$\begin{array}{c}\text { DAS-4 } \\
\text { (video) } \\
\text { filename } \\
\end{array}$} \\
\hline & & Type & $\begin{array}{l}\text { rim } \\
\text { (in.) }\end{array}$ & $\begin{array}{c}\mathrm{T}_{\mathrm{ys}} \\
\mathrm{H} / \mathrm{D}(\mathrm{Pa}) \mathrm{k}\end{array}$ & $\mathrm{K}(\mathrm{CP})$ & & & & PJM A & PJM B & PJM C & PJM D & PJM A & PJM B & PJM C & PJM D & & $\mathrm{H} 1$ & $\mathrm{H} 2$ & $\mathrm{H} 3$ & 14 & & & & & \\
\hline $\begin{array}{ll}\text { E1134B } \\
L\end{array}$ & 4 & Clay & 95.25 & $0.55-$ & & & & & & & & & & & & & & 0 & 0 & $\mathrm{O}$ & 0 & $\mathrm{~N}$ & 1 & $\begin{array}{l}\text { E1134-D1-BL- } \\
\text { On70828 }\end{array}$ & & no video \\
\hline E1135B & 4 & Clay & 95.25 & 0.55 & - & - & - & - & - & - & - & - & & 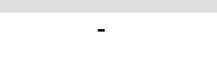 & - & - & - & 0 & O & o & o & N & 1 & $\begin{array}{l}\text { E1135-D1-BL- } \\
\text { 070829.ASC }\end{array}$ & $\begin{array}{l}\text { E1135-D2-BL-Channel|t/Aug } 292007 \text { 09-51- } \\
\text { 11.txt }\end{array}$ & no video \\
\hline E1135 & 4 & Clay & 95.25 & 0.5533 .51 & NA & 1 & A & 4.5 & $\begin{array}{l}7.15 / \\
6.86\end{array}$ & - & - & - & $\begin{array}{l}21000 / 1 / 14500 / \\
75000\end{array}$ & - & - & - & 12 & 0 & 0 & 0 & 0 & $\mathrm{~N}$ & 1 & $\begin{array}{l}\text { E1135-D1- } \\
07029 \text { ASC }\end{array}$ & E1135-D2-Channel\# Aug 292007 09-56-38.txt & no video \\
\hline E1136 & 4 & Clay & 95.25 & 0.5533 .51 & NA & 1 & A & 4 & $\begin{array}{l}0.15 / \\
6.86\end{array}$ & - & - & - & $\begin{array}{l}21000 / 1 / 14500 / \\
75000\end{array}$ & - & - & - & 12 & 0 & O & o & o & $\mathrm{N}$ & 2 & $\begin{array}{l}\text { E1136-D1- } \\
\text { 070829.ASC }\end{array}$ & E1136-D2-Channel\# Aug 292007 10-02-21.txt & no video \\
\hline E1137 & 4 & Clay & 95.25 & 0.5533 .51 & NA & 1 & A & 4.5 & $7.15 l$ & - & - & - & $\begin{array}{l}21000 / 1 / 14500 / \\
75000\end{array}$ & & - & - & 12 & 0 & O & 0 & $\mathrm{O}$ & N & 3 & $\begin{array}{l}\text { E1137-D1- } \\
070829 \text { ASC }\end{array}$ & E1137-D2-Channel\# Aug 292007 10-07-41.txt & no video \\
\hline E1138 & 4 & Clay & 95.25 & 0.5533 .51 & NA & 2 & $A, B$ & 4.5 & $\begin{array}{l}0.00 \\
6.85 ! \\
6.47\end{array}$ & $\begin{array}{l}6.841 \\
6.50\end{array}$ & & - & $\begin{array}{l}21000 / 1 / 14500 / 2 \\
75000\end{array}$ & $\begin{array}{l}21000 / 1 / 14500 / \\
75000\end{array}$ & & & 12 & 0 & O & o & o & $\mathrm{N}$ & 1 & $\begin{array}{l}\text { E1138-D1- } \\
\text { 070829.ASC }\end{array}$ & E1138-D2-Channel\# Aug 292007 10-12-55.txt & no video \\
\hline E1139 & 4 & Clay & 95.25 & 0.5533 .51 & NA & 2 & $A, B$ & 4.5 & $\begin{array}{l}6.851 \\
6.47\end{array}$ & $\begin{array}{l}6.841 \\
6.50\end{array}$ & & & $\begin{array}{l}21000 / 1 / 14500 / 2 \\
75000\end{array}$ & $\begin{array}{l}21000 / 1 / 14500 / \\
75000\end{array}$ & & & 12 & 0 & O & o & o & $\mathrm{N}$ & 2 & $\begin{array}{l}\text { E1139-D1- } \\
\text { 070829.ASC }\end{array}$ & E1139-D2-Channel\# Aug 292007 10-25-35.txt & no video \\
\hline E1140 & 4 & Clay & 95.25 & 0.5533 .51 & NA & 2 & $A, B$ & 4.5 & $\begin{array}{l}6.85 / \\
6.47\end{array}$ & $\begin{array}{l}6.841 \\
6.50\end{array}$ & & - & $\begin{array}{l}21000 / 1 / 14500 / 2 \\
75000\end{array}$ & $\begin{array}{l}21000 / 1 / 14500 / \\
75000\end{array}$ & & & 12 & 0 & 0 & 0 & 0 & $\mathrm{~N}$ & 3 & $\begin{array}{l}\text { E1140-D1- } \\
\text { 070829.ASC }\end{array}$ & E1140-D2-Channel\# Aug 292007 10-28-24.txt & no video \\
\hline E1141 & 4 & Clay & 95.25 & 0.5533 .51 & NA & 3 & $A, B, C$ & 4 & $\begin{array}{l}6.21 / \\
5.86\end{array}$ & $\begin{array}{l}6.171 \\
5.84\end{array}$ & $\begin{array}{l}5.971 \\
5.83\end{array}$ & - & $\begin{array}{l}21000 / 1 / 14500 / 2 \\
75000\end{array}$ & $\begin{array}{l}21000 / 1 / 14500 / \\
75000\end{array}$ & $\begin{array}{l}21000 / 1 / 144500 / \\
75000\end{array}$ & - & 12 & 0 & 0 & 0 & 0 & $\mathrm{~N}$ & 1 & $\begin{array}{l}\text { E1141-D1- } \\
070829 \text { ASC }\end{array}$ & E1141-D2-Channel\# Aug 292007 11-08-09.txt & no video \\
\hline E1142 & 4 & Clay & 95.25 & 0.5533 .51 & NA & 3 & $A, B, C$ & 4 & $\begin{array}{l}5.00 \\
6.21 / \\
586\end{array}$ & $\begin{array}{l}5.84 \\
6.171 \\
5.84\end{array}$ & $\begin{array}{l}5.83 \\
5.971 \\
5.83\end{array}$ & - & $\begin{array}{l}21000 / 1 / 14500 / 2 \\
75000\end{array}$ & $\begin{array}{l}21000 / 1 / 14500 / \\
75000\end{array}$ & $21000 / 1 / 144500 /$ & - & 12 & 0 & 0 & 0 & 0 & $\mathrm{~N}$ & 2 & $\begin{array}{l}\text { E1142-D1- } \\
017829 \text { ASC }\end{array}$ & E1142-D2-Channel\# Aug 292007 11-18-21.txt & no video \\
\hline E1143 & 4 & Clay & 95.25 & 0.5533 .51 & NA & 3 & $A, B, C$ & 4 & $\begin{array}{l}6.21 / \\
5.26\end{array}$ & $\begin{array}{l}6.171 \\
584\end{array}$ & $\begin{array}{l}5.071 \\
5.83\end{array}$ & - & $\begin{array}{l}21000 / 1 / 14500 / 2 \\
75000\end{array}$ & $\begin{array}{l}21000 / 1 / 14500 / \\
75000\end{array}$ & $\begin{array}{l}21000 / 1 / 14500 / \\
75000\end{array}$ & - & 12 & 0 & O & o & $\mathrm{O}$ & N & 3 & $\begin{array}{l}\text { E1143-D1- } \\
070829 \text { ASC }\end{array}$ & E1143-D2-Channel\# Aug 292007 11-20-50.txt & no video \\
\hline E1144 & 4 & Clay & 95.25 & 0.5533 .51 & NA & 4 & $A, B, C, D$ & 4 & $\begin{array}{l}5.831 \\
5.42\end{array}$ & $\begin{array}{l}5.671 \\
5.53\end{array}$ & $\begin{array}{l}5.741 \\
5.31\end{array}$ & $\begin{array}{l}5.68 / \\
4.98\end{array}$ & $\begin{array}{l}21000 / 1 / 145500 / 2 \\
75000\end{array}$ & $\begin{array}{l}21000 / 1 / 14500 / \\
75000\end{array}$ & $\begin{array}{l}21000 / 1 / 145000 / \\
75000\end{array}$ & $\begin{array}{l}21000 / 1 / \\
14500 / \\
75000\end{array}$ & 12 & 0 & 0 & 0 & 0 & $\mathrm{~N}$ & 1 & $\begin{array}{l}\text { E1144-D1- } \\
\text { 070829.ASC }\end{array}$ & E1144-D2-Channel\# Aug 292007 11-25-37.txt & no video \\
\hline E1145 & 4 & Clay & 95.25 & 0.5533 .51 & NA & 4 & $A, B, C, D$ & 4 & $\begin{array}{l}5.831 \\
5.42\end{array}$ & $\begin{array}{l}5.671 \\
5.53\end{array}$ & $\begin{array}{l}5.741 \\
5.31\end{array}$ & $\begin{array}{l}5.681 \\
4.98\end{array}$ & $\begin{array}{l}21000 / 1 / 14500 / 2 \\
75000\end{array}$ & $\begin{array}{l}21000 / 1 / 14500 / \\
75000\end{array}$ & $\begin{array}{c}21000 / 1 / 1 / 1500 / 75 \\
000\end{array}$ & $\begin{array}{l}21000 / 1 / \\
14500 / \\
75000\end{array}$ & 12 & 0 & 0 & 0 & 0 & $\mathrm{~N}$ & 2 & $\begin{array}{l}\text { E1145-D1- } \\
\text { 070829.ASC }\end{array}$ & E1145-D2-Channel\# Aug 292007 11-31-26.txt & no video \\
\hline E1146 & 4 & Clay & 95.25 & 0.5533 .51 & NA & 4 & $A, B, C, D$ & 4 & $\begin{array}{l}5.831 \\
5.42\end{array}$ & $\begin{array}{l}5.67 / \\
5.53\end{array}$ & $\begin{array}{l}5.741 \\
5.31\end{array}$ & $\begin{array}{l}5.68 / \\
4.98\end{array}$ & $\begin{array}{c}21000 / 1 / 14500 / 2 \\
75000\end{array}$ & $\begin{array}{c}21000 / 1 / 14500 / \\
75000\end{array}$ & $\begin{array}{c}21000 / 1 / 144500 / \\
75000\end{array}$ & $\begin{array}{c}21000 / 1 / \\
14500 / \\
75000\end{array}$ & 12 & 0 & 0 & 0 & 0 & $\mathrm{~N}$ & 3 & $\begin{array}{l}\text { E1146-D1- } \\
\text { 070829.ASC }\end{array}$ & E1146-D2-Channel\# Aug 292007 11-35-46.txt & no video \\
\hline $\begin{array}{l}\text { Clay, mid } \\
\text { E1147 }\end{array}$ & Uuid le & $\begin{array}{l}\text { vel; hyd } \\
\text { Clay }\end{array}$ & $\begin{array}{l}\text { Irophone } \\
95.25\end{array}$ & $\begin{array}{l}\text { e level =M } \\
0.5533 .51\end{array}$ & NA & 1 & A & 4.5 & $\begin{array}{l}7.131 \\
6.83\end{array}$ & - & - & - & $\begin{array}{l}21000 / 1 / 144500 / \\
75000\end{array}$ & & - & - & 12 & M & M & M & M & $\mathrm{N}$ & 1 & $\begin{array}{l}\text { E1147-D1- } \\
\text { 010829.ASC }\end{array}$ & E1147-D2-Channel\# Aug 292007 13-05-32.txt & no video \\
\hline E1148 & 4 & Clay & 95.25 & 0.5533 .51 & NA & 1 & A & 4.5 & $\begin{array}{l}7.13 l \\
6.83\end{array}$ & - & - & - & $\begin{array}{l}21000 / 1 / 14500 / \\
75000\end{array}$ & & - & - & 12 & M & M & M & M & $\mathrm{N}$ & 2 & $\begin{array}{l}\text { E1148-D1- } \\
\text { 070829.ASC }\end{array}$ & E1148-D2-Channel\# Aug 292007 13-08-42.txt & no video \\
\hline E1149 & 4 & Clay & 95.25 & 0.5533 .51 & NA & 1 & A & 4.5 & $\begin{array}{l}7.131 \\
6.83\end{array}$ & - & & - & $\begin{array}{l}21000 / 1 / 14500 / \\
75000\end{array}$ & & - & & 12 & M & M & M & M & $\mathrm{N}$ & 3 & $\begin{array}{l}\text { E1149-D1- } \\
\text { 070829.ASC }\end{array}$ & E1149-D2-Channel\# Aug 292007 13-12-14.txt & no video \\
\hline E1150 & 4 & Clay & 95.25 & 0.5533 .51 & NA & 2 & $A, B$ & 4 & $\begin{array}{l}6.821 \\
6.37\end{array}$ & $6.74 /$ & &. & $\begin{array}{l}21000 / 1 / 14500 / 2 \\
75000\end{array}$ & $\begin{array}{l}21000 / 1 / 14500 / \\
75000\end{array}$ & & & 12 & M & M & M & M & $\mathrm{N}$ & 1 & $\begin{array}{l}\text { E1150-D1- } \\
\text { E7020 }\end{array}$ & E1150-D2-Channel\# Aug 292007 13-18-06.txt & no video \\
\hline E1151 & 4 & Clay & 95.25 & 0.5533 .51 & NA & 2 & $A, B$ & 4 & $\begin{array}{l}6.821 \\
6.37\end{array}$ & $\begin{array}{l}6.741 \\
6.42\end{array}$ & & - & $\begin{array}{l}21000 / 1 / 14500 / 2 \\
75000\end{array}$ & $\begin{array}{l}21000 / 1 / 14500 / \\
75000\end{array}$ & 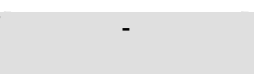 & & 12 & M & M & M & M & $\mathrm{N}$ & 2 & $\begin{array}{l}\text { E1151-D1- } \\
\text { 070829.ASC }\end{array}$ & E1151-D2-Channel\# Aug 292007 13-23-40.txt & no video \\
\hline E1152 & 4 & Clay & 95.25 & 0.5533 .51 & NA & 2 & $A, B$ & 4 & 6.821 & 6.741 & & - & $21000 / 1 / 14500 / 2$ & $\begin{array}{l}21000 / 1 / 144500 / \\
75000\end{array}$ & & & 12 & M & M & $\mathrm{M}$ & M & $\mathrm{N}$ & 3 & $\begin{array}{l}\text { E1152-D1- } \\
\text { E7020 }\end{array}$ & E1152-D2-Channel\# Aug 292007 13-26-35.txt & no video \\
\hline E1153 & 4 & Clay & 95.25 & 0.5533 .51 & NA & 3 & $A, B, C$ & 4 & $\begin{array}{l}0.471 \\
6.491\end{array}$ & $\begin{array}{l}0.42 \\
6.401 \\
5.91\end{array}$ & $\begin{array}{l}6.051 \\
5.83\end{array}$ & - & $\begin{array}{l}21000 / 11 / 14500 / 2 \\
75000\end{array}$ & $\begin{array}{l}21000 / 1 / 14500 / \\
75000\end{array}$ & $\begin{array}{l}21000 / 1 / 14500 / \\
75000\end{array}$ & - & 12 & M & M & M & M & N & 1 & $\begin{array}{l}\text { E1153-D1- } \\
\text { 070829.ASC }\end{array}$ & E1153-D2-Channel\# Aug 292007 13-32-18.txt & no video \\
\hline E1154 & 4 & Clay & 95.25 & 0.5533 .51 & NA & 3 & $A, B, C$ & 4 & $\begin{array}{l}6.441 \\
5.91\end{array}$ & $\begin{array}{l}6.401 \\
5.91\end{array}$ & $\begin{array}{l}6.05 / \\
5.83\end{array}$ & - & $21000 / 1 / 14500 / 2$ & $\begin{array}{l}21000 / 1 / 14500 / \\
75000\end{array}$ & $21000 / 1 / 145000$ & - & 12 & M & M & M & M & $\mathrm{N}$ & 2 & $\begin{array}{l}\text { E1154-D1- } \\
\text { 070829ASC }\end{array}$ & E1154-D2-Channel\# Aug 292007 13-35-36.txt & no video \\
\hline E1155 & 4 & Clay & 95.25 & 0.5533 .51 & NA & 3 & $A, B, C$ & 4 & $\begin{array}{l}6.91 \\
6.91 \\
5.91\end{array}$ & $\begin{array}{l}5.91 \\
6.401 \\
5.91\end{array}$ & $\begin{array}{l}5.83 \\
6.053 \\
5.83\end{array}$ & - & $\begin{array}{l}21000 / 1 / 14500 / 2 \\
75000\end{array}$ & $\begin{array}{l}21000 / 1 / 14500 / \\
75000\end{array}$ & $21000 / 1 / 144500 /$ & - & 12 & $\mathrm{M}$ & M & M & M & N & 3 & $\begin{array}{l}\text { E1155-D1- } \\
017829 \text { ASC }\end{array}$ & E1155-D2-Channel\# Aug 292007 13-40-52.txt & no video \\
\hline E1156 & 4 & Clay & 95.25 & 0.5533 .51 & NA & 4 & $A, B, C, D$ & 4 & $\begin{array}{l}6.05 / \\
5.41\end{array}$ & $\begin{array}{l}5.831 \\
5.43\end{array}$ & $\begin{array}{l}5.761 \\
5.33\end{array}$ & $\begin{array}{l}5.231 \\
5.47\end{array}$ & $\begin{array}{c}21000 / 1 / 14500 / 2 \\
75000\end{array}$ & $\begin{array}{c}21000 / 1 / 14500 / \\
75000\end{array}$ & $\begin{array}{l}21000 / 1 / 145500 / \\
75000\end{array}$ & $\begin{array}{l}21000 / 1 / \\
14500 / \\
75000\end{array}$ & 12 & M & M & M & M & $\mathrm{N}$ & 1 & $\begin{array}{l}\text { E1156-D1- } \\
\text { 070829.ASC }\end{array}$ & E1156-D2-Channel\# Aug 292007 13-49-13.txt & no video \\
\hline E1157 & 4 & Clay & 95.25 & 0.5533 .51 & NA & 4 & $A, B, C, D$ & 4 & $\begin{array}{l}6.05 / \\
5.41\end{array}$ & $\begin{array}{l}5.831 \\
5.43\end{array}$ & $\begin{array}{l}5.761 \\
5.33\end{array}$ & $\begin{array}{l}5.231 \\
5.47\end{array}$ & $\begin{array}{l}21000 / 1 / 14500 / 2 \\
75000\end{array}$ & $\begin{array}{l}21000 / 1 / 14500 / \\
75000\end{array}$ & $\begin{array}{l}21000 / 1 / 145000 \\
75000\end{array}$ & $\begin{array}{l}21000 / 1 / \\
14500 / \\
75000\end{array}$ & 12 & M & M & M & M & $\mathrm{N}$ & 2 & $\begin{array}{l}\text { E1157-D1- } \\
\text { 070829.ASC }\end{array}$ & E1157-D2-Channel\# Aug 292007 14-04-07.txt & no video \\
\hline E1158 & 4 & Clay & 95.25 & 0.5533 .51 & NA & 4 & $A, B, C, D$ & 4 & $\begin{array}{l}6.05 / \\
5.41\end{array}$ & $\begin{array}{l}5.831 \\
5.43\end{array}$ & $\begin{array}{l}5.76 / \\
5.33\end{array}$ & $\begin{array}{l}5.231 \\
5.47\end{array}$ & $\begin{array}{l}21000 / 1 / 14500 / 2 \\
75000\end{array}$ & $\begin{array}{l}21000 / 1 / 14500 / \\
75000\end{array}$ & $\begin{array}{l}21000 / 1 / 14500 / \\
75000\end{array}$ & $\begin{array}{l}21000 / 1 / \\
14500 / \\
75000\end{array}$ & 12 & M & M & M & M & $\mathrm{N}$ & 3 & $\begin{array}{l}\text { E1158-D1- } \\
\text { 070829.ASC }\end{array}$ & E1158-D2-Channel\# Aug 292007 14-08-18.txt & no video \\
\hline E1159 & 4 & Clay & 95.25 & 0.5533 .51 & NA & 1 & A & 4.5 & 4.814 .8 & - & - & - & $\begin{array}{l}21000 / 1 / 16000 / \\
75000\end{array}$ & & - & 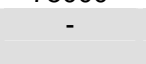 & 10 & M & M & M & in & in & 1 & $\begin{array}{l}\text { E1159-D1- } \\
070829 \text { ASC }\end{array}$ & E1159-D2-Channel\# Aug 292007 14-27-47.txt & no video \\
\hline E1160 & 4 & Clay & 95.25 & 0.5533 .51 & NA & 1 & A & 4.5 & $4.81 / 4.8$ & - & - & - & $\begin{array}{l}21000 / 1 / 16000 / \\
75000\end{array}$ & & - & - & 10 & M & M & M & M & N & 2 & $\begin{array}{l}\text { E1160-D1- } \\
\text { E70829ASC }\end{array}$ & E1160-D2-Channel\# Aug 292007 14-31-35.txt & no video \\
\hline E1161 & 4 & Clay & 95.25 & 0.5533 .51 & NA & 1 & A & 4.5 & $\underset{0}{4.81 / 4.8}$ & - & & & $\begin{array}{l}000 / 1 / 16000 / \\
75000\end{array}$ & & & & 10 & M & M & M & $\mathrm{M}$ & $\mathrm{N}$ & 3 & $\begin{array}{l}\text { E1161-D1- } \\
\text { 070829.ASC }\end{array}$ & E1161-D2-Channel\# Aug 292007 14-35-51.txt & no video \\
\hline E1162 & 4 & Clay & 95.25 & 0.5533 .51 & NA & 2 & $A, B$ & 4.5 & $4.77 / 4.7$ & 4.821 & & & $21000 / 1 / 16000 / 2$ & 21000/1/16000/ & & & 10 & $\mathrm{M}$ & M & M & $\mathrm{M}$ & N & 1 & E1162-D1- & E1162-D2-Channel\# Aug 292007 14-39-47.txt & no video \\
\hline
\end{tabular}


Table B.1. Master Run Log, 4-PJM Configuration

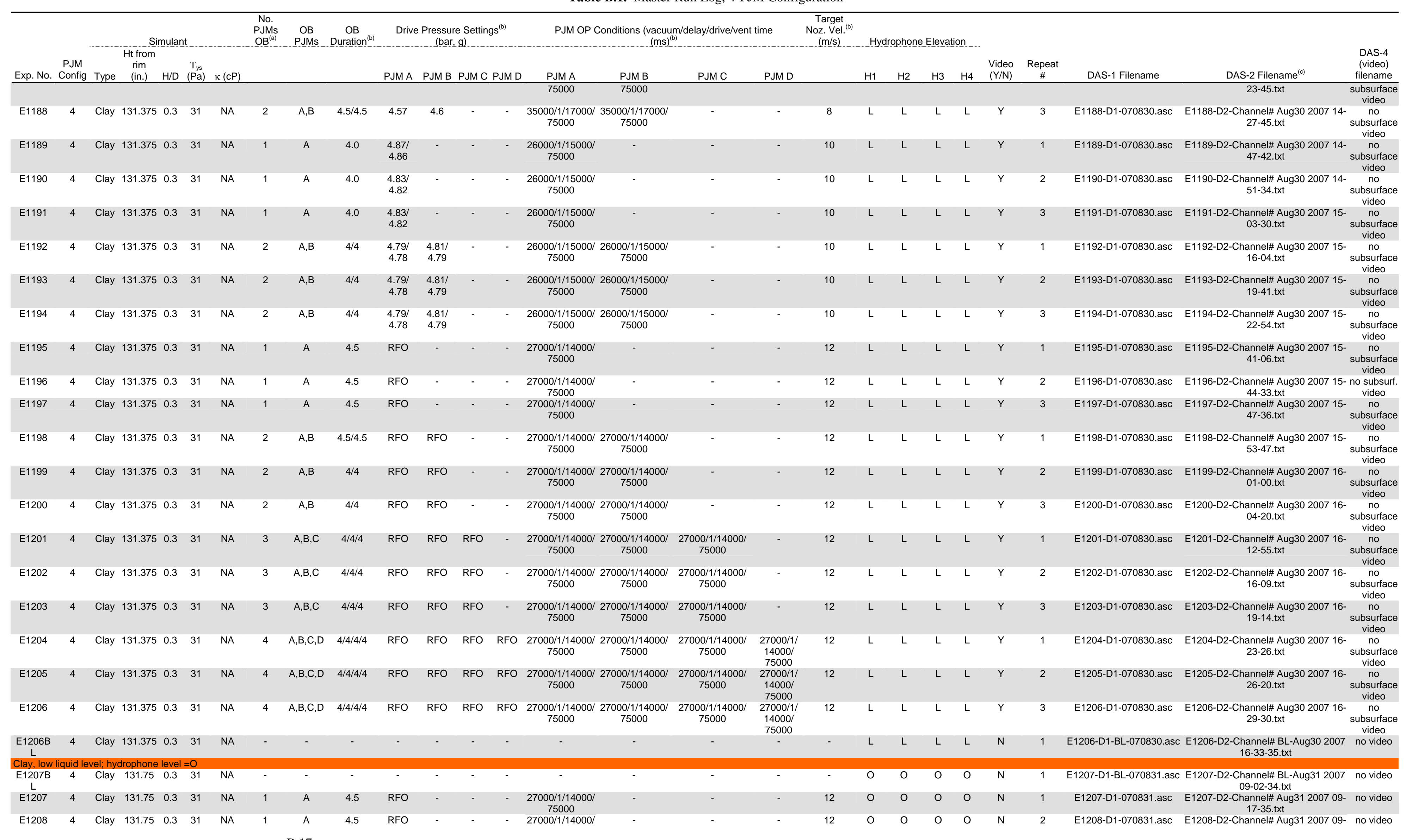


Table B.1. Master Run Log, 4-PJM Configuration

\begin{tabular}{|c|c|c|c|c|c|c|c|c|c|c|c|c|c|c|c|c|c|c|c|c|c|c|c|c|c|c|c|}
\hline \multirow[b]{2}{*}{ Exp. No. } & \multirow[b]{2}{*}{$\begin{array}{l}\text { PJM } \\
\text { Config } \\
\end{array}$} & \multicolumn{5}{|c|}{ Simulant } & \multirow[t]{2}{*}{ 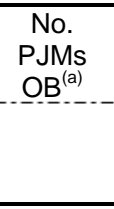 } & \multirow[t]{2}{*}{$\begin{array}{c}\text { OB } \\
\text { PJMS }\end{array}$} & \multirow[t]{2}{*}{$\underset{\mathrm{OB}}{\mathrm{OB}}$} & \multicolumn{4}{|c|}{$\begin{array}{l}\text { Drive Pressure Settings }{ }^{(b)} \\
\text { (bar, }, g)\end{array}$} & \multicolumn{4}{|c|}{$\begin{array}{l}\text { PJM OP Conditions (vacuum/delay/drive/vent time } \\
\text { (ms) }\end{array}$} & \multirow[t]{2}{*}{$\begin{array}{c}\text { Target } \\
\text { Noz. velol. } \\
\text { Nols/s) }\end{array}$} & \multicolumn{4}{|c|}{ Hydrophone Elevation } & \multirow[b]{2}{*}{$\begin{array}{l}\text { Video } \\
(\mathrm{Y} / \mathrm{N})\end{array}$} & \multirow[b]{2}{*}{$\begin{array}{c}\text { Repeat } \\
\#\end{array}$} & \multirow[b]{2}{*}{ DAS-1 Filename } & \multirow[b]{2}{*}{ DAS-2 Filename ${ }^{(c)}$} & \multirow[b]{2}{*}{$\begin{array}{c}\text { DAS-4 } \\
\text { (video) } \\
\text { filename }\end{array}$} \\
\hline & & & $\begin{array}{c}\text { Hit from } \\
\text { rim } \\
\text { (in.) }\end{array}$ & H/D & $\begin{array}{l}\mathrm{T}_{\mathrm{ys}} \\
(\mathrm{Pa})\end{array}$ & $\kappa(c P)$ & & & & PJM A & PJM B & PJM C & PJM D & PJM & PJM B & PJM C & PJM D & & $\mathrm{H} 1$ & $\mathrm{H} 2$ & $\mathrm{H} 3$ & $\mathrm{H} 4$ & & & & & \\
\hline E1209 & 4 & Clay & 131.75 & 0.3 & 31 & NA & 1 & A & 4 & RFO & Tor & & & $\begin{array}{l}75000 \\
27000 / 11 / 4000 / \\
75000\end{array}$ & & & & 12 & 0 & 0 & 0 & 0 & $\mathrm{~N}$ & 3 & E1209-D1-070831.asc & $\begin{array}{c}\text { E1-30.txt } \\
\text { E1209-D2-ChannellA Aug31 } 2007 \text { 09- } \\
\text { 24-44.txt }\end{array}$ & no video \\
\hline E1210 & 4 & Clay & 131.75 & 0.3 & 31 & NA & 2 & $A, B$ & $4 / 4.5$ & RFO & RFO & - & - & $\begin{array}{l}27000 / 1 / 14000 / \\
75000\end{array}$ & $\begin{array}{l}27000 / 1 / 14000 / \\
75000\end{array}$ & - & & 12 & 0 & O & O & $\mathrm{O}$ & N & 1 & E1210-D1-070831.asc & $\begin{array}{l}\text { E1210-D2-Channel|A Aug31 } 2007 \text { 09- } \\
\text { 29-25 txt }\end{array}$ & no video \\
\hline E1211 & 4 & Clay & 131.75 & 0.3 & 31 & NA & 2 & $A, B$ & $4 / 4.5$ & RFO & RFO & & - & $\begin{array}{l}27000 / 1 / 14000 / \\
75000\end{array}$ & $\begin{array}{l}27000 / 1 / 14000 / \\
75000\end{array}$ & & & 12 & o & o & o & o & $\mathrm{N}$ & 2 & E1211-D1-070831.asc & $\begin{array}{l}\text { E1211-D2-Channel|A Aug31 } 2007 \text { 09- } \\
\text { 32-41.txt }\end{array}$ & no video \\
\hline E1212 & 4 & Clay & 131.75 & 0.3 & 31 & NA & 2 & $A, B$ & $4 / 4.5$ & RFO & RFO & - & & $\begin{array}{l}27000 / 1 / 14000 / \\
75000\end{array}$ & $\begin{array}{l}27000 / 1 / 14000 / \\
75000\end{array}$ & - & - & 12 & 0 & 0 & 0 & 0 & $\mathrm{~N}$ & 3 & E1212-D1-070831.asc & $\begin{array}{l}\text { E1212-D2-Channel|\# Aug31 } 2007 \text { 09- } \\
\text { 35-38.txt }\end{array}$ & no video \\
\hline E1213 & 4 & Clay & 131.75 & 0.3 & 31 & NA & 3 & $A, B, C$ & $4 / 4 / 4$ & RFO & RFO & RFO & - & $\begin{array}{l}27000 / 1 / 14000 / \\
75000\end{array}$ & $\begin{array}{l}27000 / 1 / 14000 / \\
75000\end{array}$ & $\begin{array}{l}27000 / 1 / 14000 / \\
75000\end{array}$ & - & 12 & 0 & 0 & 0 & 0 & $\mathrm{~N}$ & 1 & E1213-D1-070831.asc & $\begin{array}{c}\text { E1213-D2-Channel|\# Aug31 } 2007 \text { 09- } \\
\text { 40-54.txt }\end{array}$ & no video \\
\hline E1214 & 4 & Clay & 131.75 & 0.3 & 31 & NA & 3 & $A, B, C$ & $4.5 / 4.5 / 4.5$ & RFO & RFO & RFO & - & $\begin{array}{l}27000 / 1 / 14000 / \\
75000\end{array}$ & $\begin{array}{l}27000 / 1 / 14000 / \\
75000\end{array}$ & $\begin{array}{l}27000 / 1 / 14000 / \\
75000\end{array}$ & - & 12 & 0 & 0 & 0 & 0 & $\mathrm{~N}$ & 2 & E1214-D1-070831.asc & E1214-D2-Channel\# Aug31 2007 09- & no video \\
\hline E1215 & 4 & Clay & 131.75 & 0.3 & 31 & NA & 3 & $A, B, C$ & $4.5 / 4.5 / 4.5$ & RFO & RFO & RFO & - & $\begin{array}{l}27000 / 1 / 14000 / \\
75000\end{array}$ & $\begin{array}{l}27000 / 1 / 14000 / \\
75000\end{array}$ & $\begin{array}{l}27000 / 1 / 140000 / \\
75000\end{array}$ & - & 12 & o & o & 0 & o & $\mathrm{N}$ & 3 & E1215-D1-070831.asc & $\begin{array}{c}\text { E1215-D2-Channel|At Aug31 } 2007 \text { 09- } \\
\text { 46-47.tut }\end{array}$ & no video \\
\hline E1216 & 4 & Clay & 131.75 & 0.3 & 31 & NA & 4 & $A, B, C, D$ & $4 / 4 / 4 / 4$ & RFO & RFO & RFO & RFO & $\begin{array}{l}27000 / 1 / 14000 / \\
75000\end{array}$ & $\begin{array}{l}27000 / 1 / 14000 / \\
75000\end{array}$ & $\begin{array}{l}27000 / 1 / 14000 / \\
75000\end{array}$ & $\begin{array}{c}27000 / 1 / \\
14000 / \\
7500\end{array}$ & 12 & 0 & 0 & 0 & 0 & $\mathrm{~N}$ & 1 & E1216-D1-070831.asc & $\begin{array}{l}\text { E1216-D2-Channel\# Aug31 } 2007 \text { 09- } \\
\text { 51-53.txt }\end{array}$ & no video \\
\hline E1217 & 4 & Clay & 131.75 & 0.3 & 31 & NA & 4 & $\mathrm{~A}, \mathrm{~B}, \mathrm{C}, \mathrm{D}$ & $\begin{array}{l}4.5 / 4.5 / \\
4.5 / 4.5\end{array}$ & RFO & RFO & RFO & RFO & $\begin{array}{l}27000 / 1 / 14000 / \\
75000\end{array}$ & $\begin{array}{l}27000 / 1 / 14000 / \\
75000\end{array}$ & $\begin{array}{l}27000 / 1 / 14000 / \\
75000\end{array}$ & $\begin{array}{l}27000 / 1 / \\
14000 / \\
7500\end{array}$ & 12 & 0 & 0 & 0 & 0 & $\mathrm{~N}$ & 2 & E1217-D1-070831.asc & $\begin{array}{l}\text { E1217-D2-Channel\# Aug31 } 2007 \text { 09- } \\
\text { 54-59.txt }\end{array}$ & no video \\
\hline E1218 & 4 & Clay & 131.75 & 0.3 & 31 & NA & 4 & $A, B, C, D$ & $\begin{array}{l}4.5 / 4.5 / \\
4.5 / 4.5\end{array}$ & RFO & RFO & RFO & RFO & $\begin{array}{l}27000 / 1 / 14000 / \\
75000\end{array}$ & $\begin{array}{l}27000 / 1 / 14000 / \\
75000\end{array}$ & $\begin{array}{l}27000 / 1 / 14000 / \\
75000\end{array}$ & $\begin{array}{l}27000 / 1 / \\
14000 / \\
75000\end{array}$ & 12 & 0 & o & 0 & 0 & $\mathrm{~N}$ & 3 & E1218-D1-070831.asc & $\begin{array}{l}\text { E1218-D2-Channel\# Aug31 } 2007 \text { 09- } \\
\text { 58-38.txt }\end{array}$ & no video \\
\hline E1219 & 4 & Clay & 131.75 & 0.3 & 31 & NA & 1 & A & 4 & NR & & & - & $\begin{array}{l}26000 / 1 / 15000 / \\
75000\end{array}$ & & & & 10 & 0 & 0 & 0 & 0 & $\mathrm{~N}$ & 1 & E1219-D1-070831.asc & $\begin{array}{c}\text { E1219-D2-Channel\# Aug31 } 2007 \text { 10- } \\
\text { 30-51.txt }\end{array}$ & no video \\
\hline E1220 & 4 & Clay & 131.75 & 0.3 & 31 & NA & 1 & A & 4 & $\begin{array}{l}4.84 / \\
4.84\end{array}$ & - & - & - & $\begin{array}{l}26000 / 1 / 15000 / \\
75000\end{array}$ & - & - & - & 10 & 0 & 0 & o & $\mathrm{o}$ & $\mathrm{N}$ & 2 & E1220-D1-070831.asc & $\begin{array}{c}\text { E1220-D2-Channelly Aug31 } 2007 \text { 10- } \\
\text { 34-30.tut }\end{array}$ & no video \\
\hline E1221 & 4 & Clay & 131.75 & 0.3 & 31 & NA & 1 & A & 4 & $\begin{array}{l}4.04 \\
4.841 \\
4.84\end{array}$ & - & - & - & $\begin{array}{l}26000 / 1 / 15000 / \\
75000\end{array}$ & - & - & - & 10 & o & o & o & o & $\mathrm{N}$ & 3 & E1221-D1-070831.asc & $\begin{array}{c}\text { E1221-D2-Channel|At Aug31 } 2007 \text { 10- } \\
\text { 37-15.tut }\end{array}$ & no video \\
\hline E1222 & 4 & Clay & 131.75 & 0.3 & 31 & NA & 2 & $A, B$ & $4 / 4$ & $\begin{array}{l}4.821 \\
4.78\end{array}$ & $\begin{array}{l}4.801 \\
4.79\end{array}$ & - & - & $\begin{array}{l}26000 / 1 / 15000 / \\
75000\end{array}$ & $\begin{array}{l}26000 / 1 / 15000 / \\
75000\end{array}$ & - & - & 10 & 0 & 0 & 0 & 0 & $\mathrm{~N}$ & 1 & E1222-D1-070831.asc & $\begin{array}{c}\text { E1222-D2-Channell Aug31 } 2007 \text { 10- } \\
\text { 42-19.txt }\end{array}$ & no video \\
\hline E1223 & 4 & Clay & 131.75 & 0.3 & 31 & NA & 2 & $A, B$ & $4 / 4$ & $\begin{array}{l}4.81 \\
4.821 \\
4.78\end{array}$ & $\begin{array}{l}4.801 \\
4.79\end{array}$ & & 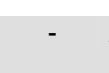 & $\begin{array}{l}26000 / 1 / 15000 / \\
75000\end{array}$ & $\begin{array}{l}26000 / 1 / 15000 / \\
75000\end{array}$ & - & & 10 & 0 & 0 & 0 & 0 & $\mathrm{~N}$ & 2 & E1223-D1-070831.asc & $\begin{array}{l}\text { E1223-D2-Channel| Aug31 } 2007 \text { 10- } \\
\text { 45-00 tut }\end{array}$ & no video \\
\hline E1224 & 4 & Clay & 131.75 & 0.3 & 31 & NA & 2 & $A, B$ & $4 / 4$ & $\begin{array}{l}4.821 \\
4.78\end{array}$ & $\begin{array}{l}4.801 \\
4.79\end{array}$ & & - & $\begin{array}{l}26000 / 1 / 15000 / \\
75000\end{array}$ & $\begin{array}{l}26000 / 1 / 15000 / \\
75000\end{array}$ & - & & 10 & 0 & 0 & 0 & 0 & $\mathrm{~N}$ & 3 & E1224-D1-070831.asc & $\begin{array}{l}\text { E1224-D2-Channel\# Aug31 } 2007 \text { 10- } \\
\text { 47-50.txt }\end{array}$ & no video \\
\hline E1225 & 4 & Clay & 131.75 & 0.3 & 31 & NA & 1 & A & 4 & 4.64 & & & & $\begin{array}{l}35000 / 1 / 17000 / \\
75000\end{array}$ & & & & 8 & 0 & 0 & 0 & 0 & $\mathrm{~N}$ & 1 & E1225-D1-070831.asc & $\begin{array}{c}\text { E1225-D2-Channel|A Aug31 } 2007 \text { 11- } \\
\text { 10-54.txt }\end{array}$ & no video \\
\hline E1226 & 4 & Clay & 131.75 & 0.3 & 31 & NA & 1 & A & 4 & 4.64 & - & - & - & $\begin{array}{l}35000 / 1 / 17000 / \\
75500\end{array}$ & & - & & 8 & 0 & 0 & 0 & 0 & $\mathrm{~N}$ & 2 & E1226-D1-070831.asc & $\begin{array}{l}\text { E1226-D2-Channel\# Aug31 } 2007 \text { 11- } \\
\text { 14-40.txt }\end{array}$ & no video \\
\hline E1227 & 4 & Clay & 131.75 & 0.3 & 31 & NA & 1 & A & 4 & 4.64 & - & - & - & $\begin{array}{l}35000 / 1 / 17000 / \\
75000\end{array}$ & 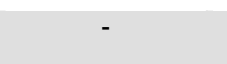 & - & - & 8 & 0 & 0 & 0 & 0 & $\mathrm{~N}$ & 3 & E1227-D1-070831.asc & $\begin{array}{l}\text { E1227-D2-Channelf Aug31 } 2007 \text { 11- } \\
\text { 17-18 }\end{array}$ & no video \\
\hline E1228 & 4 & Clay & 131.75 & 0.3 & 31 & NA & 2 & $A, B$ & $4 / 4$ & 4.61 & 4.56 & - & - & $\begin{array}{l}35000 / 1 / 17000 / \\
75000\end{array}$ & $\begin{array}{l}35000 / 1 / 17000 / \\
75000\end{array}$ & - & - & 8 & 0 & 0 & 0 & 0 & $\mathrm{~N}$ & 1 & E1228-D1-070831.asc & $\begin{array}{l}\text { E1228-D2-Channeltt Aug31 } 2007 \text { 11- } \\
\text { 12?-18 trt }\end{array}$ & no video \\
\hline E1229 & 4 & Clay & 131.75 & 0.3 & 31 & NA & 2 & $A, B$ & $4 / 4$ & 4.61 & 4.56 & - & - & $35000 / 1 / 17000 /$ & $35000 / 1 / 17000 /$ & - & - & 8 & 0 & O & O & 0 & N & 2 & E1229-D1-070831.asc & E1229-D2-Channelly Aug31 2007 11- & no video \\
\hline E1230 & 4 & Clay & 131.75 & 0.3 & 31 & NA & 2 & $A, B$ & 4/4 & 4.61 & 4.56 & - & - & $\begin{array}{l}35000 / 1 / 1717000 / \\
75000\end{array}$ & $\begin{array}{l}35000 / 1 / 170000 / \\
75000\end{array}$ & - & - & 8 & 0 & o & 0 & o & N & 3 & E1230-D1-070831.asc & $\begin{array}{l}\text { E1230-D2-Channel\# Aug31 } 2007 \text { 11- } \\
\text { 26-10 At }\end{array}$ & no video \\
\hline E1231 & 4 & Clay & 131.75 & 0.3 & 31 & NA & 1 & A & 4 & 2.61 & - & - & 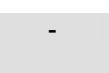 & $\begin{array}{l}35000 / 1 / 20000 / \\
75000\end{array}$ & & - & - & 6 & 0 & 0 & 0 & 0 & $\mathrm{~N}$ & 1 & E1231-D1-070831.asc & $\begin{array}{l}\text { E1231-D2-Channel|A Aug31 } 2007 \text { 11- } \\
\text { 41-56.txt }\end{array}$ & no video \\
\hline E1232 & 4 & Clay & 131.75 & 0.3 & 31 & NA & 1 & A & 4 & 2.61 & - & - & - & $\begin{aligned} & 35000 / 1 / 1 \\
& 750\end{aligned}$ & & - & - & 6 & 0 & 0 & 0 & $\mathrm{O}$ & $\mathrm{N}$ & 2 & E1232-D1-070831.asc & E1232-D2-Channel\# Aug31 2007 11- & no video \\
\hline E1233 & 4 & Clay & 131.75 & 0.3 & 31 & NA & 1 & A & 4 & 2.61 & - & - & - & $\begin{array}{l}35000 / 1 / 20000 / \\
75000\end{array}$ & & - & & 6 & 0 & 0 & 0 & o & $\mathrm{N}$ & 3 & E1233-D1-070831.asc & $\begin{array}{c}\text { E1233-D2-Channel|A Aug31 } 2007 \text { 11- } \\
\text { 48-30.txt }\end{array}$ & no video \\
\hline E1234 & 4 & Clay & 131.75 & 0.3 & 31 & NA & 2 & $A, B$ & $4 / 4$ & 2.61 & 2.6 & - & - & $\begin{array}{l}35000 / 1 / 20000 / \\
75000\end{array}$ & $\begin{array}{l}35000 / 1 / 20000 / \\
75000\end{array}$ & - & - & 6 & 0 & 0 & 0 & $\mathrm{o}$ & $\mathrm{N}$ & 1 & E1234-D1-070831.asc & E1234-D2-Channelf Aug31 2007 11- & no video \\
\hline E1235 & 4 & Clay & 131.75 & 0.3 & 31 & NA & 2 & $A, B$ & 4/4 & 2.61 & 2.6 & - & - & $\begin{array}{l}35000 / 1 / 20000 / \\
75000\end{array}$ & $\begin{array}{l}35000 / 1 / 20000 / \\
75000\end{array}$ & - & - & 6 & o & 0 & 0 & 0 & $\mathrm{~N}$ & 2 & E1235-D1-070831.asc & $\begin{array}{c}\text { E1235-D2-Channel|At Aug31 } 2007 \text { 11- } \\
\text { 55-43.tut }\end{array}$ & no video \\
\hline E1236 & 4 & Clay & 131.75 & 0.3 & 31 & NA & 2 & $A, B$ & $4.5 / 4.5$ & 2.61 & 2.6 & - & - & $\begin{array}{l}35000 / 1 / 20000 / \\
75000\end{array}$ & $\begin{array}{l}35000 / 1 / 20000 / \\
75000\end{array}$ & - & - & 6 & 0 & 0 & 0 & 0 & $\mathrm{~N}$ & 3 & E1236-D1-070831.asc & $\begin{array}{l}\text { E1236-D2-Channel\# Aug31 } 2007 \text { 11- } \\
\text { 58-19.txt }\end{array}$ & no video \\
\hline E1236B & 4 & Clay & 131.75 & 0.3 & 31 & NA & - & - & - & - & - & - & - & & & - & - & - & 0 & 0 & 0 & 0 & $\mathrm{~N}$ & - & E1236-D1-BL-070831.asc & $\begin{array}{l}\text { E1236-D2-BL-Channel|H Aug31 } 2007 \\
12-01-53 . t x t\end{array}$ & no video \\
\hline$\underset{L}{E 1237 B}$ & 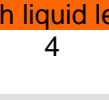 & Clay & 50 & & 36.34 & NA & & & & & & 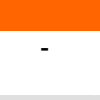 & & & & & & & $\mathrm{O}$ & 0 & 0 & 0 & $\mathrm{~N}$ & & E1237-D1-BL-070918.asc & $\begin{array}{l}\text {-Channel\# Sept } 18 \\
\text { 99-08-47.txt }\end{array}$ & o video \\
\hline
\end{tabular}




\begin{tabular}{|c|c|c|c|c|c|c|c|c|c|c|c|c|c|c|c|c|c|c|c|c|c|c|c|c|c|c|c|}
\hline \multirow[b]{3}{*}{ Exp. No. } & \multirow{3}{*}{$\begin{array}{c}\text { PJM } \\
\text { Config }\end{array}$} & \multicolumn{4}{|c|}{ Simulant } & \multirow[t]{3}{*}{$\begin{array}{l}\text { No. } \\
\text { PJMS } \\
\text { POB }^{(a)}\end{array}$} & \multirow[t]{3}{*}{$\begin{array}{c}\text { OB } \\
\text { PJMS }\end{array}$} & \multirow[t]{3}{*}{$\begin{array}{l}\text { OB } \\
\text { Durationon } \\
\text { (b) }\end{array}$} & \multicolumn{4}{|c|}{$\begin{array}{l}\text { Drive Pressure Settings } \\
\quad(b)\end{array}$} & \multicolumn{4}{|c|}{$\begin{array}{l}\text { PJM OP Conditions (vacuum/delay/drive/vent time } \\
\qquad(\mathrm{ms})^{(0)}\end{array}$} & \multirow[t]{3}{*}{ 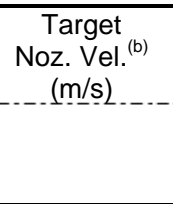 } & \multicolumn{5}{|c|}{ Hydrophone Elevation } & \multirow{3}{*}{$\begin{array}{l}\text { Video } \\
\text { (Y/N) }\end{array}$} & \multirow{3}{*}{$\underset{\#}{\text { Repeat }}$} & \multirow[b]{3}{*}{ DAS-1 Filename } & \multirow[b]{3}{*}{ DAS-2 Filename $\mathrm{e}^{(\mathrm{c})}$} & \multirow{3}{*}{$\begin{array}{l}\text { DAS-4 } \\
\text { (video) } \\
\text { filename }\end{array}$} \\
\hline & & & $\begin{array}{c}\text { Ht from } \\
\text { rim }\end{array}$ & $T_{y s}$ & & & & & & & & & & & & & & & & & & & & & & & \\
\hline & & Type & & $\mathrm{H} / \mathrm{D}(\mathrm{Pa})$ & $\kappa(C P)$ & & & & PJM A & PJM B & PJMCF & PJM D & PJM A & PJM B & PJMC & PJM D & & $\mathrm{H} 1$ & $\mathrm{H} 2$ & & $\mathrm{H} 3$ & $\mathrm{H} 4$ & & & & & \\
\hline E1238 & 4 & Clay & 56 & 0.836 .34 & NA & 2 & $A, C$ & 4.5 & $\begin{array}{r}6.49 \\
6.6 / 6.5\end{array}$ & & $\begin{array}{l}6.38 \\
6.4 / 6.4\end{array}$ & & $\begin{array}{l}75000 \\
11000 / 1 / 15500 / \\
75000\end{array}$ & & $\begin{array}{l}75000 \\
11000 / 500 / 15500 / \\
75000\end{array}$ & & 12 & $\mathrm{O}$ & 0 & & 0 & 0 & $\mathrm{~N}$ & 1 & E1238-D1-070918.ASC & $\begin{array}{l}\text { 09-21-07.txt } \\
\text { E1238-D2-Channel\# Sept } 182007 \\
\text { 09-33-31.txt }\end{array}$ & no video \\
\hline E1239 & 4 & Clay & 56 & 0.836 .34 & NA & 2 & $A, C$ & 4.5 & 6.816 .6 & - & $6.5 / 6.4$ & & $\begin{array}{l}11000 / 1 / 15500 / \\
75000\end{array}$ & & $\begin{array}{l}11000 / 400 / 15500 / \\
75000\end{array}$ & & 12 & 0 & 0 & & 0 & 0 & $\mathrm{~N}$ & 1 & E1239-D1-070918.ASC & $\begin{array}{l}\text { E1239-D2-Channel\# Sept } 182007 \\
\text { 09-44-37.txt }\end{array}$ & no video \\
\hline E1240 & 4 & Clay & 56 & 0.836 .34 & NA & 2 & $A, C$ & 4.5 & $6.9 / 6.6$ & - & $6.6 / 6.5$ & 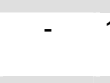 & $\begin{array}{l}11000 / 1 / 1 / 15500 / \\
75000\end{array}$ & - & $\begin{array}{l}11000 / 400 / 15500 / \\
75000\end{array}$ & & 12 & 0 & 0 & & 0 & 0 & $\mathrm{~N}$ & 1 & E1240-D1-070918.ASC & $\begin{array}{l}\text { E1240-D2-Channel\# Sept } 182007 \\
\text { 09-49-10.txt }\end{array}$ & no video \\
\hline E1241B & 4 & Clay & 54.50 & 0.833 .55 & NA & - & - & - & - & - & - & - & - & - & - & - & - & 0 & 0 & & 0 & 0 & $\mathrm{~N}$ & - & E1241-D1-BL-070918.asc & $\begin{array}{l}\text { E1241-D2-BL-Channel\# Sept } 18 \\
\text { 2007 12-14-59.txt }\end{array}$ & no video \\
\hline $\begin{array}{l}\text { Clay, high } \\
\text { E1242B } \\
\text { L }\end{array}$ & $\begin{array}{c}\text { th liquid } \\
4\end{array}$ & $\begin{array}{l}\text { level; } h \text { hy } \\
\text { Clay }\end{array}$ & $\begin{array}{l}\text { ydrophor } \\
54.50\end{array}$ & $\begin{array}{l}\text { ne level=O } \\
0.833 .55\end{array}$ & NA & - & - & - & - & - & - & - & & - & - & & - & $\mathrm{O}$ & o & & o & 0 & $\mathrm{~N}$ & - & E1242-D1-BL-070919.asc & $\begin{array}{l}\text { E1242-D2-BL-Channel\# Sept } 19 \\
\text { 2007 09-16-11.txt }\end{array}$ & no video \\
\hline E1242 & 4 & Clay & 54.5 & 0.833 .55 & NA & 1 & A & 4.5 & $\begin{array}{l}7.171 \\
6.88\end{array}$ & - & - & - & $\begin{array}{l}11000 / 1 / 15500 / \\
75000\end{array}$ & - & - & - & 12 & $\mathrm{O}$ & 0 & & 0 & 0 & Y & 1 & E1242-D1-070919.ASC & $\begin{array}{l}\text { E1242-D2-Channel\# Sept } 192007 \\
\text { 09-29-01.txt }\end{array}$ & $\begin{array}{l}\text { no } \\
\text { subsurface } \\
\text { video }\end{array}$ \\
\hline E1243 & 4 & Clay & 54.5 & 0.833 .55 & NA & 1 & A & 4.5 & $\begin{array}{l}7.171 \\
6.88\end{array}$ & & & & $\begin{array}{l}11000 / 1 / 15500 / \\
75000\end{array}$ & & & & 12 & 0 & 0 & & 0 & 0 & $\mathrm{Y}$ & 2 & E1243-D1-070919.ASC & $\begin{array}{l}\text { E1243-D2-Channel\# Sept } 192007 \\
\text { 09-35-39.txt }\end{array}$ & $\begin{array}{l}\text { no } \\
\text { sussurface } \\
\text { video }\end{array}$ \\
\hline E1244 & 4 & Clay & 54.5 & 0.833 .55 & NA & 1 & A & 4.5 & $\begin{array}{l}7.171 \\
6.88\end{array}$ & & - & & $\begin{array}{l}11000 / 1 / 15500 / \\
75000\end{array}$ & & - & & 12 & 0 & 0 & & 0 & 0 & $\mathrm{~N}$ & 3 & E1244-D1-070919.ASC & $\begin{array}{l}\text { E1244-D2-Channel\# Sept } 192007 \\
\text { 09-40-47.txt }\end{array}$ & $\begin{array}{l}\text { no } \\
\text { subsurface } \\
\text { video }\end{array}$ \\
\hline E1245 & 4 & Clay & 54.5 & 0.833 .55 & NA & 2 & $A, B$ & 4.5 & $\begin{array}{l}6.66 / \\
6.37\end{array}$ & $\begin{array}{l}6.681 \\
6.40\end{array}$ & - & - & $\begin{array}{l}11000 / 1 / 15500 / \\
75000\end{array}$ & $\begin{array}{l}11000 / 1 / 15500 / \\
75000\end{array}$ & - & - & 12 & 0 & 0 & & O & 0 & $Y$ & 1 & E1245-D1-070919.ASC & $\begin{array}{c}\text { E1245-D2-Channel\# Sept } 192007 \\
\text { 09-48-12.txt }\end{array}$ & $\begin{array}{l}\text { no } \\
\text { subsurface } \\
\text { video }\end{array}$ \\
\hline E1246 & 4 & Clay & 54.5 & 0.833 .55 & NA & 2 & $A, B$ & 4.5 & $\begin{array}{l}6.661 \\
6.37\end{array}$ & $\begin{array}{l}6.681 \\
6.40\end{array}$ & - & - & $\begin{array}{l}11000 / 1 / 15500 / \\
75000\end{array}$ & $\begin{array}{l}11000 / 1 / 15500 / \\
75000\end{array}$ & - & - & 12 & 0 & 0 & & 0 & 0 & Y & 2 & E1246-D1-070919.ASC & $\begin{array}{c}\text { E1246-D2-Channel\# Sept } 192007 \\
\text { 09-55-26.txt }\end{array}$ & $\begin{array}{l}\text { no } \\
\text { subsurface } \\
\text { video }\end{array}$ \\
\hline E1247 & 4 & Clay & 54.5 & 0.833 .55 & NA & 2 & $A, B$ & 4.5 & $\begin{array}{l}6.661 \\
6.37\end{array}$ & $\begin{array}{l}6.681 \\
6.40\end{array}$ & & & $\begin{array}{l}11000 / 1 / 15500 / \\
75000\end{array}$ & $\begin{array}{c}11000 / 1 / 15500 / \\
75000\end{array}$ & - & & 12 & 0 & 0 & & 0 & 0 & $\mathrm{~N}$ & 3 & E1247-D1-070919.ASC & $\begin{array}{l}\text { E1247-D2-Channel\# Sept } 192007 \\
\text { 10-00-40.txt }\end{array}$ & $\begin{array}{l}\text { no } \\
\text { subsurface } \\
\text { video }\end{array}$ \\
\hline E1248 & 4 & Clay & 54.5 & 0.833 .55 & NA & 3 & $A, B, C$ & 4.5 & $\begin{array}{l}6.791 \\
5.93\end{array}$ & $\begin{array}{l}6.641 \\
5.94\end{array}$ & $\begin{array}{l}6.30 / \\
5.84\end{array}$ & & $\begin{array}{l}11000 / 1 / 15500 / \\
75000\end{array}$ & $\begin{array}{l}11000 / 1 / 15500 / \\
75000\end{array}$ & $\begin{array}{l}11000 / 1 / 15500 / \\
75000\end{array}$ & & 12 & 0 & 0 & & 0 & 0 & Y & 1 & E1248-D1-070919.ASC & $\begin{array}{c}\text { E1248-D2-Channel\# Sept } 192007 \\
\text { 10-14-58.txt }\end{array}$ & $\begin{array}{l}\text { no } \\
\text { no } \\
\text { subsurface } \\
\text { video }\end{array}$ \\
\hline E1249 & 4 & Clay & 54.5 & 0.833 .55 & NA & 3 & $A, B, C$ & 4.5 & $\begin{array}{l}6.79 / \\
5.93\end{array}$ & $\begin{array}{l}6.641 \\
5.94\end{array}$ & $\begin{array}{l}6.30 / \\
5.84\end{array}$ & - & $\begin{array}{l}11000 / 1 / 15500 / \\
75000\end{array}$ & $\begin{array}{l}11000 / 1 / 15500 / \\
75000\end{array}$ & $\begin{array}{l}11000 / 1 / 15500 / \\
75000\end{array}$ & - & 12 & 0 & 0 & & $\mathrm{O}$ & 0 & $\mathrm{Y}$ & 2 & E1249-D1-070919.ASC & $\begin{array}{c}\text { E1249-D2-Channel\# Sept } 192007 \\
\text { 10-20-07.txt }\end{array}$ & $\begin{array}{l}\text { no } \\
\text { subsurface } \\
\text { video }\end{array}$ \\
\hline E1250 & 4 & Clay & 54.5 & 0.833 .55 & NA & 3 & $A, B, C$ & 4.5 & $\begin{array}{l}6.79 / \\
5.93\end{array}$ & $\begin{array}{l}6.641 \\
5.94\end{array}$ & $\begin{array}{l}6.30 / \\
5.84\end{array}$ & - & $\begin{array}{l}11000 / 1 / 15500 / \\
75000\end{array}$ & $\begin{array}{c}11000 / 1 / 15500 / \\
75000\end{array}$ & $\begin{array}{l}11000 / 1 / 15500 / \\
75000\end{array}$ & 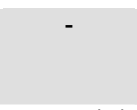 & 12 & 0 & 0 & & 0 & 0 & $\mathrm{~N}$ & 3 & E1250-D1-070919.ASC & $\begin{array}{l}\text { E1250-D2-Channel\# Sept } 192007 \\
\text { 10-24-38.txt }\end{array}$ & $\begin{array}{l}\text { no } \\
\text { subsurface } \\
\text { video }\end{array}$ \\
\hline E1251 & 4 & Clay & 54.5 & 0.833 .55 & NA & 4 & $\mathrm{~A}, \mathrm{~B}, \mathrm{C}, \mathrm{D}$ & 4.5 & $\begin{array}{l}5.921 \\
5.74\end{array}$ & $\begin{array}{l}6.271 \\
5.65\end{array}$ & $\begin{array}{l}5.931 \\
5.52\end{array}$ & $\begin{array}{l}5.66 / \\
5.51\end{array}$ & $\begin{array}{l}11000 / 1 / 15500 / \\
75000\end{array}$ & $\begin{array}{l}11000 / 1 / 15500 / \\
75000\end{array}$ & $\begin{array}{l}11000 / 1 / 15500 / \\
75000\end{array}$ & $\begin{array}{l}11000 / 1 / \\
155000 \\
75000\end{array}$ & 12 & 0 & $\mathrm{o}$ & & 0 & 0 & $\mathrm{Y}$ & 1 & E1251-D1-070919.ASC & $\begin{array}{l}\text { E1251-D2-Channel\# Sept } 192007 \\
\text { 10-35-54.txt }\end{array}$ & $\begin{array}{l}\text { no } \\
\text { subsurface } \\
\text { video }\end{array}$ \\
\hline E1252 & 4 & Clay & 54.5 & 0.833 .55 & NA & 4 & $\mathrm{~A}, \mathrm{~B}, \mathrm{C}, \mathrm{D}$ & 4.5 & $\begin{array}{l}5.921 \\
5.74\end{array}$ & $\begin{array}{l}6.271 \\
5.65\end{array}$ & 5.931 & $\begin{array}{l}5.66 / \\
5.51\end{array}$ & $\begin{array}{l}11000 / 1 / 15500 / \\
75000\end{array}$ & $\begin{array}{l}11000 / 1 / 15500 / \\
75000\end{array}$ & $\begin{array}{l}11000 / 1 / 15500 / \\
75000\end{array}$ & $\begin{array}{l}11000 / 1 / \\
15500 / \\
75000\end{array}$ & 12 & 0 & 0 & & 0 & 0 & $\mathrm{Y}$ & 2 & E1252-D1-070919.ASC & $\begin{array}{c}\text { E1252-D2-Channel\# Sept } 192007 \\
\text { 10-42-20.txt }\end{array}$ & $\begin{array}{l}\text { no } \\
\text { sussurface } \\
\text { video }\end{array}$ \\
\hline E1253 & 4 & Clay & 54.5 & 0.833 .55 & NA & 4 & $\mathrm{~A}, \mathrm{~B}, \mathrm{C}, \mathrm{D}$ & 4.5 & $\begin{array}{l}5.921 \\
5.74\end{array}$ & $\begin{array}{l}6.271 \\
5.65\end{array}$ & 5.931 & $\begin{array}{l}5.66 / \\
5.51\end{array}$ & $\begin{array}{l}11000 / 1 / 15500 / \\
75000\end{array}$ & $\begin{array}{l}11000 / 1 / 15500 / \\
75000\end{array}$ & $\begin{array}{l}11000 / 1 / 1 / 15500 / 75 \\
000\end{array}$ & $\begin{array}{l}11000 / 1 / \\
15500 / \\
75000\end{array}$ & 12 & 0 & o & & 0 & 0 & $\mathrm{~N}$ & 3 & E1253-D1-070919.ASC & $\begin{array}{l}\text { E1253-D2-Channel\# Sept } 192007 \\
\text { 10-48-58.txt }\end{array}$ & $\begin{array}{l}\text { no } \\
\text { subsurface } \\
\text { video }\end{array}$ \\
\hline E1254 & 4 & Clay & 54.5 & 0.833 .55 & NA & 2 & $A, B$ & 4.5 & $\begin{array}{l}4.771 \\
4.81\end{array}$ & $\begin{array}{l}4.811 \\
4.77\end{array}$ & - & - & $\begin{array}{l}11000 / 1 / 16500 / \\
75000\end{array}$ & $\begin{array}{c}11000 / 1 / 16500 / \\
75000\end{array}$ & - & - & 10 & 0 & 0 & & 0 & 0 & $\mathrm{Y}$ & 1 & E1254-D1-070919.ASC & $\begin{array}{c}\text { E1254-D2-Channel\# Sept } 192007 \\
\text { 11-29-54.txt }\end{array}$ & $\begin{array}{l}\text { no } \\
\text { subsurface } \\
\text { video }\end{array}$ \\
\hline E1255 & 4 & Clay & 54.5 & 0.833 .55 & NA & 2 & $A, B$ & 4 & $\begin{array}{l}4.771 \\
4.81\end{array}$ & $\begin{array}{l}4.81 / \\
4.77\end{array}$ & - & - & $\begin{array}{l}11000 / 1 / 16500 / \\
75000\end{array}$ & $\begin{array}{l}11000 / 1 / 16500 / \\
75000\end{array}$ & - & & 10 & $\mathrm{O}$ & $\mathrm{O}$ & & $\mathrm{O}$ & 0 & $\mathrm{Y}$ & 2 & E1255-D1-070919.ASC & $\begin{array}{c}\text { E1255-D2-Channel\# Sept } 192007 \\
\text { 11-38-27.txt }\end{array}$ & $\begin{array}{l}\text { no } \\
\text { subsurface } \\
\text { video }\end{array}$ \\
\hline E1256 & 4 & Clay & 54.5 & 0.833 .55 & NA & 2 & $A, B$ & 4.5 & $\begin{array}{l}4.771 \\
4.81\end{array}$ & $\begin{array}{l}4.811 \\
4.77\end{array}$ & & & $\begin{array}{l}11000 / 1 / 16500 / \\
75000\end{array}$ & $\begin{array}{c}11000 / 1 / 16500 / \\
75000\end{array}$ & & & 10 & 0 & 0 & & 0 & 0 & $\mathrm{~N}$ & 3 & E1256-D1-070919.ASC & $\begin{array}{c}\text { E1256-D2-Channel\# Sept } 192007 \\
\text { 11-42-54.txt }\end{array}$ & $\begin{array}{l}\text { no } \\
\text { sussurface } \\
\text { video }\end{array}$ \\
\hline E1257 & 4 & Clay & 54.5 & 0.833 .55 & NA & 1 & A & 4 & $\begin{array}{l}4.81 / \\
4.87\end{array}$ & - & & & $\begin{array}{l}11000 / 1 / 16500 / \\
75000\end{array}$ & 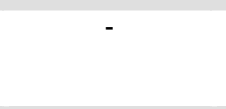 & - & & 10 & 0 & 0 & & 0 & 0 & $\mathrm{Y}$ & 1 & E1257-D1-070919.ASC & $\begin{array}{l}\text { E1257-D2-Channel\# Sept } 192007 \\
\text { 11-51-24.txt }\end{array}$ & $\begin{array}{l}\text { no } \\
\text { sussurface } \\
\text { video }\end{array}$ \\
\hline E1258 & 4 & Clay & 54.5 & 0.833 .55 & NA & 1 & A & 4.5 & $\begin{array}{l}4.81 / \\
4.85\end{array}$ & & & & $\begin{array}{l}11000 / 1 / 16500 / \\
75000\end{array}$ & & & & 10 & $\mathrm{O}$ & $\mathrm{O}$ & & O & 0 & $\mathrm{Y}$ & 2 & E1258-D1-070919.ASC & $\begin{array}{c}\text { E1258-D2-Channel\# Sept } 192007 \\
\text { 11-56-12.txt }\end{array}$ & $\begin{array}{l}\text { no } \\
\text { subsurface } \\
\text { video }\end{array}$ \\
\hline E1259 & 4 & Clay & 54.5 & 0.833 .55 & NA & 1 & A & 4.0 & $\begin{array}{l}4.81 / \\
4.85\end{array}$ & - & - & - & $\begin{array}{c}11000 / 1 / 16500 / \\
75000\end{array}$ & - & - & - & 10 & 0 & 0 & & $\mathrm{O}$ & 0 & $\mathrm{~N}$ & 3 & E1259-D1-070919.ASC & $\begin{array}{l}\text { E1259-D2-Channel\# Sept } 192007 \\
\text { 11-59-49.txt }\end{array}$ & $\begin{array}{c}\text { no } \\
\text { subsurface } \\
\text { video }\end{array}$ \\
\hline
\end{tabular}




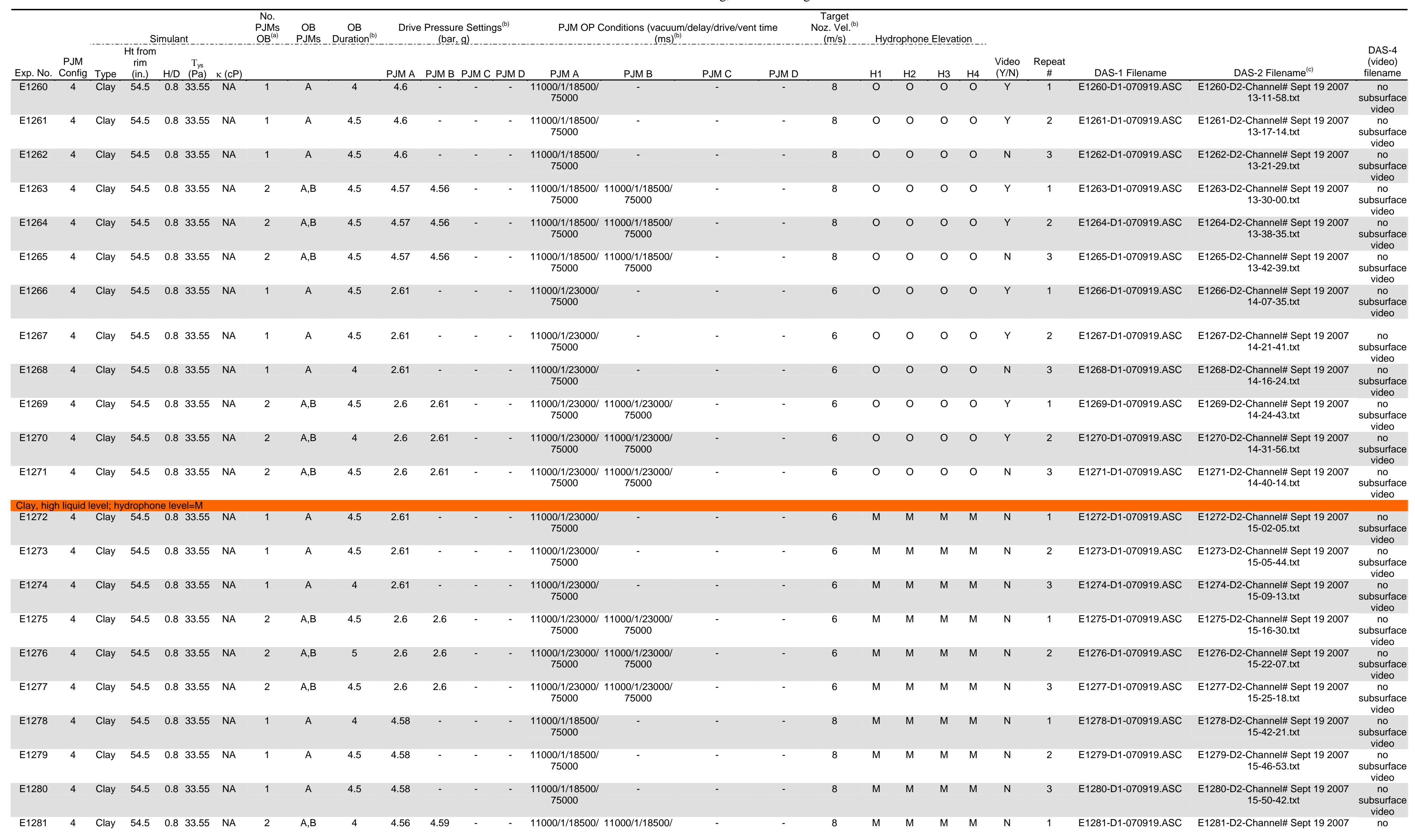




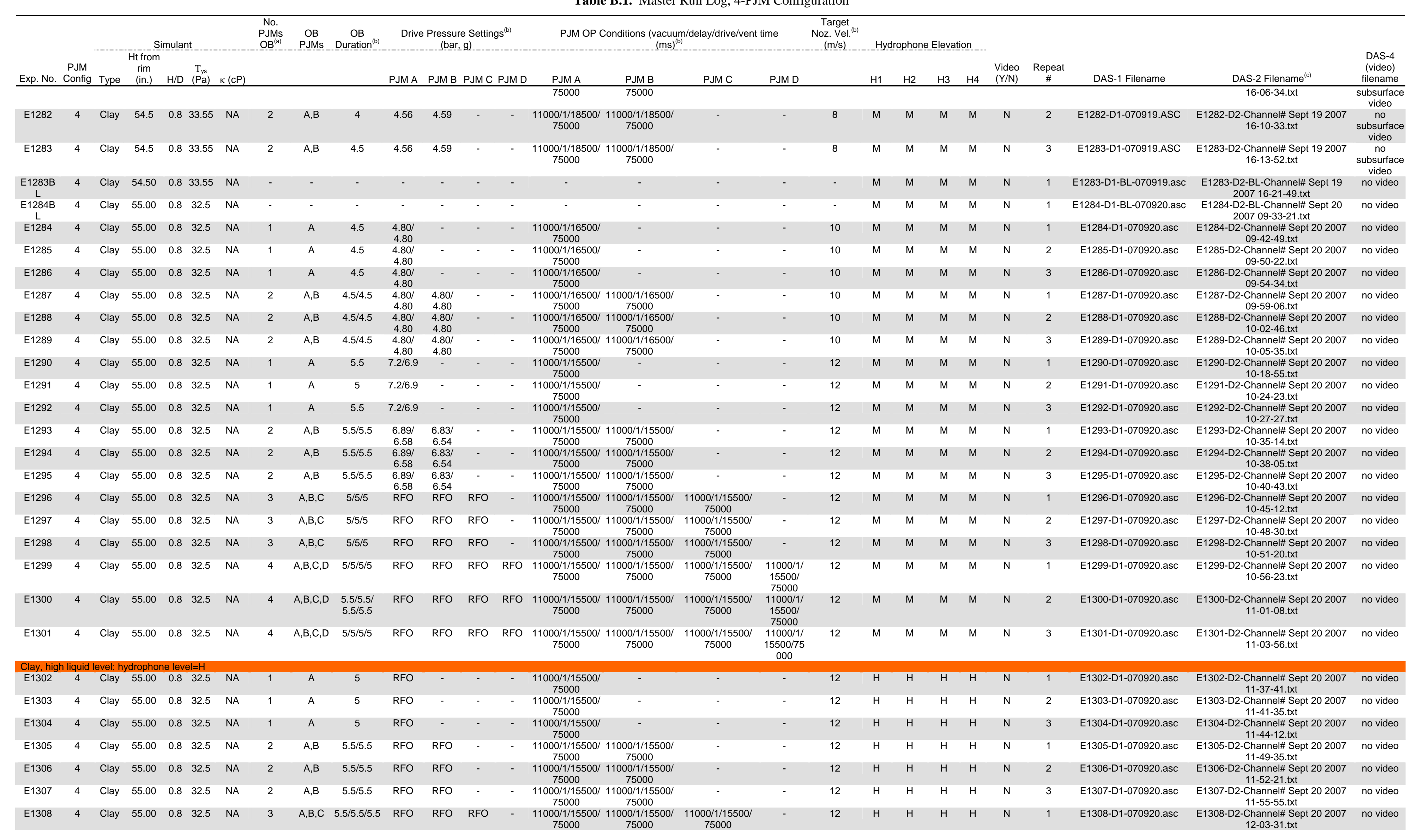


Table B.1. Master Run Log, 4-PJM Configuration

\begin{tabular}{|c|c|c|c|c|c|c|c|c|c|c|c|c|c|c|c|c|c|c|c|c|c|c|c|c|c|c|c|c|}
\hline Exp. No. & $\begin{array}{c}\text { PJM } \\
\text { Config }\end{array}$ & & $\begin{array}{l}\text { Hit from } \\
\text { rim } \\
\text { (in.) }\end{array}$ & $H / D$ & $\begin{array}{l}\mathrm{T}_{\mathrm{ys}} \\
(\mathrm{Pa})\end{array}$ & & & & & PJM A & PJM B & PJM C & C PJM D & PJM $f$ & PJM B & PJM C & PJM D & & $\mathrm{H} 1$ & & $\mathrm{H} 2$ & $\mathrm{H} 3$ & $\mathrm{H} 4$ & $\begin{array}{l}\text { Video } \\
\text { (Y/N) }\end{array}$ & $\begin{array}{c}\text { Repeat } \\
\#\end{array}$ & DAS-1 Filename & DAS-2 Filename ${ }^{(c)}$ & $\begin{array}{l}\text { DAS-4 } \\
\text { (video) } \\
\text { filename }\end{array}$ \\
\hline E1309 & 4 & Clay & 55.00 & 0.8 & 32.5 & NA & 3 & $\mathrm{~A}, \mathrm{~B}, \mathrm{C}$ & $5 / 5 / 5$ & RFO & RFO & RFO & & $\begin{array}{l}11000 / 1 / 1 / 15500 / \\
75000\end{array}$ & $\begin{array}{l}\mid 11000 / 1 / 1 / 155000 / \\
75000\end{array}$ & $\begin{array}{l}11000 / 1 / 1 / 15500 / \\
75000\end{array}$ & & 12 & $\mathrm{H}$ & & $\mathrm{H}$ & $\frac{\mathrm{H}}{\mathrm{H}}$ & $\mathrm{H}$ & $\mathrm{N}$ & 2 & E1309-D1-070920.asc & $\begin{array}{l}\text { E1309-D2-Channel\# Sept } 202007 \\
\text { 12-05-13.txt }\end{array}$ & no video \\
\hline E1310 & 4 & Clay & 55.00 & 0.8 & 32.5 & NA & 3 & $A, B, C$ & $5 / 5 / 5$ & RFO & RFO & RFO & - & $\begin{array}{l}11000 / 1 / 15500 / \\
75000\end{array}$ & $\begin{array}{l}\text { / 11000/1/15500/ } \\
75000\end{array}$ & $\begin{array}{l}11000 / 1 / 15500 / \\
75000\end{array}$ & - & 12 & $\mathrm{H}$ & & $\mathrm{H}$ & $\mathrm{H}$ & $\mathrm{H}$ & $\mathrm{N}$ & 3 & E1310-D1-070920.asc & $\begin{array}{c}\text { E1310-D2-Channel\# Sept } 202007 \\
\text { 12-08-07.txt }\end{array}$ & no video \\
\hline E1311 & 4 & Clay & 55.00 & 0.8 & 32.5 & NA & 4 & $\mathrm{~A}, \mathrm{~B}, \mathrm{C}, \mathrm{D}$ & $5 / 5 / 5 / 5$ & RFO & RFO & RFO & RFO & $\begin{array}{c}11000 / 1 / 1 / 15500 / \\
75000\end{array}$ & $\begin{array}{l}\text { 11000/1/15500/ } \\
75000\end{array}$ & $\begin{array}{l}11000 / 1 / 15500 / \\
75000\end{array}$ & $\begin{array}{l}11000 / 1 / \\
15500 / \\
75000\end{array}$ & 12 & $\mathrm{H}$ & & $\mathrm{H}$ & $\mathrm{H}$ & $\mathrm{H}$ & $\mathrm{N}$ & 1 & E1311-D1-070920.asc & $\begin{array}{l}\text { E1311-D2-Channel\# Sept } 202007 \\
\text { 12-11-34.txt }\end{array}$ & no video \\
\hline E1312 & 4 & Clay & 55.00 & 0.8 & 32.5 & NA & 4 & $\mathrm{~A}, \mathrm{~B}, \mathrm{C}, \mathrm{D}$ & $5 / 5 / 5 / 5$ & RFO & RFO & RFO & RFO & $\begin{array}{l}11000 / 1 / 15500 / \\
75000\end{array}$ & $\begin{array}{l}11000 / 1 / 1 / 15500 / \\
75000\end{array}$ & $\begin{array}{l}11000 / 1 / 15500 / \\
75000\end{array}$ & $\begin{array}{l}110000 / 1 / \\
15500 / \\
75000\end{array}$ & 12 & $\mathrm{H}$ & & $\mathrm{H}$ & $\mathrm{H}$ & $\mathrm{H}$ & $\mathrm{N}$ & 2 & E1312-D1-070920.asc & $\begin{array}{c}\text { E1312-D2-Channel|\# Sept } 202007 \\
\text { 12-15-55.txt }\end{array}$ & no video \\
\hline E1313 & 4 & Clay & 55.00 & 0.8 & 32.5 & NA & 4 & $\mathrm{~A}, \mathrm{~B}, \mathrm{C}, \mathrm{D}$ & $5 / 5 / 5 / 5$ & RFO & RFO & RFO & RFO & $\begin{array}{l}11000 / 1 / 15500 / \\
75000\end{array}$ & $\begin{array}{l}11000 / 1 / 15500 / \\
75000\end{array}$ & $\begin{array}{l}\text { 11000/1/15500/75 } \\
000\end{array}$ & $\begin{array}{l}11000 / 1 / \\
15500 / \\
75000\end{array}$ & 12 & $\mathrm{H}$ & & $H$ & $\mathrm{H}$ & $\mathrm{H}$ & $\mathrm{N}$ & 3 & E1313-D1-070920.asc & $\begin{array}{l}\text { E1313-D2-Channel\# Sept } 202007 \\
\text { 12-18-30.txt }\end{array}$ & no video \\
\hline E1314 & 4 & Clay & 55.00 & 0.8 & 32.5 & NA & 1 & A & 4.5 & $\begin{array}{l}4.821 \\
4.78\end{array}$ & - & - & & $\begin{array}{l}11000 / 1 / 16500 / \\
75000\end{array}$ & & & & 10 & $\mathrm{H}$ & & $H$ & $\mathrm{H}$ & $\mathrm{H}$ & $\mathrm{N}$ & 1 & E1314-D1-070920.asc & $\begin{array}{l}\text { E1314-D2-Channel\# Sept } 202007 \text { 14-17-39.txt } \\
\text { 1.t. }\end{array}$ & no video \\
\hline E1315 & 4 & Clay & 55.00 & 0.8 & 32.5 & NA & 1 & A & 4.5 & $\begin{array}{l}4.821 \\
4.78\end{array}$ & - & - & & $\begin{array}{l}11000 / 1 / 16500 / \\
75000\end{array}$ & & - & & 10 & $\mathrm{H}$ & & $\mathrm{H}$ & $\mathrm{H}$ & $\mathrm{H}$ & $\mathrm{N}$ & 2 & E1315-D1-070920.asc & $\begin{array}{c}\text { E1315-D2-Channel\# Sept } 202007 \\
\text { 14-20-10.txt }\end{array}$ & no video \\
\hline E1316 & 4 & Clay & 55.00 & 0.8 & 32.5 & NA & 1 & A & 4.5 & $\begin{array}{l}4.821 \\
4.78\end{array}$ & - & - & - & $\begin{array}{l}11000 / 1 / 16500 / \\
75000\end{array}$ & I & - & - & 10 & $\mathrm{H}$ & & $\mathrm{H}$ & $\mathrm{H}$ & $\mathrm{H}$ & $\mathrm{N}$ & 3 & E1316-D1-070920.asc & $\begin{array}{l}\text { E1316-D2-Channel\# Sept } 202007 \\
14-23-25 \text { trt }\end{array}$ & no video \\
\hline E1317 & 4 & Clay & 55.00 & 0.8 & 32.5 & NA & 2 & $A, B$ & $5 / 5$ & $\mathrm{NR}$ & NR & - & - & $\begin{array}{l}11000 / 1 / 116500 / \\
75000\end{array}$ & $\begin{array}{l}\text { | 11000/1/16500/ } \\
75000\end{array}$ & - & - & 10 & $\mathrm{H}$ & & $\mathrm{H}$ & $\mathrm{H}$ & $\mathrm{H}$ & $\mathrm{N}$ & 1 & E1317-D1-070920.asc & E1317-D2-Channel\# Sept 202007 & no video \\
\hline E1318 & 4 & Clay & 55.00 & 0.8 & 32.5 & NA & 2 & $A, B$ & $5 / 5$ & $\begin{array}{l}4.80 / \\
4.81\end{array}$ & $\begin{array}{l}4.771 \\
4.77\end{array}$ & - & - & $\begin{array}{l}11000 / 1 / 1 / 16500 / \\
75000\end{array}$ & 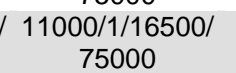 & - & - & 10 & $\mathrm{H}$ & & H & $H$ & $\mathrm{H}$ & $\mathrm{N}$ & 2 & E1318-D1-070920.asc & $\begin{array}{l}\text { E1318-D2-Channel\# Sept } 202007 \\
\text { 14-29-51.txt }\end{array}$ & no video \\
\hline E1319 & 4 & Clay & 55.00 & 0.8 & 32.5 & NA & 2 & $A, B$ & $5 / 5$ & $\begin{array}{l}4.801 \\
4.801\end{array}$ & 4.771 & - & - & $11000 / 1 / 16500 /$ & / 11000/1/1/16500/ & - & - & 10 & $\mathrm{H}$ & & $\mathrm{H}$ & $\mathrm{H}$ & H & $\mathrm{N}$ & 3 & E1319-D1-070920.asc & E1319-D2-Channelt\# Sept 202007 & no video \\
\hline E1320 & 4 & Clay & 55.00 & 0.8 & 32.5 & NA & 1 & A & 4.5 & $\begin{array}{l}4.81 \\
4.62\end{array}$ & 4.77 & . & & $\begin{array}{c}75000 \\
11000 / 1 / 18500 / \\
75000\end{array}$ & 75000 & & & 8 & $\mathrm{H}$ & & $\mathrm{H}$ & $\mathrm{H}$ & $\mathrm{H}$ & $\mathrm{N}$ & 1 & E1320-D1-070920.asc & $\begin{array}{l}\text { 14-32-41.txt } \\
\text { E1320-D2-Channel\# Sept } 202007 \\
\text { 14-45-22.txt }\end{array}$ & no video \\
\hline E1321 & 4 & Clay & 55.00 & 0.8 & 32.5 & NA & 1 & A & 4.5 & 4.62 & - & - & - & $\begin{array}{c}11000 / 1 / 18500 / \\
75000\end{array}$ & & - & 列 & 8 & $\mathrm{H}$ & & $\mathrm{H}$ & $\mathrm{H}$ & $\mathrm{H}$ & $\mathrm{N}$ & 2 & E1321-D1-070920.asc & $\begin{array}{l}\text { E1321-D2-Channel\# Sept } 202007 \text { 14-48-12.txt } \\
\text { (t) }\end{array}$ & no video \\
\hline E1322 & 4 & Clay & 55.00 & 0.8 & 32.5 & NA & 1 & A & 4.5 & 4.62 & - & - & - & $\begin{array}{l}11000 / 1 / 18500 / \\
75000\end{array}$ & & - & - & 8 & $\mathrm{H}$ & & $\mathrm{H}$ & $\mathrm{H}$ & $\mathrm{H}$ & $\mathrm{N}$ & 3 & E1322-D1-070920.asc & $\begin{array}{l}\text { E1322-D2-Channel\# Sept } 202007 \text { 14-51-26.txt } \\
\text { 1.t. }\end{array}$ & no video \\
\hline E1323 & 4 & Clay & 55.00 & 0.8 & 32.5 & NA & 2 & $A, B$ & $4,5 / 4.5$ & 4.59 & 4.6 & - & - & $\begin{array}{l}11000 / 1 / 18500 / \\
75000\end{array}$ & $\begin{array}{l}\text { / 11000/1/18500/ } \\
75000\end{array}$ & - & - & 8 & $\mathrm{H}$ & & $\mathrm{H}$ & $\mathrm{H}$ & $\mathrm{H}$ & $\mathrm{N}$ & 1 & E1323-D1-070920.asc & E1323-D2-Channel\# Sept 202007 & no video \\
\hline E1324 & 4 & Clay & 55.00 & 0.8 & 32.5 & NA & 2 & $A, B$ & 4.5/4.5 & 4.59 & 4.6 & - & - & $\begin{array}{l}11000 / 1 / 18500 / \\
75000\end{array}$ & $\begin{array}{l}\text { | 11000/1/18500/ } \\
75000\end{array}$ & - & - & 8 & $\mathrm{H}$ & & H & H & $\mathrm{H}$ & $\mathrm{N}$ & 2 & E1324-D1-070920.asc & $\begin{array}{l}\text { E1324-D2-Channel\# Sept } 202007 \\
\text { 14-58-31 Strt }\end{array}$ & no video \\
\hline E1325 & 4 & Clay & 55.00 & 0.8 & 32.5 & NA & 2 & $A, B$ & $4.5 / 4.5$ & 4.59 & 4.6 & - & - & $\begin{array}{l}11000 / 1 / 18500 / \\
75000\end{array}$ & $\begin{array}{l}\text { / 11000/1/18500/ } \\
75000\end{array}$ & - & & 8 & $\mathrm{H}$ & & $\mathrm{H}$ & $\mathrm{H}$ & $\mathrm{H}$ & $\mathrm{N}$ & 3 & E1325-D1-070920.asc & $\begin{array}{c}\text { E1325-D2-Channel\# Sept } 202007 \\
\text { 15-01-06.txt }\end{array}$ & no video \\
\hline E1326 & 4 & Clay & 55.00 & 0.8 & 32.5 & NA & 1 & A & 4 & 2.61 & & & & $\begin{array}{l}11000 / 1 / 23000 / \\
75500\end{array}$ & & - & & 6 & $\mathrm{H}$ & & $\mathrm{H}$ & $\mathrm{H}$ & $\mathrm{H}$ & $\mathrm{N}$ & 1 & E1326-D1-070920.asc & $\begin{array}{l}\text { E1326-D2-Channel\# Sept } 202007 \\
\text { 15-14-49.txt }\end{array}$ & no video \\
\hline E1327 & 4 & Clay & 55.00 & 0.8 & 32.5 & NA & 1 & A & 4.5 & 2.61 & - & - & - & $\begin{array}{l}11000 / 1 / 23000 / \\
75000\end{array}$ & & - & & 6 & $\mathrm{H}$ & & $\mathrm{H}$ & $\mathrm{H}$ & $\mathrm{H}$ & $\mathrm{N}$ & 2 & E1327-D1-070920.asc & E1327-D2-Channel\# Sept 202007 & no video \\
\hline E1328 & 4 & Clay & 55.00 & 0.8 & 32.5 & NA & 1 & A & 4 & 2.61 & - & - & - & $\begin{array}{l}11000 / 1 / 23000 / \\
75000\end{array}$ & & - & & 6 & $\mathrm{H}$ & & $\mathrm{H}$ & H & H & $\mathrm{N}$ & 3 & E1328-D1-070920.asc & $\begin{array}{l}\text { E1328-D2-Channel\# Sept } 202007 \\
15-20-21 \text { txt }\end{array}$ & no video \\
\hline E1329 & 4 & Clay & 55.00 & 0.8 & 32.5 & NA & 2 & $A, B$ & 4/4 & 2.60 & 2.61 & - & - & $\begin{array}{c}11000 / 1 / 23000 / \\
75000\end{array}$ & 1 11000/1/23000/ & - & - & 6 & $\mathrm{H}$ & & $\mathrm{H}$ & $\mathrm{H}$ & $\mathrm{H}$ & $\mathrm{N}$ & 1 & E1329-D1-070920.asc & E1329-D2-Channel\# Sept 202007 & no video \\
\hline E1330 & 4 & Clay & 55.00 & 0.8 & 32.5 & NA & 2 & $A, B$ & $4.5 / 4.5$ & 2.60 & 2.61 & - & - & $\begin{array}{l}11000 / 1 / 23000 / \\
75000\end{array}$ & $\begin{array}{l}\text { / 11000/1/23000/ } \\
75000\end{array}$ & - & - & 6 & $\mathrm{H}$ & & $\mathrm{H}$ & $H$ & $\mathrm{H}$ & $\mathrm{N}$ & 2 & E1330-D1-070920.asc & $\begin{array}{l}\text { E1330-D2-Channe } \\
15-27-\mathrm{C}\end{array}$ & no video \\
\hline E1331 & 4 & Clay & 55.00 & 0.8 & 32.5 & NA & 2 & $A, B$ & 4/4 & 2.60 & 2.61 & - & - & $\begin{array}{c}11000 / 1 / 23000 / \\
75000\end{array}$ & $\begin{array}{l}\text { / 11000/1/23000/ } \\
75000\end{array}$ & - & - & 6 & $\mathrm{H}$ & & $\mathrm{H}$ & $\mathrm{H}$ & $\mathrm{H}$ & $\mathrm{N}$ & 3 & E1331-D1-070920.asc & $\begin{array}{l}\text { E1331-D2-Channel\# Sept } 202007 \\
\text { 15-29-55.txt }\end{array}$ & no video \\
\hline $\begin{array}{c}\text { E1331B } \\
L \\
C\end{array}$ & 4 & Clay & 55.00 & 0.8 & 32.5 & NA & - & & - & & & - & & & & - & - & - & $\mathrm{H}$ & & $\mathrm{H}$ & $\mathrm{H}$ & $\mathrm{H}$ & $\mathrm{N}$ & 1 & E1331-D1-BL-070920.asc & $\begin{array}{l}\text { E1331-D2-BL-Channel\# Sept } 20 \\
\text { 2007 15-36-48.txt }\end{array}$ & no video \\
\hline $\begin{array}{l}\text { Clay, higt } \\
\text { E132B } \\
\text { L }\end{array}$ & 4 & $\begin{array}{l}\text { level; hy } \\
\text { Clay }\end{array}$ & $\begin{array}{l}55.00 \\
5500\end{array}$ & $\begin{array}{l}\text { e leve } \\
0.8\end{array}$ & 32.5 & NA & & & & & & & & & & & & & $\mathrm{L}$ & & L & L & L & $\mathrm{N}$ & 1 & E1332-D1-BL-070921.asc & $\begin{array}{l}\text { E1332-D2-BL-Channel\# Sept } 21 \\
\text { 2007 09-21-43.txt }\end{array}$ & no video \\
\hline E1332 & 4 & Clay & 55.00 & 0.8 & 32.5 & NA & 1 & A & 4.5 & 2.61 & - & & - & $\begin{array}{l}11000 / 1 / 23000 / \\
75500\end{array}$ & & - & & 6 & L & & L & L & L & $\mathrm{N}$ & 1 & E1332-D1-070921.asc & $\begin{array}{l}\text { E1332-D2-ChannelH Sept } 212007 \\
\text { 09-31-15.txt }\end{array}$ & no video \\
\hline E1333 & 4 & Clay & 55.00 & 0.8 & 32.5 & NA & 1 & A & 4.5 & 2.61 & - & - & - & $\begin{array}{l}11000 / 1 / 23000 / \\
75000\end{array}$ & & - & - & 6 & L & & L & L & $\mathrm{L}$ & $\mathrm{N}$ & 2 & E1333-D1-070921.asc & $\begin{array}{l}\text { E1333-D2-Channel\# Sept } 212007 \\
\text { 09-34-14 txt }\end{array}$ & no video \\
\hline E1334 & 4 & Clay & 55.00 & 0.8 & 32.5 & NA & 1 & A & 4.5 & 2.61 & - & - & - & $\begin{array}{l}11000 / 1 / 23000 / \\
75000\end{array}$ & I & - & - & 6 & $\mathrm{~L}$ & & L & L & L & $\mathrm{N}$ & 3 & E1334-D1-070921.asc & $\begin{array}{l}\text { E1334-D2-Channel\# Sept } 212007 \\
\text { 09-36-39.txt }\end{array}$ & no video \\
\hline E1335 & 4 & Clay & 55.00 & 0.8 & 32.5 & NA & 2 & $A, B$ & $4.5 / 4.5$ & 2.61 & 2.61 & - & - & $\begin{array}{l}11000 / 1 / 23000 / \\
75000\end{array}$ & $\begin{array}{l}\text { / 11000/1/23000/ } \\
75000\end{array}$ & - & - & 6 & $\mathrm{~L}$ & & L & L & L & $\mathrm{N}$ & 1 & E1335-D1-070921.asc & $\begin{array}{l}\text { E1335-D2-Channel\# Sept } 212007 \\
\text { 09-40-38.txt }\end{array}$ & no video \\
\hline E1336 & 4 & Clay & 55.00 & 0.8 & 32.5 & NA & 2 & $A, B$ & 4.5/4.5 & 2.61 & 2.61 & - & & $\begin{array}{l}11000 / 1 / 23000 / \\
75000\end{array}$ & $\begin{array}{l}\text { / 11000/1/23000/ } \\
75000\end{array}$ & - & - & 6 & & & L & L & L & $\mathrm{N}$ & 2 & E1336-D1-070921.asc & $\begin{array}{l}\text { E1336-D2-Channel\# Sept } 212007 \\
\text { 09-43-12.txt }\end{array}$ & no video \\
\hline E1337 & 4 & Clay & 55.00 & 0.8 & 32.5 & NA & 2 & $A, B$ & 4.5/4.5 & 2.61 & 2.61 & - & & 11000/1/23000/ & / 11000/1/23000/ & & & 6 & $\mathrm{~L}$ & & L & L & L & $\mathrm{N}$ & 3 & $\equiv$ 1337-D1-070921.asc & 1337-D2-Channel\# Sept 212007 & o video \\
\hline
\end{tabular}

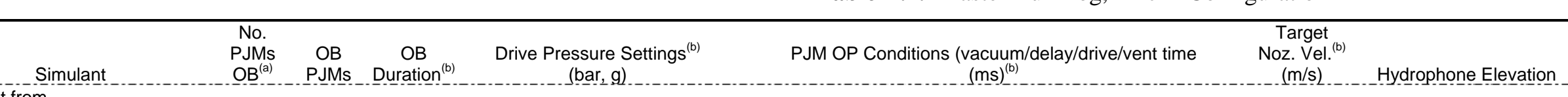

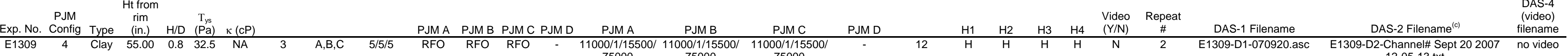

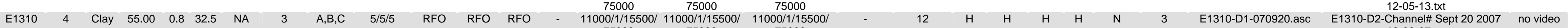

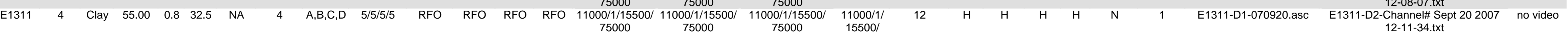

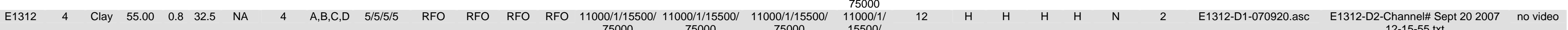

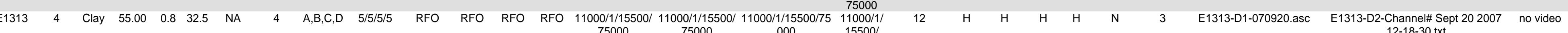


Table B.1. Master Run Log, 4-PJM Configuration

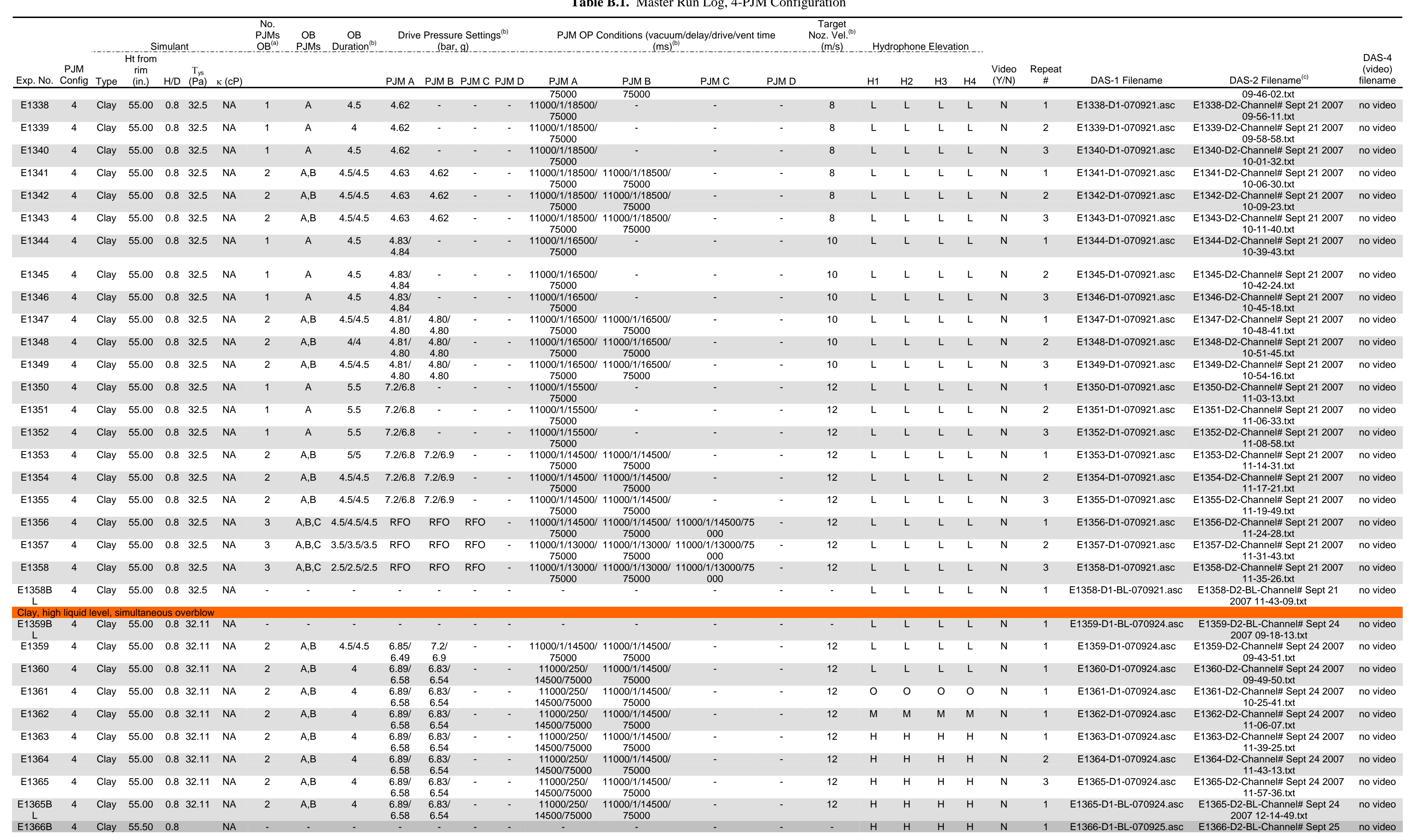


Table B.1. Master Run Log, 4-PJM Configuration

\begin{tabular}{|c|c|c|c|c|c|c|c|c|c|c|c|c|c|c|c|c|c|c|c|c|c|c|c|c|c|}
\hline \multirow[b]{2}{*}{ Exp. No. } & \multirow[b]{2}{*}{$\begin{array}{l}\text { PJM } \\
\text { Config }\end{array}$} & \multicolumn{4}{|c|}{ Simulant } & \multirow[t]{2}{*}{$\begin{array}{l}\text { No. } \\
\text { PJMs } \\
\text { PJB(a) }\end{array}$} & \multirow[t]{2}{*}{$\begin{array}{c}\text { OB } \\
\text { PJMS }\end{array}$} & \multirow[t]{2}{*}{$\begin{array}{l}\text { OB } \\
\text { Duration } \\
\text { (b) }\end{array}$} & \multicolumn{3}{|c|}{$\begin{array}{l}\text { Drive Pressure Settings } \\
\text { (bar, }\end{array}$} & \multicolumn{4}{|c|}{$\begin{array}{l}\text { PJM OP Conditions (vacuum/delay/drive/vent time } \\
(\mathrm{ms})^{(0)}\end{array}$} & \multirow[t]{2}{*}{$\begin{array}{c}\text { Target } \\
\text { Noz. Vel. } \\
\text { (b) } \\
\text { (bls) }\end{array}$} & \multicolumn{4}{|c|}{ Hydrophone Elevation } & \multirow[b]{2}{*}{$\begin{array}{l}\text { Video } \\
(Y / N)\end{array}$} & \multirow[b]{2}{*}{$\underset{\#}{\text { Repeat }}$} & \multirow[b]{2}{*}{ DAS-1 Filename } & \multirow[b]{2}{*}{ DAS-2 Filename ${ }^{(c)}$} & \multirow[b]{2}{*}{$\begin{array}{c}\text { DAS-4 } \\
\text { (video) } \\
\text { filename }\end{array}$} \\
\hline & & Type & $\begin{array}{c}\text { Ht from } \\
\text { rim } \\
\text { (in.) }\end{array}$ & $\begin{aligned} T_{y s} \\
H / D \\
(P a)\end{aligned}$ & $\kappa(c P)$ & & & & PJM A & PJM B & PJM C PJM D & PJMA & PJM B & PJM C & PJM D & & $\mathrm{H} 1$ & $\mathrm{H} 2$ & $\mathrm{H} 3$ & $\mathrm{H} 4$ & & & & & \\
\hline $\begin{array}{ll}\mathrm{L} \\
\mathrm{E} 1366\end{array}$ & 4 & Clay & 55.50 & 0.8 & NA & 2 & $A, C$ & - & $\begin{array}{l}-6.71 \\
-6.7\end{array}$ & $\begin{array}{c}-6.5 / \\
-6.5\end{array}$ & - & $\begin{array}{c}11000 / 400 / \\
14500 / 75000\end{array}$ & - & $\begin{array}{l}11000 / 1 / 14500 / \\
75000\end{array}$ & - & 12 & $\mathrm{H}$ & $\mathrm{H}$ & $\mathrm{H}$ & $\mathrm{H}$ & N & 1 & E1366-D1-070925.asc & $\begin{array}{c}\text { 2007 10-45-25.txt } \\
\text { E1366-D2-Channell Sept } 252007 \\
\text { 10-53-14.txt }\end{array}$ & no video \\
\hline E1367 & 4 & Clay & 55.50 & 0.8 & NA & 2 & $A, C$ & - & -6.71 & $\begin{array}{c}-6.5 / \\
-65\end{array}$ & - & $\begin{array}{l}11000 / 300 / \\
14000775000\end{array}$ & - & $\begin{array}{l}11000 / 1 / 1414500 / \\
75000\end{array}$ & - & 12 & $\mathrm{H}$ & $\mathrm{H}$ & $\mathrm{H}$ & $\mathrm{H}$ & $\mathrm{N}$ & 1 & E1367-D1-070925.asc & E1367-D2-Channel\# Sept 252007 & no video \\
\hline E1368 & 4 & Clay & 55.50 & 0.8 & NA & 2 & $A, C$ & - & $\begin{array}{l}-6.1 \\
-6.71 \\
-6.7\end{array}$ & $\begin{array}{l}-0.5 \\
-6.5 \\
-6.5\end{array}$ & - & $\begin{array}{l}145000 / 100 / \\
14500 / 75000\end{array}$ & - & $\begin{array}{l}11000 / 150014500 / \\
75000\end{array}$ & - & 12 & $\mathrm{H}$ & H & $\mathrm{H}$ & $\mathrm{H}$ & N & 1 & E1368-D1-070925.asc & $\begin{array}{l}\text { E1368-D2-Channe-\# Sept } 252007 \\
\text { 11-06-53.txt }\end{array}$ & no video \\
\hline E1369 & 4 & Clay & 55.50 & 0.8 & NA & 2 & $A, C$ & - & $-6.71-6$. & $\begin{array}{l}-6.5 / \\
-6.5\end{array}$ & - & $\begin{array}{l}11000 / 200 / \\
14500 / 75000\end{array}$ & - & $\begin{array}{l}11000 / 1 / 144500 / \\
70000\end{array}$ & - & 12 & $\mathrm{H}$ & $\mathrm{H}$ & $\mathrm{H}$ & $\mathrm{H}$ & N & 1 & E1369-D1-070925.asc & E1369-D2-Channel|l Sept 252007 & no video \\
\hline E1370 & 4 & Clay & 55.50 & 0.8 & NA & 2 & $\mathrm{~A}, \mathrm{C}$ & - & $\begin{array}{l}-6.71 \\
-6.7\end{array}$ & $\begin{array}{l}-0.5 \\
-6.5 /\end{array}$ & - & $\begin{array}{l}145000 / 400 / \\
115000 / 75000\end{array}$ & - & $\begin{array}{l}11000 / 1 / 1 / 14500 / \\
75000\end{array}$ & - & 12 & $\mathrm{H}$ & $\mathrm{H}$ & $\mathrm{H}$ & $\mathrm{H}$ & $\mathrm{N}$ & 1 & E1370-D1-070925.asc & $\begin{array}{c}\text { E1370-D2-Channel\# Sept } 252007 \\
\text { 11-20-13.txt }\end{array}$ & no video \\
\hline E1371 & 4 & Clay & 55.50 & 0.8 & NA & 2 & $A, C$ & - & $\begin{array}{l}-6.71 \\
-6.7\end{array}$ & $\begin{array}{l}-6.5 / \\
\sim 6.5\end{array}$ & - & $\begin{array}{l}11000 / 600 / \\
14500 / 75000\end{array}$ & - & $\begin{array}{l}11000 / 1 / 14500 / \\
75000\end{array}$ & - & 12 & $\mathrm{H}$ & H & H & $\mathrm{H}$ & $\mathrm{N}$ & 1 & E1371-D1-070925.asc & $\begin{array}{c}\text { E1371-D2-Channel/ Sept } 252007 \\
\text { 11-24-47.txt }\end{array}$ & no video \\
\hline E1372 & 4 & Clay & 55.50 & 0.8 & NA & 2 & $A, C$ & - & $\begin{array}{l}-6.71 \\
-6.7\end{array}$ & $\begin{array}{l}-6.5 / \\
-6.5\end{array}$ & - & $\begin{array}{c}11000 / 600 / \\
14500 / 75000\end{array}$ & - & $\begin{array}{l}11000 / 1 / 14500 / \\
75000\end{array}$ & - & 12 & $\mathrm{H}$ & H & $\mathrm{H}$ & $\mathrm{H}$ & $\mathrm{N}$ & 1 & E1372-D1-070925.asc & $\begin{array}{l}\text { E1372-D2-Channel\# Sept } 252007 \\
\text { 11-29-38.txt }\end{array}$ & no video \\
\hline E1373 & 4 & Clay & 55.50 & 0.8 & NA & 2 & $\mathrm{~A}, \mathrm{C}$ & - & $\begin{array}{l}-6.71 \\
-6.7\end{array}$ & $\begin{array}{l}-6.5 / \\
-6.5\end{array}$ & - & $\begin{array}{l}11000 / 700 / \\
14500 / 75000\end{array}$ & - & $\begin{array}{l}11000 / 1 / 1 / 4500 / \\
75000\end{array}$ & - & 12 & $\mathrm{H}$ & $\mathrm{H}$ & $\mathrm{H}$ & $\mathrm{H}$ & N & 1 & E1373-D1-070925.asc & $\begin{array}{l}\text { E1373-D2-Channel|l Sept } 252007 \\
11-35-41 \text { txt }\end{array}$ & no video \\
\hline E1374 & 4 & Clay & 55.50 & 0.8 & NA & 2 & $\mathrm{~A}, \mathrm{C}$ & - & $\begin{array}{l}-6.1 \\
-6.71\end{array}$ & $\begin{array}{l}-0.5 \\
-6.5\end{array}$ & - & $\begin{array}{l}145000 / 700 / \\
115000 / 75000\end{array}$ & - & $\begin{array}{l}11000 / 1 / 14500 / \\
75000\end{array}$ & - & 12 & M & M & M & M & $\mathrm{N}$ & 1 & E1374-D1-070925.asc & $\begin{array}{c}\text { E1374-D2-Channe-\# Sept } 252007 \\
\text { 12-45-36.txt }\end{array}$ & no video \\
\hline E1375 & 4 & Clay & 55.50 & 0.8 & NA & 2 & $\mathrm{~A}, \mathrm{C}$ & - & $\begin{array}{l}-0.1 \\
-6.71 \\
-6.7\end{array}$ & $\begin{array}{l}-0.5 \\
-6.5 / \\
-6.5\end{array}$ & - & $\begin{array}{l}14500 / 700 / \\
11500 / 75000\end{array}$ & - & $\begin{array}{l}11000 / 1 / 144500 / \\
75000\end{array}$ & - & 12 & M & M & M & M & $\mathrm{N}$ & 2 & E1375-D1-070925.asc & $\begin{array}{c}\text { E1375-D2-Channel|l Sept } 252007 \\
\text { 12-53-15.txt }\end{array}$ & no video \\
\hline E1376 & 4 & Clay & 55.50 & 0.8 & NA & 2 & $\mathrm{~A}, \mathrm{C}$ & - & $\begin{array}{l}-0.1 \\
-6.71 \\
-6.7\end{array}$ & $\begin{array}{l}-0.5 \\
-6.5 / \\
-6.5\end{array}$ & - & $\begin{array}{l}145000 / 850 / \\
11000 / 75000\end{array}$ & - & $\begin{array}{l}11000 / 1 / 144500 / \\
75000\end{array}$ & - & 12 & M & M & M & M & N & 1 & E1376-D1-070925.asc & $\begin{array}{c}\text { E1376-D2-Channel|l Sept } 252007 \\
\text { 13-02-19 trt }\end{array}$ & no video \\
\hline E1377 & 4 & Clay & 55.50 & 0.8 & NA & 2 & $A, C$ & - & -6.71 & 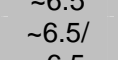 & - & $\begin{array}{l}145000 / 75000 \\
11000 / 850 /\end{array}$ & - & $\begin{array}{l}75000 \\
11000 / 1 / 14500 /\end{array}$ & - & 12 & 0 & 0 & 0 & 0 & $\mathrm{~N}$ & 1 & E1377-D1-070925.asc & E1377-D2-Channel|\# Sept 252007 & no video \\
\hline E1378 & 4 & Clay & 55.50 & 0.8 & NA & 2 & $A, C$ & - & $\begin{array}{l}-6.7 \\
-6.71 \\
-67\end{array}$ & $\begin{array}{l}-6.5 \\
-6.5 / \\
-65\end{array}$ & - & $\begin{array}{l}145000775000 \\
11000 / 850 / \\
14500 / 75000\end{array}$ & - & $\begin{array}{l}75500 \\
11000 / 1 / 14500 / \\
75500\end{array}$ & - & 12 & $\mathrm{~L}$ & $\mathrm{~L}$ & $\mathrm{~L}$ & L & $\mathrm{N}$ & 1 & E1378-D1-070925.asc & $\begin{array}{l}\text { 13-21-28.txt } \\
\text { E1378-D2-Channel\# Sept } 252007 \text { 13-37-42 } 2 \text { trt }\end{array}$ & no video \\
\hline E1378B & 4 & Clay & 55.50 & 0.8 & NA & - & - & - & & $\sim 6.5$ & - & $14500 / 75000$ & - & 75000 & - & - & L & L & L & L & $\mathrm{N}$ & 1 & E1378-D1-BL-070925.asc & $\begin{array}{c}\text { 13-37-42.txt } \\
\text { E1378-D2-BL-Channel\# Sept } 25 \\
\text { 2007 13-45-25.txt }\end{array}$ & no video \\
\hline $\begin{array}{l}\text { Notes: } \\
\text { (a) OB } \\
\text { (b) Valt } \\
\text { (c) Cha } \\
\text { (d) RFC } \\
\text { Shaded }\end{array}$ & & & & & & & & 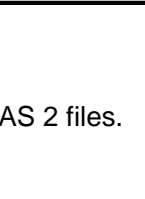 & & & & & & & & & & & & & & & & & \\
\hline
\end{tabular}




\section{Appendix C}

Nozzle Loss Coefficients 



\section{Appendix C: Nozzle Loss Coefficients}

The following discussion of nozzle loss coefficients and their calculation has been previously presented (see Bontha 2005) and for continuity is being presented here once again.

\section{C.1 Balance Equations for PJM Fluid}

Consider the period of time in which the liquid level is within the cylindrical cross-section the PJM. Assuming conservation of liquid volume, we can write $\mathrm{A}_{\mathrm{PJM}}(\mathrm{dx} / \mathrm{dt})=\mathrm{A}_{\mathrm{PJM}} \dot{x}=\mathrm{A}_{\mathrm{o}} \mathrm{u}$, where $\mathrm{A}_{\mathrm{PJM}}$ is $\mathrm{PJM}$ cross-section area, ${ }^{(a)} A_{o}$ is nozzle area, $u$ is nozzle velocity, and (dx/dt) or $\dot{x}$ is velocity of the PJM liquid surface inside the PJM cylinder. Similarly, the balance equation on power can be written in the form:

$$
\begin{aligned}
{\left[P+\rho g(L-x)-P_{2}\right] Q } & =Q\left[\frac{1}{2} \rho\left(\frac{A_{P J M}}{A_{o}}\right)^{2} \dot{x}^{2}-\frac{1}{2} \rho \dot{x}^{2}\right] \\
& +Q\left[K \frac{1}{2} \rho\left(\frac{A_{P J M}}{A_{o}}\right)^{2} \dot{x}^{2}\right]+Q \rho(L-x) \ddot{x}
\end{aligned}
$$

where

$$
\begin{aligned}
& \mathrm{P}, \mathrm{P}_{2}=\text { pressure in the PJM overhead space and in the tank liquid outside } \\
& \text { the PJM nozzle } \\
& \left(\mathrm{P}-\mathrm{P}_{2}\right) \mathrm{Q}=\text { net power applied by external pressure on the PJM liquid contents } \\
& \mathrm{Q}=\text { volume flow rate in PJM cross section or out of PJM nozzle } \\
& \mathrm{L}=\text { initial or reference level of liquid surface in PJM, measured up from } \\
& \text { nozzle level } \\
& \mathrm{x}=\text { instantaneous position of PJM liquid level, measured positive downward } \\
& \text { from initial or reference liquid level } \\
& \rho=\text { liquid density } \\
& \mathrm{g}=\text { acceleration of gravity } \\
& \rho g(\mathrm{~L}-\mathrm{x}) \mathrm{Q}=\text { power exerted by the flow if liquid at flow rate } Q=A_{P J M} \dot{x} \text { at added } \\
& \text { gravitational pressure head } \rho g(\mathrm{~L}-\mathrm{x}) \text { from a column of liquid of instantaneous } \\
& \text { length L-x and cross section } \mathrm{A}_{\mathrm{PJM}} \text { at velocity } \dot{x} \\
& \frac{1}{2} \rho\left(\frac{\mathrm{A}_{\mathrm{PJM}}}{\mathrm{A}_{\mathrm{O}}}\right)^{2} \dot{\mathrm{x}}^{2}=\text { kinetic energy per unit volume carried out of the nozzle by liquid } \\
& \frac{1}{2} \rho \dot{\mathrm{x}}^{2}=\begin{array}{l}
\text { kinetic energy per unit volume carried by liquid before entering } \\
\text { nozzle constriction region }
\end{array} \\
& \mathrm{K} \frac{1}{2} \rho\left(\frac{\mathrm{A}_{\mathrm{PJM}}}{\mathrm{A}_{\mathrm{O}}}\right)^{2} \dot{\mathrm{x}}^{2}=\begin{array}{l}
\text { Energy per liquid volume dissipated by wall friction and turbulence, } \\
\text { according to classical form loss model }
\end{array} \\
& \mathrm{K}=\text { friction form loss coefficient for flow through the nozzle region, different } \\
& \text { for forward or backward flow }
\end{aligned}
$$

(a) For the 8- and 4-PJM configuration, APJM $=433.3 \mathrm{in}^{2}$, as determined by subtracting the area of the pulse tube (ID 23.5 inches) from the area of the level probe (diameter $=0.75$ inches) 


$$
\begin{aligned}
Q \rho(L-x) \ddot{x}= & \text { Power applied to give column of length L-x acceleration } \ddot{x} \text {, product of a } \\
& \text { force } \rho(L-x) \ddot{x} A_{P J M} \text { and a velocity } \dot{x} \text {, with } Q=A_{P J M} \dot{x} \\
\mathrm{P}_{2}= & \text { Pressure in tank outside of the nozzle, given by } P_{2}=P_{a t m}+\rho g H, \text { where } \\
& \text { H is the height of the liquid level in the tank measured upward from the } \\
& \text { nozzle level. }
\end{aligned}
$$

It has been demonstrated that the acceleration term $Q \rho(L-x) \ddot{x}$ can typically be neglected for PJM operation in WTP vessels or their scaled versions.

Equation C.1 has tank pressure at nozzle level affected by tank level $\mathrm{H}$ according to:

$$
P_{2}=P_{a t m}+\rho g H=P_{a t m}+\rho g\left(H_{O}+x \frac{N_{P J M s} A_{P J M}}{A_{\text {tan } k}}\right)
$$

In Eq. (C.2), $\mathrm{N}_{\mathrm{PJMs}}$ is number of PJMs operating, $\mathrm{A}_{\mathrm{tank}}$ is tank cross-sectional flow area in the current range of tank liquid surface motion, and $\mathrm{H}_{\mathrm{o}}$ is the tank liquid level at the initial or reference condition when $\mathrm{x}=0$. The change in pressure with tank level during a pulse is typically not very important.

Eq. (C.1) and (C.2) have the dependence on tank level and PJM liquid level entering only through the combination H-L. Hence an important initial condition in simulations of a PJM cycle is the value of $\mathrm{H}_{0}-$ $\mathrm{L}$, which by definition is coincident with $\mathrm{x}=0$. In simulating tests in which liquid is drawn previous to each pulse up into the air supply tubes supplying the PJMs from above, we note very little liquid moves at the start of the pulse until the liquid level descends to the tops of the main parts of the PJMs, and also that Eq. C.1 and C.2 are valid only after the liquid level drops to the tops of the PJMs, where the flow area becomes $A_{\text {PJM. }}$. Hence it is useful to define the reference conditions by $\mathrm{x}=0$ at that instant and to set $\mathrm{H}_{0}-\mathrm{L}$ to the appropriate value at that instant.

\section{C.2 Solution Procedure for Determining K}

Eq. (C.1), with defining Eq. (C.2) for $\mathrm{P}_{2}$, can be used to obtain instantaneous velocities $\dot{x}$ and to step PJM liquid surface position $x$ through a cycle. Assuming pressure $\mathrm{P}(\mathrm{t})$ known in the PJM headspace at a time when position $\mathrm{x}$ is also known, and neglecting inertial reaction, $\dot{x}^{2}$ can be found from

$$
\dot{x}^{2}=\frac{P(t)+\rho g(L-x)-P_{a t m}-\rho g\left(H_{o}+x N_{P J M s} A_{P J M} / A_{\tan k}\right)}{(1+K) \frac{1}{2} \rho\left(\frac{A_{P J M}}{A_{o}}\right)^{2}-\frac{1}{2} \rho}
$$

from which we obtain $\dot{x}$ with correct algebraic sign by

$$
\dot{x}=\operatorname{sqrt}\left(\dot{x}^{2}\right) \operatorname{sign}\left[P(t)+\rho g(L-x)-P_{a t m}-\rho g\left(H_{o}+x N_{P J M s} A_{P J M} / A_{\tan k}\right)\right]
$$


We assume in Eq. (C.3) that we choose $\mathrm{K}$ as the forward or backward form loss coefficient depending on the sign of the numerator in Eq. (C.3). With the value of $\dot{x}$ from Eq. (C.4), we obtain a first-order estimate $x_{1, t 2}$ of $x$ at time $t_{2}$ by

$$
x_{1, t 2}=x+\left(t_{2}-t\right) \dot{x}
$$

Using an Excel spreadsheet, we performed a second-order refinement of this first-order estimate to obtain $\mathrm{x}_{2}$ at time $\mathrm{t}_{2}$. We proceed in this manner to obtain $\mathrm{x}$ and $\dot{x}$ values at each time point for which data are stored. Nozzle velocity $\mathrm{u}$ is obtained at each time point from $\mathrm{u}=\left(\mathrm{A}_{\mathrm{PJM}} / \mathrm{A}_{\mathrm{O}}\right) \dot{x}$.

Calculated points $\mathrm{x}(\mathrm{t})$ from this pressure-based calculation can be compared with level-based values, and both forward flow and backflow values of $\mathrm{K}$ determined for optimum agreement. Alternatively, nozzle velocities $\mathrm{u}=\left(\mathrm{A}_{\mathrm{PJM}} / \mathrm{A}_{\mathrm{O}}\right) \dot{x}$ from the pressure-based calculation can be compared with ones inferred from finite differencing of tank level data, $u=(\Delta \mathrm{H} / \Delta \mathrm{t}) \mathrm{A}_{\text {tank }} /\left(\mathrm{N}_{\mathrm{PJMs}} \mathrm{A}_{\mathrm{PJM}}\right)$. An advantage of the comparison of $\mathrm{x}(\mathrm{t})$ rather than $\mathrm{u}$ data is that the $\mathrm{x}(\mathrm{t})$ comparison can be made for data whose noise level is excessively enhanced by differencing. 

Appendix D

\section{Example 8-PJM Data}




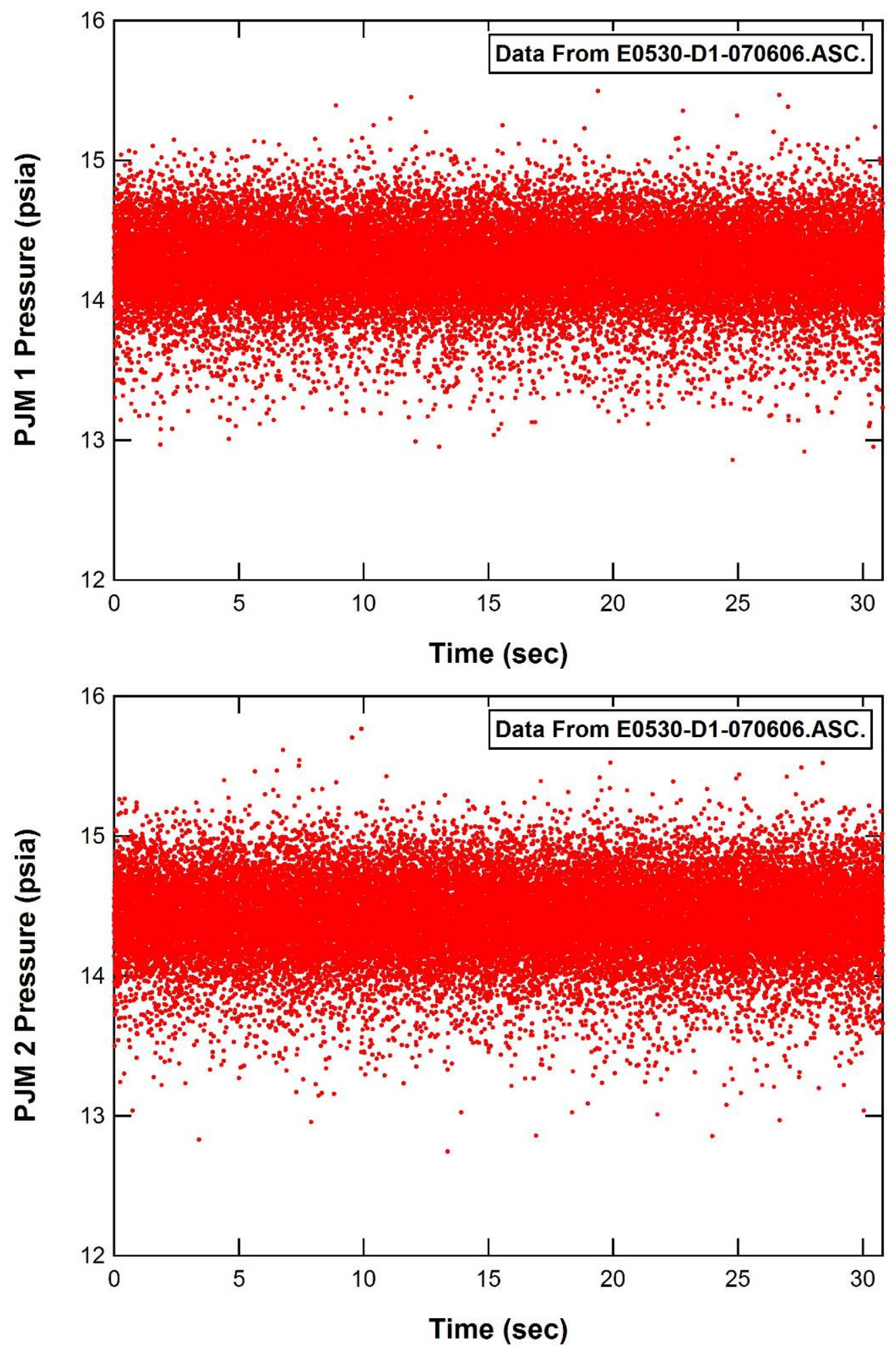

D. 1 

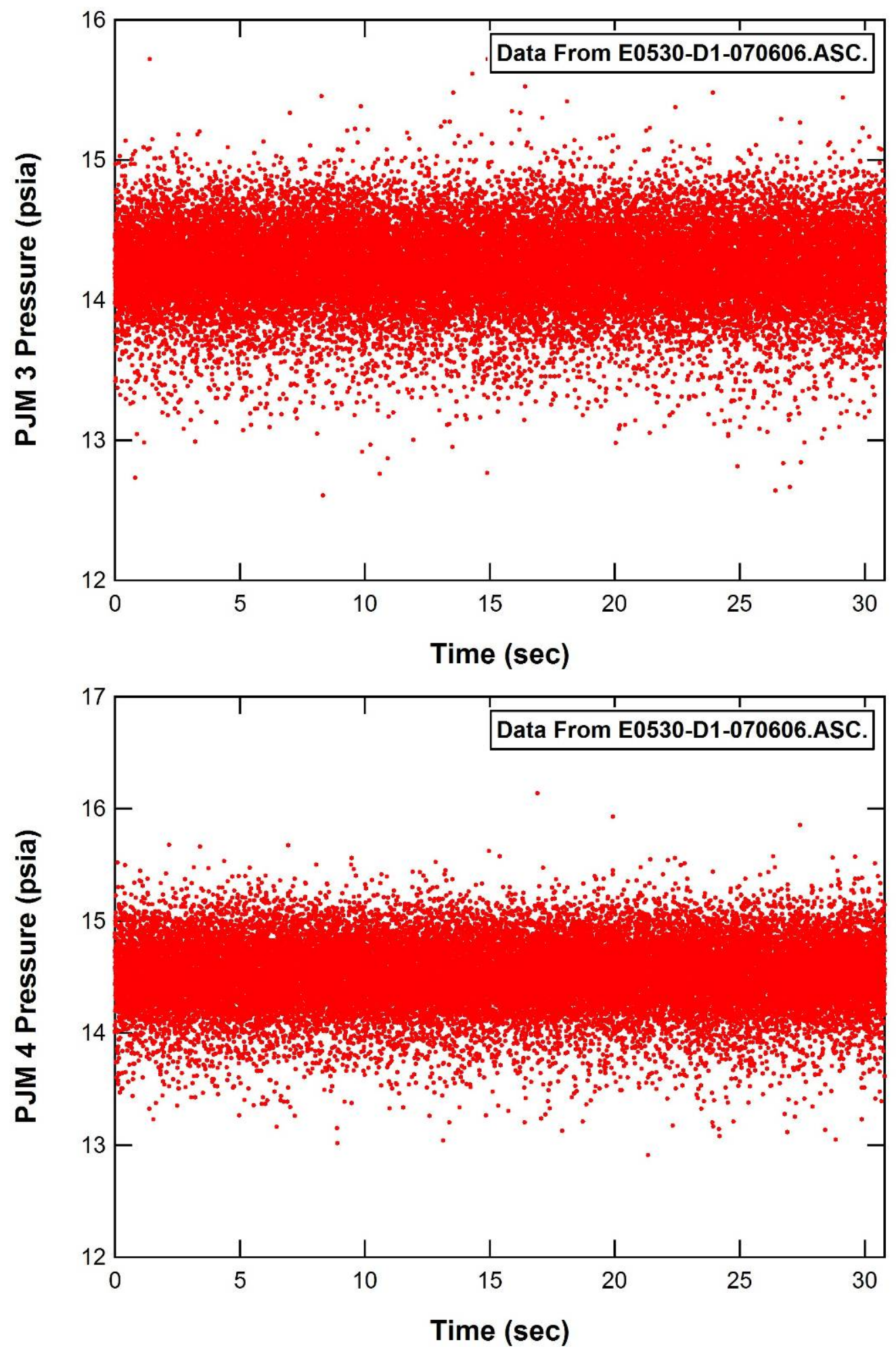

D. 2 

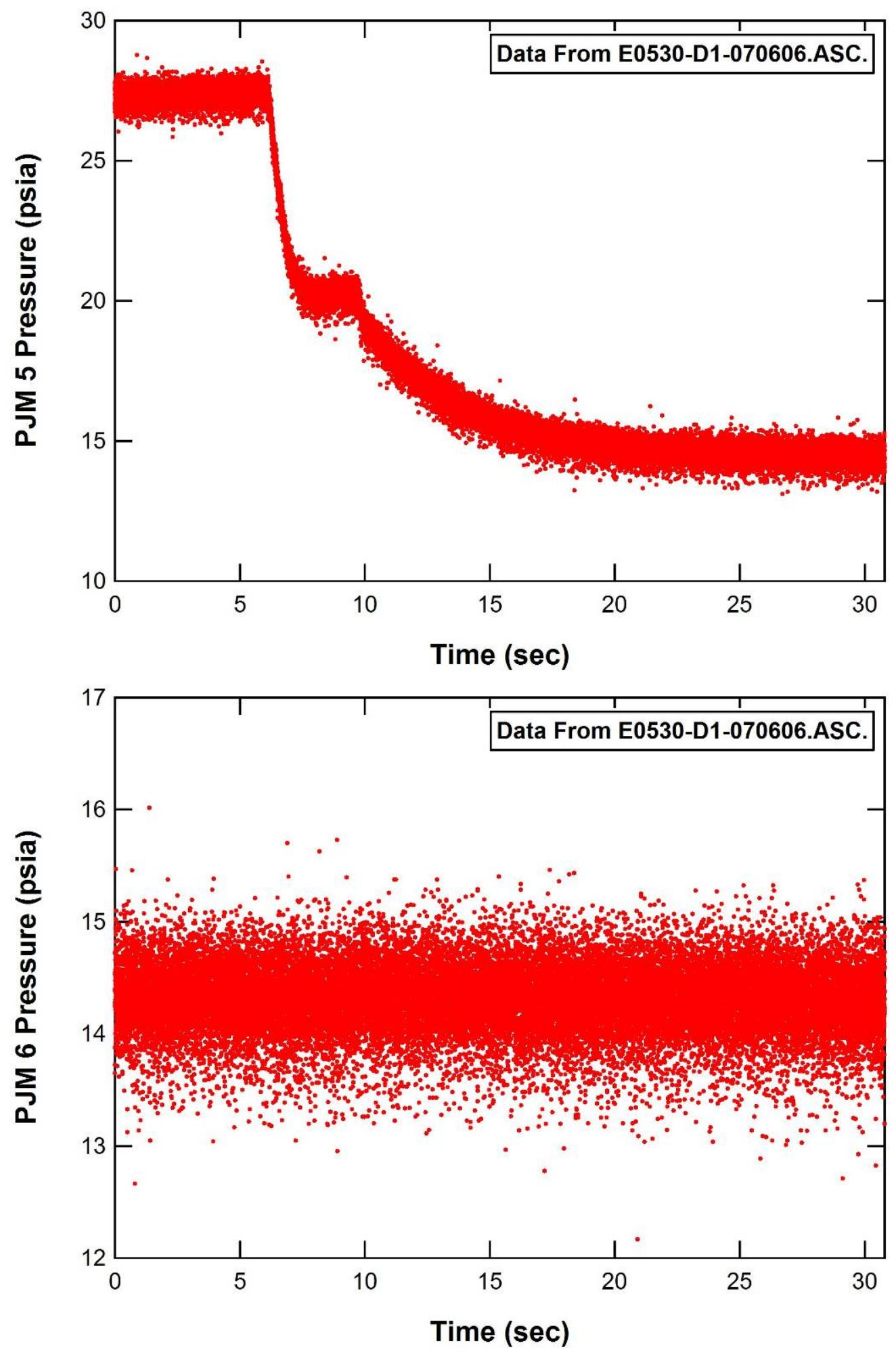

D. 3 

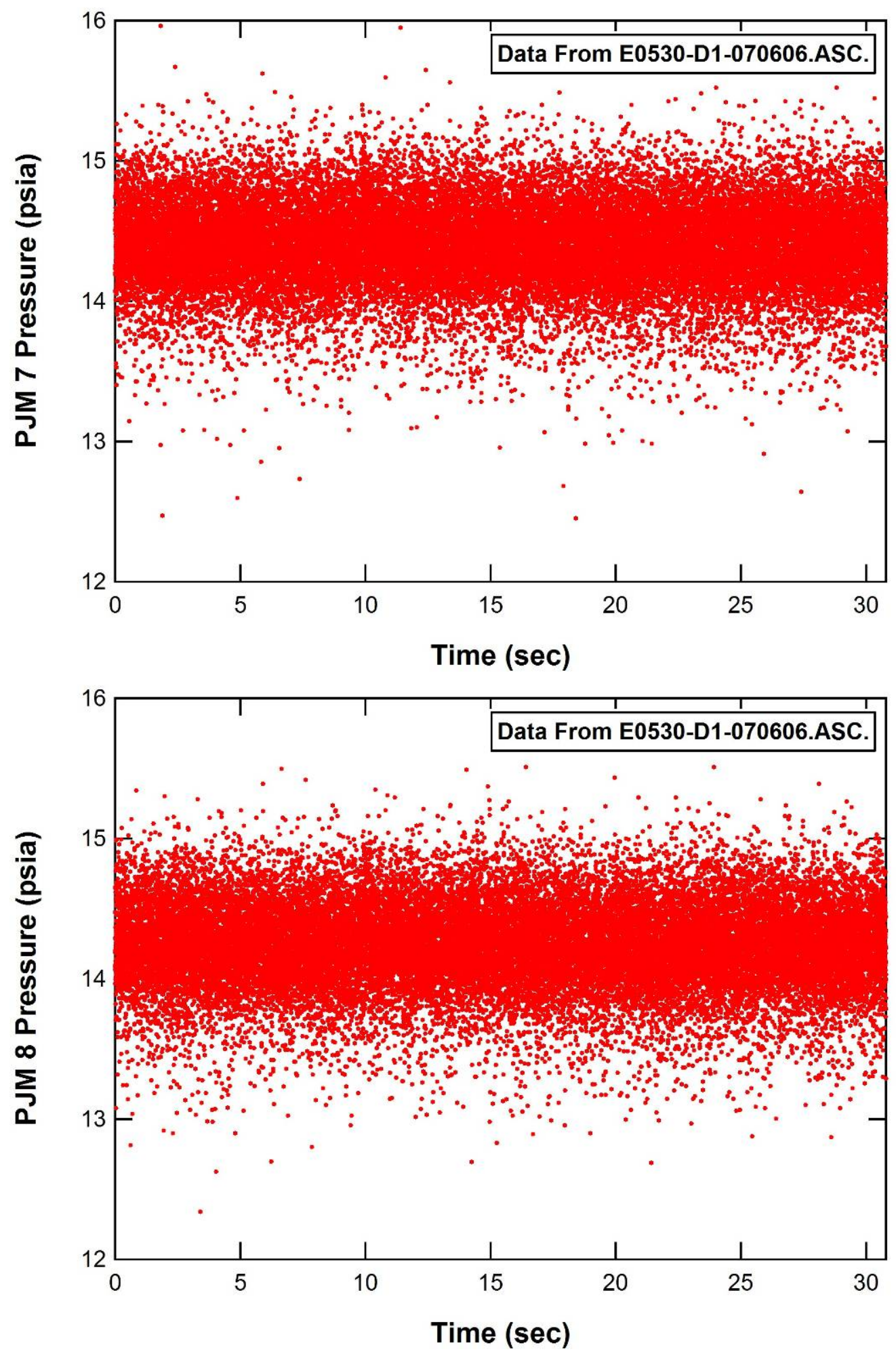

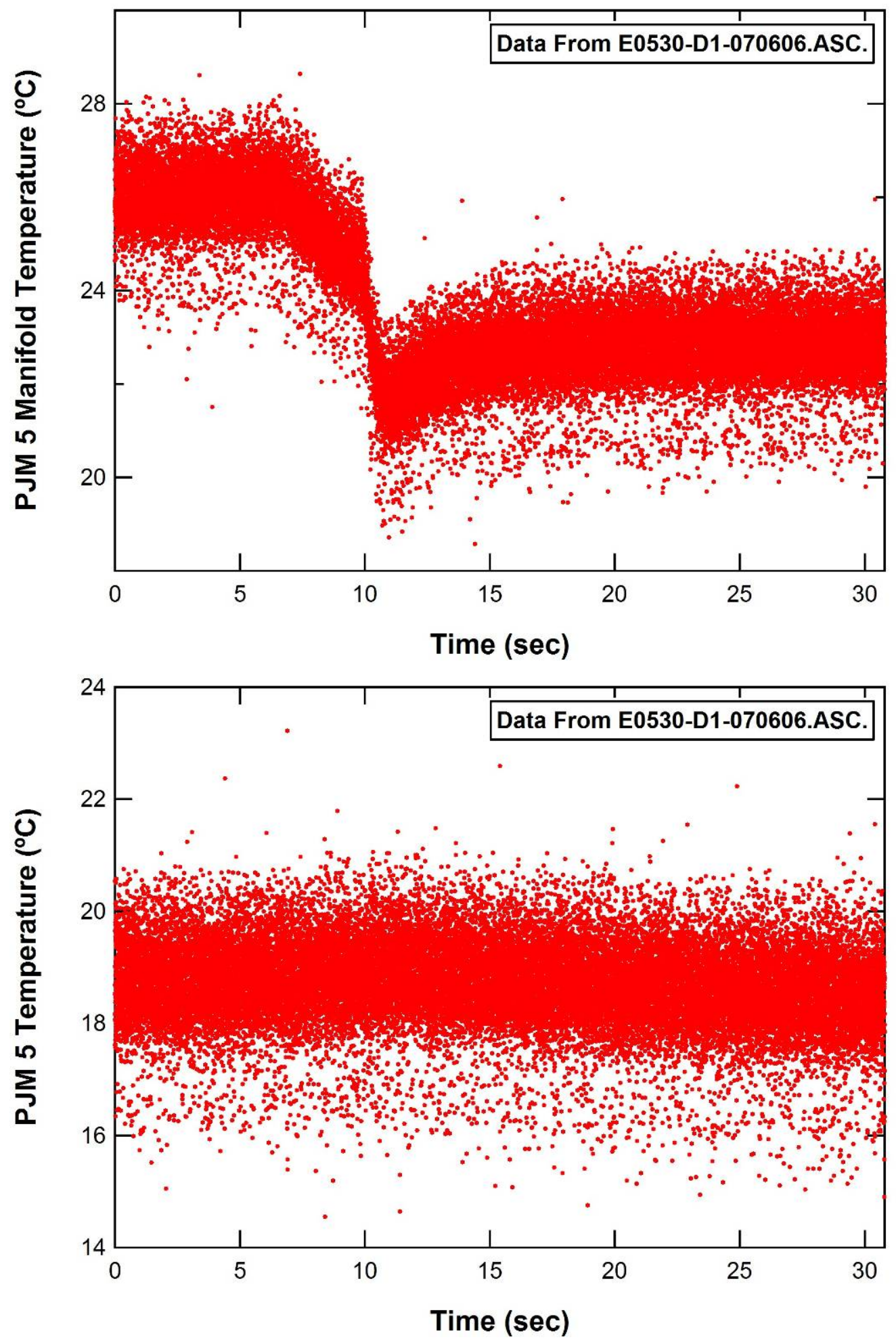

D. 5 

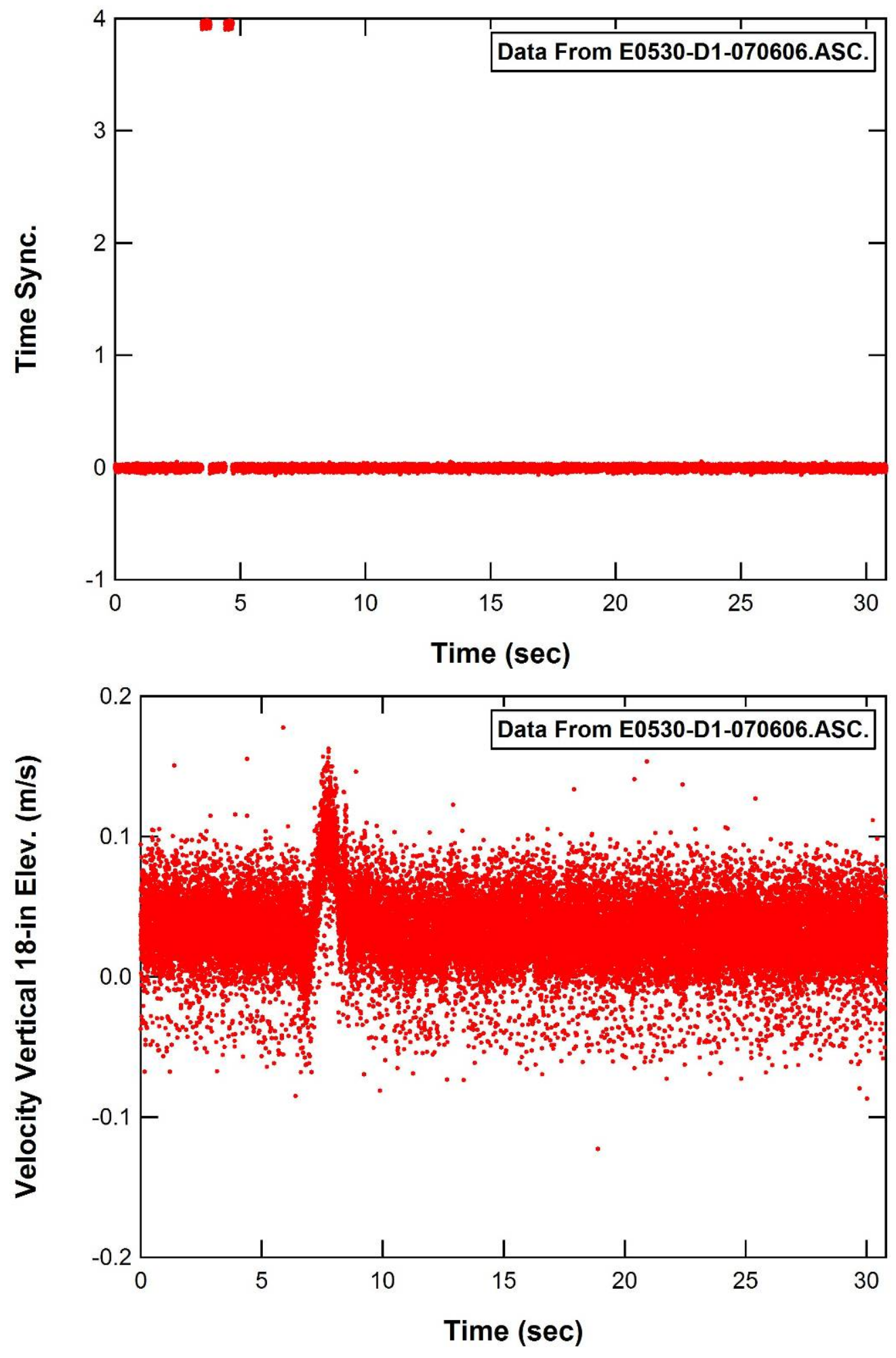

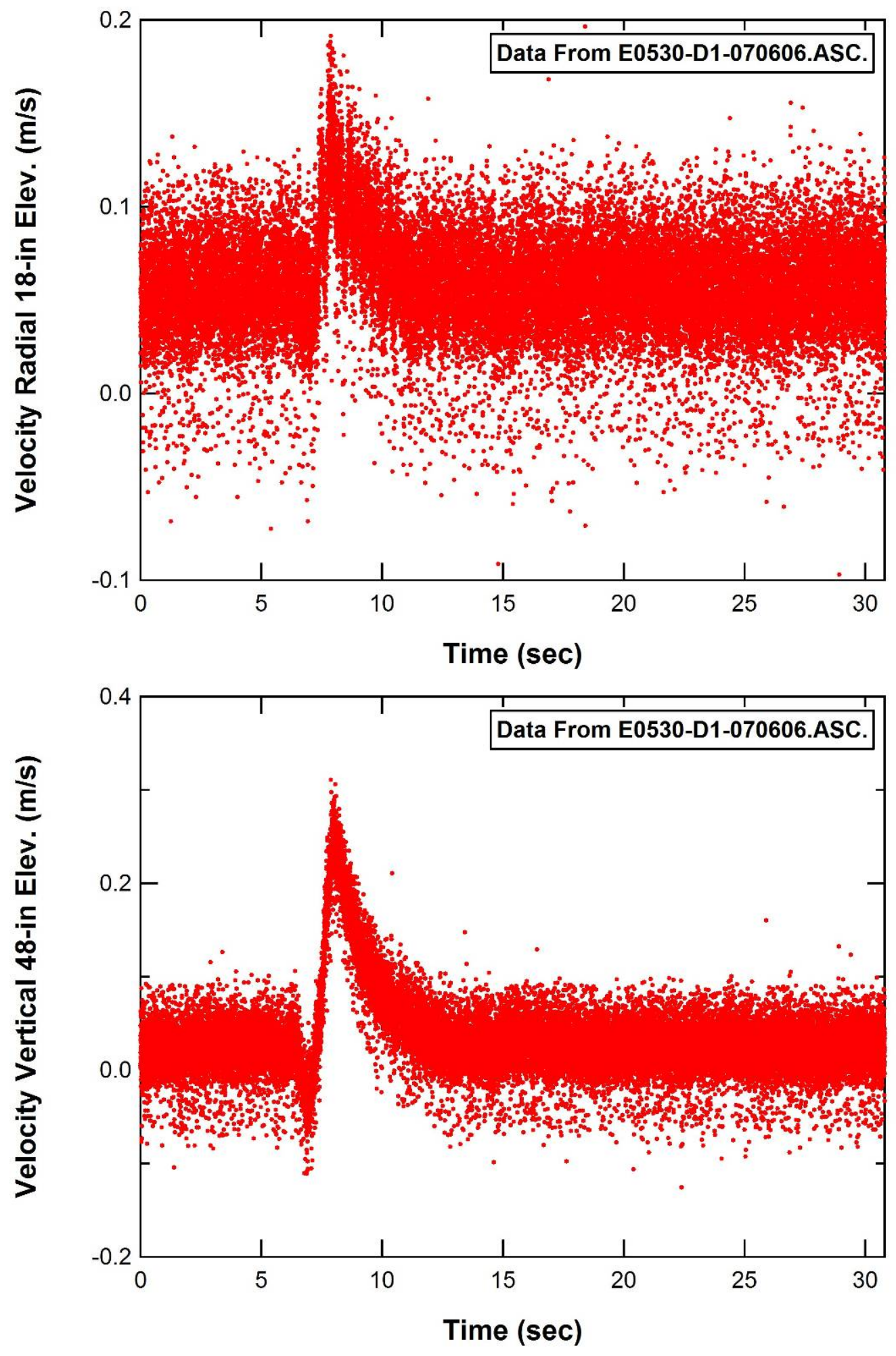

D.7 

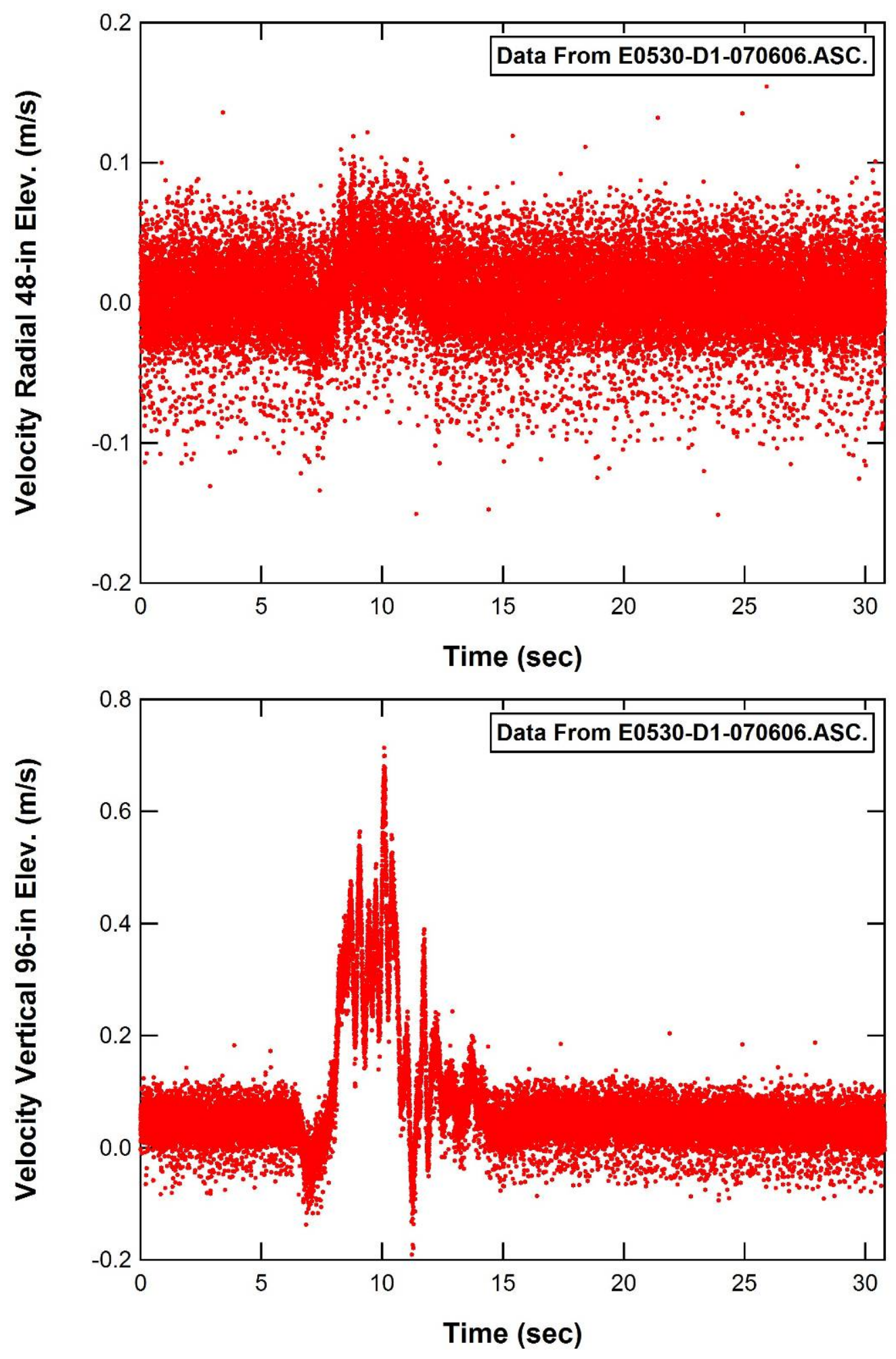

D. 8 

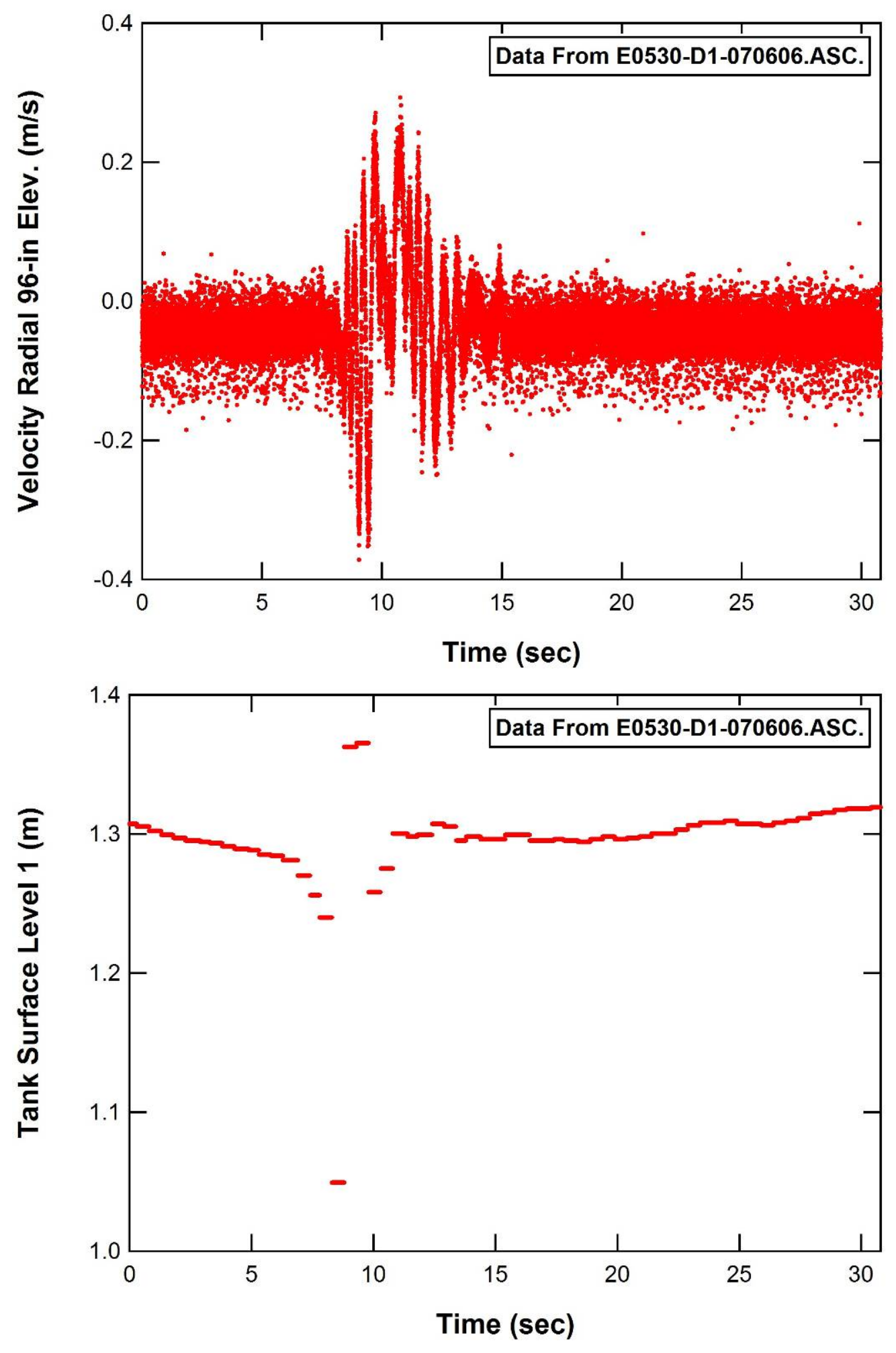

D.9 

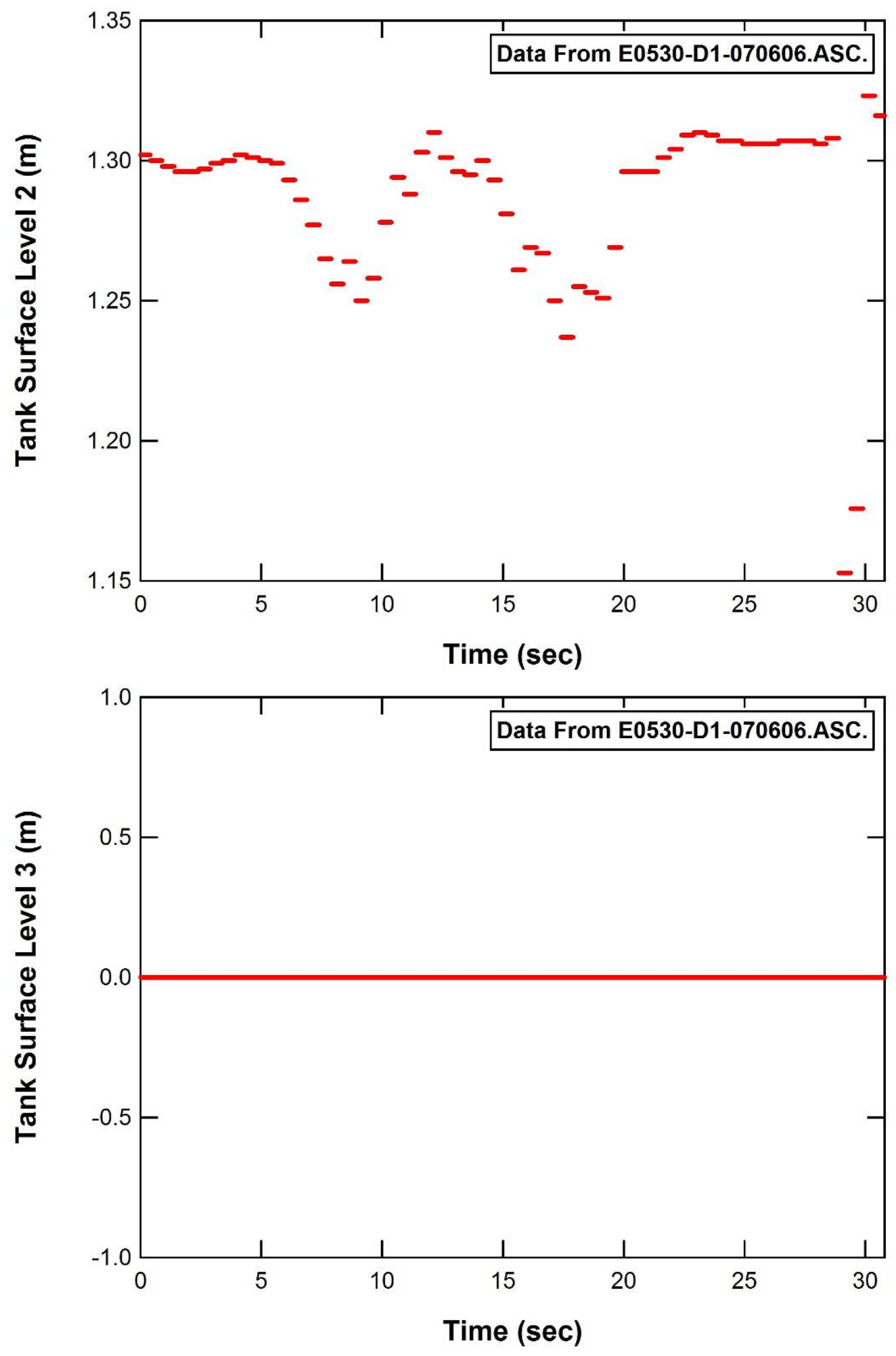

D.10 

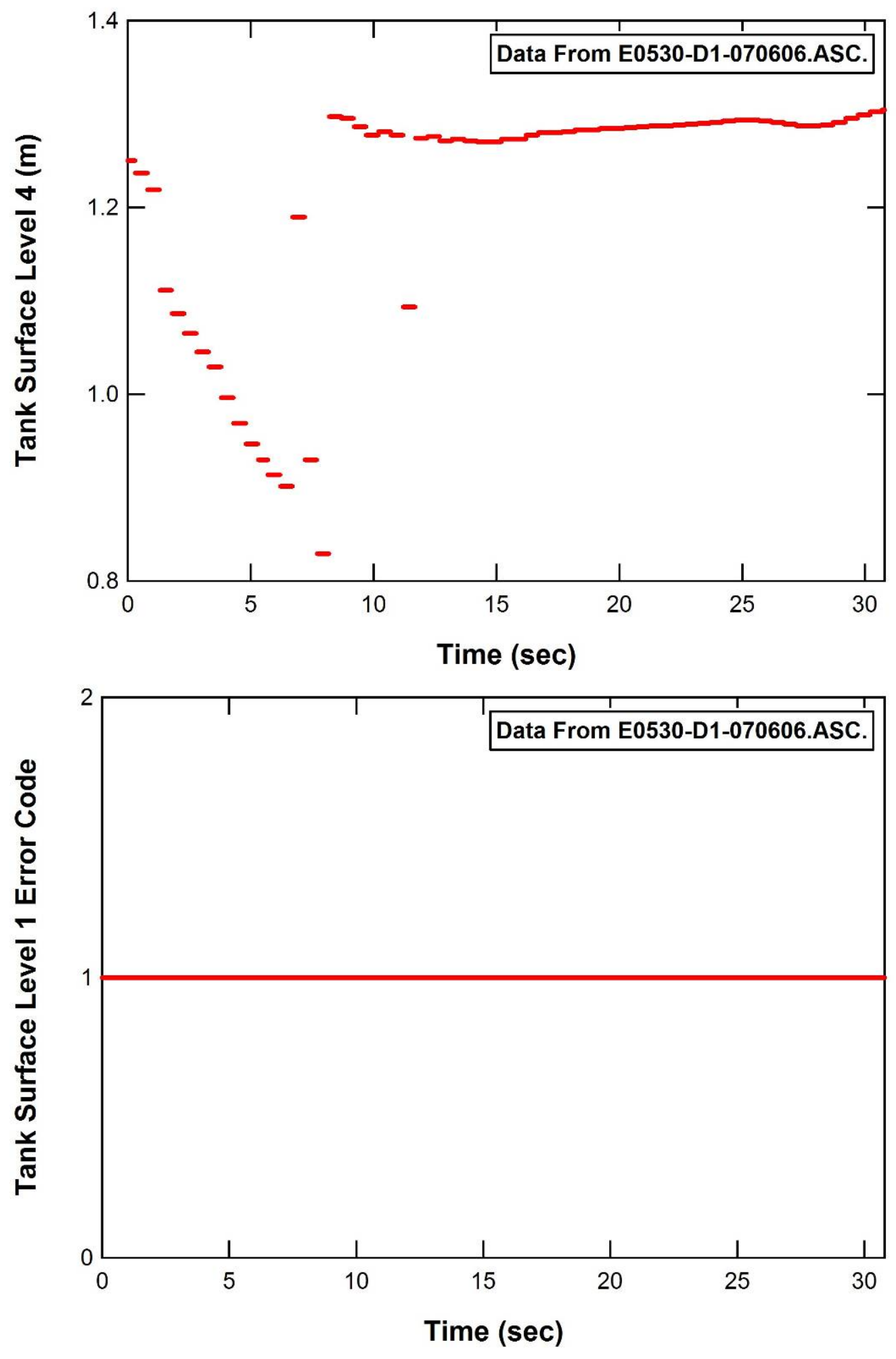

D.11 

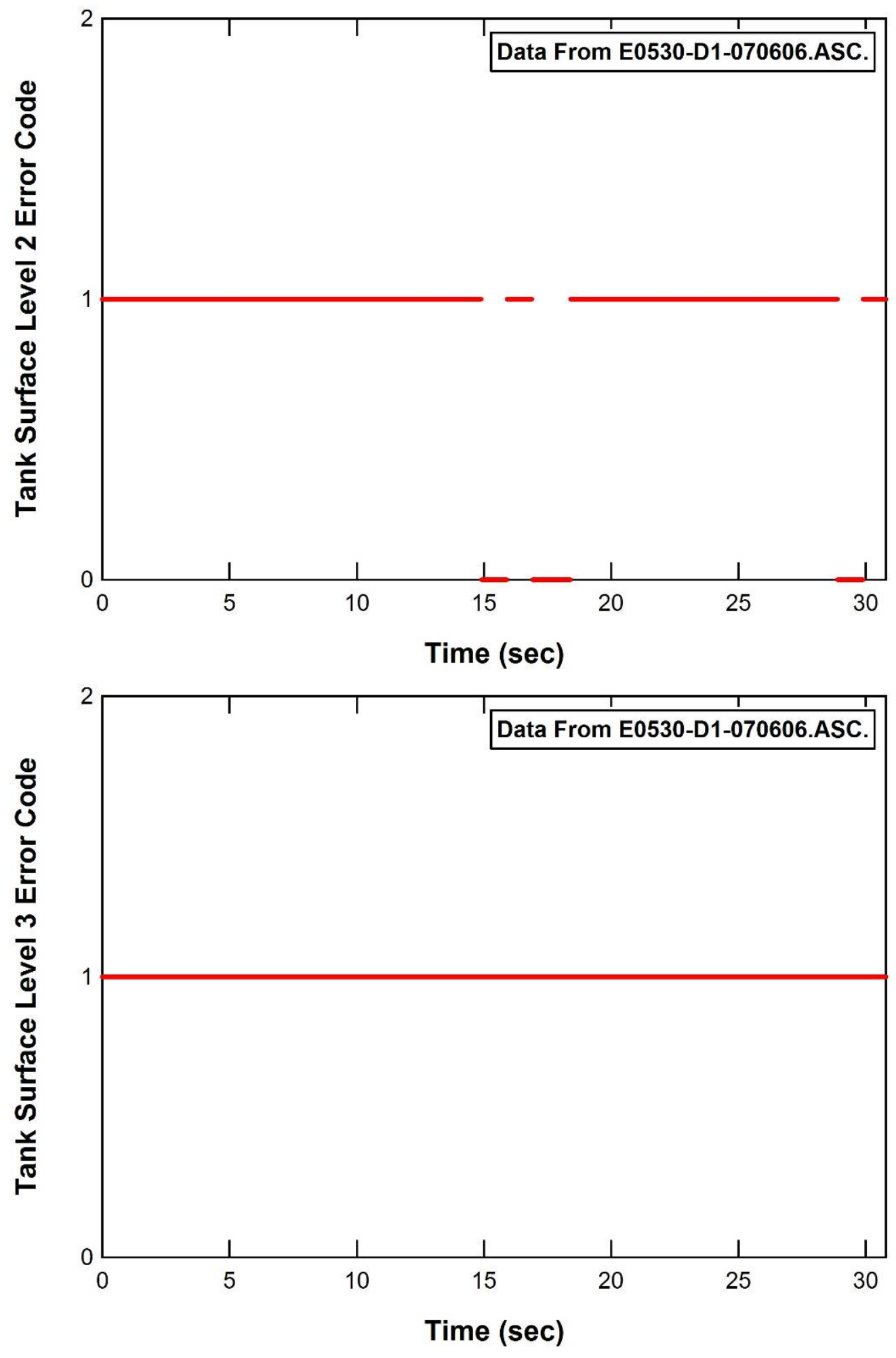

D.12 


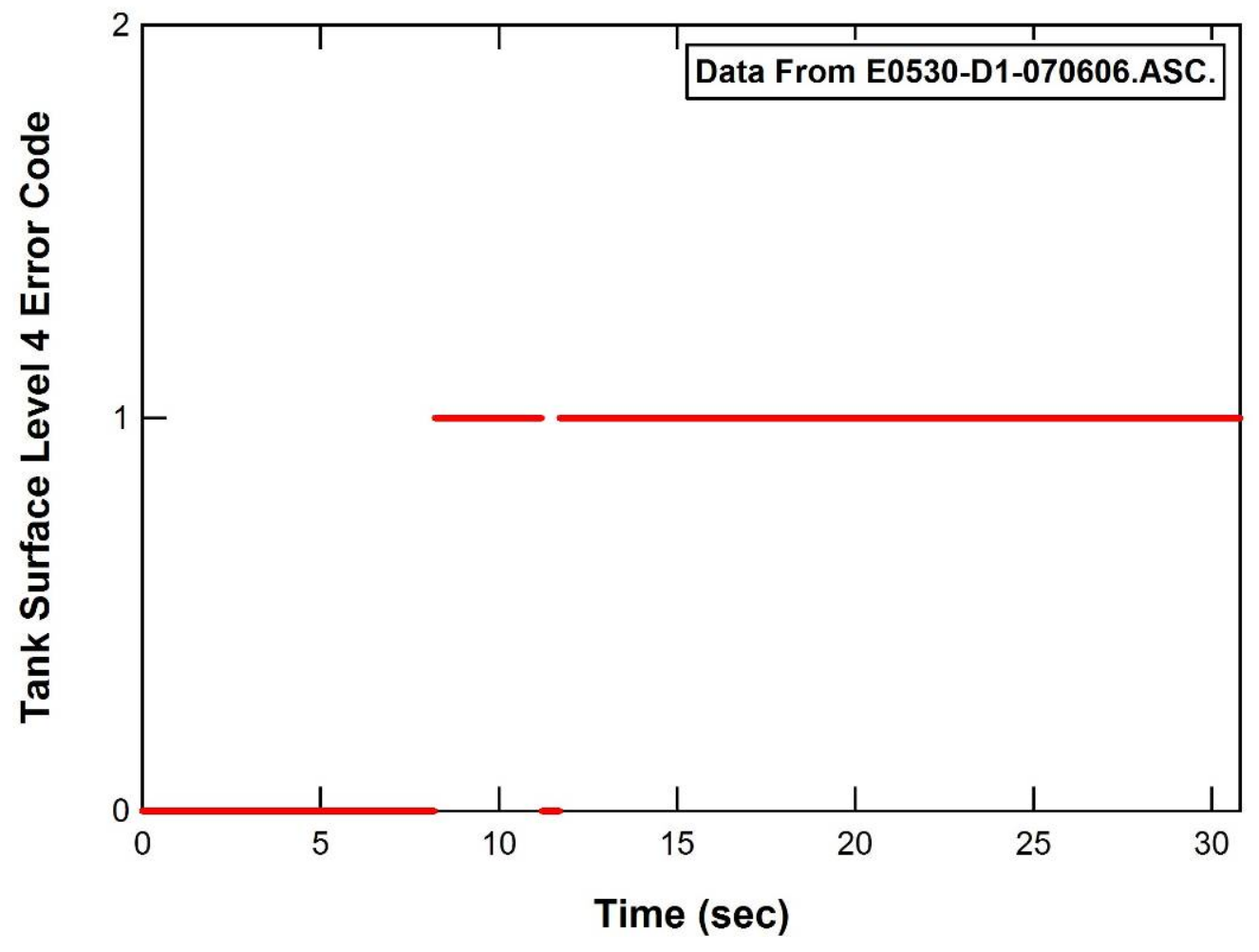

D.13 

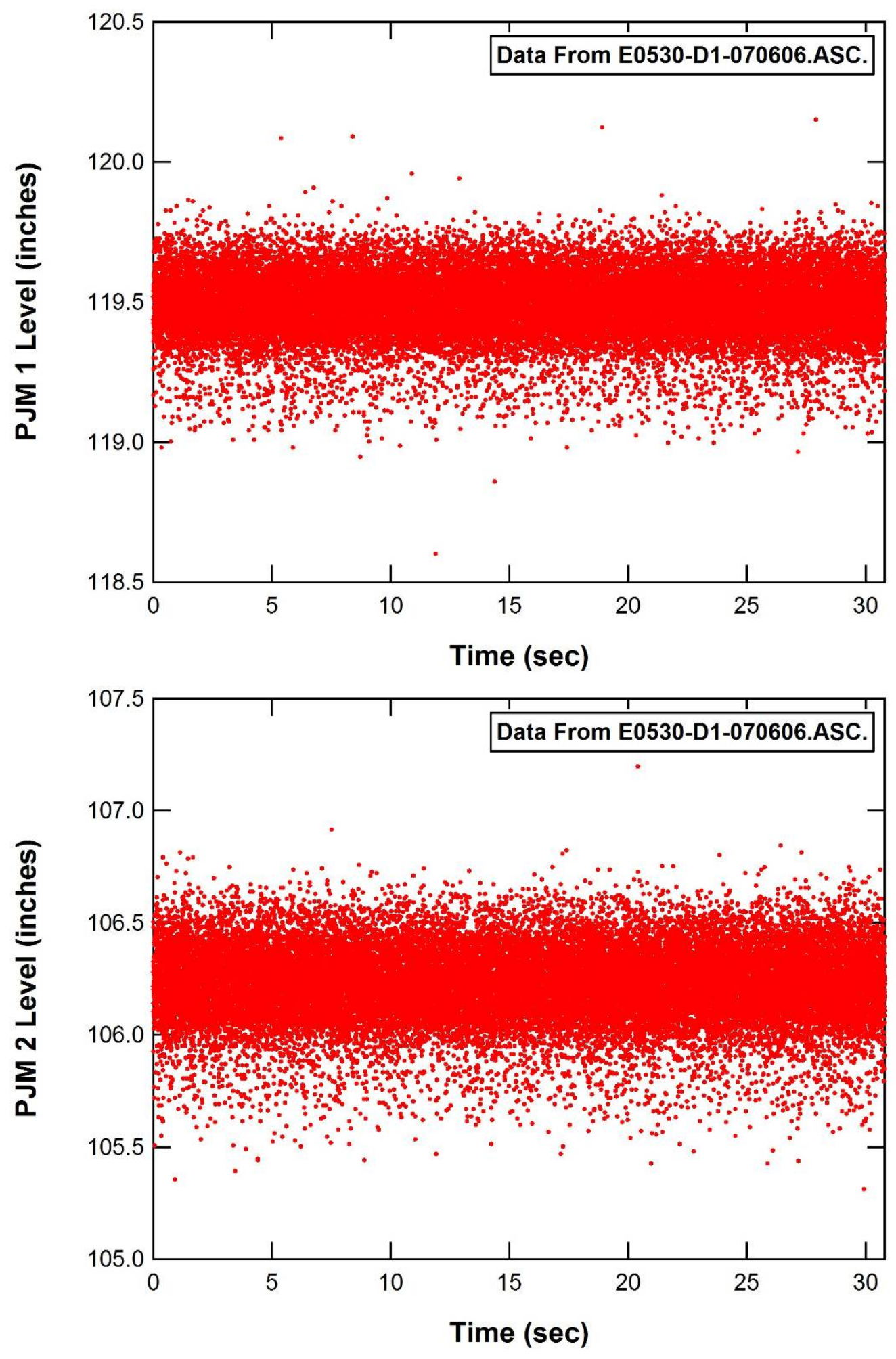

D.14 

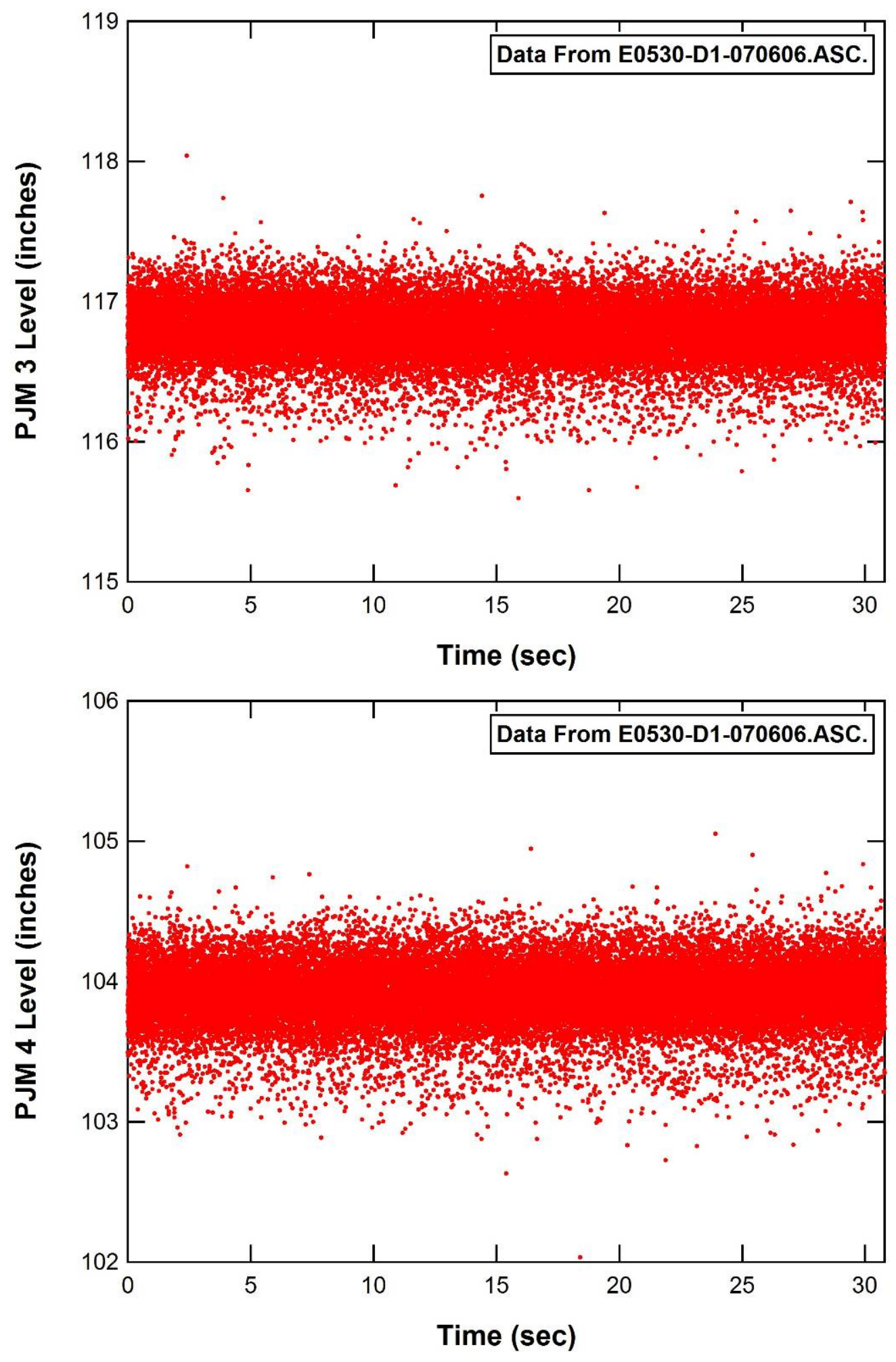

D.15 

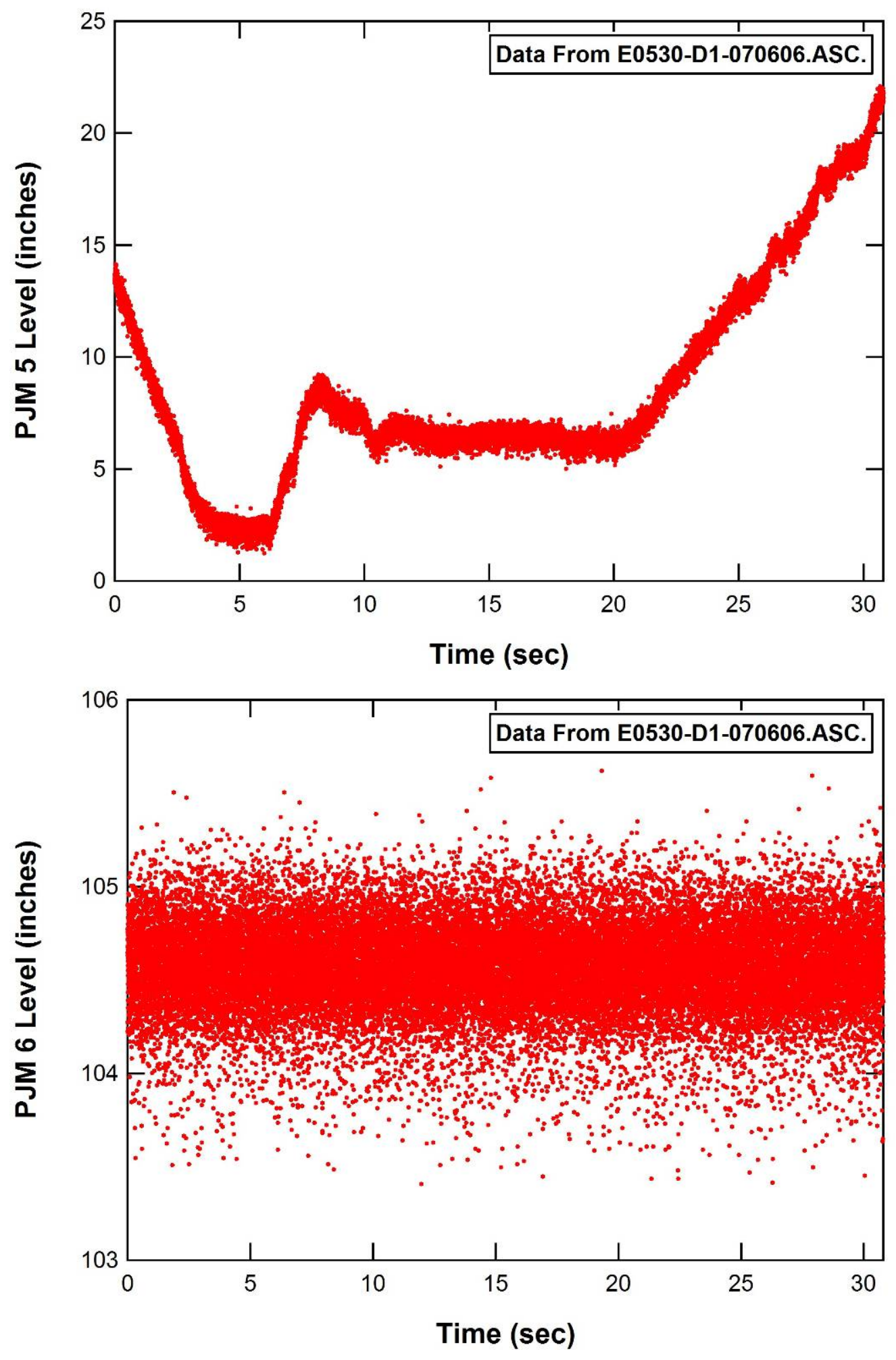

D.16 

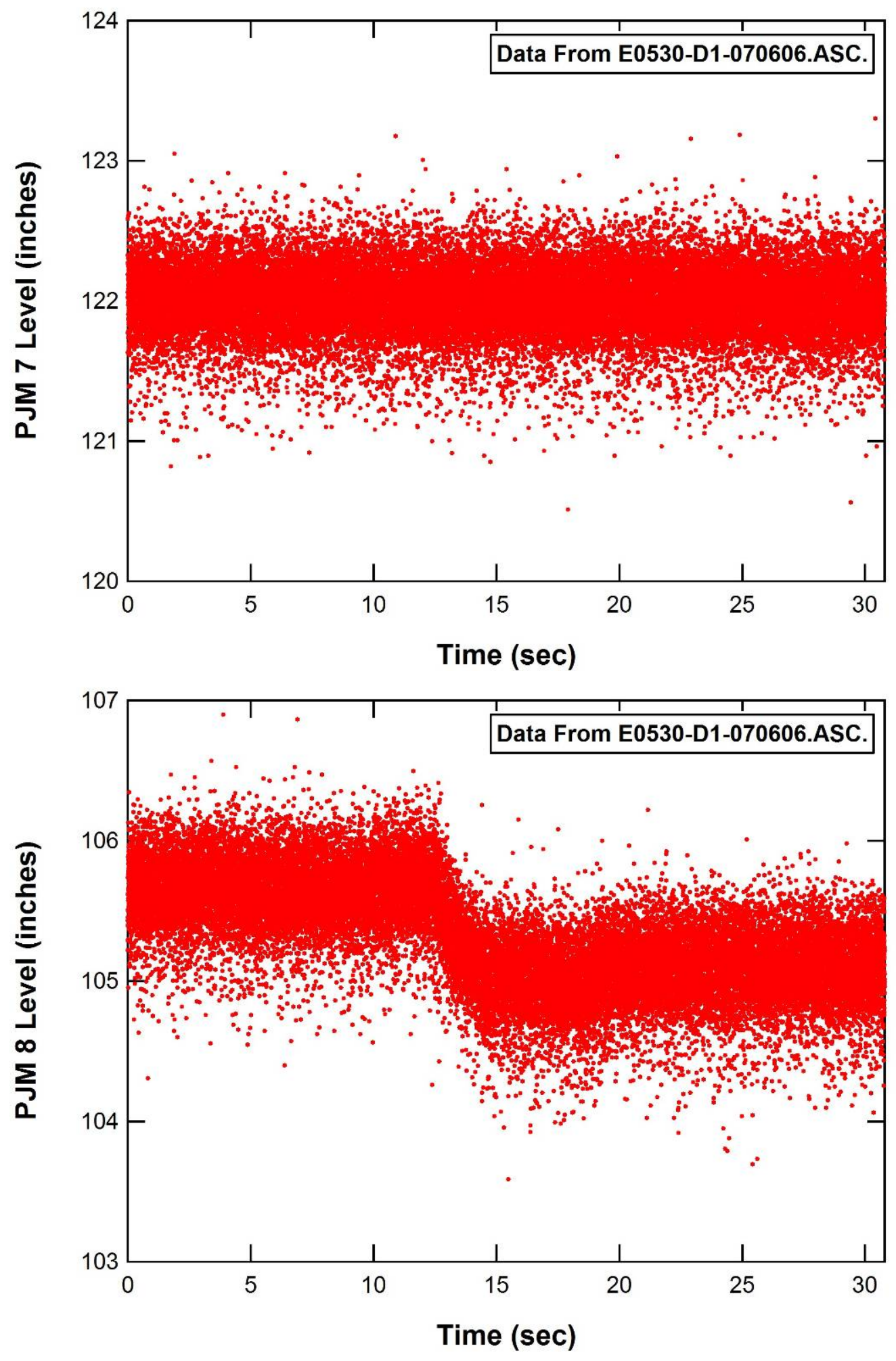

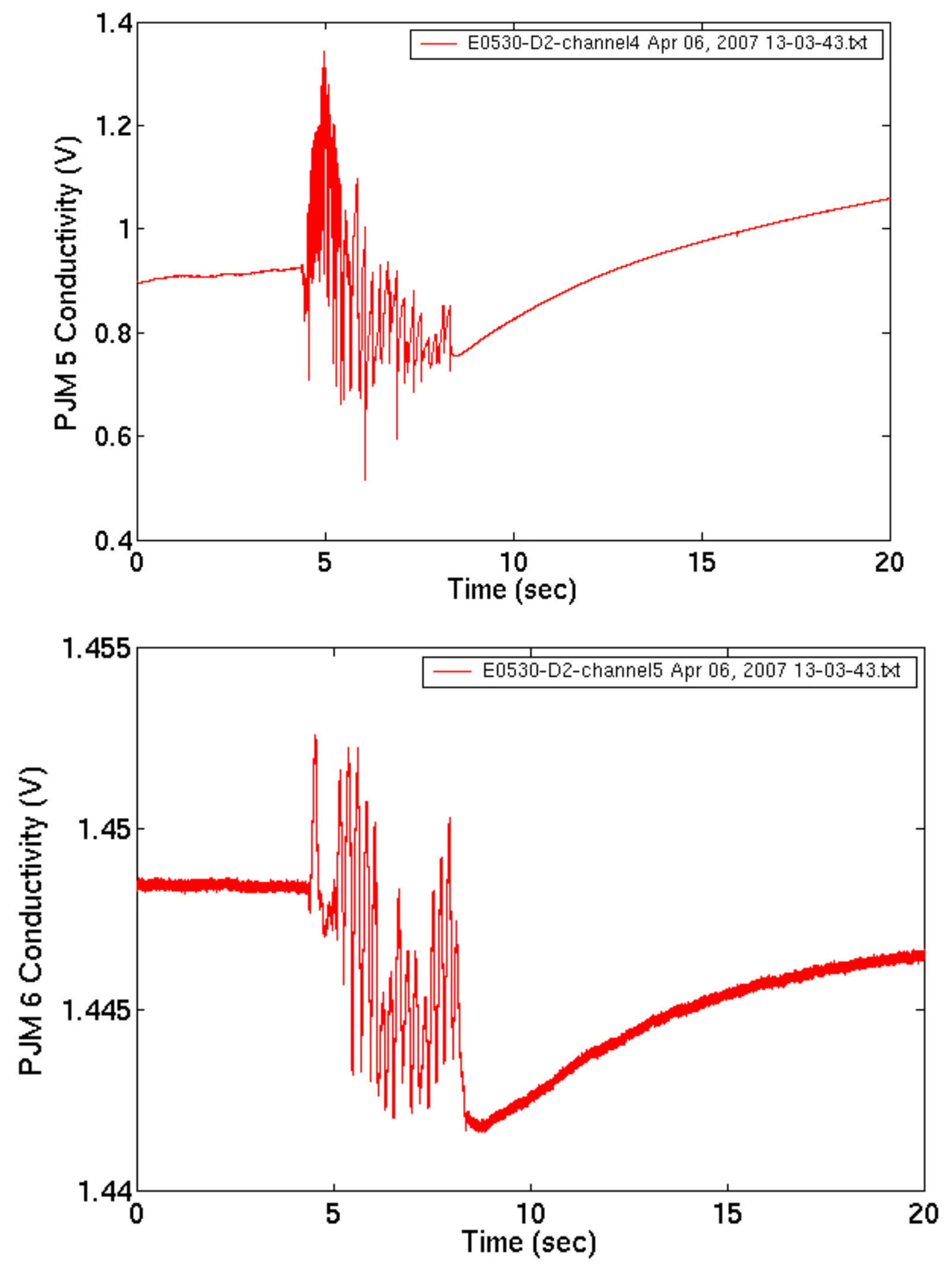

D.18 

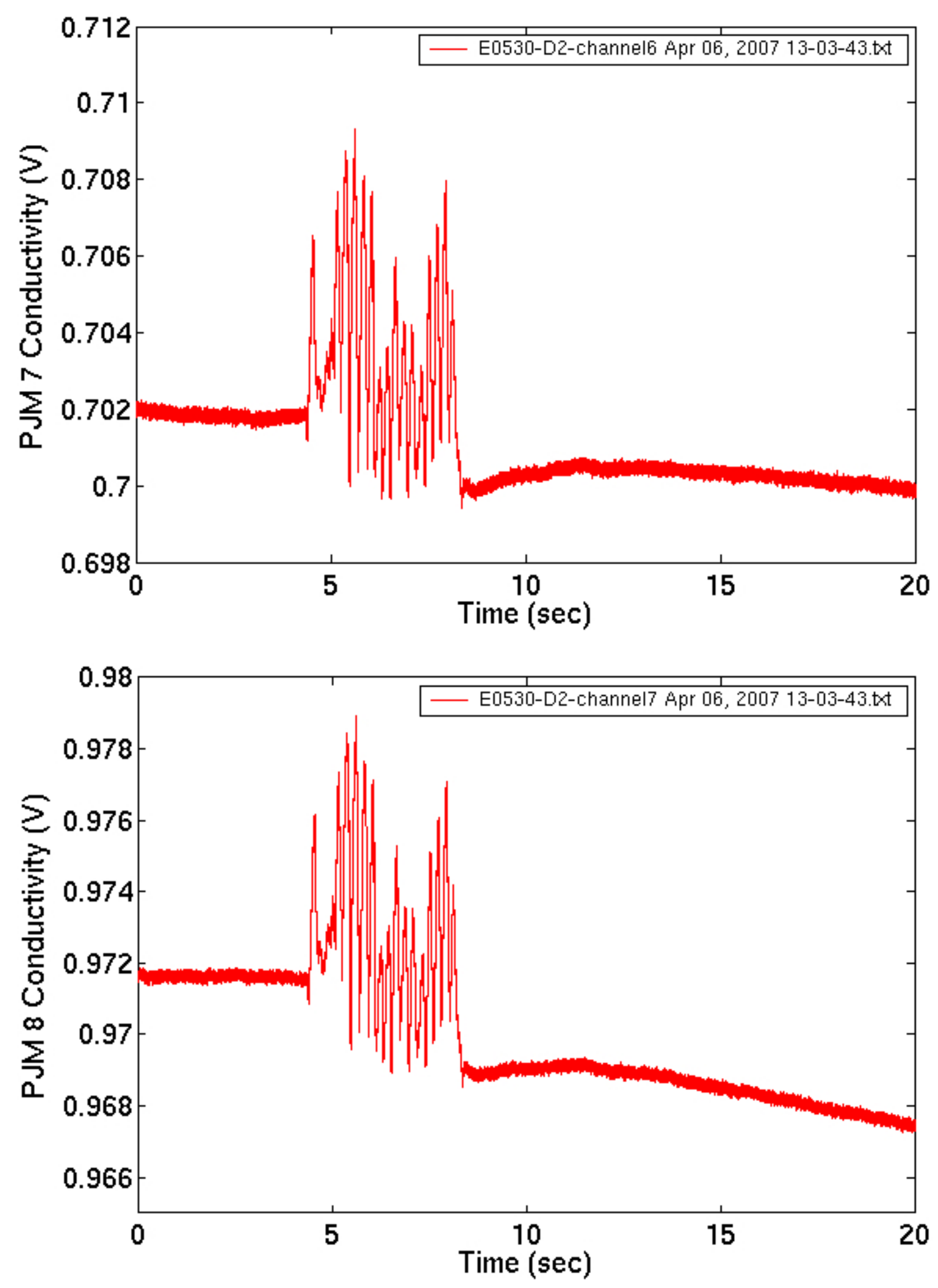

D.19 

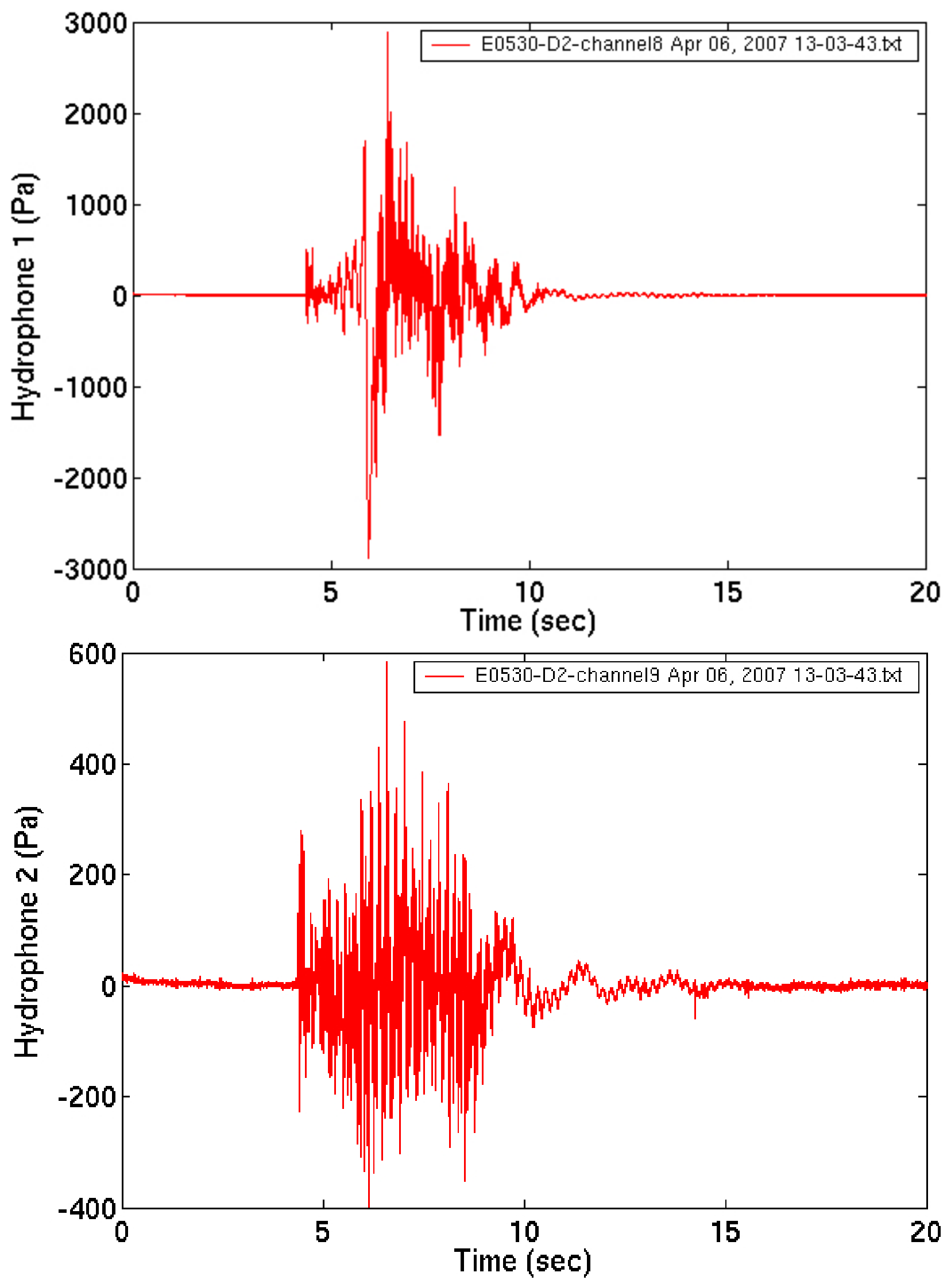

D.20 

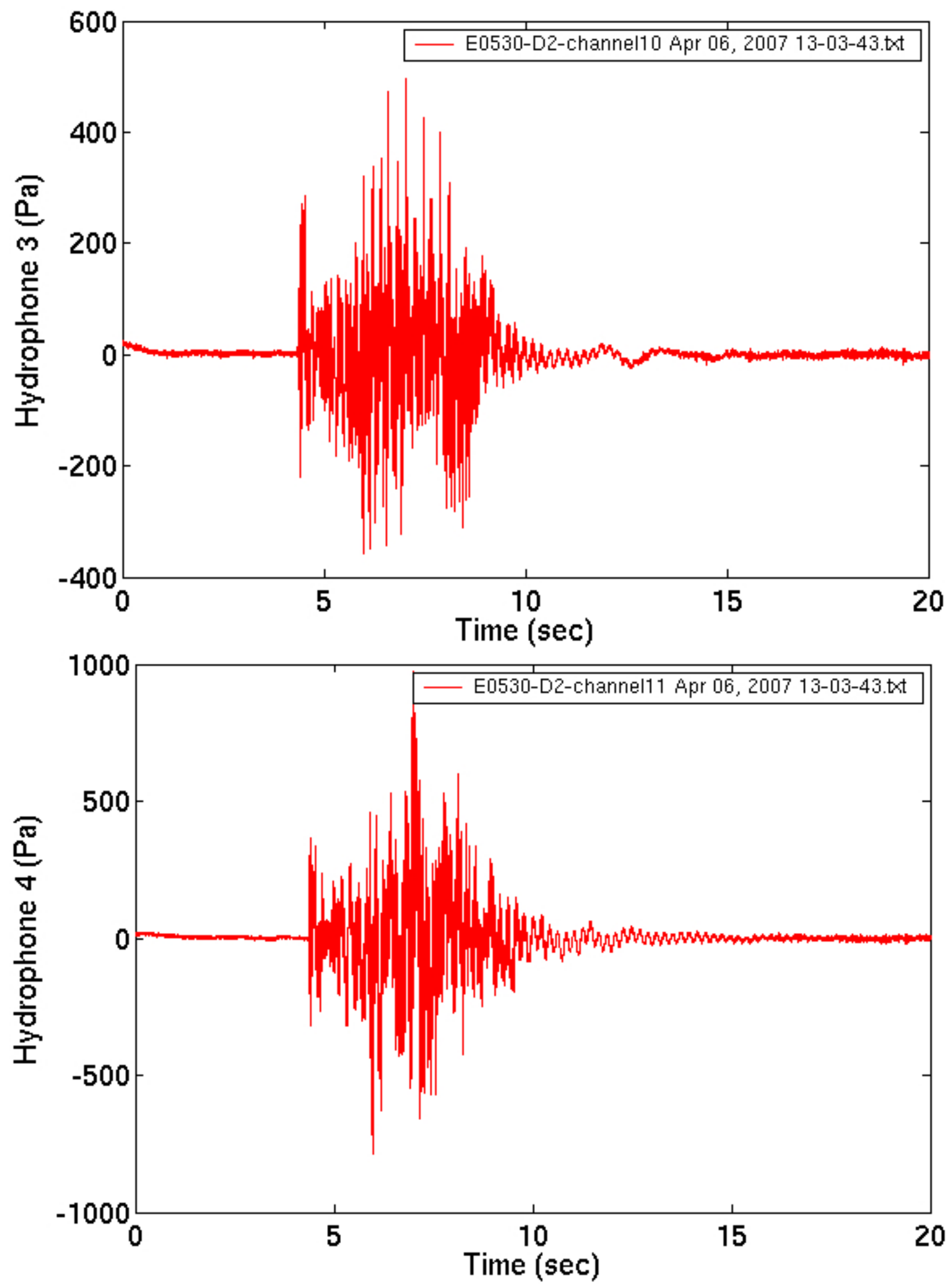

D.21 

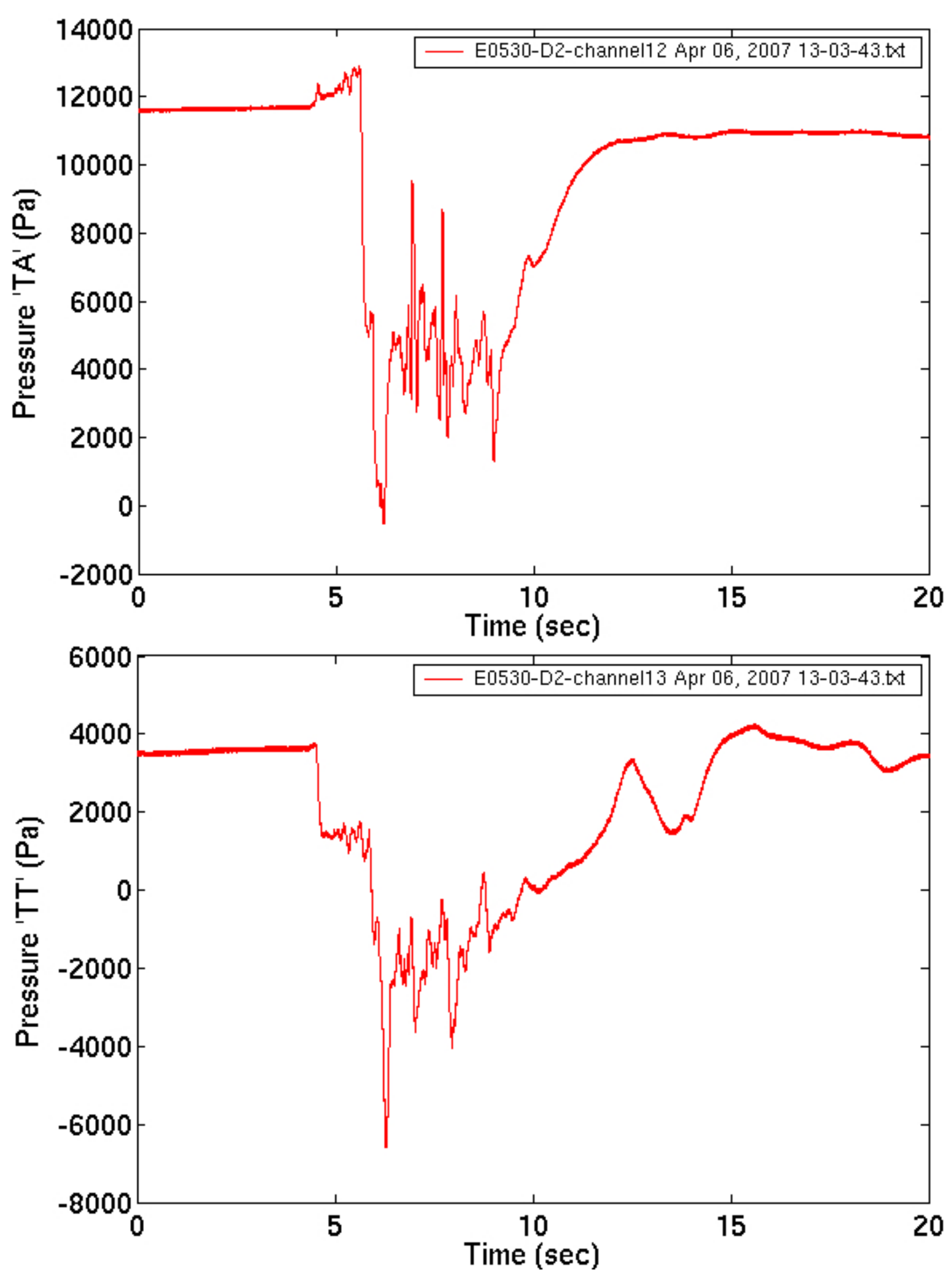

D.22 

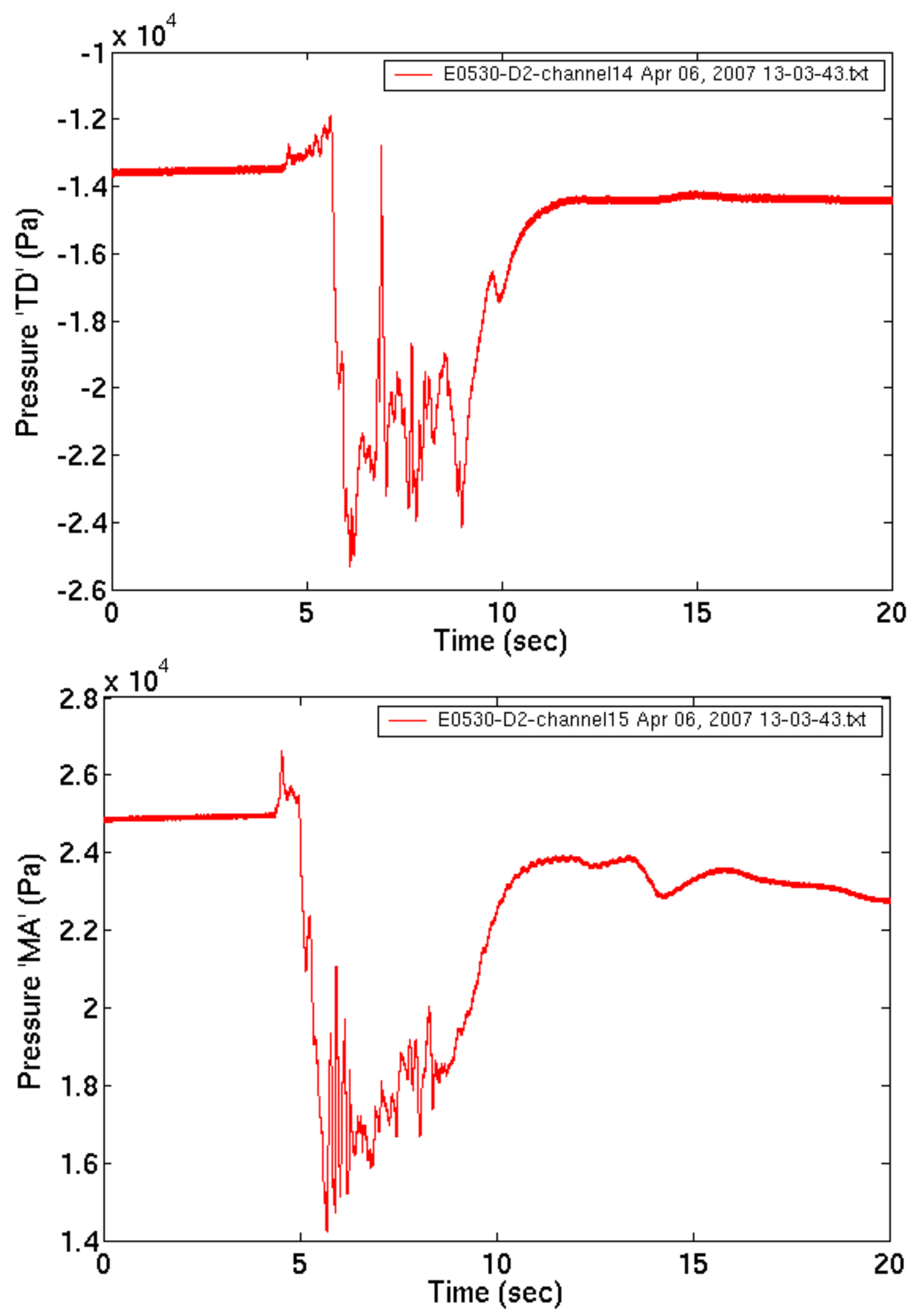

D.23 

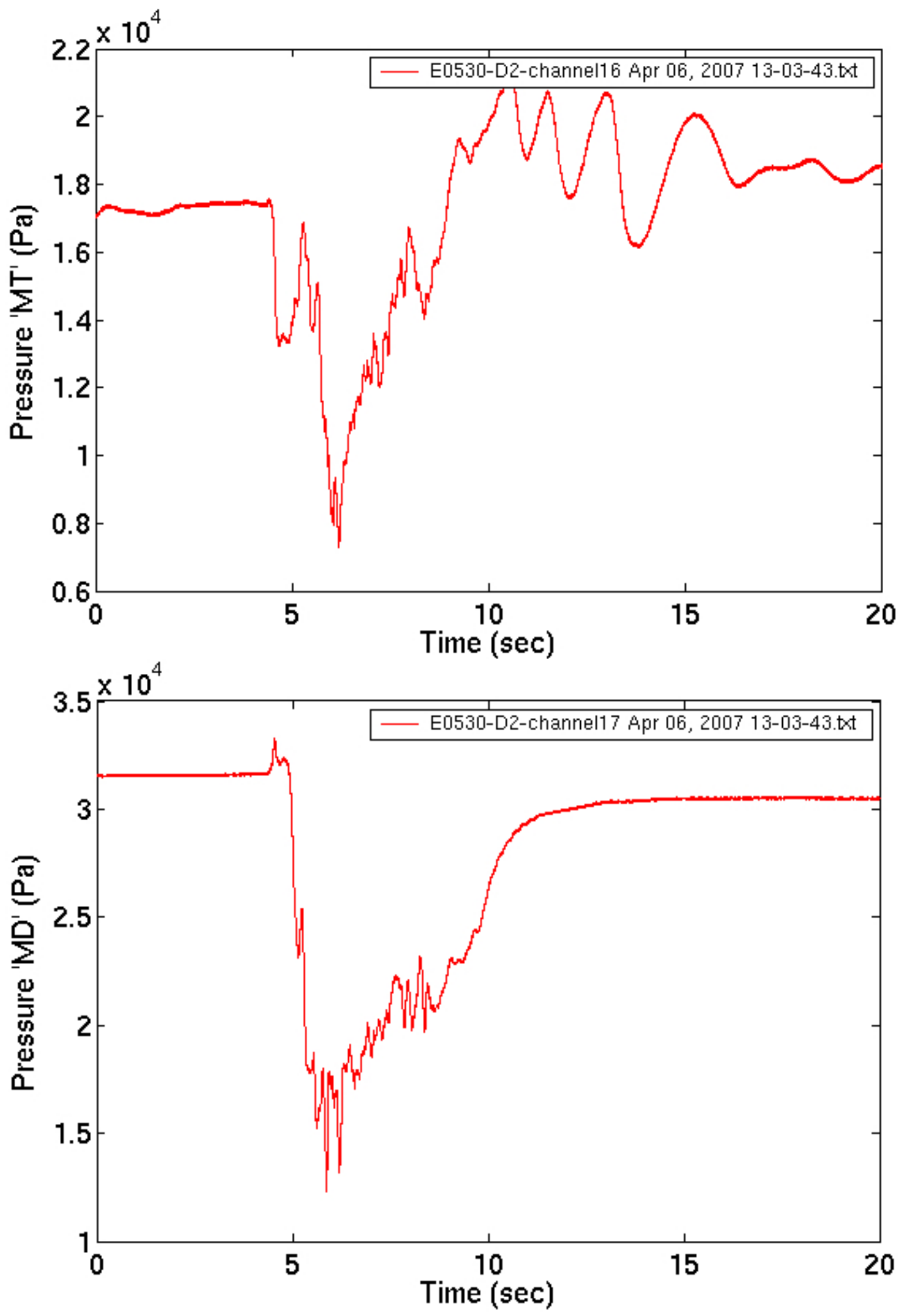

D.24 

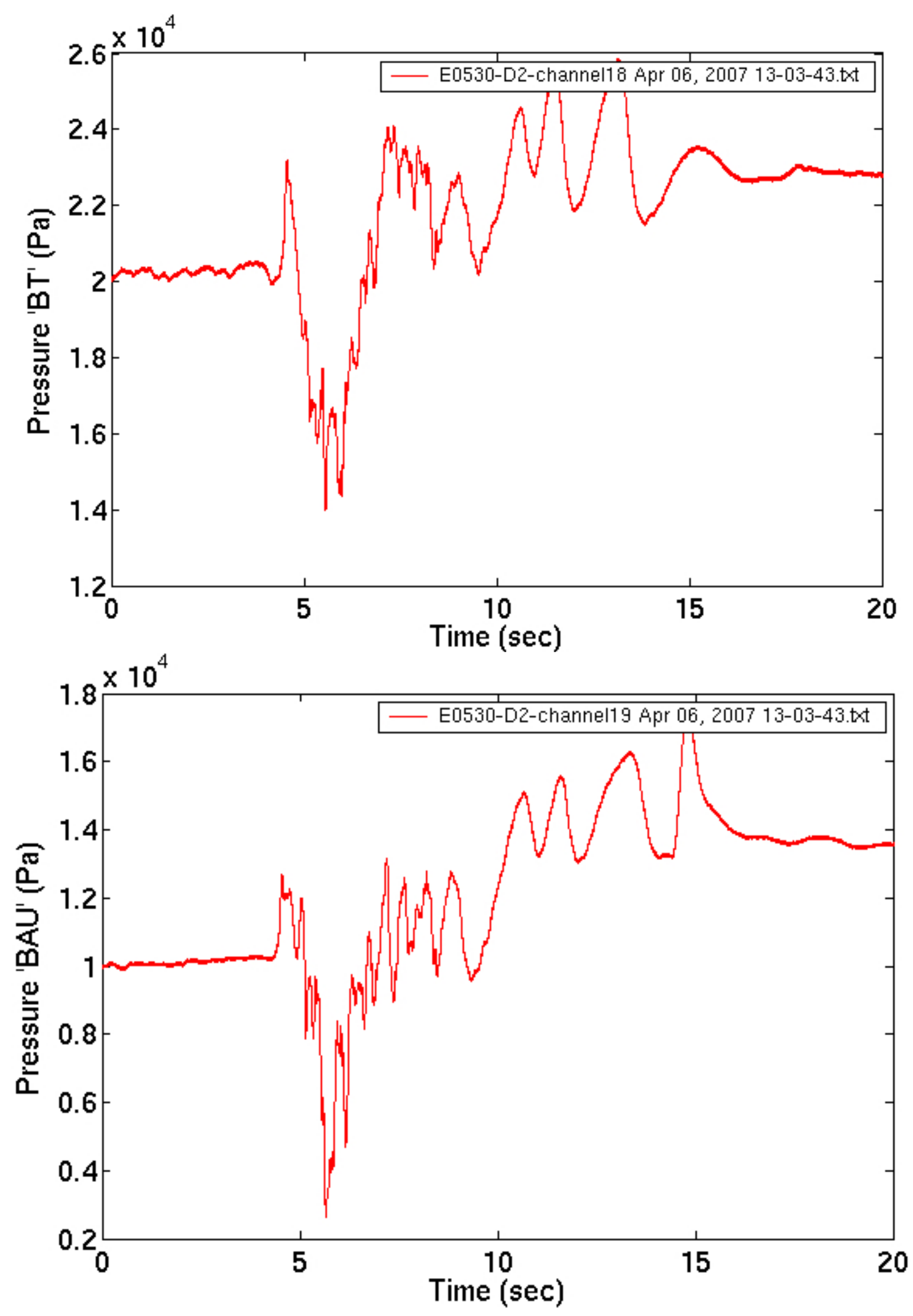

D. 25 

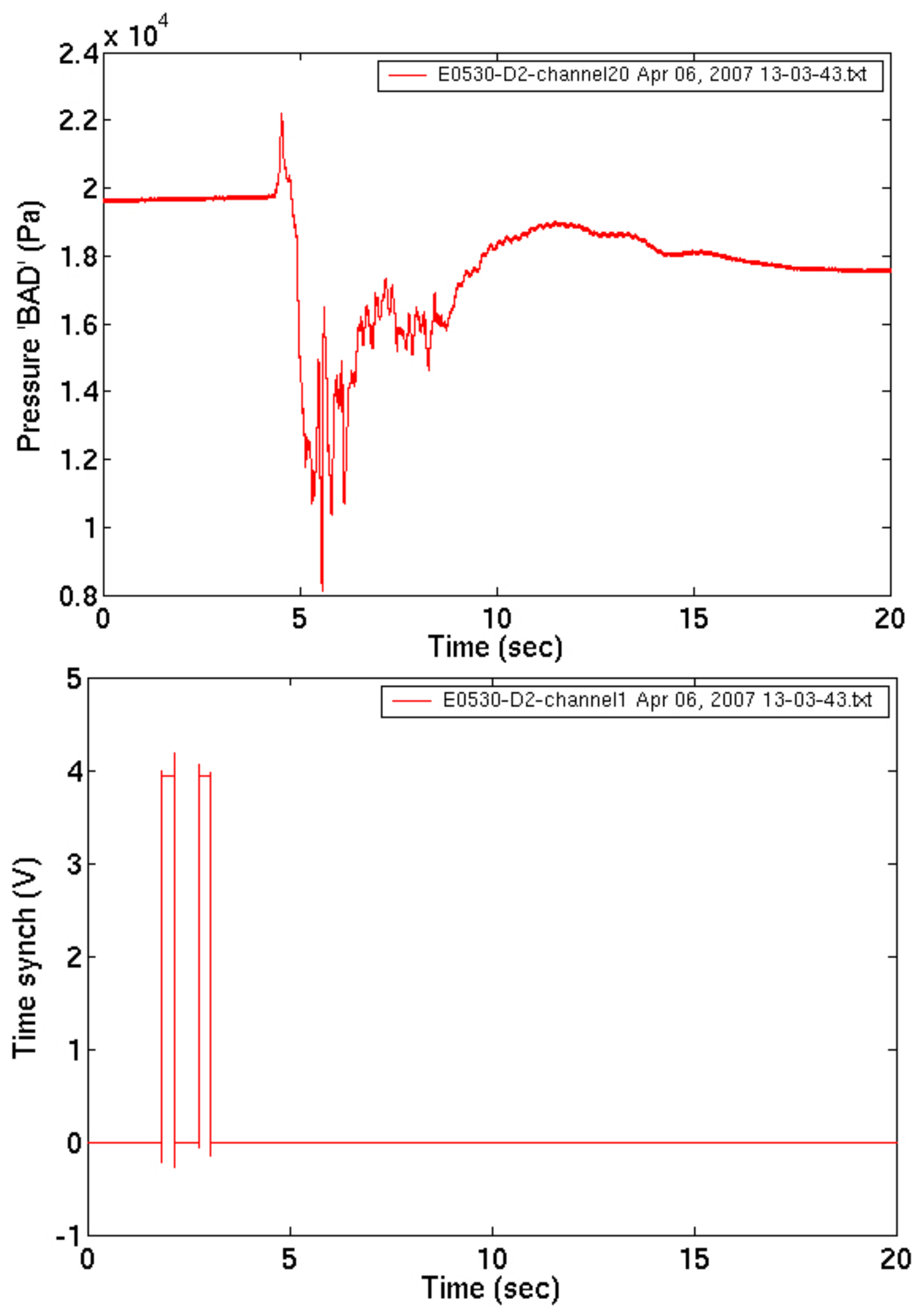

D.26 

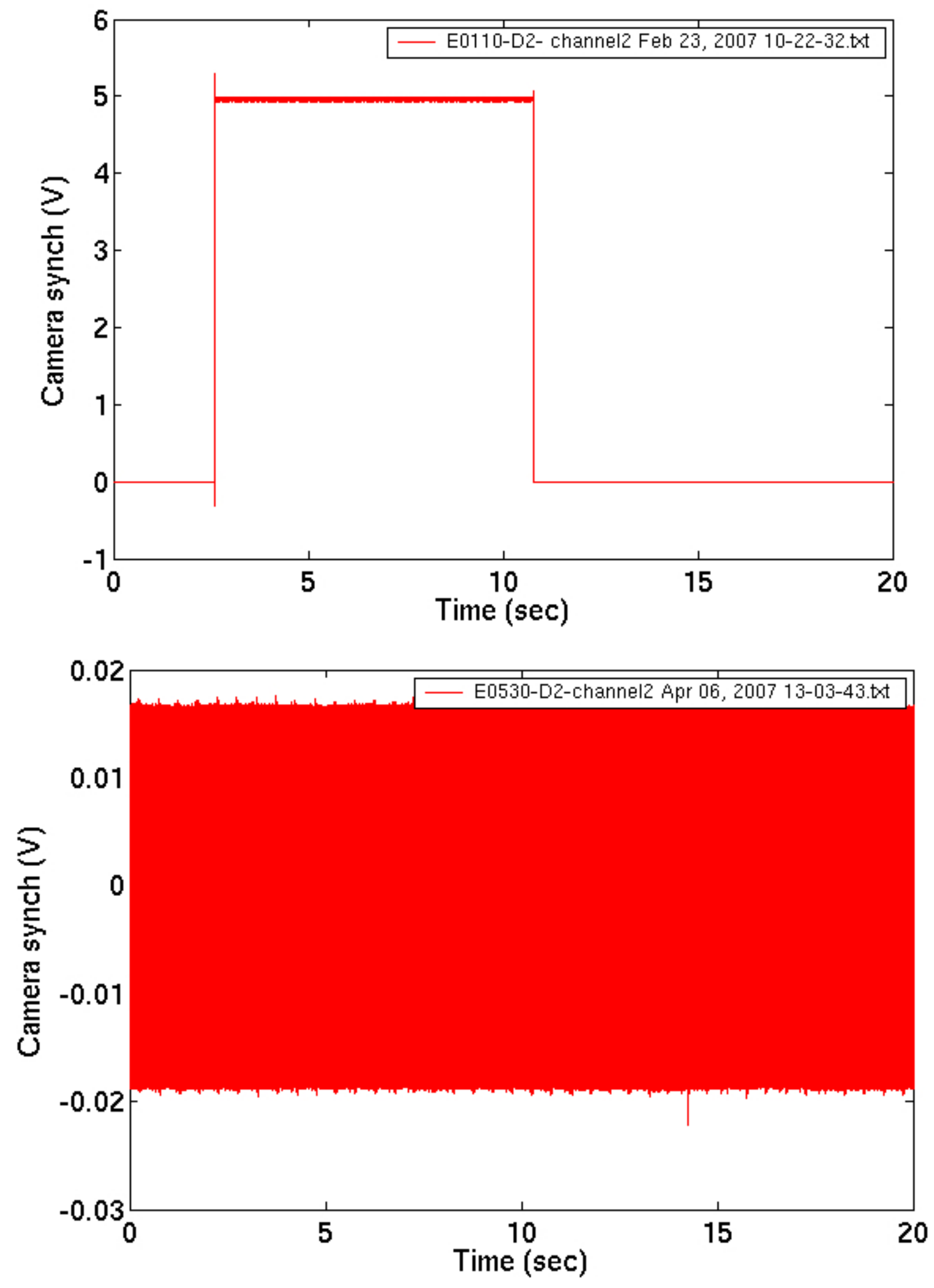

D.27 


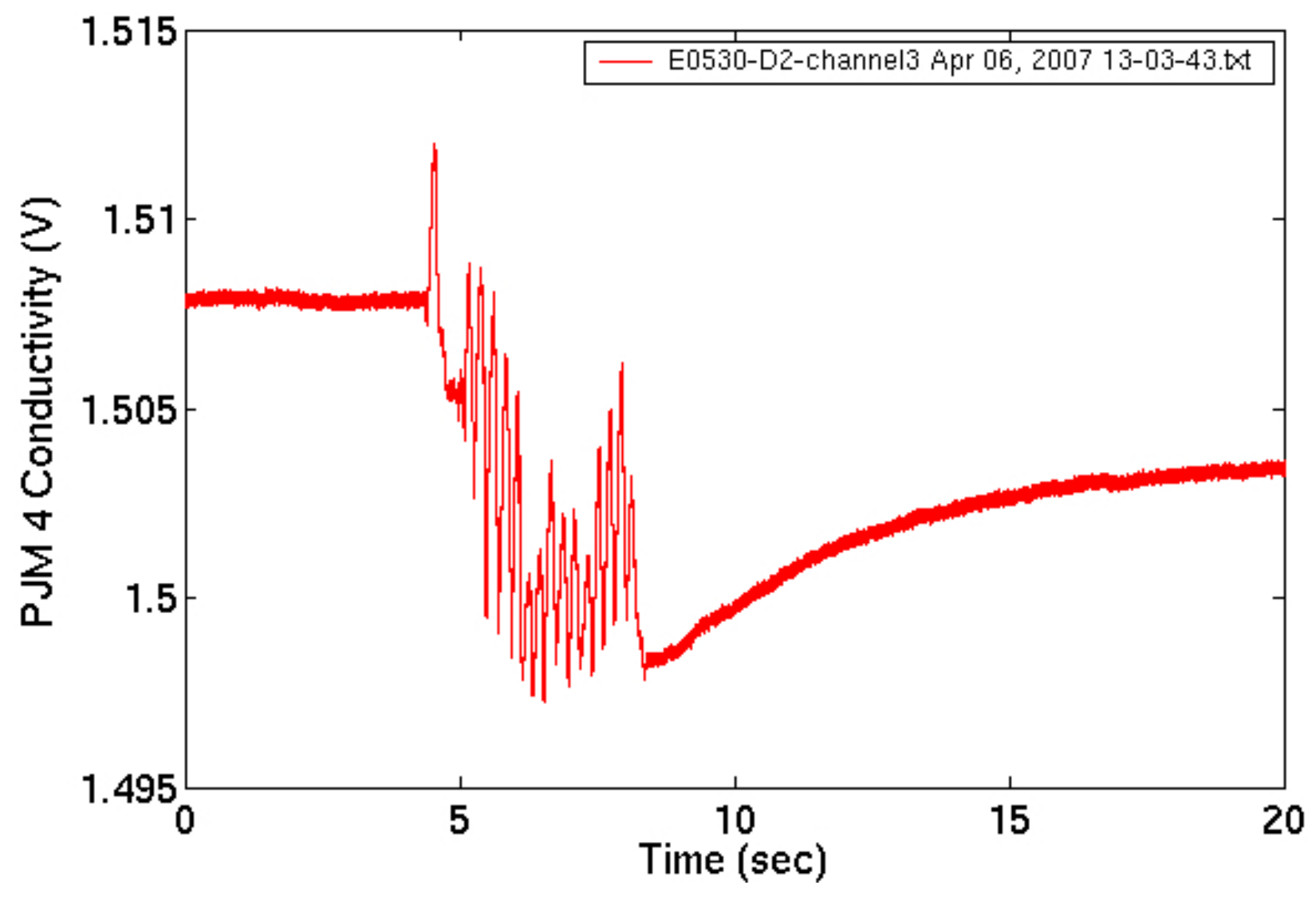

D. 28 
Appendix E

Example 4-PJM Data 


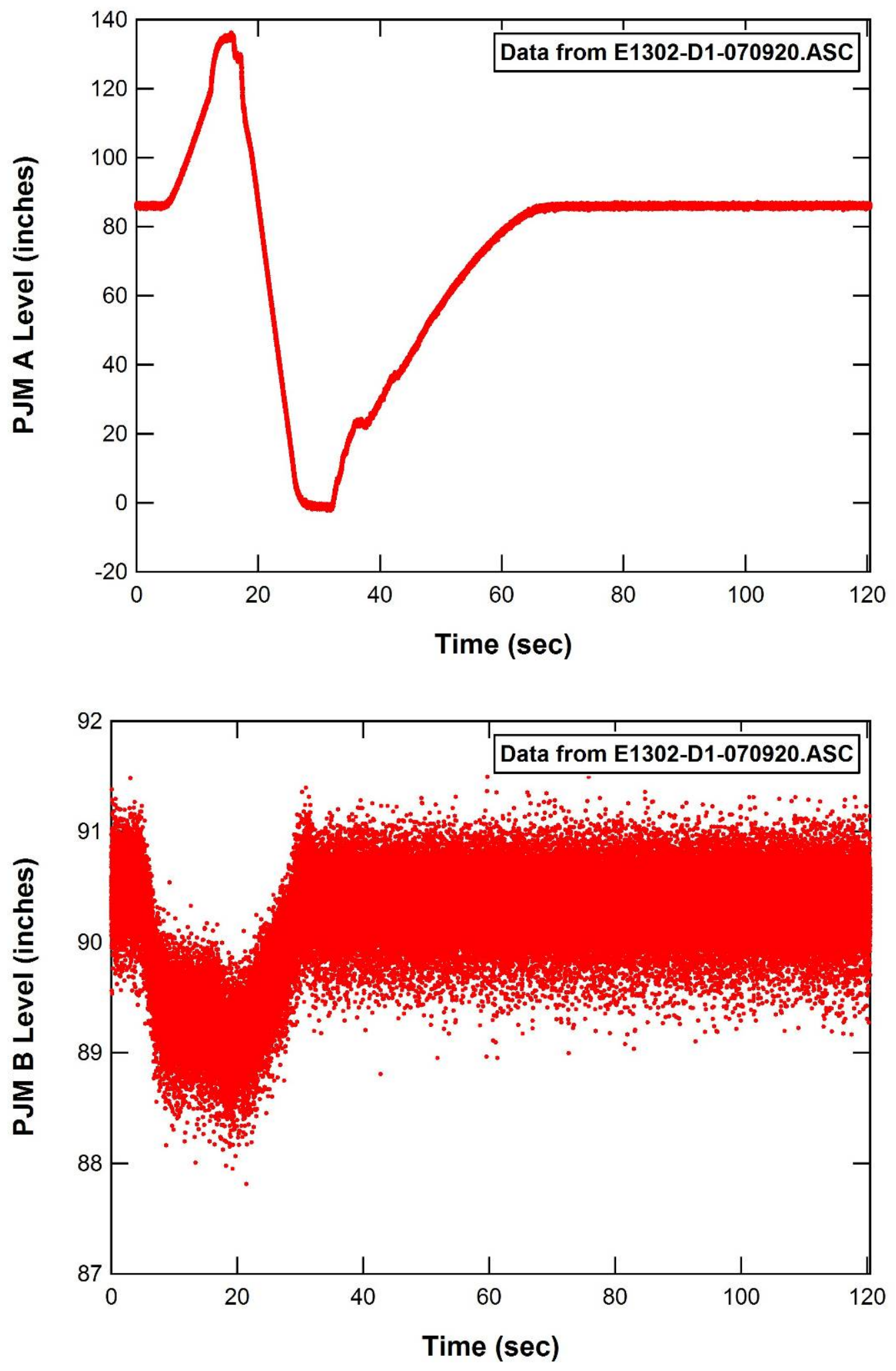

E.1 

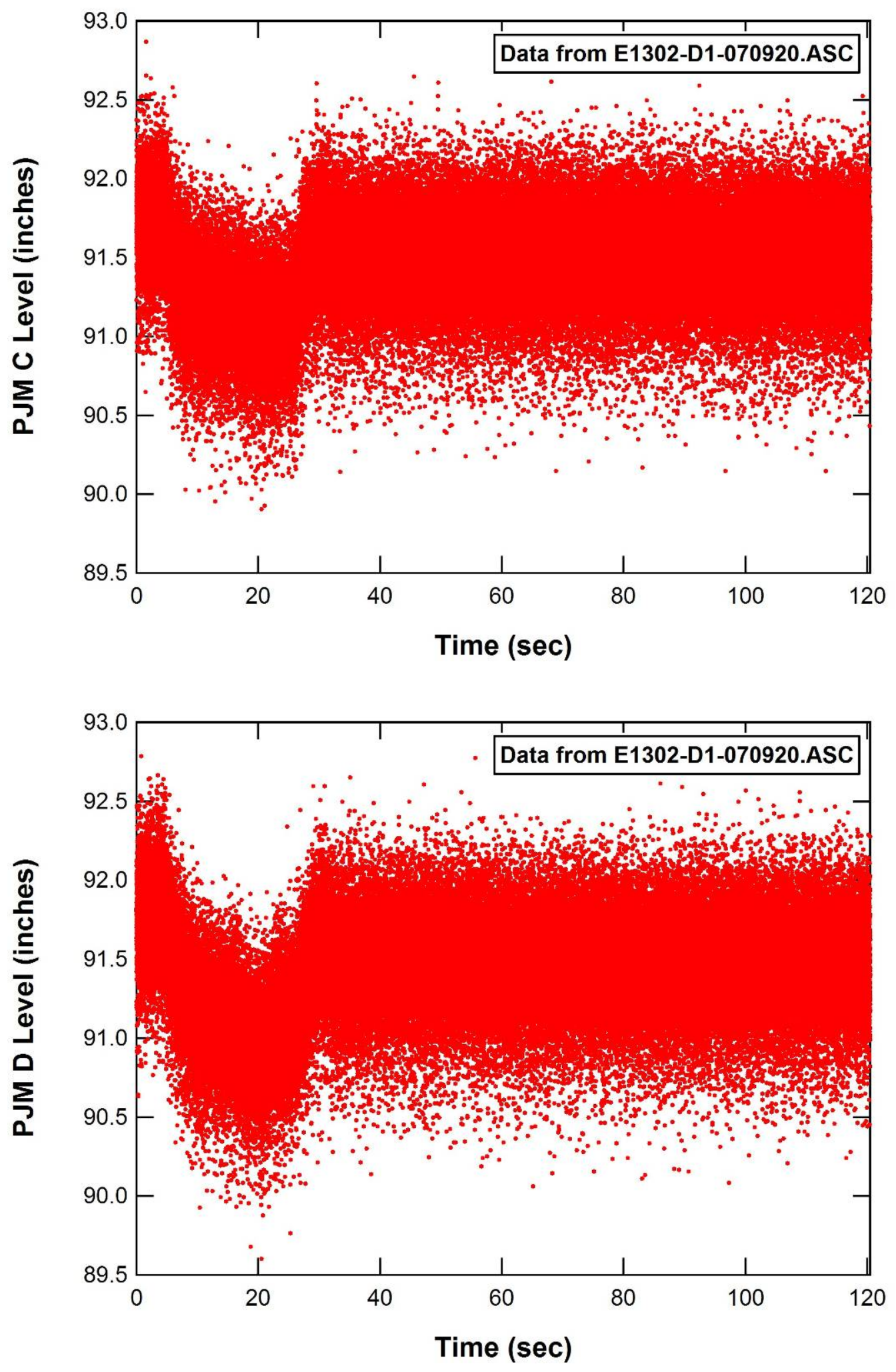

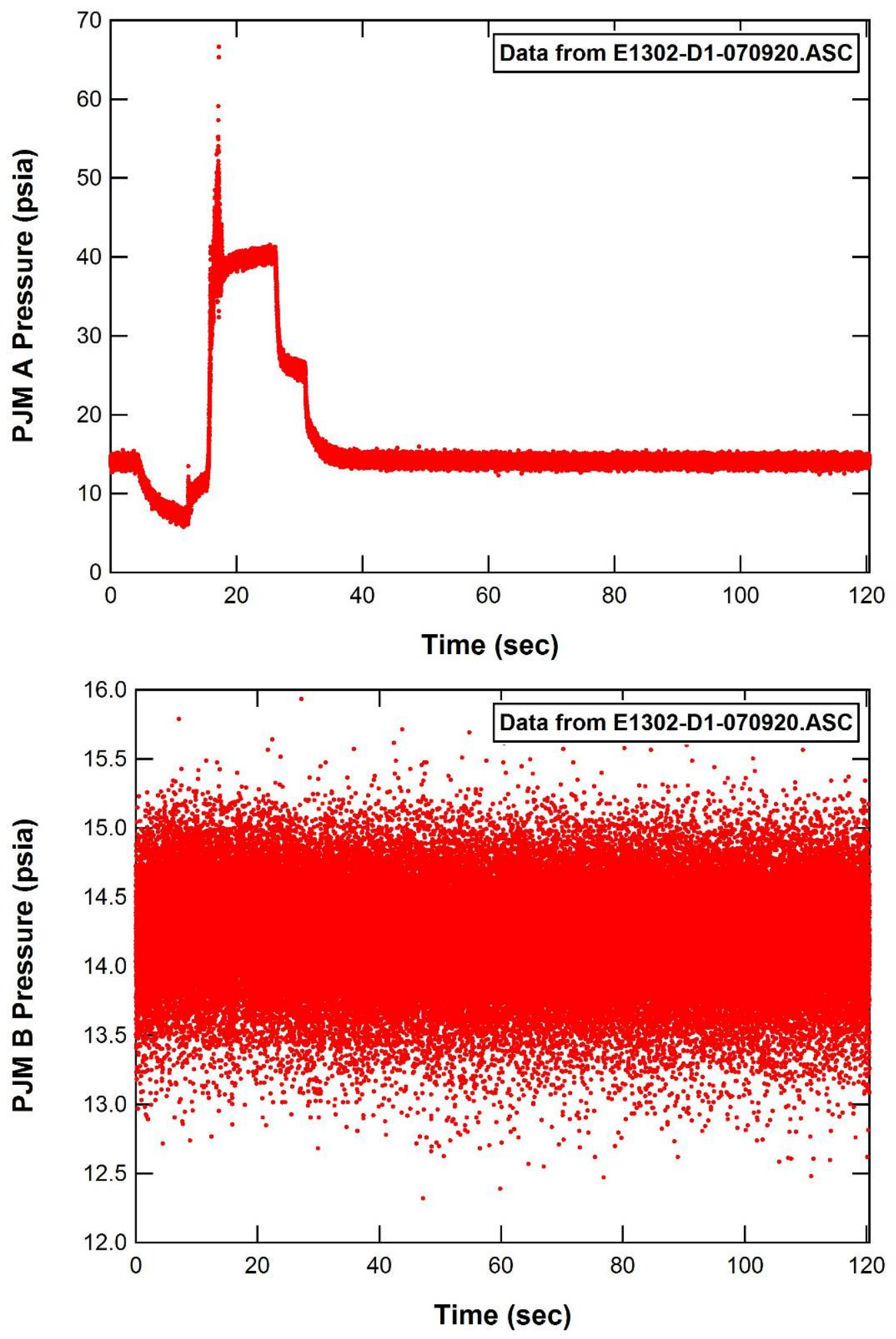

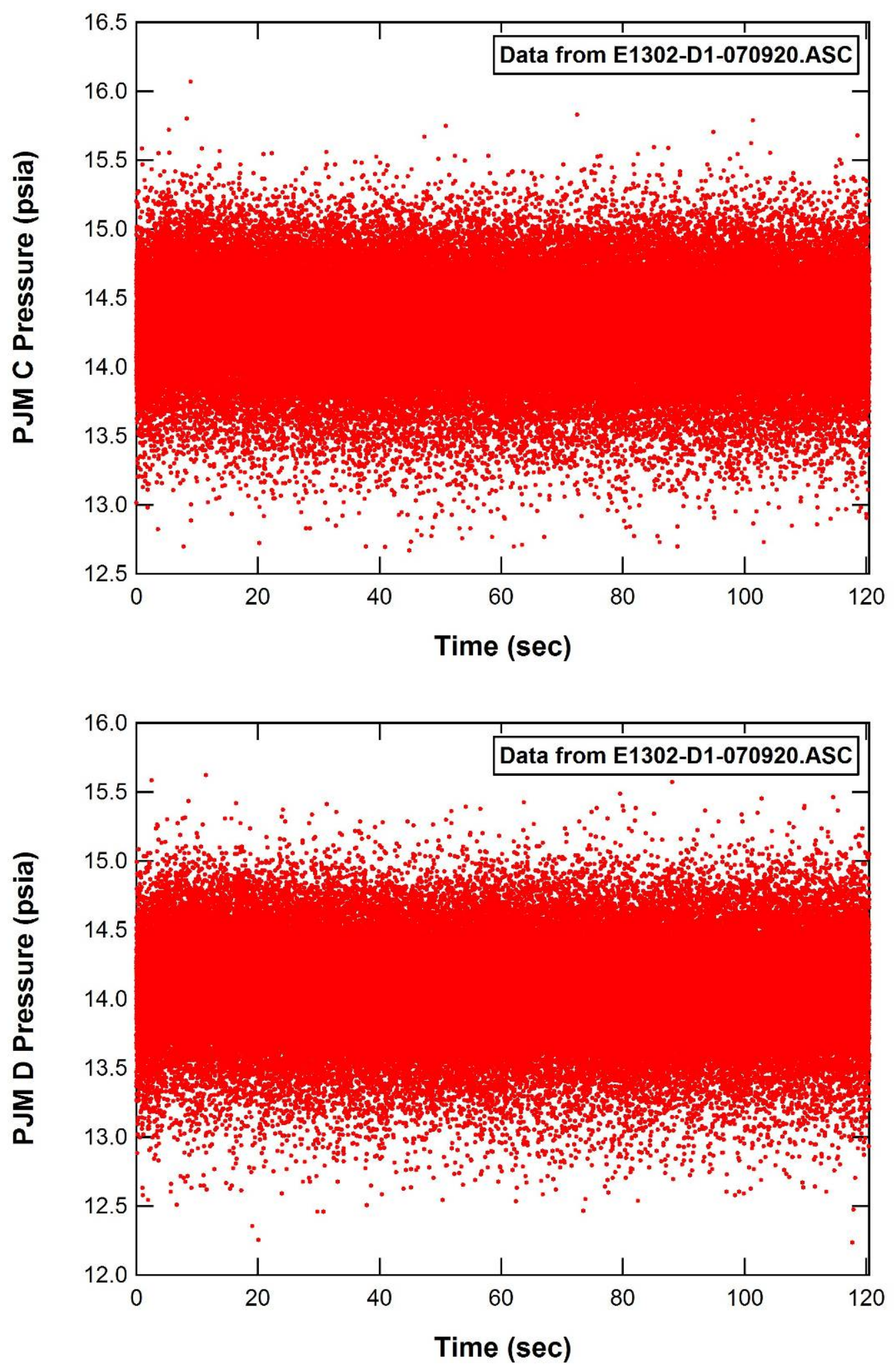

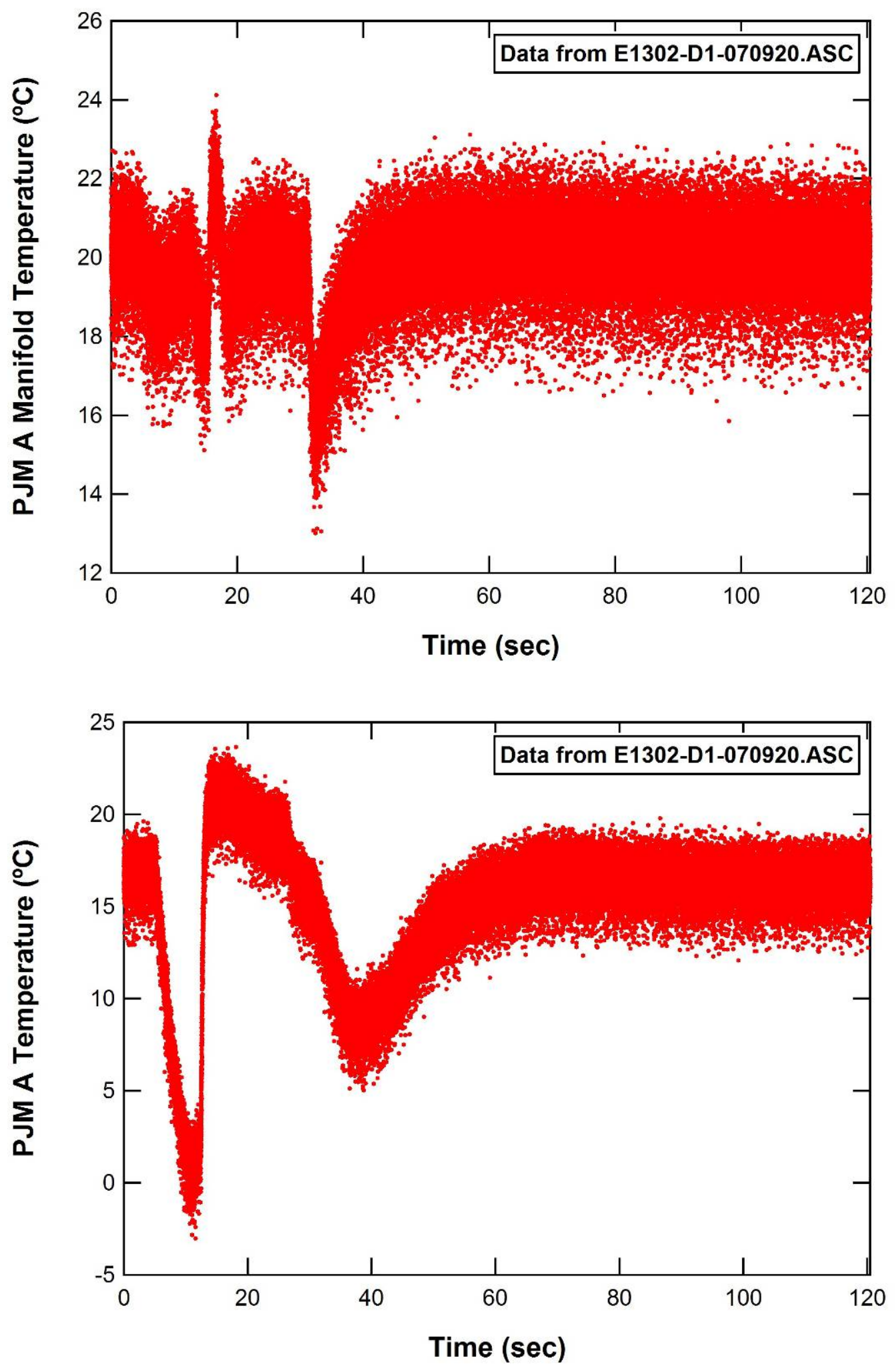

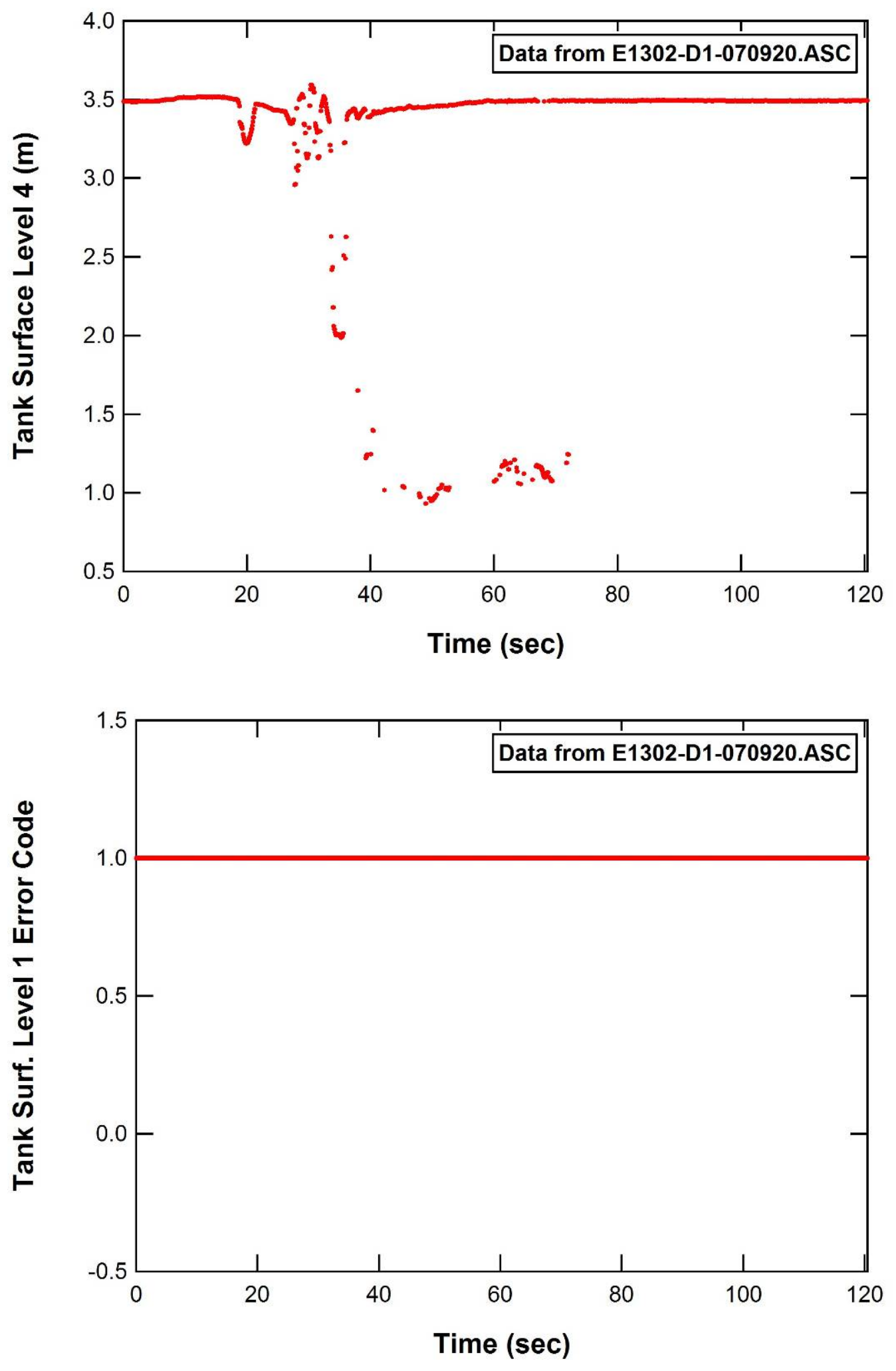

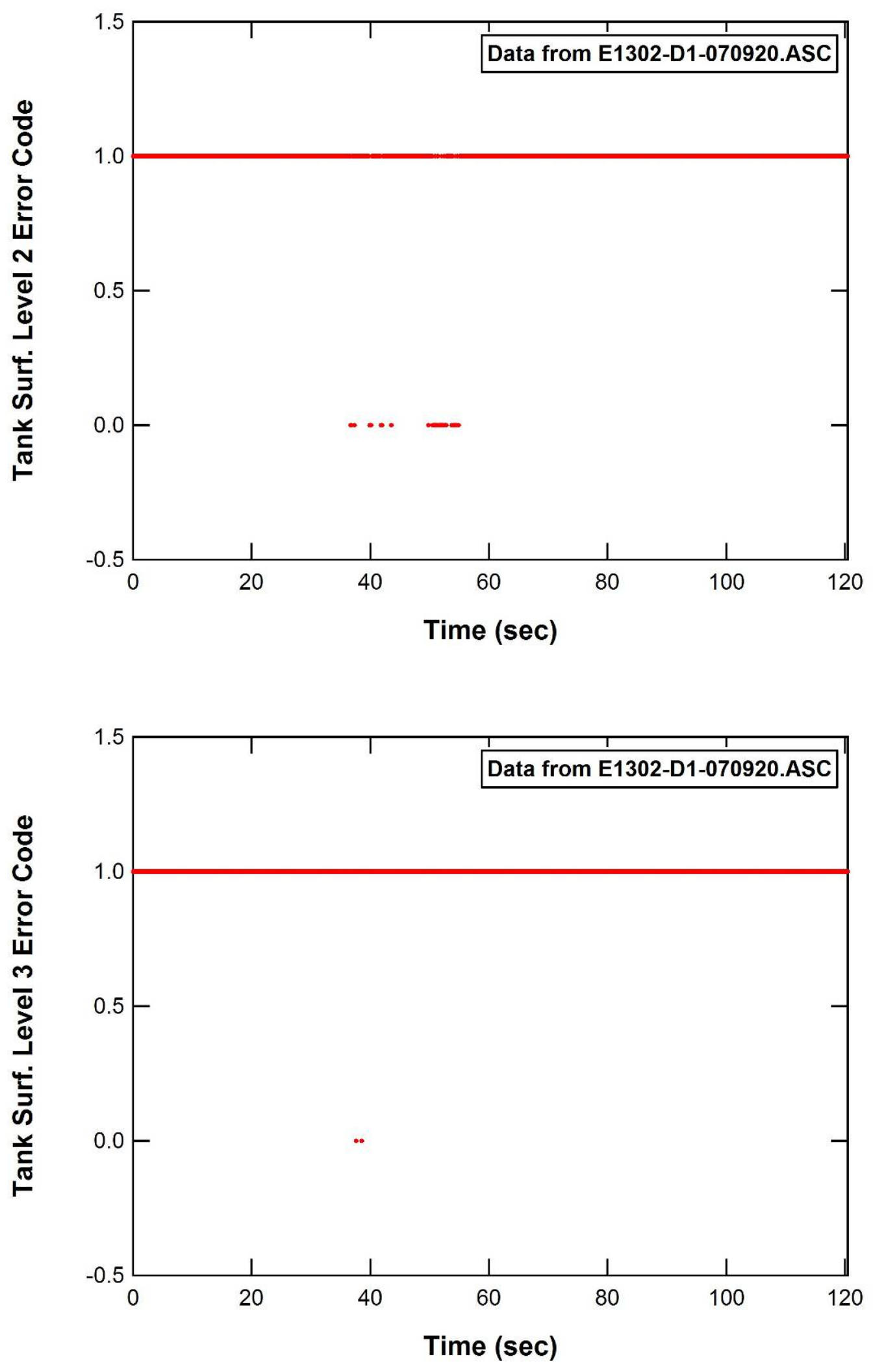

E.7 

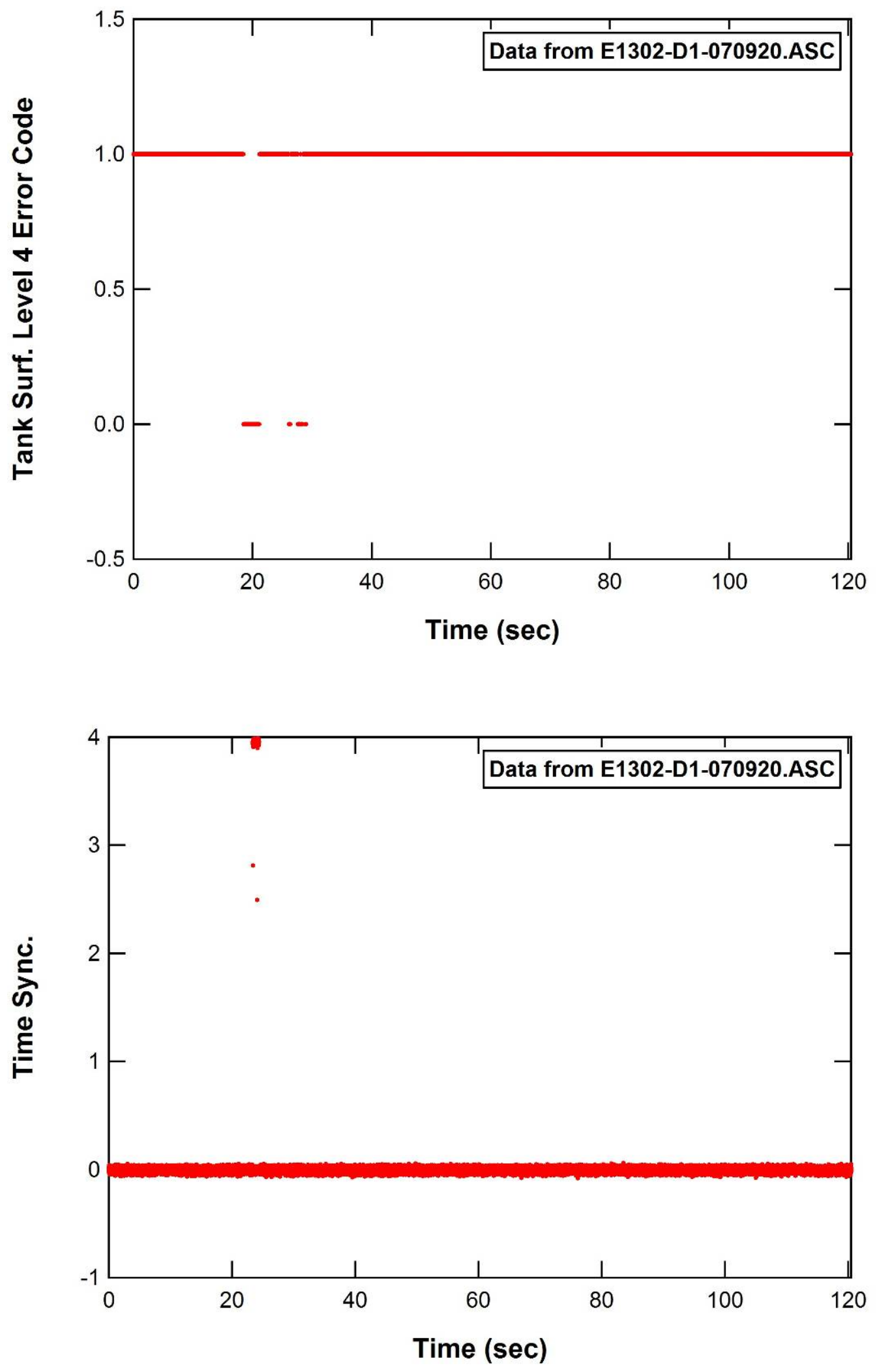

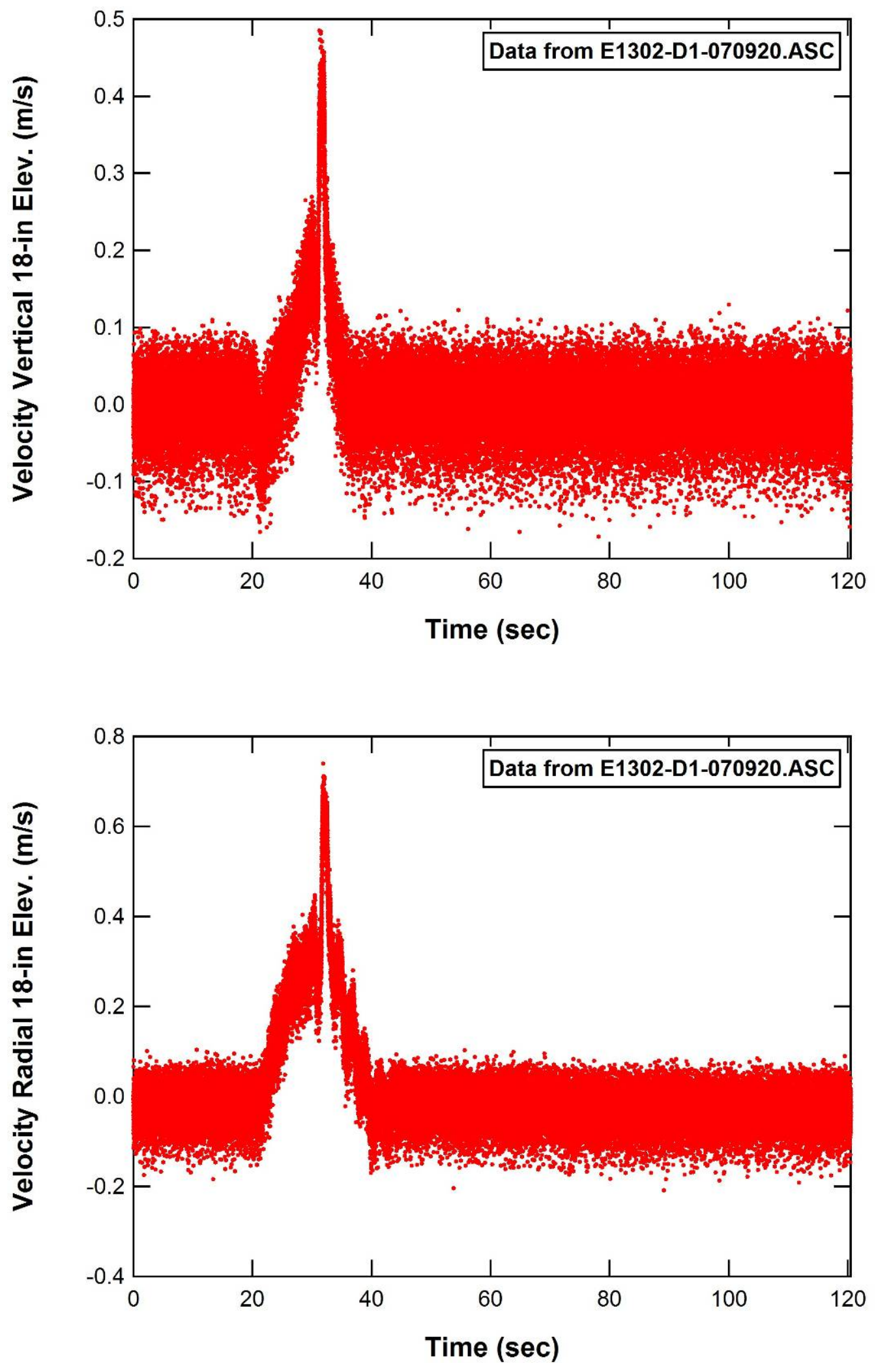

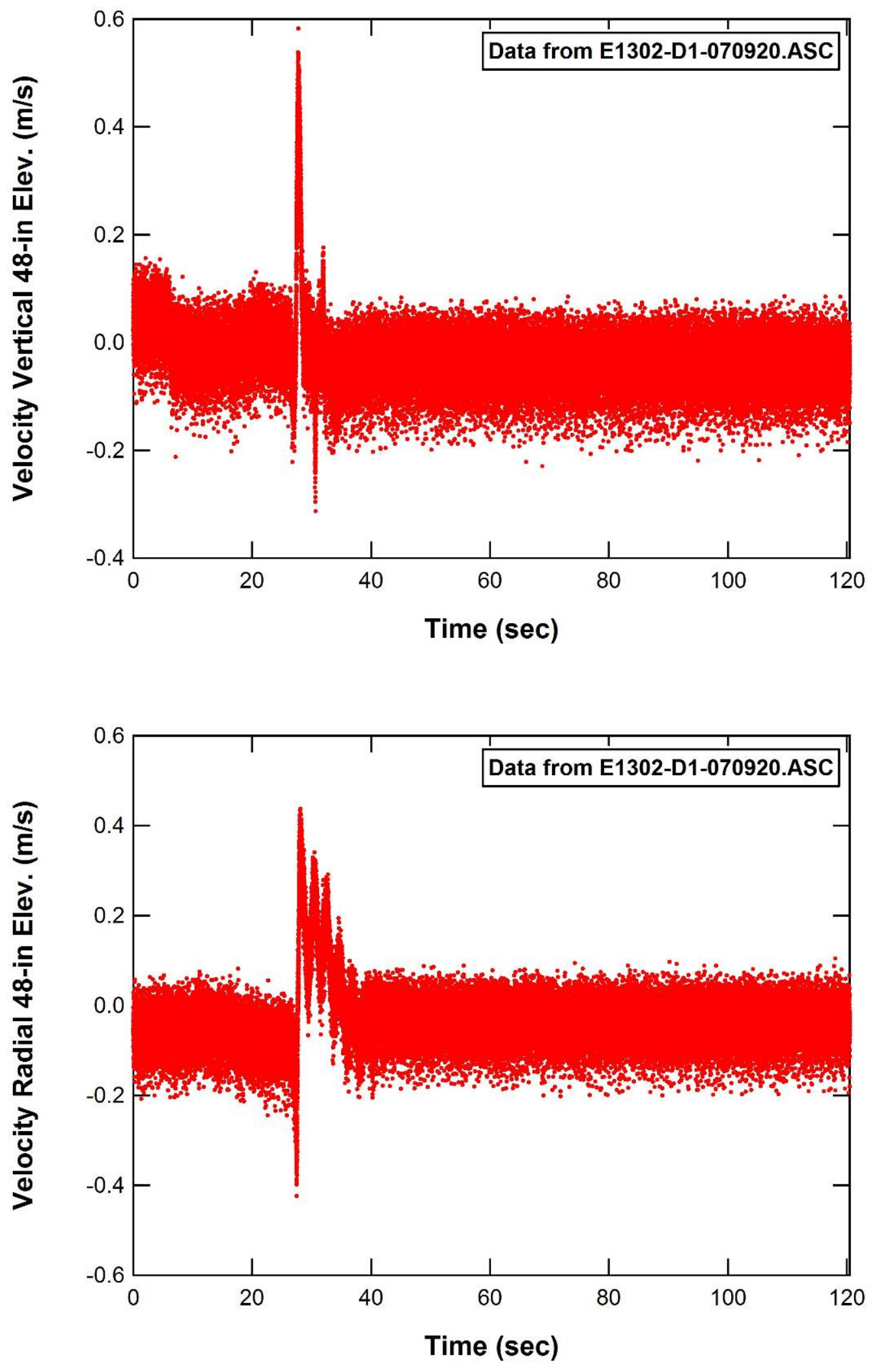

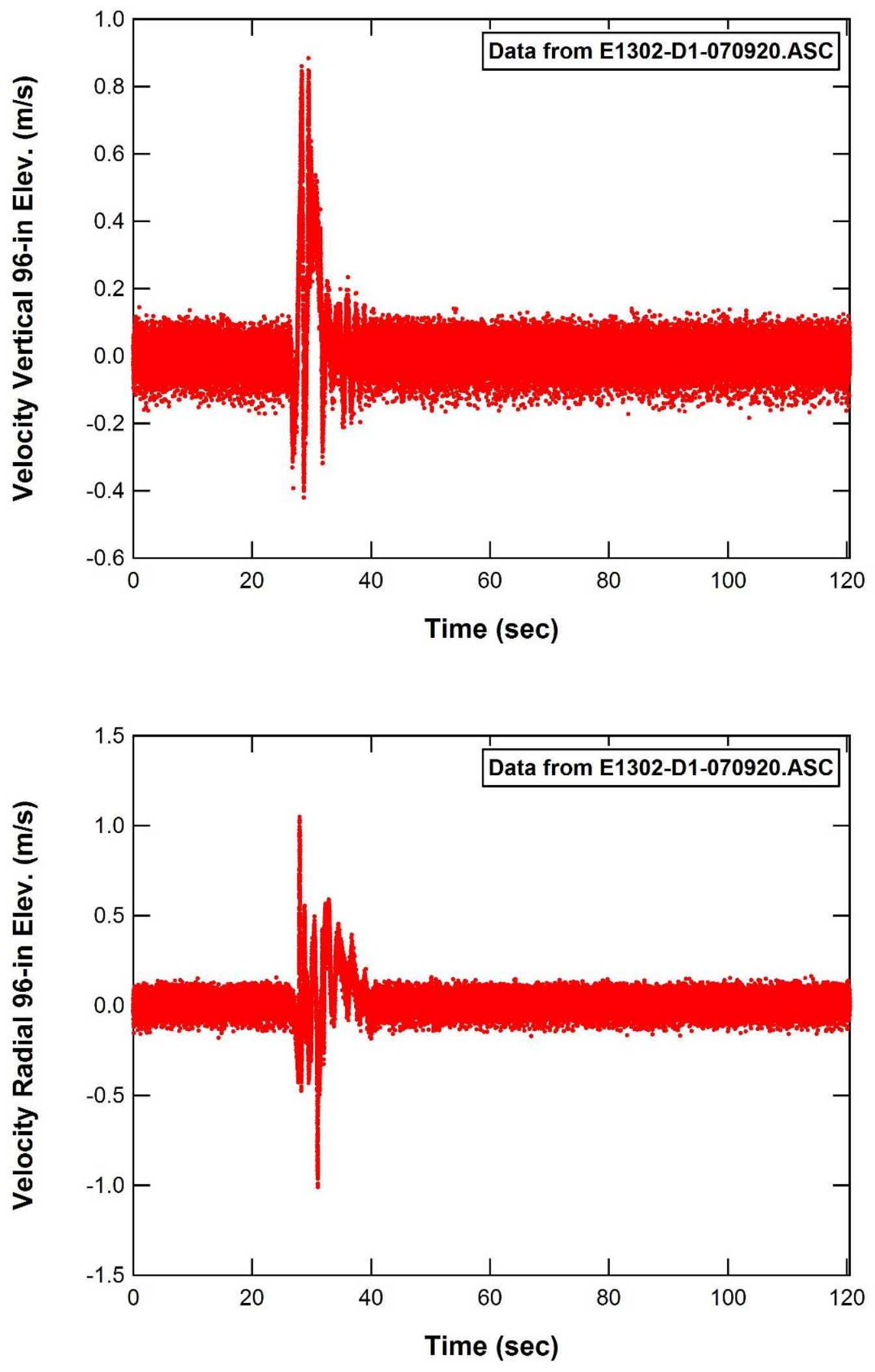

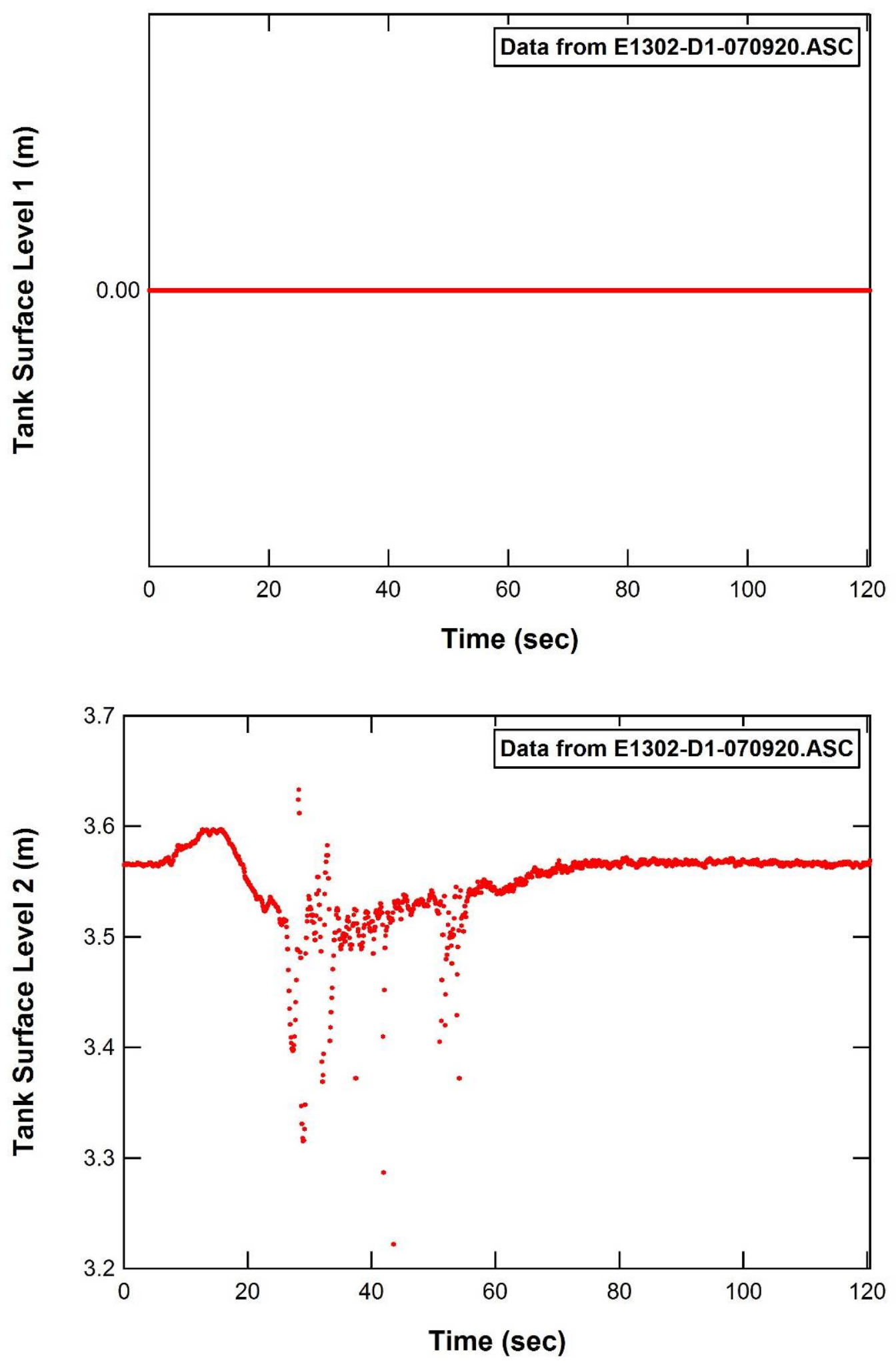

E.12 

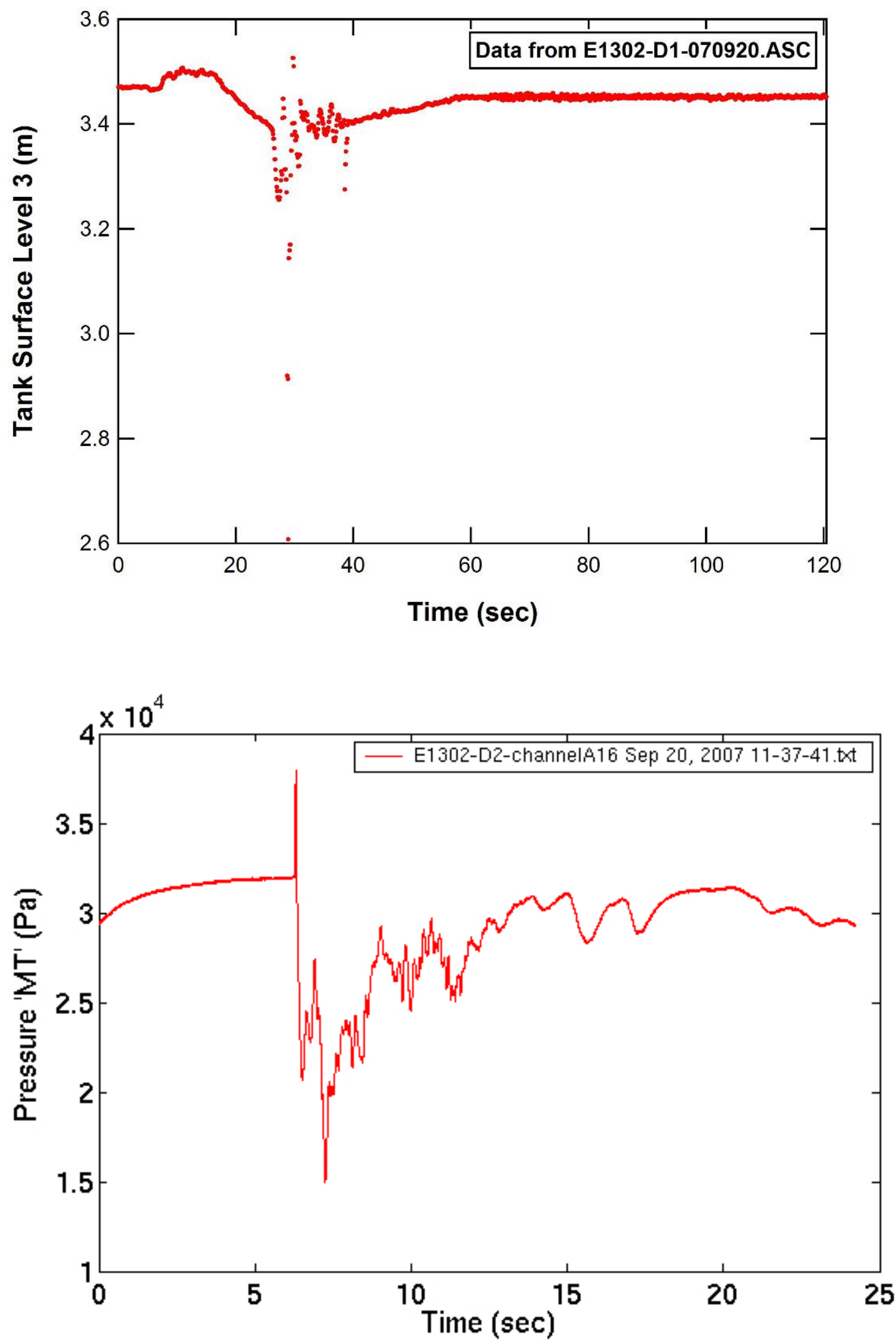

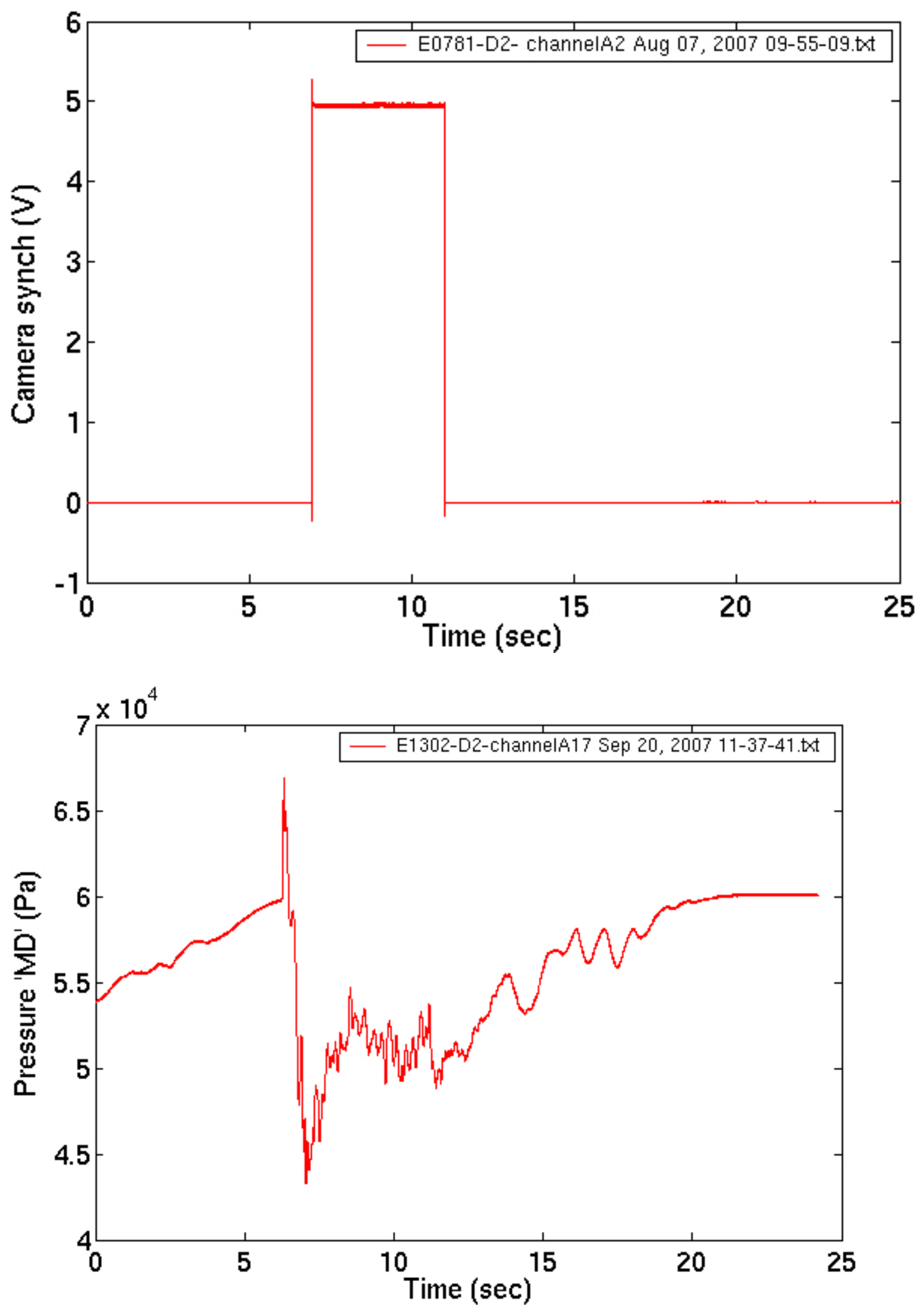

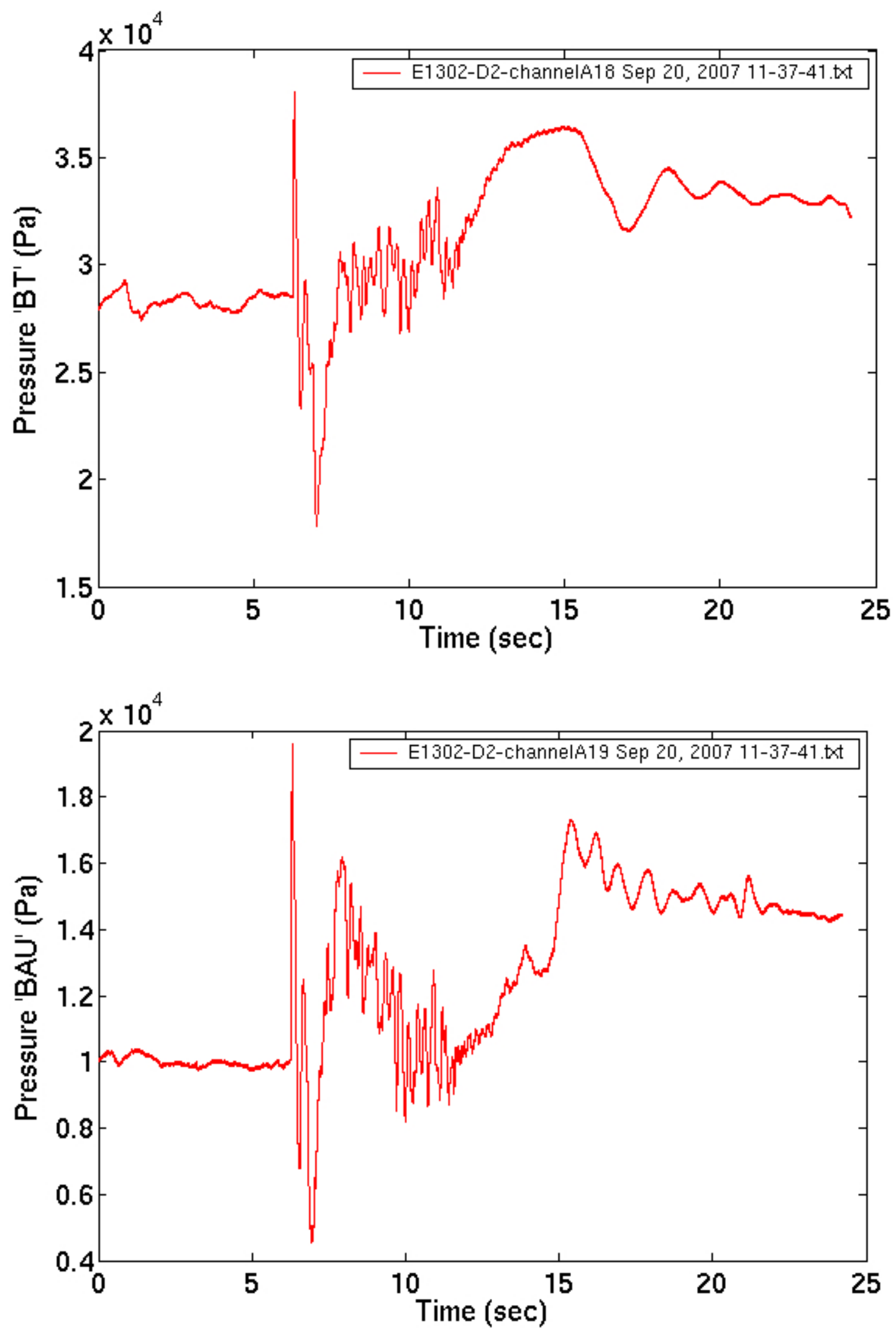

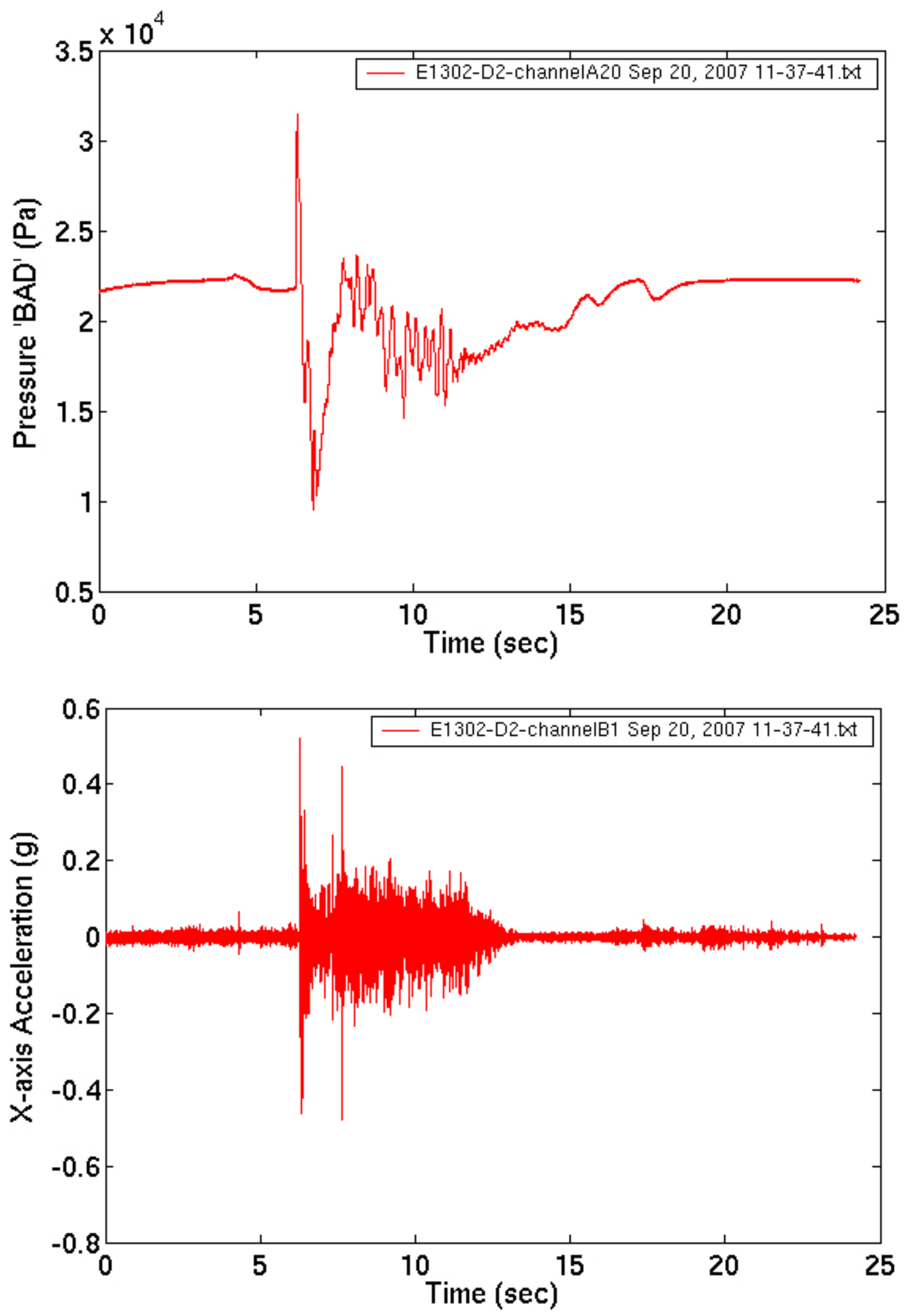

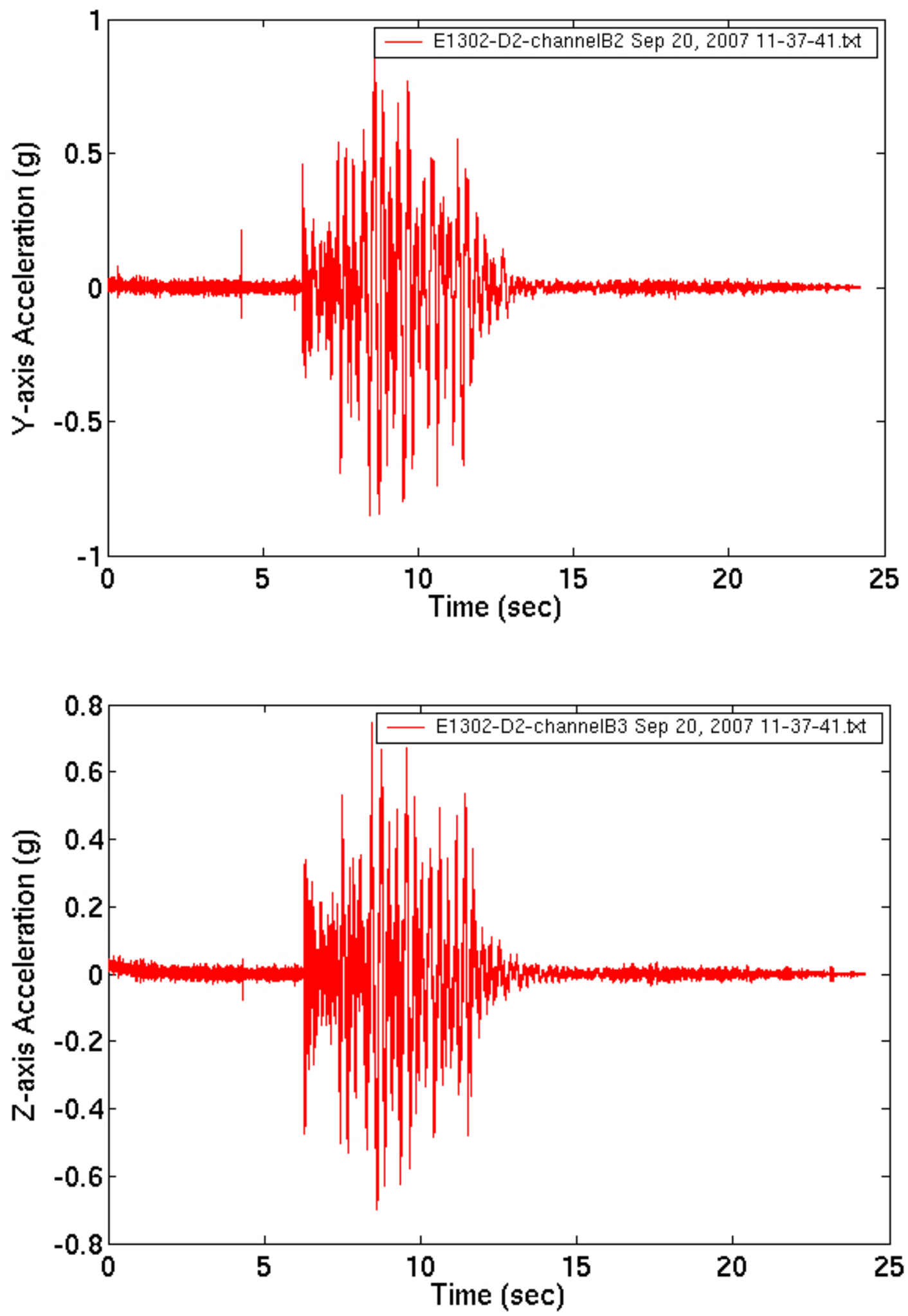

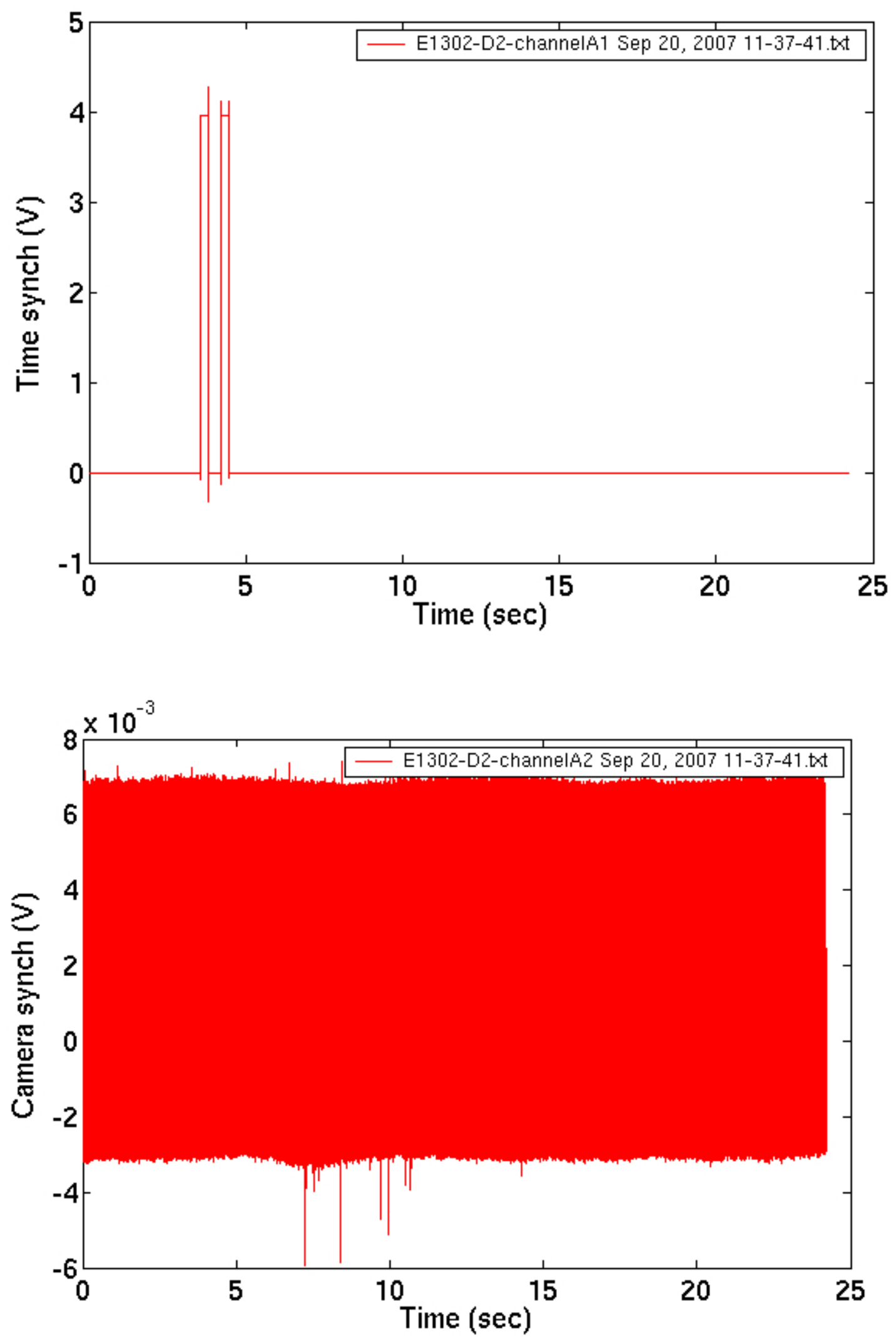

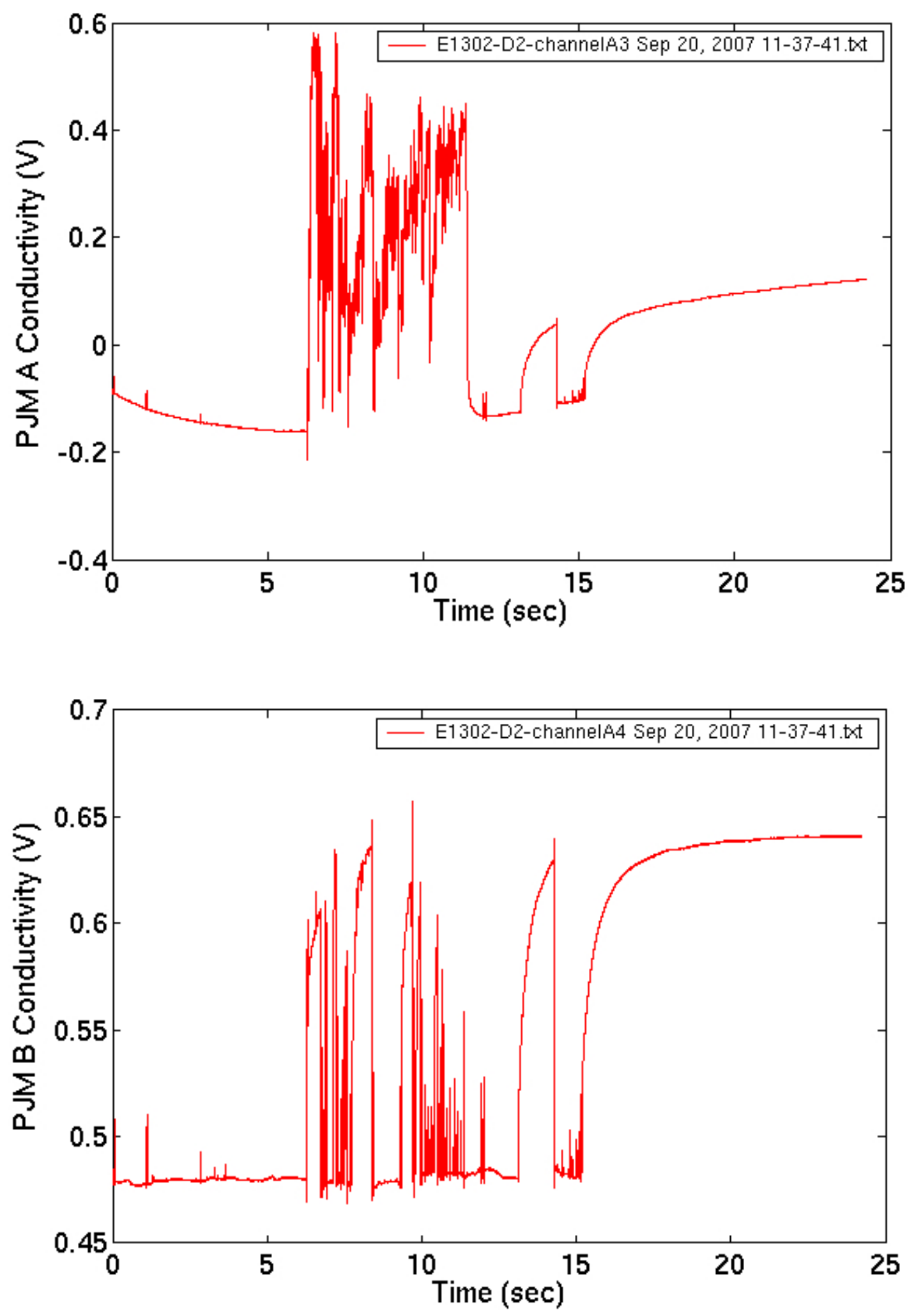

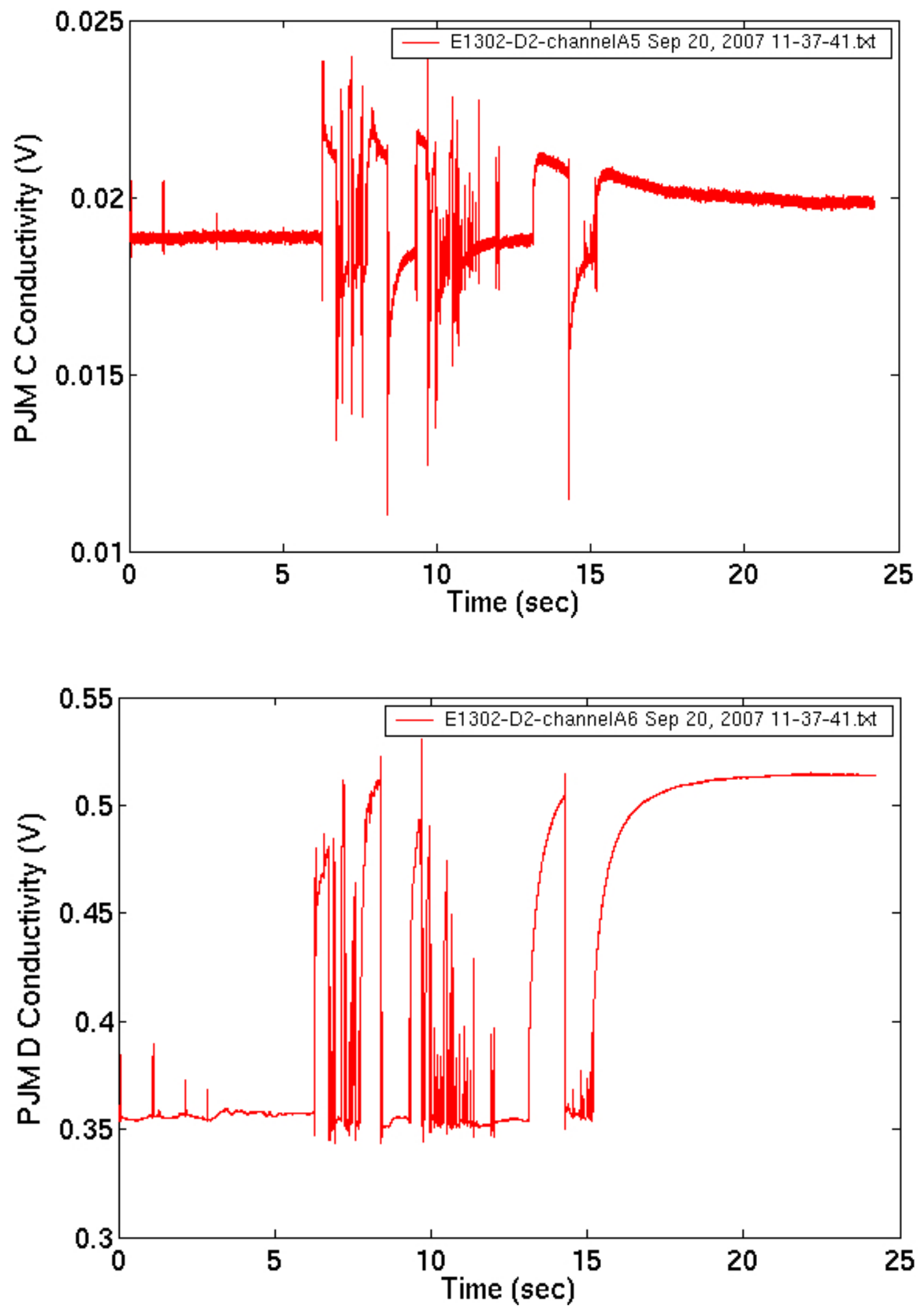

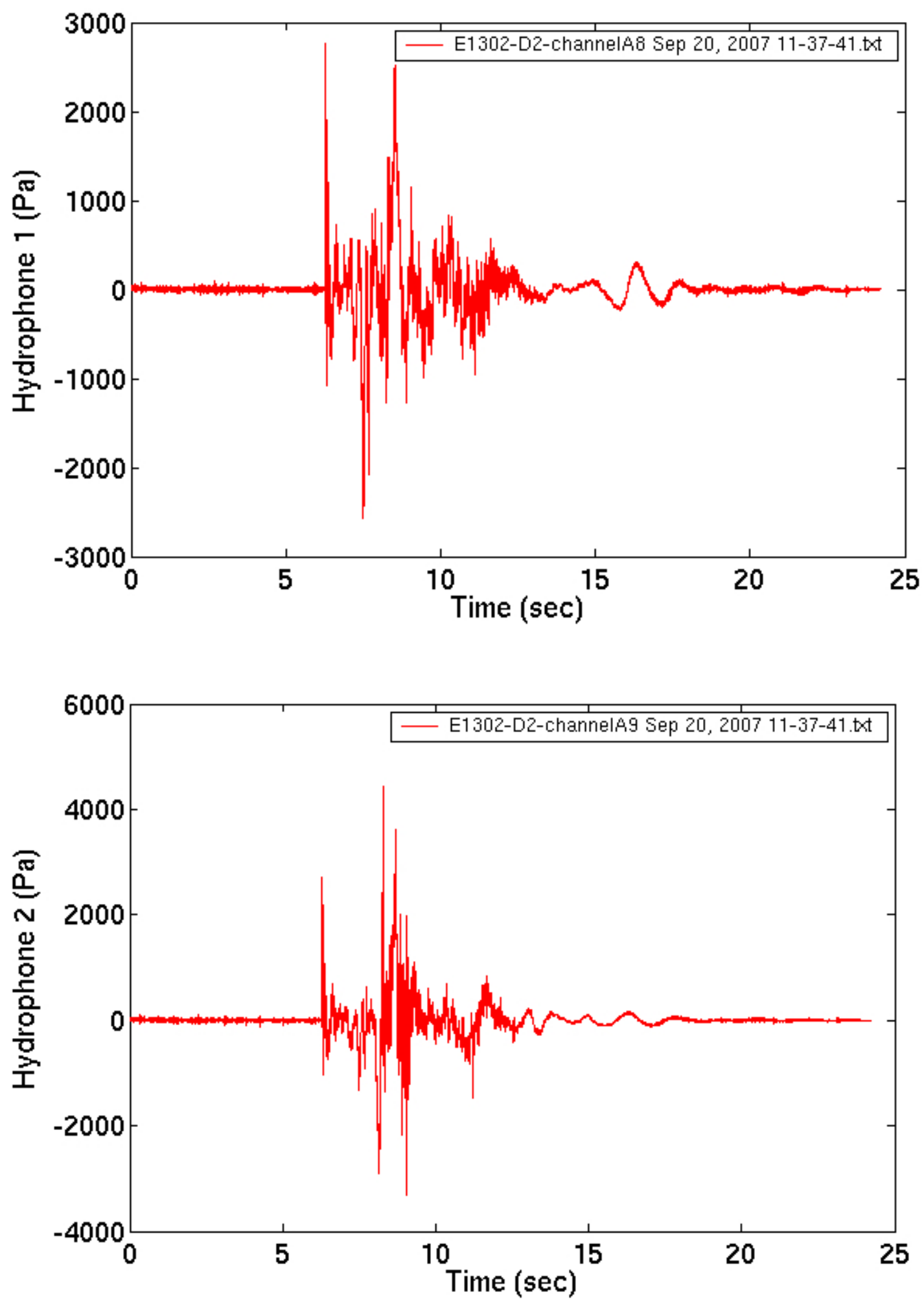

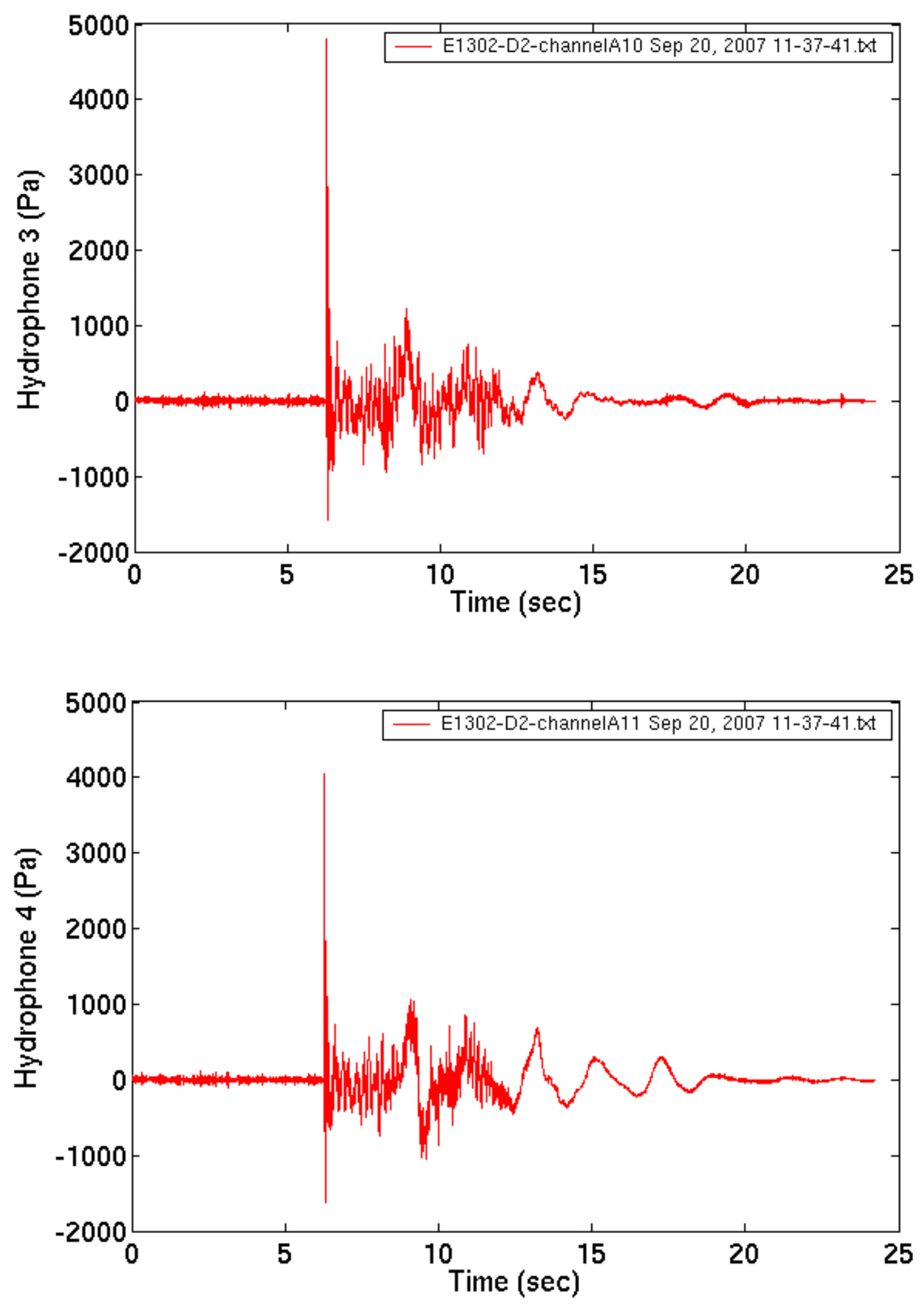

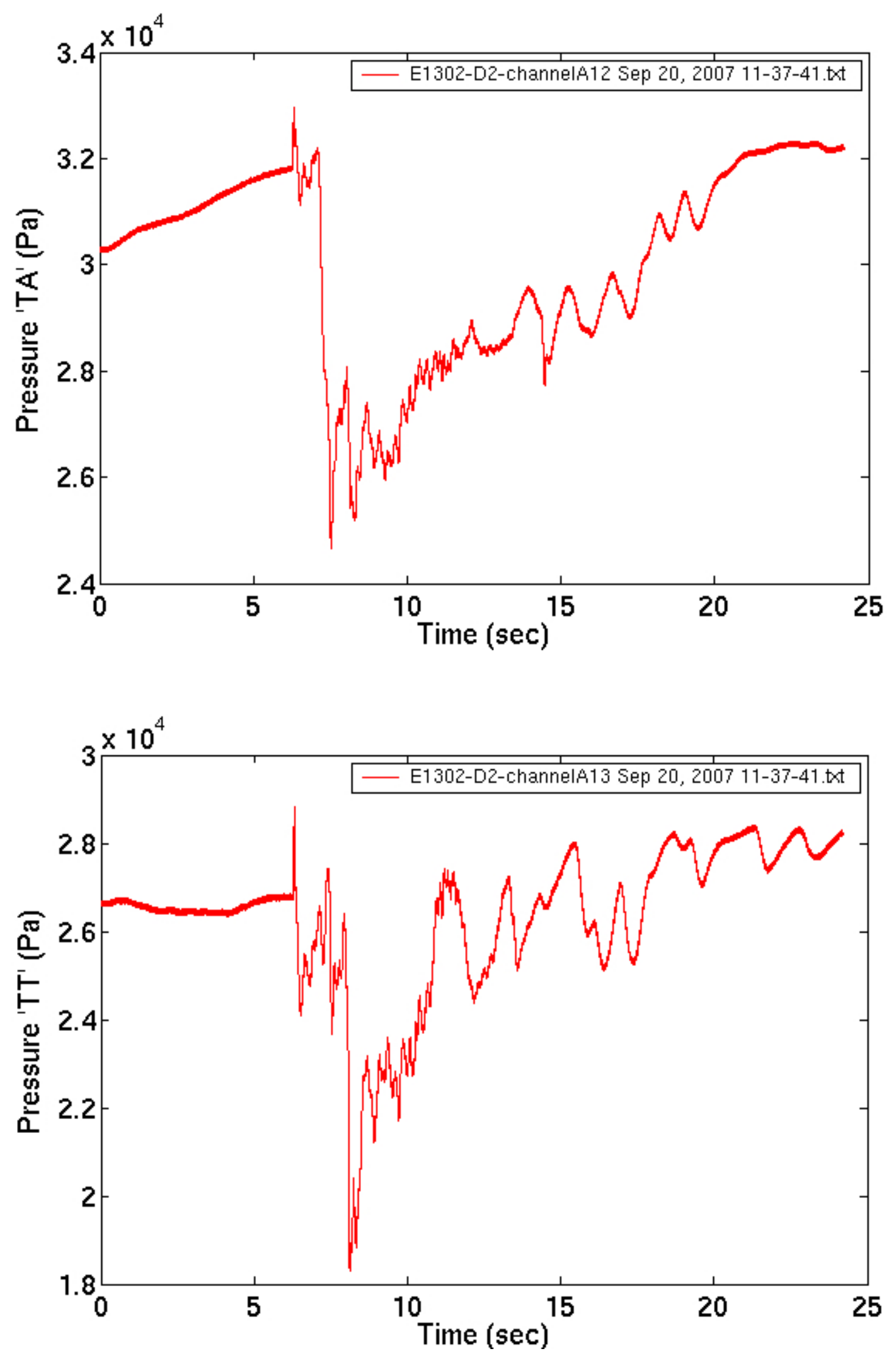

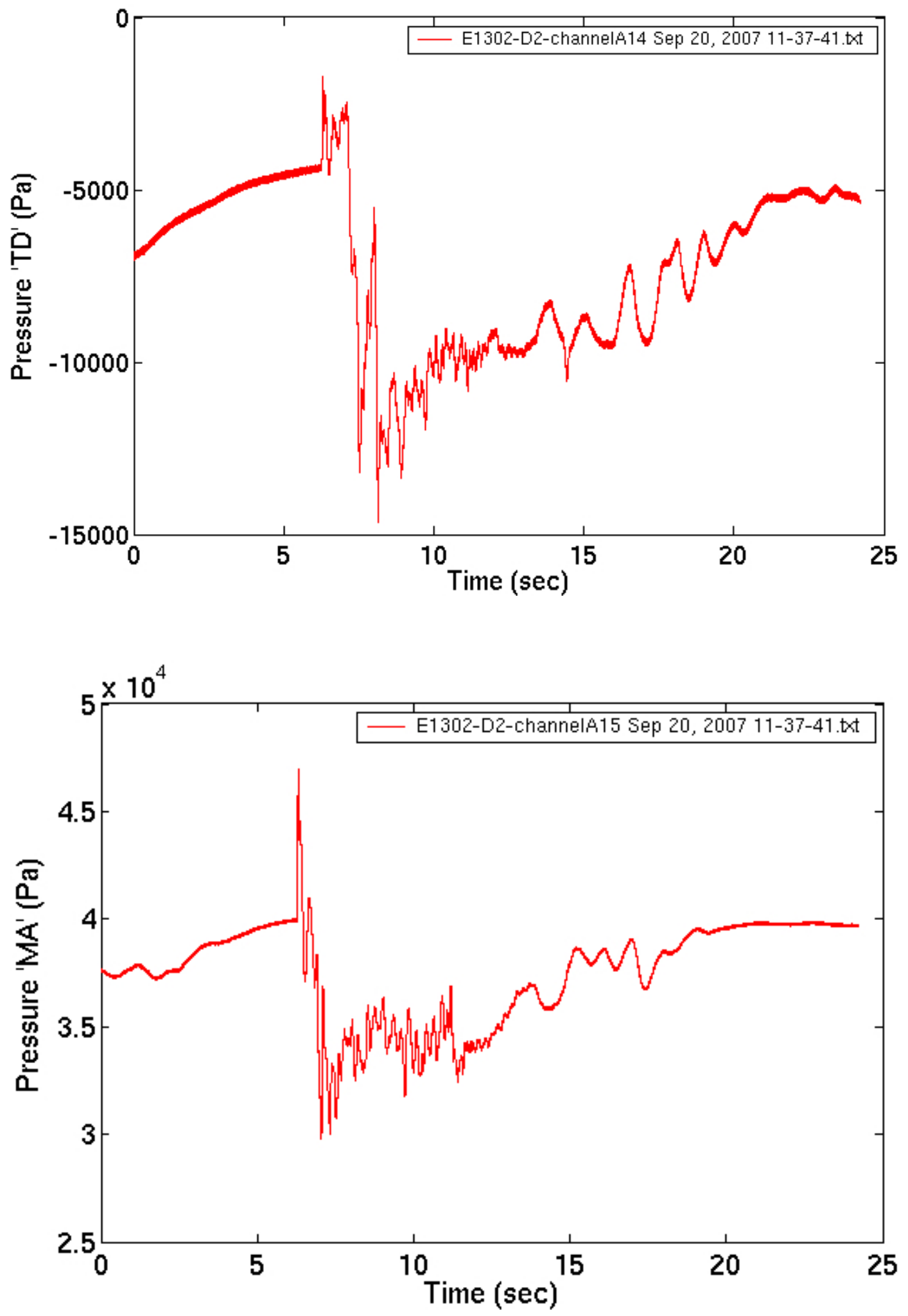


\section{Appendix F}

\section{Clay Simulant Density Data}





\section{Appendix F: Clay Simulant Density Data}

The measured densities of the clay simulant used in the PJM overblow testing for both are shown in Table F.1. Refer to the master run-logs in Appendices A and B for the tests during which these samples were collected.

Table F.1. Density Measurements of Clay Simulant During PJM Overblow Testing ${ }^{(1)}$

\begin{tabular}{|c|c|c|}
\hline Date of Sample $^{(2)}$ & Sample ID & Density, $\mathrm{g} / \mathrm{mL}^{(3)}$ \\
\hline April 2, 2007 & 070402_D2_1012 & 1.1923 \\
\hline April 3, 2007 & 070403_D2_0942 & 1.1902 \\
\hline April 5, 2007 & 070405_S1_0955 & 1.1904 \\
\hline April 9, 2007 & 070409_D2_1017 & 1.1878 \\
\hline August 27, 2007 & 070827_D1_0832 & 1.193, 1.194 \\
\hline August 27, 2007 & 070827_S1_0830 & 1.193 \\
\hline August 28, 2007 & 070828_S1_0955 & 1.194, 1.194, 1.194 \\
\hline August 29, 2007 & 070829_S1_0845 & $1.187,1.192,1.185$ \\
\hline August 30, 2007 & 070830_D1_1032 & $1.194,1.195^{(4)}$ \\
\hline September 18, 2007 & 070918_D1_0817 & $1.2009,1.1980,1.1901$ \\
\hline September 18, 2007 & 070918_D2_1202 & 1.1974, 1.1975, 1.1986 \\
\hline \multicolumn{3}{|c|}{$\begin{array}{l}\text { (1) Density=(total weight - tare)/(pychnometer volume). The values are documented } \\
\text { in CCP-WTPSP-511. }\end{array}$} \\
\hline \multicolumn{3}{|c|}{$\begin{array}{l}\text { Those dated August } 27 \text { through September 18, } 2007 \text { were obtained during 4-PJM } \\
\text { testing. }\end{array}$} \\
\hline \multicolumn{3}{|l|}{ (3) The number o } \\
\hline \multicolumn{3}{|c|}{$\begin{array}{l}\text { operator believes the third value is in error because of a bubble in the } \\
\text { pychnometer. }\end{array}$} \\
\hline
\end{tabular}



PNNL-17231 Rev. 1

WTP-RPT-150 Rev. 1

\section{Distribution}

No. of

Copies

OFFSITE
No. of

Copies

ONSITE

13 Pacific Northwest National Laboratory
A. W. Baumann
K7-28
J. R. Bontha
K7-15

O. P. Bredt

K6-50

W. H. Combs

$\mathrm{K} 7-15$

J. A. Fort

K7-15

E. C. Golovich

K5-25

D. E Kurath

K3-52

R. J. Leigh

K7-50

T. E. Michener

K7-15

F. Nigl

K7-15

K7-15

K7-15

K3-52

Information Release (pdf)

2 Bechtel National, Inc. WTP R\&T Docs (2)

H4-02

Distr. 1 